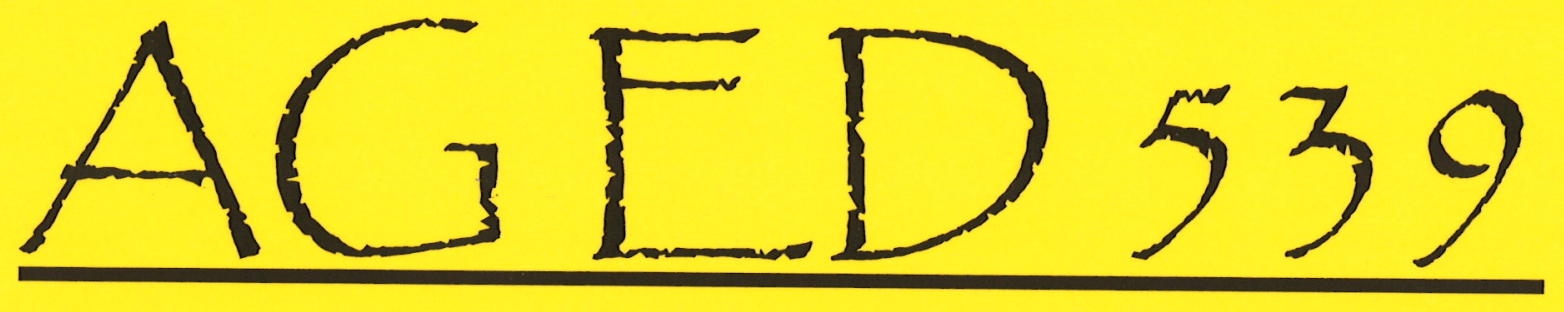

$$
\begin{aligned}
& \text { LASPLUMAS HIGH } \\
& \text { SCHOOL } \\
& \text { QWALITYCRITERIA }
\end{aligned}
$$
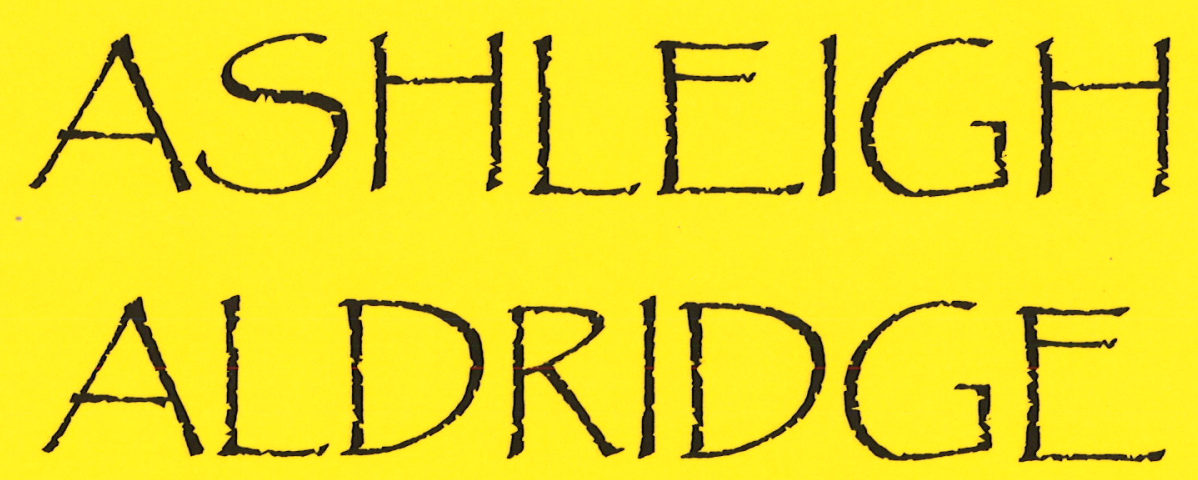


\section{Table of}

Contents

\section{Quality Criteria 1 \\ Curriculum \& Instruction}

Quality Criteria 2

Leadership \& Citizenship Development

3

Quality Criteria 3

Practical Application of Occupational Skills

Las

Plumas

4

Quality Criteria 4

Qualified \& Competent Personnel

High

School

Agriculture

Quality

Criteria
5

Quality Criteria 5

Facilities, Equipment and Materials
Quality Criteria 6

Community, Business \& Industry Involvement
6

7
Quality Criteria 7 Career Guidance

8

Quality Criteria 8 Program Promotion
Quality Criteria 9

Program Accountability \& Planning

Instructors:

Quality Criteria 10

Student Teacher Ratio
Asthleigh

Aldridge, Andree

Earley, Jim

Knapp, and

Carlos Díaz
Quality Criteria 11

Full Year Employment
Quality Criteria 12

Program Achievement 


\section{Quality Criteria One:}

\section{Curriculum and Instruction}

The curriculum has been organized and sequenced around career paths with clear performance standards leading to entry level employment, job advancement, entrepreneurship, advanced education and training, and personal use. Instruction is performance-based and integrates academic knowledge and skills which reflect current and emerging technologies and practices in business, industry, and home environment.

The Las Plumas High School Agriculture program is comprised of a 4-person department offering students a variety of courses focused around the California Agriculture Standards. Every course also incorporates the other two circles of three-ring model including FFA and SAE.

Many of our courses in the program offer far more than elective credit; College Agriculture Biology and Agriculture Life Science follow the curricular guidelines of standard Biology and Life Science, offering students credit in those courses while incorporating FFA and SAE opportunities. The ROP Heavy Equipment Operation \& Maintenance course and the Animal Science course are articulated with Butte Community College, thus students receive $2+2$ articulation credit. This year after a five year battle our Floriculture I class received board approval and now counts as fine art requirement for graduation, so students can take an $\mathrm{Ag}$ class and receive fine art credit.

Industry representatives and guest speakers are incorporated into courses and students are instructed with industry current and relevant technologies, equipment, and facilities. We are fortunate to have an extra classroom in our Agriculture Department that we have turned into a multi-purpose computer lab. The computer lab is available and utilized for career research, scholarship applications, cover letter and resume' building in majority of our upper level agriculture courses offered.

Each year, student's needs and abilities are assessed and they are placed in Agriculture classes were they will be successful. Every student in an agriculture class is encouraged to be engaged and involved. Curriculum and Instruction at Las Plumas High School Agriculture Department evolves each year to meet and exceed curricular standards, the needs of industry and the needs of our students.

\section{Evidence Documents Include:}

- Master Schedule

- Course Handbook

- Course Selection Sheet

- Ag Course Pathways

- College Agriculture Biology Course Description

- Animal Science Course Description

- Ag Life Science Course Description

- Student Evaluation Samples: Class timecards, Biology Quarterly Exams, Beef Production Exam

- Performance Standards for Program Completers

- Example Documents: C-Course Outlines: Grading Policy

- Example Documents: D- Copy of Daily Grade Sheets from each class taught. 
\begin{tabular}{lr}
\hline SECTIONS $=$ & 256
\end{tabular}

6/7/2011

Enrollment 1285(Minus $17 \mathrm{CC}$ and $23 \mathrm{CIS}$ )

\begin{tabular}{|c|c|c|c|c|c|c|c|c|c|c|c|c|c|c|c|}
\hline Ejbject Area & Room & FTE & 1st Period & 1 & 2nd Period & & \multirow{2}{*}{\multicolumn{2}{|c|}{$\begin{array}{l}\text { 3rdPeriod } \\
\text { Sections }=\end{array}$}} & 4th Period & & 5th Period & \multicolumn{2}{|r|}{ 6th Period } & \\
\hline GLISH & 45 & 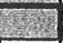 & FTE & & 7.4 & & & & 37 & & & & & & \\
\hline -torvath Teacher B & & 0.4 & English 9 ELD & 20 & English 11 & 35 & PREP & & $\mathrm{OHS}$ & & $\mathrm{OHS}$ & & $\mathrm{OHS}$ & & 55 \\
\hline Bruce, C. & 1015 & 1.0 & English $10 \mathrm{H}$ & 27 & AP Eng Lit/Comp & 19 & AP Eng Lit/Comp & 20 & PREP & & English 11 & 33 & English 11 & 34 & 133 \\
\hline Lawson, B. & 110 & 1.0 & English 10 & 24 & Eng 10 ELD & 19 & English 11 & 24 & English 11 ELD & 18 & PREP & 35 & English 10 & & 120 \\
\hline Lovgren, $\mathrm{K}$. & 628 & 0.8 & English 12 ELD & 22 & PREP & & English 9 & 35 & English $10 \mathrm{H}$ & 29 & English 9 & 31 & & & 117 \\
\hline Aldrich Teacher A & 105 & 0.6 & & & English 10 & 33 & English 10 & 34 & PREP & 33 & English 10 & & & & 100 \\
\hline Ross, L. & 1013 & 1.0 & English 9 & 35 & & 34 & English 10 & 35 & English 10 & 26 & & & PREP & 33 & 163 \\
\hline Sorenson, R. & 1014 & 1.0 & English 12 & 34 & English 12 & 35 & English 12 & 32 & PREP & & English 12 & 34 & English 12 & 33 & 168 \\
\hline Steinhaus, $\mathrm{K}$. & 104 & 1.0 & PREP & & AP Engl Lng/Com & 35 & Ap Eng Lng/Com & 37 & English 9 & 26 & English 9 & 31 & English 9 & 33 & 162 \\
\hline Hashim Teacher H & 105 & 0.6 & English 11 & 33 & English 9 & & English 9 & 24 & English 9 & & PREP & & English 11 & 33 & \\
\hline SOCIAL SCIENCE & $x>x_{1}$ & & FTE $=$ & & 7.2 & & Sections = & & 36 & & & & & & \\
\hline Bruce, $\mathrm{A}$. & 112 & 1.0 & World History & 34 & Geography & 35 & World History & 35 & Geography & 27. & PREP & & Geography & 35 & 166 \\
\hline Burnett, S. & 1206 & 1.0 & AP Gov & 23 & Gov & 33 & Gov & 33 & Government & 33 & US History & 35 & PREP & & 157 \\
\hline Busby, B. & 1205 & 1.0 & U.S. History & 36 & World History H & 23 & World History $\mathrm{H}$ & 23 & World History & 35 & PREP & & US History & 34 & 151 \\
\hline Chew, T. & 1203 & 1.0 & Geography & 35 & Economics & 32 & Economics & 33 & Economics & 32 & Geography & 30 & PREP & & 162 \\
\hline Kermen, $\mathrm{M}$. & 102 & 1.0 & AP Micro Economi & 23 & US History & 36 & U.S. History & 33 & US History & 36 & US History & 35 & PREP & & 163 \\
\hline Osterlund Teacher C & 1207 & 1.0 & AP US History & 29 & World History & 35 & PREP & & AP US History & 29 & World History & 33 & World History & 35 & 161 \\
\hline Taylor, $\mathrm{T}$. & 1016 & 1.0 & Health/Dr Ed & 35 & Health/Dr Ed & 38 & PREP & & Health/Dr Ed & 28 & Health/Dr Ed & 31 & Health/Dr & 35 & 167 \\
\hline Aldrich Teacher A & 1204 & 0.2 & World History & \begin{tabular}{|l|l|}
34 & \\
\end{tabular} & & & & & & & & & & & \\
\hline MATH & 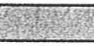 & t & FTE $=$ & & 5.6 & E. & Sections $=$ & & 28 & & & & & & \\
\hline Anderson $\mathrm{T}$ & 618 & 1.0 & Algebra B & 31 & Algebra B & 33 & PREP & & Algebra B & 34 & Adv Algebra & 35 & Adv Algebra & 34 & 167 \\
\hline Boehme, Tे. & 220 & 1.0 & Geometry & 36 & Geometry & 36 & AP Calculus & 14 & PREP & & Geometry & 36 & Geometry & 36 & 158 \\
\hline Dempsey, N. & 619 & 1.0 & Geometry & \begin{tabular}{|l|l}
36 \\
\end{tabular} & Algebra I & 35 & Adv Algebra & 30 & Geometry & 36 & PREP & & Geometry & 36 & 173 \\
\hline Gnesda, D. & 609 & 0.8 & & & PREP & & Algebra A & 36 & Algebra A & 17 & Algebra A & 37 & Geometry & 25 & 115 \\
\hline Howard, R. & 612 & 1.0 & Adv Algebra & 34 & PREP & & Pre Calculus & \begin{tabular}{l|l}
37 & 1 \\
\end{tabular} & Algebra I & 17 & Algebra I & 25 & Algebra I & 34 & 147 \\
\hline Upton, C. & 219 & 0.8 & Algebra I & \begin{tabular}{|l|l|}
35 & 1 \\
\end{tabular} & Pre Calculus & 38 & Algebra I & 35 & & & Algebra I & 25 & PREP & & 133 \\
\hline
\end{tabular}

Las Plumas High School

\section{1-2012 MASTER SCHEDULE}

Fall 11-12 


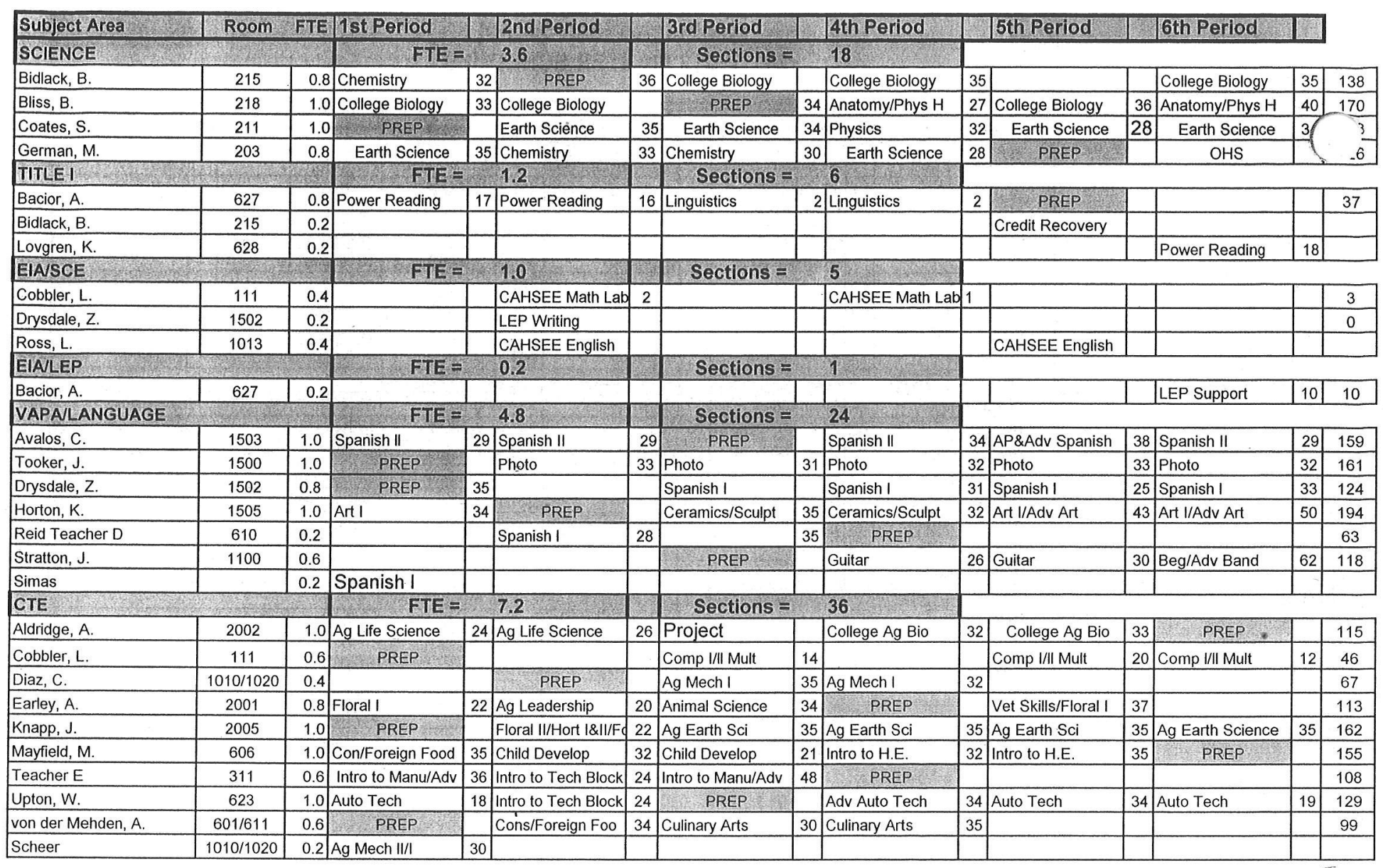




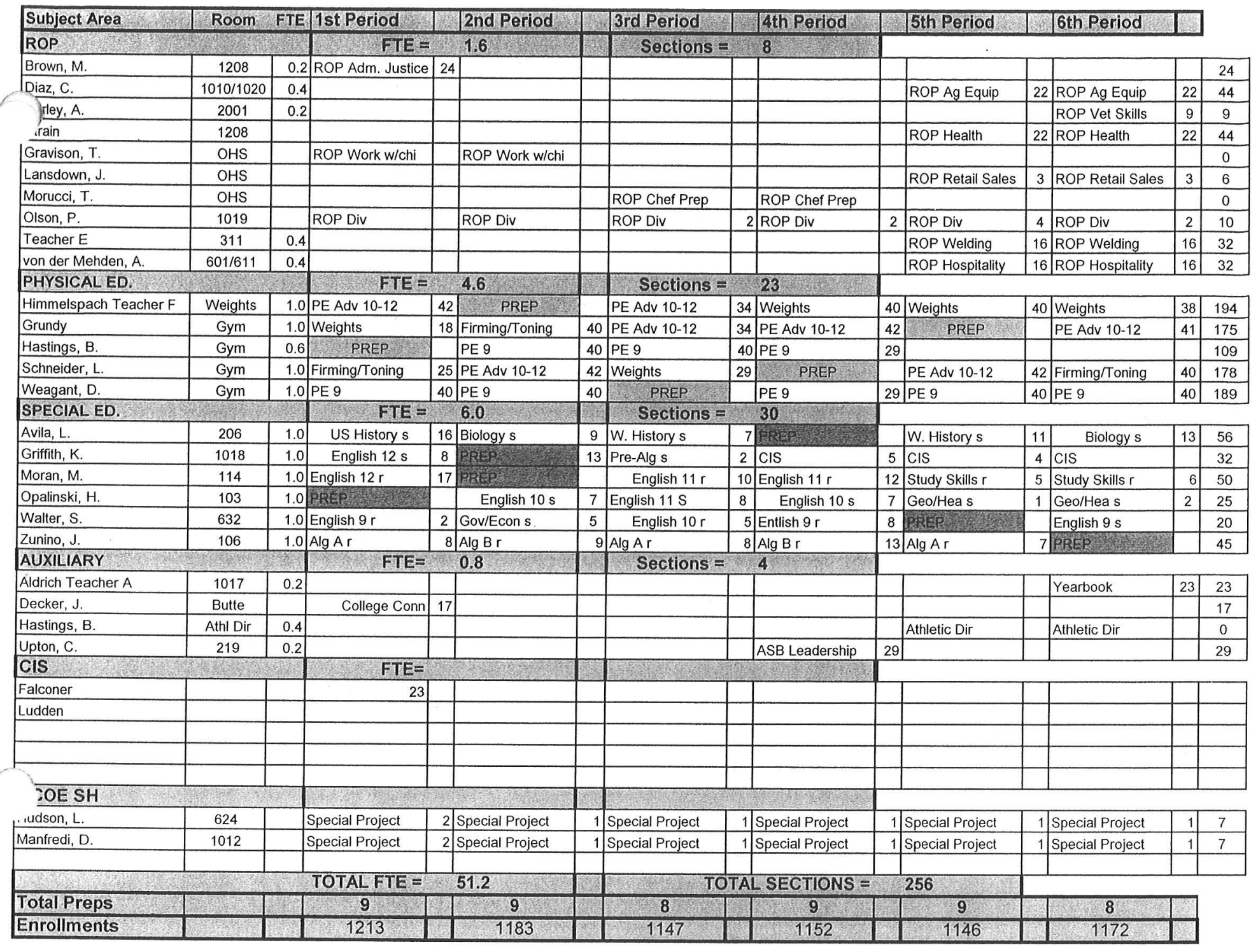



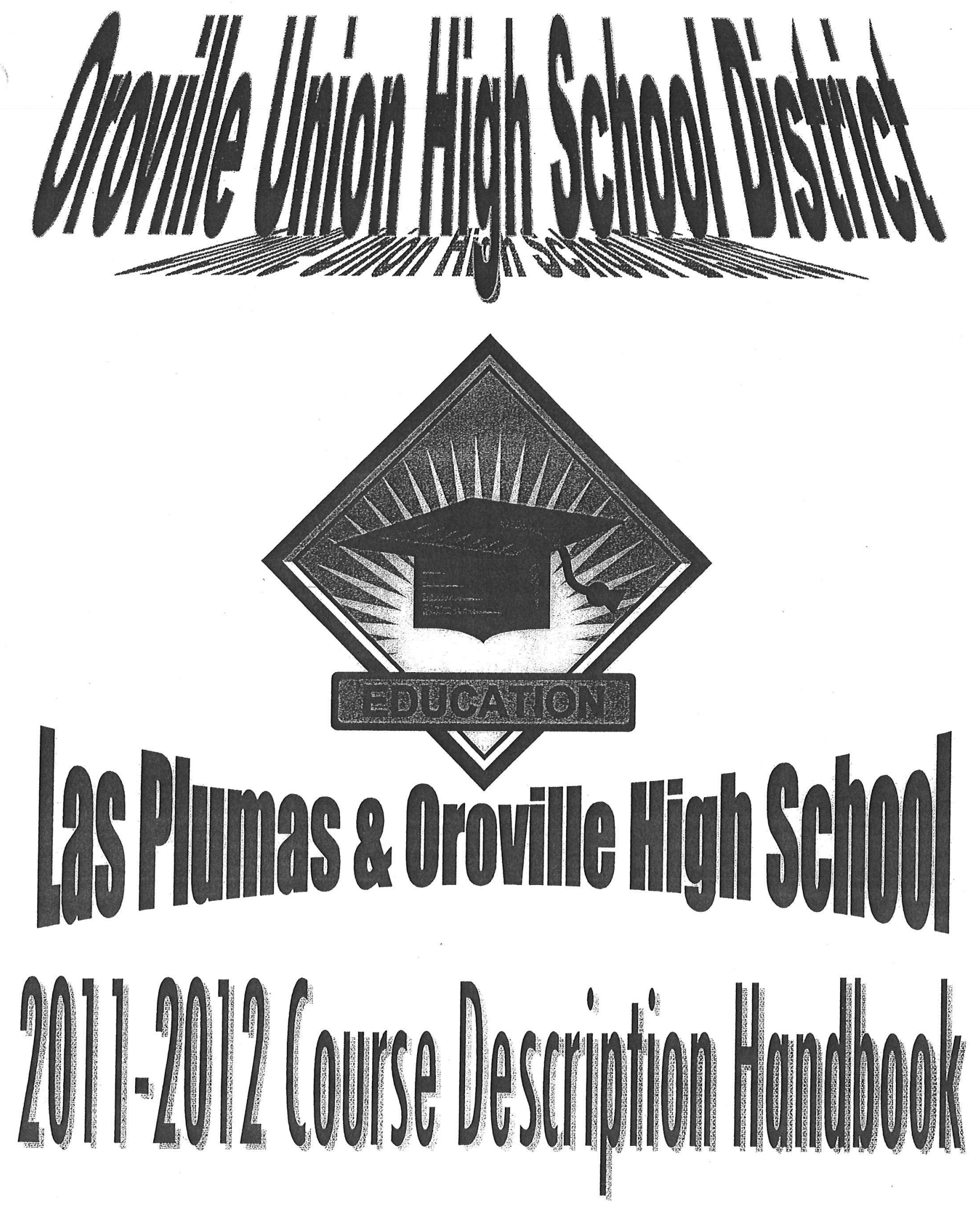


\section{COLLEGE ADMISSION REQUIREMENTS}

Students should contact their counselor at the earliest possible time to discuss college admissions requirements.

\section{BASIC COLLEGE REQUIREMENTS}

Three systems of higher education exist in California: the Community Colleges, the California State University schools and the University of California schools. To attend any of these schools requires careful preparation in high school. Following are the requirements for the three different systems.

\section{COMMUNITY COLLEGES}

Graduation from high school, a minimum age of 18 , or passing the CHSPE examination is the only requirement for admission. There are no subject or grade point average requirements. At the Community Colleges, one can earn a degree (A.A.) or (A.S.), undertake a transfer program, get vocational training in a Certificate Program, or improve basic academic skills.

\section{CSU SYSTEM}

To qualify for regular admission as a first-time freshman, one must graduate from high school, and complete with grades of $C$ or better a pattern of college preparatory subject requirements (see below). Student must submit scores from the SAT Reasoning or ACT.

\section{UC SYSTEM}

Admission to the University of California requires one to graduate from high school, complete the courses listed below with grades of $\mathrm{C}$ or better, and submit scores from the SAT Reasoning or ACT as well as two SAT Subject Tests. Starting with the class of 2012, UC's will no longer require the SAT Subject Tests.

\section{CSU AND UC SUBJECT REQUIREMENTS}

All applicants will be required to complete the same pattern of high school courses with $\mathrm{C}$ or better to be eligible for both CSU and UC systems. These courses are listed below:

English 4 years

Lab Science -2 Years (1Year Physical Science and 1Year Life Science)

Foreign Language -2 Years (Must be the same language for both years)

History/Social Science -2 Years

Mathematics - 3 Years (Algebra, Geometry, and Advanced Algebra)

Visual/Performing Arts - 1 Year

College-Prep Elective - 1 Year

\section{Non-Discrimination in District Programs and Activities}

The Oroville Union High School District Governing Board is committed to equal opportunity for all individuals in education. District programs and activities shall be free from discrimination based on gender, race, color, religion, ancestry, national origin, ethnic group, marital or parental status, physical or mental disability, sexual orientation or the perception of one or more of such characteristics. The Board shall promote programs which ensure that discriminatory practices are eliminated in all district activities.

Le mesa directiva del distrito escolar de Oroville Union High se compromete a proveer opportunidades iguales para todos los individos en la educacion. Los programas y actividades de este distrito seran libres de discriminacion basada en sexo, raza, color, religion, antepasados, nacionalidad, etnicidad, estado civil, paternidad o maternidad, discapacidad fisica o mental, orientacion sexual, o la percepcion de una o mas de estas caracteristicas. La falta de habilidades en el idioma ingles no sera una barrera para admicion y participacion en los programas y actividades del distrito.

Cov thawj tswj ntawm Oroville Union High School District Governing Board txaus siab muab kev vaj huam sib luag rau txhua tus nyob rau hauv kev kawm txuj. Huav pos tsev kawm ntawv yuav tsis cais los ntxub ib tus twg txawm nws yog pojniam txivneeg, haiv neeg, xim nqaij daim tawv, kev cia dab qhua, poj koob yawg koob, lub teb chaws nws tuaj, pab pawg, muaj txij nkawm, xiam hlwb los sis xiam oob khab, tus yam ntxwv thiab Iwm yam uas hais tsis txhua. Txawm tsis paub ntawv Askiv los yeej tsis txwv los muaj feem xyuam txog kev kawm txuj. 
ENGLISH

40 Credits Required

ENGLISH 9

LPHS-OHS - One Year Course

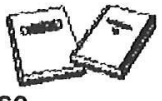

English 9 is a required course for all English proficient freshmen. The study of literature includes a basic survey of core literary works, extended reading and recreational reading. Students are introduced to various literary genres: short story, novel, poetry, mythology, essay and drama. Students give oral presentations and practice active listening strategies. Students use a variety of writing types for various purposes and audiences using the writing process. Writing assignments are based primarily on personal experience and on the study of literature, moving from basic sentence structure and paragraph writing to formal essays and research papers, using technology where appropriate.

\section{ENGLISH 9 HONORS}

OHS - One Year Course

English 9 Honors is an accelerated course that meets the graduation requirement for freshman English. A primary goal of this class is to prepare students for advanced placement coursework. The study of literature includes world literary works and extended reading. Students deepen their understanding of various literary genres through intensive study of short stories, novels, poetry, essays and drama. Students give oral presentations and practice active listening strategies. Students use a variety of writing types for various purposes and audiences using the writing process and technology when appropriate. Students respond to literature by writing narrative, descriptive and analytical essays and research papers. Interpretive essays and explications are emphasized.

\section{ELD-INTRODUCTION TO CONVERSATIONAL ENGLISH AND} CONTENT VOCABULARY

Grades: 9-12 OHS-One Year Course

This course is designed to provide students new to English with basic oral and aural competence in a wide variety of English language settings. Students will develop English receptive and productive skills as they master basic elements of the sound system and alphabet. Most coursework is centered on helping students to develop oral English skills that are immediately useful in school, classroom and community settings. An emphasis is placed on introducing a wide range of relevant content vocabulary words. Students also learn about academic culture related to school success.

\section{ELD-INTRODUCTION TO ENGLISH READING}

Grades: 9-12 OHS-One Year Course

This is a beginning English reading course for students whose first language is not English. Students will develop reading skills in four areas: word analysis, fluency and vocabulary, comprehension, and basic literary analysis and response. Students use sequential reading instructional materials at their level to establish a base for further content area and narrative reading tasks. Students develop a sight word vocabulary as well as receive explicit phonics and decoding skills instruction.

\section{ELD-INTRODUCTION TO ENGLISH GRAMMAR AND WRITING} Grades: 9-12 OHS-One Year Course

This course introduces students to foundational English language grammar and structure. Students will study basic syntactic elements of English (nouns, verbs, modifiers, etc.) along with phonemic and semantic aspects of the language. Word construction is also taught, as well as how to produce the four kinds of sentences in English (declarative, imperative, interrogative, and exclamatory). Students are expected to study and be able to identify all eight parts of speech. Writing skills that are taught include sentence expansion and writing forms (paragraphs, essay, descriptive, narrative, and first person). Students will learn specific skills for pre-writing, draft composition and editing using a process-writing format. Students also are responsible for learning the spelling of a list of commonly used English words.

\section{BEGINNING ENGLISH WRITING}

Grades: 9-12 LPHS-One Year Course

Beginning English Writing is a course designed for: students who

have delayed age or grade-level writing skills and/or English

Revised 1/2011
Language Learners performing at a beginning or early intermediate and below basic writing levels. Beginning English Writing is designed to instruct students in writing with a strong skills orientation. Students learn through direct instruction that spelling, punctuation, and grammar are essential to effective communication. This course is designed to take students from their own developmental levels to the stage of writing at which they can function independently with gradelevel materials.

\section{ELD-ADVANCED ENGLISH GRAMMAR AND WRITING Grades: 9-12 OHS-One Year Course}

Students in this course study advanced aspects of English language structure and writing with a focus on literacy tasks that students encounter in academic courses. Instruction is guided by discrete language skills from the district's ELD Skills Inventory and the California ELD Standards. Rigorous writing tasks are the framework for the exploration and practice of advanced grammar skills related to expository and narrative writing. This is a stand-alone course that is not linked to the student's grade-appropriate English language arts class.

\section{ELD-ENGLISH 9}

LPHS- One Year Course

English 9-ELD meets the English 9 requirement for all beginning, non-native speakers of English. Students will become more proficient in the English language while being exposed to the freshman level of core curriculum through the teacher's use of SDAIE strategies and modified instruction.

\section{POWER READING (ELECTIVE CREDIT)}

\section{Grades: 9-10 LPHS-OHS - One Year Course}

Power Reading is a course designed primarily for ninth grade students who need further reading instruction. It provides both group and independent level reading activities. It emphasizes the improvement of vocabulary; reading comprehension; reading rate fluency, flexibility, and purpose; study skills; reading in the content areas; oral reading; and/or personal reading.

\section{CAHSEE ENGLISH LAB (ELECTIVE CREDIT) \\ Grades: 11-12 LPHS-OHS - One Year Course}

CAHSEE English Lab is a course designed primarily for students requiring further reading support beyond Power Reading or Linguistics. While its primary focus is to improve reading skills, fluency and rate, it also develops students' overall academic skills including note-taking, paragraph building supporting expository and analytical writing, work place writing, content area writing, time management, and test taking strategies. In order to improve academic skills, these students need the time, resources and support which this course provides.

\section{LINGUISTICS (ELECTIVE CREDIT)}

Grades: 9-12 - LPHS - One Year Course

Linguistics is a course designed for: (1) students who have delayed age or grade-level literacy skills; (2) English Language Learners; (3) students with learning disabilities that affect the acquisition of reading, writing, and/or spelling. Linguistics is designed to teach students all the essential skills of reading, language comprehension, and composition in an accelerated, systematic, cumulative, sequential curriculum. This course is designed to take students from their own developmental levels to the stage of literacy at which they can begin to function independently with grade-level materials.

\section{ENGLISH 10}

\section{LPHS-OHS - One Year Course}

English 10 is a required course for all English proficient sophomore students. The study of literature includes world literary works, extended reading and recreational reading. Students deepen their understanding of various literary genres, including short story, novel, poetry, essay and drama. Students give oral presentations and practice active listening strategies. Students use a variety of writing types for various purposes and audiences using the writing process. Students respond to literature by writing narrative, descriptive and analytical paragraphs, essays and research papers, using technology when appropriate. 


\section{ENGLISH 10 HONORS}

LPHS-OHS - One Year Course

English 10-Honors is an accelerated course that meets the graduation requirement for sophomore English. A primary goal of this class is to prepare students for advanced placement coursework. The study of literature includes world literary works and extended reading. Students deepen their understanding of various literary genres through intensive study of short stories, novels, poetry, essays and drama. Students give oral presentations and practice active listening strategies. Students use a variety of writing types for various purposes and audiences using the writing process using technology when appropriate. Students respond to literature by writing narrative, descriptive and analytical essays and research papers. Interpretive essays and explications are emphasized.

\section{ELD-ENGLISH 10}

\section{LPHS-One Year Course}

English 10-ELD meets the English 10 requirements for all intermediate, non-native speakers of English. Students will become more proficient in the English language while being exposed to the sophomore level of core curriculum through the teacher's use of SDAIE strategies and modified instruction.

\section{ENGLISH 11 \\ LPHS-OHS - One Year Course}

English 11 is a survey course that focuses on great American authors. There will be a concentrated examination of each author's style, form, and philosophy, place in history, and perceptions of human values and struggles. Through these great writers and thinkers, students will gain a greater understanding of the American journey. Students will demonstrate an understanding of each author's themes and writing style.

\section{ELD-ENGLISH 11}

\section{LPHS-One Year Course}

English 11-ELD meets the English 11 requirement for all advanced non-native speakers of English. Students will become more proficient in the English language while being exposed to the junior level of core curriculum through the teacher's use of SDAIE strategies and modified instruction.

\section{ENGLISH 12}

\section{LPHS-One Year Course}

OHS (Special Education Students Only)

English 12 is a survey course that focuses on great authors. There will be a concentrated examination of each author's style, form, and philosophy, place in history, and perceptions of human values and struggles. Through these great writers and thinkers, students will gain a greater understanding of how the works are both products of their times and expressions of universal, timeless values. Students will demonstrate an under-standing of each author's themes and writing style.

\section{ELD-ENGLISH 12}

\section{LPHS-One Year Course}

English 12-ELD meets the English 12 requirement for all advanced, non-native speakers of English. Students will become more proficient in the English language while being exposed to the senior level of core curriculum through the teacher's use of SDAIE strategies and modified instruction.

\section{ADVANCED PLACEMENT ENGLISH LANGUAGE/COMPOSITION}

Grade: 11-12 LPHS, 11- OHS - One Year Course

Prerequisite: Application and/or teacher approval.

A.P. English Language/Composition is an accelerated course. The primary goals of this class are to prepare students for college level work and the opportunity of earning college credit by passing the Advanced Placement examination. Sponsored by the College Board, the AP Program is based on the premise that college-level materia can be taught successfully to able and well-prepared secondary students. The study of literature includes world literary works and extended reading. Students deepen their understanding of various literary genres through intensive study of short stories, novels, poetry, essays and drama. Students give oral presentations and practice active listening strategies. Students use a variety of writing types for various purposes and audiences using the writing process and using technology when appropriate. Students respond to literature by writing narrative, descriptive and analytical essays and research papers. Main emphasis is on style analysis, argumentation and rhetorical strategies.

\section{ADVANCED PLACEMENT ENGLISH \\ LITERATURE AND COMPOSITION}

Grade: 11-12 LPHS, 12 -OHS - One Year Course

Prerequisite: Application and/or teacher approval.

A.P. English Literature and Composition is an accelerated. The primary goals of this class are to prepare students for college-level work and the opportunity of earning college credit by passing the Advanced Placement examination. Sponsored by the College Board, the AP Program is based on the premise that college-level material can be taught successfully to able and well-prepared secondary school students. The study of literature includes world literary works and extended reading. Students deepen their understanding of various literary genres through intensive study of short stories, novels, poetry, essays and drama. Students give oral presenfations and practice active listening strategies. Students use a variety of writing types for various purposes and audiences using the writing process and using technology when appropriate. Students respond to literature by writing narrative, descriptive and analytical essays and research papers. Interpretive essays and explications are emphasized.

\section{JOURNALISM}

\section{Grades: 10-12 - LPHS One Year Course}

Sophomores receive 10 Elective Credits. Juniors and Seniors receive 5 English Credits and 5 Elective Credits

Prerequisite: Must fill out application.

This course provides training in journalistic style writing, editing, interviewing and newspaper production, as well as an understanding of press law and ethical issues, through a lab method of instruction. Students produce a monthly school newspaper; learn the skills and standards of professional journalism and accurate reporting; strengthen writing skills; improve listening and speaking skills through interviews, lecture and discussions; develop computer skills through word processing, desktop publishing and Internet research; and understand the rights and responsibilities of journalists. In addition, students create a portfolio of their work and explore the career options available in the field of journalism. Interested students should demonstrate ability in writing, art, word processing, photography, layout (Pagemaker), be self-motivated, and be able to meet deadlines. Students are required to sell ads to pay for the publication of the newspaper. Class is subject to enrollment.

\section{$12^{\text {TH }}$ GRADE ENGLISH COURSE OFFERINGS AT Oroville High School Only}

\section{BRITISH LITERATURE - One Semester Course}

British Literature provides an in-depth examination of the authors, literary works, and historical periods of Great Britain. There will be a concentrated examination of authors' styles, forms, and philosophies, places in history, and perceptions of human values and struggles. Through the great writers and thinkers, students will gain a greater understanding of how the works are both products of their times and expressions of universal, timeless values. Students will demonstrate an understanding of different themes and writing styles employed by noteworthy authors.

FEAR \& TREMBLING (CLASSIC \& NEO-GOTHIC LITERATURE) One Semester Course

Fear and Trembling is an investigative and reflective celebration of the literature of the supernatural. Through the study of novels, short stories and films, the student will experience and enjoy the shudders of terror delivered by the otherworldly genre since the mid-18th century. The course will deliver a delectably macabre feast of ghosts, ghouls, haunted castles, decaying graveyards, crumbling churches, and things that go bump in the night for those with an appetite for fear and trembling. An additional emphasis will be on the dark side of human nature that is both attracted to and repulsed by evil, resulting in unpredictable and sometimes nightmarish mayhem that must ultimately be vanquished by agents of goodness. 
HEROES JOURNEY (GILGAMESH TO SKYWALKER)

\section{One Semester Course}

Myths and legends telling of journeys and quests are among the world's oldest stories. From earliest times and in most cultures, heroes left the safety of their known worlds on seemingly impossible tasks. Some were physical adventures; others were spiritual quests; all dealt with the universal themes of the triumph of courage over adversity, virtue over evil. Today, many of the stories we read and films we enjoy are a continuation of the Hero's Journey pattern. This class will explore the connection between ancient and modern quest stories. Students will make comparisons between the fictional journeys and the challenges facing people in the real world. They can learn from the experiences of others while keeping alive a sense of adventure and wonder.

\section{BRIDGES TO THE FUTURE- One Semester Course}

This class is designed for students who like to delve into big ideas: What would happen if human beings could change space and time? What if parallel universes really did exist? What if there is alien intelligence? What if human beings could achieve, through evolution or technology, a whole spectrum of mental powers? What if part or all of humanity could become immortal? The concepts in this course test our humanity against the challenges of different realities.

\section{TOUGH GUYS AND MEAN STREETS LITERATURE- One} Semester Course

Tough Guys and Mean Streets is designed as a celebration of one of the most exciting schools of writing during the $20^{\text {th }}$ century. The hardboiled genre, once viewed by many critics as a mere sub current to mainstream American literature, has, in recent years become widely accepted for its tremendous and enduring influence on the development of American and European letters. Paced with express train velocity, and crackling with lean and muscular prose, the tough guy/hard-boiled detective story pits the lone hero against brutal urban landscapes seething with criminal conduct, no-holds-barred violence, and most crucially, moral ambiguities. Standing shoulder to shoulder with the vicious underworld and antagonistic police, the tough guy hero/heroine is a modern day extension of the Western hero, whose guns blaze and spit the same righteous punishment once meted out by the likes of Wild Bill Hickok, Bat Masterson and Wyatt Earp. The odds for survival, however, are weighted heavily against him/her. The hours are endless and he/she drives a beat-up sedan; but, most importantly, his/her code is honor and his/her courage drives the carriage of justice to safety.

LITERATURE OF CONTROVERSY (PUBLIC SPEAKING) One Year Course - Meets UC/CSU "B" Requirement

Butte College $2+2$ Credit

Prerequisite: Application and/or teacher approval.

This is a project-based course that will give students opportunities for reading fiction (The Catcher in The Rye, The Things They Carried, and The Kite Runner) and non-fiction. Students will give informative, impromptu and persuasive speeches, and develop skills in oral presentations. First quarter will provide students with many activities designed to help achieve confidence in oral presentations. Second quarter will focus on techniques of rhetoric that will contribute to effective communication. The second semester will continue to be a project-based course that will give students an opportunity for reading fiction and non-fiction. The semester will conclude with students orchestrating a multi-media presentation on a target work of literature.

\section{SHAKESPEARE FROM PAGE TO STAGE}

One Semester Course

Shakespeare: From Page to Stage is a class for students, college bound or not, to explore the text of Shakespeare's work as it relates to their lives and in performance. The course focuses on reading, writing, interpretation, and language. Students use discussion groups, writing for a variety of audiences, performance of scenes with differing interpretations, compare characters, themes and plots. Students read at least three plays, whether across genre or within one area or theme. They gain a background in interpreting, appreciating and staging dramatic choices.

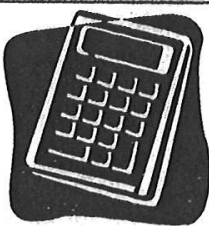

ALL INCOMING FRESHMEN MUST SHOW PROFICIENCY TO BE PLACED IN THEIR MATH CLASS. CONSIDERATION FOR PLACEMENT INCLUDES: 1 . CST SCORES OF PROFICIENT IN PRIOR CLASS, 2. DISTRICT PLACEMENT TEST SCORES, 3. TEACHER RECOMMENDATION.

\section{CAHSEE MATH LAB (ELECTIVE CREDIT)}

\section{Grades: 11-12 - LPHS-OHS - One Year Course}

Math Lab is designed for students that have failed, or are in danger of failing the California High School Exit Exam. The Exit Exam tests students on 6th grade, 7th grade, and some Algebra standards. Students will focus on the mathematics standards that they have not yet mastered. The course is designed to increase the application of mathematical skills necessary for a student's daily life.

\section{ALGEBRA LAB (ELECTIVE CREDIT)}

Grades: 10-12 - OHS - One Year Course

Algebra $L a b$ is designed for students that have passed the mathematics portion of the California High School Exit Exam but have not met the district's Algebra graduation requirement. Students will focus on the mathematics standards that they have not yet mastered. The course is designed to increase the application of mathematical skills necessary for a student's daily life.

\section{FOUNDATIONS OF ALGEBRA}

Grades: 9-10 - OHS (Special Education Students Only) - One Year Course

Students master the four arithmetic operations with whole numbers, positive fractions, positive decimals, and positive and negative integers; they accurately compute and solve problems. They apply their knowledge to statistics and probability. Students understand the concepts of mean, median, and mode of data sets and how to calculate the range. They analyze data and sampling processes for possible bias and misleading conclusions; they use addition and multiplication of fractions routinely to calculate the probabilities for compound events. Students conceptually understand and work with ratios and proportions; they compute percentages (e.g., tax, tips, interest). Students know about pi and the formulas for the circumference and area of a circle. They use letters for numbers in formulas involving geometric shapes and in ratios to represent an unknown part of an expression. They solve one-step linear equations.

\section{PRE-ALGEBRA}

Grades: 9 -10 - One Year Course

LPHS-OHS (Special Education Students Only) Note: Sharyl Backues said a district wide pre-algebra program is on the way per Corey. Not sure if we should delete the statement spec. ed students only)

Students are adept at manipulating numbers and equations and understand the general principles at work. Students understand and use factoring of numerators and denominators and properties of exponents. They know the Pythagorean Theorem and solve problems in which they compute the length of an unknown side. Students know how to compute the surface area and volume of basic three-dimensional objects and understand how area and volume change with a change in scale. Students make conversions between different units of measurement. They know and use different representations of fractional numbers (fractions, decimals, and percents) and are proficient at changing from one to another. They increase their facility with ratio and proportion, compute percents of increase and decrease, and compute simple and compound interest. They graph linear functions and understand the idea of slope and its relation to ratio. 
ALGEBRA A

Grades: 9-11 - LPHS and OHS - One Year Course

Prerequisite: Enrollment requires teacher recommendation

based on final second semester grade.

Algebra A is a course that will prepare students to take the Algebra B (or possibly the Algebra I) course. It is designed for students who require intense remediation in order to successfully complete the Algebra course requirements. Algebra A includes the topics taught in the first semester of Algebra I and provides remediation in the prerequisite (arithmetic) skills required for success in an algebra course. Enrollment requires teacher recommendation.

\section{ALGEBRA B}

Grades: 9-12 - LPHS - One Year Course

Prerequisite: Grade of C- or better in Algebra A and teacher recommendation based on final second semester grade.

Algebra B is a course that will meet the district's Algebra graduation requirement and prepares students for the CAHSEE. This course includes topics taught in the second semester of Algebra I and provides remediation as needed. Enrollment requires teacher recommendation.

\section{ALGEBRA I}

\section{Grades: 9-12 - LPHS-OHS - One Year Course}

Algebra $I$ is a course that will meet the district's algebra graduation requirement and prepares students for the CAHSEE. Students should have a solid background in arithmetic, including fractions, decimals, and negative numbers. Areas of emphasis in Algebra I include deeper understanding of rational numbers, solving equations and inequalities, linear and quadratic functions and their graphs, factoring polynomials, and rational expressions.

\section{BRIDGES TO GEOMETRY}

Grades: 9 -12-OHS - One Year Course

Prerequisite: Completion of a full year of Algebra 1.

Bridges to Geometry is a course designed for students who have completed Algebra. It is a progressive step between Algebra and Geometry. The skills taught will reinforce Algebra standards and present selected geometry standards, as covered in the Integrated Math I CST exam. Students will identify and use the properties of subsets of integers and rational, irrational and real numbers. Students will also learn to use properties of the number system to judge the validity of results, to justify each step of a procedure and to prove or disprove statements.

\section{GEOMETRY A}

Grades: 10-12 - LPHS - One Year Course

Prerequisite: Grade of "C-" or better in Algebra I or Algebra B and/or teacher recommendation made after 2 nd semester grades are posted.

Geometry A is designed to meet the needs of students who do not yet have the skills to complete geometry in one year. These skills will be taught and reinforced in this course as the geometry concepts are introduced. The course will cover the $1^{\text {st }}$ semester content of geometry over the course of one year. Major emphasis is placed on gaining skill in geometric proof as a means to develop the logic required for deductive reasoning in life.

\section{GEOMETRY}

Grades: 9-12 - LPHS-OHS - One Year Course

Prerequisite: Grade of "C-" or better in Algebra I, Algebra B, Bridges to Geometry or Geometry A and/or teacher recommendation made after 2 nd semester grades are posted. Geometry is a college preparatory course designed to present the essential geometric facts. The course relates these facts to the arts, trades, and sciences. Major emphasis is placed on developing a mode of geometric proof as an example of a definite system of logic basic to all deductive thinking in life.

\section{ADVANCED ALGEBRA}

Grades: 9-12 - LPHS-OHS - One Year Course

Prerequisite: Grade of "C-" or better in Geometry and/or teacher recommendation made after 2 nd semester grades are posted.

Advanced Algebra is a course designed to encourage interest and proficiency in basics and advanced algebra, such as quadratic equations, the imaginary number system, logarithms, and matrices. This course will satisfy minimum college entrance requirements in the fields of mathematics, science, engineering, and architecture.

\section{PRE CALCULUS}

Grades: 10-12 - LPHS-OHS - One Year Course

Prerequisite: Grade of "C-" or better in Advanced Algebra and/or teacher recommendation made after 2 nd semester grades are posted.

Pre Calculus is a course designed to prepare students for the first course of college calculus. Intermediate algebra, analytic geometry, and trigonometry are integrated with other important topics emphasizing functions, limits, sequences, and derivatives. The presentations of these topics develop an intuitive base and tools for the study of more advanced mathematics.

\section{AP CALCULUS}

Grades: 11-12 - LPHS-OHS - One Year Course - Prerequisite: Grade of "C." of better in Pre Calculu's and/or teacher recommendation based on final second semester grade.

The advanced placement (AP) calculus course is taught with the same level of depth and rigor as are entry-level college and university calculus courses. It will prepare students for success on the College Board Advanced Placement Calculus AB Examination. The course presents elements of analytic geometry, methods, and application of differentiation and integration. Calculators are required with $\log$ and trig functions; no instruction is given with log and trig functions. In the spring, students are encouraged to take the College Board Advanced Placement Mathematics Examination, Calculus $A B$, which, if passed with a score of 3 or higher (according to a college' or university's policy), allows them to receive college credit in mathematics. The test is not a requirement of the course.

Other Mathematics options

- MECHANICAL DRAFTING 1 A/B

- R.O.P. RETAILING

\section{EARTH SCIENCE}

Grades: 9-10 - LPHS-OHS - One Year Course

This course offers a foundation in the earth sciences and the scientific method. The course provides students an opportunity to learn science by receiving direct instruction, reading textbooks and supplementary materials, using technology to acquire and process information, solving standards-based problems, performing laboratory investigations and experiments. The major units of study include: solar system; stars, galaxies, and the universe; dynamic earth processes; energy in the earth system; heating of earth's surface/atmosphere; climate; biogeochemical cycles; structure and composition of the atmosphere; California geology; scientific method statistics, data analysis and probability. This course meets the " $G$ " requirements for $\mathrm{CSU}$.

\section{AGRICULTURE EARTH SCIENCE}

Grades: 9-10 (11-12 grades need instructor approval)

This integrated academic-vocational course is recommended for all freshman students interested in exploring science related careers in agriculture and applying their classroom learning to real life and workplace situations. It offers a foundation in earth science, the California agriculture basic core and preparation for the STAR Earth Science test. The major units of study include space, solar system and the universe, earth processes, weather, atmosphere, climate, California geology, energy in the earth system, biogeochemical cycles, scientific method, careers in agriculture, FFA leadership development, SAE projects and record keeping. This course meets the " $G$ " requirements for entrance into the California State University systems. 
AGRICULTURAL LIFE SCIENCE I

\section{Grades: 9-11 - LPHS- One Year Course}

This introductory course is recommended for all freshmen Interested in agriculture. It covers the fundamentals of plant and animal science and gives training in leadership. Production and processing of agricultural products and related services and businesses are studied. Students will develop a foundation in science while acquiring a broad understanding of the major facets of modern agriculture. It offers a foundation in the life sciences, the California agriculture basic core, and the scientific method. It also provides opportunities to participate in laboratory experiments, Supervised Agricultural Experience projects, and FFA leadership activities. This course meets the minimum science graduation requirement of one year of life science and prepares the students for other science and agricultural courses offered.

\section{GENERAL BIOLOGY}

Grades: 10-12 - LPHS-OHS - One Year Course

Prerequisite: Must have taken Earth Science.

A non-college preparatory biology course designed for students without a strong science background. This course introduces major biological concepts including cell biology, genetics, ecology, evolution, and physiology. Emphasis is placed on laboratory investigation including optional dissection to reinforce understanding and provide practical application of biological principles. This class satisfies the life science core curriculum requirement for graduation.

\section{COLLEGE PREPARATORY AGRICULTURAL BIOLOGY}

Grades: 9-12 - LPHS - One Year Course Prerequisite: Students must be enrolled in Algebra A or higher (exceptions must be made by approval of the instructor)

Agricultural Biology is a one-year laboratory science course designed for the college-bound student with career interests in agriculture. Using agriculture as the learning vehicle, the course emphasizes the biological principles and central concepts. The course centers on an extensive laboratory component to connect the principles of life science with agricultural applications, other curricular areas and other scientific disciplines. This course meets the Life Science laboratory " $D$ " requirements for entrance into the University of California and California State University systems.

\section{COLLEGE PREPARATORY BIOLOGY}

Grades: $10-12\left(9^{\text {th }}\right.$ grade placed in Geometry or higher are eligible) LPHS-OHS - One Year Course

This course emphasizes cell biology, genetics, ecology, evolution, and human physiology. Emphasis is placed on laboratory investigation including optional dissection to reinforce understanding and provide practical application of biological principles.

\section{AP BIOLOGY}

Grades: 10-12 - OHS - One Year Course

Prerequisite: Grade of "B" or better in College Prep Biology or instructor approval. Students who are taking Chemistry concurrently or have had Chemistry will be given preference in case of "over enrollment".

The Advanced Placement Biology course is designed to be the equivalent of a college introductory biology course usually taken by biology majors during their first year. AP Biology is an in-depth survey of molecular, cellular, organismal, and population biology. Students who pass the AP Biology exam receive six units of credit at most colleges, including the University of California.

\section{CHEMISTRY}

\section{Grades: 10-12 - LPHS-OHS - One Year Course}

Prerequisite: One Year Course of laboratory science. Students enrolled at OHS must be concurrently enrolled or have completed Advanced Algebra.

Chemistry is an inquiry into the composition of and interactions between substances. It is designed to acquaint the student with the laws of the physical environment through the use of laboratory experiments. Chemistry includes the study of characteristics of chemical reactions, chemical periodicity, and chemical bonding in solids, liquids and gases. The chemistry laboratory is the basis from which the advanced sciences are developed. This course meets the lab science entrance requirement into the California State University and University of California system.

\section{PHYSICS}

Grades: 10-12 - LPHS-OHS - One Year Course - Prerequisite:

One Year Course of laboratory science. Students must be concurrently enrolled or have completed Advanced Algebra.

Physics is quantitative study which includes energy, mechanics, wave motion, light, sound, heat and electricity. It is designed to acquaint the student with the laws of the physical environment through the use of laboratory experiments. Applications to modern Physics are emphasized. Physics is an essential course for those students considering technical or engineering careers. This course meets the lab science entrance requirement into the California State University and University of California system.

PHYSICS (B) AP

Grades: 10-12 - OHS - One Year Course

Prerequisite: One Year Course of laboratory science. Students must : be concurrently enrolled or have completed Advanced Algebra.

AP Physics is a college-level course, offering students an enriching scientific experience in the fundamentals of physics, with the challenge and breadth of a college pace. The course is intended to prepare students for the Advanced Placement exam in physics through an emphasis on the scientific method and laboratory experiences. AP Physics is an essential course for students considering scientific or technical careers.

\section{ANATOMY AND PHYSIOLOGY}

Grades: 10-12 - LPHS-OHS - One Year Course - Prerequisite: Grade of "C" or better in College Prep Biology or instructor approval. Students who are taking Chemistry concurrently or have had Chemistry will be given preference in case of "over enrollment".

This course will provide students with a foundation of knowledge regarding the structures and functions of the systems of the human body. Emphasis will be placed on laboratory and clinical case studies to illustrate anatomical and physiological concepts.

\section{HONORS ANATOMY AND PHYSIOLOGY}

Grades: 11-12 - LPHS - One Year Course - Prerequisite:

Grade of "B" or better in College Prep Biology, "C" or better in Chemistry, or Instructor approval. Students must be concurrently enrolled or have completed Advanced Algebra. This course is intended for college bound students who are interested in a medical or science related field. It will provide students with a foundation of knowledge regarding the structures and functions of the systems of the human body. Emphasis will be placed on laboratory and clinical case studies to illustrate anatomical and physiological concepts. A research and practical application component are included.

ANIMAL SCIENCE (Science or Vocational Credit)

Grades: 11-12 - LPHS - One Year Course

Prerequisite: Ag Science or Agricultural Earth Science and/or pre-approval by instructor

Animal science is a one year advanced agricultural science course that will provide advanced understanding of livestock agriculture and issues affecting society, animal welfare, and production systems. Animal nutrition, anatomy and physiology, health, reproduction, genetics, and management through evaluation and selection will be stressed. Biotechnology and emerging technologies are creating excitement in agricultural industry. This course allows students to be actively involved in the learning process. Note: This course has been approved for UC/CSU elective credit. 
SOCIAL SCIENCE 35 Qredits

\section{GEOGRAPHY}

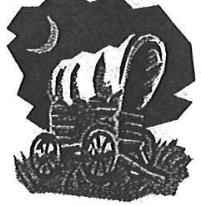

Grade: 9 - LPHS-OHS Semester Course

Students in grade nine must realize one of the realities of the contemporary world is the increasing influence of other nations in the daily life of the American citizen. This course in 20th Century Geography and Technology is designed to provide an understanding of the distribution and characteristics of the world's major cultures and of the dynamics of human migration and cultural diffusion. Emphasis will be placed on the cultures of the world and a technology based student presentation. Ninth grade geography is a foundation course to World History, United States History, Government, and Economics. Study skills are incorporated in this class.

\section{WORLD HISTORY - THE MODERN WORLD}

Grade: 10 - LPHS-OHS - One Year Course

Students in grade ten study major turning points that shaped the modern world, from the late 18th century through the present, including the cause and course of the two world wars. They trace the rise of democratic ideas and develop an understanding of the historical roots of current world issues, especially as they pertain to international relations. They extrapolate from the American experience that democratic ideals are often achieved at a high price, remain vulnerable and are not practiced everywhere in the world. Students develop an understanding of current world issues and relate them to their historical, geographic, political, economic, and cultural contexts. Students consider multiple accounts of events in order to understand international relations from a variety of perspectives.

\section{HONORS WORLD HISTORY - THE MODERN WORLD}

Grade: 10 - LPHS - One Year Course

Students must complete all of the assignments for World History and two additional research assignments determined by the student and the instructor.

\section{UNITED STATES HISTORY: CONTINUITY AND CHANGE IN THE 20TH CENTURY}

Grade: 11 - LPHS-OHS - One Year Course

Students in grade eleven study the major turning points in American history in the 20th century. Following a review of the nation's beginnings and the impact of the Enlightenment on United States' democratic ideals, students build upon the tenth grade study of global industrialization to understand the emergence and impact of new technology and a corporate economy, including the social and cultural effects. They trace the change in the ethnic composition of American society, the movement towards equal rights for racial minorities and women, and the role of the United States as a major world power. An emphasis is placed on the expanding role of the federal government and federal courts as well as the continuing tension between the individual and the state. Students consider the major social problems of our time and trace their causes in historical events. They learn that the United States has served as a model for other nations and that the rights and freedoms we enjoy are not accidents, but the results of a defined set of political principles that are not always basic to citizens of other countries. Students understand that our rights under the United States Constitution comprise a precious inheritance that depends on an educated citizenry for their preservation and protection.

\section{A.P. UNITED STATES HISTORY}

GRADE: 11 - LPHS-OHS - One Year Course

The Advanced Placement Program in United States History is designed to provide students with the analytic skills and factual knowledge necessary to deal critically with the problems and materials in United States history. The program prepares students for intermediate and advanced college courses by making demands upon them equivalent to those made by full-year introductory college

Revised 1/2011 courses. This course meets and exceeds the California standards in that there is intensive study on the pre-Civil War era of American history. This course will begin with the discovery of the New World. Students should learn to assess historical materials -- their relevance to a given interpretive problem, their reliability, and presented in historical scholarship. An Advanced Placement United States History course will develop the skills necessary to arrive at conclusions on the basis of an informed judgment and to present reasons and evidence clearly and persuasively in essay format. Students taking the Advanced Placement course are expected but not required to take the Advanced Placement test.

\section{GOVERNMENT - PRINCIPLES OF AMERICAN DEMOCRACY \\ Grade: 12 - LPHS-OHS - One Semester Course}

Students in grade twelve pursue a deeper understanding of the institutions of American government. They compare systems of government in the world today and analyze the life and changing interpretations of the Constitution, the Bill of Rights, and the current state of the legislative, executive, and judiciary branches of government. An emphasis is placed on analyzing the relationships among federal, state, and local governments, with particular attention paid to important historical documents such as The Federalist Papers. These standards represent the culmination of civic literacy as students prepare to vote, participate in community activities, and assume the responsibilities of citizenship.

\section{ADVANCED PLACEMENT GOVERNMENT AND POLITICS \\ Grade: 12 - LPHS-OHS - One Semester Course}

Prerequisite: Teacher Approval

AP U.S. Government and Politics studies the structure and operations of the U.S. government and the behavior of the electorate and politicians. Students will gain the analytic perspective necessary to critically evaluate political data, hypotheses, concepts, opinions, and processes. Along the way, they will learn how to gather data about political behavior and develop their own theoretical analysis of American politics. They will also build the skills they need to examine general propositions about government and politics, and to analyze the specific relationships between political, social, and economic institutions. The equivalent of an introductory college-level course, AP U.S. Government and Politics prepares students for the AP Exam and for further study in political science, law, education, business and history. Students are encouraged but not required to take the AP Exam.

\section{PRINCIPLES OF ECONOMICS}

\section{Grade: 12 - LPHS-OHS - One Semester Course}

In addition to studying government in grade twelve, students will also master fundamental economic concepts, applying the tools (graphs, statistics, and equations) from other subject areas to the understanding of operations and institutions of economic systems. Studied in a historic context are the basic economic principles of micro and macroeconomics, international economics, comparative economics system measurement, and methods.

\section{AP MICROECONOMICS}

\section{Grade: 12-LPHS-One Semester Course}

This course is an introduction to microeconomics. Microeconomics introduces students to the cost benefit analysis that is in the economic way of thinking. This analysis is used to understand smaller segments of the economy-specifically, consumers and producers-as they interact in output markets and to understand the government's impact on these specific economic units. Note: This course has been approved for UC/CSU credit.

\section{AP Macroeconomics}

Grade: 12-LPHS-1 year course

The purpose of an AP course in macroeconomics is to give students a thorough understanding of the principles of economics that apply to an economic system as a whole. Such a course places particular emphasis on the study of national income and price-level determination and also develops students' familiarity with economic performance measures, the financial sector, stabilization policies, economic growth and international economics. Pending OUHSD Board Approval 


\section{PHYSICAL EDUCATION \\ 20 Credits Required}

PHYSICAL EDUCATION

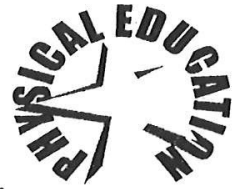

Grades: 9 - LPHS-OHS - One Year Course

This is a foundation program required of all students. The students are exposed to most of the activities that are offered in school. Emphasis is based on safety, big muscle activities that develop endurance, strength, agility, flexibility and coordination.

\section{ADVANCED PHYSICAL EDUCATION}

Grades: 10-12 - LPHS-OHS - One Year Course

Students will be involved in a program with wider variety of carryover, recreational skills as well as opportunities to continue in some competitive group activities. Emphasis will be based on safety, understanding the significance of physical fitness and conditioning as a life time pursuit.

\section{WEIGHTS AND CONDITIONING}

Grades: 10-12 - LPHS-OHS - One Year Course

Prerequisite: Sophomores must pass $9^{\text {th }}$ grade PE with a " $\mathrm{C}$ " or better

Weights and Conditioning involves developing muscular strength and endurance through weight training and cardiovascular conditioning. The students will learn to identify muscle groups and what training techniques develop them. They will also learn several types of programs suitable for various sports and lifestyles.

\section{NAVAL SCIENCE I (JROTC)}

\section{Grades: 9-12 - LPHS - One Year Course}

The purpose of this course is to introduce students to the precepts of citizenship, the elements of leadership, and the value of scholarship in attaining life goals. This course is also designed to engender a sound appreciation for the heritage and traditions of America, with recognition that the role of sea power will be important in America's future, and develop in each cadet a growing sense of pride in his//her organizational, associates, and self. Another goal in this course is to promote habits of orderliness and precision; familiarize the student with the concept of leadership and individual discipline; and introduces military courtesy, customers, and traditions. This class includes instruction in basic military skills, naval ships (missions, terminology, and construction) and naval aviation. NJROTC students have the opportunity to perform in competitive teams including color guard, marching drill units, and air rifle. Uniforms are provided at no cost. No recruiting by military recruiters is allowed.

Note: Freshman and sophomores may take this course for PE credit or career technical credit.

\section{FIRMING AND TONING}

Grades: 10-12 - LPHS-OHS - One Year Course

Prerequisite: Sophomores must pass $9^{\text {th }}$ grade PE with a " $C$ " or better. Juniors at LPHS must pass $10^{\text {th }}$ grade PE with a "C" or better.

Strength training, including weight lifting and the use of resistance equipment offers a host of positive health benefits from increasing bone density and building strength to fighting heart disease. Results can be seen by strength training as little as twice a week for 20 minutes.

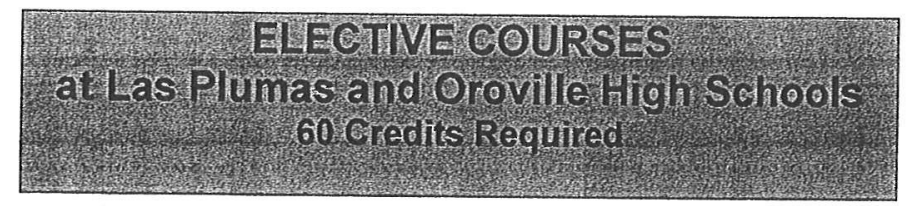

\section{CAREER TECHNOLOGY EDUCATION} 10 Credits Required

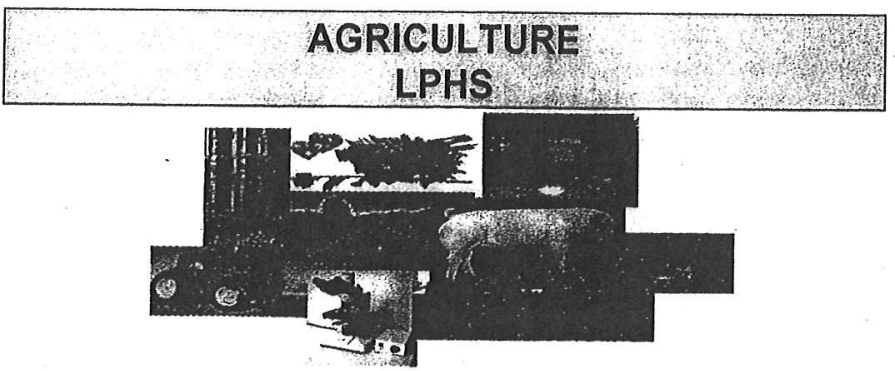

In the Las Plumas High School Agriculture Department, students that follow one of the four year plans will be prepared to attend a four year college, junior college or technical school to complete their education. They will also be trained in an area in which they may gain employment immediately after graduation from high school.

In addition to career skills, students in the Las Plumas High School Agriculture Department will gain public speaking skills, develop leadership skills, participate in student directed projects, and experience FFA co-curricular activities.

Course Sequence for Agricultural Mechanics

\begin{tabular}{|c|c|c|}
\hline $\begin{array}{c}\text { Career Prep Core } \\
\text { Grades 9 \& 10 }\end{array}$ & $\begin{array}{c}\text { Career Transition } \\
\text { Grades 10 \&11 }\end{array}$ & $\begin{array}{l}\text { Career Cluster } \\
\text { Grades 11 \& 12 }\end{array}$ \\
\hline $\mathrm{Ag}$ Mechanics I & $\mathrm{Ag}$ Mechanics II & $\begin{array}{l}\text { ROP Ag } \\
\text { Equip/Const }\end{array}$ \\
\hline
\end{tabular}

Course Sequence for Animal Science

\begin{tabular}{|l|l|l|}
\hline $\begin{array}{l}\text { Career Prep Core } \\
\text { Grades 9 \& 10 }\end{array}$ & $\begin{array}{c}\text { Career Transition } \\
\text { Grades 10 \&11 }\end{array}$ & \multicolumn{1}{|c|}{$\begin{array}{l}\text { Career Cluster } \\
\text { Grades 11 \& 12 }\end{array}$} \\
\hline $\begin{array}{l}\text { Ag Science or } \\
\text { Ag Earth } \\
\text { Science }\end{array}$ & Animal Science & ROP Ag Veterinary \\
\hline
\end{tabular}

Course Sequence for Environmental Horticulture

\begin{tabular}{|c|l|l|}
\hline $\begin{array}{c}\text { Career Prep Core } \\
\text { Grades } 9 \& 10\end{array}$ & $\begin{array}{c}\text { Career Transition } \\
\text { Grades 10 \&11 }\end{array}$ & \multicolumn{1}{|c|}{$\begin{array}{c}\text { Career Cluster } \\
\text { Grades 11 \& 12 }\end{array}$} \\
\hline $\begin{array}{l}\mathrm{Ag} \text { Science or } \\
\mathrm{Ag} \text { Earth Science }\end{array}$ & $\begin{array}{l}\text { Floriculture I or } \\
\text { Environ. Horticulture I }\end{array}$ & $\begin{array}{l}\text { Floriculture II or } \\
\text { Environ. Horticulture II }\end{array}$ \\
\hline
\end{tabular}

\section{AGRICULTURAL EARTH SCIENCE (Science Credit)}

Grades: 9-11 - One Year Course

This integrated academic-vocational course is recommended for all freshmen who are interested in exploring science-related careers in agriculture and applying their classroom learning to real life and workplace situations. It offers a foundation in the earth sciences, the California agriculture basic core, and the scientific method. The course provides students an opportunity to learn science by receiving direct instruction, reading textbooks and supplementary materials, using technology to acquire and process information, solving standards-based problems, performing laboratory investigations and experiments, and participating in supervised occupational experience projects and FFA leadership activities. The major units of study include: solar system; stars, galaxies, and the universe; dynamic earth processes; energy in the earth system; heating of earth's surface/atmosphere; climate; biogeochemical cycles; structure and composition of the atmosphere; California geology; scientific method; statistics, data analysis and probability; careers and employability in agriculture; projects; record keeping, and interpersonal leadership development.

\section{AGRICULTURAL LIFE SCIENCE I (Science Credit)}

Grades: 9-11 - One Year Course

This introductory course is recommended for all freshmen Interested in agriculture. It covers the fundamentals of plant and animal science and gives training in leadership. Production and processing of agricultural products and related services and businesses are studied. Students will develop a foundation in science while acquiring a broad understanding of the major facets of modern agriculture. It offers a foundation in the life sciences, the California agriculture basic core, and the scientific method. It also provides opportunities to participate in laboratory experiments, Supervised Agricultural 
Experience projects, and FFA leadership activities. This course meets the minimum science graduation requirement of one year of life science and prepares the students for other science and agricultural courses offered.

\section{COLLEGE AGRICULTURAL BIOLOGY (Science Credit)}

Grades: $10-12\left(9^{\text {th }}\right.$ w/ instructor approval) - One Year Course Prerequisite: Students must be enrolled in Algebra A or higher (exceptions must be made by approval of the instructor).

Agricultural Biology is a one-year laboratory science course designed for the college-bound student with career interests in agriculture. Using agriculture as the learning vehicle, the course emphasizes the biological principles and central concepts. The course centers on an extensive laboratory component to connect the principles of life science with agricultural applications, other curricular areas and other scientific disciplines. This course meets the Life Science laboratory "D" requirements for entrance into the University of California and California State University systems.

\section{ANIMAL SCIENCE (Science or Vocational Credit) \\ Grades: 11-12 - One Year Course \\ Prerequisite: Ag Science or Agricultural Earth Science and/or pre-approval by instructor. \\ Animal science is a one year advanced agricultural science course that will provide advanced understanding of livestock agriculture and issues affecting society, animal welfare, and production systems. Animal nutrition, anatomy and physiology, health, reproduction, genetics, and management through evaluation and selection will be stressed. This course allows students to be actively involved in the learning process. Note: This course has been approved for UC/CSU} elective credit.

\section{ROP AG VETERINARY SKILLS}

\section{Grades: 11-12 - One Year Course (Periods)}

Prerequisites: Animal Science or Biology or instructor permission. This course is designed to provide students with entrylevel skills in the Veterinary medicine industry. Animal health fundamentals covered in the class include terminology, safety, production, animal care and handling. Students will gain skills and knowledge to perform a variety of clinical tasks and office procedures through classroom exposure to realistic medical situations and nonpaid internships in veterinary related businesses. Class meets at Las Plumas High School. Note: This course meets UC elective requirements. NOTE: Yuba College credits may be earned upon successful completion of this course. *Please note that the ROP course offerings are tentative and contingent upon the 2011-2012 adopted State Budget.

\section{ENVIRONMENTAL HORTICULTURE I}

Grades: 10-12 - One Year Course

Prerequisite: Agricultural Life Science

The major emphasis of this course is to provide opportunities for students to develop knowledge and skills in the booming horticulture industry. Class study includes identification and use of ornamental plants, landscaping, and nursery plant production. Similarly, outdoor labs stress soils and plant nutrients, insects and diseases, greenhouse and nursery management, pruning, and equipment maintenance. Other activities offer opportunities in landscape design and construction, turf installation and management, plant production and sales. Individual student projects and the FFA program are integral parts of the course.

\section{ENVIRONMENTAL HORTICULTURE II}

Grades: 11-12 - One Year Course

Prerequisite: Environmental Horticulture I

The major emphasis of Horticulture is to provide advanced opportunities for students to develop knowledge and skills in horticulture and related industries. Class study includes additional identification and use of ornamental plants in landscaping, and design installation and maintenance. Similarly, outdoor labs stress student driven projects, greenhouse and nursery management and development of a school site garden center. Activities offer opportunities in landscape design and construction, irrigation, turf installation and management, and plant production and sales.
Through FFA award programs students will have the opportunity to showcase their efforts.

\section{FLORICULTURE I}

Grades: 10-12 - One Year Course

Prerequisite: Agricultural Science recommended

This is a first-year course in the fundamentals of the visual arts. This process-oriented course will provide the student with a perceptual base necessary for understanding artistic perception, creative expression, historical-cultural contexts, aesthetic valuing, and applications of visual arts to the art of floral design. NOTE: This class is articulated for college credits at Butte College. This course meets VAPA for UC/CSU.

\section{FLORICULTURE ॥}

\section{Grades: 10-12 - One Year Course}

Prerequisite: Floriculture I

The major emphasis of Floriculture is to provide students with advanced activities in floral techniques, processes, and operations through floral arranging. Particular attention is given to student recognition and application of the design and arrangement skills. Students participate in design and construction activities involving dish gardens, floral displays, and live flowers. The course covers safe use of tools and materials; and the recognition, propagation, and cultural practices of common floral and foliage plants. Students will exhibit an advanced portfolio that demonstrates their floral design and display skills.

\section{FORESTRY AND NATURAL RESOURCES}

Grades: 10-12 - One Year Course

Prerequisite: Agricultural Life Science recommended or Instructor approval.

This course will provide an introduction to Forestry and Natural Resources with planned activities in ecology, plant, wood identification, land measurement and map reading, range study and wildlife observation. Students will learn and practice general FNR knowledge, compass work, forest tool identification, log scaling, and log volume. The course reflects forestry in a society that is concerned about our ecosystem and its inhabitants, keeping in mind that trees have influenced the progress and welfare of humans in our country. The course covers projects in forest resource management, ecology and forestry careers. Finally, FFA leadership, supervised agriculture experience program and record keeping will round out the topics.

\section{AGRICULTURAL MECHANICS I}

\section{Grades: 9-12 - One Year Course}

Agricultural Mechanics I is the entry level course for the Agricultural Mechanics career path. The student is prepared for further experience and education by introducing the knowledge, skills, and attitudes associated with modern Agricultural Mechanics. Instructional units will include Oxy-fuel Welding \& Cutting; Electric Welding Processes, Chains and Rope; Equipment Operation and Preventative Maintenance; Types of Engines; Agriculture Industry Employee/Employer Relations; Safety; Electrical Systems; Agricultural Structures; Record Keeping; Interpersonal Leadership Development; Supervised Agricultural Experience (SAE) Project; and Measurement, Tool Identification, Cold Metal, and Fabrication.

\section{AGRICULTURAL MECHANICS ॥}

Grades: 10-12 - One Year Course

Prerequisite: Agricultural Mechanics I

Agricultural Mechanics II is the advanced level course for the Agricultural Mechanics career path. The student is prepared for further experience and education by refining the knowledge, skills, and attitudes associated with modern Agricultural Mechanics. Instructional units will include Oxy-fuel Welding \& Cutting; Electric Welding Processes; Equipment Operation and Preventative Maintenance; Types of Engines; Agriculture Industry Employee/Employer Relations; Safety; Electrical Systems; Agricultural Structures; Record Keeping; Interpersonal Leadership Development; Supervised Agricultural Experience (SAE) Project; and Measurement, with an emphasis on Project Construction. 
ROP AG EQUIPMENT OPERATION AND CONSTRUCTION

Grades: 11-12 - One Year Course - (2 Periods)

This class will provide basic skills in agricultural equipment operation maintenance and construction. Students learn repair, routine maintenance, and operation of light trucks, tractors and construction equipment including backhoes, loaders and forklifts. Students also learn basic construction skills in surveying, framing, concrete, electrical and plumbing. Students may be placed in non-paid internships for real-world experience. Class meets at Las Plumas High School, $5^{\text {th }}-6^{\text {th }}$ periods. NOTE: Butte College credits may be earned upon successful completion of this course. "Please note that the ROP course offerings are tentative and contingent upon the 2011-2012 adopted State Budget.

\section{AG STUDENT LEADERSHIP (Elective Credit)}

Grades: 10-12 - One Year Course

Prerequisite: Must be an active member of the FFA.

This course will provide students opportunities to set and develop their personal and career goals, advance communication and teamwork skills, and to build their personal leadership style. Emphasis will be placed upon completing assigned tasks, learning to function both as a team leader and committee member, and developing and using time management and organizational skills.

\section{BUSINESS EDUCATION}

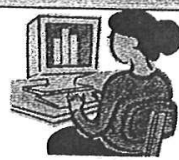

SUMMARY OF BUSINESS EDUCATION-COURSE OFFERINGS It is best to take a 3-course business sequence. Some courses are articulated with Butte Community College, which allows students to receive credit while still attending high school. Credits will also be entered on the students' transcript when the student begins taking the course work at Butte Community College. This occurs after high school graduation. Classes that are presently working with articulation agreements for college credits are Accounting, Computer Applications I and ROP Sales \& Service.

\section{Career Path Opportunities for Las Plumas}

Course Sequence for Information Technology

\begin{tabular}{|c|l|c|}
\hline $\begin{array}{c}\text { Career Prep Core } \\
\text { Grades 9 \& 10 }\end{array}$ & $\begin{array}{l}\text { Career Transition } \\
\text { Grades 10 \&11 }\end{array}$ & $\begin{array}{c}\text { Career Cluster } \\
\text { Grades 11 \& 12 }\end{array}$ \\
\hline Computer Apps I & $\begin{array}{l}\text { MultimediaNeb } \\
\text { Design }\end{array}$ & Computer Apps II \\
\hline
\end{tabular}

\section{Career Path Opportunities for Oroville High}

Course Sequence for Information Technology

\begin{tabular}{|c|c|c|}
\hline $\begin{array}{c}\text { Career Prep Core } \\
\text { Grades 9 \& 10 }\end{array}$ & $\begin{array}{c}\text { Career Transition } \\
\text { Grades 10 \&11 } \\
\text { Computer Apps I } \\
\text { Cultimedia/Web } \\
\text { Design }\end{array}$ & $\begin{array}{c}\text { Career Cluster } \\
\text { Grades 11 \& 12 }\end{array}$ \\
\hline \multicolumn{3}{|c|}{ Computer Apps II } \\
\hline $\begin{array}{c}\text { Career Prep Core Sequence for Finance \& Business } \\
\text { Grades 9 \& 10 }\end{array}$ & $\begin{array}{c}\text { Career Transition } \\
\text { Grades 10 \&11 }\end{array}$ & $\begin{array}{c}\text { Career Cluster } \\
\text { Grades 11 \& 12 }\end{array}$ \\
\hline Computer Apps I & Computer Apps II & $\begin{array}{l}\text { ROP Retail Sales \& } \\
\text { Service }\end{array}$ \\
\hline
\end{tabular}

\section{COMPUTER APPLICATIONS I}

Grades: 9-12 - LPHS-OHS - One Year Course

This course is designed to introduce computer skills and basic business concepts. This is the entry-level course for all business career pathways. Students will learn proper techniques to keyboard information into the computer using word processing, spreadsheet, database, Internet, and presentation software packages. This course is designed to assist students with leadership skill development and career exploration.

Iote: Butte College $2+2$ credit is available with a grade of " $B$ " or Detter.

Revised 1/2011

\section{COMPUTER APPLICATIONS ॥}

Grades: 10-12 - LPHS-OHS - One Year Course

Prerequisite: Computer Applications I

This is a hands-on course designed to reinforce and expand upon introductory computer skills. The students demonstrate proper techniques in keyboarding information into the computer, using word processing, spreadsheet, database, Internet, and presentation software packages. The emphasis of this class is on the concepts of computing and problem solving so that students learn how computers can be applied to a wide range of problems. Successful completion of this course will prepare the student in pursuing certification as a Microsoft Office User Specialist (MOUS). This course is designed to assist students with leadership skill development and career explorations.

\section{MULTIMEDIA AND WEB DESIGN}

Grades: 10-12 - LPHS-OHS - One Year Course

Prerequisite: Computer Applications $I$ or Permission of Instructor

This course will provide the student with the skills necessary to integrate text, graphics, sound, video, and/or animation into a document such as a letter, brochure, newsletter, Web page, or presentation. The computer platform is windows-based PC. Windows, Adobe and other software applications will be used. The most immediate result of the student's efforts will be the maintenance and enhancement of the School Site Web Page. Additionally, these new powerful technology tools will allow the student to develop presentations for other classes in ways they could not have done before. Participation in Future Business Leaders of America (FBLA) competition as well as entry in the Silver Dollar Fair are just two of the opportunities students will have to display their abilities. In the long term, although students completing this course will be prepared for a variety of entry level positions in business, students will be encouraged to consider this as a starting point in their pursuit of professional certification through institutions of higher learning.

\section{ROP RETAIL SALES AND SERVICE}

Grades: 10-12 - LPHS-OHS - One Year - (2 Periods)

Class provides training in cash register operation, inventory control, stocking, salesmanship, customer relations, advertising and display, buying, payroll and entrepreneurship. On-the-job training may take place in a variety of retail businesses. NOTE: Butte College credits may be earned upon successful completion of this course. *Please note that the ROP course offerings are tentative and contingent upon the 2011-2012 adopted State Budget.

\section{ROP ENTERTAINMENT, FOOD SERVICE \& TRAVEL}

Grades: 11-12 - LPHS-OHS - One Year - (2 Periods)

This class provides students with the entry level skills necessary for employment in the hospitality and tourism industries of travel, lodging, recreation and food service. Areas of study include guest and recreation services, management, organization, travel reservations, customer service and public safety. Students will gain hands on training in non-paid internships with local hospitality and tourism businesses. Class meets at Las Plumas High School $5^{\text {th }}-6^{\text {th }}$ periods. *Please note that the ROP course offerings are tentative and contingent upon the 2011-2012 adopted State Budget.

\section{DIVERSIFIED OCCUPATIONS}

\section{ROP DIVERSIFIED OCCUPATIONS}

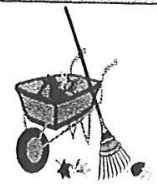

Grades: 9-12 - LPHS - One Year Course - (2 Periods)

This class is designed for students with exceptional needs and recommended to the program by a high school IEP (Individualized Education Program). Core instruction includes skills in job seeking, work ethics, personal communication and safety. Students will gain job skills in two or more diversified areas: janitorial, retail, landscaping, childcare, or food services. Class meets at Las Plumas High School $5^{\text {th }}$ and $6^{\text {th }}$ periods. *Please note that the ROP course offerings are tentative and contingent upon the 2011-2012 adopted State Budget. 
ROP MEDICAL \& HOSPITAL CAREERS

Grades: 11-12 - LPHS - One Year - (2 Periods)

Students gain entry-level skills in hospital and medical services. Classroom training includes basic patient care, CPR and First Aid, vital signs, medical terminology and safety. Job shadows and internships may take place in a variety of hospital and medical environments including but not limited to x-ray, physical therapy, respiratory therapy, pharmacy, laboratory, medical records, cardiology, surgery and medical offices. Class meets at Las Plumas High School $5^{\text {th }}-6^{\text {th }}$ periods.

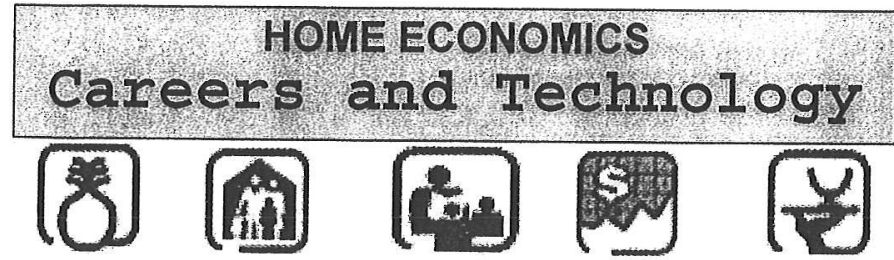

Home Economics Careers and Technology programs prepare students for living and earning a living. Leadership, teamwork, personal responsibility, problem solving, and management are skills highly valued by employers. Today, these skills are developed in Home Economics Careers and Technology programs along with the basic academic skills of reading, writing, math, science and critical thinking that are necessary to achieve personal and career goals. Home Economics Careers and Technology Education teaches students to develop self-esteem, apply decision making skills, practice communication skills essential for effective relationships with peers and family, acquire leadership and citizenship skills, and develop an awareness of career options. Students also learn personal management, leadership and interpersonal skills that are essential for productive employees. Home Economics Careers and Technology Education teaches students vital interpersonal skills and helps them develop job search and acquisition skills, recognize the value of good work habits and positive attitudes, practice effective working relationships, and acquire job retention skills including responsibility, dependability, and time management. All students enrolled in Home Economics Careers and Technology Program are encouraged to take advantage of their membership in FHA-HERO. FHA-HERO is a national vocational student organization for young men and women in grades 6-12. FHA-HERO assists students in developing occupational, citizenship and leadership skills needed for home, community and work life. FHA-HERO activities offer a wide range of opportunities for community service, career exploration, leadership development and personal growth.

\section{Career Path Opportunities for Las Plumas}

Course Sequence for Food Service \& Hospitality

\begin{tabular}{|c|l|l|}
\hline $\begin{array}{c}\text { Career Prep Core } \\
\text { Grades 9 \& 10 }\end{array}$ & $\begin{array}{l}\text { Career Transition } \\
\text { Grades 10 \&11 }\end{array}$ & \multicolumn{1}{|c|}{$\begin{array}{l}\text { Career Cluster } \\
\text { Grades 11 \& 12 }\end{array}$} \\
\hline Intro To Home Ec & Consumer/ Foreign & $\begin{array}{l}\text { ROP Chef Prep } \\
\text { Culinary }\end{array}$ \\
& Foods & $\begin{array}{l}\text { Arts/Catering } \\
\text { ROP Entertainment, } \\
\end{array}$ \\
& & Food \& Travel \\
\hline
\end{tabular}

Course Sequence for Child Development \& Education

\begin{tabular}{|c|c|c|}
\hline $\begin{array}{c}\text { Career Prep Core } \\
\text { Grades } 9 \& 10\end{array}$ & $\begin{array}{c}\text { Career Transition } \\
\text { Grades 10 \&.11 }\end{array}$ & $\begin{array}{c}\text { Career Cluster } \\
\text { Grades 11 \& 12 }\end{array}$ \\
\hline Intro to Home Ec & Child Development & $\begin{array}{l}\text { ROP Working with } \\
\text { Children }\end{array}$ \\
\hline
\end{tabular}

Revised 1/2011

\section{Career Path Opportunities for Oroville High}

Course Sequence for Child Development \& Education

\begin{tabular}{|c|c|c|}
\hline $\begin{array}{c}\text { Career Prep } \\
\text { Core } \\
\text { Grades } 9 \& 10\end{array}$ & $\begin{array}{c}\text { Career Transition } \\
\text { Grades 10 \&11 }\end{array}$ & $\begin{array}{l}\text { Career Cluster } \\
\text { Grades 11 \& 12 }\end{array}$ \\
\hline Intro to Home Ec & Child Development & $\begin{array}{l}\text { ROP Working with } \\
\text { Children }\end{array}$ \\
\hline
\end{tabular}

Course Sequence for Food Service \& Hospitality

\begin{tabular}{|l|l|l|}
\hline $\begin{array}{c}\text { Career Prep } \\
\text { Core } \\
\text { Grades 9 \& 10 }\end{array}$ & \multicolumn{1}{|c|}{$\begin{array}{c}\text { Career Transition } \\
\text { Grades 10 \&11 }\end{array}$} & $\begin{array}{l}\text { Career Cluster } \\
\text { Grades 11 \& 12 }\end{array}$ \\
\hline $\begin{array}{l}\text { Intro to Home } \\
\text { Economics }\end{array}$ & $\begin{array}{l}\text { Consumer/Foreign } \\
\text { Foods }\end{array}$ & $\begin{array}{l}\text { ROP Chef Prep } \\
\text { ROP } \\
\text { Entertainment, } \\
\text { Food \& Travel }\end{array}$ \\
\hline
\end{tabular}

Course Sequence for Fashion Design

\begin{tabular}{|l|l|l|}
\hline $\begin{array}{c}\text { Career Prep } \\
\text { Core } \\
\text { Grades 9 \& 10 }\end{array}$ & $\begin{array}{c}\text { Career Transition } \\
\text { Grades 10 \&11 }\end{array}$ & $\begin{array}{l}\text { Career Cluster } \\
\text { Grades 11 \&12 }\end{array}$ \\
\hline $\begin{array}{l}\text { Intro to Home } \\
\text { Economics }\end{array}$ & $\begin{array}{l}\text { Fashion Design/ } \\
\text { Merchandising }\end{array}$ & $\begin{array}{l}\text { Adv. Fashion } \\
\text { Design/ } \\
\text { Merchandising } \\
\text { ROP Retail Sales } \\
\text { and Service }\end{array}$ \\
\hline
\end{tabular}

INTRODUCTION TO HOME ECONOMICS

Grades: 9-12 -LPHS - OHS - One Year Course

The Consumer and Family Science (CFS) Comprehensive Core is designed to provide a strong foundation for students in home economics careers and technology pathways. The core prepares students with the skills and knowledge needed to achieve competencies in each of the seven content areas:

- Leadership

- Child Development

- Family Living and Parenthood Education

- Clothing and Textiles

- Safety, Foods and Nutrition

- Housing and Interior Design

- Consumer education

Achievement of these content area competencies enhances the management and balance of personal, home and work life. Central to the development of these competencies is the integration and application of academic skills and the application of classroom learning experiences.

\section{CHILD DEVELOPMENT}

Grades: 10-12 -LPHS-OHS - One Year Course

Students will gain an understanding of child development in the areas of growth and development, nutrition, safety, discipline, positive learning environments, materials and activities for children, exceptional children, and careers. Students will complete community based activities focusing on the needs of children in Oroville. Note: 3 Butte College credits may be earned upon successful completion of this course.

\section{ROP WORKING WITH CHILDREN}

Grades: 11-12-OHS - One Year Course - (2 Periods)

This course is designed to help students learn about career opportunities in the field of teaching and other school site educational professions. Instruction includes career preparation standards, basic academics, safety, communication, inter-personal and problem solving skills. Active class participation is enhanced by community classroom placement under the guidance of a mentor teacher. All students are required to participate in a variety of settings and classrooms at the preschool/primary/or elementary levels. This course helps prepare students for entry into college or university teacher training programs and preschool certification programs. Class meets Oroville High School $1^{\text {st }}-2^{\text {nd }}$ periods. Note: Butte College credits may be earned upon successful completion of this course. *Please note that the ROP course offerings are tentative and contingent upon the 2011-2012 adopted State Budget 
CREATIVE/INTERIOR DESIGN

Grades: 10-12 - LPHS - One Year Course

Prerequisite: Introduction to Home Economics recommended

Students will gain an understanding of the art elements and principles as they apply to interior design, clothing design, and aesthetic crafts for the home as well as for resale purposes. Students will develop entrepreneurial skills through design and marketing techniques. Students will work in small groups forming businesses, producing products, marketing and selling the products at a craft fair/bazaar. Students will focus on interior design, housing and furniture refinishing during the second semester. Each student will have the opportunity to complete a display board, complete with floor plans, wall elevations, samples and an oral presentation. Students will develop an understanding of housing needs. Students will also refinish a piece of furniture.

ROP RETAIL SALES AND SERVICE

Grades: 10-12 - OHS - One Year - (2 Periods)

Class provides training in cash register operation, inventory control, stocking, salesmanship, customer relations, advertising and display, buying, payroll and entrepreneurship. On-the-job training may take place in a variety of retail businesses. Class meets at Oroville High School $5^{\text {th }}-6^{\text {th }}$ periods. NOTE: Butte College credits may be earned upon successful completion of this course. *Please note that the ROP course offerings are tentative and contingent upon the 2011-2012 adopted State Budget.

\section{FASHION DESIGN AND MERCHANDISING}

Grades: 11-12 (10 with permission of teacher)

OHS - One Year Course

This course is designed to provide a strong foundation that prepares students to successfully enter the job market or to transition to postsecondary education. Students will develop skills in the following areas: principles and elements of design; design and manufacturing; buying and sales; and promotion. Additional units of instruction can be used in personal application and the fashion business: retail organizations, wardrobe selection, textiles, history of fashion, and job employability. A minimum of 16 hours of on-the-job training at local retail businesses is available with this course. Students receive certificate for completion of this course, which can be used in gaining employment. NOTE: Three units Butte College Credit available.

\section{FASHION DESIGN}

Grades: $11-12$ (10 with permission of teacher)

LPHS-One Year Course

This course is designed to meet the needs of both beginning and intermediate sewers, and develops students' sewing skills through the construction of garments and/or samples utilizing professional sewing techniques. You will be challenged as you complete the "Successful Sewing" notebook and create your "technique" notebook. A variety of garments will be constructed using traditional and advance techniques. Technology is incorporated into every aspect of construction. First semester focuses on attaining proficiency of equipment and perfecting a variety of techniques. Second semester is devoted to the individual student constructing, designing and altering garments for his or her personal wardrobe. NOTE: Three units Butte College Credit available.

\section{ADVANCED FASHION DESIGN AND MERCHANDISING}

Grades: 11-12 - OHS - One Year Course

Prerequisite: Fashion Design and Merchandising

This course is designed to provide further study and practice to effectively prepare students with the knowledge, skills, attitudes, and behaviors needed to successfully enter the job market, or to transition to postsecondary education. Students will further reinforce skills gained in the $1^{\text {st }}$-year course. A minimum of 16 hours of on-the-job training at local retail businesses is highly recommended for this level. Students receive a certificate for completion of this course which can be used in gaining employment.

\section{CONSUMER FOODS/FOREIGN FOODS}

Grades: $11-12\left(10^{\text {th }}\right.$ Grade $w /$ completion of Intro to Home Economics) LPHS-OHS - One Year Course
In this advanced specialized course, students explore the variety of foods available today, and learn how food and nutrition impact daily lives. Major topics will include: nutrition and health, food safety and sanitation, meal management to meet the needs of individuals and families, food purchasing and preparation, food and culture, food science and nutrition, food costs, production and technology, and careers in the field of food science, hospitality or food technology. Students will examine the unique styles of food preparation and presentation of different cultures, including various regions of the United States and foreign countries.

\section{CULINARY ARTS/CATERING}

Grades: 11-12-LPHS-One Year Course

This class covers all aspects of catering from developing the menu, costing out numbers, formulating proposals, table layout and executing the event. The hands-on curriculum will also include instruction in appetizers, fancy breads and rolls, cake decorating techniques, patisserie and buffet. Sample menus will be developed and served in class. Experience will include both on-site and community events ranging from 4 to 250 people. This class is designed for Juniors and Seniors interested in careers related to the food service and hospitality industry.

\section{ROP ENTERTAINMENT, FOOD SERVICE \& TRAVEL}

\section{Grades: 11-12 - LPHS - One Year - (2 Periods)}

This class provides students with the entry level skills necessary for employment in the hospitality and tourism industries of travel, lodging, recreation and food service. Areas of study include guest and recreation services, management, organization, travel reservations, customer service and public safety. Students will gain hands on training in non-paid internships with local hospitality and tourism businesses. Class meets at Las Plumas High School $5^{\text {th }}-6^{\text {th }}$ periods. "Please note that the ROP course offerings are tentative and contingent upon the 2011-2012 adopted State Budget.

\section{ROP CHEF PREP AND RESTAURANT OCCUPATIONS}

\section{Grades: 11-12 -OHS - One Year Course (2 Periods)}

Learn entry-level skills in food preparation and service. Students will gain hands-on experience in the areas of line cook, assistant cook, bakery/pastry, host/cashier, pantry, wait staff/bus person, and catering by working in the on-campus "Le Tigre Restaurant" and through non-paid internships at local restaurants. NOTE: Yuba College credits may be earned upon successful completion of this course. *Please note that the ROP course offerings are tentative and contingent upon the 2011-2012 adopted State Budget.

\section{INDUSTRIAL TECHNOLOGY}

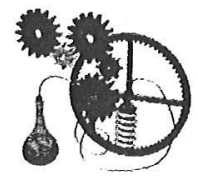

The Industrial Technology Departments provide students with an integrated selection of academic and technological courses that keep pace with our ever-changing world. The Industrial Technology programs are designed to provide students with skills, knowledge, and attitudes necessary to help them gain employment in the career of their choice.

\section{Career Path Opportunities for Las Plumas}

Course Sequence for Manufacturing Technology

\begin{tabular}{|c|c|c|}
\hline $\begin{array}{c}\text { Career Prep Core } \\
\text { Grades } 9 \& 10\end{array}$ & $\begin{array}{c}\text { Career Transition } \\
\text { Grades 10 \&11 }\end{array}$ & $\begin{array}{c}\text { Career Cluster } \\
\text { Grades 11 \& 12 }\end{array}$ \\
\hline Intro to Tech Block & Adv. Manufacturing & ROP Welding \\
\hline
\end{tabular}

Course Sequence for Transportation \& Energy

\begin{tabular}{|c|c|c|}
\hline $\begin{array}{c}\text { Career Prep Core } \\
\text { Grades } 9 \& 10\end{array}$ & $\begin{array}{c}\text { Career Transition } \\
\text { Grades 10 \&11 }\end{array}$ & \multicolumn{1}{|c|}{$\begin{array}{l}\text { Career Cluster } \\
\text { Grades 11 \& 12 }\end{array}$} \\
\hline Intro to Tech Block & Auto Technology & $\begin{array}{l}\text { Adv. Auto } \\
\text { Technology } \\
\text { ROP High Perf. Auto }\end{array}$ \\
\hline
\end{tabular}




\section{Career Path Opportunities for Oroville High}

Course Sequence for Automotive Transportation Industry

\begin{tabular}{|c|c|c|}
\hline $\begin{array}{c}\text { Career Prep Core } \\
\text { Grades } 9 \& 10\end{array}$ & $\begin{array}{c}\text { Career Transition } \\
\text { Grades } 10 \& 11\end{array}$ & $\begin{array}{c}\text { Career Cluster } \\
\text { Grades 11 \& 12 }\end{array}$ \\
\hline Intro To Tech Block & Auto Technology & ROP High Perf. Auto \\
\hline
\end{tabular}

Course Sequence for Drafting Technology

\begin{tabular}{|l|l|c|}
\hline $\begin{array}{l}\text { Career Prep Core } \\
\text { Grades } 9 \text { \& 10 }\end{array}$ & $\begin{array}{c}\text { Career Transition } \\
\text { Grades 10 \&11 }\end{array}$ & $\begin{array}{c}\text { Career Cluster } \\
\text { Grades 11 \& 12 }\end{array}$ \\
\hline $\begin{array}{l}\text { Engineering } \\
\text { Graphics }\end{array}$ & Arch Drafting I & CAD \\
\hline
\end{tabular}

Course Sequence for Graphic Communications

\begin{tabular}{|l|l|l|}
\hline $\begin{array}{c}\text { Career Prep Core } \\
\text { Grades } 9 \& 10\end{array}$ & $\begin{array}{c}\text { Career Transition } \\
\text { Grades 10 \&11 }\end{array}$ & $\begin{array}{c}\text { Career Cluster } \\
\text { Grades 11 \& 12 }\end{array}$ \\
\hline $\begin{array}{l}\text { Engineering } \\
\text { Graphics }\end{array}$ & $\begin{array}{l}\text { Visual } \\
\text { Communications }\end{array}$ & CAD \\
\hline
\end{tabular}

\section{INTRODUCTION TO TECHNOLOGY BLOCK}

Grades: 9-10 LPHS - OHS- One Year Course

Three separate technology courses have been integrated into a rotation for technology students. This rotation offers the students an opportunity to experience a variety of new technologies in an integrated, team teaching atmosphere where three instructors are responsible for their first year at the secondary level. The students (primarily freshman) will rotate between Small Engines and Introduction to Manufacturing (LPHS)

\section{INTRODUCTION TO MANUFACTURING \\ Grades: 10-12- LPHS - One Year Course}

This course introduces and develops basic skills in sheet metal bench metal, gas and arc welding, foundry, and the safe and proper use of metalworking machines. Projects are selected by the instructor on the basis of those skills necessary to develop a fundamental knowledge of general metals. Related classroom materials cover the use, care, and maintenance of machines, explores the use of various metals, and the physical characteristics and properties of each. Job opportunities and job descriptions in the various fields of metalworking are emphasized.

\section{ADVANCED MANUFACTURING TECHNOLOGY}

Grades: 10-12 - LPHS - One Year Course. Recommended: Grade of "C" or better in Introduction to Technology Block

In this course, more emphasis is allowed for individualizing "learningby-doing" and the solution of the problems encountered. In addition to project work (student selected), special emphasis is made on particular processes not necessarily given full attention by the student previously. Such processes are cutting, brazing, special castings, various positions in welding, machine and bench work are among those concentrated on. Every project, when completed, should have a neat plan to accompany it for grading purposes. When necessary, special assignments are given to help cement ideas into the mind of the student.

\section{ROP WELDING FABRICATION}

\section{Grades: 11-12 - LPHS - One Year Course - (2 Periods)}

Prerequisite: Introduction to Technology Block, Introduction to Manufacturing, Advanced Manufacturing or permission of instructor. Students will learn skills in the areas of welding, sheet metal work, hydraulics, heat treating/hard facing, light construction, use of tools and equipment and safety. Upon completion, students will be qualified for entry-level jobs in welding, cutting and metal fabrication. Course objectives are focused toward optional AWS Welding Certification. Students may be placed in internships for related hands-on. Class meets at Las Plumas High School, $5^{\text {th }}-6^{\text {th }}$ periods. NOTE: Butte College credits may be earned upon successful completion of this course.. *Please note that the ROP course offerings are tentative and contingent upon the 2011-2012 adopted State Budget.

\section{AUTOMOTIVE TECHNOLOGY 1A/1B}

\section{Grades: 10-12 - LPHS - OHS - One Year Course}

This course introduces the fundamentals of automotive and power mechanics. It covers minor repairs and adjustment of the power plant, power train, chassis, and accessories. Training in troubleshooting procedures and tune-up are included in the shop work. Classroom materials parallel the practical work. Emphasis is placed on orderly procedure, cleanup, safe work habits, and career opportunities.

\section{ADVANCED AUTOMOTIVE TECHNOLOGY}

Grades: 11-12 - LPHS - One Year Course

Grades: 10-12 - OHS - One Year Course

Prerequisite: Automotive Technology 1A/1B.

This course explores the theory and function of the various automotive components and systems. Troubleshooting procedures are also expended. Classroom materials include theory and design, job opportunities in related fields, and technical data interpretation. Emphasis is placed on orderly procedure, cleanup, and safe work habits. This course will also explore the application of aftermarket automotive components. Modifications of interior, exterior, drive train and other components will be addressed through student and shop projects that incorporate fabrication.

\section{ROP HIGH PERFORMANCE AUTO TECHNOLOGY}

Grades: 11-12 - OHS - One Year Course (2 Periods)

This course explores the application of aftermarket automotive components. Modifications of interior, exterior, drive train and other components will be addressed through student projects that incorporate fabrication, utilization of aftermarket products and other specialized automotive marketing concepts. In depth discussions will center on the legal aspects of automotive modification and being street legal. Class meets at Oroville High School, $5^{\text {th }}-6^{\text {th }}$ periods.

NOTE: Butte College credits may be earned upon successful completion of this course. "Please note that the ROP course offerings are tentative and contingent upon the 2011-2012 adopted State Budget

\section{AGRICULTURAL MECHANICS I}

\section{Grades: 9-12 - LPHS-OHS-One Year Course}

Agricultural Mechanics I is the entry level course for the Agricultural Mechanics career path. The student is prepared for further experience and education by introducing the knowledge, skills, and attitudes associated with modern Agricultural Mechanics. Instructional units will include Oxy-fuel Welding \& Cutting; Electric Welding Processes, Chains and Rope; Equipment Operation and Preventative Maintenance; Types of Engines; Agriculture Industry Employee/Employer Relations; Safety; Electrical Systems; Agricultural Structures; Record Keeping; Interpersonal Leadership Development; Supervised Agricultural Experience (SAE) Project; and Measurement, Tool Identification, Cold Metal, and Fabrication.

\section{AGRICULTURAL MECHANICS ॥}

Grades: 10-12 - LPHS-OHS-One Year Course

Prerequisite: Agricultural Mechanics I

Agricultural Mechanics II is the advanced level course for the Agricultural Mechanics career path. The student is prepared for further experience and education by refining the knowledge, skills, and attitudes associated with modern Agricultural Mechanics. Instructional units will include Oxy-fuel Welding \& Cutting; Electric Welding Processes; Equipment Operation and Preventative Maintenance; Types of Engines; Agriculture Industry Employee/Employer Relations; Safety; Electrical Systems; Agricultural Structures; Record Keeping; Interpersonal Leadership Development; Supervised Agricultural Experience (SAE) Project; and Measurement, with an emphasis on Project Construction.

GRAPHIC DESIGN - 1A/ $1 B$

Grades: 10-12 - OHS - One Year Course

Recommended: Mechanical Drafting 1.

Graphic design is a course that covers major areas of graphic communications and computer aided design (CAD), which is intended to provide students an introduction into computer-based graphics. Students also learn and use skills based on principles of design, such as: layout and design, use of color, text composition, page composition, digital image photography, and PowerPoint presentation skills. Students will use the latest industry standard 
software to learn the basics of Desktop Publishing, Digital Photography, Computer Aided Design (CAD), Multimedia (Video Production), as tools for developing an internet web page. This course will help students develop and examine future personal, education, and career needs. Students will be introduced to the technical world's primary means of communication, visual communication, which, in various forms affects people in nearly every walk of life. Students who successfully complete this course will be prepared for a variety of entry level positions in business or could continue on into Community College or earn a 4-year degree in Graphic Communications.

\section{MECHANICAL DRAFTING TECHNOLOGY 1A/1B \\ Grades: 9-12 - OHS - One Year Course}

This is a one-year course for students with little or no drafting background. Students will be introduced to many kinds of technical drawings such as: two-dimensional, orthographic projection, sectional, and pictorial drawings. Techniques, care and uses of equipment will be observed as well as work procedures and attitudes. One semester of math credit may be obtained upon completion of this course. This course is articulated with Butte College $(2+2)$.

\section{ARCHITECTURAL DESIGN 1A/1B}

\section{Grades: 10-12 - OHS - One Year Course}

Prerequisite: Grade of "C" or better in Mechanical Drafting Technology $1 \mathrm{~A} / 1 \mathrm{~B}$

This course covers topics including line, forms, values of lines, texture, volume, space, and various art forms to develop interior and exterior living areas. The student will complete a set of house plan designs using the above principles, which also meet the minimum standards of the Uniform Building Code for residential construction. This is an approved Butte College 2+2 (3-college credits) course for those students receiving a "B" or better.

\section{COMPUTER-AIDED DESIGN (CAD) TECHNOLOGY}

Grades: 10-12 - OHS - One Year Course - Prerequisite: Grade of "C" or better in Engineering Graphics. This is a course in computer aided drafting and design that introduces students to the software that is currently being used in industry today. Students will work on design projects and produce computer models, drawings, and renderings using a number of software applications (Auto CAD Solidworks, 3D Studio Max). This class prepares students for either direct entry into the workplace; or continuation with further education leading to a certificate, associate, or baccalaureate degree.

\section{LAW ENFORCEMENT}

ROP ADMINISTRATION OF JUSTICE

Grades: 11-12 - LPHS-OHS - One Year - 1 Period

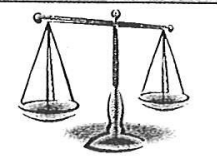

This course is designed to provide students with a basic introduction to the administration of justice system in America. Emphasis will be placed on crime, punishment, rehabilitation, ethics, education and training for professionalism in the system. Detailed topics enhancing specific knowledge related to law enforcement duties will be covered. Instruction will include investigations, report writing, search and seizure, patrol procedures, prison system, juvenile justice system, private investigations, etc. This class meets at Las Plumas High School and Oroville High School $1^{\text {st }}$ period. NOTE: Butte College credits may be earned upon successful completion of this course. *Please note that the ROP course offerings are tentative and contingent upon the 2011-2012 adopted State Budget.

\section{NJROTC}

NAVAL SCIENCE I (JROTC)

Grades: 9-12 - LPHS - One Year Course

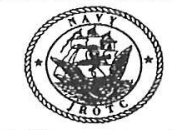

The course introduces students to the precepts of citizenship, the elements of leadership, and the value of scholarship in attaining life goals, while engendering them with a sound appreciation for America's naval heritage and traditions and the importance of sea power to maritime nations. The class emphasizes development of the "whole person," through concurrent instruction in, and opportunity

Revised 1/2011 for greater development of, leadership, fitness, and academics. Students also have the opportunity to participate in a variety of extracurricular activities, including orientation trips to military facilities and visits to colleges and universities, and join a variety of competitive JROTC teams, such as Color Guard, Drill, Fife \& Drum Corps, Air Rifle, Academic and Athletic teams. Students wear uniforms, which are provided at no cost, one day a week. No recruiting by military recruiters is allowed. Note: Freshmen and sophomores may take this course for PE credit.

NAVAL SCIENCE II (JROTC)

Grades: 10-12 - LPHS - One Year Course

Prerequisite: Naval Science I and instructor permission Course comprises a semester of naval history, spanning the Revolutionary War to current times, followed by a semester of maritime science, which includes: maritime geography, oceanography, meteorology, and astronomy. Note: Students may take this class for second semester Earth Science credit.

\section{NAVAL SCIENCE III (JROTC)}

\section{Grades: 11-12 - LPHS - One Year Course}

Prerequisite: Naval Science I \& II and instructor permission Covers a variety of naval subjects and topics, including the importance of sea power to a maritime nation; ship construction seamanship, piloting and navigation; nautical rules of the road; aviation and ship operations; naval customs, and more advanced work on topics learned the first year.

NAVAL SCIENCE IV (JROTC)

Grade: 12 - LPHS - One Year Course

Prerequisite: Naval Science I \& II and instructor permission Provides students a better understanding of leadership traits and principles and affords them the opportunity to apply these traits and principles in leadership situations within the unit while planning and implementing NJROTC activities. The course will require the student to analyze, discuss and document various leadership scenarios and vignettes. All NS4 students will have previously expressed a desire for, and have been selected, to fill cadet officer positions. In addition to carrying out their Cadet Staff responsibilities, the students will serve as mentors for underclassmen.

\section{Naval Science-In the Context of American Military History Grade 11-12-LPHS-Semester Course \\ Prerequisite: Instructor permission}

This course explores American military history chronologically from 1607 to the present. Utilizing elements of the NJROTC Naval Science curriculum, it traces the uniquely American military and focuses not only on wars, leaders, and strategy, but also on topics such as civilian attitudes on a standing army and navy, soldier motivation, defense funding, anti-war movements, and women's wartime roles. It will also include leadership skills, citizenship and American government, geography and survival skills.

\section{VISUAL, PERFORMING ARTS AND FOREIGN LANGUAGE \\ 10 Credits Required

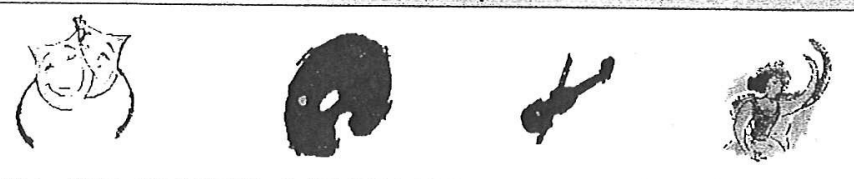 \\ ALL ART CLASSES SATISFY THE CSU AND UC ENTRANCE REQUIREMENTS WITH THE EXCEPTION OF ACOUSTIC GUITAR, FLAGS AND ARTS ALIVE.}

\section{ART I/ART APPRECIATION}

Grades: 9-12 - LPHS-OHS - One Year Course

This course is a first year art course in the fundamental of art. This course emphasizes the necessary skills to provide the student with a perceptual base leading to understanding artistic perception, creative expression, historical and cultural context(s); aesthetic valuing and connections, relations, applications of the Visual arts. Learning the tools, techniques, materials, technology and application of what is learned in other art forms, subject areas and careers. The art 
elements and principals of design serve as a foundation for each unit covered. Selected historical or cultural contexts will be applied with attention to analysis, interpretation, and judgment of student work as well as appreciation of art works from other cultures and times.

\section{ART IIIART APPRECIATION}

Grades: 10-12 - LPHS-OHS - One Year Course

Prerequisite: Grade of "C" or better in Art I or consent of instructor based on portfolio review.

This is an intermediate level visual arts course in the fundamentals of art. This course is the second year in a four course sequence of visual arts. Students will improve the necessary skills and perceptual knowledge for students to understand artistic perception, creative expression, historical and cultural context, aesthetic valuing, and the connections, relations, and applications of the visual arts. Students will learn by using the same tools, techniques, materials and technology art makers of the past and present have used to create their own individual art works. The art elements and principals of design serve as a foundation for each unit presented. The application(s) of what is experienced to learning in other arts forms subject areas and careers works of arts are also part of this foundation. Selected historical or cultural contexts will be applied with attention to analysis, interpretation, and judgment of student works and appreciation of art work, and contexts which influenced art making from other cultures and times.

\section{ADVANCED ART}

Grades: 10-12 - LPHS-OHS - One Year Course

Prerequisite: Grade of "C" or better in Art I or consent of instructor based on portfolio review.

This is an advanced course which provides the serious visual arts student with an opportunity to expand upon his/her interest in a particular idea expressed in visual form(s). This is a third year in a four year sequence of visual arts course offering. In addition to improving the necessary skills and perceptual knowledge for students to understand artistic perception, creative expression, historical and cultural contexts, aesthetic valuing, and the connections, relations, and applications of the visual arts, the instruction will direct the student to focus on the process of investigation, growth, and discovery. Students will learn by using the same tools, techniques, materials, and technology art makers of the past and present have used to create their own individual art works. The art elements and principals of design serve as a foundation for each unit presented. The application(s) of what is experienced to learning other art forms, subject areas, and career works of arts are also part of this foundation. Selected historical or cultural contexts and content will focus on contemporary arts. Attention will also be given to analysis, interpretation, and judgment of student works and appreciation of art work, and contexts which influenced art making from the past to the present. The evidence of a concentration with visual coherence will be demonstrated through the development of a portfolio and reflective writings.

\section{ADVANCED PLACEMENT STUDIO ART}

Grades: 11-12 - OHS - One Year Course - Prerequisite: ART I and ART II and/or Advanced Art, or consent of instructor based on portfolio review

This course is designed for the college bound student who is interested in developing a comprehensive Visual Arts portfolio, consisting of the following three sections which demonstrate his ability to work at a college level. Section A will reflect the student's ability to do original art works and the understanding of quality slides. Section B contains up to twelve twenty (20) slides showing depth of commitment to a specific visual idea or mode of working. Section C contains twelve twenty (20) slides showing breadth of visual competencies in drawing, color, theory, design, and sculpture. Students passing the Advanced Placement test will receive college credits.

\section{ARTS ALIVE}

Grades: 9-12 - LPHS - One Year Course

Arts Alive is a multi-media hands-on Art course designed to foster students' eye-hand coordination, imagination, creativity and selfesteem. This course will include 2-dimensional basic drawing and layout skills that will lead to successful. 3-dimensional sculpture/ceramics. Students will participate in a wide range of experiences from drawings, paintings, ceramics, sculpture, prints,

Revised 1/2011 scrap books, poetry, music, model making, and video production. All units/projects are designed to build artistic and creative confidence... thus ARTS ALIVE! After completing Arts Alive, students would be able to enroll in Art I. This course does not meet CSU/UC entrance requirements.

\section{CERAMICS/SCULPTURE}

\section{Grades: 9-12 - LPHS-OHS - One Year Course}

Recommended: Art I

This course is a technical and aesthetic exploration of 3-dimensional design through the mediums of clay, metal, glass, stone, wood, plastic, and fiber. The course will also include 2-dimensional basic drawing and layout skills. The student will participate in a wide range of experiences using additive or subtractive sculpture techniques, designed to build artistic and creative confidence. The products created in this course may serve as functional items or fine art works.

\section{ADVANCED CERAMICS/SCULPTURE}

Grades: 10-12- OHS - One Year Course

Prerequisite: Grade of B" or better in Ceramics/Sculpture or consent of instructor based on portfolio review

Advanced Ceramics and Sculpture is a course offering the serious visual art student a way to expand upon his/her creative expression, aesthetic valluing, perceptions, and historical and cultural context. Particular attention is given to student recognition and application of the relationships of the visual arts toward various ways the arts are used to create expressive communications.

\section{PHOTOGRAPHY I}

Grades: 11-12 - LPHS - One Year Course

Grades: 10-12 - OHS - One Year Course

This course is an introductory black and white photography course. This course will provide students with opportunities to extend their knowledge and skills in the field of photography. This course will familiarize the student with photographic equipment, materials, methods, and processes. Students will compile enough work to demonstrate their abilities through the use of a portfolio which can be used for college entrance or employment in a visual art field. Note: Students at LPHS will also be introduced to computer technology and digital photography. Note: This course is articulated for college credits at Butte College.

\section{Digitai Photography I}

Grades: 11-12 - LPHS - One Year Course

Grades: 10-12 - OHS - One Year Course

Credits: VAPA@ LPHS and CTE @ OHS

Introduction of the fundamental concepts and skills necessary to create, edit, store, manipulate, and print digital photographic images. Units include the History of Photography, Photography as Communication and Art, Composition Guidelines, Color Basics, How to Critique Photographs, Camera Technology, Scanners, Apple computers, Digital Imaging Software, and Integrated Projects which reinforce each unit. Most lessons are integrated within projects that utilize digital cameras, software, historical and artistic perceptions.

Digital Photography II (Graphic Arts)

Grades: 11-12 - LPHS - One Year Course

Grades: 10-12 - OHS - One Year Course

Credits: VAPA @ LPHS and CTE @ OHS

Pre-requisites: Completion of Digital Photography I.

Continuing examination of the concepts and techniques necessary to create, edit and store digital photographic images. Units include color theory, composition, image manipulation utilizing the artistic innovations and styles of several 20th Century European artists. Digital color printing options, CD-ROM storage, image compression for email and website use, as well as development of personal expression will be further explored using the technological tools available and/or developed. Projects overlap in order to integrate camera and software use. All students are encouraged to submit printed photographs into the Silver Dollar Fair photography contest in conjunction with the LPHS Industrial Technology booth. Printing paid by photography class budget or other funding sources. Other community exhibits and contests may be available for students to participate in. 
PHOTOGRAPHY II

Grades: 11-12 - OHS - One Year Course

Prerequisite: Photography I

Photography II is an advanced photography course. This course will provide students with opportunities to extend and advance their knowledge and skills in the field of photography and videography. This course will familiarize the student with advanced photographic equipment, materials, methods and processes. It will also require the student to produce digital images and video productions using computers. Note: This course is articulated for college credits at Butte College.

\section{BEGINNING BAND}

Grades: 9-12 - LPHS-OHS - One Year Course

Prerequisite: Director permission, own instrument or availability of school instrument

Individuals in this band learn music reading and instrumental performance at the novice level. In addition to the technical and musical skills needed for performing, the students learn theory and history appropriate to this level. This course offers students the foundation and skills necessary to progress to Intermediate Band.

\section{INTERMEDIATE BAND}

\section{Grades: 9-12 - LPHS - One Year Course}

Prerequisite: Recommendation of $8^{\text {th }}$ grade teacher of director Individuals in this band perform music appropriate for young high school musicians. This includes methods designed for this purpose and band music. In addition to the technical and musical skills needed for performing, the students learn theory and history appropriate to this level. This course offers students the foundation and skills necessary to progress to Honors Advanced Band. In addition to this curriculum, this band performs as part of the larger LP/O Marching Band. Performances and extra curricular practices are scheduled throughout the year as required by the band director. The course may be repeated for additional credit. Band Camp, a forty (40) hour sequence offered before the start of school, merits 2.5 elective credits for Intermediate Band. Conditions for earning credits are established by the band director.

\section{HONORS ADVANCED BAND}

Grades: 11-12 ( $9^{\mathrm{TH}}$ and $10^{\text {th }}$ by audition) - LPHS-OHS - One Year Course - Prerequisite: Previous band experience and instructor permission

This band course is designed for the most advanced instrumentalists. Although not strictly limited to, it is recommended for upperclassmen and other accomplished musicians. It performs music of collegiate level at collegiate levels of competence. Along with the most advanced technical and musical skills, students are expected to learn music theory and history appropriate to this level. Solos, small ensembles and auditions for local and/or state honor groups may be expected. This group also performs as part of the larger LP/O Marching Band. Performances and extracurricular practices are scheduled throughout the year as required by the director. This course may be repeated for additional credit. Band Camp is a 40 hour sequence of instruction before the start of school, which merits 2.5 elective credits for wind ensemble members. Conditions for earning the credits are established by the band director.

\section{BAND - PERCUSSION ENSEMBLE}

\section{Grades: 9-12 - LPHS - One Year Course}

Prerequisite: Recommendation of $8^{\text {th }}$ grade teacher of director Students in this course learn techniques and perform percussion ensemble music both as part of the larger LP/O Marching Band and concert band, and as part of a unique Percussion Ensemble. In addition to performing on a wide variety of percussion instruments the students will learn the theory and history of the music performed. Performances and extra curricular practices are scheduled as needed by the band director. The course may be repeated for additional credit. This course may be offered in the same section as, other band courses. Band Camp, a 40 hour sequence of instruction merits 2.5 elective credits for percussionists. Conditions for earning credits are established by the Band Director.

\section{ACOUSTIC GUITAR}

Grades: 9-12 - LPHS-OHS- One Year Course

This is an entry level course in acoustic guitar. Students learn proper technique for playing the guitar. This includes reading tablature and music, chord progressions (rock/blues/country/classical), rhythms, arpeggios, along with various techniques of strumming and picking. Included in the course is basic music theory, how to tune the guitar, care and maintenance, etc. This course does not use amplification or provide instruction for bass guitar. The school provides some instruments; however, the students are encouraged to have their own guitars. This course does not meet CSU/UC entrance requirements.

\section{DRAMA}

\section{Grades: 9 -12 - OHS - One Year Course}

This class provides students with experience in basic drama techniques through games, improvisation, pantomime, lip sync, vocal exercises, storytelling, self-directed scenes, and formal acting in scenes from classical and contemporary literature and plays. From these dramatic exercises and written examinations, students will gain an appreciation for the theatre, its history and influence in their lives. They will gain knowledge about the power and influence of the media so they can think for themselves and make constructive criticisms and judgments about the films, programs and plays to which they listen and view. This class may not be repeated.

\section{FOREIGN LANGUAGE}

\section{SPANISH I}

Grades: 9-12 - LPHS-OHS - One Year Course

This course is designed primarily for the non-native speaker of Spanish. It is designed to facilitate the acquisition of the target language by using the most current teaching techniques. The pace of the class and manner of instruction of the material is designed exclusively for the needs of the non-native speaker. The course will emphasize receptive and productive language skills using reading, writing, listening and speaking activities. The course will include, but not be limited to the following topics of study: Salutations; Friends; Family; School; Home; Community; Travel; Leisure Activities; Clothing; Stores; Animals; Time; Weather; Celebrations; Restaurant; Food; Geography; Health; and Environment.

\section{SPANISH II}

Grades: 10-12 - LPHS-OHS - One Year Course

Prerequisite: Grade of "C" or better in Spanish I

This course is designed primarily for the non-native speaker of Spanish. It is designed to facilitate the acquisition of the target language by using the most current teaching techniques. The pace of the class and manner of instruction of the material is designed exclusively for the needs of the non-native speaker. The course will emphasize receptive and productive language skills using reading, writing, listening and speaking activities. The course will include, but is not be limited to: reinforcement and expansion upon the content and skills acquired in level one; advanced study of linguistic structures to enhance communication; exploration of the literature of the target language; and further study of the target cultures.

\section{ADVANCED SPANISH}

\section{Grades: 11-12 - LPHS-OHS - One Year Course}

Prerequisite: Grade of "C" or better in Spanish II

This course is designed primarily for the non-native or native speaker of French or Spanish. Teachers will use a variety of techniques to further develop the students' abilities in and knowledge of the target language. The course will emphasize receptive and productive language skills using reading, writing, listening and speaking activities. The course will include, but is not be limited to: reinforcement and expansion upon the content and skills acquired in levels one and two; advanced study of linguistic structures to enhance communication; further exploration of the literature of the target language; and Increased study of the target cultures.

\section{AP SPANISH LANGUAGE}

Grades: 11-12 - LPHS-OHS - One Year Course

Prerequisite: Grade of "C" of better in Advanced Spanish

This course is designed to further develop student's communicative abilities in Spanish. The course will emphasize the use of Spanish for active communication including listening, reading, speaking, and writing activities in preparation for the AP Spanish Language exam. Teachers will use a variety of techniques to further develop the students' abilities in the knowledge of the target language. The primary course emphases will include, but not be limited to: 1) 
Reinforcement of students' comprehension of formal and informal spoken Spanish; 2) Acquisition of vocabulary and linguistic structures to facilitate the easy, accurate reading of newspaper and magazine articles as well as modern literature; 3) Composition of expository passages; 4) Oral expression of ideas; and, 5) increased study of the target culture.

\section{AP SPANISH LITERATURE}

Grade: 12 - OHS - One Year Course

Prerequisite: Grade of "C" or better in AP Spanish Language, Score of 3 or more on the AP Spanish Language Exam, or teacher recommendation

The AP Spanish Literature course is intended to be the equivalent of a third-year college Introduction to Latin American or Peninsular Literature course, covering selected works from the literatures of Spain and Spanish America. Students will read and analyze literature orally and in writing.

\section{NON-DEPARTMENTAL}

\section{ROP DIGITAL PHOTOGRAPHY}

Grades: 10-12 - OHS - One Year - 1 Period

Besides learning the art of photography, students will also learn the mechanics necessary to be successful in this industry. Topics include graphic arts, studio portraiture, landscapes and digital photograph manipulation. Students will be able to link photography to other art forms and understand its application to careers. This class meets at Oroville High School $2^{\text {nd }}$ and $3^{\text {rd }}$ periods. NOTE: Butte College credits may be earned upon successful completion of this course. This course meets the Visual/Performing Arts requirement for entrance into the University of California and OUHSD as a Visual/Performing Arts graduation requirement.

\section{ASSOCIATED STUDENT BODY LEADERSHIP \\ Grades: 10-12 - LPHS-OHS - One Year Course \\ Prerequisite: $2.0 \mathrm{GPA}$}

This course will provide students opportunities to develop their personal and career goals, advance communication and teamwork skills, and to build their personal leadership style. Emphasis will be placed upon completing assigned tasks, learning to function both as a team leader and committee member, and developing and using time management and organizational skills. Students will be expected to participate in student organizations such as Associated Student Body, FHA/HERO, VICA, FFA, FBLA, MEChA, or other.

\section{HEALTHIDRIVER EDUCATION}

Grade: 9 - LPHS-OHS - Semester Course

Health is a semester course taken in Grade 9, in which a student must earn a passing grade in order to meet graduation requirements. Information will be presented pertinent to the concerns of teens in the areas of physical development, nutrition, fitness, drugs and substance abuse, and driver's education. The course concludes with information on human reproduction, family living, dating, values and the sexually transmitted diseases. The second quarter of this course deals with the classroom instruction related to obtain and DMV driving permit. Each student that satisfactorily completes the course will receive a pink slip that authorizes them to obtain the driving permit.

\section{LEP SUPPORT}

Grades: 9-12 - LPHS - One Year Course

LEP Support is a course for all LEP and FEP students who need additional support in core courses. Students will develop their skills in cognitive academic language skills, as well as effective scholastic habits. Students will develop their academic English competency through writing, project-based work, and direct teaching of grammar, vocabulary and style. Students will be assisted in the development of effective academic habits through monitored journals and academic calendars.

\section{STUDY SKILLS}

Grades: 9-12- LPHS - One Year Course

(Special Education Only)

Study Skills is a one-year course designed to provide an understanding of the study skills necessary to ensure academic success in secondary school and beyond. Emphasis is placed on awareness of strengths and deficits, learning styles, reading

Revised 1/2011 strategies, test taking techniques, organizational skills, and career awareness. It also contains information and assistance with remediation for the California High School Exit Exam.

\section{CAFETERIA AIDE}

LPHS-OHS - One Semester (Grades 9-12 earn 2.5 credits for work during break or lunch) (9-12 earn 5 credits if they work during a regular scheduled class period). Student must have prior approval by cafeteria manager.

Provides experience in the care, preparation and handling of food as well as orderliness and cleanup procedures. Good attendance and the ability to make change are necessary for this class.

\section{LIBRARY AIDE}

Grades: 11-12 - LPHS-OHS - Semester Course - 2.5 Credits Prerequisite: Recommendation of librarian is requested. Grades: Pass or Fail

This course is a 2.5 credit class open to all grade levels. Students receive " $\mathrm{P}$ " or " $\mathrm{F}$ " grades. Students are required to help other students to use the library research resources and to help maintain the library collection. Students will be taught to use a variety of resources including computerized data bases, video recording, the Xerox machines, and a variety of computer programs. Students are expected to demonstrate their ability to use library resources by completing a variety of projects.

\section{OFFICE AIDE}

Grades: 11-12 - LPHS-OHS - One Year Course -2.5 Credits each semester - Prerequisite: Students must have good attendance, a courteous attitude and prior approval to work in the in the various offices.

Students working under the direct supervision of an office secretary, applying advanced clerical skills, receptionist, and use of office equipment. Provides experience in filing, typing, use of phones and copy machine. Work varies according to which office the student is assigned, (Counseling, Attendance, Student Store, Principal's Office, ASB/Athletics). All offices use students as "runners" to deliver call slips, messages, homework requests, etc. to classrooms.

\section{TEACHER'S AIDE}

Grades: 11-12 - OHS - One Semester 2.5 Credits Prerequisite: See individual teachers for approval.

Provides students with varied work related activities.

\section{YEARBOOK}

Grades: 10-12 - LPHS-OHS - One Year Course

Prerequisite: Teacher recommendation and/or Application/Interview

The creation of the school annual, a documentary of each year of the high school experience, involves the recording of events, individuals, and ideas in a variety of formats. Inherent to this process is an understanding of the elements and principles of art, photography, graphic design, text, business, and organization. Yearbook is a one year course. This course may be repeated for elective credit.

\section{NOTES:}


Name

Date

COURSE PLANNING GUIDE

\begin{tabular}{|c|c|}
\hline 1.) English 9 & 1.) English 10 \\
\hline 2.) Geography-Health-Driver Education & 2.) World History \\
\hline 3.) Math & 3.) Math \\
\hline 4.) Physical Education & 4.) Physical Education \\
\hline 5.) Science & 5.) Science \\
\hline 6.) & 6.) \\
\hline $\begin{array}{l}\text { Credits Earned } \\
\text { Credits Possible } \quad 60\end{array}$ & $\begin{array}{l}\text { Credits Earned } \\
\text { Credits Possible } 120\end{array}$ \\
\hline 6.1. $1^{\text {th }}$ Grade & $12^{\mathrm{h}} \mathrm{Grade}$ \\
\hline 1.) English 11 & 1.) English 12 \\
\hline 2.) US History & 2.) Economics/Government \\
\hline 3.) & 3.) \\
\hline 4.) & 4.) \\
\hline 5.) & 5.) \\
\hline 6.) & 6.) \\
\hline $\begin{array}{l}\text { Credits Earned } \\
\text { Credits Possible } 180\end{array}$ & $\begin{array}{l}\text { Credits Earned } \\
\text { Credits Possible } \quad 240 \quad 220 \text { required for graduation }\end{array}$ \\
\hline
\end{tabular}

Revised 1/2011 


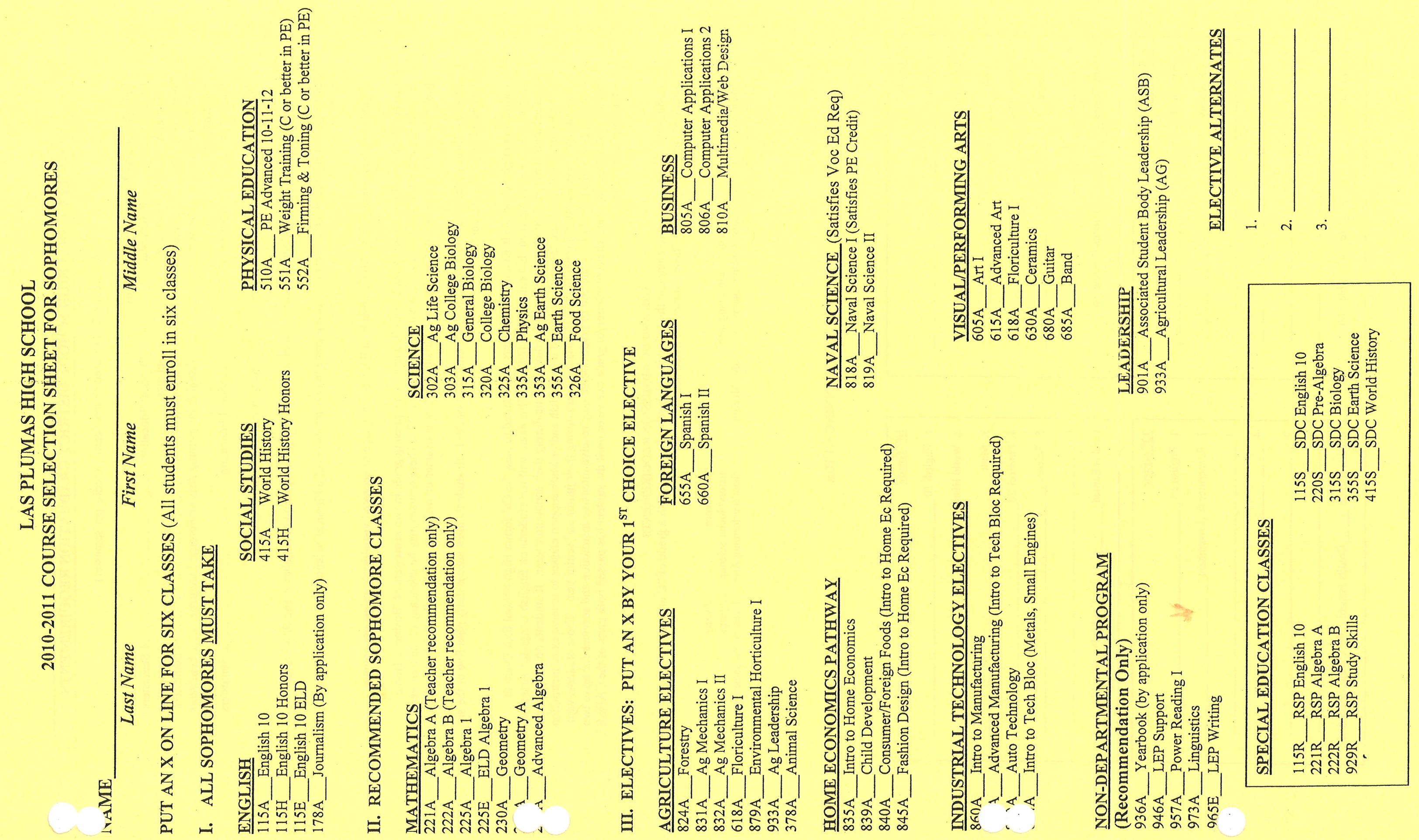




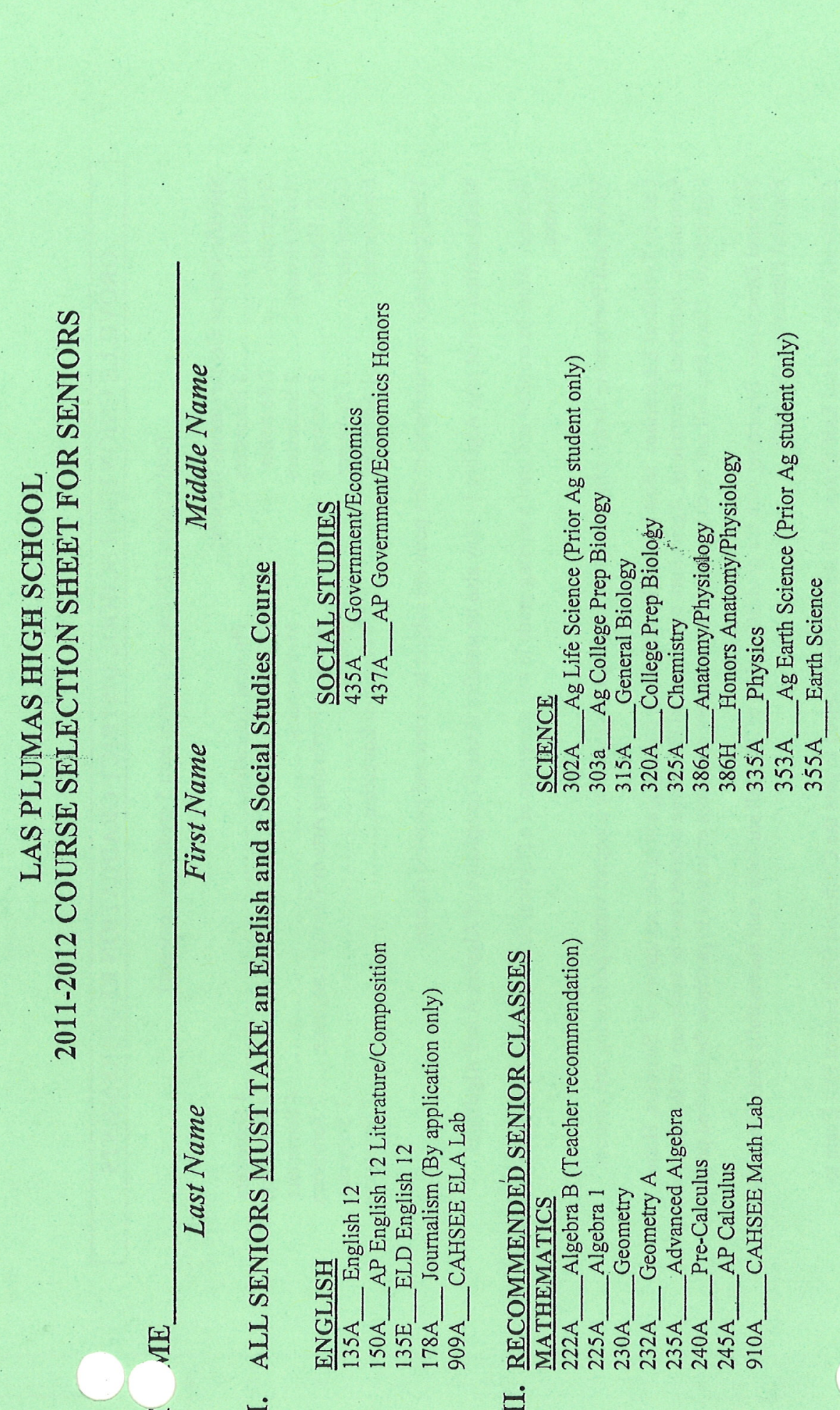

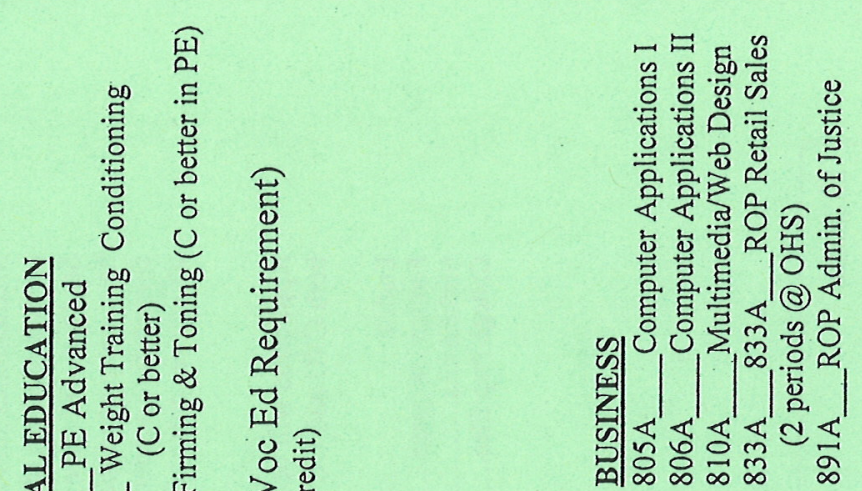

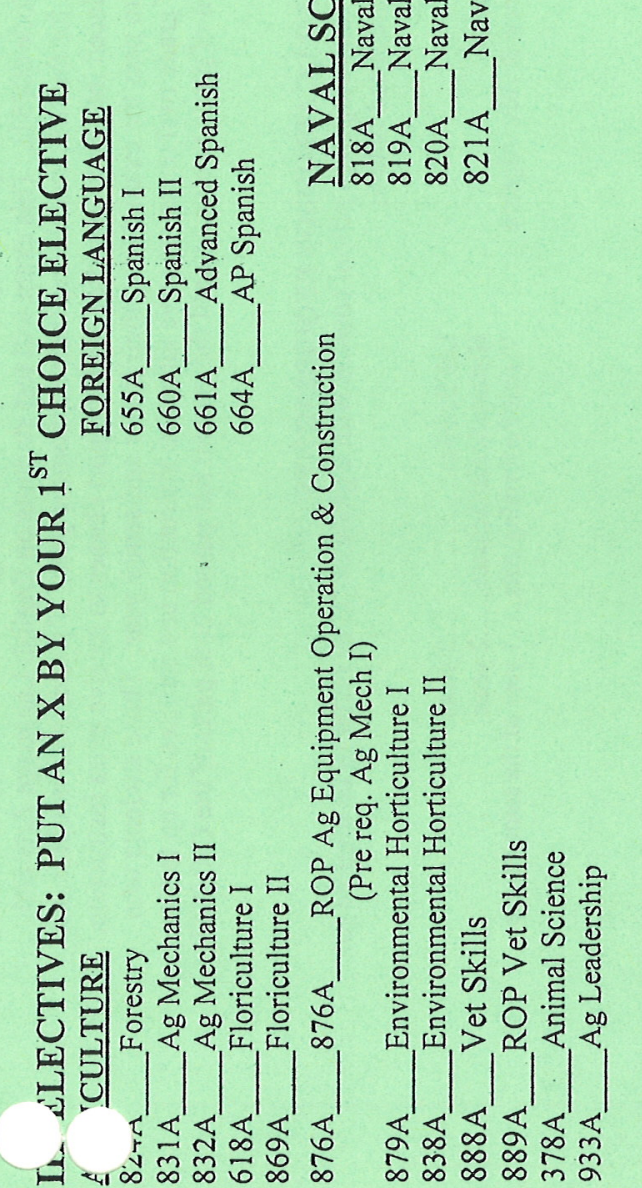

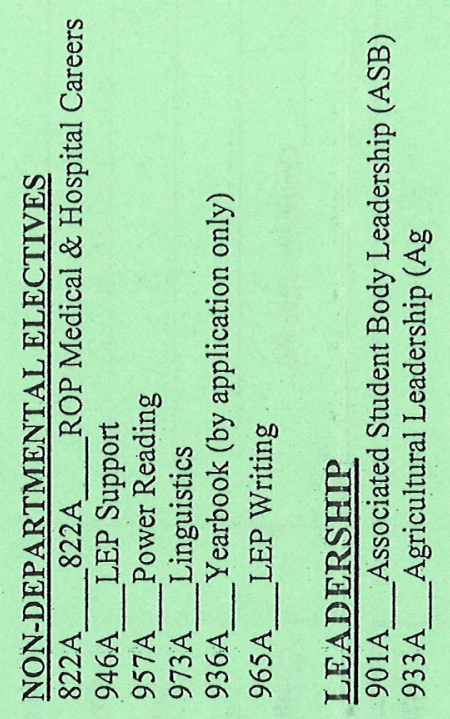
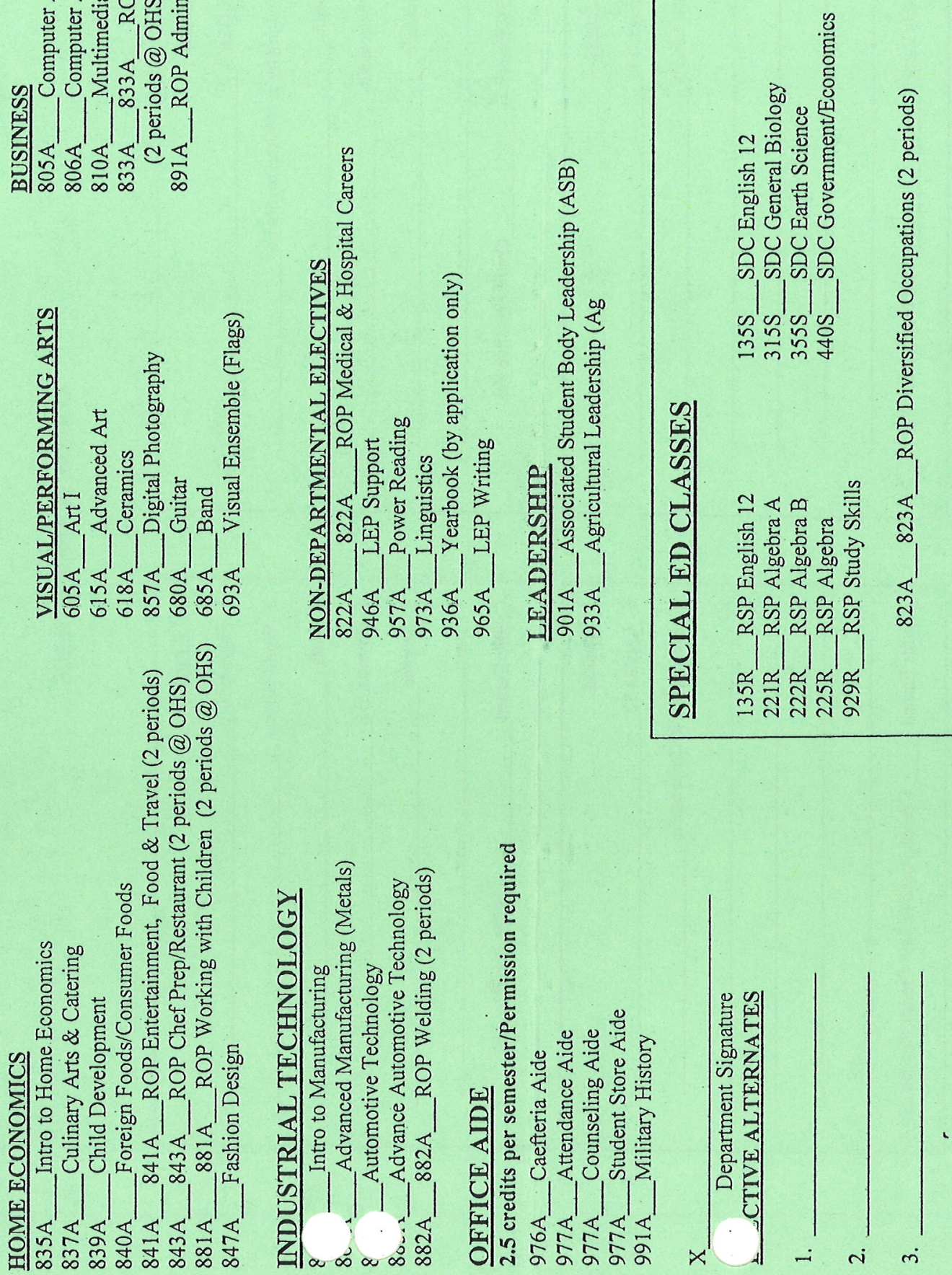

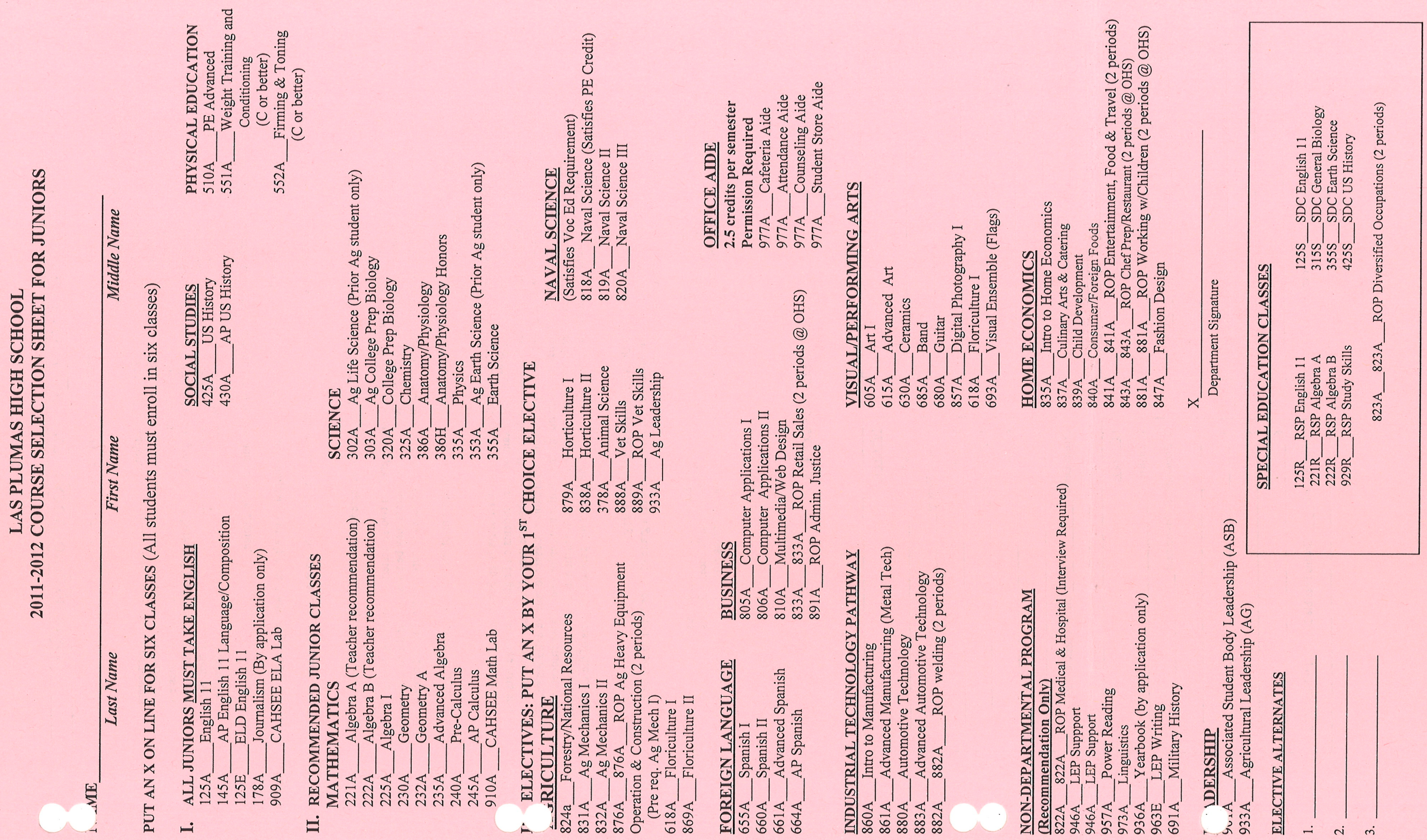

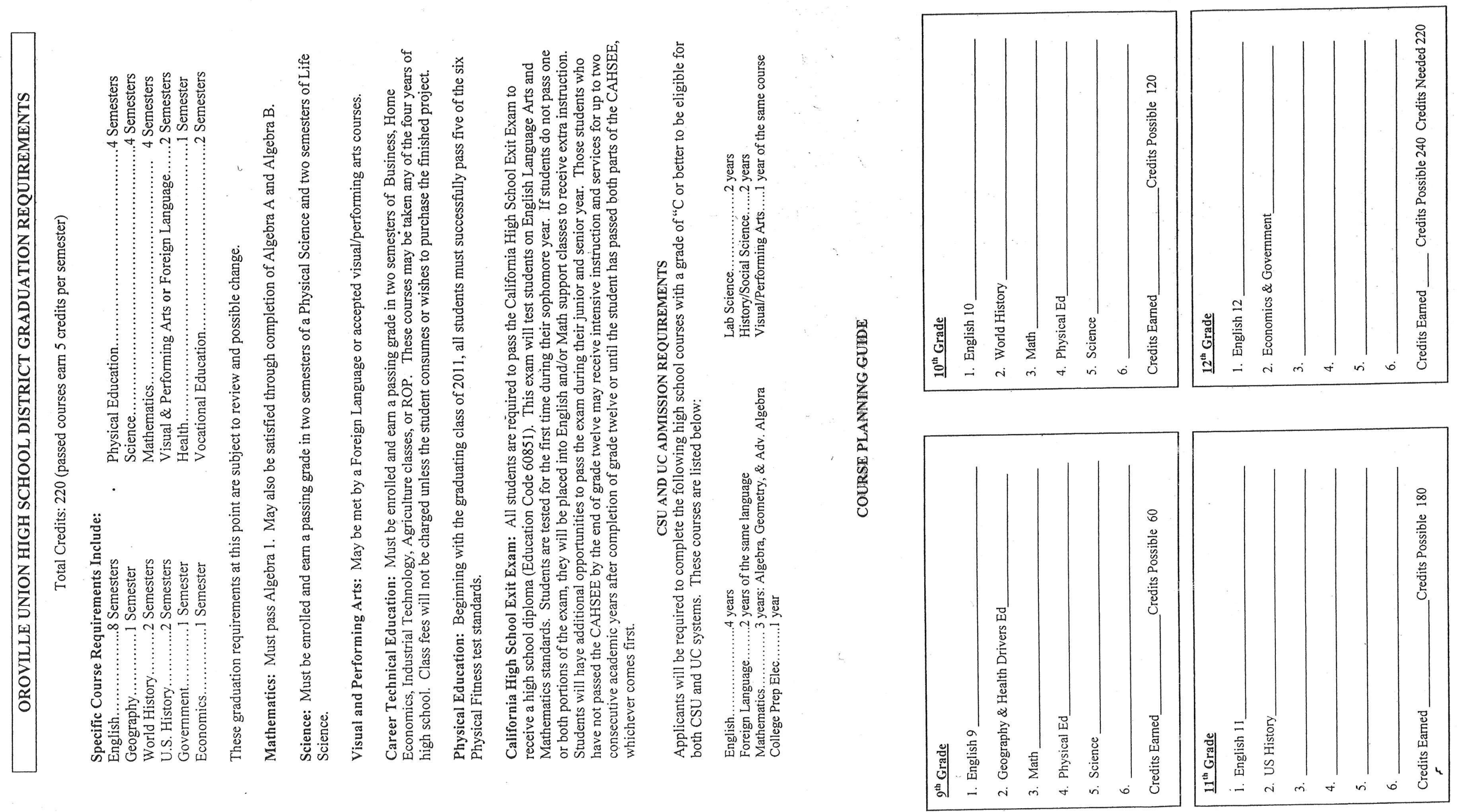


\section{Las Plumas High School Course Pathways}

Industry certificates are an important component of the coursework completion for several specific pathways within the agriculture and natural resources sector. Students completing the Heavy Equipment ROP course offered receive an industry ROP certificate that indicates what objectives and skills that student has achieved. Horticulture II students are eligible to receive a certificate from the California Association of Nurseries and Garden Centers upon completion of the horticulture pathway. Upon acquisition of new equipment, there will be the opportunity for students to receive Quality Assurance Certificates through the California Department of Agriculture in the proper care and handling of livestock. The Agriculture Department also gives certificates to students who complete each of the Career Pathways in the program.

All courses in the agriculture department utilize the State Board of Education adopted CTE Standards as a basis for instruction. The syllabus for each agriculture class reflects the new CTE standards and frameworks. In all career pathways Las Plumas Ag Department has a 2+2 articulation with Butte Community College. This allows students to receive college credit for the agriculture course taken at Las Plumas High School. The course sequence and pathways are listed in the table below:

Course Sequence and Pathway

\begin{tabular}{|c|c|c|c|}
\hline Grade Level & $\begin{array}{c}\text { Animal Science } \\
\text { Pathway }\end{array}$ & $\begin{array}{c}\text { Ornamental } \\
\text { Horticulture } \\
\text { Pathway } \\
\text { Ag Life Science or }\end{array}$ & $\begin{array}{c}\text { Ag Mechanics } \\
\text { Pathway }\end{array}$ \\
\hline $\mathbf{9}^{\text {th }}$ & $\begin{array}{c}\text { Ag Life Science or } \\
\text { College Ag Biology } \\
\text { College Ag Biology } \\
\text { and Ag Mechanics I }\end{array}$ \\
\hline $\mathbf{1 0}^{\text {th }}$ & Ag Earth & Ag Earth & $\begin{array}{c}\text { Ag Earth and Ag } \\
\text { Mechanics II }\end{array}$ \\
\hline $1^{\text {th }}$ & Animal Science & $\begin{array}{c}\text { Floriculture I or } \\
\text { Horticulture I }\end{array}$ & $\begin{array}{c}\text { Ag ROP Heavy } \\
\text { Equipment \& } \\
\text { Construction }\end{array}$ \\
\hline $\mathbf{1 2}^{\text {th }}$ & Ag ROP Vet Skills & $\begin{array}{c}\text { Floriculture II or } \\
\text { Horticulture II } \\
\text { Ag ROP Heavy } \\
\text { Equipment \& } \\
\text { Construction }\end{array}$ \\
\hline
\end{tabular}




\section{Oroville Union High School District Science Curriculum \\ Science - College Agricultural Biology}

\section{College Agricultural Biology}

COURSE TITLE: Agricultural Biology

LENGTH OF COURSE: One Year

TYPE OF CREDIT: Lab Science (10 credits, UC)

GRADE LEVEL: 9-12 (9th Approval of instructor)

PREREQUISITES:

Students must be enrolled in Algebra A or higher. Exceptions must be made by approval of the instructor.

\section{TEXTBOOK:}

Biology Principles and Explorations, Holt, Rinehart, and Winston, 2001, ISBN 0-03-051999-3

SUPPLEMENTAL MATERIALS:

Biology Visualizing Life; Holt, Rinehart, and Winston, 1994, ISBN 0-03-053817-3

The Science of Agriculture: A Biological Approach, Herren \& Ray, Delmar Publishers, 1996, ISBN 0$8273-5811-3$

COURSE DESCRIPTION:

Agricultural Biology is a one-year laboratory science course designed for the college-bound student with career interests in agriculture. Using agriculture as the learning vehicle, the course emphasizes the biological principles and central concepts. The course centers on an extensive laboratory component to connect the principles of life science with agricultural applications, other curricular areas and other scientific disciplines. This course meets the Life Science laboratory "D" requirements for entrance into the University of California and California State University systems. A grade of "B" or better will qualify the student for U.C. Credit.

NOTE: Standards that all students are expected to achieve in the course of their studies are unmarked. Standards that all students should have the opportunity to learn are marked with an asterisk (*).

BOARD ADOPTION DATE: June 20, 2001

\section{Scientific Method}

To ask meaningful questions and conduct careful investigations (California Star Earth Science Blueprint: 9 Test Items, $15 \%$ of Test) 


\section{Investigation and Experimentation}

The learner will be able to a) select and use appropriate tools and technology to perform tests, collect, and display data, b) identify and communicate sources of unavoidable experimental error, $c$ ) identify possible reasons for inconsistent results, d) formulate explanations using logic and evidence, e) distinguish between hypothesis and theory as scientific terms, f) read and interpret topographic and geographic maps, and g) analyze the locations, sequences or time intervals that are characteristic of the succession of species in an ecosystem.

$\begin{array}{lll}\text { Strand } & \text { Scope } & \text { Source } \\ \text { Science } & \text { Master } & \text { Oroville Union High School District(a) }\end{array}$

Unit Instructional Resources

- Biology Principles \& Explorations, Holt, Rinehart and Winston, 2001, Chapters 1-44 [Textbook].

\section{Cell Biology}

The fundamental life processes of plants and animals depend on a variety of chemical reactions that occur in specialized areas of the organism's cells. (California Star Biology/Life Science Science Blueprint: 9 Test Items, $15 \%$ of Test)

\section{Cell Membranes}

The learner will be able to understand that cells are enclosed within semipermeable membranes that regulate their interaction with their surroundings .

\section{Strand Scope Source}

Cell Biology Master CA: Science Content Standards, December 1998, Grades 9-12, Biology/Life Sciences, 1.a.

\section{Instructional Resources}

- Biology Visualizing Life, Holt, Hinehart, and Winston, 1994, Chapter 3 (45). [Textbook].

- Modern Livestock \& Poultry Production, Delmar, Sixth, 2002, Unit 9 (203). [Textbook].

- Biology Principles \& Explorations, Holt, Rinehart and Winston, 2001, Ch 3-5 (59-60, 74-91). [Textbook].

\section{Functions of Enzymes}

The learner will be able to understand that enzymes are proteins that catalyze biochemical reactions without altering the reaction equilibrium and the activities of enzymes depend on the temperature, ionic conditions, and the pH of the surroundings.

\section{Strand Scope Source}

Cell Biology Master CA: Science Content Standards, December 1998, Grades 9-12, Biology/Life Sciences, 1.b.

\section{Instructional Resources}

- Biology Visualizing Life, Holt, Hinehart, and Winston, 1994, Chapters 1 (37) and 5 (91-93). [Textbook].

- Biology Principles \& Explorations, Holt, Rinehart and Winston, 2001, Ch 3-4 (40-47). [Textbook].

\section{Differences in Cell Structure}

The learner will be able to understand how prokaryotic cells, eukaryotic cells (including those from plants and animals), and viruses differ in complexity and general structure .

\section{Strand Scope Source}

Cell Biology Master CA: Science Content Standards, December 1998, Grades 9-12, Biology/Life Sciences, 1.c.

\section{Instructional Resources}

- Biology Visualizing Life, Holt, Hinehart, and Winston, 1994, Chapter 3. [Textbook].

- Biology Principles \& Explorations, Holt, Rinehart and Winston, 2001, Ch 3-4 (57-58, 61-71, 452-457). [Textbook].

\section{Transcription \&Translation of Protei}


The learner will be able to understand the central dogma of molecular biology outlines the flow of information from transcription of ribonucleic acid (RNA) in the nucleus to translation of proteins on ribosomes in the cytoplasm.

Strand Scope Source

Cell Biology Master CA: Science Content Standards, December 1998, Grades 9-12, Biology/Life Sciences, 1.d.

Instructional Resources

- Biology Visualizing Life, Holt, Hinehart, and Winston, 1994, Chapters 3 (56-60) and 7 (138 and 141-142). [Textbook].

\section{Endoplasmic Reticulum \& Golgi Appara}

The learner will be able to understand the role of the endoplasmic reticulum and Golgi apparatus in the secretion of proteins.

Strand Scope Source

Cell Biology Master CA: Science Content Standards, December 1998, Grades 9-12, Biology/Life Sciences, 1.e.

Instructional Resources

- Biology Visualizing Life, Holt, Hinehart, and Winston, 1994, Chapter 3 (59). [Textbook].

- Biology Principles \& Explorations, Holt, Rinehart and Winston, 2001, Ch 3 (62-63). [Textbook].

\section{Photosynthesis}

The learner will be able to understand that usable energy is captured from sunlight by chloroplasts and is stored through the synthesis of sugar from carbon dioxide.

\section{Strand Scope Source}

Cell Biology Master CA: Science Content Standards, December 1998, Grades 9-12, Biology/Life Sciences, 1.f.

\section{Instructional Resources}

- Biology Visualizing Life, Holt, Hinehart, and Winston, 1994, Chapter 5 (96-101). [Textbook].

- Biology Principles \& Explorations, Holt, Rinehart and Winston, 2001, Ch 3, 5 (65-66, 104-107, 112, 114-115). [Textbook].

\section{Functions of the Mitochondrion}

The learner will be able to understand the role of the mitochondria in making stored chemical-bond energy available to cells by completing the breakdown of glucose to carbon dioxide .

\section{Strand Scope Source}

Cell Biology Master CA: Science Content Standards, December 1998, Grades 9-12, Biology/Life Sciences, 1.g.

\section{Instructional Resources}

- Biology Visualizing Life, Holt, Hinehart, and Winston, 1994, Chapter 3 (58). [Textbook].

- Biology Principles \& Explorations, Holt, Rinehart and Winston, 2001, Ch 3,5 (64, 104-107, 112, 114-115). [Textbook].

\section{Macromolecules}

The learner will be able to understand that most macromolecules (polysaccharides, nucleic acids, proteins, lipids) in cells and organisms are synthesized from a small collection of simple precursors .

\section{Strand Scope Source}

Cell Biology Master CA: Science Content Standards, December 1998, Grades 9-12, Biology/Life Sciences, 1.h.

Instructional Resources

- Biology Visualizing Life, Holt, Hinehart, and Winston, 1994, Chapter 2 (33 and 38). [Textbook].

\section{* Chemiosmotic Gradients}

The learner will be able to understand how chemiosmotic gradients in the mitochondria and chloroplast store energy for ATP production. 


\author{
Strand Scope Source \\ Cell Biology Master CA: Science Content Standards, December 1998, Grades 9-12, Biology/Life Sciences, 1.i*. \\ * Eukaryotic Cell Structure \\ The learner will be able to understand how eukaryotic cells are given shape and internal \\ organization by a cytoskeleton or cell wall or both . \\ Strand Scope Source \\ Cell Biology Master CA: Science Content Standards, December 1998, Grades 9-12, Biology/Life Sciences, 1.j*. \\ Instructional Resources \\ - Biology Visualizing Life, Holt, Hinehart, and Winston, 1994, Chapter 3 (56-60). [Textbook]. \\ - Modern Livestock \& Poultry Production, Delmar, Sixth, 2002, Unit 9 (203). [Textbook].
}

\title{
Genetic Variation
}

Mutation and sexual reproduction lead to genetic variation in a population. (California Star Biology/Life Science Science Blueprint: 7 Test Items, $12 \%$ of Test)

\section{Meiosis}

The learner will be able to understand that meiosis is an early step in sexual reproduction in which the pairs of chromosomes separate and segregate randomly during cell division to produce gametes containing one chromosome of each type.

\author{
Strand Scope Source \\ Genetics Master CA: Science Content Standards, December 1998, Grades 9-12, Biology/Life Sciences, 2.a. \\ Instructional Resources \\ - Biology Visualizing Life, Holt, Hinehart, and Winston, 1994, Chapter 6 (123-126). [Textbook]. \\ - Modern Livestock \& Poultry Production, Delmar, Sixth, 2002, Unit 9 (204-207). [Textbook]. \\ - Biology Principles \& Explorations, Holt, Rinehart and Winston, 2001, Ch 7 (142-147, 153-157). [Textbook].
}

\section{Multicellular Process and Meiosis}

The learner will be able to understand that only certain cells in a multicellular organism undergo meiosis.

\author{
Strand Scope Source \\ Genetics Master CA: Science Content Standards, December 1998, Grades 9-12, Biology/Life Sciences, 2.b. \\ Instructional Resources \\ - Biology Visualizing Life, Holt, Hinehart, and Winston, 1994, Chapter 6 (123-126). [Textbook]. \\ - Biology Principles \& Explorations, Holt, Rinehart and Winston, 2001, Ch 7 (146-147, 154-157). [Textbook].
}

\section{Random Chromosome Segregation}

The learner will be able to understand how random chromosome segregation explains the probability that a particular allele will be in a gamete .

\section{Strand Scope Source}

Genetics Master CA: Science Content Standards, December 1998, Grades 9-12, Biology/Life Sciences, 2.c.

\section{Instructional Resources}

- Biology Visualizing Life, Holt, Hinehart, and Winston, 1994, Chapter 6 (119-123). [Textbook].

- Modern Livestock \& Poultry Production, Delmar, Sixth, 2002, Unit 9 (203-209). [Textbook].

- Biology Principles \& Explorations, Holt, Rinehart and Winston, 2001, Chapter 7-8 (142-145, 1153, 156-157, 162 163). [Textbook].

\section{Fertilization}


The learner will be able to understand that new combinations of alleles may be generated in a zygote through the fusion of male and female gametes (fertilization).

Strand Scope Source

Genetics Master CA: Science Content Standards, December 1998, Grades 9-12, Biology/Life Sciences, 2.d.

Instructional Resources

- Biology Visualizing Life, Holt, Hinehart, and Winston, 1994, Chapter 6 (124). [Textbook].

- Modern Livestock \& Poultry Production, Delmar, Sixth, 2002, Unit 9 (207). [Textbook].

\section{Organisms DNA Sequence}

The learner will be able to understand why approximately half of an individual's DNA sequence comes from each parent.

Strand Scope Source

Genetics Master CA: Science Content Standards, December 1998, Grades 9-12, Biology/Life Sciences, 2.e.

Instructional Resources

- Biology Visualizing Life, Holt, Hinehart, and Winston, 1994, Chapter 6 (123-126). [Textbook].

- Modern Livestock \& Poultry Production, Delmar, Sixth, 2002, Unit 9 (208-210) and 11 (236-240). [Textbook].

- Biology Principles \& Explorations, Holt, Rinehart and Winston, 2001, Ch 6-7 (120-121, 142-145). [Textbook].

\section{Chromosomes and Sex Determination}

The learner will be able to understand the role of chromosomes in determining an individual's sex.

\section{Strand Scope Source}

Genetics Master CA: Science Content Standards, December 1998, Grades 9-12, Biology/Life Sciences, 2.f.

\section{Instructional Resources}

- Biology Visualizing Life, Holt, Hinehart, and Winston, 1994, Chapter 6 (123-126). [Textbook].

- Modern Livestock \& Poultry Production, Delmar, Sixth, 2002, Unit 9 (216-217). [Textbook].

- Biology Principles \& Explorations, Holt, Rinehart and Winston, 2001, Ch 6 (122). [Textbook].

\section{Predicting Genetic Makeup of Parents}

The learner will be able to understand how to predict possible combinations of alleles in a zygote from the genetic makeup of the parents .

\section{Strand Scope Source}

Genetics Master CA: Science Content Standards, December 1998, Grades 9-12, Biology/Life Sciences, 2.g.

\section{Instructional Resources}

- Modern Livestock \& Poultry Production, Delmar, Sixth, 2002, Unit 9 (210-219). [Textbook].

- Biology Principles \& Explorations, Holt, Rinehart and Winston, 2001, Ch 8-9 (164-174, 181-182, 189).

[Textbook].

\section{Phenotype and Genotype}

A multicellular organism develops from a single zygote, and its phenotype depends on its genotype, which is established at fertilization. (California Star Biology/Life Science Science Blueprint: 3 Test Items, 5\% of Test)

\section{Phenotype Prediction}

The learner will be able to understand how to predict the probable outcome of phenotypes in a genetic cross from the genotypes of the parents and mode of inheritance (autosomal or X-linked, dominant or recessive).

\section{Strand Scope Source}

Genetics Master CA: Science Content Standards, December 1998, Grades 9-12, Biology/Life Sciences, 3.a. 


\section{Instructional Resources}

- Biology Visualizing Life, Holt, Hinehart, and Winston, 1994, Chapter 6 (119-120). [Textbook].

- Modern Livestock \& Poultry Production, Delmar, Sixth, 2002, Unit 9 (208). [Textbook].

- Biology Principles \& Explorations, Holt, Rinehart and Winston, 2001, Ch 8 (173-174, 180, 184-185). [Textbook].

\section{Mendel's Law Of Segregation}

The learner will be able to understand the genetic basis for Mendel's laws of segregation and Mendel-dent assortment.

\section{Strand Scope Source}

Genetics Master CA: Science Content Standards, December 1998, Grades 9-12, Biology/Life Sciences, 3.b.

\section{Instructional Resources}

- Biology Visualizing Life, Holt, Hinehart, and Winston, 1994, Chapter 6 (117-123). [Textbook].

- Biology Principles \& Explorations, Holt, Rinehart, and Winston, 1996, Unit 9 (200). [Textbook].

- Biology Principles \& Explorations, Holt, Rinehart and Winston, 2001, Ch 8 (164-167). [Textbook].

\section{* Pedigree Evaluation}

The learner will be able to understand how to predict the probable mode of inheritance from a pedigree diagram showing phenotypes .

\section{Strand Scope Source}

Genetics Master CA: Science Content Standards, December 1998, Grades 9-12, Biology/Life Sciences, 3.c.

\section{Instructional Resources}

- Modern Livestock \& Poultry Production, Delmar, Sixth, 2002, Unit 14 (293) and 31 (656). [Textbook].

\section{* Interpreting Genetic Information}

The learner will be able to understand how to use data on frequency of recombination at meiosis to estimate genetic distances between loci and to interpret genetic maps of chromosomes .

\section{Strand Scope Source}

Genetics Master CA: Science Content Standards, December 1998, Grades 9-12, Biology/Life Sciences, 3.d.

\section{Instructional Resources}

- Biology Visualizing Life, Holt, Hinehart, and Winston, 1994, Chapter . [Textbook] [Textbook].

\section{Genes}

Genes are a set of instructions encoded in the DNA sequence of each organism that specify the sequence of amino acids in proteins characteristic of that organism. (California Star Biology/Life Science Science Blueprint: 4 Test Items, $7 \%$ of Test)

\section{Protein Synthesis by Ribosomes}

The learner will be able to understand the general pathway by which ribosomes synthesize proteins using $t R N A$ s to translate genetic information in $m R N A$.

\section{Strand Scope Source}

Genetics Master CA: Science Content Standards, December 1998, Grades 9-12, Biology/Life Sciences, 4.a.

\section{Instructional Resources}

- Biology Visualizing Life, Holt, Hinehart, and Winston, 1994, Chapter 7 (142, 145 and 154-155). [Textbook].

- Biology Principles \& Explorations, Holt, Rinehart and Winston, 2001, Ch 10 (206-212). [Textbook].

\section{Genetic Coding Rules}

The learner will be able to understand how to apply the genetic coding rules to predict the sequence of amino acids from a sequence of codons in RNA. 
$\begin{array}{ll}\text { Strand } & \text { Scope Source } \\ \text { Genetics } & \text { Master CA: Science Content Standards, December 1998, Grades 9-12, Biology/Life Sciences, 4.b. }\end{array}$

\section{Instructional Resources}

- Biology Visualizing Life, Holt, Hinehart, and Winston, 1994, Chapter 7 (143). [Textbook].

- Modern Livestock \& Poultry Production, Delmar, Sixth, 2002, Unit 9 (208-210). [Textbook].

- Biology Principles \& Explorations, Holt, Rinehart and Winston, 2001, Ch 10 (209-212, 222-223). [Textbook].

\section{Mutations in DNA}

The learner will be able to understand how mutations in the DNA sequence of a gene may or may not affect the expression of the gene or the sequence of amino acids in an encoded protein .

\section{Strand Scope Source}

Genetics Master CA: Science Content Standards, December 1998, Grades 9-12, Biology/Life Sciences, 4.c.

\section{Instructional Resources}

- Biology Visualizing Life, Holt, Hinehart, and Winston, 1994, Chapter 7 (140). [Textbook].

- Biology Principles \& Explorations, Holt, Rinehart and Winston, 2001, Ch 10 (217-220, 221-223). [Textbook].

\section{Specialization of Cells}

The learner will be able to understand the specialization of cells in multicellular organisms is usually due to different patterns of gene expression rather than to differences of the genes themselves.

\section{Strand Scope Source}

Genetics Master CA: Science Content Standards, December 1998, Grades 9-12, Biology/Life Sciences, 4.d.

\section{Instructional Resources}

- Biology Visualizing Life, Holt, Hinehart, and Winston, 1994, Chapter 7 (141-150). [Textbook].

- Biology Principles \& Explorations, Holt, Rinehart and Winston, 2001, Ch 10, 20, 32 (206-218, 437, 724-725). [Textbook].

\section{Protein Differentiations}

The learner will be able to understand that proteins can differ from one another in the number and sequence of amino acids .

\section{Strand Scope Source}

Genetics Master CA: Science Content Standards, December 1998, Grades 9-12, Biology/Life Sciences, 4.e.

\section{Instructional Resources}

- Biology Visualizing Life, Holt, Hinehart, and Winston, 1994, Chapter 2 (33-37) and 3 (51-57). [Textbook].

- Biology Principles \& Explorations, Holt, Rinehart and Winston, 2001, Ch 10 (206-209). [Textbook].

\section{* Protein Shapes and Chemical Properties}

The learner will be able to understand why proteins having different amino acid sequences typically have different shapes and chemical properties .

\section{Strand Scope Source}

Genetics Master CA: Science Content Standards, December 1998, Grades 9-12, Biology/Life Sciences, 4.f*.

\section{Instructional Resources}

- Biology Visualizing Life, Holt, Hinehart, and Winston, 1994, Chapter 2 (36) and 9 (183). [Textbook].

\section{Altered Cell Genetics}

The genetic composition of cells can be altered by incorporation of exogenous DNA into the cells. (California Star Biology/Life Science Science Blueprint: 5 Test Items, 8\% of Test) 


\section{DNA, RNA, \& Protein}

The learner will be able to understand the general structures and functions of DNA, RNA, and protein.

Strand Scope Source

Genetics Master CA: Science Content Standards, December 1998, Grades 9-12, Biology/Life Sciences, 5.a.

\section{Instructional Resources}

- Biology Visualizing Life, Holt, Hinehart, and Winston, 1994, Chapter 7 (136-150). [Textbook].

- Biology Principles \& Explorations, Holt, Rinehart and Winston, 2001, Ch 8, 9, 10 (181-194, 206-212). [Textbook].

\section{Copying of DNA}

The learner will be able to understand how to apply base-pairing rules to explain precise copying of $D N A$ during semiconservative replication and transcription of information from DNA into $m R N A$.

\section{Strand Scope Source}

Genetics Master CA: Science Content Standards, December 1998, Grades 9-12, Biology/Life Sciences, 5.b.

\section{Instructional Resources}

- Biology Visualizing Life, Holt, Hinehart, and Winston, 1994, Chapter 7 (140-142). [Textbook].

- Biology Principles \& Explorations, Holt, Rinehart and Winston, 2001, Ch 9-10 (195-197, 202-203, 206-212). [Textbook].

\section{Biotechnology in Agriculture}

The learner will be able to understand how genetic engineering (biotechnology) is used to produce novel biomedical and agricultural products .

\section{Strand Scope Source \\ Genetics Master CA: Science Content Standards, December 1998, Grades 9-12, Biology/Life Sciences, 5.c.}

\section{Instructional Resources}

- Biology Visualizing Life, Holt, Hinehart, and Winston, 1994, Chapter 8 (161-164). [Textbook].

- Modern Livestock \& Poultry Production, Delmar, Sixth, 2002, Unit 11 (236-250). [Textbook]

\section{* DNA Technology and Recombinant DNA}

The learner will be able to understand how basic DNA technology (restriction digestion by endonucleases, gel electrophoresis, ligation, and transformation) is used to construct recombinant DNA molecules .

\section{Strand Scope Source}

Genetics Master CA: Science Content Standards, December 1998, Grades 9-12, Biology/Life Sciences, 5.d*.

\section{Instructional Resources}

- Biology Principles \& Explorations, Holt, Rinehart and Winston, 2001, Ch 11 (237-243). [Textbook].

\section{* Altering Genetic Makeup}

The learner will be able to understand how exogenous DNA can be inserted into bacterial cells to alter their genetic makeup and support expression of new protein products.

\section{Strand Scope Source}

Genetics Master CA: Science Content Standards, December 1998, Grades 9-12, Biology/Life Sciences, 5.e*.

\section{Instructional Resources}

- Biology Principles \& Explorations, Holt, Rinehart and Winston, 2001, Ch 11 (226-230). [Textbook].

\section{Ecology}

Stability in an ecosystem is a balance between competing effects. (California Star Biology/Life Science Science 
Blueprint: 7 Test Items, $12 \%$ of Test)

Biodiversity

The learner will be able to understand that biodiversity is the sum total of different kinds of organisms and is affected by alterations of habitats.

Strand Scope Source

Ecology Master CA: Science Content Standards, December 1998, Grades 9-12, Biology/Life Sciences, 6.a.

Instructional Resources

- Biology Visualizing Life, Holt, Hinehart, and Winston, 1994, Chapter 12 (248). [Textbook].

- Biology Principles \& Explorations, Holt, Rinehart and Winston, 2001, Ch 19, 19 (360-364, 406-414, 442). [Textbook].

\section{Changes in Ecosystems}

The learner will be able to understand how to analyze changes in an ecosystem resulting from changes in climate, human activity, introduction of nonnative species, or changes in population size .

Strand Scope Source

Ecology Master CA: Science Content Standards, December 1998, Grades 9-12, Biology/Life Sciences, 6.b.

Instructional Resources

- Biology Visualizing Life, Holt, Hinehart, and Winston, 1994, Chapter 13 (272-279). [Textbook].

- Biology Principles \& Explorations, Holt, Rinehart and Winston, 2001, Ch 19 (406-415). [Textbook].

\section{Fluculations in Populations in Ecosystem}

The learner will be able to understand how fluctuations in population size in an ecosystem are determined by the relative rates of birth, immigration, emigration, and death.

Strand Scope Source

Ecology Master CA: Science Content Standards, December 1998, Grades 9-12, Biology/Life Sciences, 6.c.

Instructional Resources

- Biology Principles \& Explorations, Holt, Rinehart and Winston, 2001, Ch 19 (414-415). [Textbook].

\section{Water, Carbon, Nitrogen \& Oxygen Cyc}

The learner will be able to understand how water, carbon, and nitrogen cycle between abiotic resources and organic matter in the ecosystem and how oxygen cycles through photosynthesis and respiration.

Strand Scope Source

Ecology Master CA: Science Content Standards, December 1998, Grades 9-12, Biology/Life Sciences, 6.d. Instructional Resources

- Biology Visualizing Life, Holt, Hinehart, and Winston, 1994, Chapter 12 ( 254-256). [Textbook].

- Biology Principles \& Explorations, Holt, Rinehart and Winston, 2001, Ch 17 (370-376). [Textbook].

\section{Stability of Producers and Consumers}

The learner will be able to understand that a vital part of an ecosystem is the stability of its producers and decomposers.

\section{Strand Scope Source}

Ecology Master CA: Science Content Standards, December 1998, Grades 9-12, Biology/Life Sciences, 6.e.

\section{Instructional Resources}

- Biology Visualizing Life, Holt, Hinehart, and Winston, 1994, Chapter 12 (250). [Textbook].

- Biology Principles \& Explorations, Holt, Rinehart and Winston, 2001, Ch 17 (365-367, 375, 378-379). [Textbook]. 


\section{Food Webs and Energy Pyramids}

The learner will be able to understand that at each link in a food web some energy is stored in newly made structures but much energy is dissipated into the environment as heat. This dissipation may be represented in an energy pyramid.

Strand Scope Source

Ecology Master CA: Science Content Standards, December 1998, Grades 9-12, Biology/Life Sciences, 6.f.

\section{Instructional Resources}

- Biology Visualizing Life, Holt, Hinehart, and Winston, 1994, Chapter 12 (251) and 24 (537 and 542). [Textbook].

- Biology Principles \& Explorations, Holt, Rinehart and Winston, 2001, Ch 17 (368-369, 375-376, 378-379). [Textbook].

\section{* Accom. vs. Adaptation of Organisms}

The learner will be able to understand how to distinguish between the accommodation of an individual organism to its environment and the gradual adaptation of a lineage of organisms through genetic change .

\section{Strand Scope Source}

Ecology Master CA: Science Content Standards, December 1998, Grades 9-12, Biology/Life Sciences, 6.g*.

\section{Instructional Resources}

- Biology Principles \& Explorations, Holt, Rinehart and Winston, 2001, Ch 13 (286-289, 327-330). [Textbook].

\section{Gene Pool Allele Frequency}

The frequency of an allele in a gene pool of a population depends on many factors and may be stable or unstable over time. (California Star Biology/Life Science Science Blueprint: 5 Test Items, $8 \%$ of Test)

\section{Natural Selection}

The learner will be able to understand why natural selection acts on the phenotype rather than the genotype of an organism.

Strand Scope Source

Evolution Master CA: Science Content Standards, December 1998, Grades 9-12, Biology/Life Sciences, 7.a.

\section{Instructional Resources}

- Biology Visualizing Life, Holt, Hinehart, and Winston, 1994, Chapter 9 (176-182). [Textbook].

- Biology Principles \& Explorations, Holt, Rinehart and Winston, 2001, Ch 13, 16 (267, 279, 281, 346-352, 356357). [Textbook].

\section{Lethal Alleles}

The learner will be able to understand why alleles that are lethal in a homozygous individual may be carried in a heterozygote and thus maintained in a gene pool .

\section{Strand Scope Source}

Evolution Master CA: Science Content Standards, December 1998, Grades 9-12, Biology/Life Sciences, 7.b.

\section{Instructional Resources}

- Biology Principles \& Explorations, Holt, Rinehart and Winston, 2001, Ch 8 (173-174). [Textbook].

\section{Mutations}

The learner will be able to understand new mutations are constantly being generated in a gene pool. Strand Scope Source

Evolution Master CA: Science Content Standards, December 1998, Grades 9-12, Biology/Life Sciences, 7.c.

\section{Instructional Resources}


- Biology Principles \& Explorations, Holt, Rinehart and Winston, 2001, Ch 8, 13 (178-180, 276, 281). [Textbook].

\section{Species Variation}

The learner will be able to understand that variation within a species increases the likelihood that at least some members of a species will survive under changed environmental conditions .

Strand Scope Source

Evolution Master CA: Science Content Standards, December 1998, Grades 9-12, Biology/Life Sciences, 7.d.

Instructional Resources

- Biology Principles \& Explorations, Holt, Rinehart and Winston, 2001, Ch 7, 13 (145, 276, 281, 290-294). [Textbook].

\section{* Hardy-Weinberg Equilibrium}

The learner will be able to understand the conditions for Hardy-Weinberg equilibrium in a population and why these conditions are not likely to appear in nature .

\section{Strand Scope Source}

Evolution Master CA: Science Content Standards, December 1998, Grades 9-12, Biology/Life Sciences, 7.e*.

Instructional Resources

- Biology Principles \& Explorations, Holt, Rinehart and Winston, 2001, Ch 16 (346-353). [Textbook].

\section{* Solve Hardy-Weinberg Equation}

The learner will be able to understand how to solve the Hardy-Weinberg equation to predict the frequency of genotypes in a population, given the frequency of phenotypes.

Strand Scope Source

Evolution Master CA: Science Content Standards, December 1998, Grades 9-12, Biology/Life Sciences, 7.f*.

\section{Instructional Resources}

- Biology Principles \& Explorations, Holt, Rinehart and Winston, 2001, Ch 13 (276, 281-282, 290-294, 298-299). [Textbook].

\section{Genetic Changes \& Environment}

Evolution is the result of genetic changes that occur in constantly changing environments. (California Star Biology/Life Science Science Blueprint: 4 Test Items, 7\% of Test)

\section{Differential Survival}

The learner will be able to understand how natural selection determines the differential survival of groups of organisms.

Strand Scope Source

Evolution Master CA: Science Content Standards, December 1998, Grades 9-12, Biology/Life Sciences, 8.a.

\section{Instructional Resources}

- Biology Principles \& Explorations, Holt, Rinehart and Winston, 2001, Ch 13 (276, 281-282, 290-194, 298-299). [Textbook].

\section{Species Diversity vs. Species Survival}

The learner will be able to understand that a great diversity of species increases the chance that at least some organisms survive major changes in the environment.

\section{Strand Scope Source}

Evolution Master CA: Science Content Standards, December 1998, Grades 9-12, Biology/Life Sciences, 8.b.

Instructional Resources 
- Biology Visualizing Life, Holt, Hinehart, and Winston, 1994, Chapter 12 (248) and 13 ( 267-291). [Textbook].

- Biology Principles \& Explorations, Holt, Rinehart and Winston, 2001, Ch 13 (276, 290-294, 298-299). [Textbook].

\section{Genetic Drift}

The learner will be able to understand the effects of genetic drift on the diversity of organisms in a population.

Strand Scope Source

Evolution Master CA: Science Content Standards, December 1998, Grades 9-12, Biology/Life Sciences, 8.c.

Instructional Resources

- Biology Principles \& Explorations, Holt, Rinehart and Winston, 2001, Ch 16 (34-349). [Textbook].

\section{Reproductive and Geographic Isolation}

The learner will be able to understand that reproductive or geographic isolation affects speciation.

\section{Strand Scope Source}

Evolution Master CA: Science Content Standards, December 1998, Grades 9-12, Biology/Life Sciences, 8.d.

Instructional Resources

- Biology Principles \& Explorations, Holt, Rinehart and Winston, 2001, Ch 13 (281-282, 293-294). [Textbook].

\section{Fossil Analysis}

The learner will be able to understand how to analyze fossil evidence with regard to biological diversity, episodic speciation, and mass extinction.

\section{Strand Scope Source}

Evolution Master CA: Science Content Standards, December 1998, Grades 9-12, Biology/Life Sciences, 8.e.

\section{Instructional Resources}

- Biology Visualizing Life, Holt, Hinehart, and Winston, 1994, Chapter 9 (176-192) and 10 (199-214). [Textbook].

- Biology Principles \& Explorations, Holt, Rinehart and Winston, 2001, Ch 13 (283-289). [Textbook].

\section{* Evolutionary Relationships}

The learner will be able to understand how to use comparative embryology, DNA or protein sequence comparisons, and other independent sources of data to create a branching diagram (cladogram) that shows probable evolutionary relationships.

\section{Strand Scope Source}

Evolution Master CA: Science Content Standards, December 1998, Grades 9-12, Biology/Life Sciences, 8.f*.

\section{Instructional Resources}

- Biology Principles \& Explorations, Holt, Rinehart and Winston, 2001, Ch 13, 15 (286-289, 327-330). [Textbook].

\section{* Estimates of Evolutionary Divergence}

The learner will be able to understand how several independent molecular clocks, calibrated against each other and combined with evidence from the fossil record, can help to estimate how long ago various groups of organisms diverged evolve from one another.

\section{Strand Scope Source}

Evolution Master CA: Science Content Standards, December 1998, Grades 9-12, Biology/Life Sciences, 8.g*.

\section{Instructional Resources}

- Biology Principles \& Explorations, Holt, Rinehart and Winston, 2001, Ch 13, 14, 15, 28, 31, 33 (283-289, 305, 327-330). [Textbook].

\section{Organ Systems \& Homeostasis}


As a result of the coordinated structures and functions of organ systems, the internal environment of the human body remains relatively stable (homeostatic) despite changes in the outside environment. (California Star Biology/Life Science Science Blueprint: 5 Test Items, 9\% of Test)

\section{Major Body Systems}

The learner will be able to understand how the complementary activity of major body systems provides cells with oxygen and nutrients and removes toxic waste products such as carbon dioxide.

\section{Strand Scope Source}

Physiology Master CA: Science Content Standards, December 1998, Grades 9-12, Biology/Life Sciences, 9.a.

\section{Instructional Resources}

- Biology Principles \& Explorations, Holt, Rinehart and Winston, 2001, Ch 39, 40 (890-892, 998-899, 901-902). [Textbook].

\section{Nervous System Mediation}

The learner will be able to understand how the nervous system mediates communication between different parts of the body and the body's interactions with the environment.

\section{Strand Scope Source}

Physiology Master CA: Science Content Standards, December 1998, Grades 9-12, Biology/Life Sciences, 9.b.

Instructional Resources

- Biology Visualizing Life, Holt, Hinehart, and Winston, 1994, Chapter 28 (638-663). [Textbook].

- Biology Principles \& Explorations, Holt, Rinehart and Winston, 2001, Ch 42 (952-968, 975-977). [Textbook].

\section{Feedback Loops}

The learner will be able to understand how feedback loops in the nervous and endocrine systems regulate conditions in the body.

\section{Strand Scope Source}

Physiology Master CA: Science Content Standards, December 1998, Grades 9-12, Biology/Life Sciences, 9.c.

\section{Instructional Resources}

- Biology Principles \& Explorations, Holt, Rinehart and Winston, 2001, Ch 38, 42, 43 (859, 963, 983-984, 988, 1000-1001). [Textbook].

\section{Function of the Nervous System}

The learner will be able to understand the functions of the nervous system and the role of neurons in transmitting electrochemical impulses .

\section{Strand Scope Source}

Physiology Master CA: Science Content Standards, December 1998, Grades 9-12, Biology/Life Sciences, 9.d.

\section{Instructional Resources}

- Biology Visualizing Life, Holt, Hinehart, and Winston, 1994, Chapter 28 (638-663). [Textbook].

- Biology Principles \& Explorations, Holt, Rinehart and Winston, 2001, Ch 42 (952-968, 975-977). [Textbook].

\section{The Role of Neurons}

The learner will be able to understand the roles of sensory neurons, interneurons, and motor neurons in sensation, thought, and response.

\section{Strand Scope Source}

Physiology Master CA: Science Content Standards, December 1998, Grades 9-12, Biology/Life Sciences, 9.e.

\section{Instructional Resources}

- Biology Visualizing Life, Holt, Hinehart, and Winston, 1994, Chapter 28 (652). [Textbook].

- Biology Principles \& Explorations, Holt, Rinehart and Winston, 2001, Ch 42 (961-963). [Textbook]. 


\section{*Functions and Sites of Digestive Enzyme}

The learner will be able to understand the individual functions and sites of secretion of digestive enzymes (amylases, proteases, nucleases, lipases), stomach acid, and bile salts .

\section{Strand Scope Source}

Physiology Master CA: Science Content Standards, December 1998, Grades 9-12, Biology/Life Sciences, 9.f*.

Instructional Resources

- Biology Principles \& Explorations, Holt, Rinehart and Winston, 2001, Ch 3, 40 (42, 915-917, 919, 925).

[Textbook].

\section{* Homeostatic Role of the Kidneys}

The learner will be able to understand the homeostatic role of the kidneys in the removal of nitrogenous wastes and the role of the liver in blood detoxification and glucose balance.

Strand Scope Source

Physiology Master CA: Science Content Standards, December 1998, Grades 9-12, Biology/Life Sciences, 9.g*.

Instructional Resources

- Biology Principles \& Explorations, Holt, Rinehart and Winston, 2001, Ch 40 (920-923, 925). [Textbook].

\section{* Muscle Contraction}

The learner will be able to understand the cellular and molecular basis of muscle contraction, including the roles of actin, myosin, $\mathrm{Ca}+2$, and ATP .

\section{Strand Scope Source}

Physiology Master CA: Science Content Standards, December 1998, Grades 9-12, Biology/Life Sciences, 9.h*.

Instructional Resources

- Biology Principles \& Explorations, Holt, Rinehart and Winston, 2001, Ch 39 (867-869, 875). [Textbook].

\section{* Hormones and Internal Feedback}

The learner will be able to understand how hormones (including digestive, reproductive, osmoregulatory) provide internal feedback mechanisms for homeostasis at the cellular level and in whole organisms .

Strand Scope Source

Physiology Master CA: Science Content Standards, December 1998, Grades 9-12, Biology/Life Sciences, 9.i*.

Instructional Resources

- Biology Principles \& Explorations, Holt, Rinehart and Winston, 2001, Ch 43 (982-1001). [Textbook].

\section{Organisms' Immune Responses}

Organisms have a variety of mechanisms to combat disease. (California Star Biology/Life Science Science Blueprint: 5 Test Items, $8 \%$ of Test)

\section{Skin Defenses Against Infection}

The learner will be able to understand the role of the skin in providing nonspecific defenses against infection.

Strand Scope Source

Physiology Master CA: Science Content Standards, December 1998, Grades 9-12, Biology/Life Sciences, 10.a.

Instructional Resources

- Biology Visualizing Life, Holt, Hinehart, and Winston, 1994, Chapter 27 (616-618). [Textbook].

- Biology Principles \& Explorations, Holt, Rinehart and Winston, 2001, Ch 41 (932-934). [Textbook]. 


\section{Antibodies}

The learner will be able to understand the role of antibodies in the body's response to infection. Strand Scope Source

Physiology Master CA: Science Content Standards, December 1998, Grades 9-12, Biology/Life Sciences, 10.b.

\section{Instructional Resources}

- Biology Visualizing Life, Holt, Hinehart, and Winston, 1994, Chapter 39 (749-759). [Textbook].

- Modern Livestock \& Poultry Production, Delmar, Sixth, 2002, Unit 10 (232). [Textbook].

- Biology Principles \& Explorations, Holt, Rinehart and Winston, 2001, Ch 41 (935-937). [Textbook].

\section{Vaccinations}

The learner will be able to understand how vaccination protects an individual from infectious diseases.

\section{Strand Scope Source}

Physiology Master CA: Science Content Standards, December 1998, Grades 9-12, Biology/Life Sciences, 10.c.

\section{Instructional Resources}

- Biology Visualizing Life, Holt, Hinehart, and Winston, 1994, Chapter 8 (166) and 16 (351-356). [Textbook].

- Modern Livestock \& Poultry Production, Delmar, Sixth, 2002, Unit Unit 16 (358), 37 (765) and 44 (910). [Textbook].

- Biology Principles \& Explorations, Holt, Rinehart and Winston, 2001, Ch 22, 41 (492, 939-940). [Textbook].

\section{Bacteria and Viruses}

The learner will be able to understand that there are important differences between bacteria and viruses with respect to their requirements for growth and replication, the body's primary defenses against bacterial and viral infections, and effective treatments of these infections .

\section{Strand Scope Source}

Physiology Master CA: Science Content Standards, December 1998, Grades 9-12, Biology/Life Sciences, 10.d.

\section{Instructional Resources}

- Biology Visualizing Life, Holt, Hinehart, and Winston, 1994, Chapter 16 (338-359). [Textbook].

- Biology Principles \& Explorations, Holt, Rinehart and Winston, 2001, Ch 21 (452-471, 938-940). [Textbook].

\section{Compromised Immune System}

The learner will be able to understand why an individual with a compromised immune system (for example, a person with AIDS) may be unable to fight off and survive infections by microorganisms that are usually benign .

Strand Scope Source

Physiology Master CA: Science Content Standards, December 1998, Grades 9-12, Biology/Life Sciences, 10.e.

\section{Instructional Resources}

- Biology Principles \& Explorations, Holt, Rinehart and Winston, 2001, Ch 41 (942-944). [Textbook].

\section{*Phagocytes, B-lymphocytes \& T-lymph}

The learner will be able to understand the roles of phagocytes, B-lymphocytes, and T-lymphocytes in the immune system.

\section{Strand Scope Source}

Physiology Master CA: Science Content Standards, December 1998, Grades 9-12, Biology/Life Sciences, 10.f*. Instructional Resources

- Biology Principles \& Explorations, Holt, Rinehart and Winston, 2001, Ch 41 (934-937). [Textbook].

\section{Digestive Systems and Nutrition}


The principles of animal nutrition involves the the interrelationship between the digestive, endocrine, and circulatory systems.

\section{Digestive Systems}

The learner will be able to name, locate, and describe the functions of the parts of the digestive systems of ruminants and nonruminant animals.

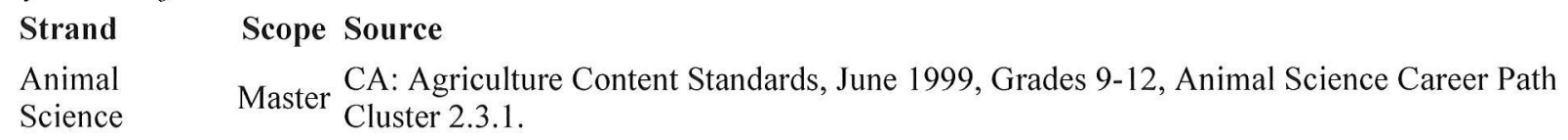

Instructional Resources

- Modern Livestock \& Poultry Production, Delmar, Sixth, 2002, Unit 5 (110-112). [Textbook].

\section{The Digestive Process}

The learner will be able to trace the digestive process in a livestock animal of their choice.

Strand Scope Source

Animal Master CA: Agriculture Content Standards, June 1999, Grades 9-12, Animal Science Career Path Cluster Science Master 2.3.1 and 2.3.2.

\section{Instructional Resources}

- Modern Livestock \& Poultry Production, Delmar, Sixth, 2002, Unit 5 (12-121). [Textbook].

\section{Feed Nutrients}

The learner will be able to identify the major functions of the basic nutrient groups and identify feeds that are sources of each.

Strand Scope Source

Animal $\quad$ Master CA: Agriculture Content Standards, June 1999, Grades 9-12, Animal Science Career Path
Ccience

Instructional Resources

- Modem Livestock \& Poultry Production, Delmar, Sixth, 2002, Unit 6 (122-130). [Textbook].

\section{Balancing Rations}

The learner will be able to classify feeds and balance livestock rations using commonly accepted practices.

Strand

Animal

Science

\section{Instructional Resources}

- Modern Livestock \& Poultry Production, Delmar, Sixth, 2002, Unit 8 (165-196). [Textbook].

\section{Plants}

\section{The Plant Body}

The learner will be able to identify the importance of plant parts and functions.

Strand Scope Source

Plant Master CA: Agriculture Content Standards, June 1999, Grades 9-12, Plant and Soil Science Career Path Science Master Cluster 3.3.1.

\section{Instructional Resources}

- Biology Visualizing Life, Holt, Hinehart, and Winston, 1994, Chapter 19 (403-407). [Textbook]. 


\section{How Plants Functions}

The learner will be able to summarize how plants function.

\section{Strand Scope Source}

Plant Master CA: Agriculture Content Standards, June 1999, Grades 9-12, Plant ans Soil Science Career Path Science Master Cluster 3.3.2.

Instructional Resources

- Biology Visualizing Life, Holt, Hinehart, and Winston, 1994, Chapter 19 (410-414). [Textbook].

\section{Reproduction in Flowering Plants}

The learner will be able to summarize the processes of pollination and fertilization.

\section{Strand Scope Source}

Plant Master CA: Agriculture Content Standards, June 1999, Grades 9-12, Plant and Soil Science Career Path Science Master Cluster 3.4.1.

\section{Instructional Resources}

- Biology Visualizing Life, Holt, Hinehart, and Winston, 1994, Chapter 19 (415-420). [Textbook].

\section{Connections, Applications and Standards}

Students will understand the importance of career awareness and the related decision making process.

\section{Agricultural Career Clusters}

The learner will be able to describe the six agriculture career clusters and give examples of entry, technical, and professional careers in each cluster.

\section{Strand Scope Source}

Agriculture Basic Introduce CA: Agriculture Content Standards, June 1999, Grades 9-12, Basic Core Career Path Core Cluster 1.8.1.

\section{Instructional Resources}

- FFA Career Center, National FFA Organization, Careers [On-line]. http://www.ffa.org/careers/index.html

- FFA Career Center, National FFA Organization, Ag Career Clusters [Online]. http://www.teamaged.org/ffa/careers/clusters.htm

\section{Resumes}

The learner will be able to develop a resume and participate in a mock job interview.

\section{Strand Scope Source}

Agriculture Basic Introduce CA: Agriculture Content Standards, June 1999, Grades 9-12, Basic Core Career Path Core Cluster 1.8.2.

\section{Instructional Resources}

- California Agricultural Education, Job Interview Contest [On-line]. http://www.calaged.org/CCode/C12.doc

\section{Career Exploration through Technology}

The learner will be able to utilize resources to learn about an agriculture occupation of their choice.

\section{Strand}

Scope Source

Agriculture Basic

Core
CA: Agriculture Content Standards, June 1999, Grades 9-12, Basic Core Career Path Introduce Cluster 1.8.3.

\section{Instructional Resources}

- EUREKA, The California Career Information System [Software]. 


\section{Supervised Agricultural Experience}

Students will understand the relationship between a supervised occupational experience (SAE) and their preparation for a career in agriculture. Students will actively engage in and manage a SAE which enables them to develop occupational skills.

\section{Supervised Occupational Experience Plan}

The learner will be able to develop an agricultural SAE plan (student data sheet).

Strand

Scope Source

Agriculture Basic

Core

\section{Supervised Occupation Experience Project}

The learner will be able to demonstrate responsibility, commitment, and time management skills by conducting and maintaining and SAE.

\section{Strand Scope Source}

Agriculture Basic Introduce CA: Agriculture Content Standards, June 1999, Grades 9-12, Basic Core Career Path Core

\section{Record Keeping}

Students will understand the importance of keeping accurate records and explain the consequences of inaccurate records. Students will maintain and complete the California Agricultural Record Book which pertains to their Supervised Occupational Experience (SAE) Program.

\section{Accurate Record Keeping}

The learner will be able to explain reasons for keeping accurate records and consequences of inaccurate records.

$\begin{array}{lrl}\text { Strand } & \text { Scope } & \text { Source } \\ \text { Agriculture Basic } & \text { Introduce } & \text { CA: Agriculture Content Standards, June 1999, Grades 9-12, Basic Core Career Path } \\ \text { Core } & \text { Cluster 1.4.1. }\end{array}$

\section{Budgets and Business Agreements}

The learner will be able to develop a budget and a business agreement for a project.

\section{Strand}

Scope Source

Agriculture Basic Core

\section{Journals}

The learner will be able to complete journal entries for two enterprises and carry entries forward to the next month.

Strand

Agriculture Basic Core

\section{Scope Source}

Introduce CA: Agriculture

\section{Financial Statements and Income Summary}

The learner will be able to prepare a financial statement and a net income summary.

\section{Strand}

Agriculture Basic Core

\section{Scope Source} Introduce CA: Agriculture Content Standards, June 1999, Grades 9-12, Basic Core Career Path
Cluster 1.4.4. 


\section{Non-Depreciable and Depreciable Property}

The learner will be able to complete non-depreciable and depreciable property inventories.

Strand

Scope Source

Agriculture Basic

Core

Introduce CA: Agriculture Content Standards, June 1999, Grades 9-12, Basic Core Career Path
Cluster 1.4.5.

\section{Straight-lime Depreciation}

The learner will be able to use the straight-line method for determining depreciation.

Strand Scope Source

Agriculture Basic

Core Introduce CA: Agriculture Content Standards, June 1999, Grades 9-12, Basic Core Career Path Cluster 1.4.6.

Interpersonal Leadership Development

\section{Interpersonal Leadership Development}

The learner will be able to participate in leadership training activities associated with the FFA including public speaking, leading group discussions, working within a committee, conducting business meetings, and problem solving.

Strand Scope Source

Ornamental Horticulture

Master CA: Agriculture Contend Standards, June 1999, Grades 9-12, 5.15.

Instructional Resources

- National FFA, Home Page [On-line]. http://www.ffa.org/

(C) 2009 by Oroville Union High School District and Scantron Corporation. All Rights Reserved. Made with Curriculum Designer by Scantron Corporation. 


\section{Oroville Union High School District \\ Science Curriculum}

Science - Animal Science

\section{Animal Science}

COURSE TITLE: Animal Science

LENGTH OF COURSE: One Year

TYPE OF CREDIT: Life Science or Vocational (10 credits)

$2+2$ Butte Community College Articulated Course

Animal Science Pathway (alternate) Capstone Course

GRADE LEVEL: $\quad 11-12$

PREREQUISITES:

Agriculture Science or Agricultural Earth Science or (pre-approval by instructor)

TEXTBOOKS: Introduction to Livestock and Companion Animal, Lee/Hutter/Rudd/Westrom/Patrick/Bull, Prentice Hall Interstate, 2004, ISBN 0-13-036432-0.

Modern Livestock \& Poultry Production, Sixth Edition, James R. Gillespie, Delmar Publishers, 2002, ISBN 0-7668-1607-9.

Principles and Practice of Veterinary Technology, Paul W. Pratt, Mosby Publishing, 1998, ISBN 08151-7308-3.

\section{SUPPLEMENTARY MATERIALS:}

Agriscience Fundamentals and Applications, Cooper, Delmar Publishers, 1997, ISBN 082736278.

Small Animal Care \& Management, Dean M. Warren, Delmar Publishers, 1994, ISBN 0827345577.

Keeping Livestock Healthy, Third Edition, N. Bruce Haynes, D.V.M., Storey Publishing, 1994, ISBN 0 882668846 .

Veterinary Guide for Professional Farmers, First Edition, William Hall, B.V.Sc. and James Ferguson, D.V. M., M.S. Hearst Books, 1985, ISBN 0688024922.

\section{COURSE DESCRIPTION:}

Animal science is a one year advanced agricultural science course that will provide advanced understanding of livestock agriculture and issues affecting society, animal welfare, and production systems. Animal nutrition, anatomy and physiology, health, reproduction, genetics, and management through evaluation and selection will be stressed. Biotechnology and emerging technologies are creating excitement in agricultural industry. This course allows students to be actively involved in the learning 
process.

BOARD ADOPTION DATE: January 21, 2004

\section{Animal Domestication and Society}

Students will understand the importance of animals, understand domestication, and role in modern society, as well as the care and uses of domesticated livestock in society

\section{Animals role in modern society}

The learner will be able to understand the importance of animals, their domestication, and role in society.

Strand Scope Source

Animal Science

Master CA: Agricultural Content Standards, June 1999, Animal Science Career Path Cluster 1.11

\section{Caring for Domesticated animals}

The learner will be able to understand how to care for domesticated animals and explain how domesticated animals have changed over time.

Strand Scope Source

Animal Science Master CA: Agricultural Content Standards, June 1999, Animal Science Career Path Cluster 1.11

\section{Domestication of animals}

The learner will be able to explain what domesticated animals are, when and how they became domesticated, and for what purposes.

Strand Scope Source

Animal Master CA: Agricultural Content Standards, June 1999, Animal Science Career Path Cluster 1.11.1,3

Science $\quad$ Master Science Content Standards, December 1998, Grades 9-12, Biology/Life Sciences 6a,b,g 7a,c 8a,b,d

\section{Animal Facilities, Equipment, \& Handling}

Students will understand the correct and safe uses and selection of animal facilities and housing, restraint equipment, and tools.

\section{Design Housing Facilities}

The learner will be able to given a site, climate and species, design and explain an animal facility. Strand Scope Source

Animal Master CA: Agricultural Content Standards, June 1999, Animal Science Career Path Cluster 2.1.1Science

Science Master Content Standards, December 1998, Grades 9-12, Biology/Life Sciences 6a.;

\section{Animal Restraint \& Equipment}

The learner will be able to demonstrate the safe and appropriate use of restraint equipment for different animal species.

Strand Scope Source

Animal Science Master CA: Agricultural Content Standards, June 1999, Animal Science Career Path Cluster 2.1.2

\section{Animal Nutrition}

Students will understand different feed types and nutrition requirements for different species used in livestock production 


\title{
Digestive Process
}

The learner will be able to trace the pathway of food through the digestive systems (ruminant, monogastric, avian, equine) and explain the digestive process occurring in each species.

\section{Strand Scope Source}

Animal Master CA: Agricultural Content Standards, June 1999, Animal Science Career Path Cluster 2.3.1 CA:

Science Master Science Content Standards, December 1998, Grades 9-12, Biology/Life Sciences 6.g, 9.a

\section{Animal Reproduction}

Understand the structure and function of the endocrine and reproductive systems and how they relate to reproductive management practices and fetal development.

\section{Reproductive Management Practices}

The learner will be able to given a scenario for the production of a species, students describe reproductive management practices and their effects on fetal development.
Strand
Scope Source
Animal
Science
CA: Agricultural Content Standards, June 1999, Animal Science Career Path Cluster 2.3.1 Science
Master CA: Agricultural Content Standards, Grades 9-12, Biology/Life Sciences 2a-g, 5a,c

\section{Artificial Insemination}

The learner will be able to explain the application of artificial insemination and embryo transfer in animal science.

\author{
Strand Scope Source \\ Animal Master CA: Agricultural Content Standards, June 1999, Animal Science Career Path Cluster 2.4.2Science \\ Science $\quad$ Master Content Standards, December 1998, Grades 9-12, Biology/Life Sciences 2a-g, 9i
}

\section{Major Breeding Systems}

The learner will be able to describe breeding systems commonly used in animal agriculture.

\section{Strand Scope Source}

Animal Science Master CA: Agricultural Content Standards, June 1999, Animal Science Career Path Cluster 2.4.3

\section{Animal Physiology}

The principles of animal nutrition and the interrelationship between the digestive, endocrine, and circulatory systems.

\section{Interrelationship of Major Body Systems}

The learner will be able to explain the interrelationship between the circulatory, respiratory, excretory, endocrine, digestive, reproductive, skeletal, and muscle systems.

\section{Strand Scope Source}

Animal Master CA: Agricultural Content Standards, June 1999, Animal Science Career Path Cluster 2.3.1 Science

Science Master Content Standards, December 1998, Grades 9-12, Biology/Life Sciences 9a-e

\section{Management of Major Body Systems}

The learner will be able to suggest management practices that enhance the function of the body systems.

\section{Strand Scope Source}

Animal Science Master CA: Agricultural Content Standards, June 1999, Animal Science Career Path Cluster 2.3.2 


\section{Animal Genetics}

understand the principles of basic genetics and the importance of genetics in livestock production.

\section{Predict Phenotypes and Genotypes}

The learner will be able to use probability to predict the phenotypic and genotypic results of a dominant/recessive gene pair to the F2 generation.

Strand Scope Source

Animal Master CA: Agricultural Content Standards, June 1999, Animal Science Career Path Cluster 2.5.1Science

Science Master Content Standards, December 1998, Grades 9-12, Biology/Life Sciences 2a-g, 3a,b

\section{Mutations and Hybrids in Agriculture}

The learner will be able to identify natural and artificial induced mutations and hybrids and discuss their value to agriculture.

Strand Scope Source

Animal Master CA: Agricultural Content Standards, June 1999, Animal Science Career Path Cluster 2.5.2Science

Science Master Content Standards, December 1998, Grades 9-12, Biology/Life Sciences 4c

\section{Animal Health}

Students will understand the cause of disease as it applies to animal health problems.

\section{The Normal Animal}

The learner will be able to demonstrate the ability to identify normal behavioral characteristics of a healthy animal.

\section{Strand Scope Source}

Animal Master CA: Agricultural Content Standards, June 1999, Animal Science Career Path Cluster 2.6.1Science

Science $\quad$ Master Content Standards, December 1998, Grades 9-12, Biology/Life Sciences 10a-f

\section{Management Practices \& Disease Preve}

The learner will be able to describe sound management practices that can prevent disease.

Strand Scope Source

Animal Master CA: Agricultural Content Standards, June 1999, Animal Science Career Path Cluster 2.6.2Science

Science $\quad$ Master Content Standards, December 1998, Grades 9-12, Biology/Life Sciences 10b, c, d

\section{Animal Parasites and Pests}

Students will understand the life cycle of internal and external parasites.

\section{Control for Pests and Parasites}

The learner will be able to explain control measures for these pests and parasites.

Strand Scope Source

Animal Master CA: Agricultural Content Standards, June 1999, Animal Science Career Path Cluster 2.7.1Science

Science Master Content Standards, December 1998, Grades 9-12, Biology/Life Sciences 6d

\section{Parasite Prevention Program}

The learner will be able to describe a parasite prevention program and describe symptoms of a 
parasite problem.

Strand Scope Source

Animal Science Master CA: Agricultural Content Standards, June 1999, Animal Science Career Path Cluster 2.7.2

Pest Life Cycle

The learner will be able to trace the life cycle of a given pest, or parasite and indicate the best stage for control.

Strand Scope Source

Animal Science Master CA: Agricultural Content Standards, June 1999, Animal Science Career Path Cluster 2.7.3

\section{Larger and Small Animal Production}

Students will understand the different principles of animal production, marketing, and production record keeping.

\section{Economic Marketing Strategies}

The learner will be able to describe the different production and marketing strategies, and their economic importance.

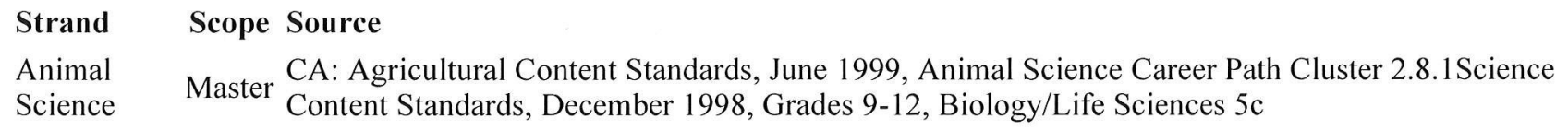

Animal Master CA: Agricultural Content Standards, June 1999, Animal Science Career Path Cluster 2.8.1Science

Science Master Content Standards, December 1998, Grades 9-12, Biology/Life Sciences 5c

\section{Production Cycles of Animals}

The learner will be able to select an animal to raise or follow from selection through marketing, keeping records of growth and production decisions and with financial considerations.

\section{Strand Scope Source}

Animal Science Master CA: Agricultural Content Standards, June 1999, Animal Science Career Path Cluster 2.8.2

\section{Production Management}

Students will demonstrate an understanding of the process of evaluation and selection of livestock based on current industry standards.

\section{Evaluating Livestock}

The learner will be able to demonstrate the use of critical thinking, problem solving, communication skills and available technology in evaluation of livestock.

\section{Strand Scope Source}

Animal Science Master CA: Agricultural Content Standards, June 1999, Animal Science Career Path Cluster 2.14.1

\section{Animal Welfare}

Students will develop an appreciation of the public's perception of animal welfare issues.

\section{Welfare of Animals}

The learner will be able to communicate the rational for various animal welfare management practices.

\section{Strand Scope Source}

Animal Science Master CA: Agricultural Content Standards, June 1999, Animal Science Career Path Cluster 2.15.1 


\section{Feeds and Feeding}

Students will understand the principles of feeds and feeding.

\section{Function of Feed Components}

The learner will be able to explain the function of feed components in animal rations for various species.

Strand

Animal

Science
Scope Source

Master CA: Agricultural Content Standards, June 1999, Animal Science Career Path Cluster 2.16.1 Science Content Standards, December 1998, Grades 9-12, Biology/Life Sciences 1b,h

\section{Waste Management}

Students will understand the challenges associated with animal waste management.

\section{Methods of Using Animal wasteland}

The learner will be able to analyze different methods for the use of animal waste including consideration of environmental impacts.

\section{Strand Scope Source}

Animal Science Master CA: Agricultural Content Standards, June 1999, Animal Science Career Path Cluster 2.10.1

\section{Range Management}

Students will understand rangeland grazing, and public land grazing practices.

\section{Range Management Practices}

The learner will be able to explain how range management practices affect pasture production, erosion control, and the overall balance of the ecosystem.

\section{Strand Scope Source}

Animal Science Master CA: Agricultural Content Standards, June 1999, Animal Science Career Path Cluster 2.9.1

\section{Record Keeping}

Students will understand the principles of record keeping

\section{California FFA Record Book}

The learner will be able to demonstrate record keeping utilizing a variety of methods and systems including the California FFA record book.

\section{Strand Scope Source}

Animal Science Master CA: Agricultural Content Standards, June 1999, Animal Science Career Path Cluster 2.11.1

\section{Farm Business Management}

The learner will be able to explain the difference between production and financial records.

Strand Scope Source

Animal Science Master CA: Agricultural Content Standards, June 1999, Animal Science Career Path Cluster 2.11.2 


\title{
Interpersonal Leadership Development
}

Students will recognize the traits of effective leaders.

\section{Leadership Training}

The learner will be able to participate in leadership activities associated with the FFA including public speaking, leading group discussions.

\section{Strand Scope Source}

Animal Science Master CA: Agricultural Content Standards, June 1999, Animal Science Career Path Cluster 2.12.1

\section{Committee Structures}

The learner will be able to working within a committee, conducting business meetings, and problem solving.

Strand

Scope Source

Animal Science Master CA: Agricultural Content Standards, June 1999, Animal Science Career Path Cluster 2.12.2

\section{Career Exploration through Technology}

Students will be aware of existing and future employment opportunities in the field of agriculture and will develop an understanding of how to conduct a job search, write a resume, and interview for a job.

\section{Career Exploration}

The learner will be able to will be able to utilize resources to learn about an agriculture occupation of their choice.
Strand
Scope Source
Animal Science
Master CA: Agricultural Content Standards, June 1999, Basic Core Career Path Cluster 1.7.2

\section{Supervised Practical Experience Project}

Students will understand the relationship between a supervised occupational experience projects (SOE) and their preparation for a career.

\section{S.O.E.P.}

The learner will be able to participate in a supervised occupational experience that employs skills and knowledge learned in the classroom.

\author{
Strand Scope Source \\ Animal Science Master CA: Agricultural Content Standards, June 1999, Animal Science Career Path Cluster 2.13.1

\section{Maintain a FFA Record Book} \\ The learner will be able to maintain an ongoing record book on their SOE.

\section{Strand Scope Source} \\ Animal Science Master CA: Agricultural Content Standards, June 1999, Animal Science Career Path Cluster 2.13.1
}

(c) 2009 by Oroville Union High School District and Scantron Corporation. All Rights Reserved. Made with Curriculum Designer by Scantron Corporation. 


\section{Oroville Union High School District \\ Science Curriculum \\ Science - Agricultural Life Science}

\section{Agricultural Life Science}

COURSE TITLE: Agricultural Life Sciences

LENGTH OF COURSE: One Year

TYPE OF CREDIT: Life Science (10 credits)

GRADE LEVEL: 9-11

PREREQUISITES: 11th graders must have completed an Agricultural Science course.

\section{TEXTBOOK:}

Agriscience Fundamentals and Applications, Cooper, Delmar Publisher, 1997 ISBN\# 0827362781

\section{COURSE DESCRIPTION:}

This introductory course is recommended for all freshmen Interested in agriculture. It covers the fundamentals of plant and animal science and gives training in leadership. Production and processing of agricultural products and related services and businesses are studied. Students will develop a foundation in science while acquiring a broad understanding of the major facets of modern agriculture It offers a foundation in the life sciences, the California agriculture basic core, and the scientific method. It also provides opportunities to participate in laboratory experiments, Supervised Occupational Experience projects, and FFA leadership activities. This course meets the minimum science graduation requirement of one year of life science and prepares the students for other science and agricultural courses offered.

BOARD ADOPTION DATE: January 21, 2004

\section{Economy of California Agriculture}

Students shall understand the economic importance of the agricultural sector in California, including leading production areas and commodities.

\section{State and Local Production}

The learner will be able to identify the major agricultural production areas of California and list three major commodities produced in each. List the dollar value of the five leading agricultural commodities produced in their county and state.

\section{Strand}

Agricultural Life

Science
Scope Source

Master CA: Agricultural Content Standards, June 1999, Grade 9-12, Basic Core Career Path Cluster 1.1.1 and 1.1.2.

\section{California and the National Ag Economy}

The learner will be able to describe and discuss the economic impact of the agricultural sector on the state and national economy. 
Strand

Agricultural Life

Science
Scope Source

Master CA: Agricultural Content Standards, June 1999, Grade 9-12, Basic Core Career Path
Cluster 1.1.3.

\section{California Ag and the Global Economy}

The learner will be able to describe and discuss the "cost-price squeeze" and understand its effects on California Agriculture.

Strand

Agricultural Life

Science

\section{Scope Source}

CA: Agricultural Content Standards, June 1999, Grade 9-12, Basic Core Career Path Cluster 1.1.4.

\section{Agriculture and Society}

Students will understand the interrelationship of agriculture and society in California, including factors which influence the development of agricultural activities.

\section{Development of Agriculture \& Our Soc}

The learner will be able to explain the relationship of the development of agriculture and our modern society in the United States.

Strand

Agricultural Life

Science
Scope Source

Master CA: Agricultural Content Standards, June 1999, Grade 9-12, Basic Core Career Path Cluster 1.1.4.

\section{Agricultural Trends}

The learner will be able to list three problems faced by California farmers caused by population shifts and social and technological trends.

$\begin{array}{lll}\text { Strand } & \text { Scope } & \text { Source } \\ \text { Agricultural Life Science } & \text { Master } & \text { Las Plumas H.S.(a) }\end{array}$

\section{Agencies for Agriculture}

The learner will be able to list five government agencies which influence and affect agricultural production in California.

Strand

Agricultural Life Science
Scope Source

Master Las Plumas H.S.(a)

\section{$\mathrm{Ag}$ and California Resources}

Students will understand the impact of agricultural production on the environment and natural resources of California. Students will develop an appreciation of energy, its effects on modern agriculture and current and potential applications of alternative sources of energy available to the field today.

\section{Agricultural Resources}

The learner will be able to describe the major watershed, forest regions of California.

\section{Strand}

Agricultural Life

Science
Scope Source Master CA: Agricultural Content Standards, June 1999, Grade 9-12, Basic Core Career Path
Cluster 1.2.1.

\section{Agriculture and the Environment}

The learner will be able to define the economic effects of air pollution on agricultural production, 
identify the major water quality and pollution problems and list three environmental effects of production agriculture in California. Begin to appreciate the role of farmers and ranchers as stewards of natural resources.

\section{Strand}

Agricultural Life

Science

\section{Scope Source}

Master CA: Agricult

\section{Energy and Agriculture}

The learner will be able to identify the major sources of energy in California and describe three ways agriculture is using alternative energy.

Strand

Agricultural Life Science

$\begin{array}{cl}\text { Scope } & \text { Source } \\ \text { Master } & \text { Las Plumas H.S.(a) }\end{array}$

\section{Domestic Animals and Production}

Students will understand the importance of animals, their domestication, and role in modern society.

\section{Animal Domestication}

The learner will be able to describe the importance of animal domestication. Identify within each domestic species four livestock enterprises that are part of production agriculture in the United States.

Strand Scope Source

Animal Master CA: Agricultural Content Standards, June 1999, Grade 9-12, Basic Core Career Path Cluster Science Master $1.11 .1,1.11 .2$, and 1.11.3.

\section{Animal Protein}

The learner will be able to describe the importance of meat production to humans as a source of protein.

Strand

Animal Science
Scope Source

Master Las Plumas H.S.(a)

\section{Growth Hormones}

The learner will be able to define hormones, steroids and discuss each of the hormones used in meat animal production and their general effect.

$\begin{array}{lll}\text { Strand } & \text { Scope } & \text { Source } \\ \text { Animal Science } & \text { Master } & \text { Las Plumas H.S.(a) }\end{array}$

\section{Animal Production}

The learner will be able to maintain an animal through a full production cycle.

Strand

Animal Science
Scope Source

Master Las Plumas H.S.(a)

\section{Animal Behavior and Biology}

Students will develop a basic understanding of animal behavior, morphology, taxonomy, general reproductive traits and natural selection.

\section{External Anatomy}


The learner will be able to using correct spelling, label the external anatomy of at least four domestic animals of economic significance. Visually identify external anatomy.

Strand Scope Source

$\begin{array}{ll}\text { Animal } & \text { Master CA: Agricultural Content Standards, June 1999, Grade 9-12, Basic Core Career Path Cluster } \\ \text { Science } & 1.12 .3 \text { and 1.12.6. }\end{array}$

\section{Conception and Gestation}

The learner will be able to accurately sketch a mammalian sperm and ovum, and identify all major parts.

Strand Scope Source

Animal Master CA: Agricultural Content Standards, June 1999, Grade 9-12, Basic Core Career Path Cluster Science Master 1.12 .2 .

Cell Structure and Function

The learner will be able to review the steps of mitosis and meiosis.

Strand Scope Source

Animal Master CA: Science Content Standards, December 1998, Grades 9-12, Investigation and

Science Master Experimentation, 1.a,b,c,d, and e.

\section{Plant and Animal Cells}

The learner will be able to distinguish the parts of a plant cell and an animal cell.

Strand Scope Source

Animal CA: Agricultural Content Standards, June 1999, Grade 9-12, Basic Core Career Path Cluster 1.12.5

Science Master and 1.17.5. CA: Science Content Standards, December 1998, Grades 9-12, Investigation and Experimentation, 1.a,b,c,d, and e.

\section{Nomenclature}

The learner will be able to understand the act or process of naming in science.

$\begin{array}{lll}\text { Strand } & \text { Scope } & \text { Source } \\ \text { Animal Science } & \text { Master } & \text { Las Plumas H.S.(a) }\end{array}$

\section{Species}

The learner will be able to identify different species of plants and animals common to agriculture.

$\begin{array}{lll}\text { Strand } & \text { Scope } & \text { Source } \\ \text { Animal Science } & \text { Master } & \text { Las Plumas H.S.(a) }\end{array}$

\section{Animal Behavior}

The learner will be able to discuss various animal behaviors and the time of occurrence, including: nest building, mating behavior, and post-partum behavior.

$\begin{array}{lll}\text { Strand } & \text { Scope } & \text { Source } \\ \text { Animal Science } & \text { Master } & \text { Las Plumas H.S.(a) }\end{array}$

\section{Dam and Offspring Interaction}

The learner will be able to discuss behavior associated with cows and calves.

$\begin{array}{lll}\text { Strand } & \text { Scope } & \text { Source } \\ \text { Animal Science } & \text { Master } & \text { Las Plumas H.S.(a) }\end{array}$

\section{Hormones and Meat Production}

The learner will be able to discuss the application for and effects of hormones when used for meat animal production. 


$\begin{array}{lll}\text { Strand } & \text { Scope } & \text { Source } \\ \text { Animal Science } & \text { Master } & \text { Las Plumas H.S.(a) }\end{array}$

\title{
Anatomy and Physiology
}

Students will understand the structure, function, and maintenance of the major mammalian body systems and their components using examples draw from humans as well as animals of economic importance.

\section{Introduction to Anatomy \& Physiology}

The learner will be able to understand the basic anatomy and physiology terms.

\author{
Strand Scope Source \\ Animal CA: Agricultural Content Standards, June 1999, Grade 9-12, Basic Core Career Path Cluster 1.12.1, \\ Science Master 1.12.3 and 1.12.4. CA: Science Content Standards, December 1998, Grades 9-12, Investigation and \\ Experimentation, 9.a,b,c,d, e and 10.a..
}

\section{Digestive Systems}

The learner will be able to compare and contrast the basic parts and functions of monogastric and ruminant digestive systems.

$\begin{array}{ll}\text { Strand } & \text { Scope Source } \\ \text { Animal } & \text { Master CA: Agricultural Content Standards, June 1999, Grade 9-12, Basic Core Career Path Cluster } \\ \text { Science } & 1.12 .1 .\end{array}$

\section{Reproductive Systems}

The learner will be able to label the basic parts and describe the functions of male and female reproductive systems.

\author{
Strand Scope Source \\ Animal Master CA: Agricultural Content Standards, June 1999, Grade 9-12, Basic Core Career Path Cluster \\ Science Master 1.12 .2 .
}

\section{Comparative Anatomy}

The learner will be able to compare and contrast the major external body parts of a bovine, porcine, and avian animal.

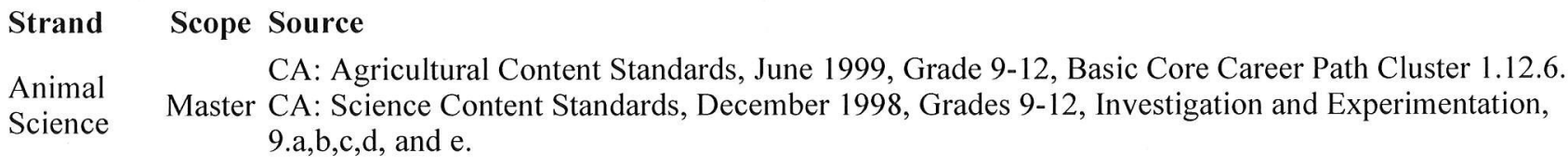

\section{Castration}

The learner will be able to understand and perform the castration techniques and the reasons for castration.

$\begin{array}{lll}\text { Strand } & \text { Scope } & \text { Source } \\ \text { Animal Science } & \text { Master } & \text { Las Plumas H.S.(a) }\end{array}$

\section{Hormone Function}

The learner will be able to become aware of the role of hormones in the body system.

$\begin{array}{lll}\text { Strand } & \text { Scope } & \text { Source } \\ \text { Animal Science } & \text { Master } & \text { Las Plumas H.S.(a) }\end{array}$

\section{Hormone Influence}

The learner will be able to give examples of the kinds of effects that hormones have on the body. 
$\begin{array}{lll}\text { Strand } & \text { Scope } & \text { Source } \\ \text { Animal Science } & \text { Master } & \text { Las Plumas H.S.(a) }\end{array}$

\section{Skeletal System}

The learner will be able to identify on a diagram the general components of the vertebrate skeletal system.

Strand

Animal

Scope Source

Science

Master CA: Agricultural Content Standards, June 1999, Grade 9-12, Basic Core Career Path Cluster
1.12.4 and 1.12.6.

\section{Livestock Selection}

The learner will be able to understand the factors involved in and the ability it evaluate and select livestock for specific uses.

$\begin{array}{lll}\text { Strand } & \text { Scope } & \text { Source } \\ \text { Veterinary Skills } & \text { Master } & \text { Oroville Union High School District(a) }\end{array}$

\section{Genetics and Breeding}

Students will understand the basic theory of inheritance, the genetic basis for animal selection, the process of fertilization, the role(s) of DNA and RNA, and the process of meiotic division to form sperm and ova.

\section{Fertilization}

The learner will be able to describe the process of fertilization.

Strand Scope Source

Animal CA: Agricultural ContCA: Agricultural Content Standards, June 1999, Grade 9-12, Basic Core

Science Master Career Path Cluster 1.13.2. CA: Science Content Standards, December 1998, Grades 9-12, Investigation and Experimentation, 2.d, and e.

\section{Inheritance}

The learner will be able to discuss the transmission of genes through meiotic division.

Strand Scope Source

Animal CA: Agricultural Content Standards, June 1999, Grade 9-12, Basic Core Career Path Cluster 1.13.3.

Science Master CA: Science Content Standards, December 1998, Grades 9-12, Investigation and Experimentation, 2.a,b,c, f, and 4.d,e.

\section{Genotypes and Phenotypes}

The learner will be able to describe the difference between genotypes and phenotypes and dominant and recessive genes with the assistance of the Punit Square.

Strand Scope Source

Animal CA: Agricultural Content Standards, June 1999, Grade 9-12, Basic Core Career Path Cluster 1.13.1.

Science Master CA: Science Content Standards, December 1998, Grades 9-12, Investigation and Experimentation, 3.a,g, and 5.a,b.

\section{Dominant and Recessive Genes}

The learner will be able to demonstrate probability by charting the possible results of a mating involving a dominant/recessive gene pair.

Strand Scope Source

Animal Master CA: Agricultural Content Standards, June 1999, Grade 9-12, Basic Core Career Path Cluster Science Master $1.13 .1,1.13 .2$ and 1.13.3. 


\section{Mutation}

The learner will be able to discuss the application for and effects of hormones when used for meat animal production.

Strand

Animal Science
Scope Source

Master Las Plumas H.S.(a)

\section{Nutrition and Feeds}

Students will develop an understanding of the factors involved in animal nutrition, animal feeding, and the basic feedstuffs available for that purpose.

\section{Nutrient Needs}

The learner will be able to describe basic guidelines for feeding animals.

Strand Scope Source

Animal Master CA: Agricultural Content Standards, June 1999, Grade 9-12, Basic Core Career Path Cluster Science Master 1.14.4.

\section{Feed Composition}

The learner will be able to develop an understanding of the chemical composition and classification offeeds.

\section{Strand}

Animal

Science

\section{Scope Source}

Master CA: Ag

\section{Digestion and Absorption}

The learner will be able to develop an develop of how feeds are digested and absorbed in the animal's body.

Strand

Scope Source

Animal Science

Master Las Plumas H.S.(a)

\section{Feed Preparation}

The learner will be able to describe the different methods of feed preparation for livestock.

$\begin{array}{lll}\text { Strand } & \text { Scope } & \text { Source } \\ \text { Animal Science } & \text { Master } & \text { Las Plumas H.S.(a) }\end{array}$

\section{Protein Needs}

The learner will be able to develop an understanding of the amount and kind of protein needed in feeding livestock.

Strand Scope Source

Animal Master CA: Agricultural Content Standards, June 1999, Grade 9-12, Basic Core Career Path Cluster Science Master 1.14.1.

\section{Carbohydrates and Fats}

The learner will be able to develop an understanding of the classes and sources of develop needed by livestock.

Strand Scope Source

Animal Master CA: Agricultural Content Standards, June 1999, Grade 9-12, Basic Core Career Path Cluster Science Master 1.14.1.

\section{Vitamins and Minerals}


The learner will be able to understand the role of vitamins and minerals in animal nutrition.

Strand Scope Source

Animal Master CA: Agricultural Content Standards, June 1999, Grade 9-12, Basic Core Career Path Cluster Science Master 1.14.1.

\section{Feed Additives}

The learner will be able to a.

Strand

Scope Source

Animal Science

Master Las Plumas H.S.(a)

\section{Computing Balanced \& Least-Cost Rati}

The learner will be able to compute a balanced and least-cost rations for livestock.

Strand

Animal Science
Scope Source

Master Las Plumas H.S.(a)

\section{Animal Health}

Students will understand the concept of animal health and become familiar with methods of identification of unhealthy animals, treatment, preventative measures and the causal agents of common health problems in animals of economic importance.

\section{Animal Health: Whose Responsibility?}

The learner will be able to understand the importance of animal health and how who is importance in what instances.

Strand

Scope Source

Animal Science

Master Las Plumas H.S.(a)

\section{Animal Health Evaluations}

The learner will be able to describe the appearance and behavior of a normal, healthy animal.

Strand Scope Source

Animal Master CA: Agricultural Content Standards, June 1999, Grade 9-12, Basic Core Career Path Cluster Science Master 1.15.1.

\section{Normal Temperature, Pulse \& Respirat}

The learner will be able to demonstrate the proper methods for determining temperature, pulse and respiration.

Strand Scope Source

Animal Master CA: Science Content Standards, December 1998, Grades 9-12, Investigation and Science Master Experimentation, 10.a,b.

\section{Factors Affecting Animal Health}

The learner will be able to list the major factors affecting animal health (housing, sanitation, nutrition).

Strand Scope Source

Animal CA: Agricultural Content Standards, June 1999, Grade 9-12, Basic Core Career Path Cluster 1.15.2. Science Master CA: Science Content Standards, December 1998, Grades 9-12, Investigation and Experimentation, 10.c, and d.

\section{Vaccinations \& Administration of Age}

The learner will be able to develop a vaccination schedule for a livestock species. 


$\begin{array}{lll}\text { Strand } & \text { Scope } & \text { Source } \\ \text { Animal Science } & \text { Masten } & \text { Las Plumas H.S.(a) }\end{array}$

\section{Development and Types of Immunity}

The learner will be able to understand how immunity is developed and its importance.

Strand Scope Source

Animal Master CA: Science Content Standards, December 1998, Grades 9-12, Investigation and

Science Master Experimentation, 10.d, and e.

\section{Meat Grading}

Students will understand the basis for meat grading and develop an appreciation of the variety of products available from meat animals.

\section{Meat Grading}

The learner will be able to identify USDA grades of beef, pork, and lamb, and the dressing percentages of the major commercial meat animals.

$\begin{array}{lll}\text { Strand } & \text { Scope } & \text { Source } \\ \text { Animal Science } & \text { Master } & \text { Las Plumas H.S.(a) }\end{array}$

Wholesale and Retail Cuts

The learner will be able to identify six wholesale and retail cuts each of beef, pork and lamb.

$\begin{array}{lll}\text { Strand } & \text { Scope } & \text { Source } \\ \text { Animal Science } & \text { Master } & \text { Las Plumas H.S.(a) }\end{array}$

\section{Basic Botany}

Students shall understand growth and development of plants, including the functions of plant parts, reproductive systems, and auxins.

\section{Plant Parts}

The learner will be able to identify plant parts including, roots, leaves, stem, fruit, and flower.

Strand Scope Source

Plant Master CA: Agricultural Content Standards, June 1999, Grade 9-12, Basic Core Career Path Cluster Science Master 1.17.1.

\section{Functions of Plant Parts}

The learner will be able to describe the general function of each the major plant parts.

\section{Strand Scope Source}

Plant Master CA: Agricultural Content Standards, June 1999, Grade 9-12, Basic Core Career Path Cluster Science Master 1.17.2.

\section{Importance of Plants to Man}

The learner will be able to list necessities of man life that are furnished by plants.

$\begin{array}{lll}\text { Strand } & \text { Scope } & \text { Source } \\ \text { Plant Science } & \text { Master } & \text { Oroville Union High School District(a) }\end{array}$

\section{Classification of Plants by Life Cycle}


The learner will be able to classify plant samples as annual, biennials or perennial.

Strand Scope Source

Plant CA: Agricultural Content Standards, June 1999, Grade 9-12, Basic Core Career Path Cluster 1.17.4

Science Master CA: Science Content Standards, December 1998, Grades 9-12, Investigation and Experimentation, 3.b.

\section{Plant Propagation by Seed}

The learner will be able to explain and demonstrate methods of sexual plant propagation.

Strand Scope Source

Plant $\quad$ Master CA: Agricultural Content Standards, June 1999, Grade 9-12, Basic Core Career Path Cluster 1.17.2
Science

Plant Propagation: Vegetative

The learner will be able to explain and demonstrate methods of asexual plant propagation.

Strand

Scope Source

Plant Science

Master Oroville Union High School District(a)

\section{Plant Mitosis}

The learner will be able to outline the process of mitosis.

Strand Scope Source

Plant Master CA: Agricultural Content Standards, June 1999, Grade 9-12, Basic Core Career Path Cluster

Science Master 1.13.3.

\section{Photosynthesis}

The learner will be able to describe the steps in the process of photosynthesis.

Strand Scope Source

Plant Master CA: Science Content Standards, December 1998, Grades 9-12, Investigation and Experimentation, Science Master $1 . f, \mathrm{~g}$, and h.

\section{Respiration}

The learner will be able to describe the steps in the process of respiration.

$\begin{array}{lcl}\text { Strand } & \text { Scope } & \text { Source } \\ \text { Plant Science } & \text { Master } & \text { Oroville Union High School District(a) }\end{array}$

\section{Transpiration}

The learner will be able to demonstrate transpiration in plants.

$\begin{array}{lcl}\text { Strand } & \text { Scope } & \text { Source } \\ \text { Plant Science } & \text { Master } & \text { Oroville Union High School District(a) }\end{array}$

\section{Translocation}

The learner will be able to demonstrate translocation in plants.

$\begin{array}{lll}\text { Strand } & \text { Scope } & \text { Source } \\ \text { Plant Science } & \text { Master } & \text { Oroville Union High School District(a) }\end{array}$

\section{Plant Growth Requirements}

The learner will be able to identify plant growth requirements.

Strand

Plant Science

\author{
Scope Source \\ Master Oroville Union High School District(a)
}




\section{Plant Nutrition}

Students will understand the role of fertilizers in agricultural production.

\section{Nutrients Essential to Plant Growth}

The learner will be able to list the primary, secondary, and micronutrients.
Strand
Scope Source
Plant Science
Master Oroville Union High School District(a)

\section{Sources of Primary Plant Nutrients}

The learner will be able to list a source for each for each of the primary elements $(N, P, K)$.
Strand
Scope Source
Plant Science
Master Oroville Union High School District(a)

\section{Fertilizer Labels and Calculations}

The learner will be able to select from a list the information that must be stamped on fertilizer bags according to law.

$\begin{array}{lcl}\text { Strand } & \text { Scope } & \text { Source } \\ \text { Plant Science } & \text { Master } & \text { Oroville Union High School District(a) }\end{array}$

\section{Determining Nutrient Deficiencies}

The learner will be able to identify three general methods for testing soil deficiency and methods one.

$\begin{array}{lll}\text { Strand } & \text { Scope } & \text { Source } \\ \text { Plant Science } & \text { Master } & \text { Oroville Union High School District(a) }\end{array}$

\section{Fertilizer Application}

The learner will be able to demonstrate three common methods for fertilizer application.

$\begin{array}{lll}\text { Strand } & \text { Scope } & \text { Source } \\ \text { Plant Science } & \text { Master } & \text { Oroville Union High School District(a) }\end{array}$

Organic and Inorganic Fertilizers

The learner will be able to list three advantages each of organic and inorganic fertilizers.

$\begin{array}{lll}\text { Strand } & \text { Scope } & \text { Source } \\ \text { Plant Science } & \text { Master } & \text { Oroville Union High School District(a) }\end{array}$

\section{Irrigation}

Students shall understand different irrigation systems and how and when to irrigate. They will understand water measurement and soil capacity used in common irrigation practices.

\section{Irrigation Systems and Practices}

The learner will be able to identify modern irrigation systems and practices.

$\begin{array}{lll}\text { Strand } & \text { Scope } & \text { Source } \\ \text { Plant Science } & \text { Master } & \text { Oroville Union High School District(a) }\end{array}$

\section{Irrigation Terminology}

The learner will be able to understand different irrigation terminology.

$\begin{array}{lll}\text { Strand } & \text { Scope } & \text { Source } \\ \text { Plant Science } & \text { Master } & \text { Oroville Union High School District(a) }\end{array}$




\section{Water Measurement \& Soil Capacity}

The learner will be able to determine soil moisture content and soil capacity.

$\begin{array}{lcl}\text { Strand } & \text { Scope } & \text { Source } \\ \text { Plant Science } & \text { Master } & \text { Oroville Union High School District(a) }\end{array}$

\section{Pest Management}

Students shall understand the importance of pest control in agricultural production and appreciate the need for safe pesticide application procedures.

\section{Introduction to Pest Management}

The learner will be able to explain how insects, weds, diseases an vertebrate pests affect plant production.

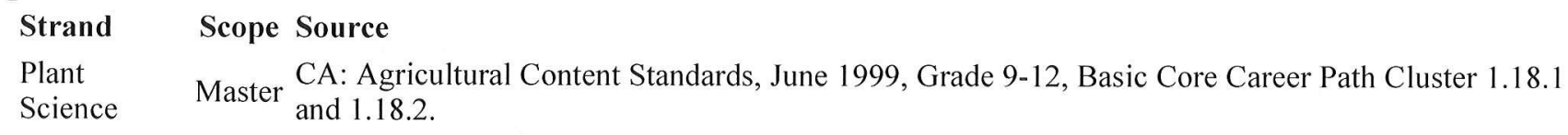

\section{Weed Control}

The learner will be able to identify different methods of wed control.

\section{Strand Scope Source}

Plant Master CA: Agricultural Content Standards, June 1999, Grade 9-12, Basic Core Career Path Cluster Science Master 1.18.3.

\section{Weed Collections}

The learner will be able to develop a twenty-five sample weed collection.

$\begin{array}{lcl}\text { Strand } & \text { Scope } & \text { Source } \\ \text { Plant Science } & \text { Master } & \text { Oroville Union High School District(a) }\end{array}$

\section{Damage Caused By Plant Pests}

The learner will be able to identify ten different types of damage caused by plant pests.

Strand Scope Source $\begin{array}{ll}\text { Plant } & \text { Master CA: Agricultural Content Standards, June 1999, Grade 9-12, Basic Core Career Path Cluster } \\ \text { Science } & \text { 1.18.1. }\end{array}$

\section{Plant Disease Identification}

The learner will be able to identify ten different types of plant diseases.

Strand Scope Source

Plant Master CA: Agricultural Content Standards, June 1999, Grade 9-12, Basic Core Career Path Cluster Science Master 1.18 .1 .

\section{Disease Control: Cultural and Chemical}

The learner will be able to describe chemical and cultural methods of plant disease control.

\section{Strand Scope Source} Plant $\quad$ Master CA: Agricultural Content Standards, June 1999, Grade 9-12, Basic Core Career Path Cluster
Science

\section{Biology of Insects}

The learner will be able to identify the different anatomical structures of different pests.

Strand Scope Source 
Plant Master CA: Agricultural Content Standards, June 1999, Grade 9-12, Basic Core Career Path Cluster Science Master 1.18.1.

\section{Pest Collection}

The learner will be able to collect and identify different types of pests.

Strand

Scope Source

Plant Science

Master Oroville Union High School District(a)

\section{Workplace Safety}

The learner will be able to understand workplace safety in pest management.

Strand Scope Source

Plant Master CA: Agricultural Content Standards, June 1999, Grade 9-12, Basic Core Career Path Cluster 1.18.1 Science Master and 1.18.3.

\section{Pesticide Safety: Low and High Toxicity}

The learner will be able to understand the concepts of low and high toxicity in pesticide safety.

Strand Scope Source

Plant Master CA: Agricultural Content Standards, June 1999, Grade 9-12, Basic Core Career Path Cluster 1.18.2 Science Master and 1.18.3.

\section{Measurement in Plant Science}

Students shall understand the basic applications of ,measurement in calculating volume. Develop an appreciation for the differences between the American and Metric systems of measurement.

\section{Measurement in Plant Science}

The learner will be able to measure to within 1/16th of an inch and calculate area and volume when given dimensions.

Strand Scope Source

Plant Master CA: Agricultural Content Standards, June 1999, Grade 9-12, Basic Core Career Path Cluster 1.9.1 Science Master and1.9.2.

\section{Careers \& Employability: Agriculture}

Students will be aware of existing and future employment opportunities in the field of agriculture and will develop an understanding of how to conduct a job search, write a resume, and interview for a job.

\section{Agricultural Career Clusters}

The learner will be able to describe the six agriculture career clusters and give examples of entry, technical, and professional careers in each cluster.

\section{Strand}

Agricultural Student

Leadership

\section{Instructional Resources}

- FFA Career Center, National FFA Organization, Careers [On-line]. http://www.ffa.org/careers/index.html

- FFA Career Center, National FFA Organization, Ag Career Clusters [Online]. http://www.teamaged.org/ffa/careers/clusters.htm

\section{Resumes}

http://www.ouhsd.org/Curriculum/Science/CP35766.HTM 
The learner will be able to develop a resume and participate in a mock job interview.

Strand

Agriculture Basic

Core
Scope Source

Master CA: Agriculture Content Standards, June 1999, Grades 9-12, Basic Core Career Path Cluster 1.8.2.

Instructional Resources

- California Agricultural Education, Job Interview Contest [On-line]. http://www.calaged.org/CCode/C12.doc

\section{Career Exploration through Technology}

The learner will be able to utilize resources to learn about an agriculture occupation of their choice.

Strand

Agriculture Basic

Core

Instructional Resources

- EUREKA, The California Career Information System [Software].

\section{Scope Source}

Master CA: Agriculture Content Standards, June 1999, Grades 9-12, Basic Core Career Path Cluster 1.8.3.

\section{Projects}

Students will understand the relationship between a supervised occupational experience (SOE) and their preparation for a career in agriculture. They will actively engage in and manage a SOE which enables them to develop occupational skills.

\section{Supervised Occupational Experience Plan}

The learner will be able to develop an agricultural SOE plan (student data sheet).

\section{Strand Scope Source}

Agriculture Basic Master CA: Agriculture Content Standards, June 1999, Grades 9-12, Basic Core Career Path Core Cluster 1.7.1.

\section{Instructional Resources}

- Agriscience Fundamentals \& Applications, Delmar Publishers, 2nd Edition, 1995, Unit 5 (67-84). [Textbook].

\section{Supervised Occupation Experience Project}

The learner will be able to demonstrate responsibility, commitment, and time management skills by conducting and maintaining and SOE.

Strand Scope Source

Agriculture Basic $\quad$ Master CA: Agriculture Content Standards, June 1999, Grades 9-12, Basic Core Career Path
Core Core

\section{Record Keeping}

Students will understand the importance of keeping records and importance the consequences of inaccurate records. The will maintain and complete the California Agricultural Record Book which pertains to their Supervised Occupational Experience (SOE) Program.

\section{Accurate Record Keeping}

The learner will be able to explain reasons for keeping accurate records and consequences of inaccurate records.

Strand

Agriculture Basic

Core

\section{Scope Source} Master CA: Agriculture Content Standards, June 1999, Grades 9-12, Basic Core Career Path
Cluster 1.4.1. 


\section{Budgets and Business Agreements}

The learner will be able to develop a budget and a business agreement for a project.

\section{Strand Scope Source}

Agriculture Basic Master CA: Agriculture Content Standards, June 1999, Grades 9-12, Basic Core Career Path Core Master Cluster 1.4.2.

\section{Instructional Resources}

- California Agriculture Education Record Book Instructional Manual, Agricultural Education Unit: CA Dept. of Edu., 1995, (17-30) and (31-37). [Textbook].

\section{Journals}

The learner will be able to complete journal entries for two enterprises and carry entries forward to the next month.

\section{Strand}

Agriculture Basic

Core Scope Source

Master CA: Agriculture Content Standards, June 1999, Grades 9-12, Basic Core Career Path

\section{Instructional Resources}

- California Agriculture Education Record Book Instructional Manual, Agricultural Education Unit: CA Dept. of Edu., 1995, (39-55). [Textbook].

\section{Financial Statements and Income Summary}

The learner will be able to prepare a financial statement and a net income summary.

Strand

Agriculture Basic Core Scope Source

Instructional Resources

- California Agriculture Education Record Book Instructional Manual, Agricultural Education Unit: CA Dept. of Edu., 1995, (113-124) and (125-133). [Textbook].

\section{Non-Depreciable and Depreciable Property}

The learner will be able to complete non-depreciable and depreciable property inventories.

Strand

Agriculture Basic

Core

\section{Scope Source}

Master CA: Agriculture Content Standards, June 1999, Grades 9-12, Basic Core Career Path

\section{Instructional Resources}

- California Agriculture Education Record Book Instructional Manual, Agricultural Education Unit: CA Dept. of Edu., 1995, (81-90) and (91-112). [Textbook].

\section{Straight-line Depreciation}

The learner will be able to use the straight-line method for determining depreciation.

\section{Strand}

Agriculture Basic

Core

\section{Scope Source}

Master $\mathrm{CA}$

CA: Agriculture Content Standards, June 1999, Grades 9-12, Basic Core Career Path

Instructional Resources

- California Agriculture Education Record Book Instructional Manual, Agricultural Education Unit: CA Dept. of Edu., 1995, (93) [Textbook].

Interpersonal Leadership Development

Students will develop a basic understanding of the FFA, recognize the traits of effective leaders and participate in leadership training activities associated with the FFA, which may include public speaking, leading group 
discussions, working within a committee, conducting business meetings, and problem solving.

\section{Benefits of FFA Membership.}

The learner will be able to explain the benefits of FFA membership.

Strand

Agriculture Basic

Core

Instructional Resources

- Agriscience Fundamentals \& Applications, Delmar Publishers, 2nd Edition, 1995, Unit 6 (89-103). [Textbook].
Scope Source

Master CA: Agriculture Content Standards, June 1999, Grades 9-12, Basic Core Career Path Cluster 1.6.1.

\section{Leadership development Skills}

The learner will be able to describe and explain leadership skills developed by participating in FFA.

Strand

Agriculture Basic

Core

\section{Scope Source}

Master CA: Agriculture Content Standards, June 1999, Grades 9-12, Basic Core Career Path

\section{Parliamentary Procedures}

The learner will be able to demonstrate the use of five parliamentary procedure skills.

Strand

Agriculture Basic

Core

Instructional Resources

- Agriscience Fundamentals \& Applications, Delmar Publishers, 2nd Edition, 1995, Unit 6 (103-106). [Textbook].

\section{Committee Development and Use}

The learner will be able to demonstrate the ability to cooperate and collaborate by serving on a committee.

Strand

Agriculture Basic

Core

Scope Source

Master CA: Agriculture Content Standards, June 1999, Grades 9-12, Basic Core Career Path Cluster 1.6.4.

\section{Oral Presentations}

The learner will be able to make an oral presentation.

Strand

Agriculture Basic

Core
Scope Source

Master CA: Agriculture Content Standards, June 1999, Grades 9-12, Basic Core Career Path

\section{Problem Solving}

The learner will be able to demonstrate the process of solving a problem by identifying the problem, proposing solutions, gathering information, testing and evaluating solutions.

Strand

Agriculture Basic Core

\section{Scope Source}

Master CA: Agriculture Content Standards, June 1999, Grades 9-12, Basic Core Career Path Cluster 1.6.6.

(C) 2009 by Oroville Union High School District and Scantron Corporation. All Rights Reserved. Made with Curriculum Designer by Scantron Corporation. 


\section{Course Description:}

\section{Agriculture Leadership \\ Mrs. Earley \\ 2011-2012}

This course will provide students opportunities to set and develop their personal and career goals, advance communication and teamwork skills, and to build their personal leadership style. Emphasis will be placed upon completing assigned tasks, learning to function both as a team leader and committee member, and developing and using time - management and organizational skills.

\section{Supplies needed: 3 Ring Binder, Binder Paper, Pencil or Pen}

Text: Official Manual. National FFA Organization

\section{Grading Policy:}

All assignments are expected to be turned in on time:

Letter grades are determined by (percentages are approximate):

$\begin{array}{ll}35 \% & \text { Agriculture Leadership Projects and assignments } \\ 10 \% & \text { Leadership Contest Participation } \\ 10 \% & \text { FFA activities outside of class time- } 3 \text { per quarter } \\ 10 \% & \text { SAE and Record Book } \\ 35 \% & \text { Participation, Attendance, Attitude }\end{array}$

I. Leadership Projects and Assignments: Projects will be lined out at the beginning of each semester for each student and modified as needed. The teacher and student will agree on the project and students will be given class time in order to work on the project. It is recommended that time be spent on the project outside of the classroom as well.

II. Leadership Contest Participation: Students will be required to participate in one leadership contest per semester and will be adequately trained during class in order to participate in the contest.

Fall Semester - November $17^{\text {th }}$ Co-Op Quiz or Novice Records or Opening/Closing Spring Semester - February Local or North Valley Section Leadership Contests

III. Participation: Students will be given $0-5$ points per day for positive participation in the course. Students will earn up to 5 points each day based upon completion of assignments, positive participation in an activity, positive class input, completion of a responsibility, etc. In order to receive participation points in case of an absence, a student must make up the work done that day and have an excused admit. Attitude will be based on student's ability to come to class with a positive class daily. Timecards must be filled out daily to receive your participation points!

IV. FFA/SAE/Record Book: In order to receive full credit for FFA activities a student must participate in at least 3 FFA activities per quarter outside of class time. The activities include but are not limited to; FFA meetings, Farm clean up days, FFA Field Trips, FFA Plant Sales, and any other FFA activity with prior approval. Each agriculture student is required to have a Supervised Agricultural Experience. These experiences can be custom fit to the student's interest in agriculture.

Examples of SAE's: agriculture work experience, garden care, home lawn care, fair animals, mechanics project, animal care project etc. Students must spend time outside of class and keep accurate records on their SAE. An agriculture teacher will make project visits. 
Teacher: $\quad$ Mrs. Earley

Email: aearley@ouhsd.org

\section{Las Plumas High School Agriculture Department \\ Classroom Policies, Expectations, and Procedures}

\section{Course Description}

Phone: 530-538-2310 ext. 306

Room: 2001

aesthetic and creative perceptuar besign provides the fundamentals of artistic and creative perceptual base including tempera, pencil, flowers and tile. Stude including aesthetic valuing through a series of projects in various media including line, shape/form, color blance. Students are also introduced to the elements and principles of visual art design such as application to visual art. Various assignhasis using a series of floral based projects to explore connections, relations and theory, color theory and Various assignments based on abstract two and three dimensional designs, historical culture and development of technical skills in floral art.

\section{Course Objectives}

$\supseteq$ Develop and create original artwork based on relating visual art design concepts and processes to their own personal experiences.

$>$ Derive meaning from artworks and floral designs, including floral symbolism, through analyzing, interpretations and judgment of various pieces developed by renowned artist of different historical and contemporary periods.

$>$ Demonstrate skills in utilizing the language of visual arts design as the foundation for creating and analyzing the visual structures and functions of art.

$>$ Safely use florist tools, equipment, and materials.

$>$ Correctly condition and handle cut flowers, foliage, and plants used in the floral industry.

$>$ Integrate art standards, mathematics standards, language arts standards, and career employability

- standards including creative thinking and problem solving skills, and technological literacy related to the floral industry.

$>$ Construct basic floral products for display or resale.

> Demonstrate an understanding of different floral design styles and arrangements.

$>$ Participate in basic horticulture production; demonstrate understanding of flower and foliage production.

$>$ Describe floral designs and styles from different historic periods.

$>$ Create a professional portfolio of career technical skills.

$>$ Motivate students to appreciate floral design as members of our community, and as a possible professional in the industry.

$>$ Exposure to FFA floral design career development events and supervised agricultural experiences in the floriculture industry.

\section{Course Outline}

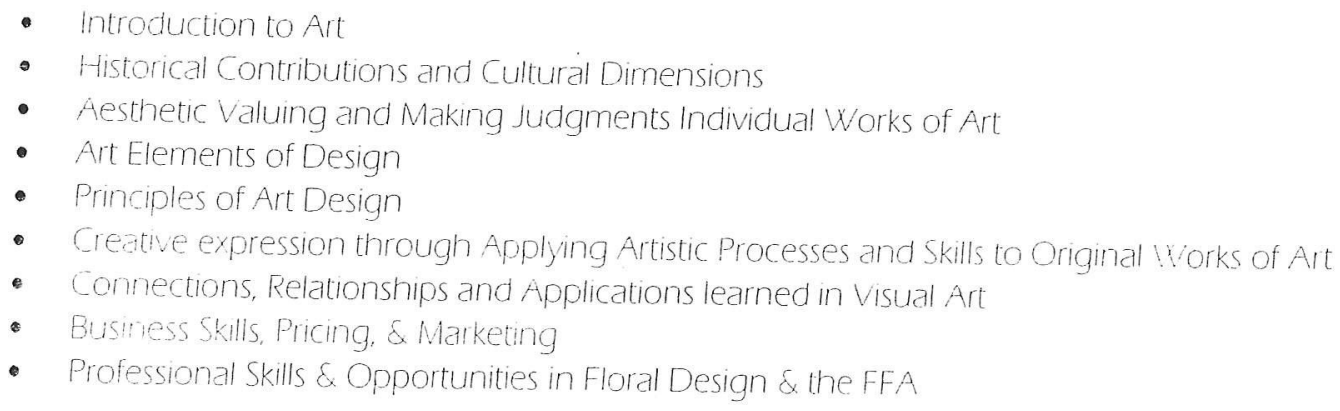

Materials Needed

- Pen \& pencil (highlighter and colored pens are helpful, but not required)

- 3 ring binder with lined paper

1 "White Binder with clear cover for Professional Portfolio (due by January) 


\title{
Las Plumas High School Agriculture Department Classroom Policies, Expectations, and Procedures
}

\author{
Grading \\ $10 \%$ \\ $10 \%$ \\ $10 \%$ \\ $10 \%$ \\ $20 \%$ \\ $20 \%$ \\ $20 \%$ \\ $\overline{100 \%}$ \\ California Agriculture Record Book / Approved SAE Project \\ FFA Participation \\ Participation, Attendance and Attitude (Timecards) \\ Class Notebook - Binder \\ Project Reports \\ (Floral Identification, Art History, Professional Portfolio) \\ Classroom Assignments and Homework (Arrangements) \\ Tests and Quizzes - Evaluations
}

$$
\begin{aligned}
& 90-100=A \\
& 80-89=B \\
& 70-79=C \\
& 59-69=D \\
& 0-58=F
\end{aligned}
$$

I. California Ágriculture Record Book / Approved SAE Project: Students will complete a Record Book and maintain the information pertaining to their approved Supervised Agricultural Experience Project, and all FFA Activities. The Record Book (properly updated and correctly completed) is worth $10 \%$ of the total grade earned. This will be primarily an in-class activity, but the activities \& participation recorded will be extracurricular. All students in the agricultural department are encouraged to maintain an SAE project; first year agriculture students will develop a plan for their SAE project for the coming year. This SAE may consist of a project in the field of agriculture, science, or industrial technology, and will allow students to experience career skills in the industry. Examples include:- metat or wood shop projects, customer service, horticulture, computer work, community service, gardening, landscaping, and livestock (breeding or market animals).

II. FFA Participation: FFA is an organization that makes a positive difference in the lives of students by : developing their potential for premier leadership, personal growth, and career success through agricultural education. The FFA is an integral part of every agricultural class. Every student's grade will be enhanced by participation in this organization. Meetings, planning events, field days, fundraisers, conferences, community service, and competitions are just a few of the ways students can become involved in the FFA. There is a requirement of 5 FFA Activities per semester.

III. Class Notebook: Each student is required to maintain a binder or notebook for this class. Binders act as a notebook and organization tool. Students should keep all handouts, notes, and class/homework organized in their notebook.

\section{Classroom Expectations}

1. Students are expected to BE RESPECTFUL and treat their teachers, classmates, and classroom environment with respect. Disrespectful and/or rude behavior will not be tolerated.

2. Students are to be SAFE while in class and follow all safety rules while working in the lab and classroom.

3. Students are expected to BE RESPONSIBLE and BE ACCOUNTABLE for their actions and behavior. Students will be held accountable for their behavior and actions during class and towards their classroom assignments/responsibilities.

\section{Student Responsibilities}

The agricultural department is successful because the students have pride in the activities of the department and care about what takes place with their class. It is essential that students who choose to take a class with the Agriculture Department be aware of and follow the expectations of the department. 


\section{Las Plumas High School Agriculture Department Classroom Policies, Expectations, and Procedures}

\section{Late Work, Class Absences and Tardies}

Make up work will be provided during consultation periods. DO NOT expect to be provided make-up work once class has started. Students will have an equal number of days as their absence to make up work without grade penalty. LATE WORK beyond this time will be accepted with the grade penalty. It is the student's responsibility to arrange to make up assignments, quizzes or tests after excused
absences on the day you return to school.

Class begins when the bell rings.

Each Tardy a student receives will be placed on the 6-stēp discipinine policy.

Students are expected to BE ON TIME, BE SEATED, BE PREPARED, and BE ATTENTIVE. Students will
be considered tardy if they are not in their proper seat when the bell and started on their quickwrite.

\section{Cell Phone \& Electronic Device Policy}

\footnotetext{
Cellular phones that are brought to schoot may not be visible or used during class time. Unauthorized or inappropriately used
electronic equipment will be confiscated and returned to the student's parents/guardians.
If disruption occurs, an employee will confiscate the devis

\section{Behavior Expectations and Consequences} 'f the problem is severe in nature or a student puts another person(s) in danger due to unsafe behavior a referral may be
warranted. The student will be placed on the 6 steps listed below for minor infractions:

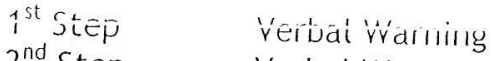
$2^{\text {nd }}$ step
$3^{\text {rd }}$ Step
$4^{\text {th }}$ Step
$5^{\text {th }}$ Step
$6^{\text {th }}$ Step
Verbal Warning and Participation Points Taken Away
Appointment with Mrs. Earley and contact your parents Consultation Time and contact your parents Teachers Discretion (Consultation Time, Parents Notified)
$7^{\text {th }}$ Step and beyond vill result in a referral to the assistant principal 


\section{Mrs. Earley's Classroom \\ Expectations}

\section{General Expectations:}

a. Respectful

- Treat all adults, whether they are teachers, administrators, staff, substitutes or visitors with respect.

- Treat fellow students and their property with respect.

- No putdowns or foul language

b. Responsible

- YOU are responsible for your own work, words and actions.

- Students are expected to BE ON TIME, BE SEATED AND BE PREPARED.

- Students will be considered tardy if they are not in their proper seat when the bell rings, with their notebook out and started on their quickwrite!

c. $\underline{\text { Safe }}$

- Follow all Safety Rules as outlined by teacher during the activity

II. - Specifie Behavior Expectations:

a. Follow directions the first time they are given.

b. No personal grooming during class time (make-up, mirrors etc).

c. No Garbage left in the room, when you leave.

d. Food or open drinks in the classroom.

e. Cell phones are to be put away during class.

III. Consequences:

If the problem is severe in natiie or a student puts another person's) in danger due to unsafe behavior a referral may be warranted.

The student will be placed on the 6 steps listed below for the above infractions: $1^{\text {st }}$ Offense: $\quad$ Verbal Warning

2nd Offense: $\quad$ Verbal Warning and Participation Points Taken Away

${ }^{\text {rd }}$ Offense: $\quad$ Appointment with Mrs. Earley - Consultation Time

$4^{\text {ti }}$ Offense: $\quad$ Consultation Time

$5^{\text {th }}$ Offense: $\quad$ Teachers Discretion (Detention, SSC)

6 6 thense: $\quad$ Teachers Discretion (Detention, SSC)

$7^{\text {th }}$ and Beyond Referral to the Office

IV. Positive Recognition:

I will see to it as your teacher that you will get positive feedback on any good work, or improvement, or if class rules have been and are being followed. I will give you this recognition through:

a. Verbal praise

b. Written notes

c. Parent acknowledgement by me in person. notes. or by phone

V. Mints for Success

a. Pay attention and take notes

b. Ask Questions!

c. Make an effort to complete all assignments (on your own)

d. Come in for extra help - I will be arailable to you! 


\title{
Las Plumas High School Agriculture Department Signature Form
}

\section{Please print NEATLY (-)}

\author{
Students Name \\ Parent/Guardian(s) Name
}

Address

Contact Information:

Daytime:

Evening:

Email Please provide your email, the Ag department will update you with activities that we are having throughout
the year and send newsletters to you.

Parents please answer the following questions:

1) I am interested in chaperoning trips for the Agriculture Department

2) I am interested in serving on the Steak and Crab Feed Committee n_ yes no no n _ n

3) I have a skill(s) that may be helpful to the Ag Department in their ques animal facility during the $2010-2011$ their quest to build a large completely functional (rreenhouse, electwical concrotc woik horticulture department 4) I agree to allow the agriculture department to take pictures of activities in which my child may appear and use them to promote the department through brochures, FFA website(s), facebook and misc other FFA publications. yes 110

I have read the enclosed materials and understand what is expected of iny child and me. I am aware of the expectations, materials, and grading policy in ihe agriculture course that my child is enrolled in. I acknowledge that the FFA and SAE activities will be included as part of the opportunities as well as requirements that exist for my child who is enrolled in this Agriculture course

Parent Signature

I have read the enclosed materials and understand what is expected of me. I am aware of the expectations, materials, and grading policy in the agriculture course that I am enrolled in. I acknowledge that the FFA and SAE activities will be included as part of the opportunities as well as requirements that exist for me in this Agriculture course.

Student Signature

Any comments or information which you feel I should know about your child and his/her ability to perform at school please make a note of these on the back of this paper. 


\title{
Butte County Regional Occupational Program COURSE DESCRIPTION
}

\author{
Course Title: $\quad$ Veterinary Science \\ CBEDS Title: $\quad$ Animal Science \\ CBEDS Number: $\quad 4020$ \\ Length of Course: 1 Year \\ Hours: $\quad 360$
}

O*NET Job Titles:

Veterinary Assistants and Laboratory Animal Caretakers:

Veterinary Technician, Kennel Attendant, Kennel Technician

Farm Worker, Farm \& Ranch Animals:

Livestock Handler, Vaccinator, Herdsman, Breeding Technician

Nonfarm Animal Caretakers:

Groomer, Kennel Aide, Zookeeper, Animal Care Giver
O*NET Number:

$31-9096.00$

$45-2093.00$

$39-2021.00$

Text Books: Introduction to Veterinary Science, Lawhead and Baker, Thompson Learning First Edition

The Merck Veterinary Manual, Aiello, Merck \& Co, Eighth Edition

Official Manual. National FFA Organization (2007).

California Agriculture Record Book, California FFA Association (2007).

Prerequisites: Animal Science

CSU/UC Requirement: UC " $\mathrm{g}$ " elective credit

\section{Class Description:}

This class provides students with entry-level skills in the veterinary medicine industry. Animal health fundamentals covered in the class include terminology, safety, production, animal care and handling. Students will gain skills and knowledge to perform a variety of clinical tasks and office procedures through classroom exposure to realistic medical situations and non-paid internships in veterinary-related businesses. 


\begin{tabular}{|c|c|c|c|}
\hline Q. & 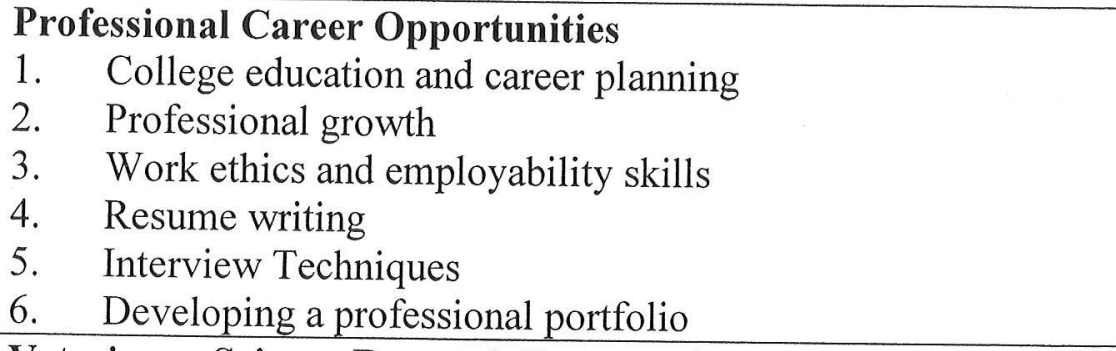 & 20 & 5 \\
\hline R. & $\begin{array}{l}\text { Veterinary Science Research Presentation } \\
\text { 1. Current animal research and investigation } \\
\text { 2. Data Presentation } \\
\text { 3. Summarization and conclusion }\end{array}$ & 20 & \\
\hline S. & $\begin{array}{l}\text { Interpersonal Skills \& Leadership Development (FFA) } \\
\text { 1. Examine leadership traits in a leader } \\
\text { 2. List components of teamwork and cooperation } \\
\text { 3. Speaking \& Seminar Presentation } \\
\text { 4. Completion of a Supervised Agricultural Experience Project } \\
\text { and Record book }\end{array}$ & 20 & \\
\hline & Total Hours: & 260 & 100 \\
\hline
\end{tabular}

\section{KEY ASSIGNMENTS:}
A. Weekly academic textbook assignments
B. Weekly laboratory activities and report
C. Supervised Agriculture Experience Project and Record Book
D. Student Seminar Presentation on a Veterinary Science Topic
E. Student Portfolio
F. FFA Leadership Participation

\section{INSTRUCTIONAL METHODS:}
A. Lecture and Discussion
B. Audio Visual Materials
C. Research Readings and Written Presentations
D. Homework Assignments
E. Group \& Individual Activities
F. Laboratory Investigation
G. Discussion \& Group Dynamics
H. Quizzes, Tests \& Final Exam
I. Internships
J. $\quad$ Field Trips
K. Projects - Individual and Group

\section{ASSESSMENT METHODS:}

A. Quizzes, Tests \& Final Exam $30 \%$

B. Laboratory Investigation \& Write-ups $20 \%$

C. Timecards - Participation, Attendance and Attitude $20 \%$

D. Notebook/Portfolio $10 \%$

E. Leadership \& Critical Thinking Activities - FFA $10 \%$

F. Supervised Agricultural Experience Project \& Record Book $\quad 10 \%$ 


\section{BUTTE COUNTY \\ REGIONAL OCCUPATIONAL PROGRAM \\ "Committed to Career Success" \\ Expected Student Learning Results}

1. Demonstrate appropriate work ethic through:

- Punctual, regular attendance

- Personal integrity, honesty, respect

- Teamwork, working cooperatively with others

- Positive attitude, enthusiasm, initiative

2. Demonstrate appropriate job preparation and search skills through:

- Assessment, career planning, goal setting

- Resume, employment application, interview

- Attainment of course specific competencies

3. Demonstrate entry level use of industry sector technology/tools through:

- Adherence to safety procedures, precautions

- Application of knowledge, skills

- Integrated use of academic skills and computer literacy skills

- Workplace Simulation/Community Classroom/Cooperative Vocational Education

4. Demonstrate effective communication through:

- Workplace appropriate verbal, written and listening skills

- Performance of verbal and written directions

- Organization of thoughts and use of articulate language

5. Demonstrate critical thinking skills through:

- Analysis/evaluation and solution of problems

- Practical/successful use of community resources/agencies

- Independent work, self management

6. Demonstrate professionalism through:

- Socially appropriate interaction

- Suitable dress and appearance

- Confidentiality 


\title{
Grading Policy
}

\author{
Participation-30\% A $90-100 \%$ \\ Lab Experiments -30\% B 80-89\% \\ Homework/Tests/Quizzes/Final-20\% C $70-79 \%$ \\ FFA $20 \% \quad$ D $60-69 \%$ \\ F 59\% and below
}

I will encourage each student to become involved in our FFA Chapter, teams and leadership events. I will actively and enthusiastically inform them of upcoming events. This will provide them with opportunities to improve their academic standing, increase their involvement in their schonl community and nrovide them with an exciting opportunity for success through leadership development. The grade follows this breakdown: $10 \%$ for 2 events per quarter, 5\% for an active S.A.E. Project, and 5\% for maintaining a Record Book. These are all or nothing points.

Thank You,

Mr. Knapp

$538-2310$ extension 305 classroom

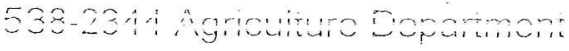

ynemantoyahoo.com

Topic Guide 2011-12

\begin{tabular}{|c|c|c|c|}
\hline $1^{\text {st Quarter }}$ & $2^{110}$ Qunatar & $3^{10}$ Warter & $4^{\text {til }}$ Quarter \\
\hline Introduction to FFA & Earth Structure & Parli Pro & Earth's Energy \\
\hline Leadership Promotion & Planets & Earth's Atmosphere & Climate \\
\hline Science Discovery & Space & Weather & California Geology \\
\hline Scientific Method & Sun and Fusion & Clouds & Writing \\
\hline Densicy & Piate Tectonics & Graphing & Internet Search \\
\hline Solar System/Planets & Earthquakes & Table Interpretation & Oral Presentation \\
\hline Earth Systems & Volcanoes & Carbon Cycle revisited & Careers \\
\hline Current Science & Rock Cycle & Energy Budget & Resume \\
\hline Events & Minerals & Alternative Energy & College Guidance \\
\hline Math Discovery & Soil & Star Test Prep & Scholarships \\
\hline Energy Systems & Earth Cycles & Current Events & Current Events \\
\hline OpeningClosing Team & Record Books & School Events & School Events \\
\hline Junior Officers & Current Events & FFA Recruitment & Record Books \\
\hline Elements & School Events & Record Books & SAE Projects \\
\hline School Events & FFA Creed & SAE Projects & \\
\hline Agrilabs & FFA Recruitment & Agrilabs & \\
\hline FFA Recruitment & SAE Projects & Oral Presentation & \\
\hline
\end{tabular}




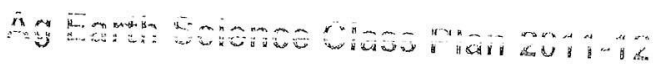

Ag Earth Science class prepares students to pass all examinations given by our district and

the State Department of Education. I use the California Earth Science Content Standards.

\section{School and Class Rules}

Be Safe: Follow class and school safety rules. No food, drink or gum allowed without

special approval. Follow activities as directed and use tools in a manner that they do not hurt you
your work or the tool.

Be Responsible: Come to class on time. Prepare yourself to learn at the scheduled time.

Bring learning material and tools to class-examples: paper, pencils, pens, notebook, flashdrive.

Make up your work from missed days. Study nightly as explained in class. =

Be Respectful: Every stıident hac valıo and noode to loarn Tront

be treated: WITH PRIDE, DIGNITY AND RESPECT!

\section{Knapp Rules:}

*As a sign of respect, students will not wear hats in class.

*Any student may use the restroom at any time provided they ask permission

*No electronic use during class, except for emergency situations.

\section{Discipline Policy}

This instructor uses the 6 step and 9 step discipline procedure The

cover bad behaviors disruption. vulgar language and off taskited to: tardies, inappropriate cell phone use, minor class behavor will lead directly and task behavior during learning time. More serious bad

A. First Offense: Verbal Warning

B. Second Offense: Verbal warning and a step

C. Third thru Sixth Offense: Note, teacher detention after school, you will phone home.

The $6^{\text {th }}$ offense is the last chance in class and every offense after that will fall under the nine step

\section{Âttendance}

A. Âttendance is paramount and does affect your grade.

B. Although attendance is not graded, poor attendance will lower your class scores.

C. It is your responsibility to make up all work missed.

D. Please arrive on time, habitual tardiness results in steps.

\section{Absences/Make-up Work}

Responsibility of all make up work falls to the student and the instructor. I will be happy to assist class' learning time for the ben, at break, at lunch or during consultation times. I will not delay the the due date, but will ask you to make it up during show make up work. I will accept work after complete the activity. If you know that you during consultation time. No points are deducted if you work. 


\section{Forestry Class Plan 2011-12}

Las Plumas High School Agriculture follows the California Agriculture Curriculum Standards in Environmental Horticulture as accepted by the California Department of Education.

\section{School and Class Rules}

Be Safe: Follow class and school safety rules. No food, drink or gum allowed without special approval. Follow activities as directed and use tools in a manner that they do not hurt you, your work or the tool.

Be Responsible: Come to class on time. Prepare yourself to learn at the scheduled time. Bring learning material and tools to class-examples: paper, pencils, pens, notebook and flashdrive. Make up your work from missed days. Study nightly as explained in class.

Be Respectful: Every student has value and needs to learn. Treat others as you want to be treated: WITH PRIDE, DIGNITY AND RESPECT!

\section{Knapp Rules:}

${ }^{*}$ As a sign of respect, students will not wear hats in class.

*Any student may use the restroom at any time provided they ask permission prior to leaving class.

* No electronic use during class, except for emergency situations.

\section{Discipline Policy}

This instructor uses the 6 step and 9 step discipline procedure. The offense list below will cover bad behaviors such as but not limited to: tardies, minor class disruption, vulgar language, off task during learning time... More serious bad behaviors will lead directly to the nine step discipline plan and may lead to class suspension.

A. First Offense: Verbal Warning-Given on the first day of class.

B. Second Offense: Verbal warning and a note.

C. Third-Sixth Offense: Teacher detention after school.

The $6^{\text {th }}$ offense is the last chance in class and every offense after that will fall under the nine step procedure as outlined in your discipline plan.

\section{Attendance}

A. Attendance is paramount and does affect your grade.

$B$. Although attendance is not graded, poor attendance will lower your score.

C. It is your responsibility to make up all work missed.

D. Although students will not receive a tardy mark until 30 minutes after the bell, any students late to class will receive a class disruption detention each time they come in after the bell rings.

\section{Absences/Make-up Work}

Responsibility of all make up work falls to the student and the instructor. I will be happy to assist you before school, after school, at break, at lunch or during consultation times. I will not delay the class' learning time for the benefit of one student to show make up work. I will accept work after the due date, but will ask you to make it up during consultation time. No points are deducted if you complete the activity. If you know that you are going to be gone in advance, I will assign you future work. 


\section{Grading Policy}

\section{I do not give 'D' grades}

Homework/Tests/Quizzes/Final, Greenhouse work Outside Labs, Plant Portfolio, Sales, Participation, Cleanup, Safety- $80 \%$

FFA-20\%
A $90-100 \%$

B $80-89 \%$

C $65-79 \%$

F 64\% and below

I will -record each student's FFA Grade at the beginning of the $2^{\text {nd }}$ and 4 th quarter. I will encourage each student to become involved in our FFA Chapter and inform them of upcoming events. This will provide them with opportunities to improve their academic standing, increase their involvement in their school community and provide them with an exciting opportunity for success through leadership development. The grade follows this breakdown: 10\% for 2 events per quarter, $5 \%$ for an active S.A.E. Project, $5 \%$ for maintaining a Record Book. These are all or nothing points.

Thank You,

Mr. Knapp

538-2310 extension 305 classroom

538-2344 Agriculture Department

vyneman1@yahoo.com

Topic Guide 2010-11

\begin{tabular}{|l|l|l|l|}
\hline $\mathbf{1}^{\text {st }}$ Quarter & $\mathbf{2}^{\text {nd }}$ Quarter & $\mathbf{3}^{\text {rd }}$ Quarter & $\mathbf{4}^{\text {th }}$ Quarter \\
\hline Class Plan & Log Scaling & Parli Pro & Prep for State Finals \\
Introduction to FFA & Tree Heights & Plant ID & Plant ID \\
Intro Forestry & Tree Diameters & Current Events & Table Interp \\
Worksheets & Clinometer & Fort Bragg & Tool/Wood ID \\
Insect pests & Biltmore Stick & Contests & Tree Heights \& Dia.'s \\
Current Forestry Event & Team Compass & Field Trips & Compass \\
Plant & Knowledge & Sales & Map Reading \\
Identification/Dendrology & Map Reading & RRLC Trade Show & Acreage \\
California Agriculture & Dot Grid & Arbuckle Contest & Oral Presentation \\
Pace & Tool ID & Weaverville & Careers \\
Acreage & Wood ID & Practice & Resume \\
Compass & Table Interpretation & School Landscape & College Guidance \\
Record Books & Forestry Team & Testing & Scholarships \\
SAE Project & Current Events & Record Books & Record Books \\
Forestry Team & School Events & SAE Project & SAE Project \\
Field Trips & Record Books & Scholarship & Current Events \\
Current Events & SAE Project & Team Recruitment & School Events \\
\hline
\end{tabular}




\section{Nursery Landscape Class Plan 2011-12}

Las Plumas High School Agriculture follows the California Agriculture Curriculum Standards in Environmental Horticulture as accepted by the California Department of Education.

\section{School and Class Rules}

Be Safe: Follow class and school safety rules. No food, drink or gum allowed without special approval. Follow activities as directed and use tools in a manner that they do not hurt you, your work or the tool.

Be Responsible: Come to class on time. Prepare yourself to learn at the scheduled time. Bring learning material and tools to class-examples: paper, pencils, pens, notebook and flashdrive. Make up your work from missed days. Study nightly as explained in class.

Be Respectful: Every student has value and needs to learn. Treat others as you want to be treated: WITH PRIDE, DIGNITY AND RESPECT!

Knapp Rules:

${ }^{*}$ As a sign of respect, students will not wear hats in class.

*Any student may use the restroom at any time provided they ask permission prior to leaving class.

* No electronic use during class, except for emergency situations.

\section{Discipline Policy}

This instructor uses the 6 step and 9 step discipline procedure. The offense list below will cover bad behaviors such as but not limited to: tardies, minor class disruption, vulgar language, off task during learning time... iviore serious bad behaviors wiii lead directiy to the nine step discipiine plan and may lead to class suspension.

A. First Offense: Verbal Warning-Given on the first day of class.

B. Second Offense: Verbal warning and a note.

C. Third-Sixth Offense: Teacher detention after school.

The $6^{\text {th }}$ offense is the last chance in class and every offense after that will fall under the nine step procedure as outlined in your discipline plan.

\section{Attendance}

A. Attendance is paramount and does affect your grade.

B. Although attendance is not graded, poor attendance will lower your score

C. It is your responsibility to make up all work missed.

D. Although students will not receive a tardy mark until 30 minutes after the bell, any students late to class will receive a class disruption detention each time they come in after the bell rings.

E. Be in your seat and attentive at all times.

\section{Absences/Make-up Work}

Responsibility of all make up work falls to the student and the instructor. I will be happy to assist you before school, after school, at break, at lunch or during consultation times. I will not delay the 
class' learning time for the benefit of one student to show make up work. I will accept work after the due date, but will ask you to make it up during consultation time. No points are deducted if you complete the activity. If you know that you are going to be gone in advance, I will assign you future work.

\section{Grading Policy}

$\begin{array}{ll}\text { Homework/Tests/Quizzes/Final, Greenhouse work, } & \text { A } 90-100 \% \\ \text { Outside Labs, Plant Portfolio, Sales, } & \text { B } 80-89 \% \\ \text { Participation, Cleanup, Safety-80\% } & \text { C } 70-79 \% \\ & \text { D } 60-69 \% \\ \text { FFA-20\% } & \text { F } 59 \% \text { and below }\end{array}$

I will record each student's FFA Grade at the beginning of the $2^{\text {nd }}$ and 4 th quarter. I will encourage each student to become involved in our FFA Chapter and inform them of upcoming events. This will provide them with opportunities to improve their academic standing, increase their involvement in their school community and provide them with an exciting opportunity for success through leadership development. The grade follows this breakdown: $10 \%$ for 2 events per quarter, $5 \%$ for an active S.A.E. Project, $5 \%$ for maintaining a Record Book. These are all or nothing points.

Thank You,

Mr. Knapp

538-2310 extension 305 classroom

538-2344 Agriculture Department

vyneman1@yahoo.com

Topic Guide 2011-12

\begin{tabular}{|l|l|l|l|}
\hline $\mathbf{1}^{\text {st }}$ Quarter & $\mathbf{2}^{\text {nd }}$ Quarter & $\mathbf{3}^{\text {rd }}$ Quarter & $\mathbf{4}^{\text {th }}$ Quarter \\
\hline Class Plan & Transplanting & Parli Pro & Plant Sales \\
Introduction to FF A & Greenhouse & Plant Sales & Nursery Production \\
Intro Greenhouses & Sales Plan & Merchandising & Field Trip \\
Plant Identification & Landscape Basics & Sinage & Flowers \\
Hort Basics & Lawns & Plant Sales & Vineyard/Orchard \\
Hort Cert/Butte Coliege & irrigation & Field Trip: Nor Cal & Oral Presentaiion \\
Soils & Garden Beds & Trade Show & Careers \\
Mother Stock & Planting & Grafting & Resume \\
Sunset Western Gar. Bk. & Seeds & Rose Pruning & College Guidance \\
Record Books & Vegetative Propagation & School Landscape & Scholarships \\
SAE Project & River Partners & Hanging Baskets & Record Books \\
Horticulture Team & Forestry Team & Record Books & SAE Project \\
Forestry Team & Horticulture Team & SAE Project & Current Events \\
Field Trips & Current Events & Scholarship & School Events \\
Clean up & School Events & Team Recruitment & Team Recruitment \\
Current Events & Record Books & Current Events & Summer Internship \\
School Events & SAE Project & School Events & Team Finals \\
\hline
\end{tabular}




\section{Floriculture Class Plan 2011-12}

Las Plumas High School Agriculture follows the California Agriculture Curriculum Standards in Environmental Horticulture and Floral design as accepted by the California Department of Education.

\section{School and Class Rules}

Be Safe: Follow class and school safety rules. No food, drink or gum allowed without special approval. Follow activities as directed and use tools in a manner that they do not hurt you, your work or the tool.

Be Responsible: Come to class on time. Prepare yourself to learn at the scheduled time. Bring learning material and tools to class-examples: paper, pencils, pens, notebook and flashdrive. Make up your work from missed days. Study nightly as explained in class.

Be Respectful: Every student has value and needs to learn. Treat others as you want to be treated: WITH PRIDE, DIGNITY AND RESPECT!

\section{Knapp Rules:}

${ }^{*}$ As a sign of respect, students will not wear hats in class.

*Any student may use the restroom at any time provided they ask permission prior to leaving class.

* No electronic use during class, except for emergency situations

\section{Discipline Policy}

This instructor uses the 6 step and 9 step discipline procedure. The offense list below will cover bad behaviors such as but not limited to: tardies, minor class disruption, vulgar language, off task during learning time... More serious bad behaviors will lead directly to the nine step discipline plan and may lead to class suspension.

A. First Offense: Verbal Warning-Given on the first day of class.

B. Second Offense: Verbal warning and a note.

C. Third-Sixth Offense: Teacher detention after school.

The $6^{\text {th }}$ offense is the last chance in class and every offense after that will fall under the nine step procedure as outlined in your discipline plan.

\section{Attendance}

A. Attendance is paramount and does affect your grade.

B. Although attendance is not graded, poor attendance will lower your score.

C. It is your responsibility to make up all work missed.

D. Please arrive on time, habitual tardiness results in steps.

\section{Absences/Make-up Work}

Responsibility of all make up work falls to the student and the instructor. I will be happy to assist you before school, after school, at break, at lunch or during consultation times. I will not delay the class' learning time for the benefit of one student to show make up work. I will accept work after the due date, but will ask you to make it up during consultation time. No points are deducted if you complete the activity. If you know that you are going to be gone in advance, I will assign you future work. 


\section{Grading Policy}

\section{I do not give 'D' grades}

Homework/Tests/Quizzes/Final, Greenhouse work, Outside Labs, Plant Portfolio, Sales,

Participation, Cleanup, Safety- $80 \%$

A $90-100 \%$

B $80-89 \%$

C $65-79 \%$

FFA-20\%

F 64\% and below

I will record each student's FFA Grade at the beginning of the $2^{\text {nd }}$ and 4 th quarter. I will encourage each student to become involved in our FFA Chapter and inform them of upcoming events. This will provide them with opportunities to improve their academic standing, increase their involvement in their school community and provide them with an exciting opportunity for success through leadership development. The grade follows this breakdown: $10 \%$ for 2 events per quarter, $5 \%$ for an active S.A.E. Project, $5 \%$ for maintaining a Record Book. These are all or nothing points.

Thank You, Mr. Knapp

538-2310 extension 305 classroom

538-2344 Agriculture Department :

vyneman1@yahoo.com

Topic Guide 2010-11

\begin{tabular}{|l|l|l|l|}
\hline $\mathbf{1}^{\text {st }}$ Quarter & $\mathbf{2}^{\text {nd }}$ Quarter & $\mathbf{3}^{\text {rd }}$ Quarter & $\mathbf{4}^{\text {th }}$ Quarter \\
\hline Class Plan & Focal Point, Rhythm & Parli Pro & Plant Sales \\
Introduction to FFA & Basic Design & Plant Sales & Graduation Flowers \\
Intro Greenhouses & Line, form, depth & Merchandising & Field Trip-Palace of \\
Plant Identification & Art Media & Drawing skills & Fine Arts \\
Principles of design & Ferns & Message of art & Flowers \\
Art History & Bow Basics & Critique Art projects & Oral Presentation \\
Library work & Analyze artists'work & Aesthetic qualities & Careers \\
Color Wheel & Electronic media & Valentine's Day & Resume \\
Design, Harmony, Unity & Prepare Portfolio & Sales & Sinage and Art \\
Art media & Boutineers & Flower Arranging & College Guidance \\
House plants & Dominance and & Prom and Formal & Scholarships \\
Floral Team & Hanging Baskets & Record Books \\
Wire Wrapping & Subordination & Record Books & SAE Project \\
Corsage & Christmas Design & SAE Project & Current Events in Art \\
Balance, scale, & Thankgiving Design & Review Elements of & School Events \\
proportion & Record Books & Art & Team Recruitment \\
School Events & SAE Project & School Events & Team Finals \\
\hline
\end{tabular}




\section{ROP: Heavy Equipment \& Construction Syllabus}

$2011-2012$

Course Title: ROP: Heavy Equipment \& Construction

Office Phone: 530-538-2344
Faculty: Mr. Carlos R. Diaz

E-Mail: cdiaz@ouhsd.org

\section{Course Description:}

This course is designed to provide students with employability skills in the areas of agriculture equipment operation, maintenance and construction. Students will perform repairs, routine maintenance and operation of light trucks, wheeled tractors, forklifts, backhoes, and construction equipment. Practical skills in safe operation, control techniques, tool usage, standard maintenance and minor repair, will be emphasized. Students will also learn basic construction skills in surveying, framing, project design, and concrete work.

\section{Attendance and Participation}

Attendance is required; missing classes will cause you to fall behind the rest of the class! Students are responsible for all work done in class. If a student must miss a class, a message prior to the missed session is expected. If the absence is excused, the student will need to arrange an alternative assignment with the instructor to make up for the work missed in class. This assignment will be figured into your overall grade. Unexcused absences will be dealt with through the ROP guidelines. Excessive absences may result in the student being dropped from the program.

\section{Expectations for Students}

This course is designed to offer students an opportunity to develop skills that are highly sought after in industry. Professionalism and thoroughness are what allows individuals from all walks of lives and backgrounds to become successful. It is expected of students enrolled in this course to succeed at a high level and to accomplish all tasks asked of them at a high level of quality and craftsmanship.

\section{Basic Expectations:}

1. Safety is number one. Always wear Personal Protective Equipment PPE.

2. Horseplay will not be tolerated especiaily in equipment operation situations.

3. Respect oneself, fellow students, the shop, the equipment, and instructor.

4. Refrain from talking when Mr.Diaz or another person is speaking.

5. Be responsible for completing and submitting all work assigned.

6. Have an open mind and allow oneself to learn new knowledge and skills.

7. Treat tools and equipment with respect and never carelessly.

8. Report any and all injuries immediately.

9. Report and safety hazards immediately.

10. Abide by the school/ Class rules.
a. Be Safe!
b. Be Respectful!
c. Be Responsible! 


\section{Course Grading and Evaluation}

Evaluation will be based on the Quality and Craftsmanship of work completed, as well as Attitude and Work Ethic of the student, good Safetv practices.

Gradling:

Competencies

Projects / Placement

Portfolio \& Interviews

Tests and Quizzes

SAE / Record Book

FFA Activities
$20 \%$

$20 \%$

$20 \%$

$20 \%$

$10 \%$

$10 \%$

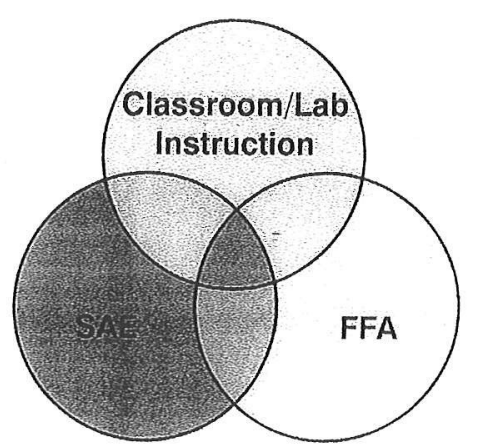

\section{Competencies}

Students will be evaluated throughout the course and given threshold standards within a skill. The student must meet or surpass the standard to qualify for that specific competency. Examples of competencies are SMAW, OFC, GMAW, FCAW, Load Handling, Lift truck operation, etc.

\section{Projects \& Placements}

Throughout the year, projects pertaining to this course will be assigned to students for completion. The overall grade for this course is predicated on the level of cooperation, work ethic, efficiency, attitude and overall quality and craftsmanship the student(s) exhibit throughout the project. For the purposes of this course a placement is graded as a project and the supervisor and the instructor will confer to determine and overall grade. One (1) project the student completes during this course is expected to be submitted to the Silver Dollar Fair in May 2012. The judge will determine the grade.

\section{Portfolie \& Interviews}

Students will be given the opportunity to create a portfolio that chronicles their achievements and assets. The purpose of the portfolio is to eventually gain employment. The students will display their portfolio and submit to an interview process by individuals from industry.

\section{Tests \& Quizzes}

Students will be evaluated throughout the course through verbal, hands-on, and written exams. It is important to be able to demonstrate one's knowledge in a variety of ways.

\section{SAE \& Record Books}

Students will maintain a record book throughout the course. The SAE the student chooses will also be documented in the record book.

\section{FFA Activities}

Students enrolled in this course offered through the agriculture department are automatically a member of the Las Plumas High School FFA Program and as such have responsibilities. The student is required to atiend iwo (2) FFA Activities per quarter. 


\section{BUTTE COUNTY \\ REGIONAL OCCUPATIONAL PROGRAM \\ "Committed to Career Success" \\ Expected Student Learning Results}

1. Demonstrate appropriate work ethic through:

- Punctual, regular attendance

- Personal integrity, honesty, respect

Teamwork, working cooperatively with others

Positive attitude, enthusiasm, initiative

2. Demonstrate appropriate job preparation and search skills through:

- Assessment, career planning, goal setting

- Resume, employment application, interview

- Attainment of course specific competencies

3. Demonstrate entry Ievel use of industry sector technology/tools through:

- Adherence to safety procedures, precautions

- Application of knowledge, skills

- Integrated use of academic skills and computer literacy skills

- Workplace Simulation/Community Classroom/Cooperative Vocational Education

4. Demonstrate effective communication through:

- Workplace appropriate verbal, written and listening skills

- Performance of verbal and written directions

- Organization of thoughts and use of articulate language

5. Demonstrate criticail thin king sikiīs through̆:

- Analysis/evaluation and solution of problems

- Practical/successful use of community resources/agencies

$\checkmark$ Independent work, self management

6. Demonstrate professionalism through:

- Socially appropriate interaction

- Suitable dress and appearance

- Confidentiality 


\section{Las Plumas High School: Expected Student Learning Results (ESLRs)}

\section{Effective Communicator}

1.1: Listens effectively and requests clarification when needed.

- Engages in spoken and written instructions and seeks further instruction as needed.

1.2: Articulates ideas clearly, creatively, and effectively in Standard English.

- Interacts and collaborates with others clearly and effectively.

\section{Critical Thinker}

2.1: Identifies the problem and information needs.

- Is able to recognize possible issues and information needed to make decisions.

2.2: Analyzes, synthesizes, and evaluates information and strategies to solve problems.

- Uses the tools, knowledge and skills to troubleshoot and solve issues.

\section{Quality Producer}

3.1: Creates intellectual, artistic, and practical products and services.

-Produces projects and works that demonstrate the skill and knowledge sets acquired in class and shop sessions to high levels of workmanship and craftsmanship. 3.2: Uses current technology to produce valued products and services.

- Effectively operate the technology available in the shop and classroom settings to design, revise, and create projects and works that conform to stringent quality parameters.

\section{Self-Directed Learner}

4.1: Assesses their strengths and weaknesses and designs, establishes and pursues academic, personal, and career goals.

- Identify your own talents, aptitudes and interests and develop means to develop these attributes further through curricular and extracurricular activities and events.

4.2: Develops their physical potential and healthy habits.

- Uses the facilities and supplies in a manner that promotes their own safety and the safety of those around them at all times.

\section{Collaborative Worker}

5.1: Develops the skills for effective cooperation and communication with peers and adults.

- Work in groups towards the safe successful completion of an assigned task, activity, or project in a professional manner.

5.2: Uses leadership and group skills to work effectively as a member of a self directed team.

- Develops personal skills of leadership to identify a group dynamic and to behave in a matter that will promote the most efficient and successful attributes of the group.

\section{Ethical Decision Maker}

6.1: Accepts responsibility for their own behavior, personal liberty, and happiness.

- Decides to make choices wise or unwise, and has the character to own and accept the consequences of their own choices.

6.2: Demonstrates a pattern of honesty and integrity through the practice of good sportsmanship, craftsmanship, and citizenship.

- Builds a reputation of an individual that is reliable, responsible, respectful, and safe.

\section{Community Contributor}

7.1: Demonstrates an awareness of their community, nation, and world.

- Shows that they are aware that they are part of a community and that their actions have effects on those around them, positive or negative.

7.2: Demonstrates tolerance and appreciation of individual differences. 
- Shows that they can accept others for being different then they are and accepting them as individuals of character, intelligence, and respect

\begin{tabular}{|c|c|}
\hline 1. & $\begin{array}{l}\text { BE SAFE! } \\
\text { Wear your personal protective equipment, operate equipment safely, follow } \\
\text { all safety and operation rules, be aware of your surroundings, and keep } \\
\text { other students safe at all times. Horseplay will not be tolerated in any } \\
\text { fashion. Ask for help if you are unsure or just need a hand, we are here to } \\
\text { help you. }\end{array}$ \\
\hline 2. & $\begin{array}{l}\text { BE RESPECTFUL! } \\
\text { Show respect for yourself, your peers, your instructors, and the shop and } \\
\text { class environments. Remove your hat while in class. Introduce yourself } \\
\text { politely to visitors to our class with a firm handshake and heartfelt welcome. } \\
\text { No cussing, spitting, dishonesty, theft, or vandalism will be tolerated. Set an } \\
\text { example for others to aspire towards. Do not use personal listening devices } \\
\text { or phones. }\end{array}$ \\
\hline 3. & $\begin{array}{l}\text { BE RESPONSIBLE! } \\
\text { Come to school prepared. Make decisions that will keep yourself and those } \\
\text { around you safe and secure. Complete the tasks and projects you are charged } \\
\text { with to the best of your ability. Be sure to leave your work area in a state } \\
\text { better than which you found it. }\end{array}$ \\
\hline
\end{tabular}

I have read and understood the above course syllabus for this course:

Student Name: (Print)

Student Signature: $\mathrm{X}$

Parent/Guardian Name: (Print)

Parent/Guardian Signature:X 


\section{Las Phmas Ktigh \\ Ag Mechanics I Syllabus \\ 201152012}

Course Title: Introduction to Agriculture Mechanics

Phone: 530-538-2344
Faculty: Mr. Carlos R. Diaz Office

E-Mail: cdiaz@ouhsd.org

\begin{tabular}{|l|l|l|l|}
\hline \multicolumn{2}{|l|}{ Course Overview } & CA. Ag. Standards & Required Materials \\
\hline 1. & Safety \& Tool ID & B1.1-B1.3 & Safety Glasses \\
\hline 2. & Measurement & B2.2 & Writing Tool \\
\hline 3. & Project Design & B $9.4-B 9.5$ & 3-Ring Binder \\
\hline 4. & Metal Working & B $5.0-B 5.5$ & \\
\hline 5. & Oxy-Acetylene Welding & B7.0-B7.5, B9.3 & \\
\hline 6. & Arc Welding & B8.0-B8.4, B9.2-B9.7 & Optional Materials \\
\hline 7. & Concrete & B6.0-B6.3 & Graph Paper \\
\hline 8. & Surveying & B12.1 & Calculator \\
\hline 9. & Rope Work & B1.3 & Combination Lock \\
\hline 10. & Electricity & B3.0-B3.5 & $16 \mathrm{ft} \mathrm{Tape} \mathrm{Measure}$ \\
\hline 11. & Plumbing & B4.0-B4.4 & $10^{\prime \prime}$ slip-joint pliers \\
\hline 12. & Basic Wood Working & B2.0-B2.4 & \\
\hline
\end{tabular}

\section{Course Description:}

This course focuses on the basic fundamentals of Agriculture Mechanics as it relates to modern Agriculture Industry practices and techniques. Emphasis will be made towards establishing safe, hazard free learning environments. Employability skills will be fostered through a variety of methods including, but not limited to, hands-on applications, collaborative projects, student presentations, research inquiries, and guest speakers. Organization skills as well as record keeping will be emphasized through the in-class binder portfolio, and the FFA record Book.

\section{Course Materials:}

The course instructor will provide all necessary personal protective equipment (PPE) to the students. A class set of safety glasses will be available for the students to share. However, if a student wishes to they may purchase their own personal equipment at their own expense. This is a projects based course; students are not financially obligated to any course project. However, if a student wishes to own a project they have completed they may purchase the project for a nominal amount that covers the material cost of that project.

\section{Supervised Agricultural Experience Project (SAEP):}

All students are required to participate in an SAE project which will allow the active application of science based principles in a "learn by doing" environment. The project will be documented in the FFA Record Book. Projects types and parameters will be discussed in class and will require periodic visits by the FFA advisor assigned to the student and their project. 


\section{Attendance and Participation}

Attendance is required; missing classes will cause you to fall behind the rest of the class! Students are responsible for all work done in class. If a student must miss a class, a message prior to the missed session is expected. If the absence is excused, the student will need to arrange an alternative assignment with the instructor to make up for the work missed in class. This assignment will be figured into your overall grade.

\section{Expectations for Students}

An effective education is vigorous, demanding, deeply satisfying and requires behavior conductive to achieving excellence. High School is a fundamental asset in building a student's character, citizenship, and employment future.

\section{Basic Expectations:}

1. Safety is number one. Horseplay will not be tolerated especially in lab situations.

a. Students that repeatedly ignore safety protocols can be removed from the class and barred from joining any other shop based class in the future.

2. Respect oneself, fellow students, the shop, and instructor.

3. Remain seated unless you have teacher permission.

4. Refrain from talking when Mr.Diaz or another person is speaking.

5. Cooperation is the key to success in agriculture courses.

6. You must keep a binder with the following-sections:
a. Time Cards
d. Tests \& Quizzes
b. Warm-ups
e. Notes/Handouts
c. Assignments
f: Projects

7. Please come to class prepared for the day's lesson with assignments completed, your binder, pen/pencils and paper.

8. Be responsible for completing and submitting all work assigned.

9. Have an open mind and allow oneself to learn new knowledge and skills.

10. Submit at least one (1) project to the fair.

11. Abide by the school/Class rules.
a. Be Safe!
b. Be Respectful!
c. Be Responsible!

12. Ilàve a gricât ýcâ!!

Grading:

Assignments

Tests and Quizzes

Lab Work

Safety

SAE / Record Book

FFA Activities
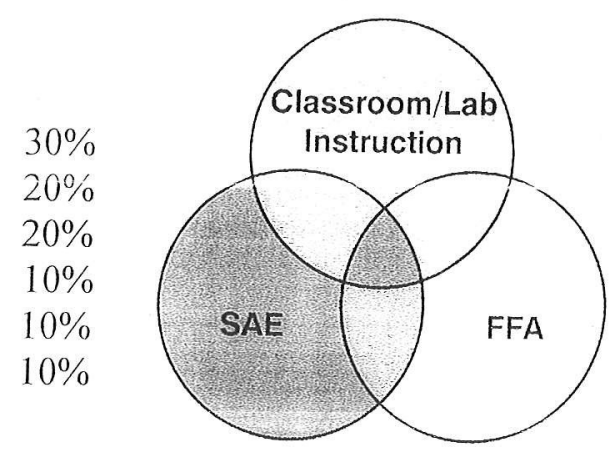

$\begin{array}{ll}90-100 \% & \text { A } \\ 80-89 \% & \text { B } \\ 70-79 \% & \text { C } \\ 60-69 \% & \text { D } \\ 0-59 \% & \text { F }\end{array}$

\section{Course Grading and Evaluation}

Evaluation will be based on the Quality and Craftsmanship of work completed, as well as Attitude and Work Ethic of the student, good Safety practices. 


\section{Las Plumas High School Expected Student Learning Results (ESLRs)}

\section{Effective Communicator}

1.1: Listens effectively and requests clarification when needed.

- Engages in spoken and written instructions and seeks further instruction as needed.

1.2: Articulates ideas clearly, creatively, and effectively in Standard English.

- Interacts and collaborates with others clearly and effectively.

\section{Critical Thinker}

2.1: Identifies the problem and information needs.

- Is able to recognize possible issues and information needed to make decisions.

2.2: Analyzes, synthesizes, and evaluates information and strategies to solve problems.

- Uses the tools, knowledge and skills to troubleshoot and solve issues.

\section{Quality Producer}

3.1: Creates intellectual, artistic, and practical products and services.

-Produces projects and works that demonstrate the skill and knowledge sets acquired in class and shop sessions to high levels of workmanship and craftsmanship.

3.2: Uses current technology to produce valued products and services.

- Effectively operate the technology available in the shop and classroom settings to design, revise, and create projects and works that conform to stringent quality parameters.

\section{Self-Directed Learner}

4.1: Assesses their strengths and weaknesses and designs, establishes and pursues academic, personal, and career goals.

- Identify your own talents, aptitudes and interests and develop means to develop these attributes further through curricular and extracurricular activities and events.

4.2: Develops their physical potential and healthy habits.

- Uses the facilities and supplies in a manner that promotes their own safety and the safety of those around them at all times.

\section{Collaborative Worker}

5.1: Develops the skills for effective cooperation and communication with peers and adults.

- Work in groups towards the safe successful completion of an assigned task, activity, or project in a professional manner.

5.2: Uses leadership and group skills to work effectively as a member of a self directed team.

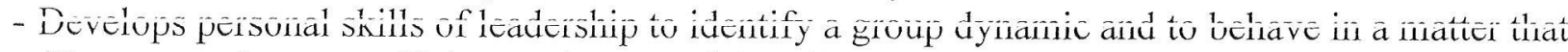
will promote the most efficient and successful attributes of the group.

\section{Ethical Decision Maker}

6.1: Accepts responsibility for their own behavior, personal liberty, and happiness.

- Decides to make choices wise or unwise, and has the character to own and accept the consequences of their own choices.

6.2: Demonstrates a pattern of honesty and integrity through the practice of good sportsmanship, craftsmanship, and citizenship.

- Builds a reputation of an individual that is reliable, responsible, respectful, and safe.

\section{Community Contributor}

7.1: Demonstrates an awareness of their community, nation, and world.

- Shows that they are aware that they are part of a community and that their actions have effects on those around them, positive or negative.

7.2: Demonstrates tolerance and appreciation of individual differences.

- Shows that they can accept others for being different then they are and accepting them as individuals of character, intelligence, and respect. 


\begin{tabular}{|c|c|}
\hline \multicolumn{2}{|r|}{ Agriculture Mechanics Fundamental Rulles } \\
\hline 1. & $\begin{array}{l}\text { BE SAFE! } \\
\text { Wear your personal protective equipment, operate equipment safely, follow } \\
\text { all safety and operation rules, be aware of your surroundings, and keep } \\
\text { other students safe at all times. Horseplay will not be tolerated in any } \\
\text { fashion. Ask for help if you are unsure or just need a hand, we are here to } \\
\text { help you. }\end{array}$ \\
\hline 2. & $\begin{array}{l}\text { BE RESPECTFUL! } \\
\text { Show respect for yourself, your peers, your instructors, and the shop and } \\
\text { class environments. Remove your hat while in class. Introduce yourself } \\
\text { politely to visitors to our class with a firm handshake and heartfelt welcome. } \\
\text { No cussing, spitting, dishonesty, theft, or vandalism will be tolerated. Set an } \\
\text { example for others to aspire towards. Do not use personal listening devices } \\
\text { or phones. }\end{array}$ \\
\hline 3. & $\begin{array}{l}\text { BE RESPONSIBLE! } \\
\text { Come to school prepared. Make decisions that will keep yourself and those } \\
\text { around you safe and secure. Complete the tasks and projects you are charged } \\
\text { with to the best of your ability. Be sure to leave your work area in a state } \\
\text { better than which you found it. }\end{array}$ \\
\hline
\end{tabular}

I have read and understood the above course syllabus for Agriculture Mechanics I.

Student Name: (Print)

Student Signature: $\mathrm{X}$

Parent/Guardian Name: (Print)

Parent/Guardian Signature:X 


\section{Las Phmas Figh School Ag Mechanies II Syllabus

Course Title: Introduction to Agriculture Mechanics Phone: 530-538-2344
Faculty: Mr. Carlos R. Diaz Office E-Mail: cdiaz@,ouhsd.org

\begin{tabular}{|l|l|l|l|}
\hline \multicolumn{2}{|l|}{ Course Overview } & CA. Ag. Standards & Required Materials \\
\hline 1. & Safety \& Tool ID & B 1.1-B 1.3 & Safety Glasses \\
\hline 2. & Measurement & B 2.2, & Writing Tool \\
\hline 3. & Project Design & B 9.4-B 9.5 & 3-Ring Binder \\
\hline 4. & Metal Working & B 5.0-B 5.5 & \\
\hline 5. & Oxy-Acetylene Welding & B 7.0-B 7.5, B 9.3 & \\
\hline 6. & Arc Welding & B 8.0-B 8.4, B 9.2-B 9.7 & Optional Materials \\
\hline 7. & Concrete & B 6.0-B 6.3 & Graph Paper \\
\hline 8. & Surveying & B 12.1 & Calculator \\
\hline 9. & Rope Work & B 1.3 & Combination Lock \\
\hline 10. & Electricity & B 3.0-B 3.5 & 16 ft Tape Measure \\
\hline 11. & Plumbing & B 4.0-B 4.4 & 10" slip-joint pliers \\
\hline 12. & Small Engines & B 10.0-B 10.6 & \\
\hline 13. & Basic Wood Working & B 2.0-B 2.4 & \\
\hline
\end{tabular}

\section{Course Description:}

This course focuses on the basic fundamentals of Agriculture Mechanics as it relates to modern Agriculture Industry practices and techniques. Emphasis will be made towards establishing safe, hazard free learning environments. Employability skills will be fostered through a variety of methods including, but not limited to, hands-on applications, collaborative projects, student presentations, research inquiries, and guest speakers. Organizational skills as well as record keeping will be emphasized through the in-class binder portfolio, and the FFA record Book.

\section{Course Materials:}

The course instructor will provide all necessary personal protective equipment (PPE) to the students. A class set of safety glasses will be available for the students to share. However, if a student wishes to they may purchase their own personal equipment at their own expense. This is a projects based course; students are not financially obligated to any course project. However, if a student wishes to own a project they have completed they may purchase the project for a nominal amount that covers the material cost of that project.

\section{Supervised Agricultural Experience Project (SAEP):}

All students are required to participate in an SAE project which will allow the active application of science based principles in a "learn by doing" environment. The project will be documented in the FFA Record Book. Projects types and parameters will be discussed in class and will require periodic visits by the FFA advisor assigned to the student and their project. 


\section{Attendance and Participation}

Attendance is required; missing classes will cause you to fall behind the rest of the class! Students are responsible for all work done in class. If a student must miss a class, a message prior to the missed session is expected. If the absence is excused, the student will need to arrange an alternative assignment with the instructor to make up for the work missed in class. This assignment will be figured into your overall grade.

\section{Expectations for Students}

An effective education is vigorous, demanding, deeply satisfying and requires behavior conductive to achieving excellence. High School is a fundamental asset in building a student's character, citizenship, and employment future.

\section{Basic Expectations:}

1. Safety is number one. Horseplay will not be tolerated especially in lab situations.

a. Students that repeatedly ignore safety protocols can be removed from the class and barred from joining any other shop based class in the future.

2. Respect oneself, fellow students, the shop, and instructor.

3. Remain seated unless you have teacher permission.

4. Refrain from talking when Mr.Diaz or another person is speaking.

5. Cooperation is the-key-to-suceess in agriculture courses.

6. You must keep a binder with the following sections:
$\begin{array}{ll}\text { a. Time Cards } & \text { d. Tests \& Quizzes } \\ \text { b. Warm-ups } & \text { e. Notes/Handouts }\end{array}$
e. Notes/Handouts
c. Assignments
f. Projects

7. Please come to class prepared for the day's lesson with assignments completed, your binder, pen/pencils and paper.

8. Be responsible for completing and submitting all work assigned.

9. Have an open mind and allow oneself to learn new knowledge and skills.

10. Submit at least one (1) project to the fair.

11. Abide by the school/ Class rules.
a. Be Safe!
b. Be Respectful!
c. Do Rospontisitiv!

12. Have a great year!

\section{Grading:}

Ássignments

Tests and Quizzes

Lab Work

Safety

SAE/ Record Book

FFA Activities
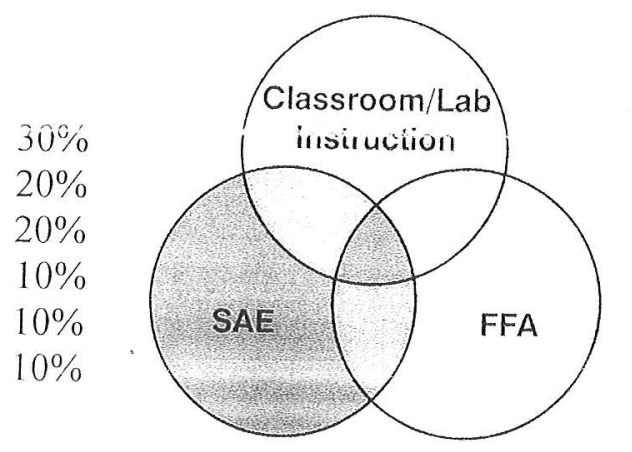

\begin{tabular}{|ll|}
\hline $90-100 \%$ & $\mathrm{~A}$ \\
$80-89 \%$ & $\mathrm{~B}$ \\
$70-79 \%$ & $\mathrm{C}$ \\
$60-69 \%$ & $\mathrm{D}$ \\
$0-59 \%$ & $\mathrm{~F}$ \\
\hline
\end{tabular}

\section{Course Grading and Evaluation}

Evaluation will be based on the Quaiiuy and Craftsmansinip of work completed, as weil as Aittitude and Work Ethic of the student, good Safety practices. 


\section{Las Plumas High School Expected Student Learning Results (ESLRs)}

\section{Effective Communicator}

1.1: Listens effectively and requests clarification when needed.

- Engages in spoken and written instructions and seeks further instruction as needed.

1.2: Articulates ideas clearly, creatively, and effectively in Standard English.

- Interacts and collaborates with others clearly and effectively.

\section{Critical Thinker}

2.1: Identifies the problem and information needs.

- Is able to recognize possible issues and information needed to make decisions.

2.2: Analyzes, synthesizes, and evaluates information and strategies to solve problems.

- Uses the tools, knowledge and skills to troubleshoot and solve issues.

\section{Quality Producer}

3.1: Creates intellectual, artistic, and practical products and services.

-Produces projects and works that demonstrate the skill and knowledge sets acquired in class and shop sessions to high levels of workmanship and craftsmanship.

3.2: Uses current technology to produce valued products and services.

- Effectively operate the technology available in the shop and classroom settings to design, revise, and create projects and works that conform to stringent quality parameters.

\section{Self-Directed Learner}

4.1: Assesses their strengths and weaknesses and designs, establishes and pursues academic, personal, and career goals.

- Identify your own talents, aptitudes and interests and develop means to develop these attributes further through curricular and extracurricular activities and events.

4.2: Develops their physical potential and healthy habits.

- Uses the facilities and supplies in a manner that promotes their own safety and the safety of those around them at all times.

\section{Collaborative Worker}

5.1: Develops the skills for effective cooperation and communication with peers and adults.

- Work in groups towards the safe successful completion of an assigned task, activity, or project in a professional manner.

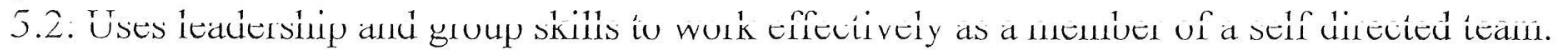

- Develops personal skills of leadership to identify a group dynamic and to behave in a matter that will promote the most efficient and successful attributes of the group.

\section{Ethical Decision Maker}

6.1: Accepts responsibility for their own behavior, personal liberty, and happiness.

- Decides to make choices wise or unwise, and has the character to own and accept the consequences of their own choices.

6.2: Demonstrates a pattern of honesty and integrity through the practice of good sportsmanship, craftsmanship, and citizenship.

- Builds a reputation of an individual that is reliable, responsible, respectful, and safe.

\section{Community Contributor}

7.1: Demonstrates an awareness of their community, nation, and world.

- Shows that they are aware that they are part of a community and that their actions have effects on those around them, positive or negative.

7.2: Demonstrates tolerance and appreciation of individual differences.

- Shows that they can accept others for being different then they are and accepting them as individuals of character, intelligence, and respect. 


\begin{tabular}{|l|l|}
\hline Agriculture Mechanics Fundamental Rulles \\
\hline 1. & $\begin{array}{l}\text { BE SAFE! } \\
\text { Wear your personal protective equipment, operate equipment safely, follow } \\
\text { other students safe at all times. Horseplay will not be tolerated in any } \\
\text { fashion. Ask for help if you are unsure or just need a hand, we are here to } \\
\text { help you. }\end{array}$ \\
\hline 2. & $\begin{array}{l}\text { BE RESPECTFUL! } \\
\text { Show respect for yourself, your peers, your instructors, and the shop and } \\
\text { class environments. Remove your hat while in class. Introduce yourself } \\
\text { politely to visitors to our class with a firm handshake and heartfelt welcome. } \\
\text { No cussing, spitting, dishonesty, theft, or vandalism will be tolerated. Set an } \\
\text { example for others to aspire towards. Do not use personal listening devices }\end{array}$ \\
or phones.
\end{tabular}

I have read and understood the above course syllabus for Agriculture Mechanics II.

Student Name: (Print)

Student Signature:X

Parent/Guardian Name: (Print)

Parent/Guardian Signature:X 
Animal Science
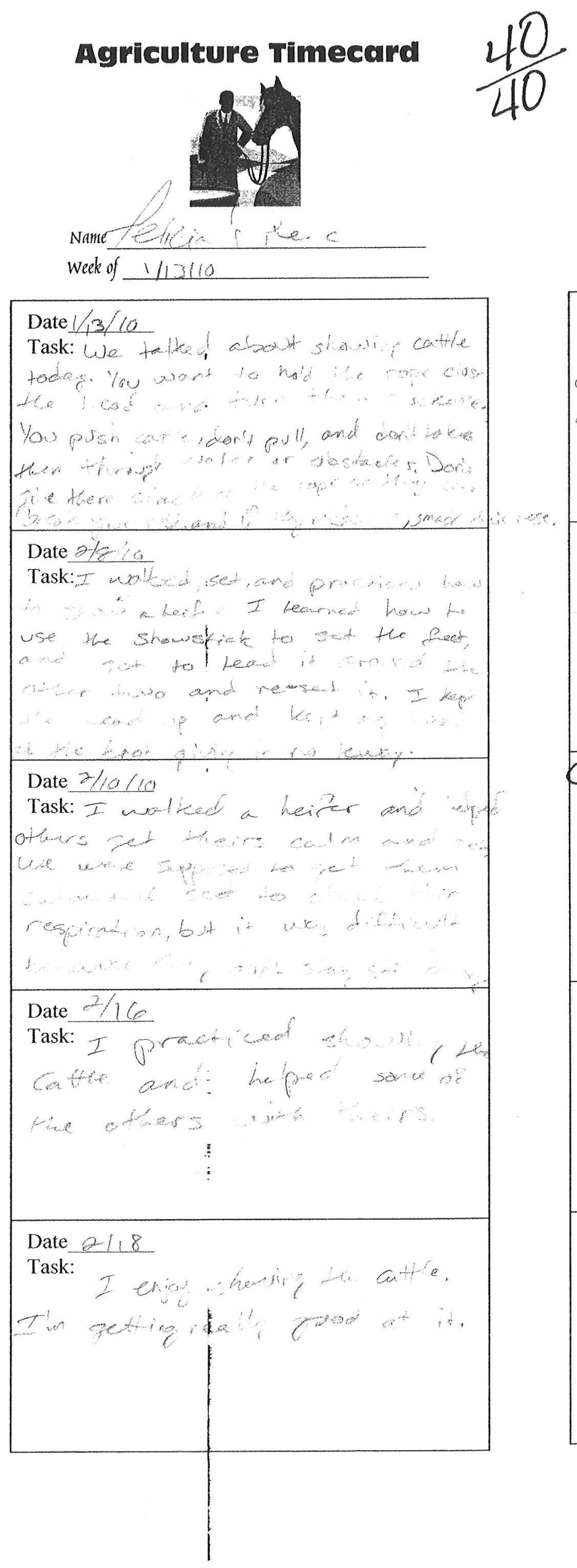

Agriculture Timecard

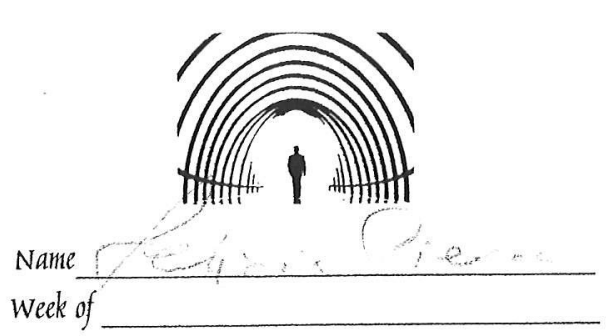

Date $\partial / 2 z$ I preaticed -hamine

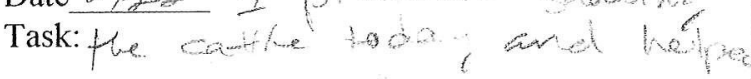
out a co, of the of the teis.

Date hlol Toden I unt w Task: we la col twe

brenglat with

Date 26ave probicat

Task: Shownanght fur

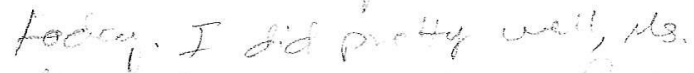

Date

Task:

Date

Task: 


\section{Biology $-2^{\text {nd }}$ Quarter Assessment \\ DO NOT WRITE ON THIS TEST!!}

\section{Multiple Choice}

Identify the letter of the choice that best completes the statement or answers the question.

1. The diffusion of water through a cell membrane is called
a. solubility
b. osmosis
c. selective transport
d. endocytosis

2. Proteins that act like selective passageways in the cell membrane are known as
a. marker proteins
c. receptor proteins
b. channel proteins
d. none of the above

3. Molecules that are too large to be moved across a cell membrane can be moved out of a cell by
a. diffusion
c. endocytosis
b. exocytosis
d. osmosis

4. One difference between prokaryotes and eukaryotes is that
a. nucleic acids are found only in prokaryotes
b. mitochondria are found in prokaryotes
c. Golgi vesicles are found only in prokaryotes
d. prokaryotes do not have an organized nucleus

5. Which of the following is characteristic of prokaryotes?
a. they have a nucleus
b. their DNA is arranged into linear chromosomes
c. the organelles in their cytoplasm are surrounded by membranes
d. none of the above

6. Which of the following is an example of a prokaryotic cell?
a. amoeba
c. bacterium
b. virus
d. liver cell

7. In humans, each gamete receives
a. 23 pairs of chromosomes from each parent
b. one chromosome from each of the 23 parental pairs
c. 46 chromosomes ,
d. 23 homologous chromosomes

8. The fusion of male and female gametes creates
a. new combinations of alleles
b. the same combinations of alleles that their parents had
c. two identical alleles for each trait
d. none of the above

9. The sex of human offspring is determined by
a. the female
c. both the female and the male
b. the male
d. neither the female nor the male 


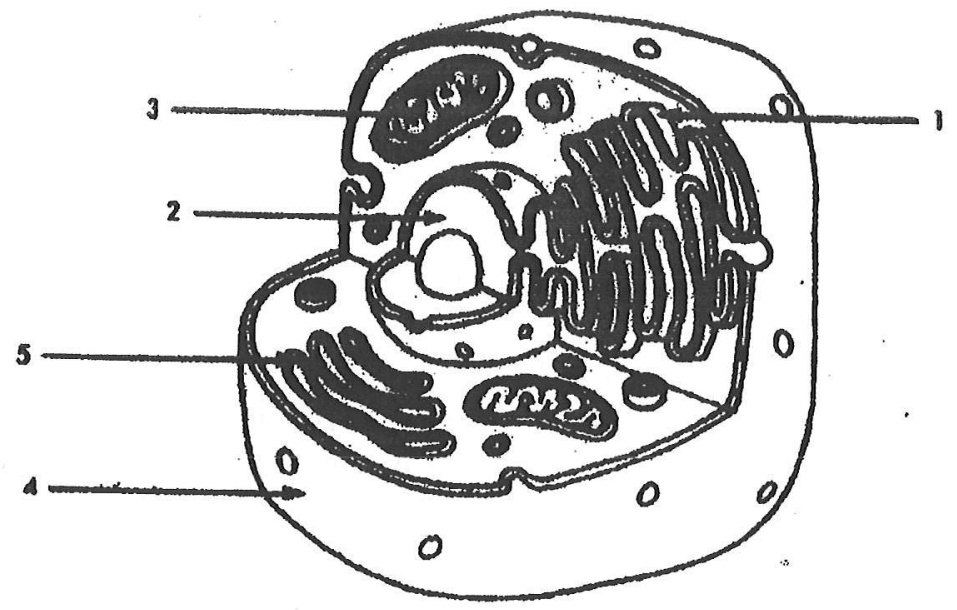

10. Refer to the illustration above. Which structure produces vesicles filled with proteins?
a. structure 1
c. structure 3
b. structure 2
d. structure 4

11. The Golgi apparatus is an organelle that
a. receives proteins and lipids from the endoplasmic reticulum.
b. packages molecules made in the endoplasmic reticulum.
c. is involved in the distribution of proteins.
d. all of the above

12. The organelle that moves proteins through the cell is the
a. mitochondria
c. endoplasmic reticulum
b. ribosome
d. nucleus

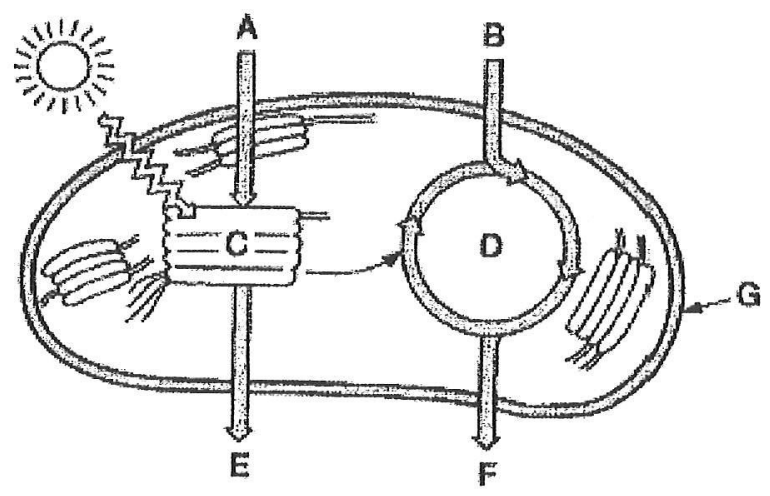

13. In the diagram above, carbon dioxide is represented by
a. E
b. C
c. $\mathrm{F}$
d. B

14. In plants, energy from sunlight is captured by
a. vacuoles
c. Golgi apparatus
b. chloroplasts
d. ribosomes 
15. Light energy captuned by plants is stored in the form of
a. ATP
b. protein
c. sugar (carbohydrates)
d. lipids

16. A cell that requires a lot of energy might contain large numbers of
a. chromosomes
c. mitochondria
b. vacuoles
d. lysosomes

17. Mitochondrion make energy available by breaking down glucose and making available.
a. ATP
c. lipids
b. protein
d. carbohydrates

18. When an animal cell breaks down glucose, which substance is released
a. water
c. carbon dioxide
b. oxygen
d. sucrose

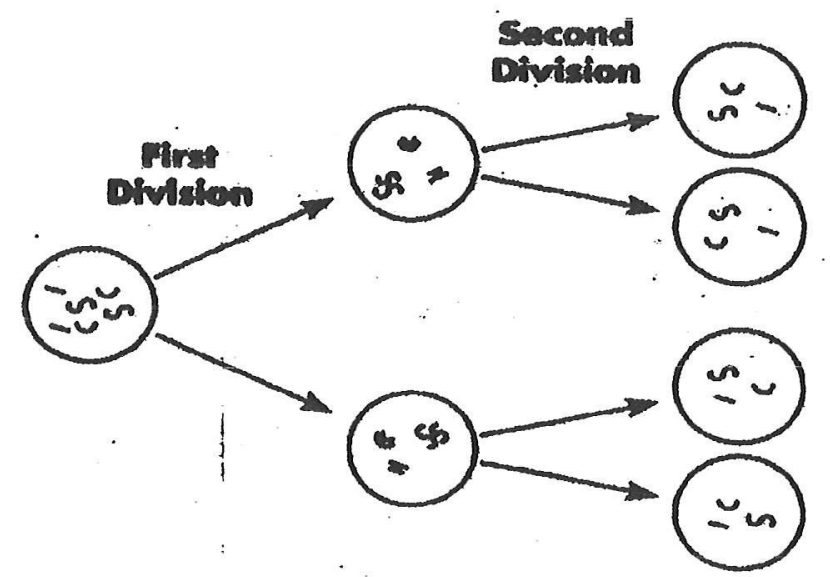

19. Refer to the illustration above. The process shown in the diagrams is
a. mitosis
c. meiosis
b. chromosomal mutation
d. dominance

20. When a cell from a male undergoes meiosis, the result is
a. two haploid cells
c. two diploid cells
b. four haploid cells
d. four diploid cells

21. During meiosis gametes are produced with each one containing
a. one of each chromosome
b. a pair of each of the chromosomes
c. the same set of chromosomes as the original
d. none of the above

22. Separation of homologues occurs during
a. mitosis
c. meiosis II
b. meiosis I
d. fertilization 
23. The genes that organisms pass on are determined by
a. the male only
b. the female only
c. duplicating half of the parent DNA
d. random segregation of parent chromosomes

24. What are the normal chromosome numbers of a sperm, egg and zygote respectively?
a. haploid, haploid, haploid
b. haploid, haploid, diploid
c. diplolid, diploid, haploid
d. diploid, diploid, diploid

25. Meiosis happens
a. only in certain cells
c. in blood cells
b. in the same cells for males and females
d. in all cells

26. Unicellular organisms, which reproduce asexually, undergo
a. mitosis
b. meiosis
c. both $\mathrm{a}$ and $\mathrm{b}$
d. none of the above

27. Which statement is true about haploid cells?
a. they are the result of mitosis
c. they are produced only by females
b. they are the result of meiosis
d. they are produced only by males

28. New combinations of alleles are generated in a
a. cell that has completed mitosis
c. zygote
b. cell that has completed translation
d. liver cell

29. Fusion of male and female gametes will form
a. ovaries
c. haploid cells
b. sperm
d. a zygote

30. A zygote contains
a. all of the original information from the male and new information from the female
b. all of the original information from the female and new information from the male
c. the same information from both the male and female
d. new information from both the male and female

31. When a zygote is formed

a. $2 / 3$ of the DNA comes from the mother

b. $2 / 3$ of the DNA comes from the father 
c. $1 / 2$ of the DNA comes from each parent

d. you cannot tell how much DNA comes from each parent

32. When fertilization occurs
a. the female always donates an X chromosome
b. the female always donates a Y chromosome
c. the male always donates an $\mathrm{X}$ chromosome
d. the male always donates a $\mathrm{Y}$ chromosome

33. An individual with the XY combination of sex chromosomes is
a. female
c. can be either
b. male
d. need more information 
1) What are the 6 main points of focus to look at when selecting an animal? Explain how to evaluate each! $+6$

- Balance-are the hips even? Does it worble?

- funish - is the animal filled out, measure the $13^{\text {th }}$ rib

- cagacity - in heifers, can she hold a calf aproportion - is the run. equal size to chest, look even?

2) What are EPD's? How are they used in livestock selection? o structure-does the anmo EPD's are a sneet full wuth Breader t 2 wfo. on his herd. Tells how mock mull production and such is un his herd.

1) Name two diseases that producers commonly vaccinate for? ciostridial and respiratury +2

2) What are two parasites that affect beef cattle? +2 lice ond wringuorm

3) Why are heifers vaccinated for brucellosis? +2 Brucellosis (aka bangs) is a state mandated vacuroton because tis zoonotic, transfer to humans, and causes heifers to abort.

Feeds/Feeding

1) How much feed should your steer/animal consume each day?

$$
3 \% \text { of is body weight: }+1
$$

2) Are steers monogastric or ruminants? Why? +2 Ruminants, because they can consume lame amountest

3) What are the four compartments to a beef animals stomach? +2 Rumen, Reficulum, Omasum, and Abomasum.

4) Name one concentrate and one roughage? (identify each) + 4 concentrate high in digestble nutments but low in fioer; ex: Corn 5) What percentage protein should a finishing feed contain? $12-14$ percent +1

6) What percentage fat should a finishing feed contain?

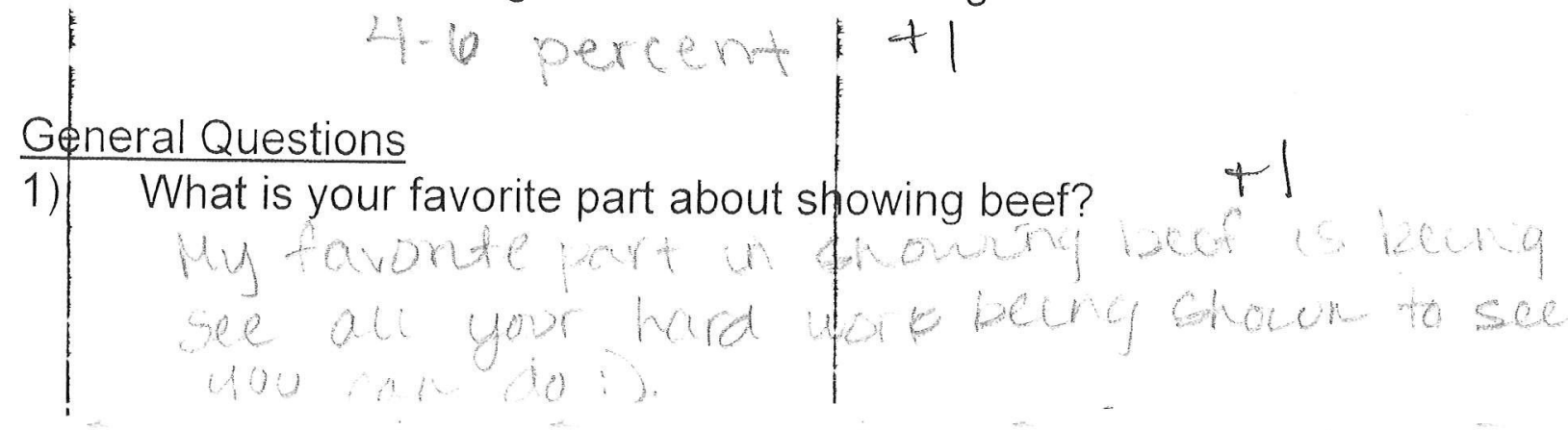




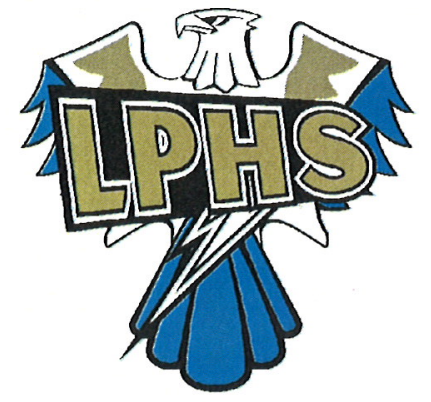

\section{LPHS Agricultural Program Completers}

\section{Graduate Certificate}

1. Must have completed at least 3 years of Vocational

Agriculture classes or same amount of agriculture courses in two years.

2. FFA Involvement

\section{Graduation Rope}

1. Must have completed at least 3 years of Vocational Agriculture classes.

2. FFA Involvement

3. One of the following Criteria:
A. Participated on a Leadership Team (2 years)
B. FFA Judging Team (2 years)
OR
C. FFA Officer
OR
D. State FFA Degree

\section{Medallion and Rope}

1. Complete 1,2, and 3 above plus

2. Mandatory State FFA Degree 


\section{College Agricultural Biology}

\section{Instructor: Ms. Aldridge}

\section{Course Description}

College Agricultural Biology is a one-year laboratory science course designed for the college-bound student with career interests in agriculture. Using agriculture as the learning vehicle, the course emphasizes the biological principles and central concepts. The course centers on an extensive laboratory component to connect the principles of life science with agricultural applications, other curricular areas and other scientific disciplines. This course meets the Life Science laboratory "D" requirements for entrance into the University of California and California State University systems. A grade of "B" or better will qualify the student for U.C. credit in Agricultural Biology.

\section{Course Outline}

$1^{\text {st }}$ Quarter: Ecology, Classifications, Populations, Ecosystems, Microscopes and Chemistry of Cells $2^{\text {nd }}$ Quarter: Cell Structure \& Environment, Photosynthesis, Respiration, Cell/Sexual Reproduction, \& Meiosis $3^{\text {rd }}$ Quarter: Genetics, DNA, Protein Synthesis, Gene technology $4^{\text {th }}$ Quarter Evolution, Human Body, Pig Dissection, Digestive, Immune, Nervous, \& Circulatory Systems Careers in Agriculture Interpersonal Leadership Development/FFA Supervised Agricultural Experience

\section{Classroom Rules}

.. Safe

- Follow all laboratory safety rules.

- No food, drinks, etc. in class without special approval of the teacher.

- Follow all laboratory activities in the outlined format.

2. Responsible

- Come to class on time and be seated and ready to begin at the scheduled time.

- Bring pen and pencil, paper, binder, and any other material to class.

- Stay on assigned tasks during the entire period.

- Ask for any missed homework either before or after class.
- Late work is not an option; turn all work in on time.

- Your first tardy is free; at four tardies Saturday School will be assigned.

\section{Respectful}

- Be positive and treat all members of the class with respect.

- Take care of all classroom materials and laboratory equipment.

- Listen and articulate with other students concerning ideas and presentation.

\section{Student Expectations:}

1. Come to class prepared to learn, with your learning materials.

2. Treat others and classroom with respect.

3. BE ON TIME! Ready to learn when the late bell rings.

4. Follow all science rules of conduct and safety

5. NO FOOD or DRINK.

Pet Peeves: "Doodling Detentioner", "The Wanderer", "Potty Mouth", "The Gatherer's", "Litter Bug" The Don'ts: Dog Ears, Grooming, Touch faucets or gas jets, Ask what we are doing today.

Extra-Credit: No extra-credit will be given to make-up low grades. Periodically, the class will be given an tra credit assignment, which is optional to all students or I will give out Biology Bucks for points. 


\section{Consequences}

\section{Classroom Management}

You will be expected to abide by school rules and the classroom rules that are posted in the classroom. You will also keep a copy of the classroom rules in your notebook. Remember, special rules apply to all laboratory activities. (Examples: Tardy, Defiance,

Language, Disruption, Other)

- $\quad 1^{\text {st }}$ offense = warning, $\quad 2^{\text {nd }}$ offense $=$ name on board $\quad 3^{\text {rd }}$ offense $=$ clean up after class,

- $\quad 4^{\text {th }}$ offense $=$ detention $(10 \mathrm{~min})$ at lunch/after school $\quad 5^{\text {th }}$ offense $=$ detention $(15 \mathrm{~min})$ at lunch/after school, parent phone call.

- $6^{\text {th }}$ offense $=$ detention $(20 \mathrm{~min})$ at lunch/after school, and parent phone call.

- $7^{\text {th }}$ offense $=$ referral

\section{Materials}

- If you fail to show up for detention automatic referral will be given.

- Three-ring binder just for biology (1-2 inch in size).

- Paper, Pen and pencils

- Calculator for mathematics applications.

- Lab Manual - Composition Book

\section{Absences / Make-Up Work}

- Arrange for make-up assignments, quizzes or tests after excused absences on the day you return to school with Ms. Aldridge.

- You have one school day for each excused absence. If you are absent on the date an assignment is due, you must turn in the assignment on the day you return to school.

- You may make up tests and quizzes (unless they are pop-quizzes) at lunch or after school arranged with Ms. Aldridge.

- Work missed during unexcused absences may not be made up. Late work will not be accepted.

\section{Organization of the Notebook}

Keep all assignments in order in your notebook using your cover sheet. (Never throw an assignment away!)

All assignments and notes must be dated and legible with period number and assignment number on them.

As graded assignments are returned, put them back into your notebook and record them on your grade sheet.

\section{Grading}

$90-100 \mathrm{~A}$

$80-89$ B

$70-79 \mathrm{C}$

$60-69 \mathrm{D}$

Below F

\section{Standard Point System}

$70 \%$ Assign, Homework, Projects, Presentations, Test/Quizzes

10\% FFA Activities (Two per quarter)

$10 \% \quad$ SAE and FFA Record Book

$10 \%$ Attitude, Participation, and conduct in class. If you do your work on time, follow directions, participate, you will receive a high conduct grade. (Usually 2 points per day!)

\section{Effective Communicator:}

\section{Expected Schoolwide Learning Results}

$>$ Give demonstrations in class

$>$ Work collaboratively in-groups on leadership projects and in Physical Education

$>$ Participating in team activities in Physical Education

$>$ Keep a tool kit log for every chapter

2. Critical Thinker:

Using mathematical terms to analyze and solve problems

Analyzing group and self performance in Physical Education activities for improved performance

3. Quality Producer:

By completing many different writing assignments, each student will improve the quality of his or her writing

Keep and maintain binders for Pre Algebra, resulting in excellent study guides

4. Self-Directed Learner:

$>$ Since late work is not accepted, students will learn to be productive students

$>$ Students are to write down homework assignments into their calendars so that they will become use to planning ahead

$>$ Students must remember to ask for makeup work after an absence, which encourages them to be responsible

5. Collaborative Worker:

$>$ Working in groups on many projects throughout the year

$>$ Working with partners on projects and assignments

$>$ Design and implement projects that work effectively as a member of a self directed team

6. Ethical Decision Maker:

$>$ Accepts responsibilities for his/her own learning, behavior and participation

Utilizes sportsmanship and citizenship in all aspects of their school life

7. Community Contributor:

- Utilizes sportsmanship and citizenship in all aspects of their school life

- Become involved in school and community activities

\section{Let's work together to have a fun and productive year!!}




\title{
Animal Science
}

\section{Instructor: Ms. Aldridge}

\section{Course Description}

Animal Science is a one year advanced agriculture course that will provide advanced understanding of livestock agriculture and issues affecting society, animal welfare, and production systems. Animal nutrition, anatomy and physiology, health, reproduction, genetics, and management through evaluation, handling and selection will be stressed. Biotechnology and emerging technologies are creating excitement in agriculture industry. This course allows students to be actively involved in the learning process.

Text: Introduction to Livestock \& Companion Animals and Modern Livestock \& Poultry Production Prerequisites: Ag Science or Ag Earth Science or (pre-approval by instructor)

\author{
Course Outline \\ Topics that can be included are: \\ Animal Domestication, Anatomy \& Physiology, Animal Health \& Nutrition \\ Animal Reproduction \& Genetics \\ Animal Evaluation, Handling, and Selection \\ Biotechnology and Emerging Technologies \\ Livestock Management of all species from gestation-processing \\ Careers in Agriculture \\ Interpersonal Leadership Development/FFA \\ Supervised Agricultural Experience
}

\section{$\underline{\text { Classroom Rules }}$}

1. Safe

- Follow all laboratory safety rules.

- No food, drinks, etc. in class without special approval of the teacher.

- Follow all laboratory activities in the outlined format.

2. Responsible

- Come to class on time and be seated and ready to begin at the scheduled time.

- Bring pen and pencil, paper, binder, and any other material to class.

- Stay on assigned tasks during the entire period.

- Ask for any missed homework either before or after class.
- Late work is not an option; turn all work in on time.

- Your first tardy is free; at four tardies Saturday School will be assigned.

\section{Respectful}

- Be positive and treat all members of the class with respect.

- Take care of all classroom materials and laboratory equipment.

- Listen and articulate with other students concerning ideas and presentation.

\section{Student Expectations:}

1. Come to class prepared to learn, with your learning materials.

2. Treat others and classroom with respect.

3. BE ON TIME! Ready to learn when the late bell rings.

4. Follow all science rules of conduct and safety

5. Participate in all learning activities

6. NO FOOD or DRINK.

Peeves: "Doodling Detentioner", "The Wanderer", "Potty Mouth", "The Gatherer's", "Litter Bug" The Don'ts: Dog Ears, Grooming, Touch faucets or gas jets, Ask what we are doing today.

Extra-Credit: No extra-credit will be given to make-up low grades. Periodically, the class will be given an extra credit assignment, which is optional to all students or I will give out Biology Bucks for points. 


\section{Consequences}

\section{Classroom Management}

You will be expected to abide by school rules and the classroom rules that are posted in the classroom. You will also keep a copy of the classroom rules in your notebook. Remember, special rules apply to all laboratory activities. (Examples: Tardy, Defiance,

Language, Disruption, Other)

- $\quad 1^{\text {st }}$ offense = warning, $\quad 2^{\text {nd }}$ offense $=$ name on board $\quad 3^{\text {rd }}$ offense $=$ clean up after class,

- $4^{\text {th }}$ offense $=$ detention $(10 \mathrm{~min})$ at lunch/after school $\quad 5^{\text {th }}$ offense $=$ detention $(15 \mathrm{~min})$ at lunch/after school, parent phone call.

- $6^{\text {th }}$ offense $=$ detention $(20 \mathrm{~min})$ at lunch/after school, and parent phone call.

- $7^{\text {th }}$ offense $=$ referral

\section{Materials}

- If you fail to show up for detention automatic referral will be given.

- Three-ring binder just for animal science (1-2 in in size).

- Paper, Pen and pencils
- Calculator for mathematics applications.

- Lab Manual

\section{Absences / Make-Up Work}

- Arrange for make-up assignments, quizzes or tests after excused absences on the day you return to school with Ms. Aldridge.

- You have one school day for each excused absence. If you are absent on the date an assignment is due, you must turn in the assignment on the day you return to school.

- You may make up tests and quizzes (unless they are pop-quizzes) at lunch or after school arranged with Ms. Aldridge.

- Work missed during unexcused absences may not be made up. Late work will not be accepted.

\section{Organization of the Notebook}

Keep all assignments in order in your notebook using your cover sheet. (Never throw an assignment away!)

All assignments and notes must be dated and legible with period number and assignment number on them.

As graded assignments are returned, put them back into your notebook and record them on your grade sheet.

\section{Grading}

$90-100 \mathrm{~A}$

$80-89 \mathrm{~B}$

$70-79 \mathrm{C}$

$60-69 \mathrm{D}$

Below F

\section{Standard Point System}

$20 \% \quad$ Test \& Quizzes

$20 \% \quad$ Labs, Classwork

$10 \% \quad$ Notebook

$10 \% \quad$ FFA Activities (2 per quarter)

$10 \% \quad$ SAE and FFA Record Book

$30 \% \quad$ Attitude, Participation, and conduct in class. If you do your Work on time, follow directions, participate, you will receive a high conduct grade. (Usually 4 points per day!)

1. Effective Communicator:

\section{Expected Schoolwide Learning Results}

$>$ Give demonstrations in class

$>$ Work collaboratively in-groups on leadership projects and in Physical Education

$>$ Participating in team activities in discussions

2. Critical Thinker:

$>$ Using mathematical terms to analyze and solve problems (ex. Feed rations)

$>$ Analyzing group and self performance

3. Quality Producer:

By completing many different lab write-ups, each student will improve the quality of his or her writing

$>$ Keep and maintain binders for Animal Science, resulting in excellent study guides for final.

4. Self-Directed Learner:

$>$ Since late work is not accepted, students will learn to be productive students

$>$ Students are to write down homework assignments into their calendars so that they will become use to planning ahead

$>$ Students must remember to ask for makeup work after an absence, which encourages them to be responsible

5. Collaborative Worker:

$>$ Working in groups on many projects throughout the year

$>$ Working with partners on projects and assignments

$>$ Design and implement projects that work effectively as a member of a self directed team

6. Ethical Decision Maker:

$>$ Accepts responsibilities for his/her own learning, behavior and participation

$>$ Utilizes sportsmanship and citizenship in all aspects of their school life

7. Community Contributor:

$>$ Utilizes sportsmanship and citizenship in all aspects of their school life

$>$ Become involved in school and community activities

\section{Let's work together to have a fun and productive year!}




\title{
Agriculture Life Science
}

\author{
Instructor: Ms. Aldridge
}

\section{Course Description:}

This introductory course is recommended for all freshmen interested in agriculture. It covers the fundamentals of plant and animal science and gives training in leadership. Production and processing of agriculture products and related services and businesses are studied. Students develop a foundation in science while acquiring a broad understanding of the major facets of modern agriculture. It offers a foundation in the life sciences, the California agriculture basic core, and scientific method. It also provides opportunities to participate in laboratory experiments, Supervised Agriculture Experience projects, and FFA leadership activities. This course meets the minimum graduation requirements of one year of life science and prepares the students for other science and agriculture classes offered.

\section{Classroom Rules}

\section{Safe}

- Follow all laboratory safety rules.

- No food, drinks, etc. in class without special approval of the teacher.

- Follow all laboratory activities in the outlined format.

\section{Responsible}

- Come to class on time and be seated and ready to begin at the scheduled time.

Bring pen and pencil, paper, binder, and any other material to class.

- Stay on assigned tasks during the entire period.

- Ask for any missed homework either before or after class.
- Late work is not an option; turn all work in on time.

- Your first tardy is free; at four tardies Saturday School will be assigned.

\section{Respectful}

- Be positive and treat all members of the class with respect.

- Take care of all classroom materials and laboratory equipment.

- Listen and articulate with other students concerning ideas and presentation.

\section{Student Expectations:}

1. Come to class prepared to learn, with your learning materials.

2. Treat others and classroom with respect.

3. BE ON TIME! Ready to learn when the late bell rings.

4. Follow all science rules of conduct and safety

5. NO FOOD or DRINK.

Pet Peeves: "Doodling Detentioner", "The Wanderer", "Potty Mouth", "The Gatherer's", "Litter Bug" The Don'ts: Dog Ears, Grooming, Touch faucets or gas jets, Ask what we are doing today.

Extra-Credit: No extra-credit will be given to make-up low grades. Periodically, the class will be given an extra credit assignment, which is optional to all students.

\section{Consequences}

\section{Classroom Management}

You will be expected to abide by school rules and the classroom rules that are posted in the classroom. You will also keep a copy of the classroom rules in your notebook. Remember, special rules apply to all laboratory activities. (Examples: Tardy, Defiance, Language, Disruption, Other)

$$
\mathbf{1}^{\text {st }} \text { offense = warning, } \quad 2^{\text {nd }} \text { offense }=\text { name on board } \quad 3^{\text {rd }} \text { offense }=\text { clean up after class, }
$$

$4^{\text {th }}$ offense $=$ detention $(10 \mathrm{~min})$ at lunch/after school $\quad \mathbf{5}^{\text {th }}$ offense $=$ detention $(15 \mathrm{~min})$ at lunch/after school, parent phone call.

- $\mathbf{6}^{\text {th }}$ offense $=$ detention $(20 \mathrm{~min})$ at lunch/after school, and parent phone call.

- $7^{\text {th }}$ offense $=$ referral 


\section{Materials}

- Three-ring binder just for $\mathrm{Ag}$ Science (1-2 inch in size).

- Paper. Pen and pencils

\section{Albsences / Make-Up Work}

- Arrange for make-up assignments, quizzes or tests after excused absences on the day you return to school.

- You have one school day for each excused absence. If you are absent on the date an assignment is due, you must turn in the assignment on the day you return to school.

- You may make up tests and quizzes (unless they are pop-quizzes) at lunch or after school.

- Work missed during unexcused absences may not be made up.

- Late work will be accepted, but will be worth no more than $1 / 2$ credit.

\section{Organization of the Notebook}

Keep all assignments in order in your notebook using your cover sheet. (Never throw an assignment away!) All assignments and notes must be dated and legible with period number and assignment number on them. As graded assignments are returned, put them back into your notebook and record them on your grade sheet.

\section{Grading}

$90-100 \mathrm{~A}$

$80-89$ B

$70-79 \mathrm{C}$

$60-69 \mathrm{D}$

Below F

\section{Standard Point System}

Letter grades are determined by (approximate values)

$20 \%$ Test and Quizzes

$40 \%$ Labs, Classwork, and Homework

20\% FFA activities, SAE and Record Book

20\% Participation, Attendance, and Attitude

\section{Expected Schoolwide Learning Results}

\section{Effective Communicator:}

$>$ Give demonstrations in class

Work collaboratively in-groups on leadership projects and in Physical Education

$>$ Participating in team activities in Physical Education

$>$ Keep a tool kit log for every chapter

2. Critical Thinker:

Using mathematical terms to analyze and solve problems

Analyzing group and self performance in Physical Education activities for improved performance

3. Quality Producer:

By completing many different writing assignments, each student will improve the quality of his or her writing

$>$ Keep and maintain binders for Pre Algebra, resulting in excellent study guides

4. Self-Directed Learner:

D Since late work is not accepted, students will learn to be productive students

Students are to write down homework assignments into their calendars so that they will become use to planning ahead

$>$ Students must remember to ask for makeup work after an absence, which encourages them to be responsible

5. Collaborative Worker:

Working in groups on many projects throughout the year

Working with partners on projects and assignments

$>$ Design and implement projects that work effectively as a member of a self directed team

6. Ethical Decision Maker:

Accepts responsibilities for his/her own learning, behavior and participation

$>$ Utilizes sportsmanship and citizenship in all aspects of their school life

7. Community Contributor:

Utilizes sportsmanship and citizenship in all aspects of their school life

Become involved in school and community activities

\section{Let's work together to have a fun and productive year!}


Page: 1

11/28/2011 1:31:00 PM

\begin{tabular}{|c|c|c|c|c|c|c|c|c|c|c|c|}
\hline Display: Points & Sub & mit Che & gges! & & Reset Ch & anges & & & & & \\
\hline Sort By Student & & & 1 & $-Q t$ & 2. $\mathrm{A}$ & Life & Sci & nce & - YA & dridg & e, $A$ \\
\hline Student Name & Grd & 1 & 2 & 3 & 4 & 5 & 6 & 7 & 8 & Perc & Mrk \\
\hline & Max Points: & 10 & 25 & 25 & 30 & 10 & 5 & 5 & 10 & & \\
\hline$* *$ Grading & Completed: & & & & & & & & & 0 Ass & mnts \\
\hline 1 & 11 & 10 & 25 & 15 & 30 & 8 & 5 & 5 & 10 & 90.00 & A- \\
\hline & 10 & 10 & 0 & 0 & 0 & 8 & 5 & 0 & 10 & 27.50 & $\mathrm{~F}$ \\
\hline & 10 & 10 & 25 & 25 & 28 & 8 & 5 & 5 & 10 & 96.66 & A \\
\hline & 11 & 10 & 25 & 0 & 18 & 8 & 5 & 5 & 10 & 67.50 & $D+$ \\
\hline & 10 & 10 & 25 & 22 & 28 & 8 & 5 & 5 & 10 & 94.16 & A \\
\hline & 10 & 10 & 15 & 0 & 30 & 8 & 5 & 0 & 10 & 65.00 & D \\
\hline & 10 & 10 & 15 & 20 & 18 & 8 & 5 & 5 & 10 & 75.83 & C \\
\hline & 10 & 10 & 25 & 5 & 0 & 8 & 5 & 5 & 10 & 56.66 & $\mathrm{~F}$ \\
\hline 9. & 9 & 10 & 0 & 0 & 0 & 8 & 5 & 0 & 10 & 27.50 & $\mathrm{~F}$ \\
\hline 10. & 10 & 10 & 20 & 0 & 19 & 8 & 5 & 5 & 10 & 64.16 & D \\
\hline 11. & 9 & 10 & 25 & 20 & 15 & 8 & 5 & 5 & 10 & 81.66 & B- \\
\hline 12. & 9 & 10 & 25 & 20 & 30 & 8 & 5 & 5 & 10 & 94.16 & A \\
\hline 13 & 10 & 10 & 25 & 25 & 30 & 8 & 5 & 0 & 10 & 94.16 & A \\
\hline 14. & 10 & 10 & 15 & 0 & 30 & 8 & 5 & 5 & 10 & 69.16 & $D+$ \\
\hline 15. & 10 & 10 & 23 & 15 & 30 & 8 & 5 & 5 & 10 & 88.33 & $B+$ \\
\hline 16. 70 & 9 & 10 & 18 & 0 & 30 & 8 & 5 & 5 & 10 & 71.66 & C- \\
\hline
\end{tabular}


Page: 1 11/28/2011 1:36:28 PM

\begin{tabular}{|c|c|c|c|c|c|c|c|c|c|c|c|}
\hline \multirow{4}{*}{$\begin{array}{l}\text { Display: Points } \\
\text { Sort By Student } \\
\text { Student Name }\end{array}$} & \multicolumn{3}{|c|}{ Submit Changes! } & \multicolumn{3}{|c|}{ Reset Changes } & \multirow{2}{*}{\multicolumn{5}{|c|}{ Science - YAldridge, $\mathbf{A}$}} \\
\hline & & & $2-$ & Qt 2 & $\mathrm{Ag}$ & Life & & & & & \\
\hline & Grd & 1 & 2 & 3 & 4 & 5 & 6 & 7 & 8 & Perc & Mrk \\
\hline & Max Points: & 10 & 25 & 25 & 30 & 10 & 5 & 5 & 10 & & \\
\hline$* * \mathrm{Gra}$ & Completed: & & & & & & & & & 0 Ass! & mnts \\
\hline & 10 & 10 & 25 & 20 & 30 & 9 & & 5 & 10 & 94.78 & A \\
\hline & 11 & 10 & 18 & 25 & 30 & 0 & 5 & 5 & 10 & 85.83 & B \\
\hline & 9 & 10 & 25 & 20 & 30 & 11 & 5 & 5 & 10 & 96.66 & A \\
\hline 4 & 10 & 10 & 22 & 0 & 0 & 0 & 5 & 5 & 10 & 43.33 & $\mathrm{~F}$ \\
\hline & 9 & 10 & 25 & 25 & 30 & 9 & 5 & 5 & 10 & 99.16 & A \\
\hline & 10 & 10 & 25 & 15 & 30 & 11 & 5 & 5 & 10 & 92.50 & A- \\
\hline & 11 & 10 & 25 & 25 & 30 & 9 & 5 & 5 & 10 & 99.16 & $A$ \\
\hline 8 & 10 & 10 & 25 & 25 & 20 & 11 & 5 & 5 & 10 & 92.50 & A- \\
\hline 9 & 10 & 10 & 25 & 0 & 0 & 11 & 5 & & 10 & 53.04 & $\mathrm{~F}$ \\
\hline 10 & 10 & 10 & 25 & 15 & 30 & 11 & 5 & 5 & 10 & 92.50 & A- \\
\hline 11 & 10 & 10 & 25 & 25 & 27 & 9 & 5 & 5 & 10 & 96.66 & $A$ \\
\hline 12 & 9 & 10 & 20 & 10 & 0 & 0 & 5 & 5 & 10 & 50.00 & $\mathrm{~F}$ \\
\hline 13 & 10 & 10 & 25 & 25 & 30 & 9 & 5 & 5 & 10 & 99.16 & $A$ \\
\hline 14 & 10 & 10 & 25 & 20 & 30 & 0 & 5 & 5 & 10 & 87.50 & $\mathrm{~B}+$ \\
\hline 15 & 10 & 10 & 25 & 25 & 20 & 9 & 5 & 5 & 10 & 90.83 & A- \\
\hline 16. & 10 & 10 & 25 & 15 & 28 & 9 & 5 & 5 & 10 & 89.16 & $\mathrm{~B}+$ \\
\hline 17. & 11 & 10 & 5 & 25 & 30 & 11 & 5 & 5 & 10 & 84.16 & $B$ \\
\hline 18 & 9 & 10 & 25 & 20 & 30 & 11 & & 5 & 10 & 96.52 & $A$ \\
\hline 19 & 10 & 10 & 25 & 20 & 30 & 11 & 5 & 5 & 10 & 96.66 & A \\
\hline 20 & 10 & 10 & 25 & 25 & 27 & 11 & 5 & 5 & 10 & 98.33 & A \\
\hline 21. & 10 & 10 & 25 & 25 & 30 & 9 & 5 & 5 & 10 & 99.16 & A \\
\hline 22. & 10 & 10 & 25 & 15 & 28 & 9 & 5 & 5 & 10 & 89.16 & $\mathrm{~B}+$ \\
\hline 23. & 10 & 10 & 15 & 0 & 0 & 0 & 5 & 5 & 10 & 37.50 & $F$ \\
\hline 24. & 10 & 10 & 25 & 25 & 30 & 11 & 5 & 5 & 10 & 100.83 & A+ \\
\hline Let- & 9 & 10 & 25 & 15 & 30 & 9 & 5 & & & 89.52 & $B+$ \\
\hline 26. V & 11 & 10 & 25 & 25 & 30 & 0 & 5 & 5 & 10 & 91.66 & A- \\
\hline
\end{tabular}


Page: 1

11/28/2011 1:37:01 PM

\begin{tabular}{|c|c|c|c|c|c|c|c|}
\hline Display: Points & Submit Changes & & Reset $C$ & anges & & & \\
\hline Sort By Student & & $3-Q$ & 2. A & nima & Scie & $\mathrm{ce}-$ & Aldridge, $\mathrm{A}$ \\
\hline Student Name & Grd & 1 & 2 & 3 & 4 & 5 & Perc Mrk \\
\hline & Max Points: & 10 & 10 & 25 & 40 & 5 & \\
\hline & Completed: & & & & & & O Assmnts \\
\hline 1. & 11 & 10 & 9 & & 40 & 5 & 98.46 \\
\hline & 11 & 10 & 10 & 25 & 30 & 5 & 88.88 \\
\hline & 11 & 10 & 10 & 23 & 30 & 4 & 85.55 \\
\hline 4 & 11 & 10 & 10 & 25 & 40 & 5 & 100.00 \\
\hline 5. & 11 & 10 & 10 & & 30 & 2 & 80.00 \\
\hline & 11 & 10 & 0 & 23 & 35 & 4 & 80.00 \\
\hline 7. & 11 & 10 & 0 & 18 & 30 & 1 & 65.55 \\
\hline 8. & 11 & 10 & 9 & 23 & 40 & 5 & 96.66 \\
\hline 9 & 11 & 10 & 9 & 23 & 20 & 4 & 73.33 \\
\hline 10. & 12 & 10 & 10 & 20 & 30 & 3 & 81.11 \\
\hline 11. & 11 & 10 & 9 & 15 & 0 & 0 & 37.77 \\
\hline 12. & 10 & 10 & 10 & 25 & 30 & 4 & 87.77 \\
\hline 13. & 11 & 10 & 10 & 25 & 30 & 5 & 88.88 \\
\hline 14. & 11 & 10 & 10 & 25 & 35 & 4 & 93.33 \\
\hline 15. & 11 & 10 & 10 & 25 & 40 & 5 & 100.00 \\
\hline 16. & 11 & 10 & 10 & 25 & 40 & 5 & 100.00 \\
\hline 17.9 & 11 & 10 & 10 & 22 & 40 & 4 & 95.55 \\
\hline 18. & 10 & 10 & 10 & 25 & 40 & 5 & 100.00 \\
\hline 19. & 11 & 10 & 9 & 25 & 40 & 5 & 98.88 \\
\hline 20. & 11 & 10 & 0 & 25 & 30 & 1 & 73.33 \\
\hline 21. & 11 & 10 & 9 & 25 & 40 & 2.5 & 96.11 \\
\hline 22. & 11 & 10 & 9 & 25 & 35 & 0 & 87.77 \\
\hline 23. & 12 & 10 & 9 & 25 & 20 & 0 & 71.11 \\
\hline 24. & 10 & 10 & 8 & 25 & 40 & 5 & 97.77 \\
\hline 25. & 11 & 10 & 9 & 25 & 40 & 5 & 98.88 \\
\hline 26. & 11 & 10 & 9 & 25 & 35 & 3 & 91.11 \\
\hline 27. & 12 & 10 & 10 & 15 & 40 & 3.5 & 87.22 \\
\hline 28. & 11 & 10 & 9 & 25 & 40 & 5 & 98.88 \\
\hline 29. & 10 & 10 & 10 & 25 & 40 & 0 & 94.44 \\
\hline 30. & 11 & 10 & 10 & 25 & 35 & 3 & 92.22 \\
\hline 31. & 11 & 10 & 10 & 25 & 40 & 0 & 94.44 \\
\hline 32. & 12 & 10 & 9 & 15 & 30 & 2 & 73.33 \\
\hline
\end{tabular}


Page: 1

11/28/2011 1:37:26 PM

Display: Points

Sort By Student

Student Name
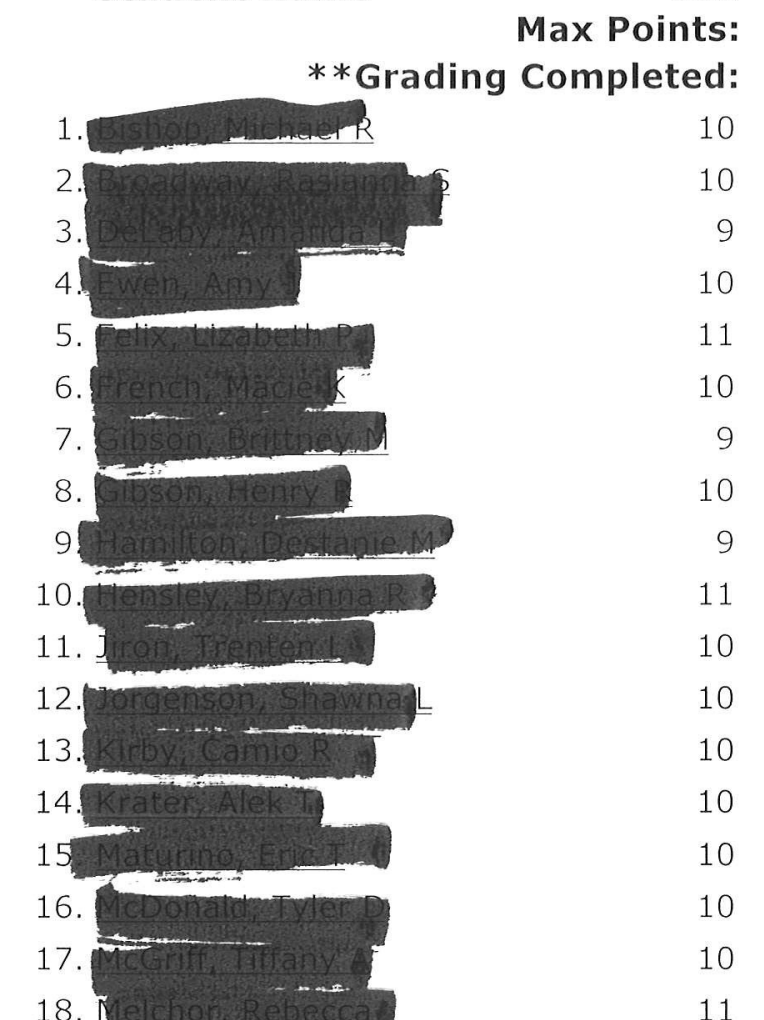

18. Melchon resect

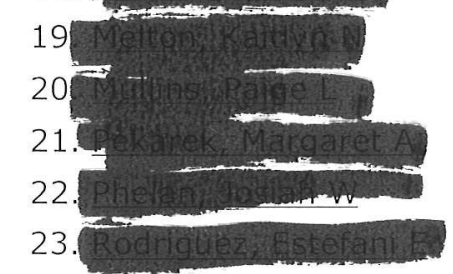

24. Sartordan
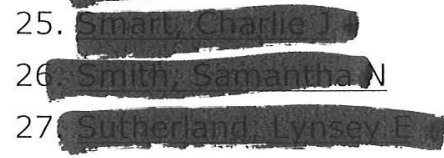

28.
Submit Changes!

$$
4 \text { - Qt 2. College Ag Bio - YAldridge, A }
$$

$\begin{array}{llllll}\text { Grd } & 1 & 2 & 3 & 4 & 5\end{array}$ $\begin{array}{lllll}10 & 25 & 25 & 10 & 50\end{array}$

Perc Mrk

0 Assmnts

53.33

56.66

95.00

81.66

33.33

33.33

35.83

56.66

33.33

76.66

55.83

39.16

26.66

87.50

29.16

83.33

85.00

94.16

88.33

81.66

87.50

95.83

85.00

91.66

97.50

65.83

56.66

90.83 
Page: 1

11/28/2011 1:37:45 PM

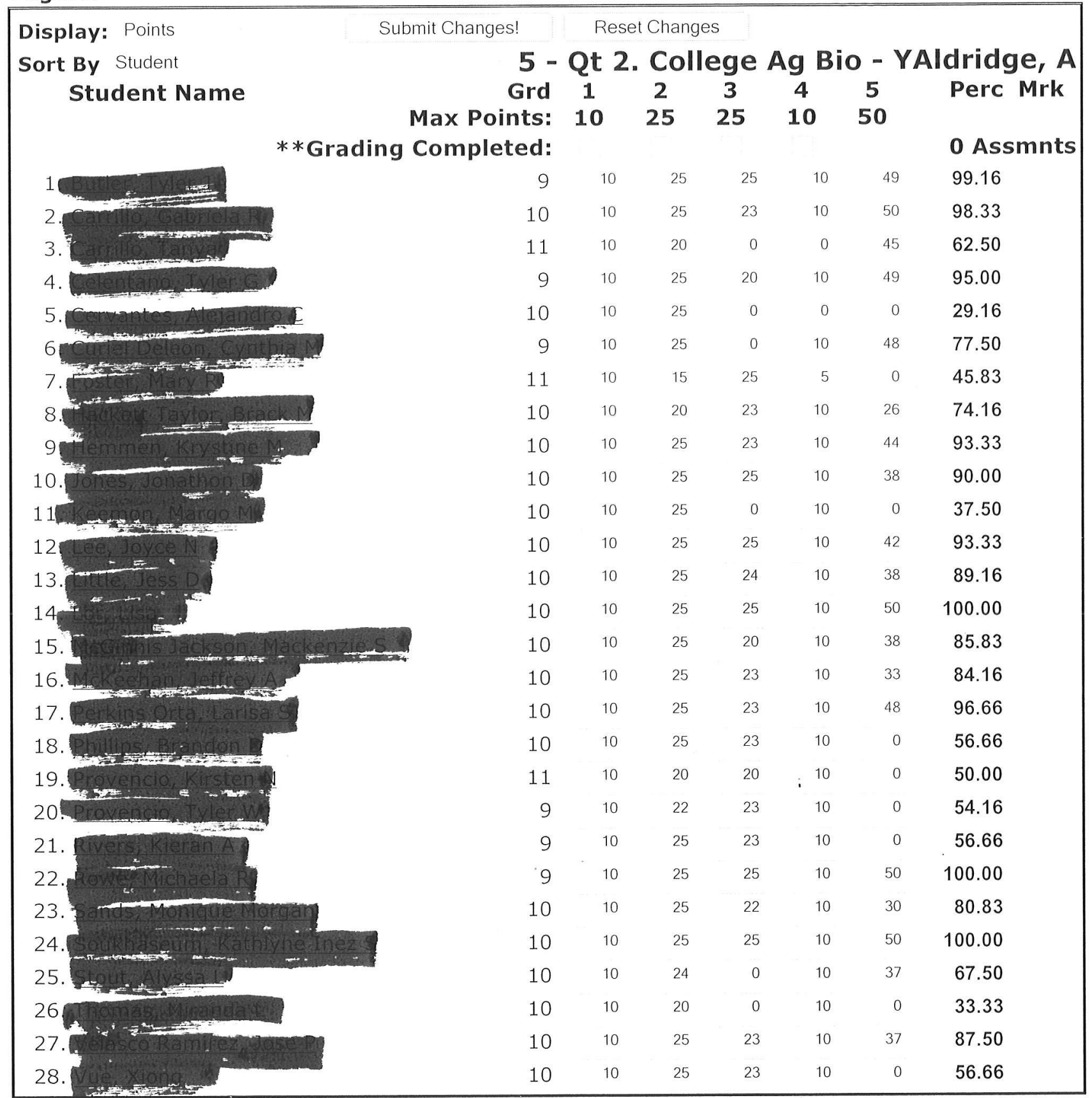




\section{Quality Criteria Two: \\ Leadership and Citizenship Development}

Students develop leadership, citizenship, interpersonal, and employment skills by participating in community service projects and cooperative individualized, and competitive instructional activities.

The students in the Las Plumas High School Agriculture program have numerous opportunities and are encouraged to be involved from the local, all the way up to the national level. Las Plumas FFA alternates years attending National Convention and I am proud to announce this upcoming year the Las Plumas FFA Chapter will be taking eight of our American Degree recipients to the FFA National Convention in Indianapolis to receive their degrees. Also this year $5 \%$ of our R-2, twenty-three students received their State FFA Degree. We also had five students win in eight different proficiency's areas at the regional level.

All four Agriculture teachers take as many students as possible to the State FFA Convention each year; with students receiving proficiencies and being actively involved in the State FFA Band the past few years. Our officer team attends COLC and all chapter members are encouraged to attend numerous other conferences such as MFE/ALA, Greenhand, and SLE. Judging Teams offered through our Agriculture Department are numerous and competitive at regional field days and State Finals each year. The Agriculture Mechanics and Forestry team has even qualified and competed each of the past two seasons. Other judging opportunities for our students include Farm Power, Floriculture, Horticulture, Livestock \& Horse Judging, and Specialty animal. One of our department goals was to push public speaking leadership contest and get as many students involved as possible. This year alone we had two advance and novice Opening \& Closing Contest teams. Two students win Farm Records contest. A local creed contest was held to distinguish our students who would move onto sectionals. We also had three students compete in Job Interview, and two students compete and move onto regional competition in prepared public speaking.

The chapter is actively involved at the local level with activities such as the most popular (with the community) fundraiser on campus, the $10^{\text {th }}$ Annual Steak \& Crab Leadership/ Scholarship Dinner, which has become a sold out event each year. Students are encouraged to participate in all chapter fundraisers and activities such as the canned food drive. These are only a few examples of how our students develop their leadership abilities and citizenship. Students are required to participate in eight FFA Activities throughout the school year as a part of their grade in each agriculture course. The number of members in our chapter has risen and the number of active members continues to raise significantly each year. The four teachers in the department share the responsibilities of leadership activities, with the advisor having more responsibility than the others.

\section{Evidence Documents Include:}

- 2011-2012 Ag Teacher Chart of Responsibilities

- Course Syllabus (with FFA as part of grade) circled

- 2011-2012 Program of Activities (POA) 
11-12 Las Plumas Ag Staff Chart of Responsibilities

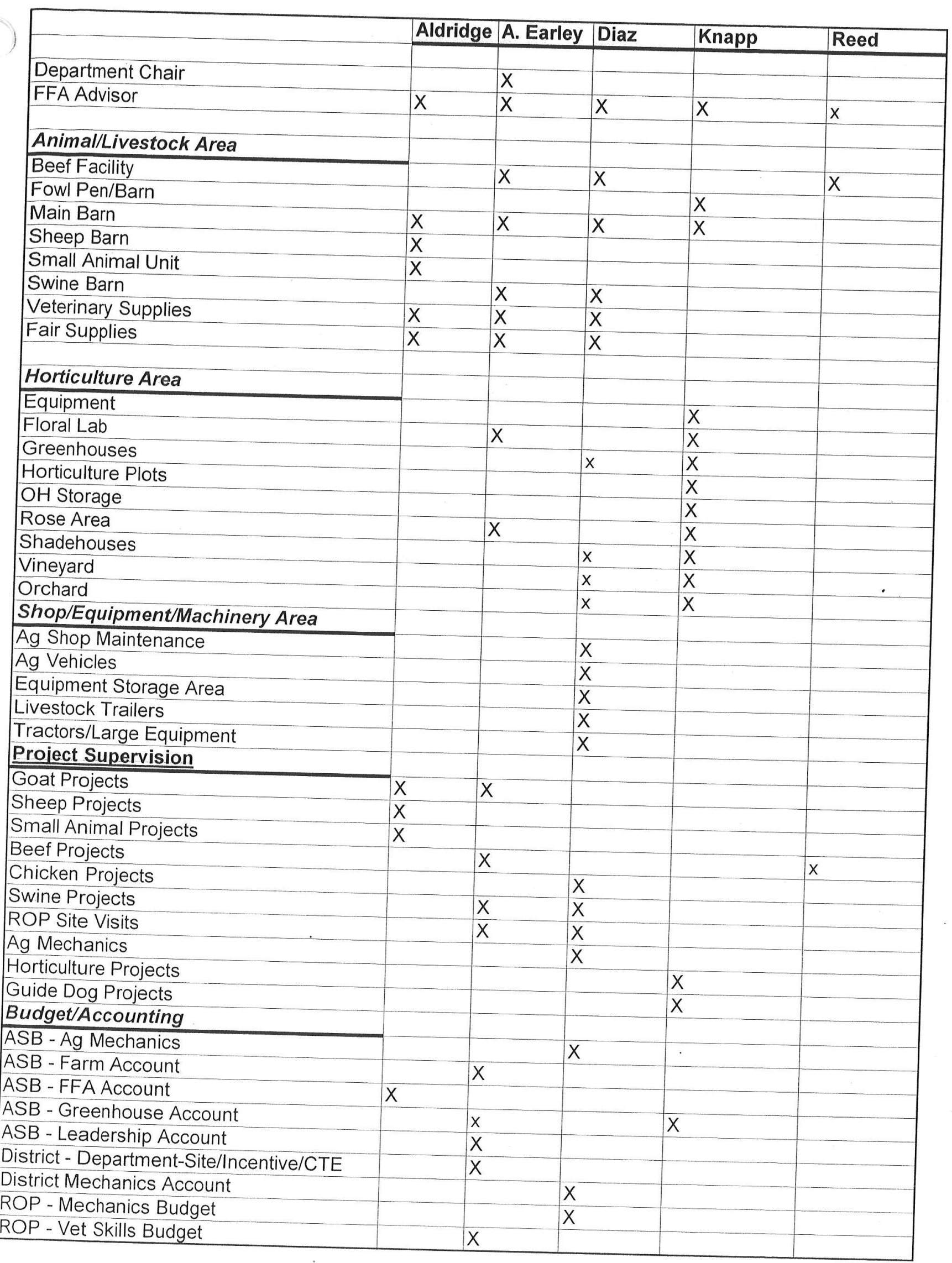


11-12 Las Plumas Ag Staff Chart of Responsibilities

\begin{tabular}{|c|c|c|c|c|c|}
\hline FFA Field Days & Aldridge & A. Earley & Diaz & Knapp & Reed \\
\hline Arbuckle Field Day & & & $x$ & $x$ & 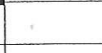 \\
\hline Cal Poly - State Finals & & & & $x$ & \\
\hline CSU, Chico & $\mathrm{x}$ & $x$ & $X$ & & \\
\hline Redwood Logging Contest & & & & $X$ & \\
\hline Sierra Cascade Logging Conference & & & & $x$ & \\
\hline Shasta College & & $x$ & & & \\
\hline UC Davis & & & & $x$ & \\
\hline Modesto/Merced Field Day & & $?$ & & $x$ & \\
\hline Reedley Field Day & & & & $x$ & \\
\hline \multicolumn{6}{|l|}{ FFA Judging Teams } \\
\hline Floriculture & & $\mathrm{X}$ & & $x$ & \\
\hline $\mathrm{BIG}$ & $x$ & & & & \\
\hline Creed & & & & $x$ & \\
\hline Farm Power & & & $x$ & & \\
\hline Forestry & & & & $x$ & \\
\hline Livestock & & & $x$ & & $x$ \\
\hline Nursery - Horticulture & & & & $x$ & \\
\hline Specialty Animal & $x$ & $x$ & & & \\
\hline Job Interview & & $x$ & & & \\
\hline Opening/Closing Advanced & $x$ & $x$ & & & \\
\hline Opening/Closing Novice & $x$ & $x$ & & & \\
\hline CO-Op and Farm Records & & $x$ & & & \\
\hline \multicolumn{6}{|l|}{ FFA Leadership Dinner } \\
\hline Correspondence/Public Relations & $x$ & $x$ & $x$ & $x$ & \\
\hline Food and Cooking & & & $x$ & & \\
\hline Serving & & & $x$ & $x$ & \\
\hline Set Up/Clean Up & & Set up & $x$ & $x$ & \\
\hline Silent Auction and Drawings & $x$ & & & & \\
\hline Tickets & & $x$ & & & \\
\hline Crab and serving crab & & & & $x$ & \\
\hline \multicolumn{6}{|l|}{ Fundraisers } \\
\hline Drive Thru BBQ & $x$ & $x$ & $X$ & $x$ & $x$ \\
\hline Cookie Dough & $x$ & $x$ & & & \\
\hline Plant/Floriculture & & $x$ & & $x$ & \\
\hline Other Fundraisers & & & & $\mathrm{X}$ & \\
\hline
\end{tabular}




\section{Animal Science}

\section{Instructor: Ms. Aldridge}

\section{Course Description}

Animal Science is a one year advanced agriculture course that will provide advanced understanding of livestock agriculture and issues affecting society, animal welfare, and production systems. Animal nutrition, anatomy and physiology, health, reproduction, genetics, and management through evaluation, handling and selection will be stressed. Biotechnology and emerging technologies are creating excitement in agriculture industry. This course allows students to be actively involved in the learning process.

Text: Introduction to Livestock \& Companion Animals and Modern Livestock \& Poultry Production Prerequisites: Ag Science or Ag Earth Science or (pre-approval by instructor)

\section{Course Outline}

Topics that can be included are: Animal Domestication, Anatomy \& Physiology, Animal Health \& Nutrition

Animal Reproduction \& Genetics

Animal Evaluation, Handling, and Selection

Biotechnology and Emerging Technologies

Livestock Management of all species from gestation-processing

Careers in Agriculture

Interpersonal Leadership Development/FFA

Supervised Agricultural Experience

\section{Classroom Rules}

1. Safe

- Follow all laboratory safety rules.

- No food, drinks, etc. in class without special approval of the teacher.

- Follow all laboratory activities in the outlined format.

2. Responsible

- Come to class on time and be seated and ready to begin at the scheduled time.

- $\quad$ Bring pen and pencil, paper, binder, and any other material to class.

- $\quad$ Stay on assigned tasks during the entire period.

- Ask for any missed homework either before or after class.
- Late work is not an option; turn all work in on time.

- Your first tardy is free; at four tardies Saturday School will be assigned.

\section{Respectful}

- Be positive and treat all members of the class with respect.

- Take care of all classroom materials and laboratory equipment.

- Listen and articulate with other students concerning ideas and presentation.

\section{Student Expectations:}

1. Come to class prepared to learn, with your learning materials.

2. Treat others and classroom with respect.

3. BE ON TIME! Ready to learn when the late bell rings.

4. Follow all science rules of conduct and safety

5. Participate in all learning activities

6. NO FOOD or DRINK.

at Peeves: "Doodling Detentioner", "The Wanderer", "Potty Mouth", "The Gatherer's", "Litter Bug" The Don'ts: Dog Ears, Grooming, Touch faucets or gas jets, Ask what we are doing today.

Extra-Credit: No extra-credit will be given to make-up low grades. Periodically, the class will be given an extra credit assignment, which is optional to all students or I will give out Biology Bucks for points. 


\section{Consequences}

\section{Classroom Management}

You will be expected to abide by school rules and the classroom rules that are posted in the classroom. You will also keep a copy of the classroom rules in your notebook. Remember, special rules apply to all laboratory activities. (Examples: Tardy, Defiance, Language, Disruption, Other)

- $\quad \mathbf{1}^{\text {st }}$ offense $=$ warning, $\quad 2^{\text {nd }}$ offense $=$ name on board $\quad 3^{\text {rd }}$ offense $=$ clean up after class,

- $4^{\text {th }}$ offense $=$ detention $(10 \mathrm{~min})$ at lunch/after school $\quad \mathbf{5}^{\text {th }}$ offense $=$ detention $(15 \mathrm{~min})$ at lunch/after school, parent phone call.

- $\quad 6^{\text {th }}$ offense $=$ detention $(20 \mathrm{~min})$ at lunch/after school, and parent phone call.

- $7^{\text {th }}$ offense $=$ referral

\section{Materials}

- If you fail to show up for detention automatic referral will be given.

- Three-ring binder just for animal science (1-2 in size).

- Paper, Pen and pencils
- Calculator for mathematics applications.

- Lab Manual

\section{Absences / Make-Up Work}

- Arrange for make-up assignments, quizzes or tests after excused absences on the day you return to school with Ms. Aldridge.

- You have one school day for each excused absence. If you are absent on the date an assignment is due, you must turn in the assignment on the day you return to school.

- You may make up tests and quizzes (unless they are pop-quizzes) at lunch or after school arranged with Ms. Aldridge.

- Work missed during unexcused absences may not be made up. Late work will not be accepted.

\section{Organization of the Notebook}

Keep all assignments in order in your notebook using your cover sheet. (Never throw an assignment away!)

All assignments and notes must be dated and legible with period number and assignment number on them.

As graded assignments are returned, put them back into your notebook and record them on your grade sheet.

\section{Grading}

$90-100 \mathrm{~A}$

$80-89$ B

$70-79 \mathrm{C}$

$60-69 \mathrm{D}$

Below $\mathrm{F}$

\author{
Standard Point System \\ $20 \% \quad$ Test \& Quizzes \\ $20 \% \quad$ Labs, Classwork \\ $10 \% \quad$ Notebook \\ $10 \% \quad$ FFA Activities (2 per quarter) \\ $10 \% \quad$ SAE and FFA Record Book \\ $30 \%$ Attitude, Participation, and conduct in class. If you do your \\ Work on time, follow directions, participate, you will receive \\ a high conduct grade. (Usually 4 points per day!)
}

\section{Effective Communicator:}

\section{Expected Schoolwide Learning Results}

$>$ Give demonstrations in class

$>$ Work collaboratively in-groups on leadership projects and in Physical Education

Participating in team activities in discussions

2. Critical Thinker:

$>$ Using mathematical terms to analyze and solve problems (ex. Feed rations)

$>$ Analyzing group and self performance

3. Quality Producer:

$>$ By completing many different lab write-ups, each student will improve the quality of his or her writing

$>$ Keep and maintain binders for Animal Science, resulting in excellent study guides for final.

4. Self-Directed Learner:

$>$ Since late work is not accepted, students will learn to be productive students

$>$ Students are to write down homework assignments into their calendars so that they will become use to planning ahead

$>$ Students must remember to ask for makeup work after an absence, which encourages them to be responsible

5. Collaborative Worker:

Working in groups on many projects throughout the year

$>$ Working with partners on projects and assignments

$>$ Design and implement projects that work effectively as a member of a self directed team

6. Ethical Decision Maker:

$>$ Accepts responsibilities for his/her own learning, behavior and participation

$>$ Utilizes sportsmanship and citizenship in all aspects of their school life

7. Community Contributor:

$>$ Utilizes sportsmanship and citizenship in all aspects of their school life

$>$ Become involved in school and community activities 


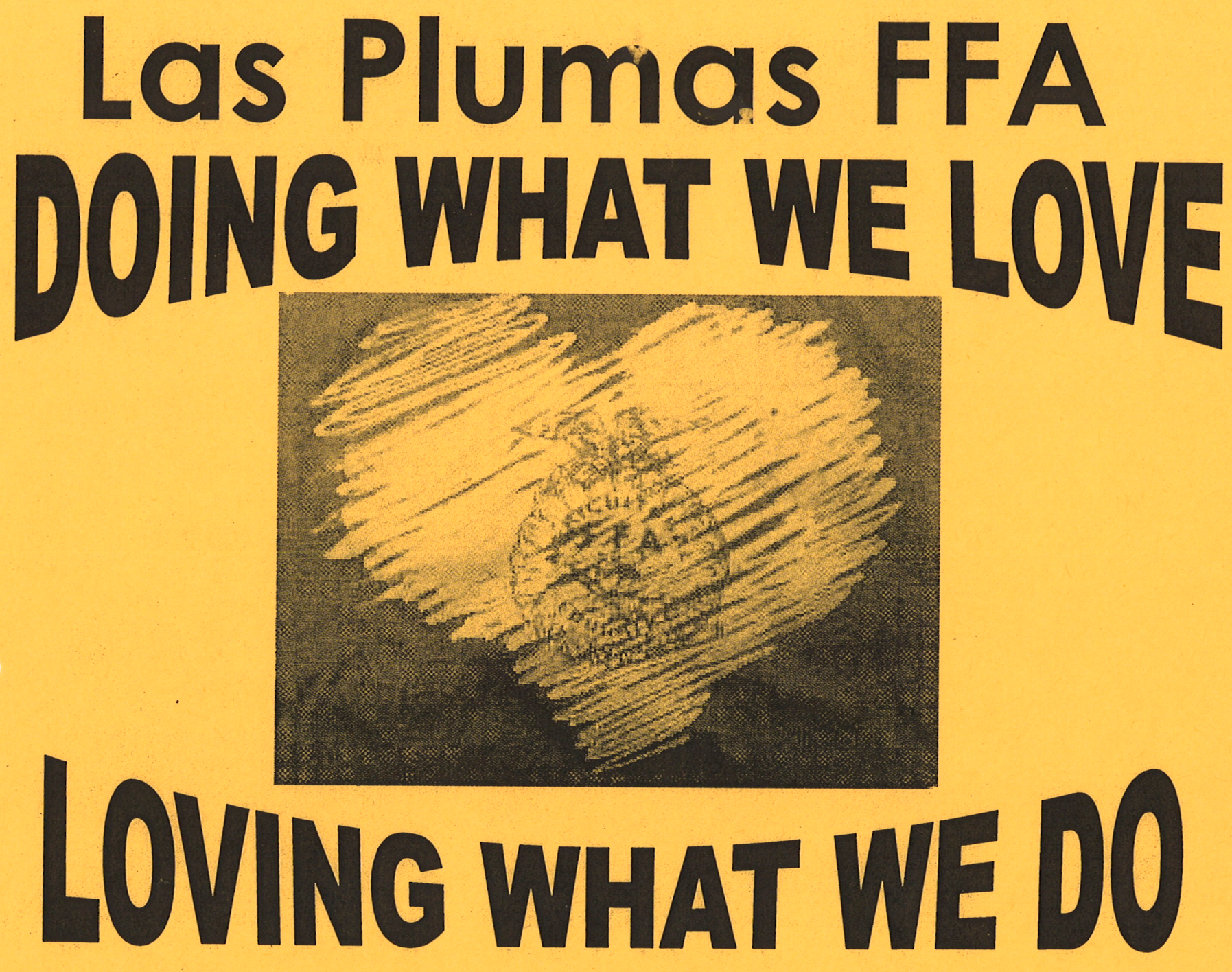

Program of Activities

$$
\begin{gathered}
\text { (POA) } \\
2011-2012
\end{gathered}
$$




\section{Table of Contents}

Pg.

Calendar of Events 3

Officer Welcome $\quad 4$

Officer's Messages $\quad$ 5-6

Standing Committees 6

$\begin{array}{ll}\text { Committee Messages } & 7\end{array}$

$\begin{array}{lc}\text { Chapter Goals } & 8\end{array}$

FFA Point Award System $\quad 8$

FFA Emblem 9

Code of Ethics 9

Mission Statement 9

$\begin{array}{lr}\text { Program Completers Criteria } & 10\end{array}$

$\begin{array}{lr}\text { Agriculture Course Offerings } & 10\end{array}$

$\begin{array}{ll}\text { Career Development Events \& Teams } & 11\end{array}$

$\begin{array}{lr}\text { Supervised Agriculture Experience } & 12-14\end{array}$

$\begin{array}{lr}2011-2012 \text { Fair Rules } & 15\end{array}$

$\begin{array}{ll}\text { Market Hog \& Steer Budgets } & 16\end{array}$

$\begin{array}{ll}\text { Market Lamb \& Goat Budgets } & 17\end{array}$

$\begin{array}{lr}\text { Las Plumas High School Constitution } & 18-21\end{array}$

$\begin{array}{lr}\text { Las Plumas FFA Bylaws } & 21-25\end{array}$

2011-2012 FFA Budget 26

$\begin{array}{ll}\text { Greenhand FFA Degree Requirements } & 27\end{array}$ 


\section{1-2012 Calendar}

August

24-28

September

$$
5
$$

14

16-18

21

21

29

26-30

October

13

12

19-22

21

19-22

November

2

11

16

17

21-25

December

14

19-2

January

2

16

19

20-21

24

28

28
Butte County Fair

No School

Back to School Night

COLC Camp Tehama

Greenhand Workshop

FFA Meeting @ 5:30

Greenhand Conference

(Colusa)

Homecoming Week

Shasta College Field

Day

FFA Meeting @ Lunch

National FFA Convention

End of First Quarter

National Convention

Local Opening/Closing

Contest

No School Veterans Day

FFA Meeting @ 5:30

Opening/Closing

Contest Colusa

Thanksgiving Break

Winter Degree Banquet

Christmas Break

Back from Break

No School

End of Semester

MFE/ALA (Redding)

State Degree Scoring

Steak and Crab Feed

CSU Chico Swine Day
February

7-8

$7-9$

11

11

17

18-25

20

24

28

March

3

6-9

10

15

17

21

31

April

2-9

18

21

21-24

May

5

14

9

23-28

June

7
CAHSEE Test

Colusa Farm Show

Proficiency Scoring

CSU Sheep Day

No School

FFA Week

No School

FFA Meeting @ 5:30 and

Dance

North Valley Speaking

Contest Orland

UC Davis Field Day

Sacramento Leadership

Experience

CSU, Chico Field Day

Superior Region meeting

Chico

Merced College Field

Day

FFA Meeting at Lunch

Modesto Field Day

Spring Break

FFA Meeting @ 3:15

Fresno Field Day

State FFA Conference

Cal Poly State Final

Reedley College Field

Day

Spring Banquet @ 6:00

Silver Dollar Fair

Graduation 


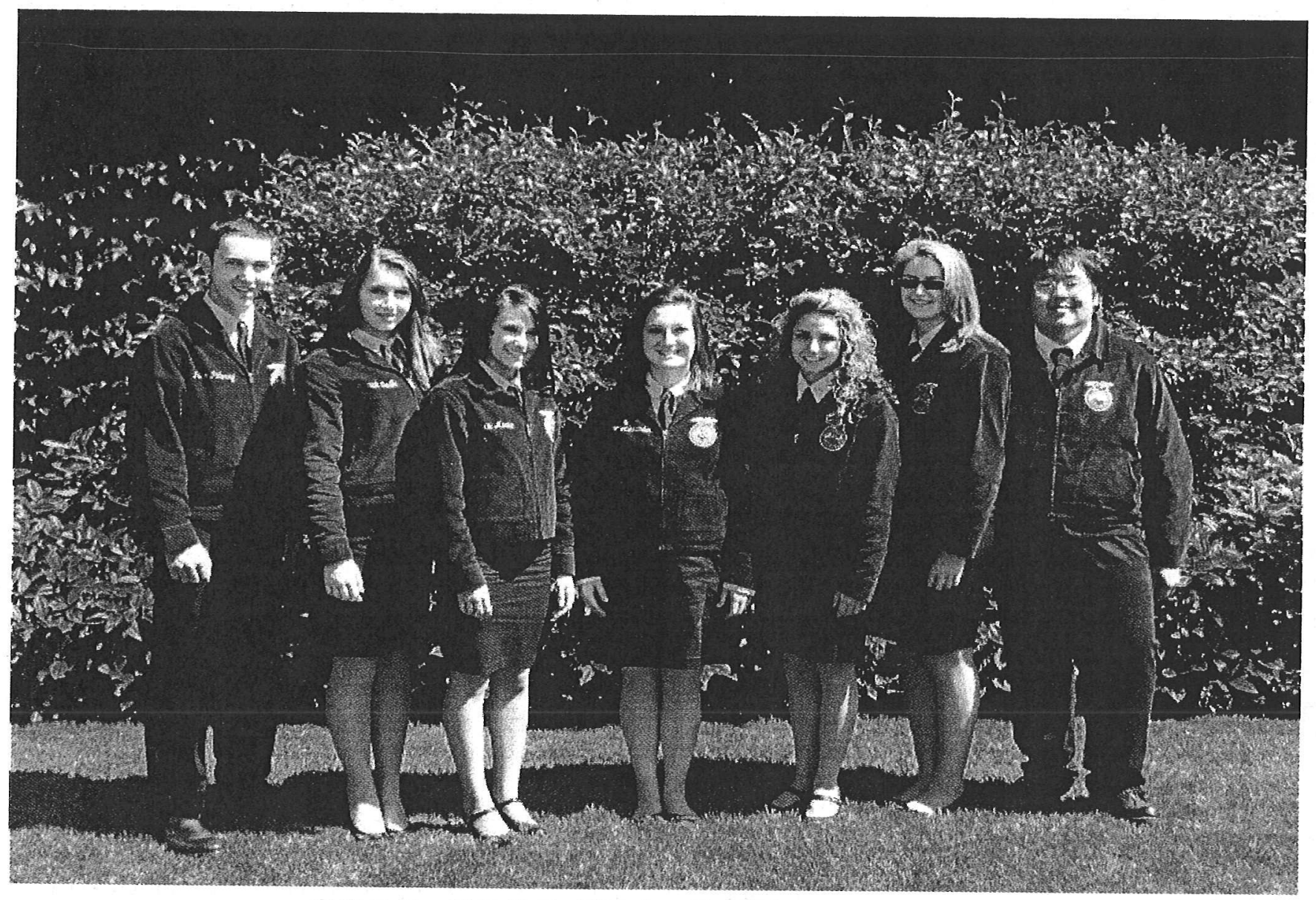

2011-2012 FFA Officer Team President - Aimee Alexander

Vice President - Jake Pickering

Secretary - Clistie Acosta

Treasurer - Kenny Saephan

Reporter - Hannah Neville

Sentinel - Alexis Avelar

Historian - Emily Delle

$\sim$ Advisors

Ms. Aldridge, Mr. Diaz, Mrs. Earley, Mr. Knapp Student Teacher

Mr. Reed 


\section{Officer Messages}

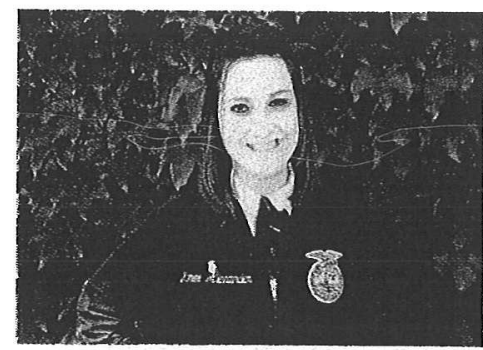

Hey FFA members, my name is Aimee Alexander and I am your 2011-2012 Chapter President. I got involved in Ag my freshmen year, but why I got involved is different than most high school students. I've wanted to be a vet since I was three and my eighth grade summer I decided to start looking at colleges. I decided I wanted to go to U.C Davis and they required two years of an Ag related course. I had no idea what that was so my mom and I looked into it and I discovered that Las PJumas had an FFA Chapter and that it counted as Ag, so two days before school started at Paradise High, I switched schools and came here to LP. My freshmen year I wasn't very involved and I regret that because, now, Ag is everything to me. I have raised Guide Dogs for the Blind and I take market hogs to the fairs as well as a breeding doe. FFA has had a huge impact in my life and has helped me decided what to do with my future. I am now planning on going to Chico State to become an Ag teacher. I encourage all of you members to get as involved as possible because we have a lot of fun coming up this school year. Do your best and get involved and you will be amazed where Ag can take you!

Sincerely, Aimee Alexander

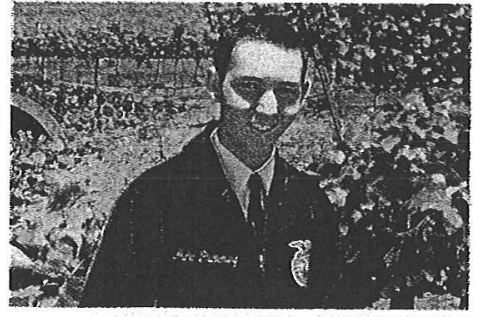

Hey everyone, my name is Jake Pickering and I'm your 2011-2012 Chapter Vice President. I am really looking forward to the upcoming year. It's going to be very fun and exciting. This year I will also be serving as your North Valley Section Reporter. I grew up going to 4-H meetings every month and always working with my animal projects. Coming into high school as a freshmen, I knew Ag was for me. It opened my eyes up to competitions, conferences, and so much more. FFA has made me the person I am today, and hopefully it can have an impact in every single member's life like it has in mine.

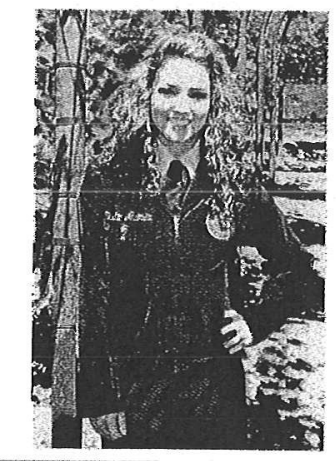

Hi my name is Clistie Acosta, I'm your 2011-2012 Secretary. I got involved in Ag my freshman year. I was encouraged to try Creed, though I regret not following through, it was a learning experience and something I would recommend to any freshman. FFA really showed me the leadership aspects I could pursue and that it's not just raising animals. Sophomore year I attended MFE and State Conference. Getting a deeper understanding and knowledge of FFA encouraged me to apply for office. Junior year I was positioned as Reporter. I also attended ALA and State Conference for another year. FFA has become a huge part of my life and I love it! I hope each of you find some aspect of the FFA beneficial to your high school career and life. I look forward to serving you this year and seeing where agriculture and FFA takes you.

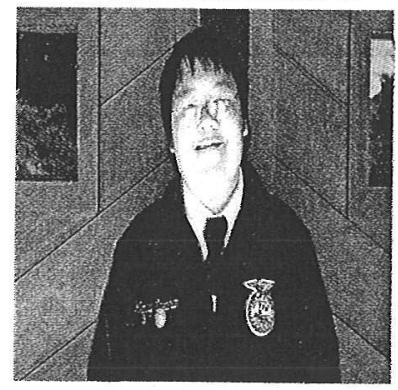

My name is Kenny Saephan and I'm your 2011-2012 Las Plumas Chapter Treasurer. I grew up in a farming family and we have farmed strawberries my whole life. I joined FFA as soon as I got into high school but I was not very involved. I had bad grades and ditched school but my junior year, Mr. Knapp convinced me to join horticulture. I found out how fun FFA was so I applied for treasurer. I'm very excited for this next year and I hope you all have as much fun as I will.

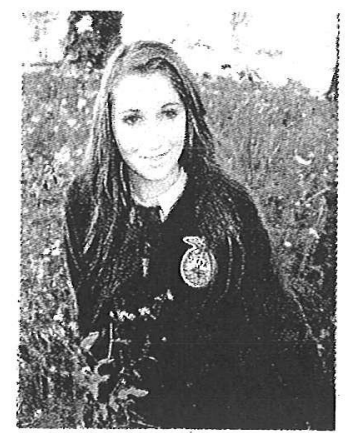

Hi, my name is Hannah Neville. I am your 2011-2012 Chapter Reporter. I have been in Ag since my freshman year and I love it. The people in our Ag department and being involved in agriculture in general, has opened so many doors for me. I have been around agriculture, mainly livestc ck, my entire life and being in FFA has given me the chance to share my abilities with all of you. The main thing I do in FFA is raise and sell livestock at our local fairs. I have raised hogs for 4 years, tried my luck with meat pen rabbits, and fallen in love with raising cattle. I also attend as many leadership conferences as I can. Outside of FFA I enjoy; cheerleading on the school squad, working on my truck with my dad, and hanging out on 
my Grandpa Joe's farm with all of his horses. FFA has been awesome for me, and I hope it will be the same for you. I wish you the very best \& good luck!

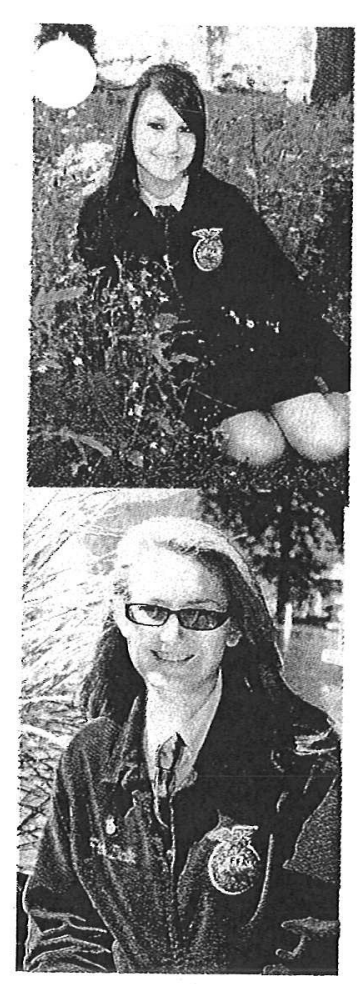

Hi my name is Alexis Avelar I am your 2011-2012 Chapter Sentinel. I am currently a junior and this is my $3^{\text {rd }}$ year in Ag. My freshman year I started to get involved in FFA by doing opening and closing in Colusa, later I took a market goat to Silver Dollar Fair and started my own goat breeding project. My sophomore year I did opening and closing again, also joined the livestock judging team, recruited $8^{\text {th }}$ graders, and took a market lamb to both Silver Dollar and Butte County fairs. Outside of Ag I play volleyball for our school, I take honors and AP classes, and work at Jakes Burgers. I enjoy doing things like wakeboarding and being with my family and friends. I hope we encourage you all to get involved!

Dear FFA Members,

My Name is Emily Delle and I will be serving as your 2011-2012 Las Plumas FFA Chapter Historian. I got involved with FFA only a year ago when the journalism class got canceled due to lack of enrollment. I got involved with Fundraising, Opening and Closing, Co-Ops, and Parliamentary Procedure competitions and the teams I was on succeeded. These experiences taught me that hard-work, dedication and high personal expectations lead to success.

Outside of FFA I play the bass for my band "Forget About The Donkeys", help lead my local church's youth group, work as an AMF (American Missionary Fellowship) Summer Missionary at Mt. Hope Bible Camp in Forbestown, California and I love to hang out with my friends and do crazy things.

I never dreamed that I would be an FFA Officer but I am excited for this year, and can' wait to see the things that our chapter will accomplish and the experiences we will have.

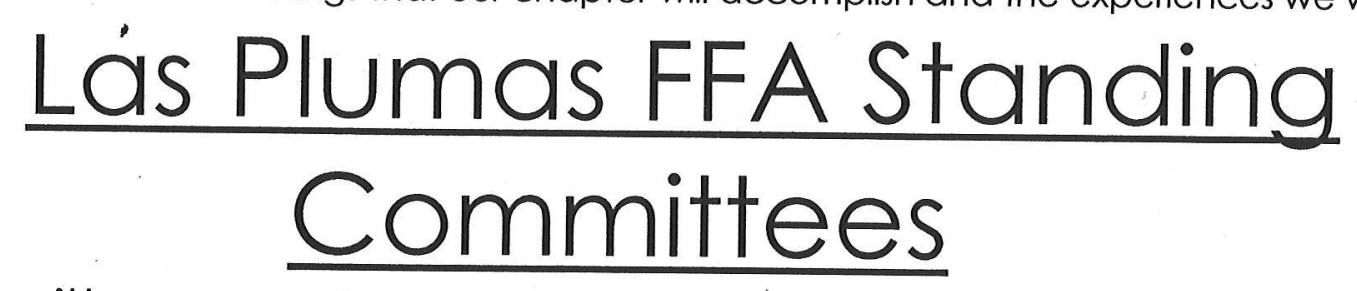

FFA committees are groups of members who help run small specific areas within the chapter. These committees are used in planning and conducting chapter activities. Las Plumas FFA has five committees this year.

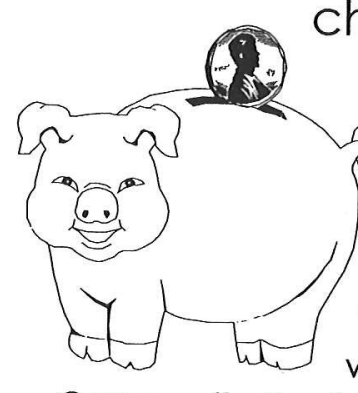

Fundraising Committee: This committee is responsible for fundraising ideas and putting

these ideas into action. This committee will work closely with the treasurer to raise money

for our chapter and help keep records of this progress. Some of the fundraising that will take place is the annual Steak and Crab Feed, Cookie Dough Sales, and Drive Thru BBQ. Incentive Committee: This committee is responsible for promoting the chapter incentive trip. This trip is designed to reward members for being active in the chapter. Get involved if you want to help decide where the end of the year trip will be held.

Community Service Committee: This committee is in charge of coordinating community service that our members can participate in. These activities will be at and above the chapter levels. Some of these activities are Las Plumas Beautification, a petting zoo for elementary school students, as well as a canned food drive to benefit the Rescue Mission in Oroville.

Fair Committee: This committee is responsible for helping with Silver Dollar and Butte County Fair. The committee chair collaborates with advisors to promote Las Plumas FFA within the community by marketing the program through local fairs. This committee deals with issues concerning fair budget and keeps inventory of
supplies.

Recruitment Committee: This is a new committee that works on programs for $8^{\text {th }}$ graders to come visit the Las $\mathrm{F}$ as Agriculture Department in order for them to have a better idea as to what we are all about. This curnmittee will come up with on campus recruitment ideas as well. Get involved if you think Las Plumas FFA is
the place to be! 


\section{Committee Chair Messages}

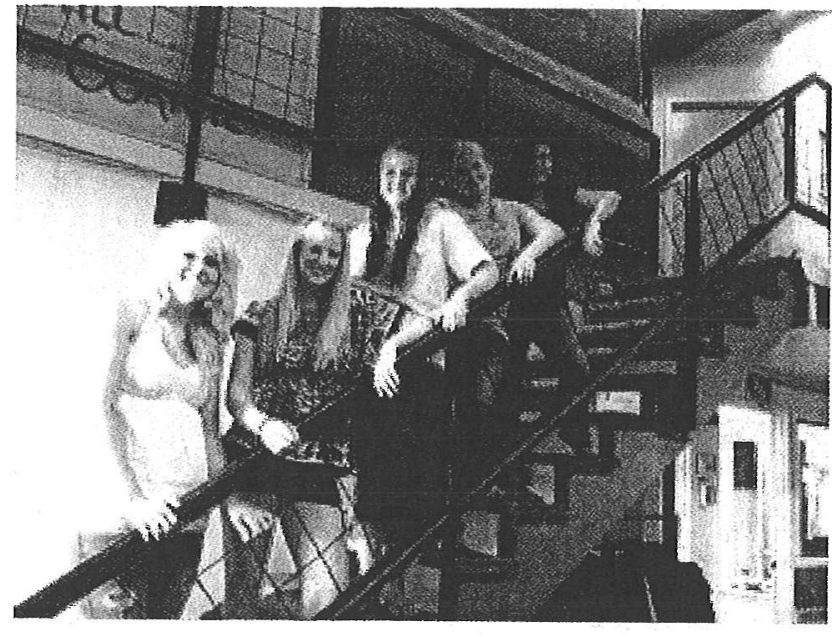

Hey! My name's Megan Adams and I'm this years Community Service Committee Chair. This is my second year in FFA. Last year, I raised a Guide Dog and also competed on the Horticulture team. I was in 4-H during elementary school, and raised three hogs. This year, I plan on staying on the horticulture team, as well as raising a lamb for the Silver Dollar fair, and possibly the Butte County Fair. I'm definitely looking forward to getting to know many more of you this year, and hopefully encourage you to get more involved in our chapter, in addition to our community!

Hey everyone, my name is Jessica Cain and I'm your 2011-2012 Recruitment Committee Chair. I am a junior this year and have been in FFA for 3 years now. I previously took market hogs to the local fairs, but changed to market goats and I also have a breeding goat project. I have participated in the sectional opening and closing contest for two years and my team won $2^{\text {nd }}$ place last year. I got interested in FFA by watching my older brother show animals at the fair and my freshman year I enrolled in Ms. Aldridge's College Ag Biology class. I wanted to get more involved within the FFA so I am now a committee chair and the North Valley Section Treasurer. This year I want to show the eighth graders what the FFA is all about and what it has to offer. I'm excited for the year to come and I encourage everyone to get more involved within the FFA!

My name is Meghan Lambert and this year as your Fundraising Committee Chair l'm ready to make our chapter bank! I've been involved in agriculture since I was seven years old and can honestly say FFA takes it to another level. I've enjoyed wearing that corduroy jacket on road trips to competitions and conferences all the way to making memories at multiple livestock shows. Outside of FFA, I do a lot of photography, writing, cheerleading, baking and of course I spend as much time as possible finding fun outdoors with my friends and family. This organization is a learning experience and has helped me be the person I am today by showing me its many life lessons. I'm always up for a new adventure and this year's officer team is bringing the fun!

$\mathrm{Hi}$, my name is Savannah Sherwood. I am your 2011-2012 Incentive Committee Chair. This is my second year in FFA and I love it!!! I love taking animals to the fair! That's one of the main things I do in FFA. I have taken a lamb to the Silver Dollar Fair and a steer to the Butte County Fair. I am planning on taking many more steers throughout my high school years. Before I joined the Las Plumas FFA Chapter, I was involved in 4-H for many years! I took a lot of pigs to the fairs when I was in 4- $\mathrm{H}$. I have loved the experience of taking a variety of animals to the fairs. I am so excited to be your 201 1-2012 Incentive Committee Chair this year! If anyone has any ideas of where we should go for our Incentive Trip, feel free to share them with me!!! I would love to hear your thoughts... Thanks! Let's make this an awesome year!

Hey there FFA members, my name is Marlee Little and I am your 2011-2012 Fair Committee Chair. This is my fourth year I have been involved in our FFA program. I became interested in FFA when I first saw my older brother show chickens at the fair, and win Grand Champion. I currently take market lambs to both Silver Dollar and Butte County fair, and for fun I also raise hogs. I competed in record book keeping and local Opening and Closing events. I have also gone to ALA and State Conference, which I highly encourage you to go to. Outside of FFA, I love playing volleyball, riding quads, and having fun with friends. I hope to see each and every one of you become more involved within our FFA Chapter. If you have any questions or are interested in going to the fair feel free to come and ask. Fair is a blast and I am hoping to see you there! 


\section{Chapter Goals}

Goal 1- Our objective is to have $65 \%$ retention of each grade level for the following year.

-Chapter workshop for $10^{\text {th }}$ and $11^{\text {th }}$ graders.

-Make our meetings more interesting.

Goal 2- Our objective is to promote our chapter in our community and school.

-Community service.

-Media awareness.

-Showing gratitude for our supporters.

\section{FFA Point}

Award System

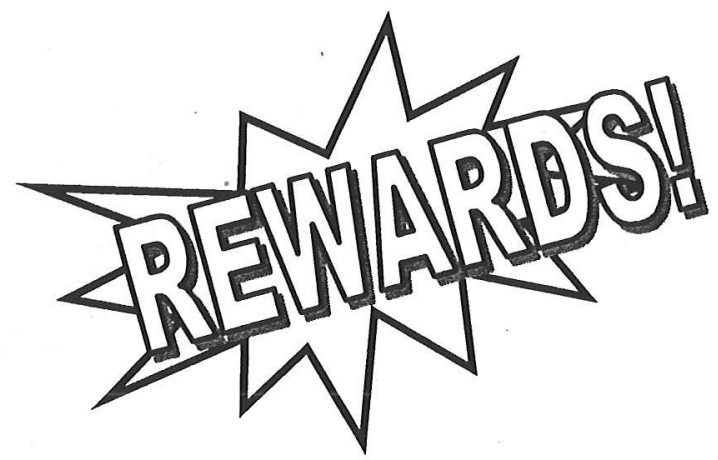

The FFA Point Awards System was established to encourage member participation as well as to recognize members who are active in their chapter. The Point Awards System will begin at the start of the Butte County

r.

- To attend the trip you must accumulate as many points over the year as possible. After every quarter, the points will be posted in the Ag. Classes in a ranking format (1 ${ }^{\text {st }}, 2^{\text {nd }}, 3^{\text {rd }}$, etc.).

- Top members will be chosen to go on a point awards trip at the end of the year. The Incentive Committee will decide this trip and how many will attend later in the year. Past years included Splash Mountain day trip, camping in Fort Bragg, Six Flags day trip, and Giants vs. A's at AT\&.T Park baseball game.

- Chapter Officers will not be in competition with the rest of the chapter's members, but will have to meet the same requirements.

- If you are interested in participating in the FFA Point Awards System, fill out a point award sheet accordingly and return them to the designated point award baskets by the correct due date.

- If you are interested in participating in the FFA Point Awards End-of-Year Incentive Trip, it is highly recommended that you attend the committee meetings, so that you can voice your opinion on where the trip will be.

- The Incentive committee chairman, with the help of the Vice President, will tally Point Awards.

- The final decision regarding Point Award sheets lies with the advisors and the executive committee.

Ask your advisors or chapter officers any questions you may have regarding Point Awards.

\section{GET INVOLVED!}




\section{The FFA Emblem}

The cross section of the ear of corn: symbol of unity

The rising sun: symbol of a new day or era in agriculture

The plow: symbol of labor \& tillage of the soil

The eagle: symbol of our freedom

The owl: symbol of wisdom

The words "Agriculture Education" and "FFA" are in the center to signify the combination of learning and leadership necessary for progressive agriculture.

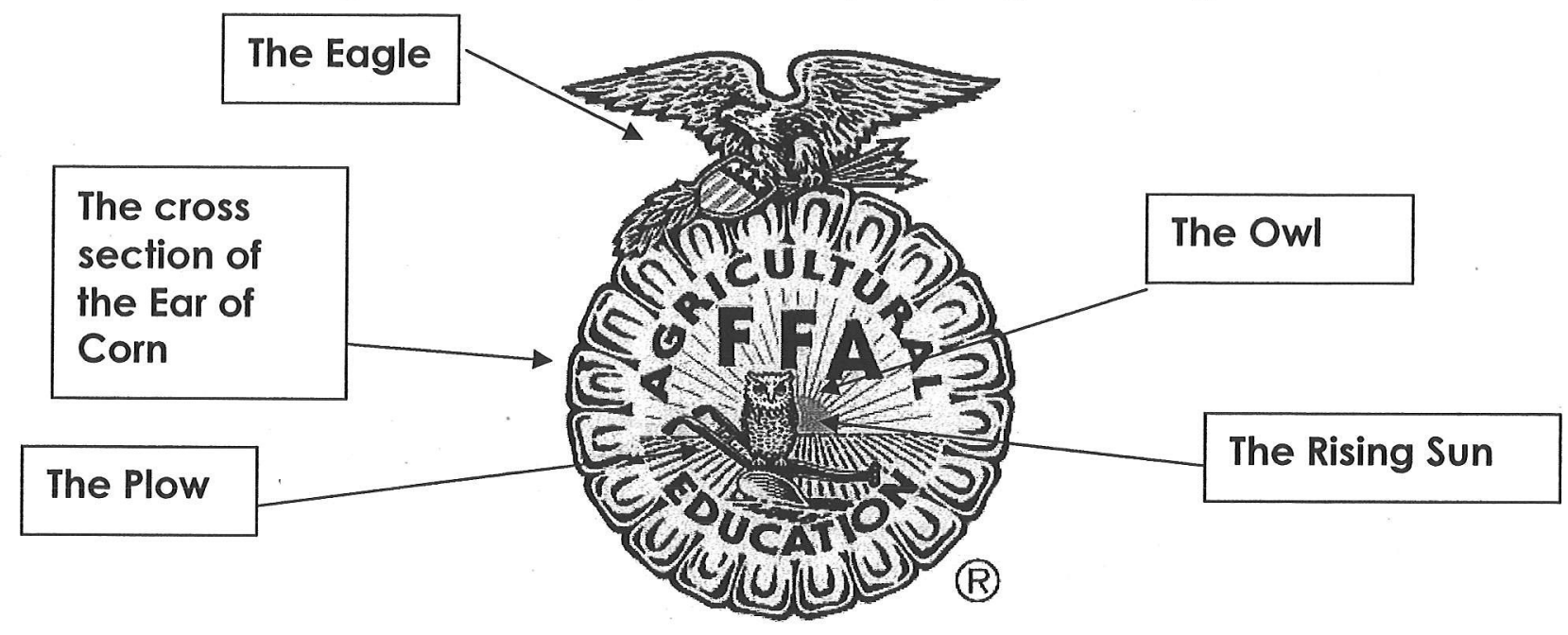

\section{FFA Code of Ethics}

We will conduct ourselves at all times in order to be a credit to our organization, chapter, school and community by:

1. Dressing neatly and appropriately for the occasion.

2. Showing respect for the rights of others and being courteous at all times.

3. Being honest and not taking unfair advantage of others.

4. Respecting the property of others.

5. Refraining from loud, boisterous talk, swearing and other unbecoming conduct.

6. Demonstrating sportsmanship in the show ring, judging contests and meetings.

7. Being modest in winning and generous in defeat.

8. Attending meetings promptly and respecting the opinion of others in discussion.

9. Taking pride in our organization, activities, supervised experience program, exhibits, and the occupation of agriculture.

10. Sharing with others experiences and knowledge gained by attending national and state meetings.

11. Striving to establish and enhance my skills through agricultural education in order to enter a successful career.

12. Appreciating and promoting diversity in our organization.

\section{The FFA Mission Statement}

FFA makes a positive difference in the lives of students by developing their potential for premier leadership, personal growth, and career success through agriculture education. 


\section{Graduate Certificate}

\section{Program Completer and Senior Awards}

1. Must have completed at least three years (or equivalent hours) of vocational agriculture classes.

2. FFA Involvement

\section{Graduation Rope}

1. Must have completed at least three years (or equivalent hours) of vocational agriculture classes.

2. FFA Involvement

3. One of the following criteria:

a. Participation on a Leadership Team (two years)

b. FFA Judging Team (two years)

c. FFA Officer Team

d. Regional Winner

Medallion and Rope

1. Complete 1,2, and 3 above

2. Mandatory State FFA Degree

\section{Agriculture Course Offerings}

Agricultural Earth Science

Agricultural Life Science

wullege Agricultural Biology

Agricultural Leadership

Animal Science

ROP Veterinary Skills

Forestry and Natural

Resources

Environmental Horticulture I

Environmental Horticulture II

Floriculture I

Floriculture II

Agricultural Mechanics I

Agriculłural Mechanics II

ROP Agricultural Equipment Operation,

Maintenance and Fabrication

\section{Grade}

9-11

9-11

9-12

10-12

11-12

11-12

10-12

10-12

11-12

10-12

11-12

9-12

10-12

11-12 


\section{Career Development Events \& Teams}

FFA judging and speaking contests are based on skills, knowledge, and leadership qualities that have been developed and perfected through practice after school and in the classroom. Some events are designed for one individual, while others require teams built of multiple participants from our chapter. These teams represent our chapter throughout California and the nation at organized events such as field days, judging contests, speaking contests, and sectional, regional, state and national contests. The following teams are offered to our FFA students.
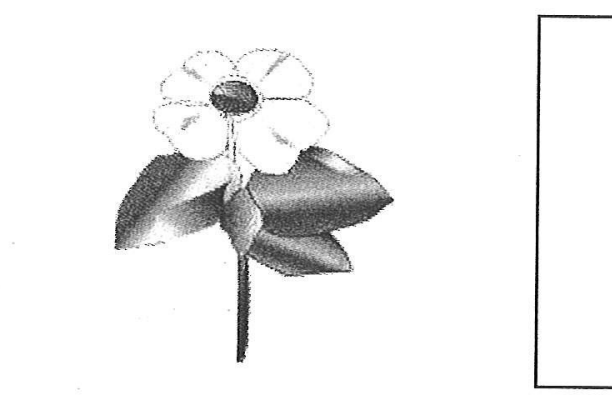

- Farm Power

- Livestock Judging

See Mr. Diaz!

- Forestry

- Opening/Closing

- FFA Creed Speaking (Freshman)

- Ornamental Horticulture/Nursery Landscape

- Floriculture

Mr. Knapp!

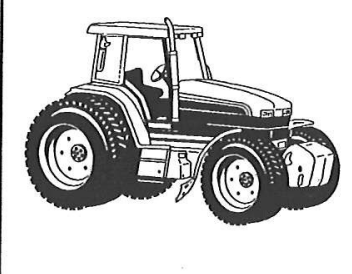

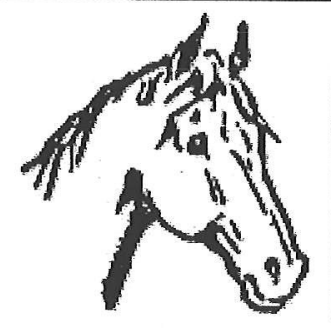

- Floriclture

- FFA Scrapbook

- Specialty Animal (enroll in ROP Vet Skills)

- Farm Records, Job Interview, Co-Op Quiz (enroll in Ag

- Leadership)
- Prepared Public Speaking

- Extemporaneous Public Speaking

See any Advisor!

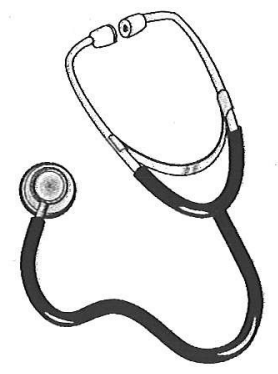

Mrs. Earley!

- Best Informed Greenhand

- Parliamentary Procedure

- Project Competition

- Novice and Advanced Opening and Closing Ceremonies Ms. Aldridge! 


\section{Supervised Agricultural Experience}

A SAE program is the actual, hands-on application of concepts and principles learned in the agricultural education classroom. Students are supervised by agricultural education teachers in cooperation with parents, employers and other adults who assist them in the development and achievement of their educational and career goals.

Supervised Agricultural Experiences are essential and a mandatory part of the FFA program. These experiences can be an ownership enterprise and/or placement enterprise. This means that the student can own a project or work at an agriculturally related work site, either paid or unpaid. This helps to teach the students responsibility, the benefit of hard work and good work ethics. Some these projects can take place at home, family place, or school.

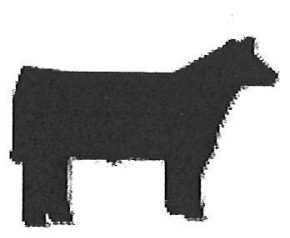

Two Basic SAE Types:

Ownership/Entrepreneurship

Plan and operate an agriculture-related business.

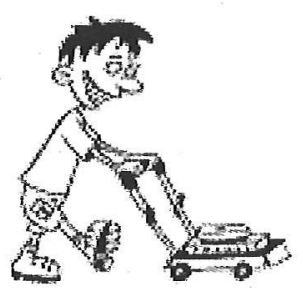

\section{Supervised Agricultural Experience (SAE) Quick Reference Listing}

Agriscience new and emerging technology

Emerging Agricultural Technology

Air conditioning installation or improvement

Ag Mechanics Energy Systems OR

Home and/or Community Development

Alfalfa Forage Production

Animal breeding services Agricultural Services

Animal hides processing/tanning Agricultural Processing

Animal hospitals Agricultural Services OR Small Animal

Production and Care Specialty Animal Production

Apples Fruit Production

Apricołs Fruit Production

Aquatic animal marketing (catfish; shrimp; crawfish; mollusks; salmon ranching; tropical fish rearing and tilapia culture) Aquaculture

Aquatic animal production (catfish; shrimp; crawfish; mollusks; salmon ranching; tropical fish rearing and tilapia culture)

Aquaculture

Aquatic plant marketing Aquaculture

Aquatic plant production Aquaculture

Barley Grain Production

1 I racing (Equine) Equine Science

Beuns (unless produced for Oil and not including Soybeans)

\author{
Vegetable Production Landscape Management OR \\ Home and/or Community Development \\ Bee production Specialty Animal Production \\ Beef marketing Beef Production \\ Beef production Beef Production \\ Berries Fruit Production \\ Biołechnology Emerging Agricultural Technology \\ Birdseed producing Specialty Crop Production \\ Building and structures improvements Agricultural \\ Mechanics Design and Fabrication \\ Calf roping Equine Science \\ Camping area Outdoor Recreation \\ Cedar shakes production or sales Forest Management \\ and Products \\ Chemical sales Agricultural Sales \\ Cherries Fruit Production \\ Chickens Poultry Production \\ Christmas tree farming Forest Management and Products \\ Citrus fruits Fruit Production \\ Commodities merchandising/sales Agricultural Sales \\ Common fruits Fruit Production \\ Communication Agricultural Communications \\ Community betterment or development Home and/or \\ Community Development \\ Composł processing Agricultural Processing
}


Computer new and emerging łechnology Emerging

Agricultural Technology

Confectionary sunflowers Specialty Crop Production

Conservation Environmental Science and Natural

Resources

Contract feeding Agricultural Services

Corn fro grain Grain Production

Crop merchandising/sales Agricultural Sales

Crop scouting Agricultural Services

Crop seed production Specialty Crop Production

Cusłom baling services Agricultural Services

Custom equipment operation and maintenance services

Agricultural Services

Dairy cattle production Dairy Production

Dairy products marketing Dairy Production

Dairy products production Dairy Production

Department of Natural Resources experience

Wildlife Production and Management

Domestic fowl production and marketing

Poultry Production

Donkeys Specialty Animal Production

Ducks Poultry Production

Ducks (wild) Wildlife Production and Management

Educating the public about the broad

Emus Specialty Animal Production

Environmental improvement Environmental Science and

Natural

Resources

Equine breeding Equine Science

Equine marketing Equine Science

Equine production Equine Science

Equine showing Equine Science

Equipment design and construction Agricultural

Mechanics Design and Fabrication

Equipment sales Agricultural Sales

Erosion prevention Environmental Science and Natural

Resources

Feed sales Agricultural Sales

Fertilizer sales Agricultural Sales

Fiber and/or oil crop marketing Fiber and/or Oil Crop

Production

Fiber and/or oil crop production Fiber and/or Oil Crop

Production

Firewood production or sales Forest Management and

Products

Fish and Wildlife Department experience Wildlife

Production and Management

Fish by-product processing Agricultural Processing

Fish stocking (income enterprise) Wildlife Production and

Management

Flower arranging Floriculture

Flower packaging Floriculture

Flowers (dried) production or marketing Floriculture

Flowers (iresh) production or marketing Floriculture

Fuliage production or marketing Floriculture

Food biochemistry Food Science and Technology

Food grading Food Science and Technology

Food inspection Food Science and Technology

Food processing Agricultural Processing

Food safety experiences and research Food Science and

Technology

Forage crops production or marketing Forage Production
Forest service employment Forest Management and Products

Forestry items for refail or whole sales Agricultural Sales Fruit crop production or marketing Fruit Production Garden production of canning vegetables Vegetable Production

Garden vegetables Vegetable Production

Geese (domestic) Poultry Production

Geese (wild) Wildlife Production and Management

Global positioning systems Emerging Agricultural

Technology

Goats (meat and dairy) Specialty Animal Production

Gourds Specialty Crop Production

Grain crops Grain Production

Grain forages Forage Production

Grapes Fruit Production

Grassland preservation Environmental Science and

Natural Resources

Greenhouse flowers production or marketing Floriculture

Grooming dogs Small Animal Production and Care

Guide services Outdoor Recreation

Guinea fowl Poultry Production

Guinea pigs Small Animal Production and Care

Hamsters Small Animal Production and Care

Heating Agricultural Mechanics Design and Fabrication

Heating installation or improvement Home and/or

Community Development

Herb processing Agricultural Processing

Herb production Specialty Crop Production

Herbs Specialty Crop Production

Historic area development and mánagement Outdoor

Recreation

Home modernization for better health and comfort

Home and/or Community Development

Honey processing (and beeswax processing) Agricultural

Processing

Horse production and management Equine Science

Horses (miniałure) Specialty Animal Production

Horseshoeing services (farrier services) Agricultural

Services

Horticulture items for retail or wholesale sales

Hunting recreation Outdoor Recreation

Improving recreational areas Turf Grass Management

Improving water quality in home Home and/or

Community Development

Insect and disease control, planting and harvesting

Forest Management and Products

Installing water in home Home and/or Community

Development

Kennel employment Small Animal Production and Care

Lab research Emerging Agricultural Technology

Labor saving devices in home Home and/or Community

Development

Land use regulations (pertaining to soil, water and air quality)

Environmental Science and Natural Resources

Landscaping Landscape Management

Lawn mowing service Turf Grass Management

Livesłock merchandising/sales Agricultural Sales

Livestock production and management of two or more

livestock related proficiency areas such as beef, dairy,

swine, equine, poultry, small animal production and care 
and specialty animal production Diversified Livestock Production

Llamas Specialty Animal Production

Magazine articles and publication Agricultural mmunications

managing golf course Turf Grass Management

Meat by-product processing Agricultural Processing

Meat processing Agricultural Processing

Meat rabbits Specialty Animal Production

Mentoring (youth) Agricultural Education

Mice Small Animal Production and Care

Microbiology Food Science and Technology

Miniature horses Specialty Animal Production

Mint production or marketing Fiber and/or Oil Crop

Production

Mulch production or sales Forest Management and

Products

Mules Specialty Animal Production

Mustard production or marketing Fiber and/or Oil Crop

Production

Natural resources improvement Environmental Science

and Natural Resources

Natural scenic area Outdoor Recreation

Nectarines Fruit Production

Nuts Fruit Production

Oats Grain Production

Onions Vegetable Production

Orchard grass Forage Production

Ornamental flowers Floriculture

Ostriches Specialty Animal Production

Outdoor beautification Landscape Management

n. itdoor recreational activities Outdoor Recreation

3 mentor Agricultural Education

Peaches Fruit Production

Peanuts production or marketing Fiber and/or Oil Crop

Production

Pears Fruit Production

Pet shop employment Small Animal Production and Care

Pet sitting Small Animal Production and Care

Pheasants (income enterprise) Wildlife Production and

Management

Plant materials production or marketing Floriculture

Diversified Horticulture Production

Plant production in nursery Nursery Operations

Plant propagation Nursery Operations

Plants or shrubs installation and maintenance Landscape

Management

Plumbing Agricultural Mechanics Design and Fabrication

Plums Fruit Production

Pollution management and control Environmental

Science and Natural Resources

Popcorn Specialty Crop Production

Potatoes Vegetable Production

Power Systems adjusting, repairing and maintaining.

Including those that run by way of mechanical, electrical,

chemical, wind, solar, fluid and/or water power.

Agricultural Mechanics Energy Systems

Print Focilities Agricultural Communications

Produce and market one livestock and at least one crop

rf' 'ed proficiency areas Diversified Agricultural

$f$ uction

Produce and market two or more crop related

proficiency areas.
Diversified Crop Production

Propagation of plants Nursery Operations

Propagation of plants Nursery Operations

Pruning forests Forest Management and Products

Pumpkins Vegetable Production

Quail (wild/restocking/management) Wildlife Production

and Management

Rabbits as companion animals Small Animal Production and Care

Rabbits for meat production Specialty Animal Production

Racing (equine) Equine Science

Radio and broadcasting Agricultural Communications

Raisins and other dried fruits processing Agricultural

Processing

Recreational area improvement Landscape

Management

Recreational area improvement Turf Grass Management

Recycling Environmental Science and Natural Resources

Reforestation Forest Management and Products

Rice Grain Production

Riding lessons (equine) Equine Science

Riding stables Outdoor Recreation

Rodeo (ownership and management of horses)

Equine Science

Rodeo event (where member does not own or manage horses)

Outdoor Recreation

Sanitary facility improvement Home and/or Community

Development

Sanitary facility installation Home and/or Community

Development

Seed (grass) Specialty Crop Production

Seed sales Agricultural Sales

Sheep production and marketing Sheep Production

Shooting preserve Outdoor Recreation

Shoreline preservation Environmental Science and

Natural

Shrubs in nursery Nursery Operations

Shrubs or plants installation and maintenance

Landscape Management

Sisal production or marketing Fiber and/or Oil Crop

Production

Small pet animals (manage, produce, care for and/or market)

Small Animal Production and Care

Sod sales Turf Grass Management

Soybeans production or marketing Fiber and/or Oil Crop

Production

Specialty animal facility employment Specialty Animal

Production

Sprinkler installation (lawn and garden) Landscape

Management

Stocking fish (game fish) Wildlife Production and

Management

Stone fruit Fruit Production

Structural land improvements Agricultural Mechanics

Design and

Fabrication

Sunfilower production or markefing Fiber and/or Oil Crop

Production

Sunflowers (confectionary) Specialty Crop Production

Sweet Corn Vegetable Production. 


\section{$2011-2012$ Fair Rules}

FFA members should read and understand the following information before purchasing an animal to show at the fair.

In order to exhibit an animal at the fair with the Las Plumas FFA Chapter the student must:

1) Maintain a $\mathrm{C}$ or better in their agriculture classes.

2) Maintain a 2.0 GPA (for Silver Dollar Fair $1^{\text {st }}$ Semester GPA) (for Butte County Fair 3rd quarter GPA)

3) Participate in at least 2 of the following FFA Fundraisers

a. Sell 5 tickets for the steak and crab feed

b. Work at the Steak and Crab Feed

c. Collect raffle items (total value equaling \$100.00)

4) Work on at least 4 hours of Ag Department/FFA improvement activities (Farm clean up/improvement)

5) Purchase insurance through the FFA on your Market animal

6) Purchase your own Jacket and Tie prior to April 1, 2012.

7) Only stay the night at the fair with a pre-approved chaperone-you must have a form on file with the fair. Ag Advisors are not present at the fair 24 hours a day.

8) Turn in record books prior to exhibiting at the fair and update them the week following the fair.

9) Attend at least 3 showmanship practices and the final drive showmanship, as well as enter showmanship with their animal at the fair.

10) Follow school rules while exhibiting at the fair and while on campus.

11) Follow the FFA Code of Ethics. If suspended from school advisor's reserve the right to terminate fair project (not allow student to show at the fair) on an individual basis.

12) Use the guidance given from the instructor on the purchase of the animal as well as the care of the animal.

13) Attend at least 5 FFA meetings/banquets (3 must be in the Fall [Sept-Dec]).

14) If you are a Junior or a Senior with LP FFA, you must be taking Animal Science or completed Animal Science at the time of the fair. Advisor may make exceptions.

15) If you received a loan to purchase your animal you must show Ms. Aldridge or Mrs. Earley a receipt showing that the loan has been paid off before the purchase of your next market animal.

16) If you are taking your $3^{\text {rd }}$ animal or more with LP FFA you must make the showmanship cut to show at Butte County Fair. Unless it's your year-out.

17) There will be no changing of species for Butte County Fair unless you have advisor approval. 


\section{Market Hog Project Budget}

ost of hog

Feed

Show supplies (shavings included)

Insurance/Entry Fee

Total Estimated expenses

Estimated Receipts

Sale of hog $(230 \mathrm{lbs} @ \$ 2.75 / \mathrm{lbs})=\$ 632.50$

Total Estimated Receipts

Total Estimated Expenses

Estimated Net Profit

$\$ 632.50$

$\$ 510.00$

$\$ 122.50$
Estimated Expenses

$\$ 250$

$\$ 213$

$\$ 20$

$\$ 27$

$\$ 510$

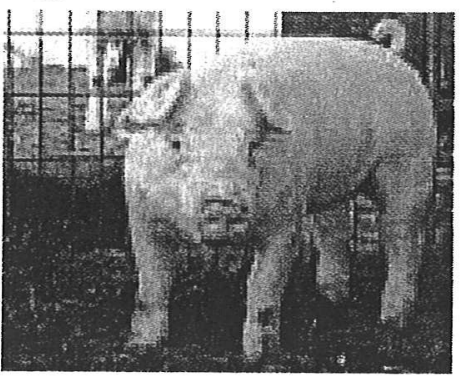

TIMELINE

SDF HOGS PURCHASED AROUND END OF JAN. BCF HOGS PURCHASED AROUND END OF MAY.

* Some materials may only need to be purchased once!

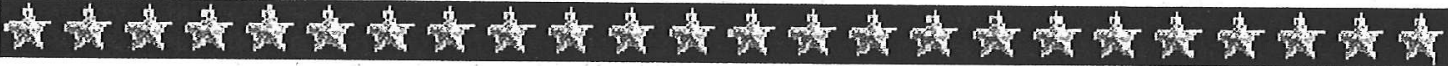

\section{Market Steer Project Budget}

Estimated Expenses

Cost of steer

Feed (grain \& hay)

Show Supplies

Insurance and entry

Total Estimated expenses

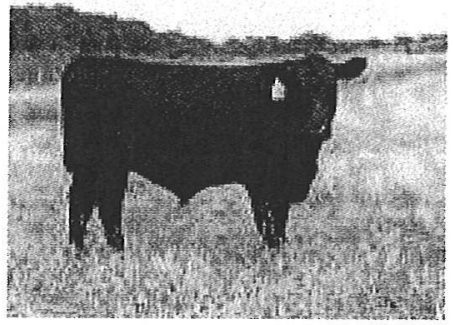

Sale of Steer (1 $125 \mathrm{lbs}$. @ 2.00/lb) = \$2,250.00

Total Estimated Receipts

Total Estimated Expenses

$\$ 2,250.00$

Estimated Net Profit

TIMELINE

*BOTH SILVER DOLLAR \& BUTTE COUNTY FAIR STEERS ARE PURCHASED IN OCTOBER!

\footnotetext{
* Some materials may only need to be purchased unce!
} 


\section{Markeł Lamb Projecł Budge†}

\section{Estimated Expenses}

Cost of lamb

Feed (grain and hay)

$\$ 300$

Show supplies

$\$ 175$

Insurance/Entry

Shavings

Estimated cost

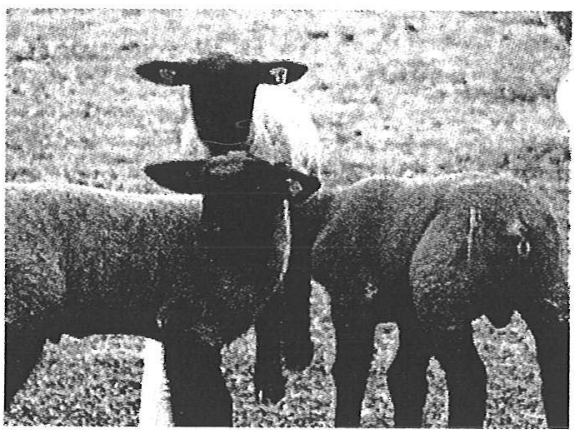

Estimated Receipts

Sale of sheep (135lbs@ \$4.50/lbs) =

$\$ 607.50$

Receipts

Expenses

$\$ 607.50$

$\$ 554.00$

Total estimated income

$\$ 53.50$

TIMELINE

*SDF LAMBS

PURCHASED BEG OF

FEB.

*BCF LAMBS

PURCHASED END OF

MAY.

* Some materials may only need to be purchased once!

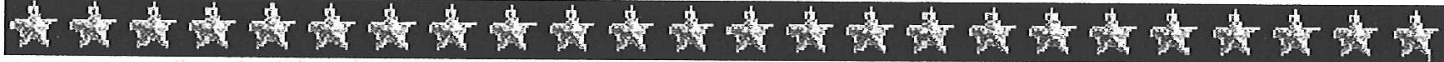 Market Goat Project Budget}

Estimated Expenses

Cost of Goat

Feed (grain and hay)

Show supplies

Insurance and Entry Fee

Total estimated cost
$\$ 250$

$\$ 40$

$\$ 20$

$\$ 20$

$\$ 330$

Estimated Receipts

Sale of goat (100lbs @ \$4.00/lbs) $=$

$$
\begin{array}{r}
\$ 400 \\
\\
\$ 400 \\
-\$ 330 \\
\hline \$ 70
\end{array}
$$

Expenses

Estimated Net Profit

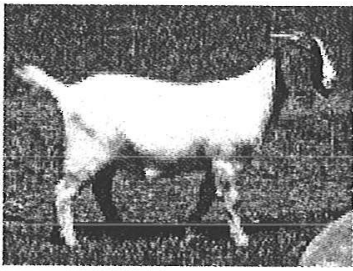

TIMELINE

* SDF Goats will be purchased first of Feb

*BCF Goats will be purchased at the end of May.

Some materials may only need to be purchased once! 


\section{Las Plumas High School FFA Chapter Constitution}

\section{Article 1: Name and Purpose}

Section A: The name and purpose of the organization shall be "The Las Plumas Chapter of the Future Farmers of America". This is chapter number 306 of the California Association of the Future Farmers of America.

Section B: The purpose for which this organization is formed is as follows:

1. To develop competent, aggressive urban and rural leadership.

2. To strengthen the confidence of the agriculture person in themselves and his/her work.

3. To create more interest in the choice of farming occupations as an intelligent alternative.

4. To encourage cooperative efforts aiming students of the vocational agriculture.

5. To promote thrift among the students of the vocational education in agriculture.

6. To promote and improve scholarships.

7. To encourage organized activities among students and vocational agriculture.

8. To supplement the regular systematic instruction offered to students of the vocational education in agriculture.

9. To advance the cause of vocational education in the agriculture in public schools in California.

10.To encourage members in the development of individual farming programs and establishments in farming.

\section{Article 2: Organization}

Section A: The Las Plumas of the FFA is a local chartered unit of the California Association of the FFA, which is chartered by the National Association of the FFA.

Section B: This chapter accepts in full the qualifications of the Constitution and Bylaws of the California Association FFA as well as those of the National FFA.

\section{Article 3: Membership}


Section A: Membership in this organization shall be active, associative, and honorary.

Section B: Qualifications for membership is outlined in the Constitution of the California Association of the FFA.

Section C: The regular work of this chapter shall be carried on by active membership.

Section D: Active members in good standing may vote on all business brought before the chapter.*

*Active members are in good standing when:

1. He/she attends local chapter meeting with responsible regularity.

2. He/she shown interest and takes part in affairs of the chapter.

3. $\mathrm{He} / \mathrm{she}$ is enrolled in an agricultural class.

\section{Article 4 : Membership Levels and Privileges}

Section A: There are five levels of membership based upon achievement. These levels are:

1. Member

2. Greenhand

3. Chapter FFA Degree

4. State FFA Degree

5. American FFA Degree

Section B: Qualification for election to the Greenhand Degree and the Chapter Farmer Degree are outlined in the Constitution of the California Association of the Future Farmers of America.

\section{Article 5: Officers}

Section A: The officers of the chapter shall be:

President, Vice President, Secretary, Treasurer, Reporter, Sentinel, and Historian.

Section B: The advisor shall be a teacher of vocational agriculture at Las Plumas High School.

Section C: All officers shall be elected as per the bylaws once yearly in the spring. They shall begin their duties upon the closure of the last meeting of the year in which they are elected.

Section D: The officers of the chapter, together with the chairpersons of the major sections of the annual program of work committee, shall constitute the chapter executive committee. The executive committee shall have full power to act as necessary for the chapter 
in accordance with the action taken at chapter meetings and various regulations and bylaws from time to time.

Section E: Honorary and associate members shall not vote, nor shall they hold an office in the chapter except that of advisor.

Section F: Chapter officers must:

- hold the Chapter FFA Degree for at least one year or receive the degree during officer year.

- have a 2.0 cumulative GPA

- maintain at least a C average and have no F's

- requirements may be waived with advisor's approval if there are not enough qualified candidates

\section{Article 6: Meetings}

Section A: Regular meetings shall be held once a month during the school year and at least one executive meeting shall be held during the summer. Special meetings shall be called at any time.

Section B: Two delegates may be elected from the membership to represent the chapter at the regional meeting and the State FFA conference. Teacher committee may also select the representatives.

Section C: A majority of the active member listed on the membership role shall constitute a quorum. A quorum must be present at any meeting at which business is transacted or a vote is taken committing the

\section{Article 7 : Dues} chapter to any proposal or action.

Section A: Local dues shall be fixed annually by majority vote of the active members.

Section B: Full local, state and national dues shall be paid by the agricultural department of the Las Plumas FFA. No dues shall be collected from associate members and honorary members.

\section{Article 8: Insignia and Uniform}

Section A: The insignia and the uniform of the FFA shall be the insignia and uniform of the chapter.

Section B: Insignia and uniform used by the members shall be those obtained from authorized officials designated by the national organization of the FFA.

\section{Article 9: Procedures}

Section A: Parliamentary procedure shall be used in all meetings of this organization in accordance with Robert's Rule of Order. 


\section{Article 10: Amendments}

Section A: This constitution may be amended or revised at anytime upon approval of the chapter, provided the amendment(s) does not conflict and is in accordance with the National Organization.

Section B: Bylaws may be adopted to fit the needs of the chapter upon the approval of the chapter, provided it is not conflicting and is still in accordance with the State Association and the National Organization.

\section{Las Plumas Chapter Bylaws}

Article 1 General Statement:

The bylaws stated should be considered as a part of the Las Plumas FFA Chapter Constitution. It takes two meetings to amend these bylaws. Changes are presented at the first meeting, and a vote on the changes takes place at the second meeting. To make the changes legal, there must be a quorum of $15 \%$ of the chapter members.

\section{Article 2 Officers:}

Section A: Election of Officers

To become an officer of the Las Plumas FFA Chapter, the following steps must be completed:

1. The member running must complete and return a Chapter Officer Application to the Advisor in charge.

2. The member must pass a qualification screening.

3. Advisors will screen and select the officers to their appointed positions.

Section B: Removal of Officers:

1. Reasons for removal are as follows: grades as stated in the Chapter Constitution

(Article5, Section F), use of alcohol or illegal drugs at public or school functions while wearing a FFA jacket, lack of performing duties i.e. not attending several meetings.

2. Steps for removal are verbal warning, a written notice, and then a conference. After the conference, if a student violates expectations again he/she shall be permanently removed from the office.

3. An officer may be removed at any grade period in which they do not meet the minimum required grades for holding an office, without warning. 
Section C: Replacement of Officers

To replace an officer:

1. A candidate must fill out an application.

2. Advisors will fill the position.

Section D: Officer Duties

Listed below are the duties of chapter officers. The duties may be exchanged or shared between officers with Advisor's approval. Additional officer positions may be appointed by the Advisor each year as needed i.e. Historian.

President

a. Presides over meetings and maintains order.

b. Prepares meeting agendas for both executive and general meetings.

c. Appoints committees when needed.

d. Represents the chapter at all local functions in addition to section, regional, state, and national functions as well as special meetings such as executive and committee meetings.

e. Alternate ASB Representative.

f. Provides a year-end report to the advisor of all activities completed throughout the year.

g. Works closely with the Advisor(s) to ensure success within the chapter.

h. In the event that a chapter officer is unable to perform his/her duties, the President will fulfill the obligations of particular officer(s) as needed.

\section{Vice President}

a. Presides over meetings in the President's absence.

b. Coordinates all aspects of the Chapter FFA Point Award System including, but not limited to creating monthly point sheets, tallying, entering data on the computer, ordering and distributing awards.

c. Responsible for maintaining the Chapter Calendar.

d. Coordinates Winter Degree Banquet

e. Actively encourages all chapter FFA members to maintain and keep accurate records of their SAE project.

f. Works closely with the reporter to ensure the bulletin board material is

\section{Secretary} accurate, informative, and posted in a timely manner.

a. Prepares and posts an agenda at least two days prior to each meeting.

b. Takes accurate minutes at all meetings.

c. Posts accurate minutes of all meetings on chapter bulletin boards no later than two days after each meeting.

d. Tends to all official chapter correspondence.

e. Fills out and distributes annual FFA membership cards.

f. Maintains and cleans the chapter files. 


\section{Treasurer}

g. Keeps a list of all awards and degrees issued during the year.

a. Prepares a budget for the coming year, and requests membership approval at the first FFA meeting of the year.

b. Keeps an accurate account on the computer of money flowing inand-out of the chapter accounts.

c. Prepares and reads a financial standing report at each general meeting.

d. Presents budget requests at ASB meetings.

e. Acts as the liaison between our FFA chapter and ASB regarding the financial status of our chapter.

f. Prepares requisitions for all purchases made by our chapter.

g. Prepares and submits to advisor a detailed report at end of May which accurately describes accounts receivable and accounts payable and correlates this information with the current budget.

\section{Reporter}

b. Responsible for all publicity for the chapter including but not limited to placing articles and photos in the school newspaper, local paper(s), state and National FFA publications, as well as overseeing the making of posters to post on campus, announcing various FFA events, radio announcements, bulletin announcements, etc.

c. Informs all the members of all the activities and functions. I.e. newsletters and bulletins.

d. Works closely with the Vice President(s) to ensure the bulletin board material is accurate, informative, and posted in a timely manner.

e. If the chapter does not slate or elect a Historian, or if the Historian resigns or is removed from office, the Reporter will take pictures and/or make sure that photos are taken at all (or as many as possible) FFA functions.

f. In the event the chapter does not have a Historian, the Reporter is responsible for compiling the scrapbook as well as entering it in the Regional competition.

g. Works closely with the Chapter Advisor to make sure pictures are printed in a timely manner.

h. As needed, attend staff meetings, board meetings, advisory meetings, Ag Booster meetings, etc.

\section{Sentinel}

a. Organizes refreshments (if needed) and prepares the meeting room for all meetings executives, general and specific.

b. Attends the meeting room door and welcomes all members and guests.

c. Responsible for having a roll sheet to keep accurate account of all students attending general meetings and banquets. A copy of the roll 
sheets should be given to each ag teacher within 24 hours of the meeting.

d. Assists the President in maintaining order in the meting room.

e. Organizes and prepares all equipment and supplies needed for FFA events. i.e. FFA Week obstacle course, bleachers for meetings in the barn, reserving the ASB sound system, etc.

f. Works closely with the Chapter Advisor to inventory supplies.

g. Responsible for maintaining cleanliness and order in the FFA storage area.

\section{Historian}

a. Works closely with the Chapter Reporter to take pictures of all chapter activities.

b. Compiles the chapter scrapbook.

c. Assumes duties $d, f, e$, and $g$ of the Reporter.

d. If available, the Historian will tape chapter activities with the video camera.

e. Assumes the duties of any officer who is removed from office.

\section{Article 3 Chapter Delegates:}

1. Chapter officers are the representatives of the chapter and shall have priority as chapter delegates.

2. If necessary, chapter delegates shall be done by an application and screening process.

3. All delegates will be in good standing in order to be representatives of the chapter.

\section{Article 4 Money:}

\section{Section A: Budget}

1. The budget will be presented and approved at the first general meeting of the Las Plumas FFA Chapter. Once approved, all expenses related to the budget may be made by the officer team.

2. Any new expenditures not in the budget should be brought forward to the chapter

membership and approved by the Advisor and Chapter Treasurer.

\section{Section B: Spending}

1. Any expenditure of chapter funds must be approved by the membership and requires the Chapter Treasurer and Advisor to sign the requests.

2. Emergency spending may take place to finish a chapter activity with the Advisor's approval.

\section{Article 5 Fairs:}




\section{Section A: Rules for Participation}

There are many rules relating to the fair (see Fair Rules). The basic rule is: in order to be at the fair during class time, a student must verify a 2.0 GPA in all classes. Students not meeting this requirement must attend classes. Special arrangements must be made to be at the fair on show day. Additional rules, entry forms, and additional information may be acquired by request from the Advisor.

\section{Article 6 Awards:}

\section{Section A: Point Awards}

1. A point award system shall be revised and/or updated before the school year

begins and will be followed throughout the school year. For each activity or function attended, a certain amount of points will be awarded which will be recorded by the Vice President. If there is a chairman for the activity, he/she shall report to the Vice President all members who participate in the activity.

2. Awards will be given as determined by the current officer team and advisors.

3. At the end of each school year, there will be some type of activity to honor the top

point award members. The current officer team will decide the activity.

\section{Section B: Scholarship}

The FFA has a scholarship fund through the Oroville Union High School District. There will be a committee made up of teachers only. The minimum qualifications to earn a scholarship are:

1. Must be an active member in the Las Plumas FFA Chapter for three years or equivalent

of three (3) Ag courses.

2. Must be a member in good standing.

3. Must fill out an application.

\section{Section C: Other Awards}

Other awards, such as Star Greenhand, Star Chapter FFA Degree and Honorary Chapter Degree shall be presented each year. 


\section{FFA Budget 2011-2012}

Expenditures

Leadership

State FFA Leadership Conference

-Registration

FFA Officer Retreats \& Polo Shirts

-Summer Officer Retreat

-COLC

- Officer Shirts \& Jackets

Greenhand Workshop \& Conference

Leadership Conference

Promotional Expenditures

- MFE/ALA

Career Development Activities (Field Days and Contests)

State Degree Dinner

American Degree Recipients

\section{Banquets}

$\$ 5,100$

Winter Degree (pins, etc)

Spring Awards

Senior Awards

-Ropes \& Medallions

- Scholarships

Activities/Fundraisers

$\$ 1750$

FFA Meeting Activities

Point Award Trip

FFA Week

Mailing Charges

Supplies

$\$ 600$

Officer Supplies

Committee Supplies

Scrapbook

ASB Fee

$\$ 10$

Total Expenses

$\$ 13,375$

Income

Annual Leadership/Scholarship Dinner

$\$ 7,000$

Drive Thru BBQ

$\$ 2,875$

FFA Savings (If needed)

$\$ 3,500$

Total Expected Income

$\$ 13,375$

Estimated Profit or Loss

$\$ 0$ 


\section{Greenhand FFA Degree Requirements Checklist}

Name

To be eligible to receive the Greenhand FFA Degree from this chapter, a member must meet the following minimum qualifications:

1.Be regularly enrolled in an agriculture education.

2. Have a satisfactory plan for a Supervised Agricultural Experience Program.

3.Learn and explain the FFA Creed.

4.Learn and explain the FFA Motto.

5.Learn and eplain the FFA Salute.

6. Learn and explain the FFA Mission Statement.

7.Describe the FFA emblem.

8.Describe the FFA colors.

9.Describe the FFA symbols.

10.Explain the proper use of the FFA jacket.

11. Have satisfactory knowledge of the history of the organization.

12.Know the duties and responsibilities of FFA members.

13.Personally own or have access to an Official FFA Manual.

14.Submit a written application for the Greenhand FFA Degree.

Applicant Signature

Agriculture Teacher's Signature

Date Completed 


\section{Quallity Criteria Three: \\ Practical Application of Occupational Skills}

Practical application of occupational skills is accomplished through classroom simulation of work-site experiences, community-based learning or entrepreneurship. These practical experiences are combined, coordinated, and evaluated with the classroom instruction.

The students at LPHS have many opportunities to participate in a wide variety of Supervised Agricultural Experiences, both on and off campus. On campus projects include but are not limited to: Market animals (beef, sheep, swine, goats, poultry and rabbits), shop/mechanical maintenance and greenhouse/plant SAE's. Currently our students attend two fairs one at the end of May, Silver Dollar Fair and one at the end of August, Butte County Fair. We currently have 22 students exhibiting market lambs, 18 students exhibiting market hogs, 8 students exhibiting market steers, 5 students exhibiting goat projects, and two students plan on taking meat pen of rabbits to the Silver Dollar Fair in May. We also have several students with breeding projects. Numerous students have placement/work experience projects.

We currently offer two ROP classes, ROP Agriculture Equipment Operation \& Maintenance and ROP Vet Skills class. These classes have a job placement component, where students are typically continue to work long after school hours and on weekends to incorporate classroom instruction with the SAE component. Project visits are performed by all instructors on a regular basis. Two teachers out of four including myself have a project period that is essential to monitoring our student's progress towards their SAE goals. We meet with each of our students at least twice a year, usually numerous times throughout the school year and summer months to make sure they are gaining knowledge and skills at their placement, or through their projects.

The agriculture department currently has two vehicles; an older suburban for local detail and a newer truck for department needs, project visits, fairs and leadership activities travel. We also have a newer gooseneck livestock trailer. There are also numerous district suburbans and buses to be utilized as needed for agriculture related activities and trips.

\section{Evidence Documents Include:}

- SAE Project Visit Form \& Completed Project Visit Forms (10)

- ROP Placement Site Visitation Log

- ROP Student Individualized Training Plan

- Community Classroom Placement Agreement

- Evidence of Department Vehicles for SAE Visits 


\section{Las Plumas High School Agricultural Department 538-2344 \\ RECORD OF SUPERVISED AGRICULTURE EXPERIENCE}

Name of Student:

Project:

Conditions Found at Time of Visit:

1. GENERAL CONDITION OF PROJECT: 

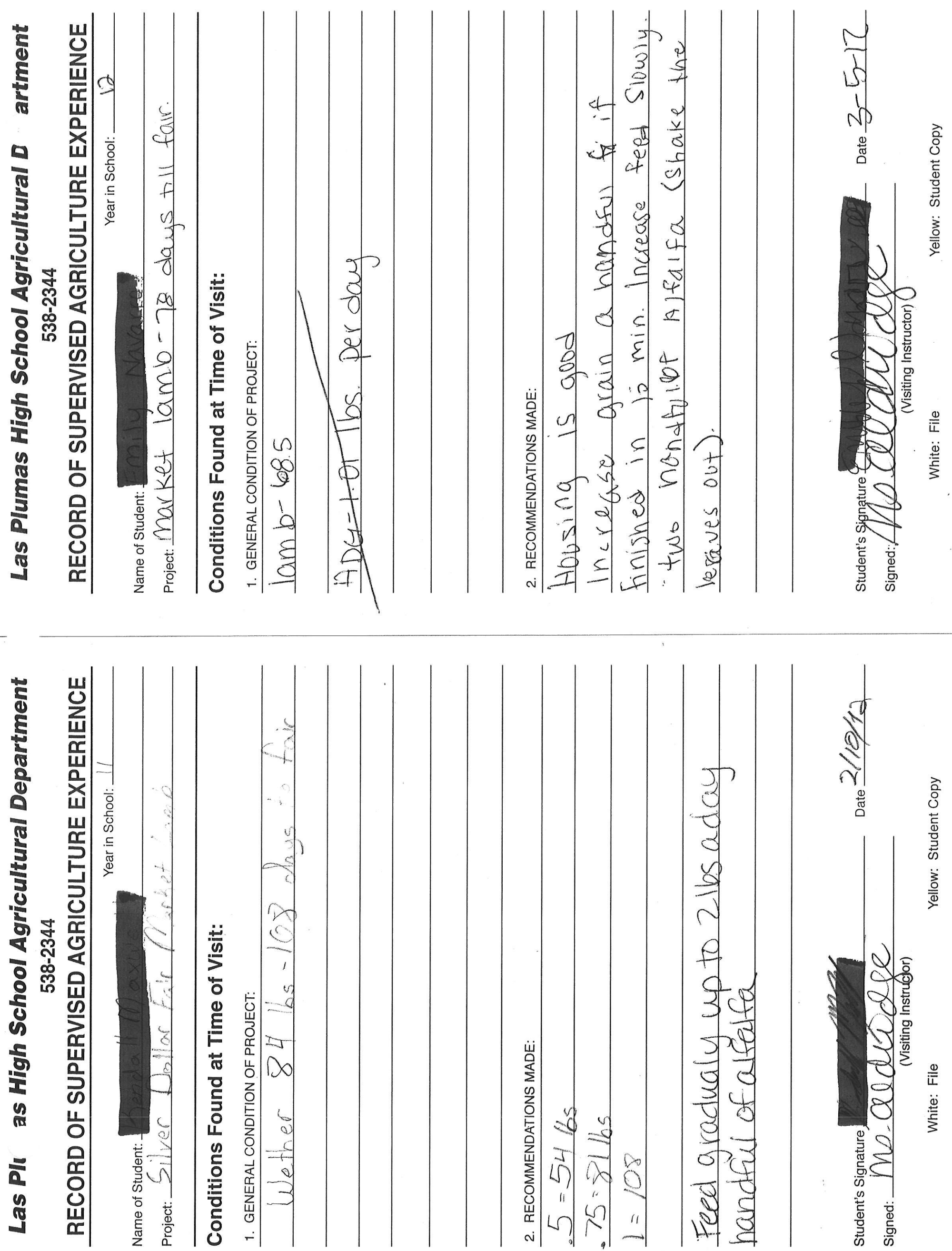

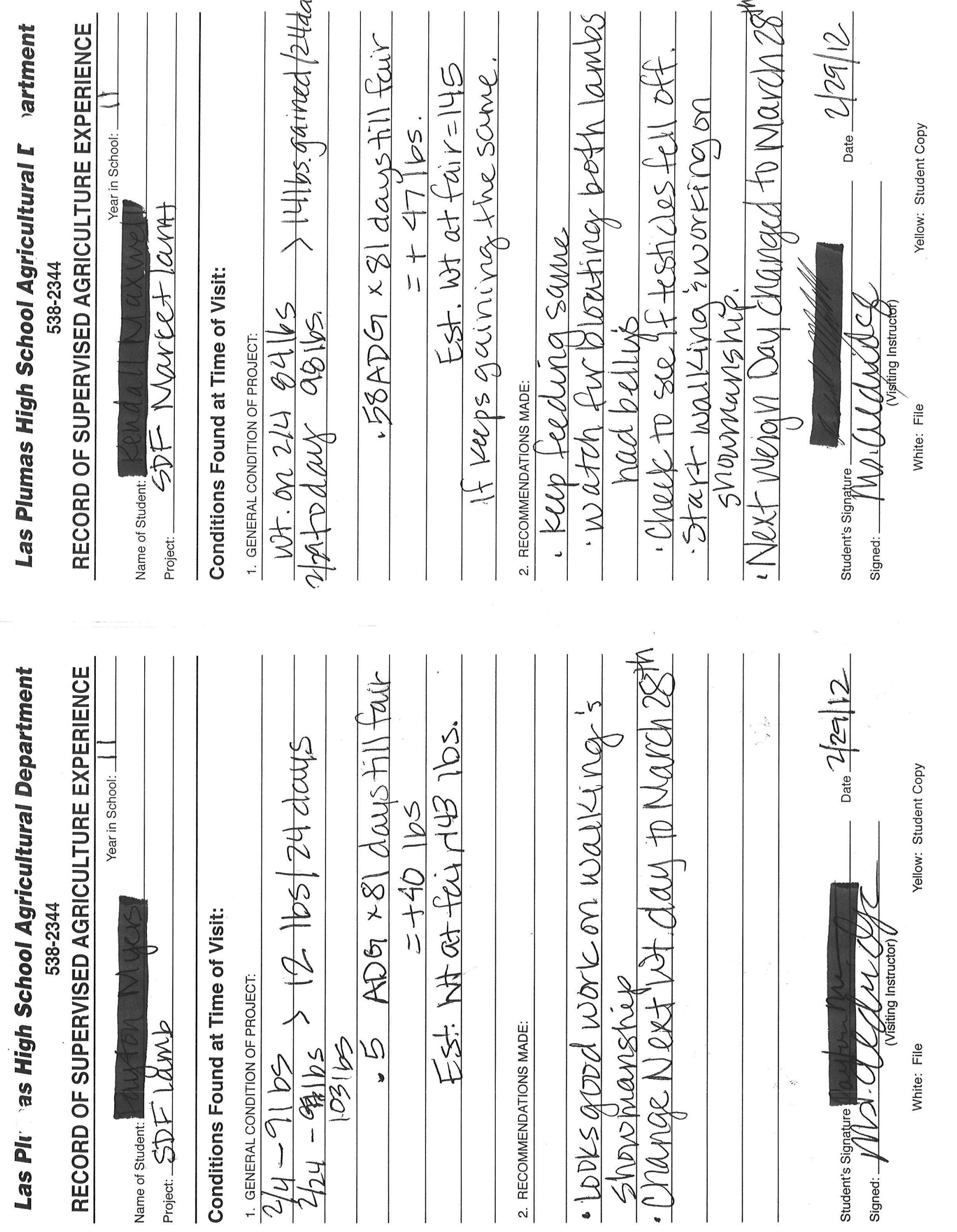
离

- 㓯

똔

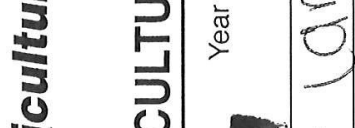

产券类

ㅇํㅇ

仓

호 엻

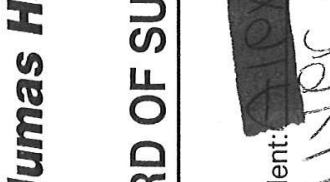

흠

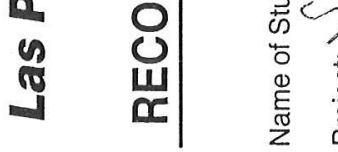

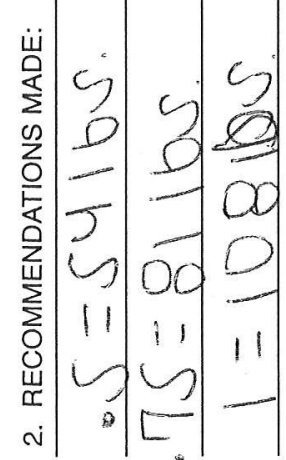

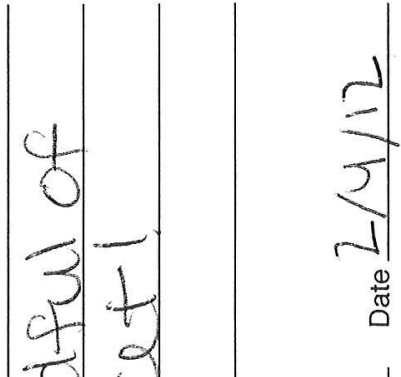
वे
0
0
$\frac{0}{0}$
$\frac{0}{0}$
0
$\dddot{3}$
$\frac{0}{\overline{0}}$

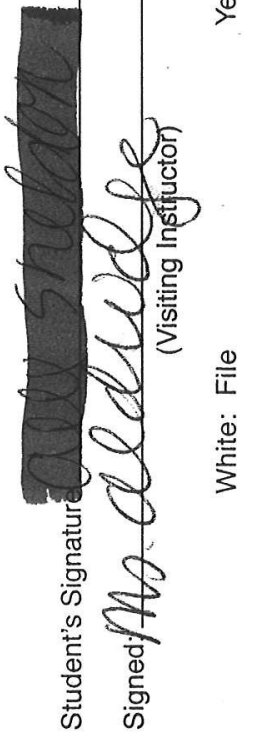

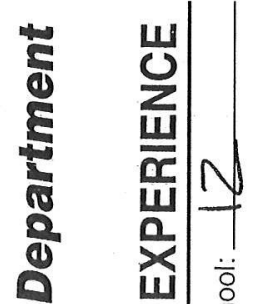

(1) ш

눈

인

言害产

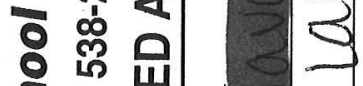

政

(x)

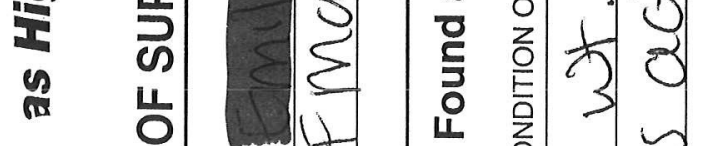

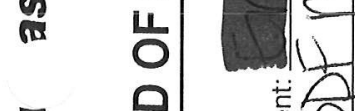

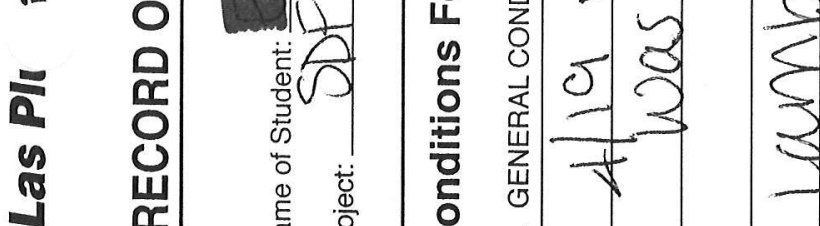

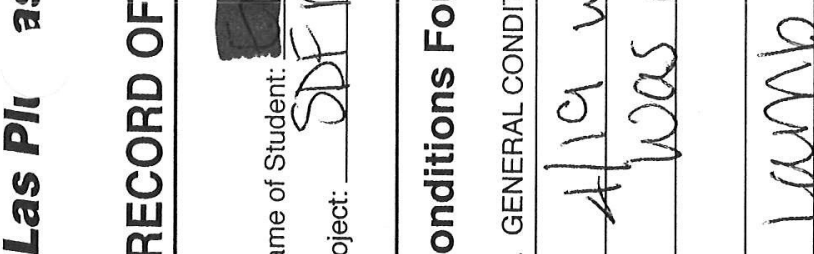

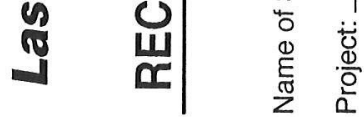




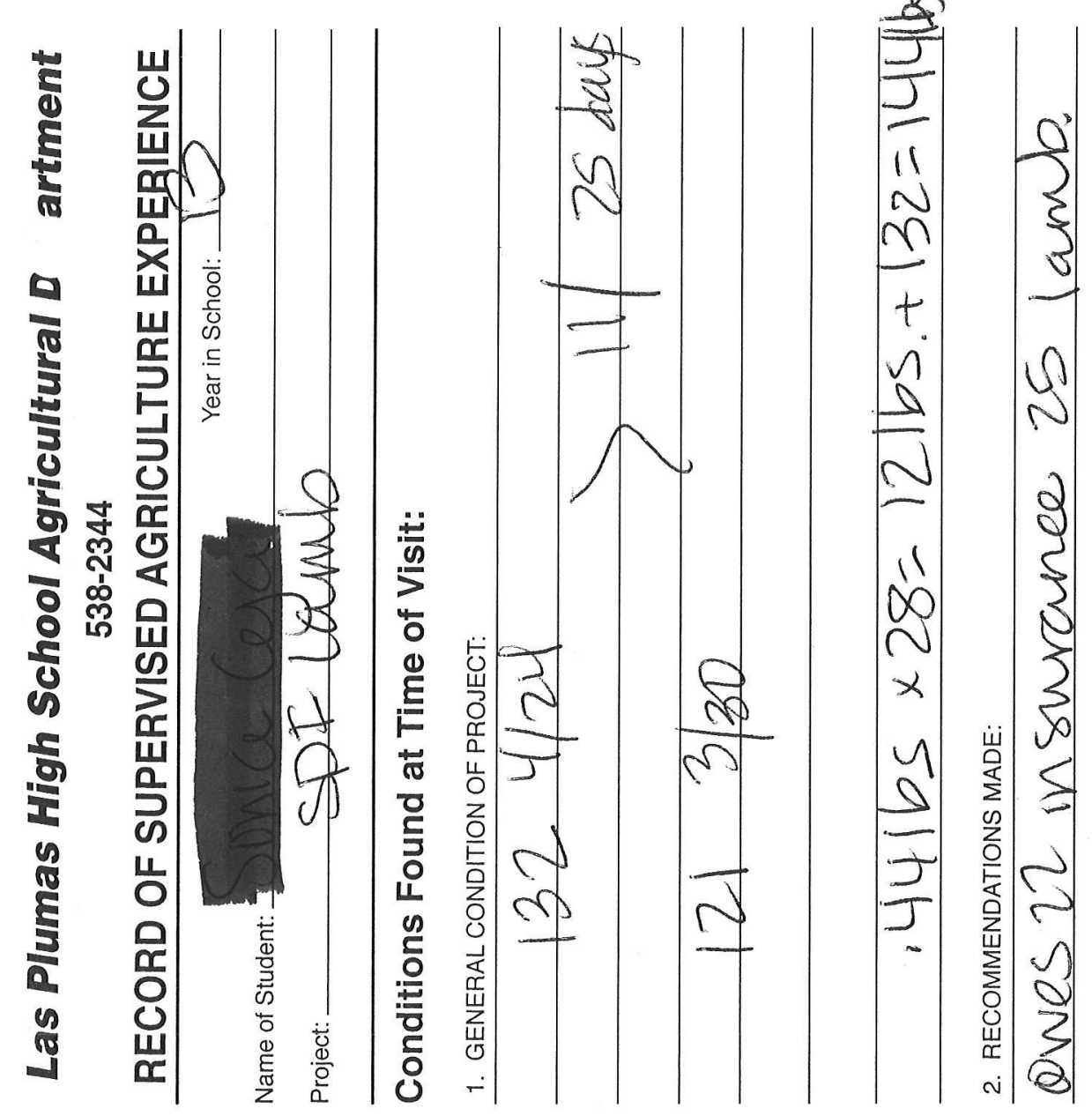




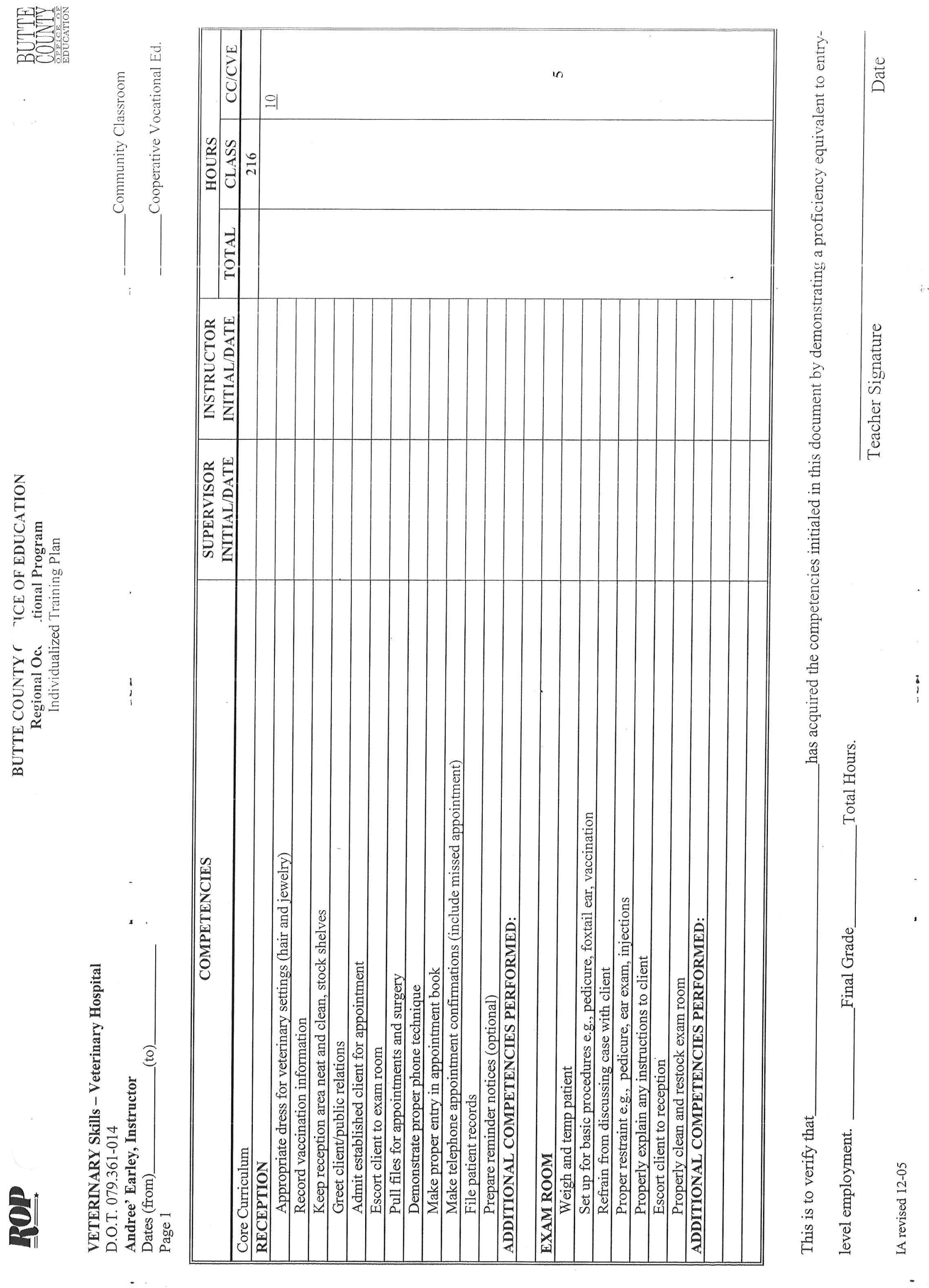




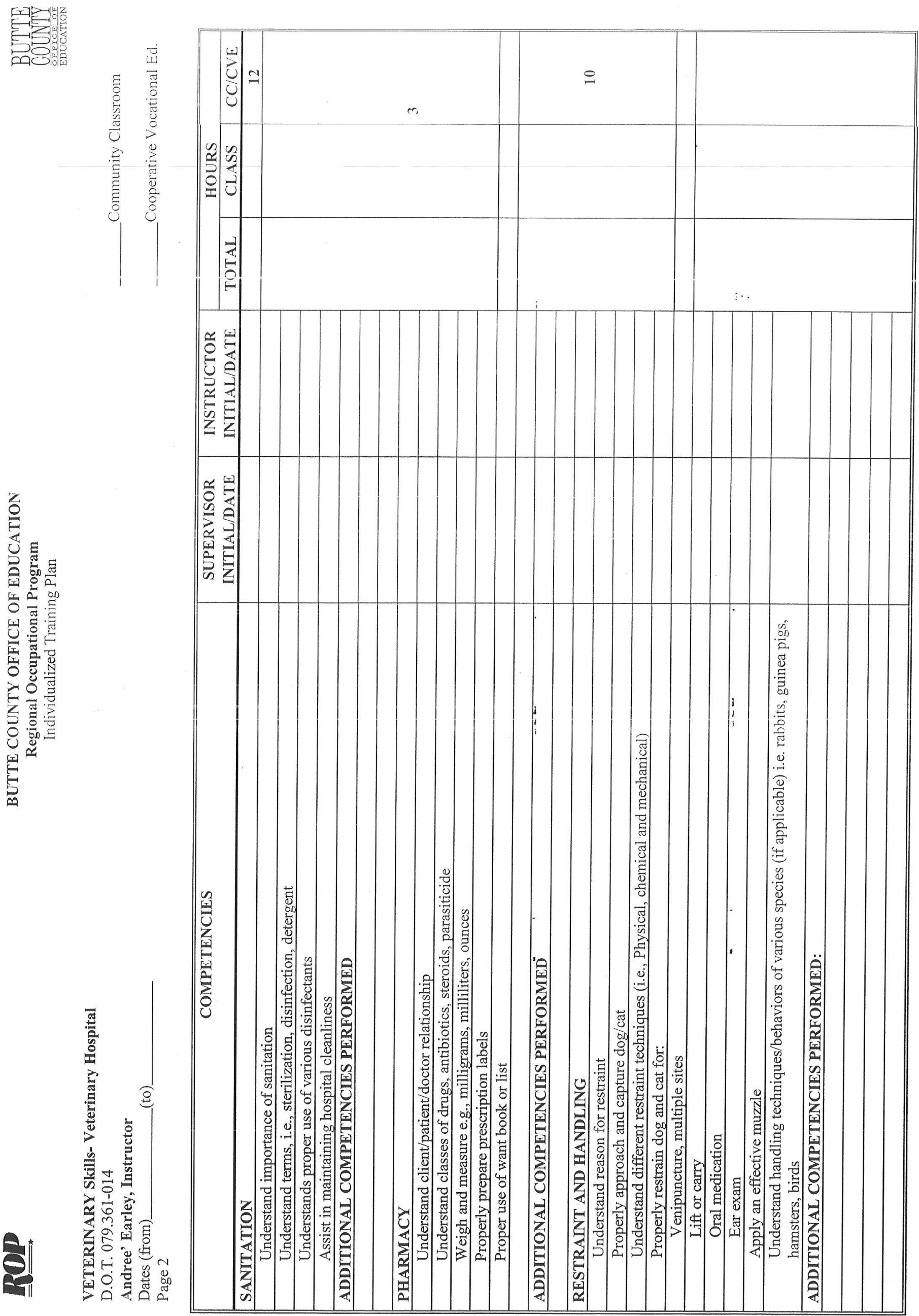




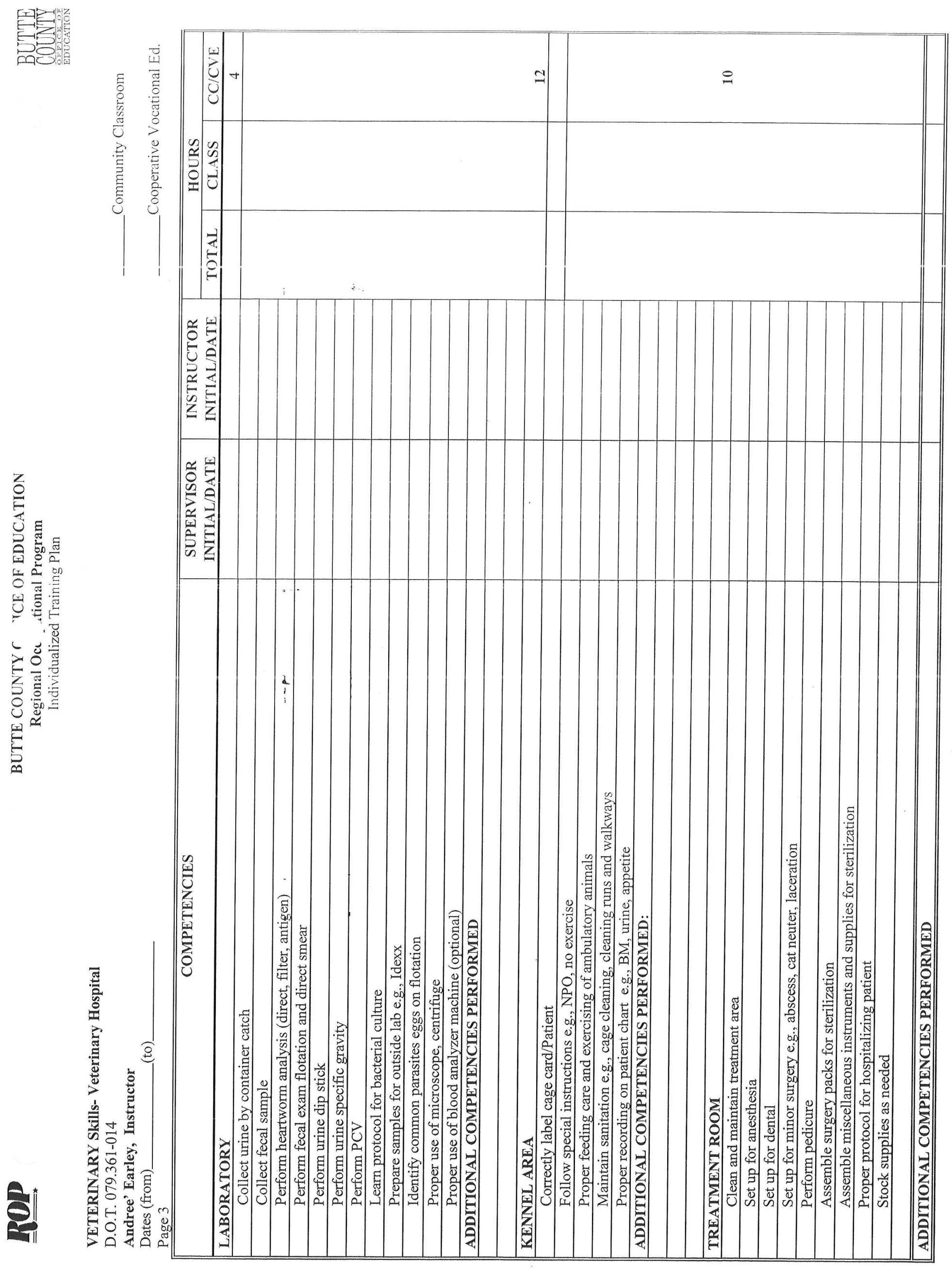




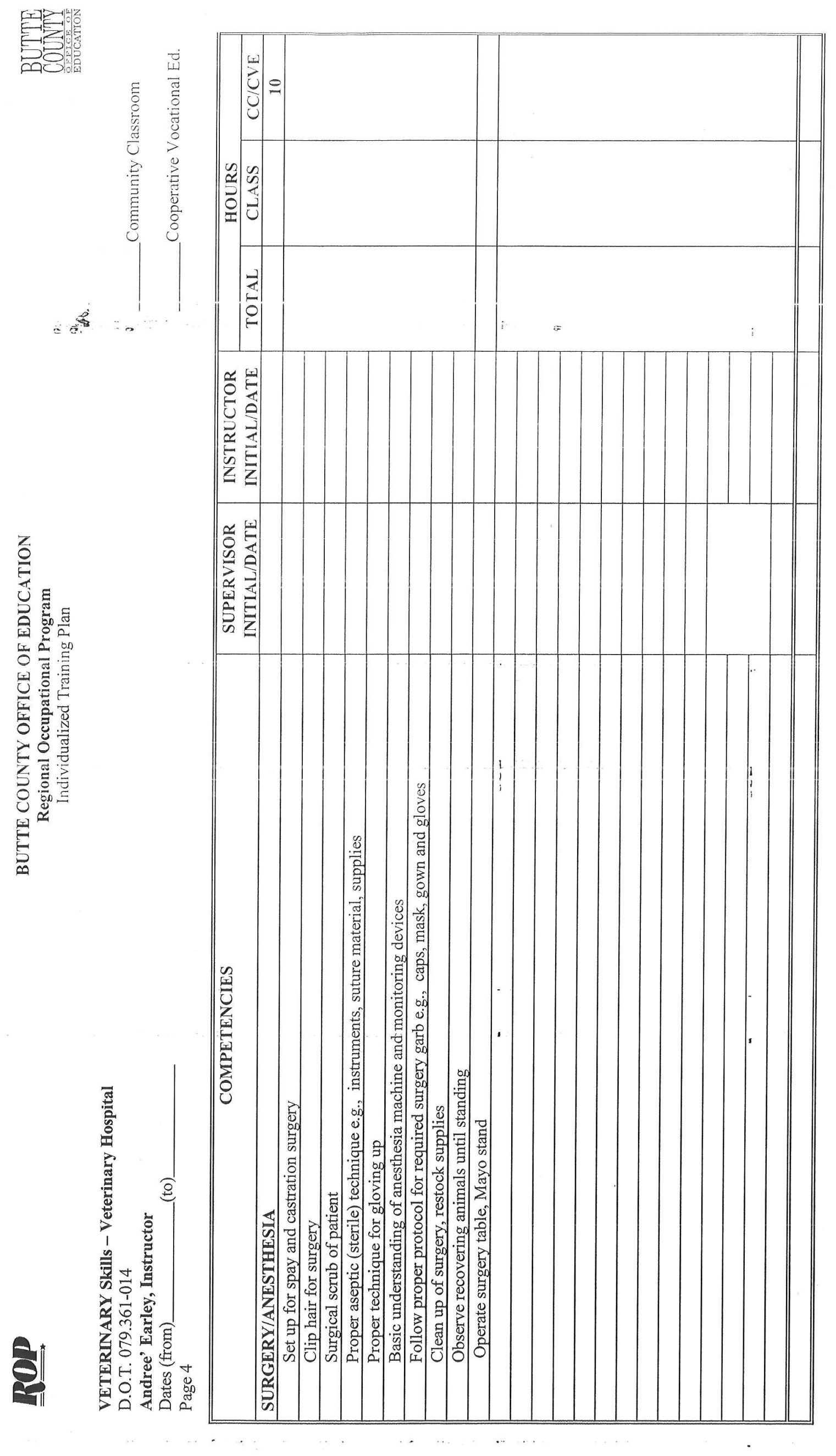




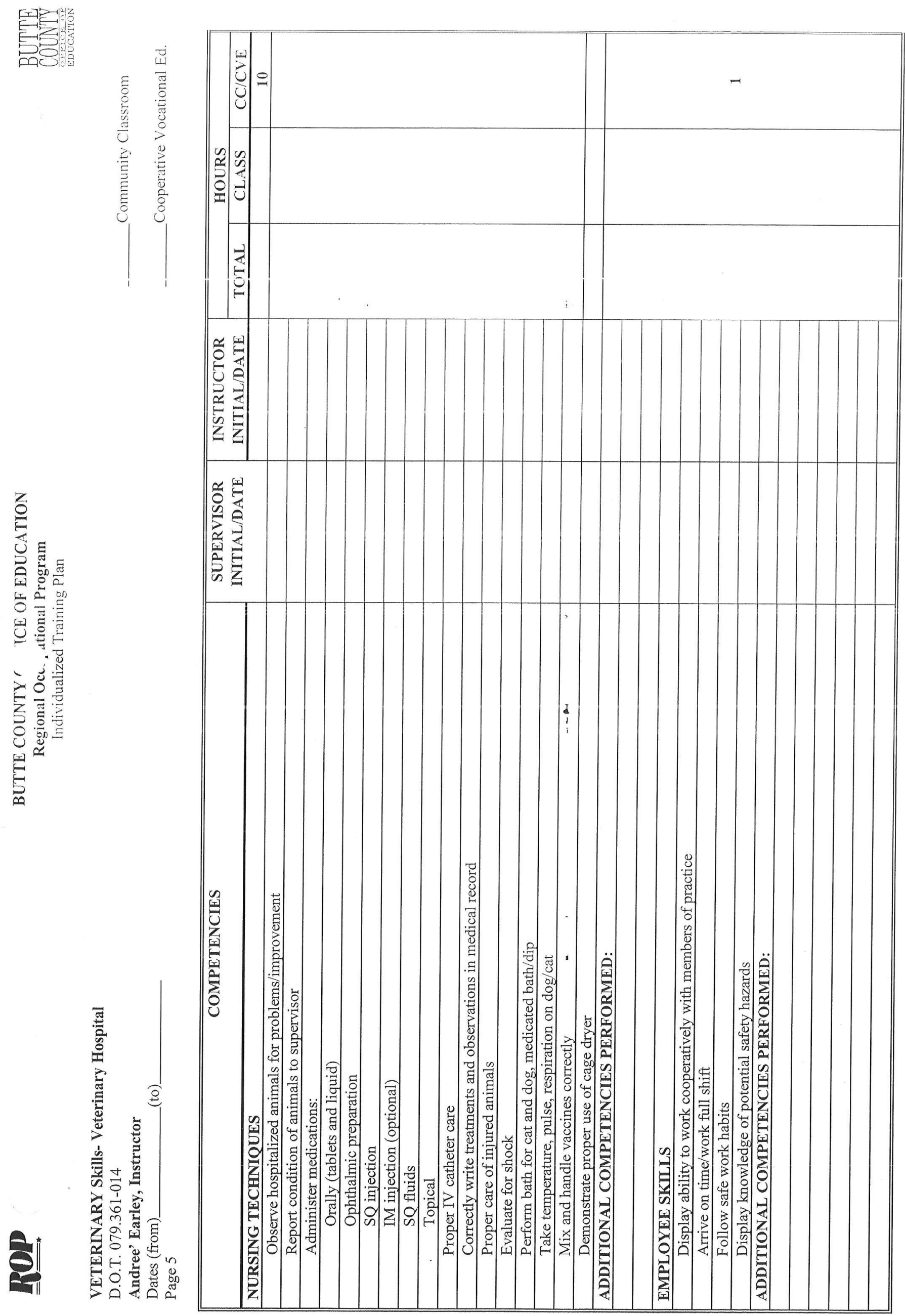




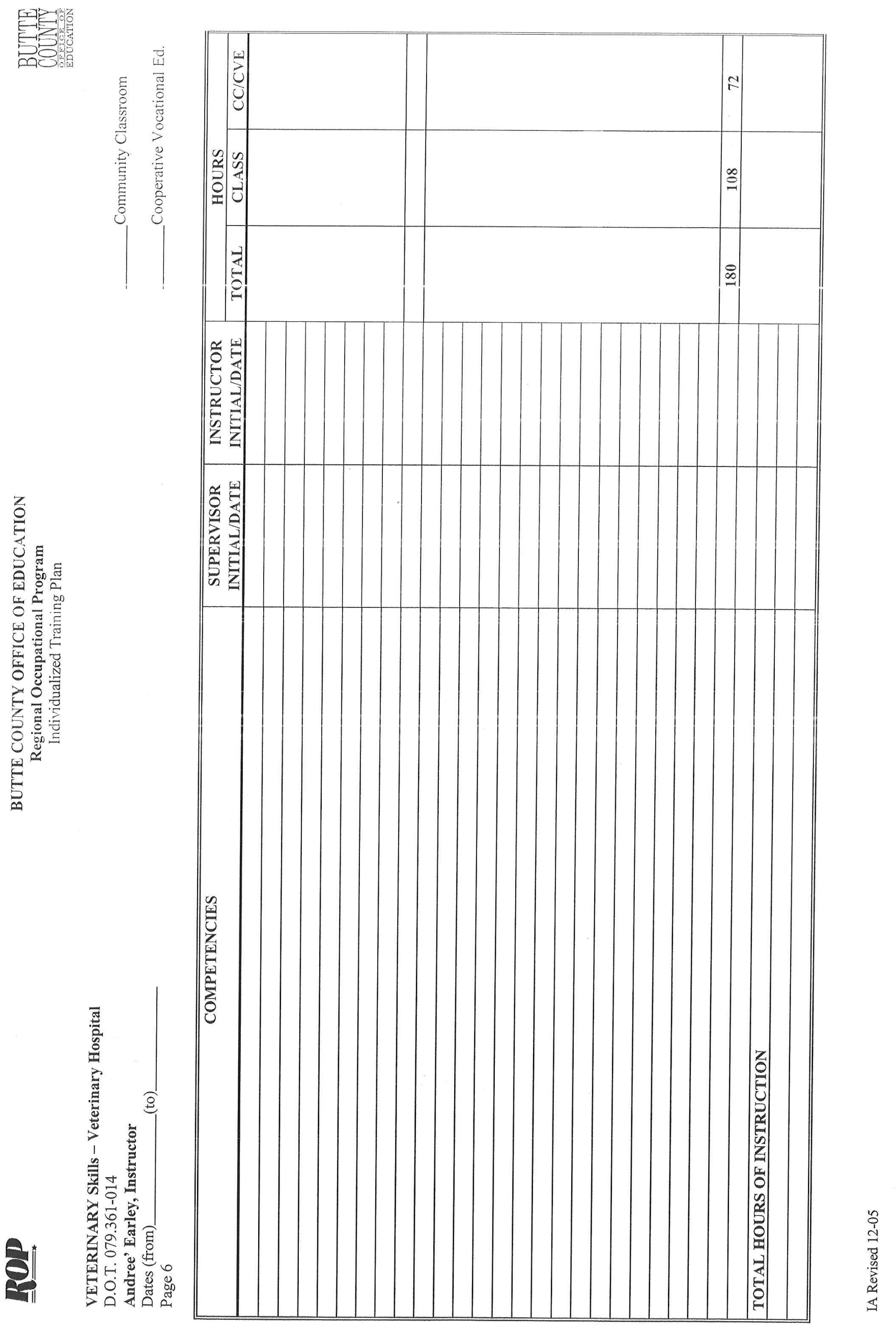


Student Name

ROP Course

ROP Instructor
Date

$\square$ Community Classroom $\square$ CVE

Business

Dear Employer: Please assist us by completing this form for the above student. Your ratings and comments will help determine grades and certificate ratings for the student. Please check one box per section and make comments below.

1. ATTENDANCE: punctual, reliable

$\square$ Meets expectations

$\square$ Fails to meet expectations

2. ATTITUDE: appropriate behavior and interaction

$\square$ Demonstrates enthusiasm and initiative

$\square$ Meets expectations

$\square$ Needs improvement

3. TEAMWORK: works cooperatively

$\square$ Works very well with others

$\square$ Gets along satisfactorily

Needs improvement

4. ATTIRE: meets company dress code policy

$\square$ Meets company policy
$\square$ Occasionally fails to meet company policy
$\square$ Fails to comply

5. RESPONSIBILITY: follows directions, completes work

$\square$ Very dependable

$\square$ Requires direction

Needs improvement
6. COMMUNICATION SKILLS: appropriate verbal and written

$\square$ Written and verbal skills exceed expectations

$\square$ Written and verbal skills meet expectations

$\square$ Needs improvement

7. CRITICAL THINKING SKILLS: problem solving

$\square$ Creative and skilled in problem solving

$\square$ Meets expectations

Needs improvement

8. QUALITY OF WORK:

$\square$ Exceeds expectations

$\square$ Meets expectations

Below expectations

9. QUANTITY OF WORK:

$\square$ Exceeds expectations

$\square$ Meets expectations

$\square$ Below expectations

10.OVERALL RATING:

$\square$ Exceeds expectations

Meets expectations

Below expectations

Comments

Please return this form to ROP instructor by

mployer's Signature

Date

Thank you for your interest and participation with ROP.

(White - Student; Yellow - Teacher/File; Pink - Employer) 


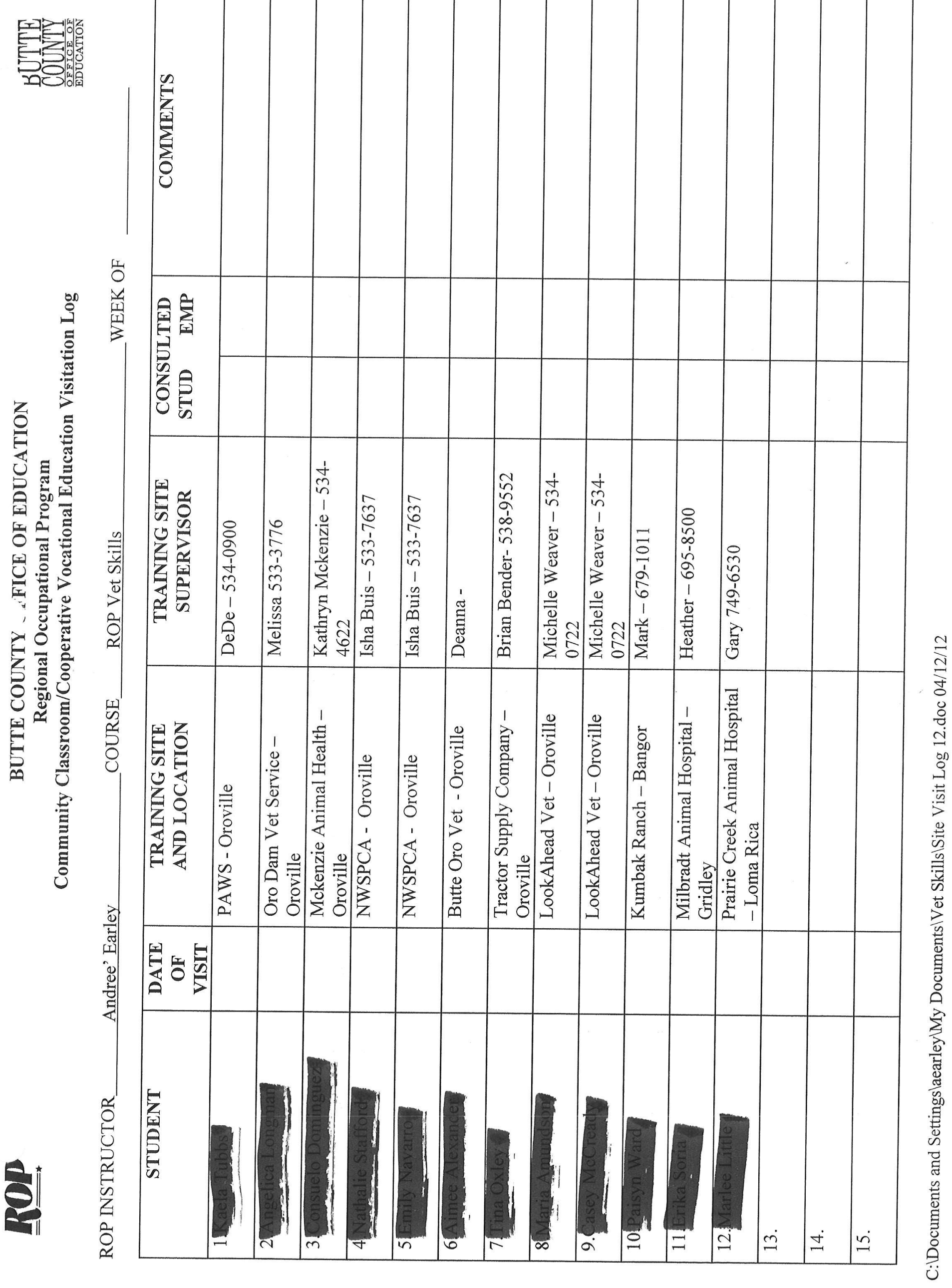



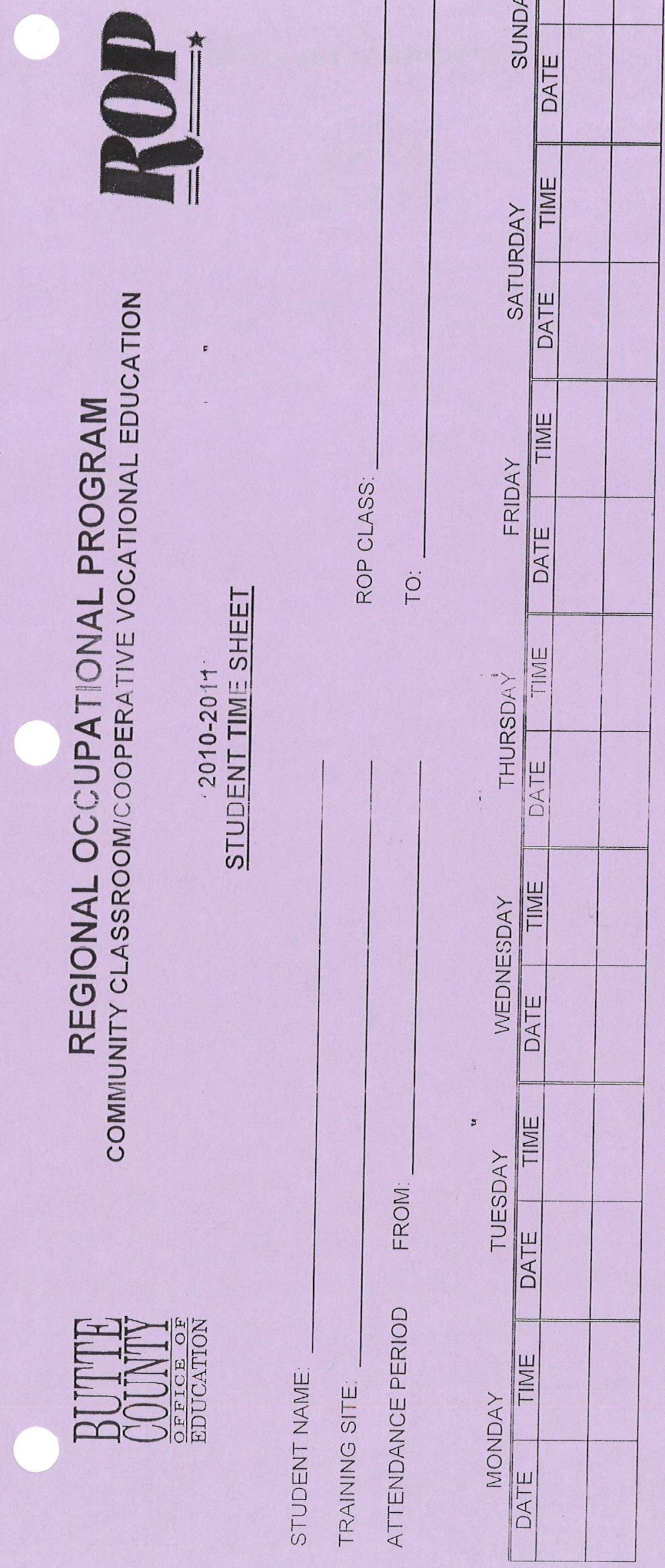

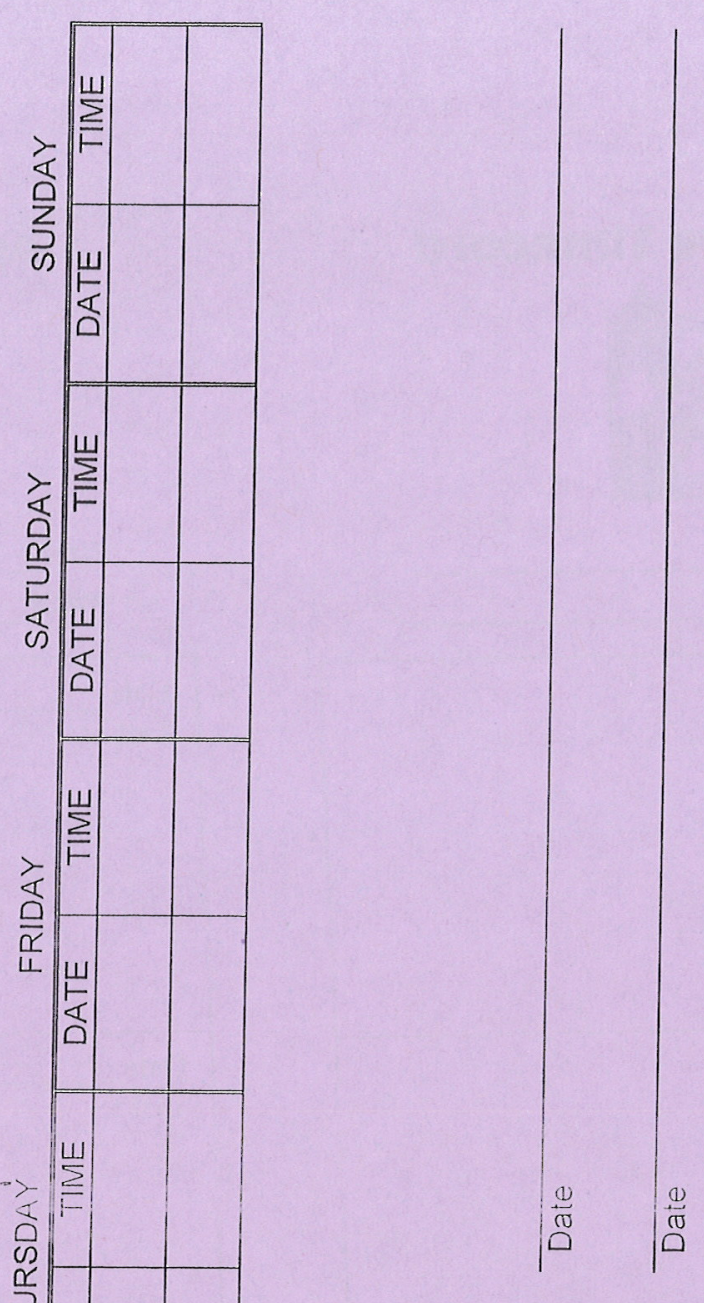


Agriculture Timecard

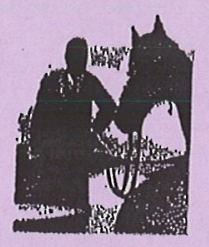

Natke

week of

\section{Date}

Task:

Date

Task:

Date

Task:

Task

Date

Tast
Agrilculture Timecard

2

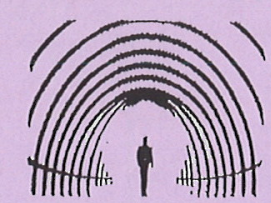

Naime

Week of

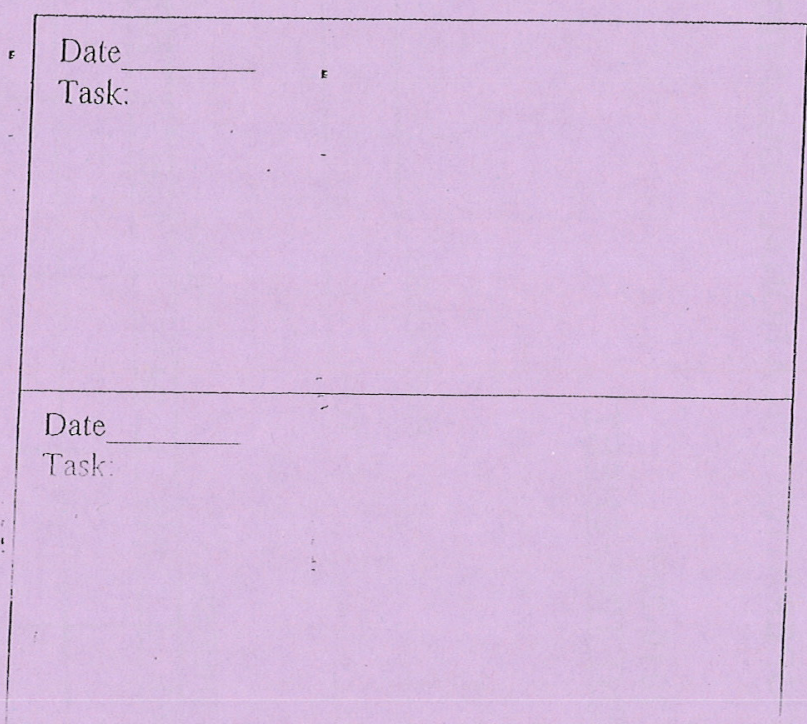

Date

Task

Tast 


\title{
BUTTE COUNTY REGIONAL OCCUPATIONAL PROGRAM
}

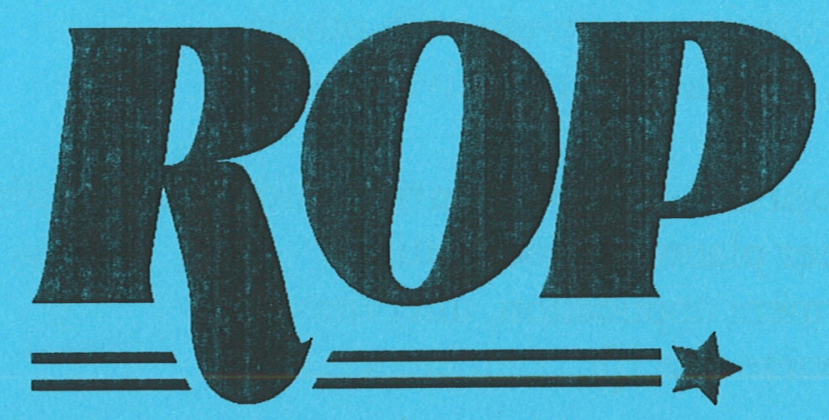

\section{STUDENT HANDBOOK 2011-2012}

Paul Watters, Director

\author{
BUTTE COUNTY ROP \\ 2491 CARMICHAEL DRIVE, SUITE 100 \\ CHICO, CA 95928 \\ (530) $879-7457$
}

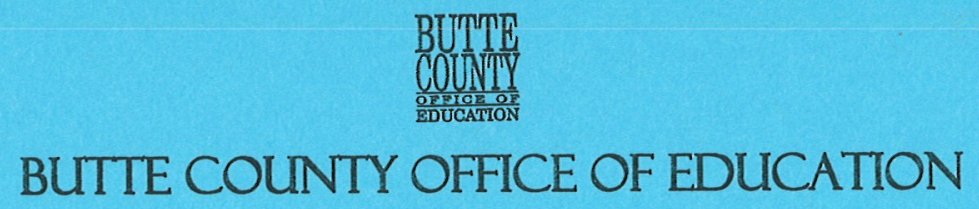




\section{BUTTE COUNTY \\ REGIONAL OCCUPATIONAL PROGRAM \\ "Committed to Career Success" \\ Expected Student Learning Results}

1. Demonstrate appropriate work ethic through:

- Punctual, regular attendance

- Personal integrity, honesty, respect

- Teamwork, working cooperatively with others

- Positive attitude, enthusiasm, initiative

2. Demonstrate appropriate job preparation and search skills through:

- Assessment, career planning, goal setting

- Resume, employment application, interview

- Attainment of course specific competencies

3. Demonstrate entry level use of industry sector technology/tools through:

- Adherence to safety procedures, precautions

- Application of knowledge, skills

- Integrated use of academic skills and computer literacy skills

- Workplace Simulation/Community Classroom/Cooperative Vocational Education

4. Demonstrate effective communication through:

- Workplace appropriate verbal, written and listening skills

- Performance of verbal and written directions

- Organization of thoughts and use of articulate language

5. Demonstrate critical thinking skills through:

- Analysis/evaluation and solution of problems

- Practical/successful use of community resources/agencies

- Independent work, self management

6. Demonstrate professionalism through:

- Socially appropriate interaction

- Suitable dress and appearance

- Confidentiality 


\section{DON MCNELIS} STPERINTENDENT

Student Programs and Services

Dr. Steve Olmos Assistant Superintendent

Paul Watters, Director Regional

Occupational

Program

-11 Carmichael Dr.

Suite 100

Chico, CA 95928

(530) 879-7457

Fax (530) 879-7454

pwatters@bcoe.org

email: ROP@bcoe.org web: www.bcoe.org/rop

Board of

Education

Dr. Ladd Johnson Jeannine MacKay Brenda J. McLaughlin Dr. Robert W. Purvis

Pat Matthews Spear Betty Vassar Mike Walsh

\section{Dear ROP Student:}

I would like to take this opportunity to welcome you to the Regional Occupational Program and to say thank you for selecting ROP for your career and technical education coursework. Our intent is to provide the very best instruction and training possible.

In this booklet you will find the major policies and regulations that ROP follows concerning student performance and behavior.

If you have any questions or concerns, please call the ROP office at 879-7457.

Sincerely,

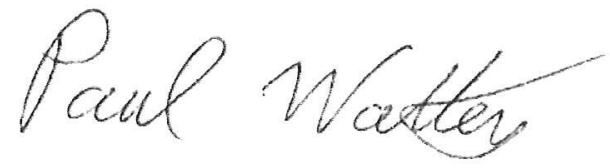

Paul Watters ROP Director 


\section{STUDENT RESPONSIBILITIES}

In order to maintain a classroom climate in which all students can learn it is vital for all students to assume responsibility for their behavior. To aide students in making appropriate decisions governing their behavior, the following guidelines have been developed based on provisions of the various California Government Codes. These expectations apply to all students.

Your ROP instructor will review class specific rules and procedures. In general, student responsibilities include:

\section{Academic Growth}

- Be prepared for class with appropriate materials

- Participate in class activities

- Follow classroom procedures

- Complete assignments

- Meet proficiency standards

- Progress toward earning a Certificate of Proficiency

\section{Good Attendance}

- Be in school every day

- Be prompt to class

- Remain in class until given permission to leave

- Always attend ROP class

- Maintain a $90 \%$ attendance rate to be eligible for an ROP Proficiency Certificate

\section{Good Behavior}

- Demonstrate cooperation and responsible behavior in the classroom

- Show respect for ROP teachers, guest speakers, substitute teachers and other students

- Do not display rudeness, defiance or disrespect through words or gestures

- Respect the property of others

- Be honest

- Use acceptable language

- Have pride in your work

- Have respect for cultural and ethnic differences

\section{ROP Student Transportation}

ROP does not provide transportation. Some classes require transportation to off campus ROP classroom sites and for the purpose of an ROP internship. It is the student/parent responsibility to provide transportation. If you are a high school student and will be driving to an off campus ROP classroom site or for the purpose of an ROP internship, a Student Permission to Drive form must be approved and on file with the ROP office. Students are not permitted to transport other students. 


\section{ROP Student Dress Code}

ROP students are expected to comply with the following standards:

- Clothes will be clean, safe and not be disruptive to the instructional process

- All students must wear shoes appropriate to the industry/setting

- Clothing that displays illegal substance, racial/ethnic slurs, gang activity or that are sexually suggestive are not allowed

- Sunglasses (except prescription) are not to be worn in the classroom

- Outer clothing should adequately cover all undergarments. No bare midriffs

- Students may be required to wear uniforms and/or safety apparel and meet industry/business standard clothing and grooming requirements (including nails, hair, makeup, tattoos, piercings, etc.)

\section{BUTTE COUNTY OFFICE OF EDUCATION AND ROP RESPONSIBILITIES}

\section{The Board of Education}

The Board of Education wishes to work cooperatively with ROP students and parents to develop policies for pupil behavior which will be in the best interest of all concerned.

(Education Code Section 35291)

\section{ROP Teachers}

Teachers are required to utilize all available ROP services when confronting routine cases of student discipline. Serious and repeated cases of student misconduct will be reported to the principal and/or ROP Coordinator or designee, who will assist the teacher, student and parents (if student is a minor) in attempting to work out a solution to resolve the problem.

\section{ROP Administration}

The ROP shall publish and enforce rules and regulations for student conduct with the following guidelines:

- The rules will not be arbitrary

- The rules will not discriminate among students

- The rules will not demean students

- The rules will not violate any individual rights constitutionally guaranteed to students

Those cases requiring discipline beyond the ROP administration's authority shall be reported to the County Superintendent. When student behavior is clearly in violation of the law, the act shall be reported to the police. 


\section{PERFORMANCE REVIEW PROCESS}

In the event that the ROP instructor or administration identifies inadequate student academic growth, poor attendance or unacceptable behavior, the ROP administration has established the following process:

\section{Conference}

A meeting between the student and ROP personnel, which may also include a parent/guardian if the student is a minor and/or a partner agency representative, in order to resolve the issue or issues in need of attention.

\section{Performance Contract}

A performance contract may be utilized in order to address specific issues. This contract will clearly state performance expectations and the outcome if the expectations are not met.

\section{Student Drop/Permanent Dismissal}

The ROP administration may drop/permanently dismiss a student for:

- Failing to meet class attendance standards

- Failing to meet class performance standards

- Failing to follow class/ROP rules

- Attempting to cause physical injury or threatening another person

- Possessing, sales of, or otherwise furnishing any controlled substance, alcoholic beverage or an intoxicant of any kind

- Offering, arranging or negotiation to sell any controlled substance, paraphernalia or an alcoholic beverage

- Possessing or using tobacco in a ROP classroom or during a ROP activity

- Committing robbery or extortion

- Causing or attempting to cause damage to ROP/private property

- Knowingly receiving stolen ROP/private property

- Possession or sale of weapons

- Committing an obscene act or engaging in habitual profanity or vulgarity

- Disrupting ROP activities 


\section{COMPLAINT PROCEDURES}

As a student in the Butte County ROP, you have the right to file a complaint if you feel your rights as a student have been violated.

The following procedures have been established for participants to file a complaint if they feel their rights have been violated:

A. The County Superintendent believes that the quality of the educational program can improve when the Butte County Office of Education listens to complaints, considers differences of opinion and resolves disagreements through an established, objective process.

If your complaint alleges a violation of the Butte County ROP regulations you should use the following procedures:

1. Submit a written complaint to the Butte County ROP, 2491 Carmichael Drive, Suite 100, Chico, CA 95928.

2. Complaints will be forwarded to the Director of the Butte County ROP. An investigation will be preformed in accordance with the Butte County Office of Education's Superintendent's Policies and Regulations under the direction of the Superintendent or designee.

3. If not settled informally, a hearing will be held and a final written decision will be made along with the right of appeal.

B. Under Cooperative Vocational Education ROP courses, if your complaint alleges a violation of the terms and conditions of employment, you should use the procedures of your employer. The complaint procedures of your employer should be given to you at the time you begin employment.

C. The Butte County Office of Education shall follow uniform complaint procedures when addressing complaints alleging unlawful discrimination against any protected group, including actual or perceived sex, sexual orientation, gender, ethnic group identification, race, ancestry, national origin, religion, color, or mental or physical disability, or age, or on the basis of a person's association with a person or group with one or more of these actual or perceived characteristics in any program or activity that receives or benefits from state financial assistance. Uniform complaint procedures shall also be used when addressing complaints alleging failure to comply with state and/or federal laws in career technical education programs per Butte County Office of Education's Superintendent's Policies and Regulations.

If you have any questions about your rights or if you need assistance in filing a complaint, please write or call the ROP administrators at (530) 879-7457. 


\section{DETACH AND RETURN THIS FORM TO THE ROP INSTRUCTOR}
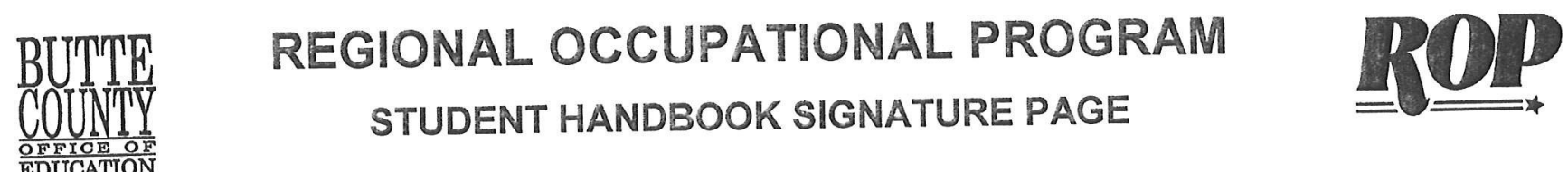

I have received and read a copy of the Student Handbook.

I am knowledgeable of the ROP Policies and Regulations for students. I have been informed by my instructor that I have the right and opportunity to ask questions and discuss this information at any time.

\section{COMPLAINT PROCEDURE}

I certify that I have been notified, in writing, of the complaint procedures of the Butte County Office of Education.

Initials (Parent or Guardian if minor)

\section{PERMISSION TO FEATURE, PUBLISH, PHOTOGRAPH OR VIDEO}

It is of great help, when training staff that work with ROP students and also when trying to inform the public about ROP, to publish names and show pictures and video of ROP students. We are required to have a signed permission slip on file for any ROP student who is to be featured or photographed in any way.

I give permission to Butte County Regional Occupational Program to feature, photograph, video, publish in print/other media or display on the Butte County Office of Education web site for the student listed below.

YES __ Initials (Parent or Guardian if minor)

NO Initials (Parent or Guardian if minor)

I agree to fully participate in the ROP course I have selected and to abide by all stated policies and regulations. I received and read the Student Handbook on

Date

Student Name (Print)

ROP Course Title, Location

Student Signature

Parent/Guardian Signature

(Sign only if ROP student is a minor) 


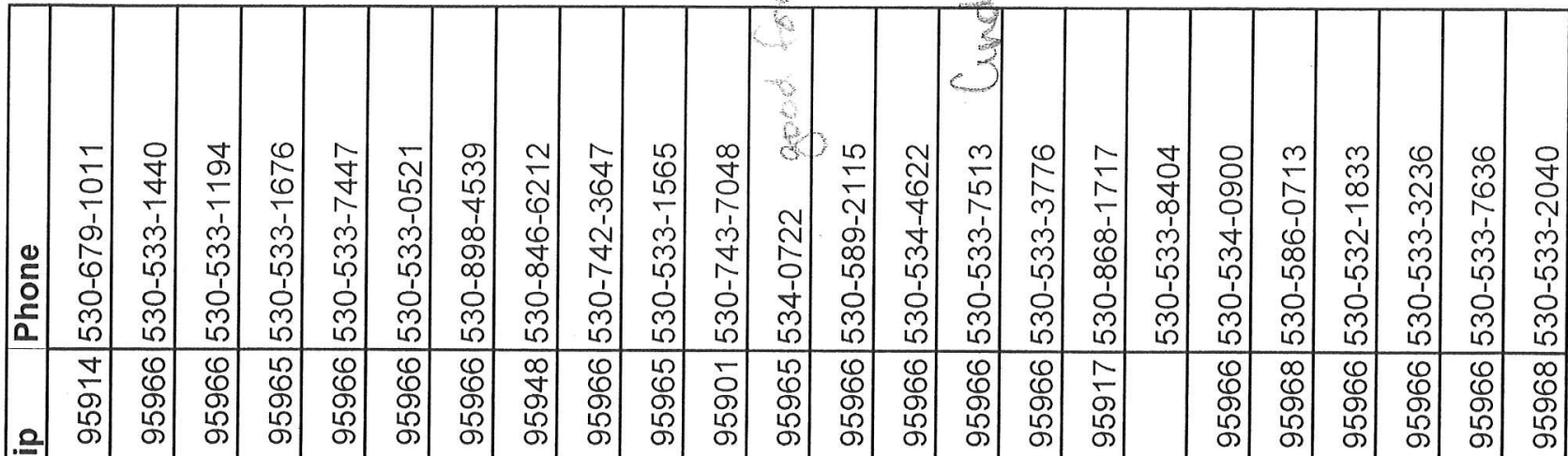

N

幽

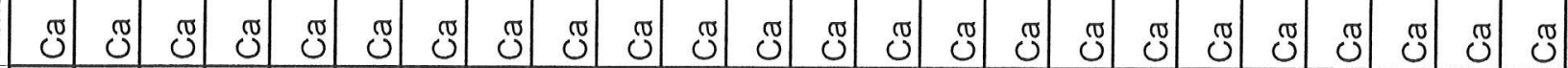

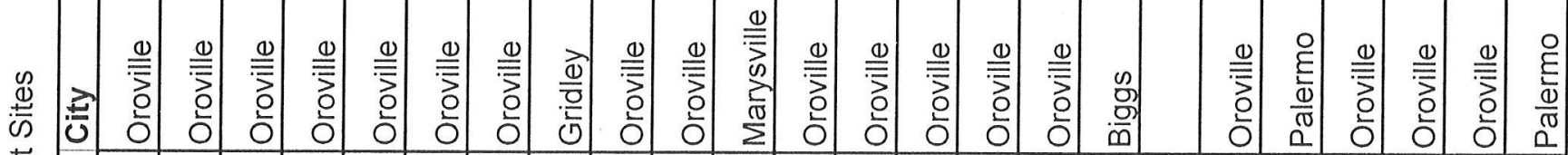

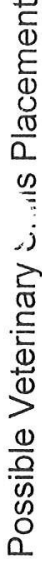

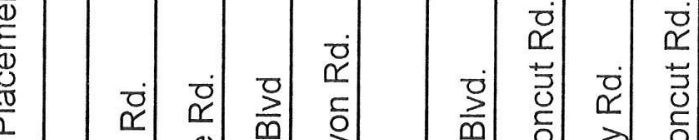

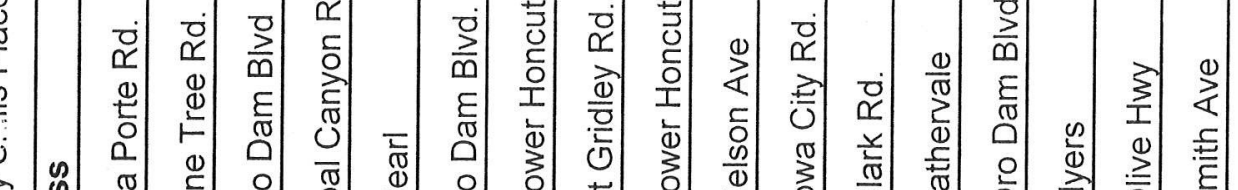

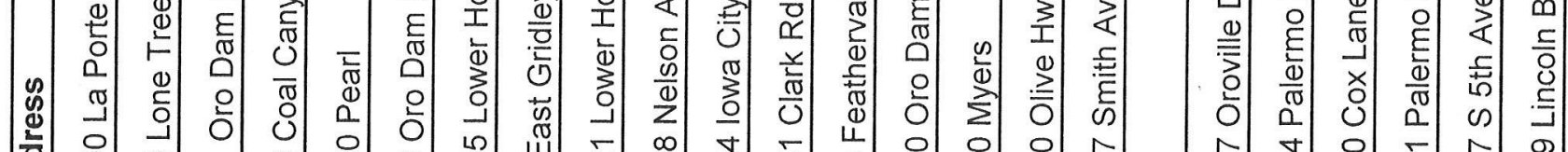

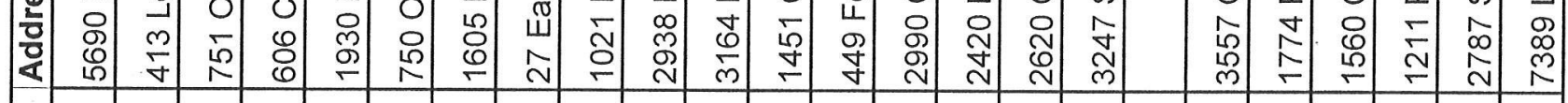

\begin{tabular}{lll}
$\bar{\Phi}$ & $\bar{\pi}$ \\
\hline & $\mathbb{0}$
\end{tabular}

«

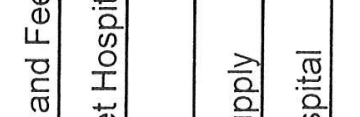

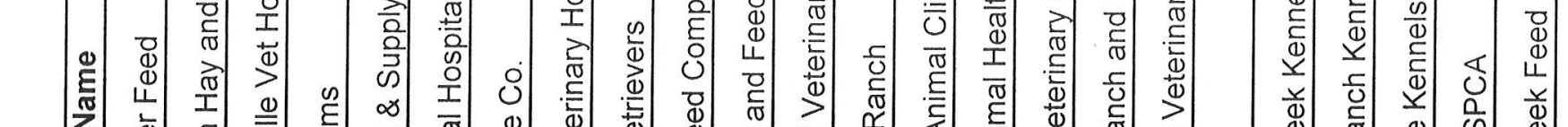

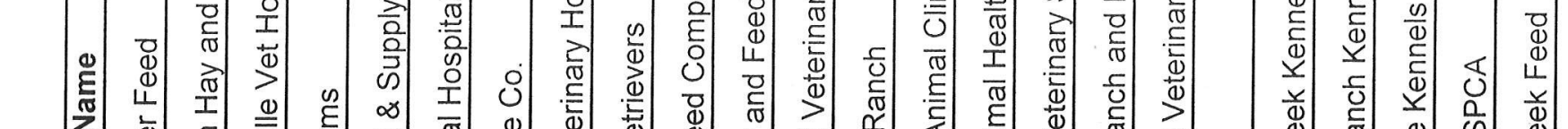

त्ञ

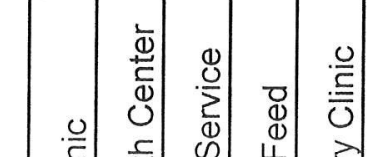

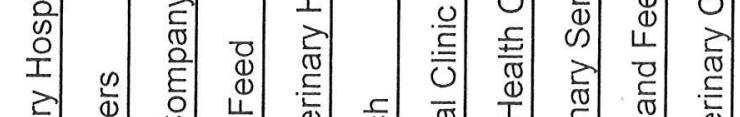

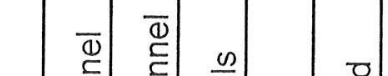

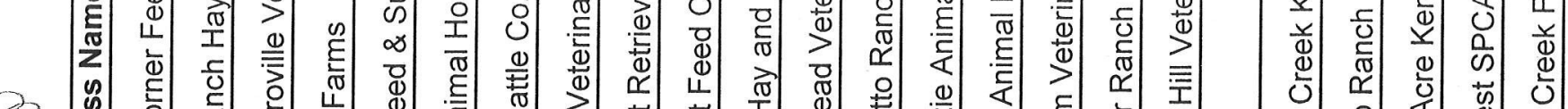

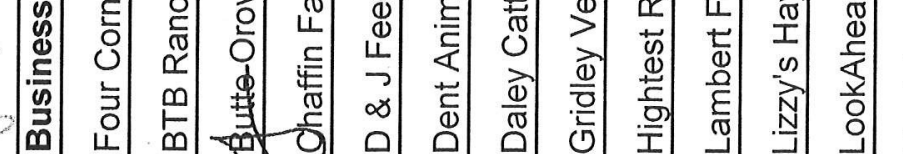

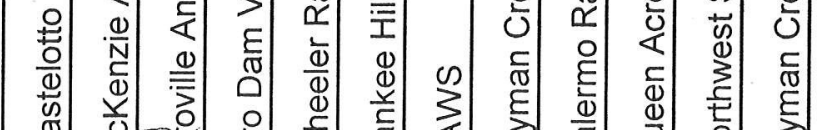

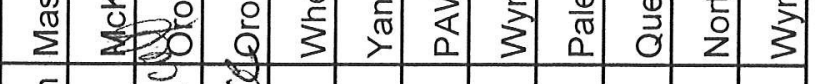
की

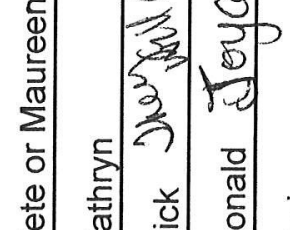

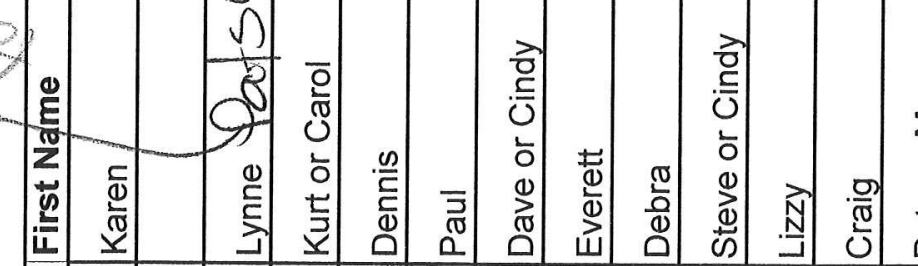

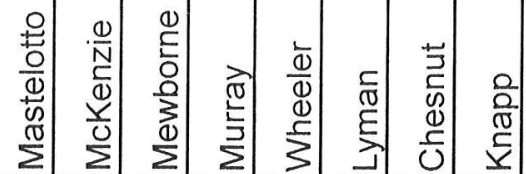




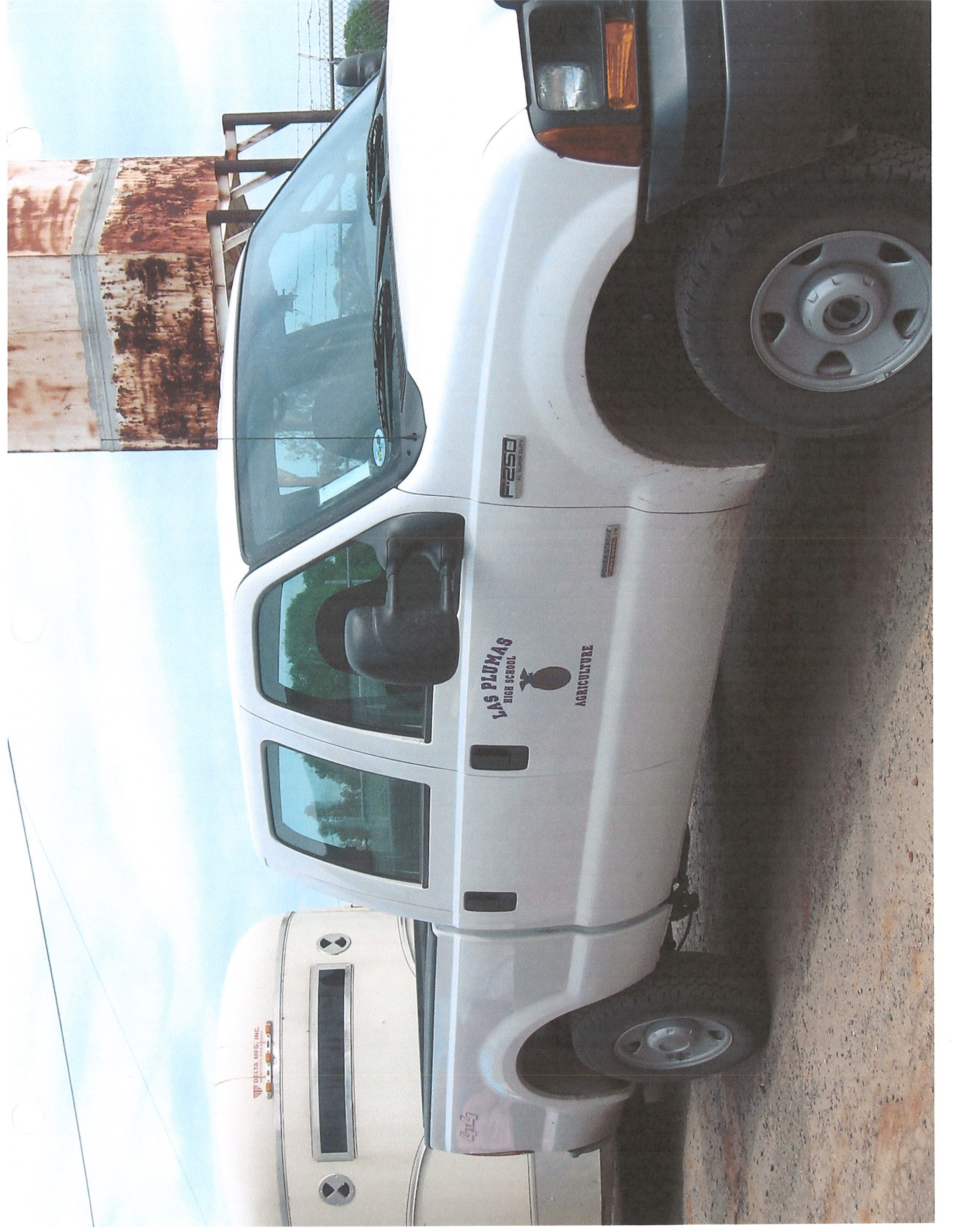


All career-vocational education teachers are competent and qualified within the appropriate occupational proficiency. In addition, instructors, administrators, guidance/counseling staff, and instructional support staff are involved in and ongoing program for professional development designed to enhance the quality of instruction.

There are four teachers in the Las Plumas High School Agriculture Program. Andree' Earley is the department chair and all four teachers co-advise as the FFA Advisors. Andree' has been teaching for seven years the last four years at Las Plumas before taking the position here she taught high school agriculture at Lindhurst high school. Andree' currently teaches Floriculture, Agriculture Leadership/Horticulture, and ROP Vet Skills. She has developed and put into place a grant to receive a much needed large animal beef barn that would complete our school farm facilities. Jim Knapp has been teaching at Las Plumas the longest and has been teaching Ag for nineteen years. He teaches four sections of Ag Earth Science, and one section of Floriculture. Carlos Diaz is the most recent addition to our department he was hired last year because our Agriculture Mechanics teacher took a better position. Carlos has a designated subjects credential in Agriculture. Ashleigh Aldridge is starting her $5^{\text {th }}$ year of teaching at Las Plumas she even completed her phase II student teaching at Las Plumas. All instructors are fully credentialed and highly qualified and are active in CATA at the Las Plumas High School Agriculture Department.

Most of the administration is very supportive of the Agriculture Program at Las Plumas. Dan Ramos, our principal, is a former Agriculture Mechanics teacher her at LP, and is very supportive of our staff and students, and continues to aid the agriculture instructors in educating those members of the administration who are less aware of all the opportunities agriculture education has to offer. He is asked along with our Vice Principle, Darin Williams to attend almost every school wide function by multiple organizations, yet seems to be able to attend almost every FFA/Agriculture activity in which an invitation was extended. Paul Watters is our county ROP Director, and has been very supportive monetarily in recent years, and supporting our newly hired Agriculture Mechanics teacher.

\section{Evidence Documents Include:}

- Ashleigh Aldridge's Credentials in Agriculture

- Other Agriculture Teacher Credentials

- PPS Credential from University of La Verne

- Individualized Induction Plan \& BTSA Completion 


\section{ASHLEIGH ROSE ALDRIDGE}

DOCUMENT NUMBER: 070246923

VALID: $05 / 31 / 2007$ to $06 / 01 / 2012$

DOCUMENT TITLE: Preliminary Single Subject Teaching Credential

\section{SUBJECT(S) AND AUTHORIZATION(S):}

Agriculture

(R1S) This document authorizes the holder to teach the subject area(s) listed in grades twelve and below, including preschool, and in classes organized primarily for adults.

(R142) This document authorizes the holder to provide the following services to English learners: (1) instruction for English language development in grades twelve and below, including preschool, and in classes organized primarily for adults; and (2) specially designed content instruction delivered in English in single-subject-matter (departmentalized) courses as authorized on this document. This authorization also covers classes authorized by other valid, non-emergency credentials held, as specified in Education Code Section 44253.3.

\section{RENEWAL CODE(S):}

(R14I) This credential may not be renewed. To qualify for the clear credential, the holder of this document must complete a Commission-approved Induction program including Verification of Completion by the program sponsor.

Specific information pertaining to credential renewal requirements may be obtained under

Credential Renewal Statements and Requirements at www.ctc.ca.gov

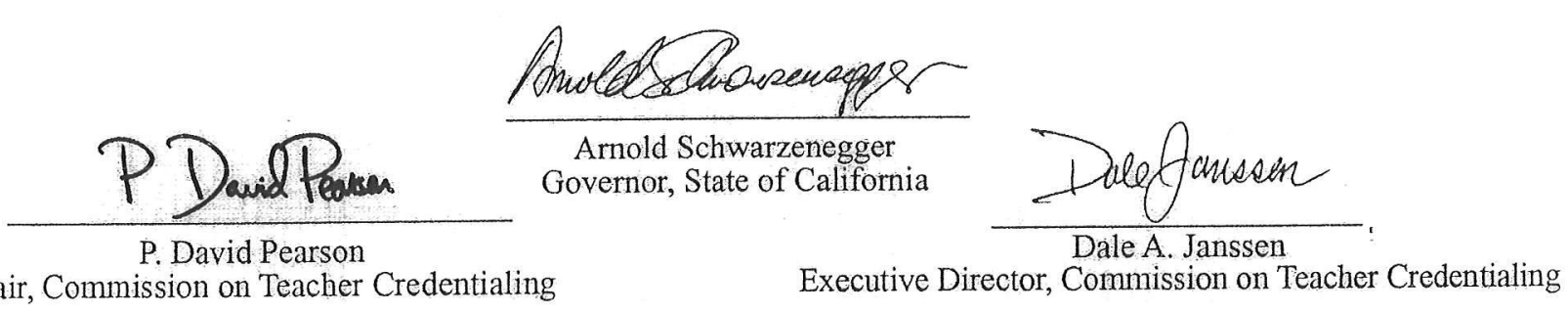

Chair, Commission on Teacher Credentialing

Executive Director, Commission on Teacher Credentialing 


\section{ASHLEIGH ROSE ALDRIDGE}

DOCUMENT NUMBER: 070268601

VALID: $05 / 31 / 2007$ to $06 / 01 / 2012$

DOCUMENT TITLE: Clear Specialist Instruction Credential (Agriculture)

\section{SUBJECT(S) AND AUTHORIZATION(S):}

Agriculture

(R3A1) This credential authorizes the holder to teach agriculture in grades twelve and below, including preschool, and in classes organized primarily for adults. It also authorizes the holder to develop and coordinate curriculum, develop programs, and deliver staff development for agriculture education programs coordinated by school districts or county offices of education.

RENEWAL CODE(S):

(R15P). The term of this credential is limited by the term of the prerequisite credential. To renew this credential, the holder must also renew the prerequisite credential.

Specific information pertaining to credential renewal requirements may be obtained under

Credential Renewal Statements and Requirements at www.ctc.ca.gov

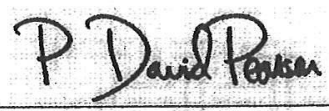

P. David Pearson

Chair, Commission on Teacher Credentialing

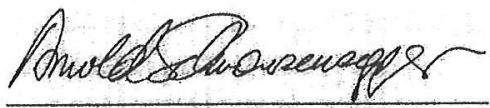

Arnold Schwarzenegger Governor, State of California

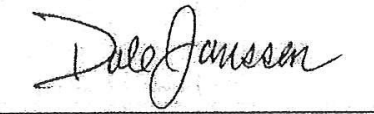

Dale A. Janssen

Executive Director, Commission on Teacher Credentialing 


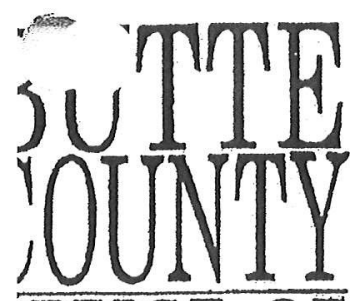

FETCE OF

DUCATION

IRRY McGUIRE JPERINTENDENT

Board of Education

Besste Hironimus Barbara Johnson Charles Larsen inenda d. Mclaughlin Robert W. Purvis Pat Matthews Spear Betty Vassar

?ersonnel Services 1859 Bird Streel roville, CA 95965 (530) 538-7859 1X: (530) 538-2063

I. Equal Opportunity vloyer
PERSONNEL DEPARTMENT

FAX TRANSMTTTAL

TO:

Pat

of LP.High School

FROM: Dawn.

SUBJECT: Credentials

DATE: 9 Nor 98

TIME: $12: 40$

A.M.M.M.

Length (including cover letter): $\quad 1 \quad$ pages.

Destination FAX number: (530) 534 -5974

Transmitting FAX machine is a Canon CFX-L4000, telephone number (530) 538-2063.

If you do not receive all pages, please call Dawn

At (530) $538-7860$

COMMENTS: NORECORD OF CLIFF SCHEER

JAMES KNAPP - DPROFESSIONAL CLEAR SINGLE SUBJECT AGRICULTURE, ANIMAL SCIENKE KVI2 GENERAL SCIENCE $K-9$ EXPIRES $7 / 1 / 99$

(2) CLEAR AGRICULTURE SPEOIALIST K-12 EXPIRES $7 / 1 / 99$

LISA ROSS - PROFESSIONAL CLEAR SINGLE SUBTECT ENGLISH, AGRICUCTURE K-12 EXPIRES $5 / 1 / 02$

DANIEL RAMOS OPROFESSIONML CLEAR SINELE SUBTECT AGRICULTURE K-12 EXPIRES $6 / 1 / 03$

(2) PROFESSIONAL CLEAR AERICULTURE SPECIALIST E-12 EXPIRES 6/1/03

KAREN FALCONER - O CLEAR SINGZE SUGJECT AgRICULTURE BIOLOGY $k-12$ EXPIRES $6 / 1 / 99$

(2) clear agricuLtUre speciazIST k-12

S:PERSONNEL.FAX.DOC Expires G/199

11198

"WHERE CHILDREN ARE OUR MOST VALUABLE RESOURCE" 


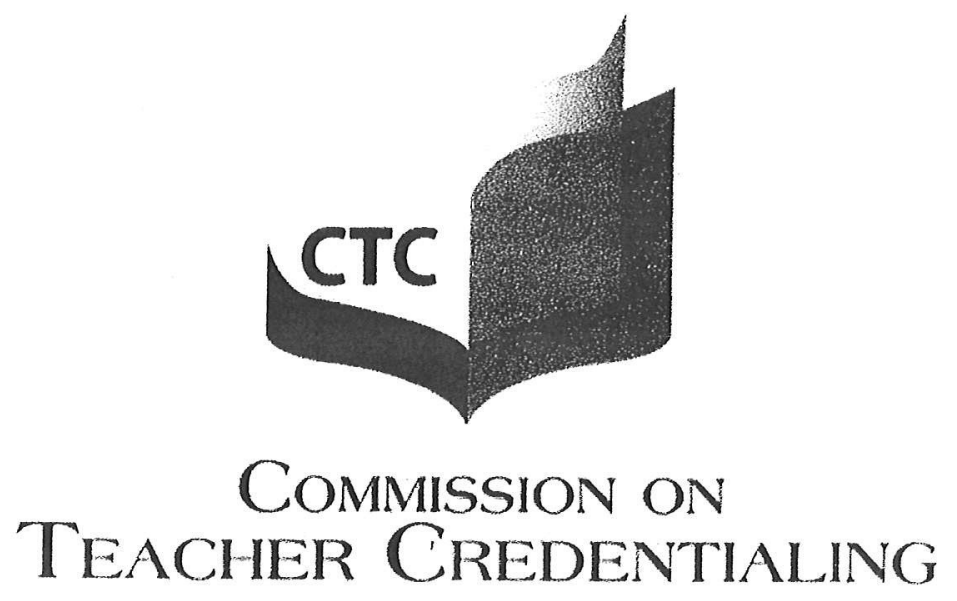

Ensuring Educator Excellence

By virtue of the authority vested in the Commission on Teacher Credentialing in recognition of preparation to serve in California public schools

\section{CARLOS R. DIAZ}

is hereby awarded a

Certificate of Clearance 

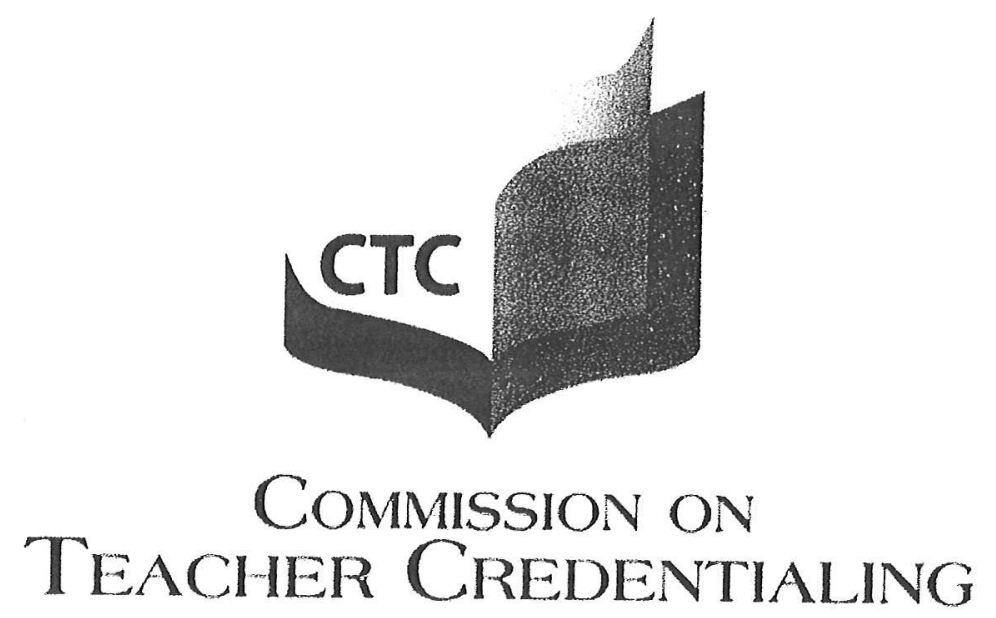

Ensuring Educator Excellence

By virtue of the authority vested in the Commission on Teacher Credentialing in recognition of preparation to serve in California public schools

\section{CARLOS R. DIAZ}

is hereby awarded a

\section{Clear Specialist Instruction Credential (Agriculture)}

AUTHORIZED SUBJECT(S):

Agriculture 


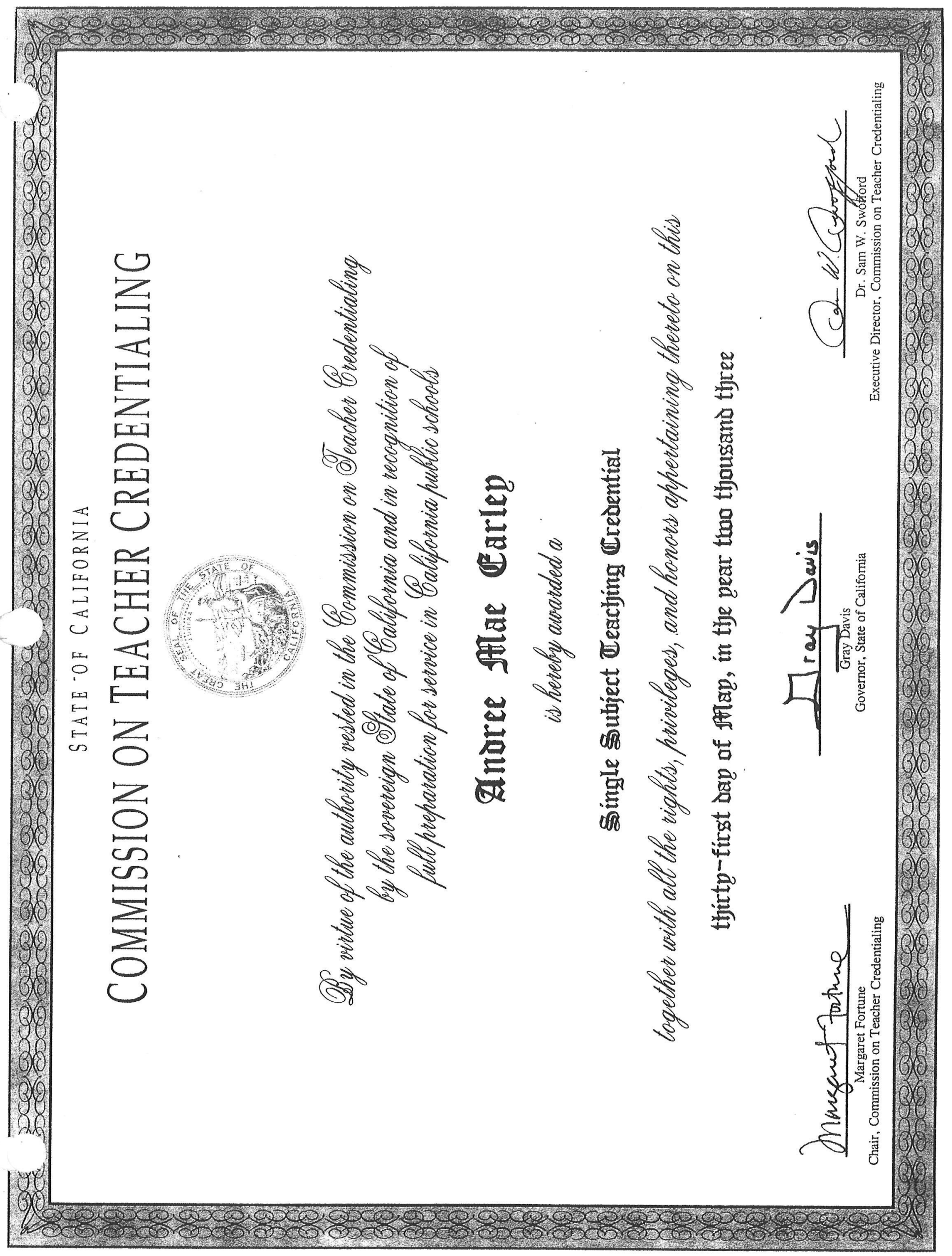




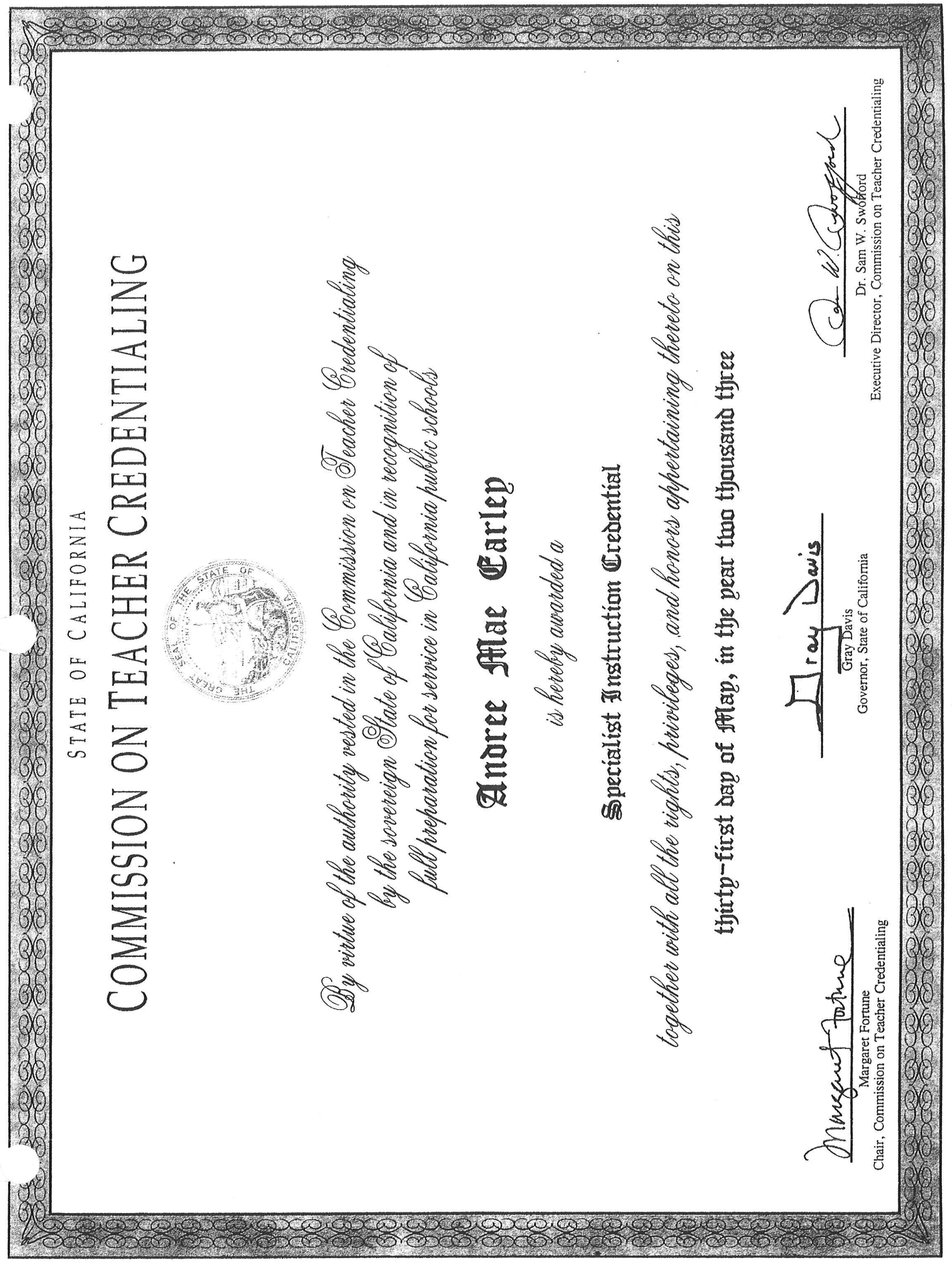




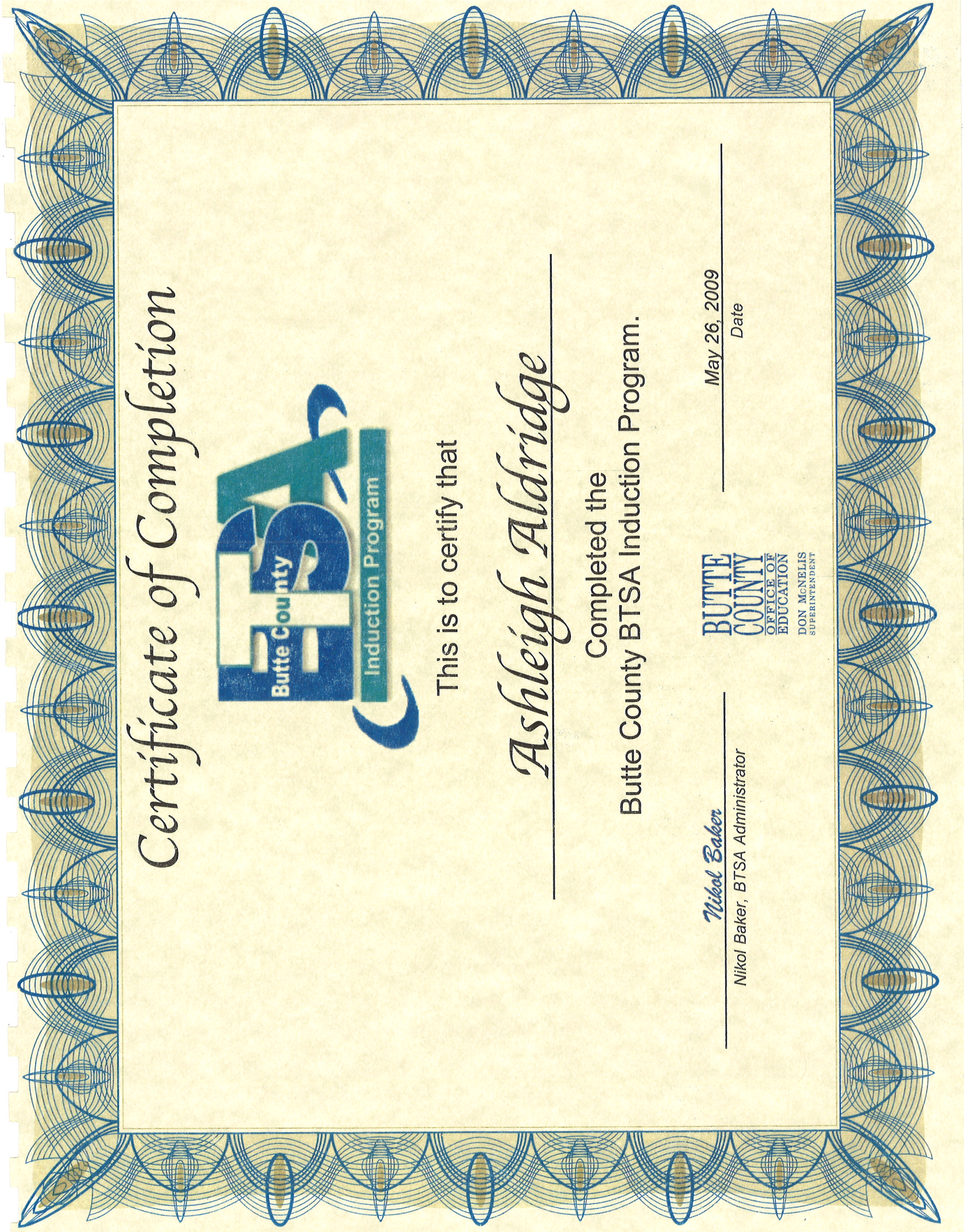




\section{Quality Criteria Five: Facilities, Equipment and Materials}

Facilities, equipment, instructional material and supplies comply with health and safety standards, reflect and/or simulate current and emerging technologies and applications, and are of sufficient quantity to meet the instructional objectives and individual needs of all students.

The facilities and equipment at the Las Plumas High School Agriculture Department have improved exponentially in the last five years, due greatly in-part to a highly motivated agriculture staff. With the assistance of a bond measure and the support of the administration a new, fully equipped Agriculture Science building was completed in 2006 and now fully utilized for Agriculture Science, Animal Science, Vet Skills, and Agriculture Earth Science. The new facility has three classrooms, a full lab classroom with chemical supply storage room that is accessible by all four agriculture teachers.

This addition allowed for the Agriculture Mechanics program to have a separate classroom located in the same building as a shop that use to be utilized for Agriculture Biology. This has allowed more room in the shop to re-arrange welding stations to better accommodate more students. With Prop 1D funds are agriculture department this year finished the final steps of the ground breaking on our addition to our already existing school farm a new beef barn, complete with wash rack, eight side pens, and an enclosed show ring. Currently the metal building is up and now we are just working with the ROP students to complete other parts such as wash rack, and establishing runs for the cattle. This will allow animal science class to get hands on experience no matter what the weather conditions are like. This barn will give more students the opportunity who can't house their animal projects at their house another option.

Most agriculture classes 2 out of 3 of the lab science classes have LCD capability and have attached Smart Board technology. The last science classroom is going to be receiving a Smart Board by the end of the quarter. In addition, the Agriculture Mechanics lab has been modernized through hard work and grant writing and uses newer; industry current tools, machines and curriculum. We just purchased eighteen small engines for our Agriculture Mechanics I \& II classes.

The Ag Department purchased a new truck in 2006 for the department purposes and student needs. The facilities of Las Plumas Agriculture Department meet or exceed the instructional objectives of the program and the individual needs of all students. We have in our goals within the next three years to purchase a new Ag suburban also.

\section{Evidence Documents Include:}

- Specialized Ag Incentive Grant

- Receipts of recent equipment purchases

- Pictures of current facility with recent improvements/new construction and new barn! 


\section{Las Plumas Agricultural Department Five Year Plan Equipment Acquisition Schedule}
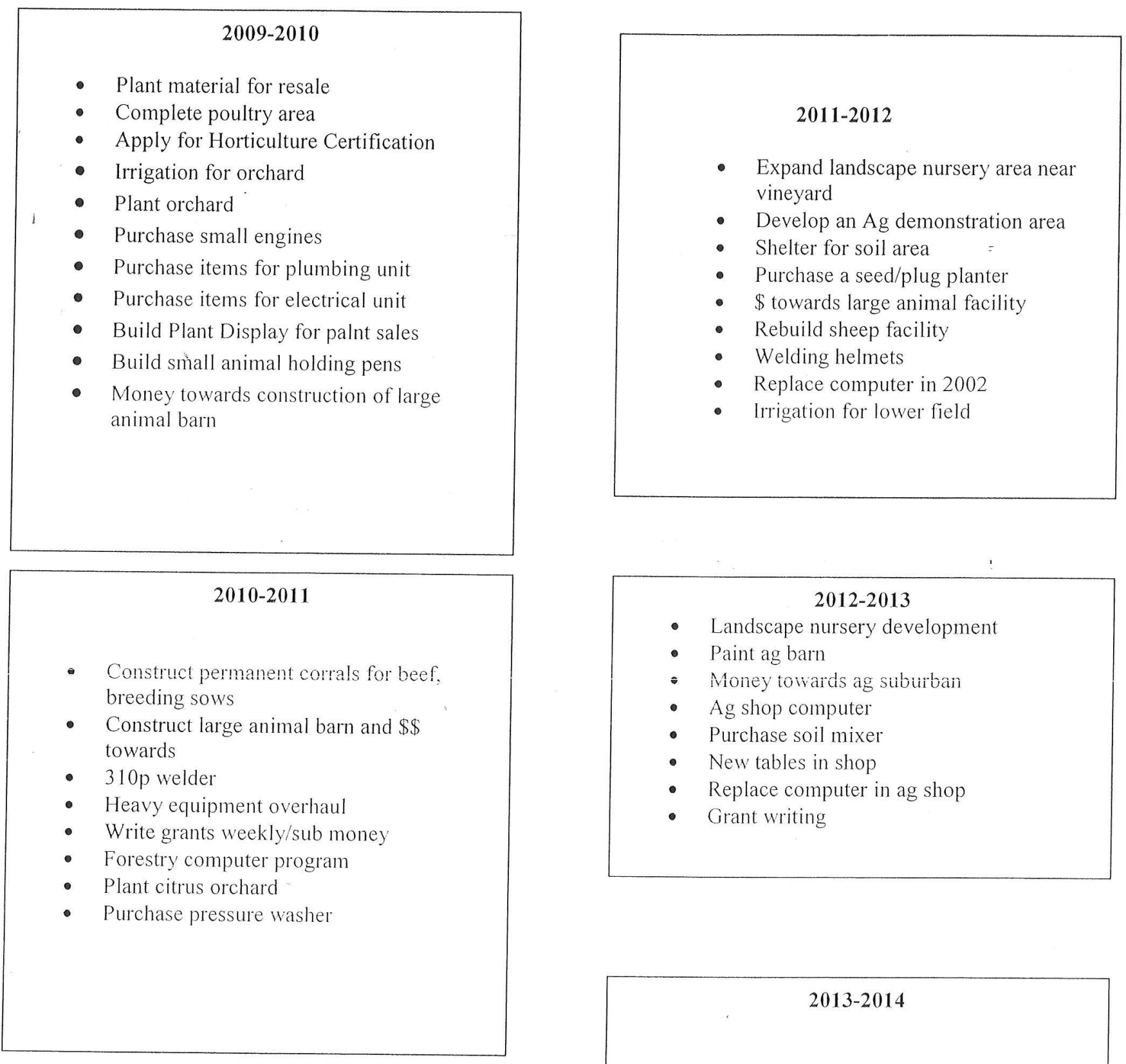

\begin{tabular}{|c|}
\hline 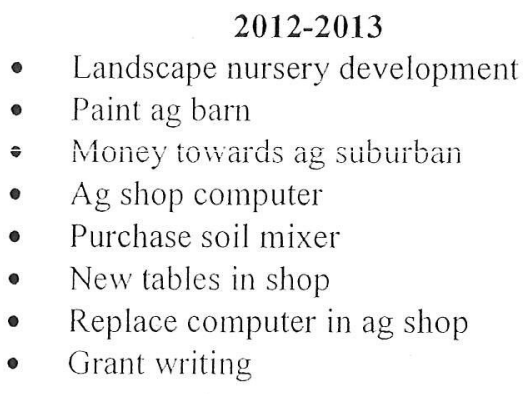 \\
\hline
\end{tabular}

\section{3-2014}

- Excavator

- Money towards ag suburban

- Reseal and patch parking area behind shop

- Grant writing

- Flat filler and conveyor system

- Purchase new floral box 
California Department of Education

AGRICULTURAL CAREER TECHNICAL EDUCATION INCENTIVE GRANT

2011-12 APPLICATION FOR FUNDING

(Due Date: To be received in Regional Supervisor's Office by June 30, 2011)

DATES OF PROJECT DURATION - JULY 1, 2011, TO JUNE 30, 2012

Las Plumas High School

(School Site)
Oroville Union High School District

(District)

Certification: I hereby certify that all applicable state and federal rules and regulations will be observed; that to the best of my knowledge, the information contained in this application is correct and complete; and that the attached assurances are accepted as the basic conditions of the operations in this project/program for local participation and assistance.
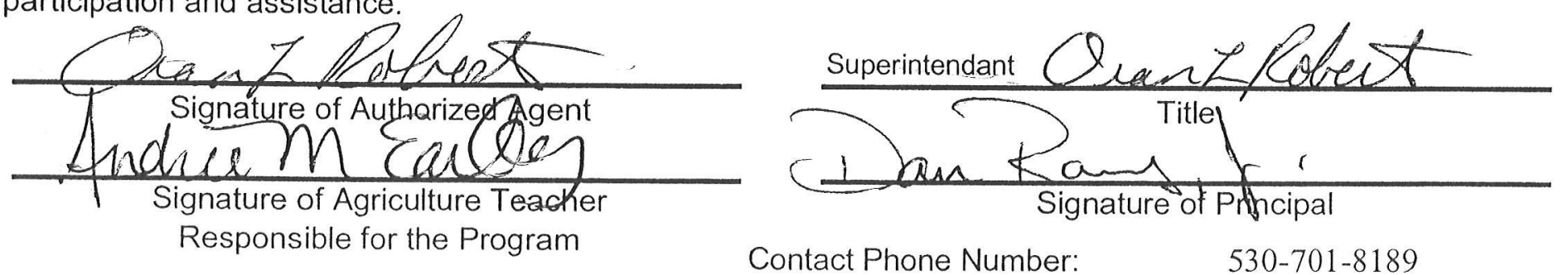

Contact Phone Number:

530-701-8189

Date of Approval of Local Agency Board:

Funds Requested - Part I

Part II

Part III

Part IV

Part $V$

Total

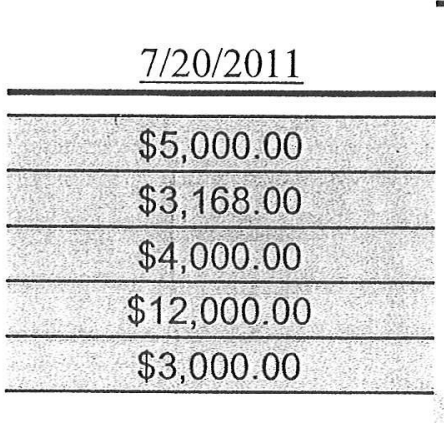

Number of Different Agriculture Teachers at Site:

PART I - QUALITY CRITERIA 1-9 (REQUIRED) ALLOCATION

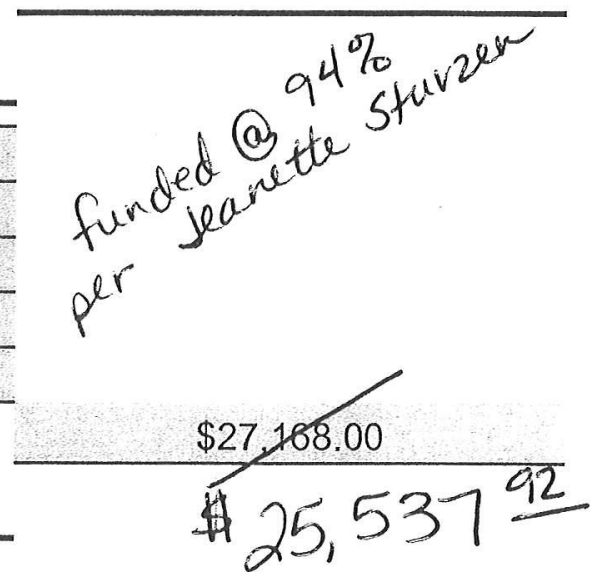

\begin{tabular}{|c|c|c|}
\hline Quality Criteria & $\begin{array}{c}\text { Will Meet } \\
\text { Criteria }\end{array}$ & $\begin{array}{l}\text { Variance } \\
\text { Requested }\end{array}$ \\
\hline 1. Curriculum and Instruction & Yes & \\
\hline 2. Leadership and Citizenship Development & Yes & \\
\hline 3. Practical Application of Occupational Skills & Yes & \\
\hline 4. Qualified and Competent Personnel & Yes & \\
\hline 5. Facilities, Equipment, and Materials & Yes & \\
\hline 6. Community, Business, and Industry Involvement & Yes & \\
\hline 7. Career Guidance & Yes & \\
\hline 8. Program Promotion & Yes & \\
\hline 9. Program Accountability and Planning & Yes & \\
\hline
\end{tabular}

Formal Variance Request must be included if requesting a variance. A variance is a proposed plan for bringing the program into compliance with required quality criteria. Variances should result in compliance prior to the following year's application. All variances must be approved with the application. Non-compliance with the terms of the approved variance will result in a loss of funds. 
PART́ I - CONTINUED

Departmental Allocation: Meeting the criteria in PART I makes the program eligible for the following amounts based on the number of teachers in the program.

\begin{tabular}{lccc} 
Total Number of Teachers & Amount Eligible & Amount Requested \\
\hline One Teacher or Less & $\$ 4,000$ & \\
Two Teachers & $\$ 4,500$ & \\
Three Teachers or More & $\$ 5,000$ & $\$ 5,000.00$
\end{tabular}

PART II - PROGRAM ENROLLMENT ALLOCATION

Total Number of Students 2010-11 R2 Number Amount Requested

List Number from R2 Report (\$8/Member) $\quad 396 \quad \$ 3,168.00$

PART III - SAE AND RETENTION ALLOCATION

Number of State Degrees in 2010

Percent of Students (R2) Receiving

State Degree

$\begin{array}{r}20 \\ \hline 5 \% \\ \hline\end{array}$

SAE/Retention Standard Funds - If percentage of State

Degree recipients is 5 percent or greater, then you are eligible for $\$ 200$ per degree awarded. Maximum of $\$ 10,000$.

$\$ 4,000.00$

\section{PART IV - QUALITY CRITERIA 10-11 (OPTIONAL) ALLOCATION}

Schoals which qualify for a Departmental Allocation may apply for additional amounts for each specific Quality Criteria (10 and 11) met.

* Amounts requested in Quality Criterion 10 will be the indicated amount for that criterion, multiplied by the full-time equivalent (FTE). To count a preparation period, the teacher must be teaching Career Technical Education courses in Agriculture for 50 percent or more of their teaching periods.

* Amounts requested in Quality Criterion $11 \mathrm{~A}$ will be the indicated amount for each teacher who was compensated a minimum of $\$ 2,000$ for year-round employment.

* Amounts requested in Quality Criterion $11 \mathrm{~B}$ will be the indicated amount for each teacher who is provided a project supervision period. Project periods will be counted if the teacher has a preparation period as part of the regular teaching day.

Number of FTE Agriculture Teachers at Site:

4

List the Names of the Agriculture Teachers:

1. James Knapp

\begin{tabular}{l} 
2. Andree' Earley \\
3. Ashleigh Aldridge \\
\hline
\end{tabular}

4. Carlos Diaz

5.

6.

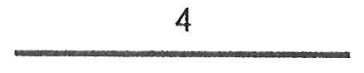

Number Meeting

Amount

Criterion 10 - Student/Teacher Ratio

Criterion 11A - Year-Round Employment

Criterion 11B - Project Supervision Period

$\frac{\text { Criteria }}{1}$

Requested

$\$ 2,000.00$

$\$ 8,000.00$

$\$ 2,000.00$

TOTAL FUNDS REQUESTED PART IV

$\$ 12,000.00$

FART V - QUALITY CRITERION 12 (OPTIONAL) ALLOCATION 
Quality Criterion 12 Form is attached and all criteria has been met. If the answer is yes, list $\$ 3,000$ (funds requesting) in space to the right.

- RT VI - FINANCIAL SCHEDULE

irt A

\begin{tabular}{|c|c|c|c|c|c|}
\hline & & & A & B & C \\
\hline Line & $\begin{array}{l}\text { Acct. } \\
\text { No. }\end{array}$ & Classification & $\begin{array}{l}\text { Description of Item for } \\
\text { Which Funds Will be } \\
\text { Expended }\end{array}$ & $\begin{array}{c}\text { Incentive } \\
\text { Grant Funds }\end{array}$ & $\begin{array}{l}\text { Matching } \\
\text { Funds }\end{array}$ \\
\hline 1 & 4000 & Books \& Supplies & & $11,168.00$ & $11,168.00$ \\
\hline 2 & & & Subtotal for 4000 & $\$ 11,168.00$ & $\$ 11,168.00$ \\
\hline 3 & \multirow[t]{6}{*}{5000} & \multirow{6}{*}{$\begin{array}{l}\text { Services and Other Operating } \\
\text { Expenses such as: Services of } \\
\text { Consultants, Staff Travel, and } \\
\text { Conference; Rentals, Leases, and } \\
\text { Repairs; Bus Transportation }\end{array}$} & 1. Conferences & $5,000.00$ & $5,000.00$ \\
\hline 4 & & & 2. repairs and maintenar & $1,000.00$ & $1,000.00$ \\
\hline 5 & & & 3. barn & $10,000.00$ & $10,000.00$ \\
\hline \multirow[t]{2}{*}{6} & & & 4. & & \\
\hline & & & 5. & & \\
\hline 7 & & & 6. & & \\
\hline 8 & & & Subtotal for 5000 & $\$ 16,000.00$ & $\$ 16,000.00$ \\
\hline 9 & \multirow[t]{5}{*}{6000} & \multirow{5}{*}{$\begin{array}{l}\text { Capital Outlay: Includes Sites and } \\
\text { Improvements of Sites; Buildings and } \\
\text { Improvement of Buildings; Equipment }\end{array}$} & 1. & & \\
\hline 10 & & & 2. & & \\
\hline 1 & & & 3. & & \\
\hline & & & 4. & & \\
\hline 12 & & & 5. & & \\
\hline 13 & & & Subtotal for 6000 & $\$ 0.00$ & $\$ 0.00$ \\
\hline 14 & & & $\begin{array}{c}\text { Total for } 4000-6000 \\
\text { Lines } 2,8,13\end{array}$ & $\$ 27,168.00$ & $\$ 27,168.00$ \\
\hline
\end{tabular}

TOTAL 2011-2012 Incentive Grant Allocation:

$\$ 27,168.00$

Part B - Complete this portion if a waiver of the matching requirement was granted:

\begin{tabular}{|r|r|l|l|l|l|}
\hline Line & $\begin{array}{c}\text { Acct } \\
\text { No. }\end{array}$ & \multicolumn{1}{|c|}{ Classification } & $\begin{array}{l}\text { A } \\
\text { Description of Item for } \\
\text { Which Funds Were } \\
\text { Expended }\end{array}$ & $\begin{array}{c}\text { Incentive } \\
\text { Grant Funds }\end{array}$ & $\begin{array}{c}\text { Amount of } \\
\text { Salary and } \\
\text { Benefits }\end{array}$ \\
\hline 15 & 1000 & Salaries & $\begin{array}{l}\text { Teachers' Summer } \\
\text { Service Salaries }\end{array}$ & & \\
\hline 16 & 1000 & Salaries & $\begin{array}{l}\text { Teachers' Salaries for } \\
\text { Project Supervision } \\
\text { Period }\end{array}$ & & \\
\hline 17 & 3000 & Benefits & $\begin{array}{l}\text { Benefits for the Above } \\
\text { Items (1000) }\end{array}$ & & \\
\hline 18 & & TOTSL & & \\
\hline
\end{tabular}


TOTAL Amount of Waiver Requested: 


\section{AGRICULTURAL CAREER TECHNICAL EDUCATION INCENTIVE GRANT QUALITY CRITERION 12}

Agricultural programs meeting all of the required Quality Criteria (Criteria 1-9) and Criterion 12 may qualify for an additional $\$ 3,000$. This form along with the appropriate verification must be attached to the Agricultural Career Technical Education Incentive Grant Application. The Incentive Grant application is due in the Regional Supervisor's office on June 30, 2011.

Number of Students on Previous Year's R-2 Report: 396

12A Leadership and Citizenship Development

Number of activities on the approved FFA Activity list in which the local chapter participated (must participate in at least 80 percent of 21 the activities)

12B Practical Application of Occupational Skills

Number of students who received the State FFA Degree (must be 20 at least 5 percent of the R2 number)

\section{C Qualified and Professional Activities}

Number of teachers who attended a minimum of five professional inservice activities (must attach approved Inservice Activities 4 Verification Page)

12D Community, Business, and Industry Involvement

Number of meetings held by the local Agriculture Advisory

3 Committee (must be at least three, with minutes attached)

\section{Name of Agriculture Advisory Committee Chair:}

Owen Peterson

Phone Number of Agriculture Advisory Committee Chair:

12E Retention

Number of students who were in their $3 r d$ and 4 th year of

98 agriculture instruction (must be at least 25 percent of the R2

12F Graduate Follow-Up

42 Number of program completers graduating last year

Number of those who graduated who are employed in agriculture,

in the military, or continuing their education (must be at least 75

percent of the program completers). Attach graduate follow-up 34 report. 


\section{ANNUAL FFA CHAPTER ACTIVITIES CHECK SHEET}

\section{Criteria 2e Year $\quad 10-11$ School_Las Plumas High School \\ Must meet at least 12 areas}

\begin{tabular}{|c|c|c|}
\hline LEADERSHIP ACTIVITY & YES & NO \\
\hline Attended State Leadership Conference & 1 & \\
\hline Attended Regional Meeting & 1 & \\
\hline Attended Regional Leadership Conference & $\overrightarrow{1}$ & \\
\hline Attended Greenhand Conference & 1 & \\
\hline Attended Made for Excellence Conference & 1 & \\
\hline Attended Advanced Leadership Academy & 1 & \\
\hline Attended Sacramento Experience & 1 & \\
\hline Participated in Opening-Closing Contest - Sectional & 1 & \\
\hline Participated in Best Informed Contest - Sectional & 1 & \\
\hline Participated in Parliamentary Pro Contests - Sectional & 1 & \\
\hline Participated in Prepared Public Speaking - Sectional & 1 & \\
\hline \multicolumn{3}{|l|}{ Participated in Extemporaneous Speaking - Sectional } \\
\hline Participated in Creed Recitation - Sectional & 1 & \\
\hline Participated in Job Interview Contest - Sectional & 1 & \\
\hline Participated in Agricultural COOP Quiz Contest - Sectional & 1 & \\
\hline Submitted State FFA Degree Application & 1 & \\
\hline \multicolumn{3}{|l|}{ Submitted American FFA Degree Application } \\
\hline Submitted Proficiency Application - Sectional or Regional & 1 & \\
\hline Submitted Chapter Award Application - Sectional or Regional & 1 & \\
\hline Participated in Project Competition - Sectional & 1 & \\
\hline Participated in any FFA Judging Activity (other than above) & 1 & \\
\hline Participated in any other FFA Sectional Activity & 1 & \\
\hline \multicolumn{3}{|l|}{ Participated in Local Leadership Activities ( 3 maximum - list below) } \\
\hline 1 Greenhand Workshop & 1 & \\
\hline 2 Summer Officer Leadership Retreat & 1 & \\
\hline 3 Executive Team Meetings and Trainings & 1 & \\
\hline TOTAL AREAS MET & 21 & \\
\hline
\end{tabular}



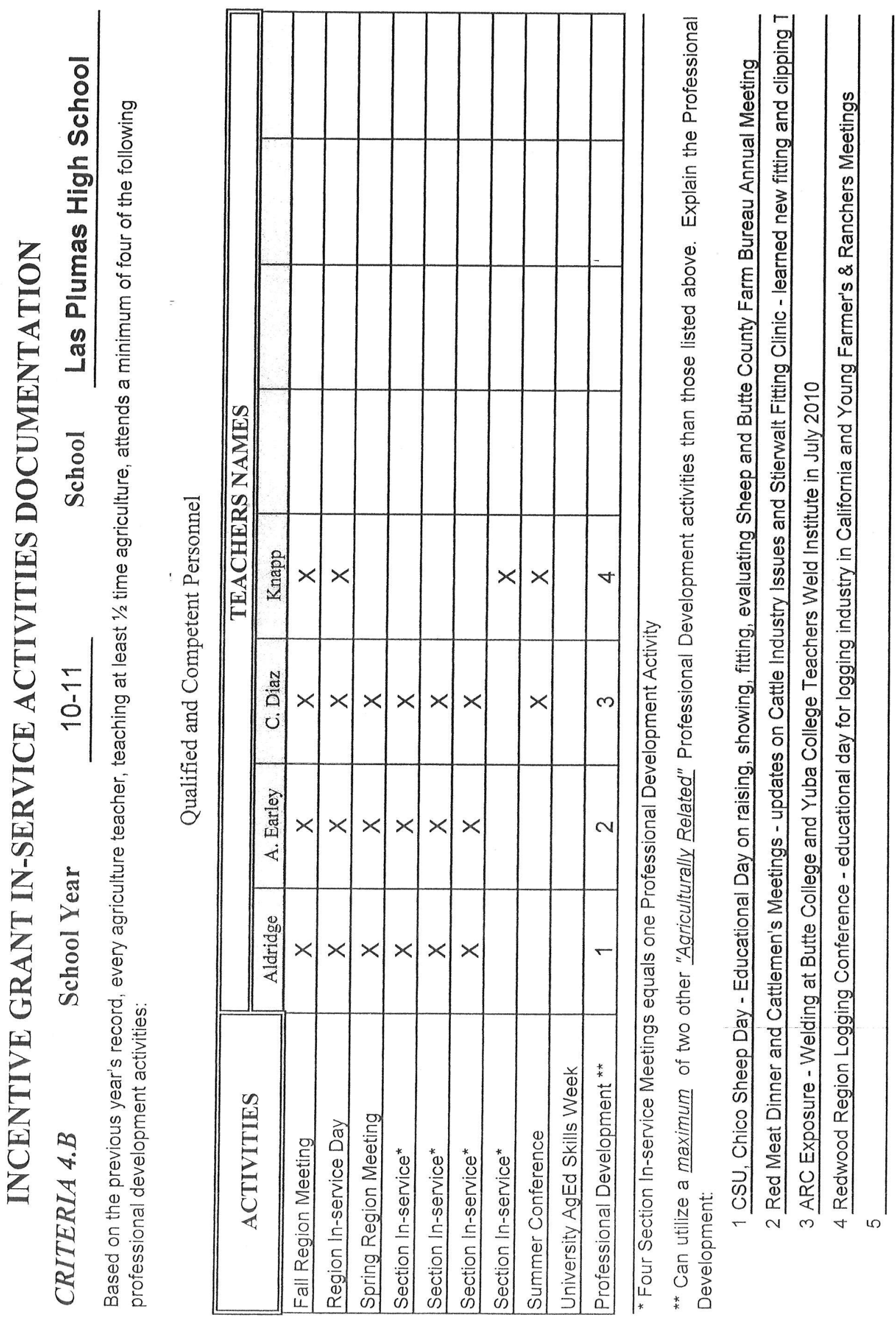
Las Plumas Agriculture Department

Advisory Committee Meeting Minutes

October 5, 2010

6:00pm

Room 2001

The meeting was called to order by Chairperson, Owen Peterson at 6:00 p.m., October $5^{\text {th }} 2010$, in room 2001 at Las Plumas High School Agriculture Department.

The minutes of the previous meeting were read, and approved.

The call for additional items was made.

Introductions of members in attendance included Cindy Quigley (Ag Parent), Susan Watts (Assis. Superintendent of District), Doug Flesher instructor for 52 years, Owen Peterson (Chair) retired Butte College Instructor, Sean Earley, Dave Daley (Agriculture Parent), Steve Lambert, Chuck Crete (MJB representative), Bill Heath (Former agriculture parent), Lyman Hagen (Butte College Instructor) and Agriculture Staff Mr. Diaz, Mr. Knapp, Mrs. Earley, and Ms. Aldridge.

The Agriculture staff walked the Ag Advisory members through our facilities and gave them an update on the new barn that is being put in and groundwork has already started. Maintaining facilities and keeping them looking good. Mr. Diaz is working on getting our big barn cleared so we can drive through. Dr. Daley asked about a anticipating date for the barn to be up. Mrs. Earley thought she would hope to see it up by the $1^{\text {st }}$ of the year. We might have to change the size of the barn depending on the fficial bid for the barn.

Mrs. Earley reported on the great news that our Administration had our second and only project period left on the chopping block for the upcoming Board meeting but is taking it off using one-time funds. It will be an issue we have to address every year.

Mrs. Earley also discussed about scheduling an upcoming ROP Advisory meeting.

Ms. Aldridge discussed how her animal science class is at full capacity at 35 students and how they are just starting on animal feeds \& nutrition and after the quarter ends they will begin halter breaking the steers and learning about animal reproduction. College Ag Biology two sections at 35 each. I also have two sections of Ag Life Science classes at around 30 students in each.

Mrs. Earley reported that her Horticulture class is doing great because of a student teacher that can be more hands on with them. Ag Life science has about 30 and Ag Leadership and Vet skills class combined. The combo classes are difficult.

Mr. Knapp discussed about how his horticulture class has been working on cleaning up around and landscaping around the agriculture department and working on getting our greenhouses functional. Mr. Knapp announced that his Agriculture Earth has average 35 students in each section and one with 38. Mr. Knapp thinks are numbers are because of our recruiting in the spring. Mr. Knapp reported that we have two floral classes at around 33 students each. Mrs. Earley teaches one and Mr. Knapp teaches the ther.

Mr. Diaz reported on how are Ag Mechanics II 26 students, Ag Mechanics I two sections at 35 students each. ROP Heavy Equipment has 15 gentlemen and it's a good class. They have been trying to solve the 
leak in the Agriculture department when we get it fix we can celebrate with a BBQ. Mr. Diaz brought to the attention that he was looking for an inverter multipurpose it takes a lot of economic cost to buy and plus eliminates two more machines. Owen reported that he does like to have diversity with different welders in the Ag Shop but that Carlos should try to utilize your funding to buy more welders. Mr. Diaz reported that he mainly wanted it for space requirements and brings another TIG machine and giving my students a little more opportunity. Mr. Knapp reported that we may need to look at restructuring and designing the Agriculture Shop.

The recommendation of the group would be to maybe look at upgrading what you have. Owen and Chuck volunteered to walk through the shop with Mr. Diaz and come up with a list of possible changes that would help maximize space and provide the most opportunity to the students in the Mechanics departiment.

Mr. Diaz also discussed with members about setting a date for an ROP Heavy Equipment meeting later.

Mrs. Earley reported the Jeanette our regional supervisor is visiting our high school for Ag Incentive Grant review on the $14^{\text {th }}$ at 10:00 a.m. Andree is also working on getting our $\mathrm{R}-2$ data finalized that is due by the $15^{\text {th }}$.

Mrs. Earley talked about upcoming FFA Activities that our chapter is participating in including Shasta College Field Day which Mr. Diaz is chaperoning students. LP is taking a Farm Power, Specialty Animal, Livestock Judging, Horticulture, Floriculture, and Forestry Teams to Shasta College Field Day. Mrs. Earley and student teacher Miss. Yates are taking eleven Juniors \& Senior students interested in majoring in Agriculture or attending/transferring to Chico State to Ag Unplugged. Mrs. Earley also informed the advisory members that this year we are holding our own local Opening \& Closing Contest November $1^{\text {st }}$ at $5 \mathrm{p.m}$. if any of them are interested in observing or possible being judges. The actual ,ectional contest isn't until Nov. $18^{\text {th }}$ and we will take the top two scoring individuals for each office and form our two novice teams. Our Fall Drive Thru BBQ is going to be held on November $17^{\text {th }}$, and that is the same weekend that our Fall Plant sale is going to be Nov 19-20 ${ }^{\text {th }}$. Mrs. Earley also reported that she is taking a couple interested freshman \& sophomores that are exhibiting steers to Stierwalt Fitting Clinic on November $19-20^{\text {th }}$. Students have to pay $\$ 350$ registration cost and have their own animal halter broke and chute ready to take down their by then. Mrs. Earley also informed our Advisory that our Winter Degree Banquet will be held on December $15^{\text {th }}$.

Mrs. Earley reported that she would also be attending the National FFA Convention on the 20th with a five of our students who received their American FFA Degrees. The following students received their American degrees this year Julia Brown, Kate Daley, Stephanie Fairbank, Michelle Lindsey, Mario Mastelotto, Todd Quigley, Ashley Van Buren, Jacqlyn Van Buren, and Melissa Watkins.

Mr. Peterson asked about the Oroville High School Agriculture Department. Cliff is wanting to join Ag Advisory and making it more district wide program.

The next meeting is scheduled for Wednesday November $10^{\text {th }}$ (a) 5:30 p.m. discuss Steak \& Crab Feed Fundraiser. Spring Ag Advisory Friday May $20^{\text {th }}$ ( $)$ 4:30 p.m.

The meeting was adjourned at 7:40 p.m. by Chairperson Owen Peterson.

Respectfully Submitted, ils. Aldridge, Recorder 


\section{AGENDA}

1. Review and approve minutes of the previous meeting.

2. Call for additional agenda items to be added to this meeting's agenda

3. Introductions

4. Facilities Update and walk thru

5. Report on Classes and Class numbers and suggestions

a. Earley - great news from Admin on Project Periods, ROP Meeting

b. Aldridge - Animal Science Update

c. Knapp - Horticulture Update

d. Diaz - Ag Mech Update and Purchase Options, ROP Meeting

6. Report and review of F.F.A Activities and suggestions

a. R-2 Review - Jeanette Visit October 14 ${ }^{\text {th }} @$ 9:00am

b. Shasta College Field Day, Ag Unplugged, Local Sectional Contest Nov $1^{\text {st }}$, Drive Thru BBQ Nov

$17^{\text {th }}$, Plant Sale Nov 19-20, Stierwalt Clinic Nov 19-21, Winter Degree Banquet December 15

c. American Degree Recipients - Julia Brown, Kate Daley, Stephanie Fairbank, Michelle Lindsex,

\section{Mario Mastelotto, Todd Quigley, Ashley Van Buren, Jacqlyn Van Buren, Melissa Watkins}

7. Other Agenda Items

8. Set date, time, and place Steak and Crab Feed Meetings.

8. Set date, time, and place for next meeting

10. Adjournment. 
Las Plumas Agriculture Department

Steak \& Crab Feed/ Ag Advisory Meeting Minutes

Date: January $4^{\text {th }}, 2011 @$ 5:30 p.m.

The meeting was called to order by Chair Owen Peterson at 5:30 p.m.

Introductions followed: Agriculture Department Teachers- Mr. Knapp, Mrs. Earley, Mr. Diaz, and Ms. Aldridge. Chair Owen Peterson, Yvette Castanon (parent), Susan Bertis (parent).

Mrs. Earley started with the upcoming big fundraiser. Our $9^{\text {th }}$ Annual Steak \& Crab Feed Leadership dinner coming up on January $29^{\text {th }}$, 2011. Owen reported that he would not be there to pick up the crab, so we are asking another student parent to go pick up the crab the day of the dinner. Mrs. Earley reported we currently have 100 tickets sold with money brought in and another 80 out at Lal berts feed store \& Butte County Fair office. We are down on ticket sales for the time being but are hopeful we will sell all 400. Susan volunteered to take ten tickets home and sell them. Owen reported we should contact Butte College again about purchasing tickets.

Ms. Aldridge reported that corporate donations were down this year and we have received a lot of gift certificates. We need more actual items for raffle and to put in our baskets. Owen said he would go to DIRKS transmission and ALL METALS but someone might have to pick up the items since he is leaving mid this week. The annual basket making donation party was set for January 26 ${ }^{\text {th }}$, Wednesday @ 5:30. Show up whenever and bring any donations you have collected bring them that night.

The meeting was adjourned by Owen Peterson at 6:15p.m. The next Ag Advisory meeting is TBA. An email will be sent to all Ag Advisory members.

Submitted by

Ashleigh Aldridge

Agriculture Teacher 
Las Plumas Agriculture Department

Advisory Committee Meeting Minutes

June6,2011@5:30p.m.

Our Spring Advisory Committee meeting was held on Monday June $6^{\text {th }}$ at local restaurant in Oroville and was called to order at 5:30 p.m. Roll was taken and committee members in attendance were Chuck Crete, Doug Flesher, Steve Lambert, Bill Heath, and Sean Earley, all agriculture instructors were also present Andree Earley, Ashleigh Aldridge, Carlos Diaz, and Jim Knapp.

Andree made a call for additional items to be added to the agenda at this time and at that time nothing needed to be added. The first main agenda item was a re-cap of Silver Dollar Fair in May. Andree and Ashleigh both spoke of how this was the best fair so far for Las Plumas FFA. We had numerous animal projects that did outstanding. Rachel Castanon won her market class and was third in Swine showmanship. In the sheep ring 6 out of the top 8 in showmanship drive. Five out of the six in the Champion drive were Las Plumas FFA students. Las Plumas won FFA Champion and FFA Reserve Champion Lamb. Las Plumas student also won Reserve Grand Champion market lamb. Sonia Ceja also won sheep showmanship. In the beef ring we reciprocated what happened in the sheep ring. We had Stacy Ogletree win Beef showmanship and Meghan Lambert win FFA Reserve Champion Market Steer. For our breeding goat exhibitors we had 7 out of 8 in the final drive in showmanship and Sonia Ceja also won Goat showmanship. Our meat pens did great. We also had numerous educational class posters, a landscape booth that took $1^{\text {st }}$, educational display that took $2^{\text {nd }}$, and numerous wine barrel and ag mechanics projects entered that did quite well. Las Plumas also took home Clean Barn \& Public Image award in Sheep, Goats, and Beef.

The next fair coming up and on our agenda that was discussed was the Butte County Fair. We are working with getting entries from students before school gets out. It is looking like we will have 8 steers, 10 lambs, 2 goats, and about 5 hogs. We will also be exhibiting a booth and taking some ag mechanics projects over to the fair. The fair this year is the first week of school.

Our Master schedule for next year we discussed and a lot of our elective classes we are having to combine in order to meet the \#'s needed in order to make the class (around 30-36 students). As of right now Ag Mech II will be backfilled with Ag Mech I students in order to meet the number requirements. The Ag Advisory committee would like to address this issue with the Superintendent about both a safety issue and it not being good for Ag Mech II students who will be learning same material.

Andree next discussed how we will be sharing our project period for next year as we did for this year because we lost a project period last year. The project period funding for the future is unknown since we are using one time monies in order to pay for the project period.

Our Barn is being started with the footings and will hopefully be up by next school year although we are hoping by the end of July. We are asking Ag Advisory members for help in the fall with adding the finishing touches, water, electrical, fencing, etc. If we could get as much help as possible from $\mathrm{Ag}$ Advisory members to help Diaz 
classes to make sure it is completed correct and in a timely manner before we get the steers in October.

Under Teacher Updates Knapp announced how his Forestry team placed $1^{\text {st }}$ in state and is qualified and will be making the trip to National convention in October along with Ms. Aldridge and our top 2 sophomores and top 2 juniors will also be attending National Convention. He also announced how his Horticulture team came in second by only 40 point difference and that contest is a little bit more challenging. Knapp also described our new recruitment that we did for this year by bringing the $8^{\text {th }}$ graders to our campus about three times this year. We also tried to focus on in-house recruitment by doing a three week switch around to show students what other classes had to offer. However, we are undecided on if it was as successful we will get it one more year and then adapt the program if needed.

Mr. Diaz informed the Ag Advisory that his classes are going great. He also informed them about the name change of his ROP class that would allow more opportunity for placing students in the spring. All students will still learn how to operate heavy equipment except it will be a more farm management class and we will be allowed to place students in areas on our school farm in the spring.

Mrs. Earley informed the Ag Advisory that her Specialty Animal team that qualified for state actually did quite well and placed in the top 10 out of like 60 teams at State Finals at Cal Poly in May. It is a contest that goes of the curriculum from her ROP Vet skills class the only component we need to work on is rabbit judging since it is half the points.

Andree also discussed our plan for her maternity leave she will be teaching three days and Matt (a student teacher from Chico) will be there the three days she will be and cover the other two days she is gone. This way it isn't just a sub coming in but a person that will be tied to our department and we feel will benefit our program more.

There were no additional items added and the meeting was adjourned around 7:00 p.m.

Respectfully submitted

Ashleigh Aldridge 


\section{Graduate Follow-up Report \\ Year $=2010$}

\# CA0166 Oroville - Las Plumas

Las Plumas HS

2380 Las Plumas Ave.

Oroville, CA 95966

Printed: 6/27/2011 11:28:20 AM

\begin{tabular}{|l|l|}
\hline $\begin{array}{l}\text { Total Seniors (Year=2009 ): } \\
\text { Total Seniors having completed } \\
3 \text { or more years of Ag Instruction: }\end{array}$ & 53 \\
\hline \multicolumn{2}{|l|}{ Program Completer Status } \\
\hline Two Year College Ag Major & 5 \\
\hline Two Year College Non-Ag Major & 15 \\
\hline Four Year College Ag Major & 3 \\
\hline Four Year College Non-Ag Major & 2 \\
\hline Employed - Parttime Ag Job & 4 \\
\hline Employed - Parttime Non-Ag Job & 4 \\
\hline Employed - Fulltime Ag Job & 5 \\
\hline Employed - Fulltime Non-Ag Job & 3 \\
\hline Location or Position Unknown & 1 \\
\hline
\end{tabular}

CalAgEd Home | R-2 Home | R-2 Online Home | Roster | Teacher | FAQ | Help | Log $\underline{\text { Out }}$

Site developed and maintained by ATI Net, California State University, Fresno with funds from the California Department of Education, Agricultural Education Unit. 


\section{NEW FACILITIES}

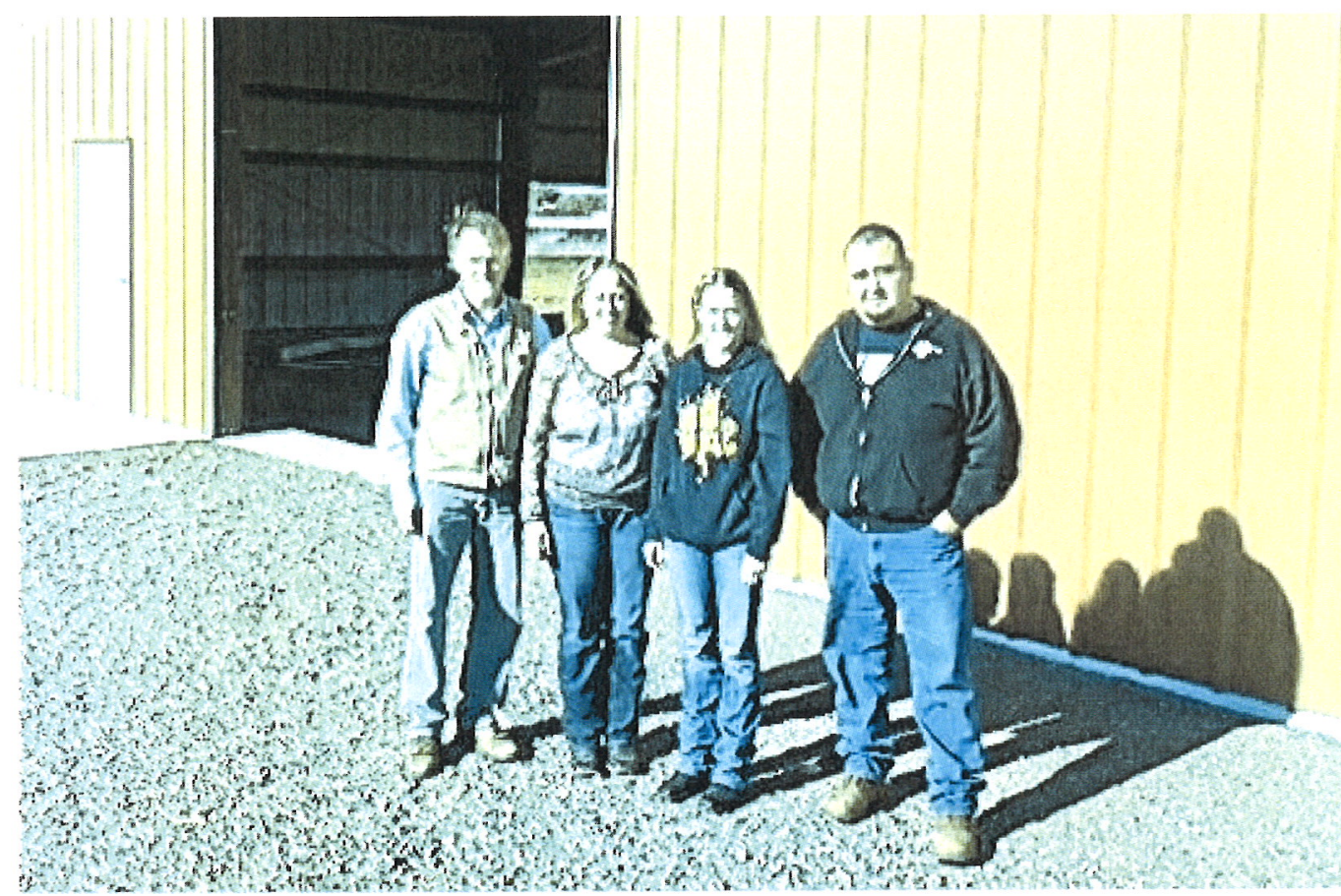

Prop 1D Funding: New Animal Project Barn. Constructed in March 2012 and our ROP Heavy Equipment class has been adding improvements such as pen runs for beef cattle, cement slabs, and water troughs for animal projects.

Goals for 2012-13 school year will be getting water lines in and extended pen runs for other animals such as sheep. Also work on purchasing mats for cattle en areas.

\section{Horticulture Gireenhouse \& Old Barn:}

We reconstructed the greenhouse from frames. We also re-painted all the exterior buildings on our school farm including the equipment barn, hog barn, sheep barn, and chicken coop. We also painted our feed holding tank which gives the school farm a more cohesive look.

It is more appealing to the ommunity who comes to our local plant sales twice a year.

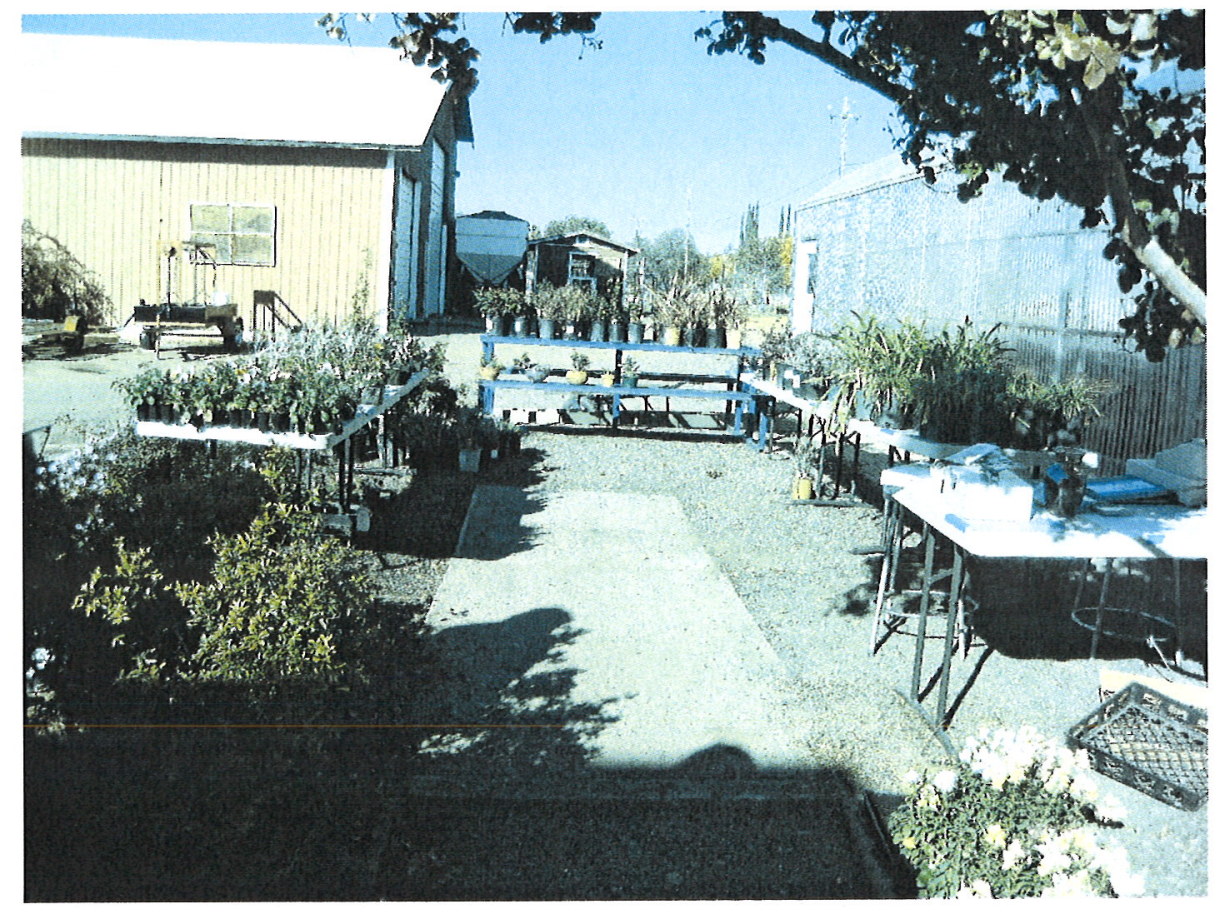




\section{Quality Criteria Six: \\ Community, Business and Industry Involvement}

Individuals who represent the community, business, industry, students, parents, districts, staff, post-secondary agencies, and labor serve on a subject area advisory committee to provide guidance. Staff uses the advice of the advisory committee in the design, development, operation, evaluation and support of each program area.

The Agriculture Advisory Committee at Las Plumas High School is comprised of a blend of industry representatives from mechanics, plant, animal, and Ag Business backgrounds, as well as post-secondary agriculture instructors from Butte-Glenn Community College. It is a minimum requirement that this committee meets twice a year, and more as needed. The committee is active and involved in giving valuable suggestions and advice to agriculture staff, and has met on average 3-5 times per year the past couple of years. The committee plays a vital role in making sure our curriculum is relevant, but provides SAE/FFA opportunities to our students with the many agriculture business contacts that they share with us. One member on the committee is the Head of Planning and development for the school district and has played a major role in expediting the process of our new Beef Facility.

Due to a recent need for a rapidly growing multi-person program, there have been sub-committees formed to address specific issues and directions to better serve our students. There are currently four sub-committees in the department: ROP Equipment Operation, Agriculture Mechanics/Welding, Ornamental Horticulture, and most recent Animal Science/Vet Skills.

Our theme for this year's officer is "Absolutely Agriculture" and we have presented at each meeting a commodity of the month, facts about that commodity, and an activity that relates to that commodity. During FFA week our commodity was "Beef," and as part of their support with our local fundraiser we honored the Butte County Cattlemen's at our February meeting. We also had a guest speaker who is about as current in the industry Dr. Dave Daley from CSU Chico come talk to our students about beef production, and how they can be lobbyist for Agriculture and the beef industry.

\section{Evidence Documents Include:}

- Samples of interactions with industry and community supporting program integration with industry and community: Contact Lists, ROP business partner/student placement visitation log.

- Involvement with CSU Chico and Butte Community College. 


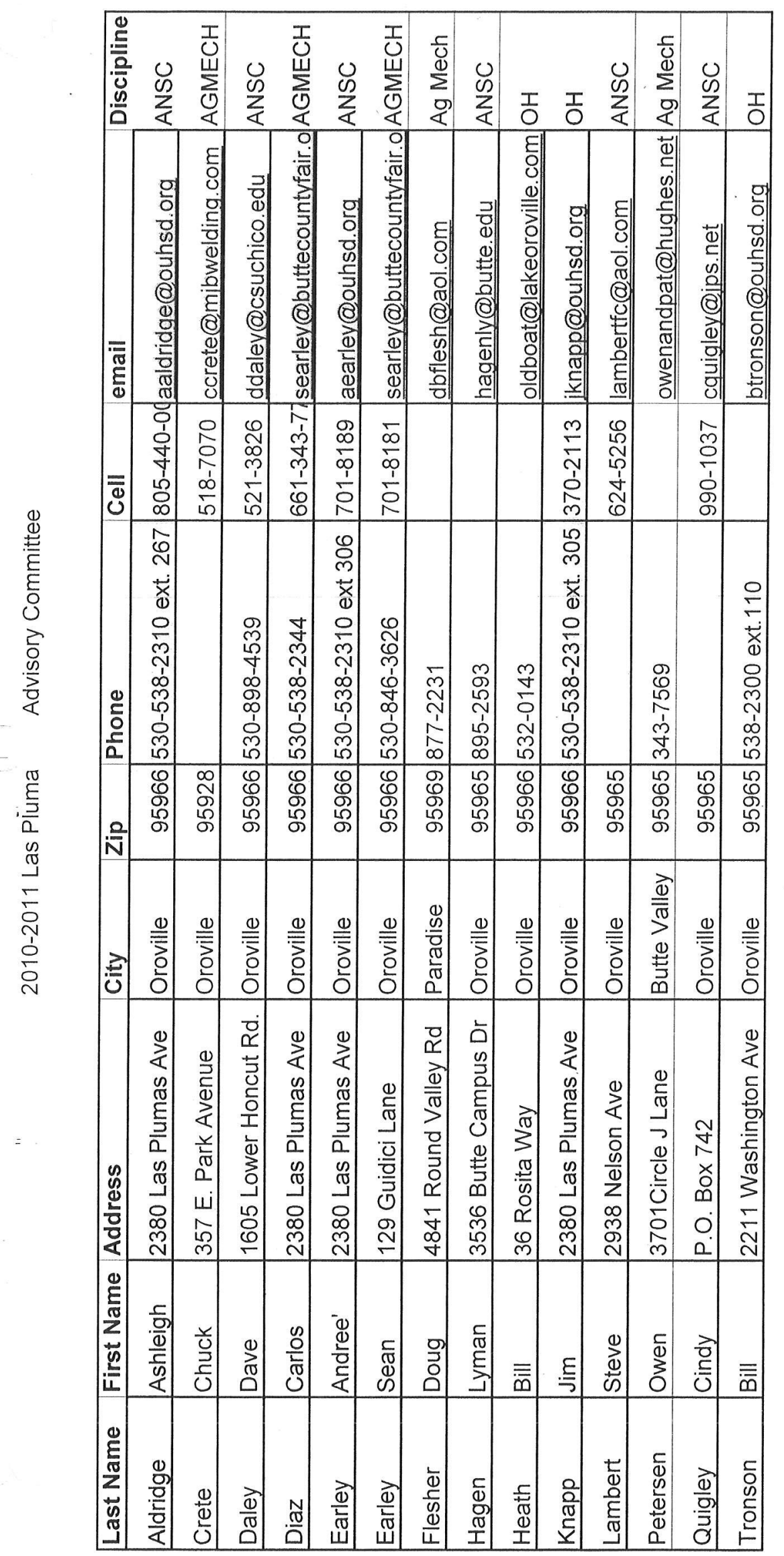




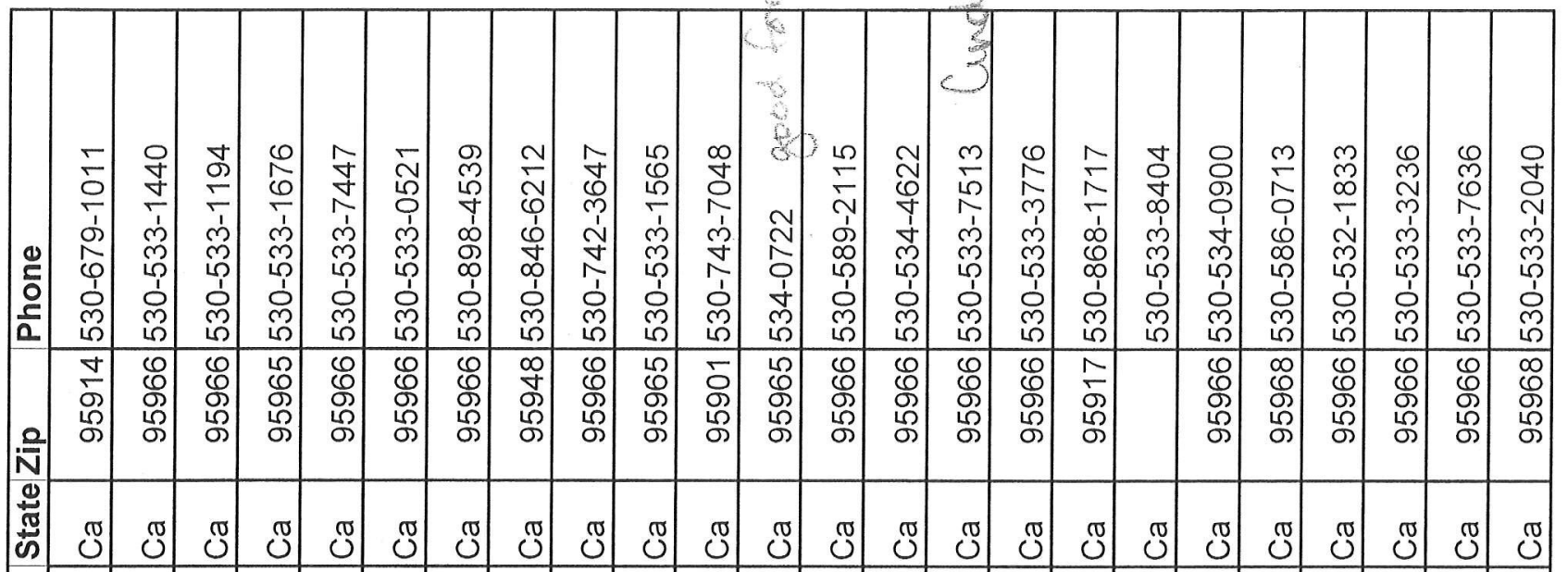

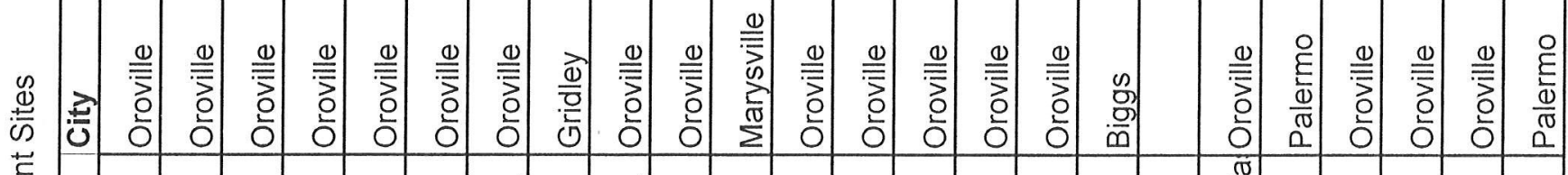

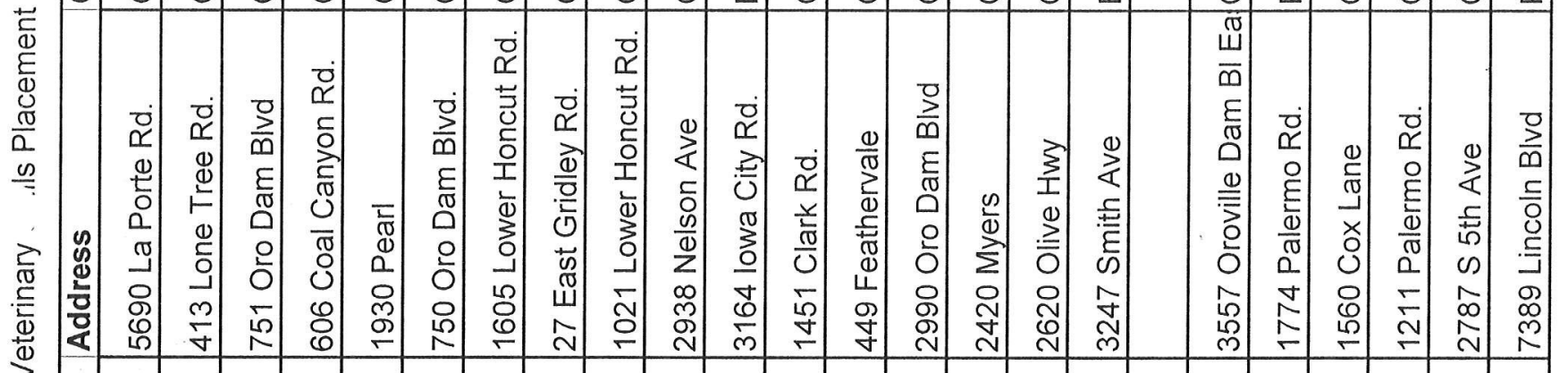

$\frac{1}{0}$
$\frac{0}{5}$
0
0
0

\begin{tabular}{|c|c|c|c|c|c|c|c|c|c|c|c|c|c|c|c|c|c|c|c|c|c|c|c|}
\hline 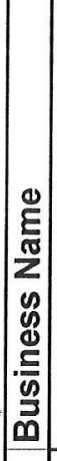 & 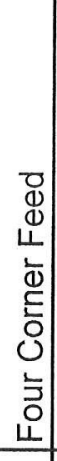 & 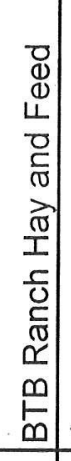 & 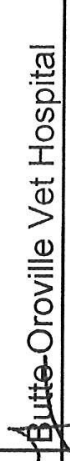 & 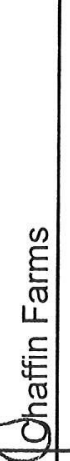 & 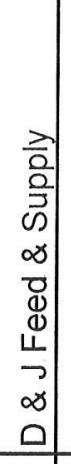 & 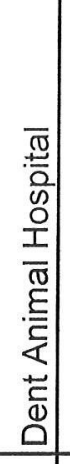 & 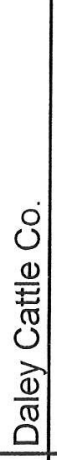 & 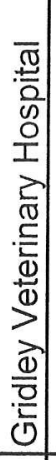 & 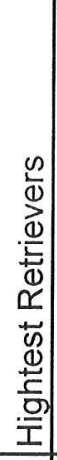 & 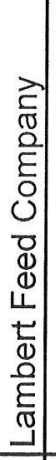 & 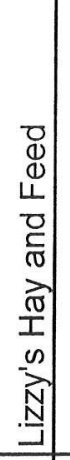 & 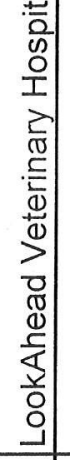 & 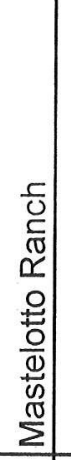 & 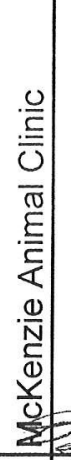 & 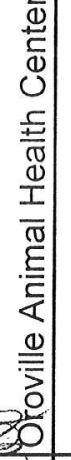 & 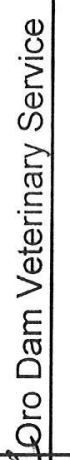 & 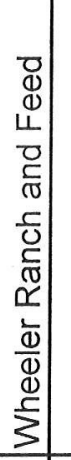 & 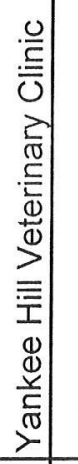 & $\begin{array}{l} \\
\\
\infty \\
3 \\
\vdots \\
0\end{array}$ & 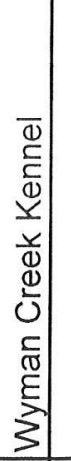 & 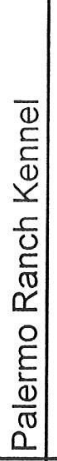 & 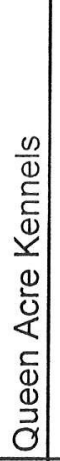 & 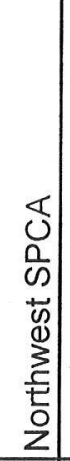 \\
\hline 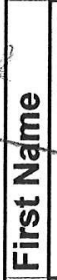 & 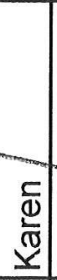 & & $\begin{array}{c}5 \\
5 \\
5 \\
0 \\
0 \\
0 \\
5 \\
5\end{array}$ & $\begin{array}{l}\overline{0} \\
\frac{0}{0} \\
0 \\
\vdots \\
\bar{t} \\
\bar{y}\end{array}$ & 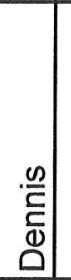 & $\begin{array}{c}\overline{3} \\
0 \\
0\end{array}$ & 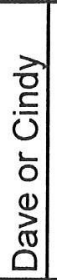 & 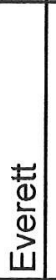 & 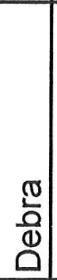 & 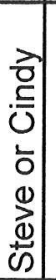 & $\frac{\sqrt[N]{ }}{J}$ & $\begin{array}{l}. \frac{9}{\pi} \\
\frac{\pi}{0}\end{array}$ & 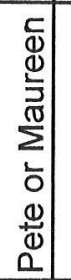 & 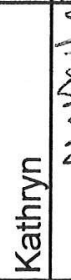 & $\begin{array}{l}\frac{3}{2} \\
\frac{\partial}{x}\end{array}$ & इ & $\begin{array}{l}\text { 듬 } \\
\underline{\mathbb{N}}\end{array}$ & 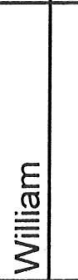 & \begin{tabular}{l|l}
0 \\
$z$ \\
$\Sigma$
\end{tabular} & $\begin{array}{l}\overline{\mathbb{D}} \\
\stackrel{\Phi}{\vdash}\end{array}$ & & & \\
\hline 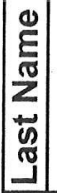 & $\begin{array}{l}\frac{4}{3} \\
\text { I }\end{array}$ & & $\begin{array}{l}\bar{x} \\
0 \\
0 \\
\frac{y}{\bar{D}} \\
0\end{array}$ & 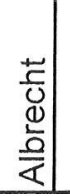 & 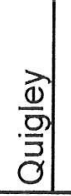 & 苛 & $\frac{\frac{\overrightarrow{0}}{\sigma}}{0}$ & $\begin{array}{l}5 \\
\frac{5}{3} \\
0 \\
0\end{array}$ & $\begin{array}{c}E \\
0 \\
0 \\
0 \\
\text { ㄴ. }\end{array}$ & 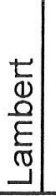 & $\begin{array}{l}0 \\
0 \\
0 \\
0 \\
3\end{array}$ & $\begin{array}{l}5 \\
0 \\
0 \\
0\end{array}$ & $\begin{array}{l}0 \\
\pm \\
0 \\
\frac{0}{0} \\
\stackrel{0}{0} \\
\Sigma\end{array}$ & $\begin{array}{l}\frac{d}{N} \\
\frac{1}{d} \\
\frac{1}{2} \\
\sum\end{array}$ & $\begin{array}{l}\stackrel{0}{c} \\
0 \\
0 \\
3 \\
\sum \\
\sum\end{array}$ & 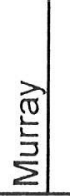 & $\begin{array}{l}\frac{0}{0} \\
0 \\
\frac{1}{3}\end{array}$ & 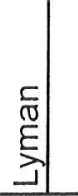 & $\begin{array}{l}\overrightarrow{3} \\
\overline{0} \\
\stackrel{0}{0} \\
\frac{1}{0}\end{array}$ & $\begin{array}{l}0 \\
\frac{0}{0} \\
\frac{1}{5} \\
\frac{1}{2}\end{array}$ & & & \\
\hline
\end{tabular}




\section{October Chapter Meeting Minutes Ag Barn October $10^{\text {th }}, 2011$ at Lunch}

Meeting started at 12:18 pm

Aimee Alexander opened the meeting, introduced the theme of the meeting. "Doing what we love, loving what we do, Fall Harvest" The treasurers report was read by Kenny Saephan described our expenses for Greenhand Workshop. It was moved by Megan Adams and seconded by Anthony Sierra.

The Secretary's minutes was read by Clistie Acosta. It was moved by Megan Adams and seconded by Jon Jones.

Jessica Cain, the Recruitment Chair, explained her meeting on Tuesday October $11^{\text {th }}$. Saying if you are interested in recruiting eighth graders you must attend all meetings. Meghan Lambert, the Fundraising Chair, announced the Arboune sales started. It was announced at the last Fundraising meeting. Savannah Sherwood, the Incentive committee, announced to keep coming to the meetings to vote on the top five ideas. Megan Adams, Community Service Chair, declared the "Save a Life" soda tops is now a competition between all the classes, the winning class gets root beer floats. Marlee Little, the Fair Chair, announced that there are two more meetings until the end of semester for showing requirements.

In New Business Hannah Hurte talked about Greendhand Conference. She said she had a lot of fun and learned a lot about FFA and how she can get involved. In Old Business Aimee talked about National Convention and how the Forestry teamis going to compete and a few kids to watch the national officers get installed. Hannah talked about Cow Palace on the $14^{\text {th }}$. It is to make kids better showman in San Francisco. Alexis announced on the $28^{\text {th }}$ Oakdale kids are coming to hunt for pumpkins for her SAE. Mrs. Earley talked about the Local Opening and Closing Contest and how it will be ran with the top officer of each office moving on to Colusa. Jon Jones talked about Shasta College Field Day on the $13^{\text {th }}$. They are taking all the new tcams in an effort to practice their skills and ineet other kids from different chapters. hand.

Aimee then closed the meeting and everyone got and October themed popcorn

The meeting closed at $12: 37 \mathrm{pm}$ 
Las Plumas Agriculture Department

Advisory Committee Meeting Minutes

June 6,2011@5:30p.m.

Our Spring Advisory Committee meeting was held on Monday June $6^{\text {th }}$ at local restaurant in Oroville and was called to order at 5:30 p.m. Roll was taken and committee members in attendance were Chuck Crete, Doug Flesher, Steve Lambert, Bill Heath, and Sean Earley, all agriculture instructors were also present Andree Earley, Ashleigh Aldridge, Carlos Diaz, and Jim Knapp.

Andree made a call for additional items to be added to the agenda at this time and at that time nothing needed to be added. The first main agenda item was a re-cap of Silver Dollar Fair in May. Andree and Ashleigh both spoke of how this was the best fair so far for Las Plumas FFA. We had numerous animal projects that did outstanding. Rachel Castanon won her market class and was third in Swine showmanship. In the sheep ring 6 out of the top 8 in showmanship drive. Five out of the six in the Champion drive were Las Plumas FFA students. Las Plumas won FFA Champion and FFA Reserve Champion Lamb. Las Plumas student also won Reserve Grand Champion market lamb. Sonia Ceja also won sheep showmanship. In the beef ring we reciprocated what happened in the sheep ring. We had Stacy Ogletree win Beef showmanship and Meghan Lambert win FFA Reserve Champion Market Steer. For our breeding goat exhibitors we had 7 out of 8 in the final drive in showmanship and Sonia Ceja also won Goat showmanship. Our meat pens did great. We also had numerous educational class posters, a landscape booth that took $1^{\text {st }}$, educational display that took $2^{\text {nd }}$, and numerous wine barrel and ag mechanics projects entered that did quite well. Las Plumas also took home Clean Barn \& Public Image award in Sheep, Goats, and Beef.

The next fair coming up and on our agenda that was discussed was the Butte County Fair. We are working with getting entries from students before school gets out. It is looking like we will have 8 steers, 10 lambs, 2 goats, and about 5 hogs. We will also be exhibiting a booth and taking some ag mechanics projects over to the fair. The fair this year is the first week of school.

Our Master schedule for next year we discussed and a lot of our elecilve classes we are having to combine in order to meet the \#'s needed in order to make the class (around 30-36 students). As of right now Ag Mech II will be backfilled with Ag Mech I students in order to meet the number requirements. The Ag Advisory committee would like to address this issue with the Superintendent about both a safety issue and it not being good for Ag Mech II students who will be learning same material.

Andree next discussed how we will be sharing our project period for next year as we did for this year because we lost a project period last year. The project period funding for the future is unknown since we are using one time monies in order to pay for the project period.

Our Barn is being started with the footings and will hopefully be up by next school year although we are hoping by the end of July. We are asking Ag Advisory members for help in the fall with adding the finishing touches, water, electrical, fencing, etc. If we could get as much help as possible from Ag Advisory members to help Diaz 
classes to make sure it is completed correct and in a timely manner before we get the steers in October.

Under Teacher Updates Knapp announced how his Forestry team placed $1^{\text {st }}$ in state and is qualified and will be making the trip to National convention in October along with Ms. Aldridge and our top 2 sophomores and top 2 juniors will also be attending National Convention. He also announced how his Horticulture team came in second by only 40 point difference and that contest is a little bit more challenging. Knapp also described our new recruitment that we did for this year by bringing the $8^{\text {th }}$ graders to our campus about three times this year. We also tried to focus on in-house recruitment by doing a three week switch around to show students what other classes had to offer. However, we are undecided on if it was as successful we will get it one more year and then adapt the program if needed.

Mr. Diaz informed the Ag Advisory that his classes are going great. He also informed them about the name change of his ROP class that would allow more opportunity for placing students in the spring. All students will still learn how to operate heavy equipment except it will be a more farm management class and we will be allowed to place students in areas on our school farm in the spring.

Mrs. Earley informed the Ag Advisory that her Specialty Animal team that qualified for state actually did quite well and placed in the top 10 out of like 60 teams at State Finals at Cal Poly in May. It is a contest that goes of the curriculum from her ROP Vet skills class the only component we need to work on is rabbit judging since it is half the points.

Andree also discussed our plan for her maternity leave she will be teaching three days and Matt (a student teacher from Chico) will be there the three days she will be and cover the other two days she is gone. This way it isn't just a sub coming in but a person that will be tied to our department and we feel will benefit our program more.

There were no additional items added and the meeting was adjourned around 7:00 p.m.

Respectfully submitted

Ashleigh Aldridge 


\section{Las Plumas Agriculture Department \\ Advisory Committee Meeting \\ June 6, 2011 \\ $5: 30 \mathrm{pm}$}

\section{Tong Fong Low's \\ Oroville}

\section{AGENDA}

1. Review and approve minutes of the previous meeting.

2. Call for additional agenda items to be added to this meeting's agenda

3. Introductions

4. Silver Dollar Fair Results

5. Butte County Fair

6. Master Schedule for Next Year -Update from Dr. Roberts and/or Mr. Ramos on .2 FTE reduction at Las Plumas High School

7. Project period Funding for future - Dr Roberts and/or Mr. Ramos

8. Barn Construction Report and Ag Advisory Help in the fall

9. Teacher Updates

10. Additional Items

11. Adjournment 


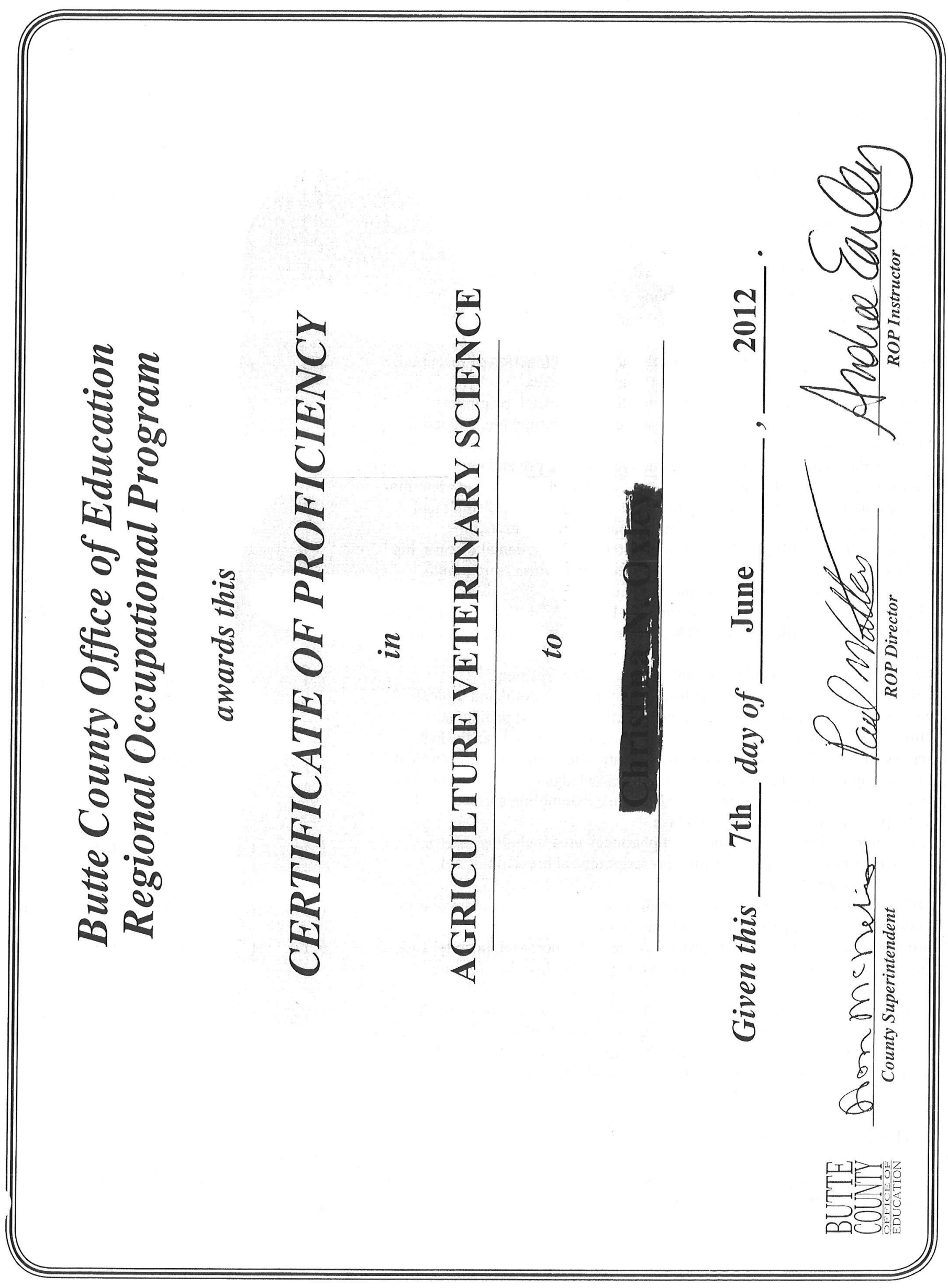


This certificate is awarded for the level of proficiency recorded in each of the following performance areas of $\underline{\text { ROP Ag Veterinary }}$ Skills.

Hours of Instruction: \)

PERFORMANCE AREAS:

1. Attendance: punctual, reliable

2. Attitude: appropriate behavior and interaction

3. Teamwork: good citizenship, works cooperatively

4. Attire: meets company policy

5. Responsibility: follows directions, completes work

6. Communication Skills: appropriate verbal, listening \& written

7. Critical Thinking Skills: problem solving

8. Leadership: develop leadership qualities and practice good decision making skills

9. Facility/Site Orientation: understands the layout and function of reception, exam room, pharmacy, surgery, treatment and kennel areas

10. Anatomy and Physiology: basic understanding of skeletal, respiratory, circulatory, digestive, reproductive, urinary, ear, eye, lymphatic, endocrine and nervous systems

11. Behavior Patterns: understands reproductive (estrous, pre and post parturition, male sexual behavior), dominant versus submissive and abnormal

12. Diseases: understands the systems, treatment and prevention of small and large animal infectious diseases: distemper, parvo, tracheo bronchitis, heartworms, FELV, FIP, URI and noninfectious diseases: dental disease, hip dysplasia and Zoonotic diseases including rabies, ringworm, sore mouth, internal and external parasites and tuberculosis.

13. Laboratory Tests: perform heart worm test; Fecal ; PCV; WBC count; Urine dip stick; Urine specific gravity: DTM; prepare outside lab samples; setup skin scraping

14. Nursing Techniques: handling of animals; procedure restraint; hospitalization care; administer medications by injection, oral and topical; emergency care; sample collections: blood, urine and feces; pedicures, bathing and grooming; suture removal; enemas; dentistry and ear flushes.

15. Surgery: basic skills in types of anesthetics; anesthesia monitoring; surgical prep; post op monitoring; aseptic technique; knowledge of common surgical procedures; surgical equipment and instructions; assembling surgical packs and supplies; proper use of the autoclave

16. Pharmacology: basic understanding of pharmacy area including: Metric System, common drug classes; filling prescriptions; abbreviations and ordering procedures

17. Nutrition: understands small/large animal food metabolism, commercial vs. premium label foods; prescription and special diets.

18. Sanitation: understand products/procedures used for personal, hospital and animal sanitation; importance of proper sanitation; facility/site cleaning protocols

19. Reception: client relations; phone techniques; appointment book procedures; filing records; importance of complete, legible medical records

20. General: basic knowledge of breed identification, human/animal bond; laws governing veterinary medicine; marketing of products and services; uses of animals; special care for neonates and geriatrics; veterinary terminology

\begin{tabular}{|c|c|c|c|c|}
\hline & \multicolumn{3}{|c|}{ Level of Proficiency* } & \\
\hline$\underline{0}$ & 1 & $\underline{2}$ & $\underline{3}$ & $\underline{4}$ \\
\hline ( ) & ( ) & ( ) & & ( ) \\
\hline ( ) & ( ) & ( ) & $(6)$ & ( \\
\hline ( ) & () & ( ) & & ( ) \\
\hline ( ) & ( ) & ( ) & & ( ) \\
\hline ( ) & ( ) & ( ) & & ( ) \\
\hline ( ) & ( ) & ( ) & & ( ) \\
\hline ( ) & ( ) & ( ) & & ( ) \\
\hline ( ) & ( ) & ( ) & & ( ) \\
\hline ( ) & ( ) & ( ) & & ( ) \\
\hline ( ) & ( ) & ( ) & & ( ) \\
\hline ( ) & ( ) & & ( ) & ( ) \\
\hline ( ) & () & ( ) & & \\
\hline ( ) & ( ) & & ( ) & ( ) \\
\hline ( ) & ( ) & $(v)$ & ( ) & ( ) \\
\hline ( ) & () & (v) & ( ) & ( ) \\
\hline ( ) & () & ( ) & & ( ) \\
\hline ( ) & ( ) & (V) & ( ) & ( ) \\
\hline ( ) & ( ) & K & ( ) & ( ) \\
\hline ( ) & ( ) & ( ) & & ( ) \\
\hline ( ) & ( ) & ( ) & 4 & \\
\hline
\end{tabular}

$3=$ Has entry level proficiency in this area.

$4=$ Has above entry level proficiency in this area.

\footnotetext{
* Level of Proficiency Rating

$0=$ Has no experience in this area.

$1=$ Has understanding of basic concepts in this area.

$2=$ Has some proficiency rating in this area.
} 

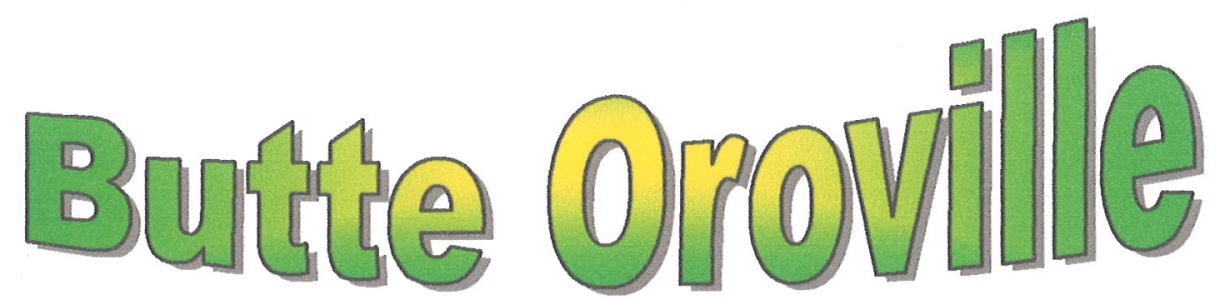

My time at Butte Oroville Veterinary Hospital was an amazing experience. I learned so many new skills and facts that I did not know before. The staff are very welcoming and generous. They welcomed me with open arms and I was eventually hired on as an employee. The atmosphere and knowledge here is tremendous and I would recommend any ROP Vet Skills student to come and do their placement here. It is a lot of fun and you'll learn so much!
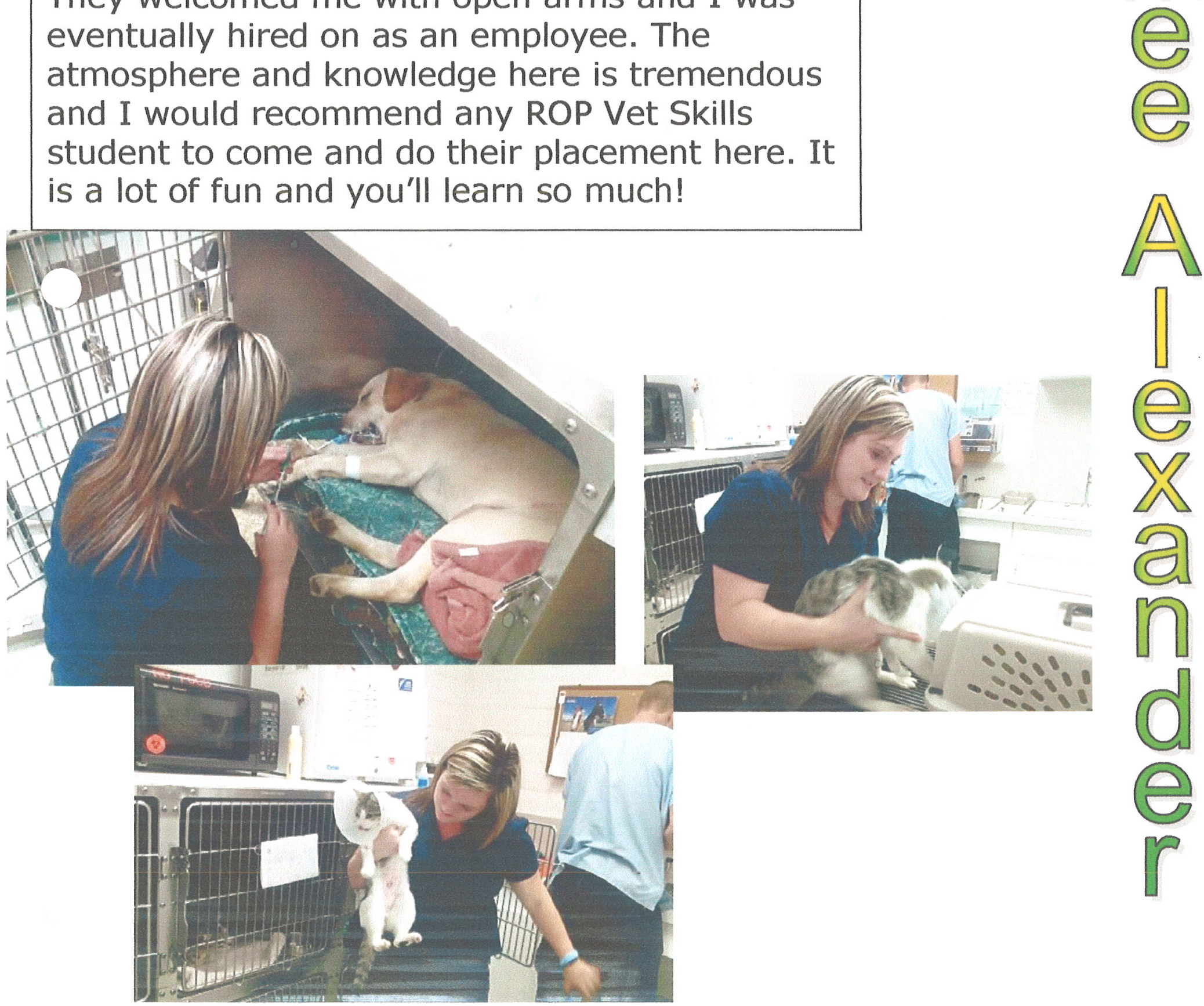


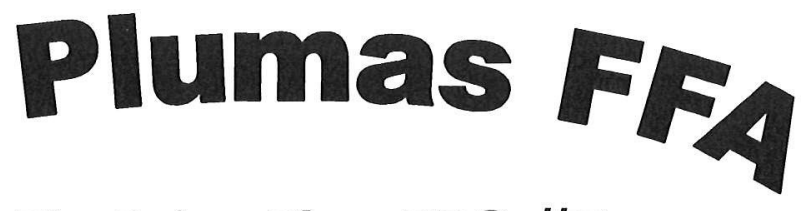

Tri-Tip Drive Thru BBQ \#7

MondayJuly $9^{\text {th }}, 2012$ 3:30-5:30pm@

the Ag Department

Cooked, packaged and ready to take

home to enjoy!

DRIVE THRU BBQ PRE-ORDER TICKET FORM

\begin{tabular}{|l|l|l|l|l|l|l}
\hline Customer Name & $\begin{array}{c}\text { Tic } \\
\text { ket } \\
\#\end{array}$ & Phone & Student Name & Check \# & \\
\hline \hline & & & & & \\
\hline & & & & & \\
\hline & & & & & & \\
\hline & & & & & & \\
\hline & & & & & & \\
\hline & & & & & & \\
\hline & & & & & & \\
\hline & & & & & & \\
\hline
\end{tabular}

$\$ 30$ includes:

1 whole tri-tip, 1 salad, 1 quart Beans, 6 rolls - feeds approximately 4 people

The funds earned will help support students attending the National FFA Leadership Conference in October of 2012. 
Statement of Intent: In an effort to prepare high school students for college and motivate students to attend college and be successful, Las Plumas High School and Butte College mutually subscribes to the following Articulation/Credit by Examination Agreement:
$\square$ ROP or $\bigotimes$ Regular
High School Course Title: Animal Science

$\begin{array}{lllll}\square & \text { New or } & \bigotimes & \text { Renewal of Agreement } & \text { Agreement Commences: } \\ \square \text { Annual or } & \square & \text { Biannual Review } & \end{array}$

High School Site(s): Las Plumas High School

Site Coordinator: West Upton

Address: 2380 Las Plumas Ave

Email Address: wupton@ouhsd.org Contact Phone \#: 530-538-2310

Name of high school/ROP teacher:

Name: Ashleigh Aldridge \& Andreé Earley

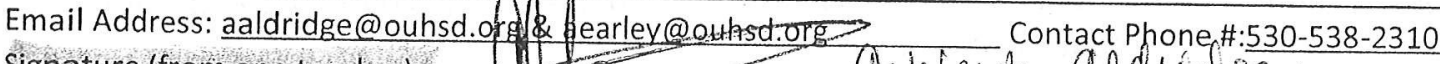

Signature (from one teacher):
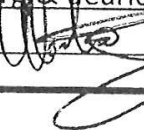

Prospective Articulated College Course Numbers: ANS 20

Course Title(s): Introduction to Animal Science

Units: 3 units

Recommended assessment level(s): $\underline{\mathrm{R}}$ III

E III

M II

Credit will be awarded upon completion of high school course with grades of $\mathrm{B}$ or better and final examination/performance, approved by college faculty member as measuring competence in the course objectives.

\section{COLLEGE \& HIGH SCHOOL ACTION}

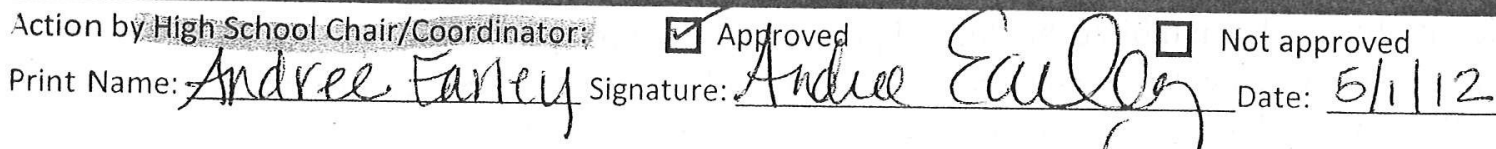

Action by High School Principal/Rep Director: $\mathbb{Q}$ Approved $\square$ Not approved

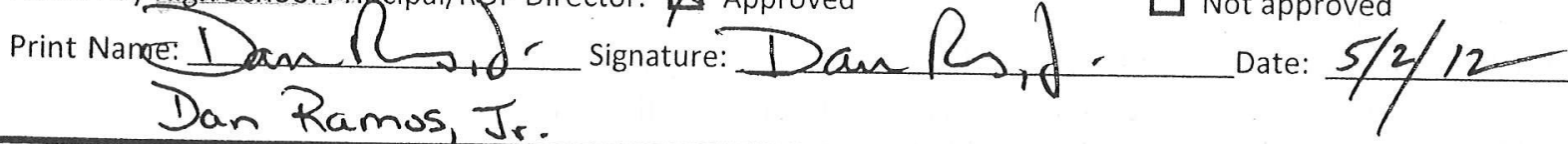

Action by Butte College Chair/Coordinator: $\square$ Ápproved $\square$ Not approved

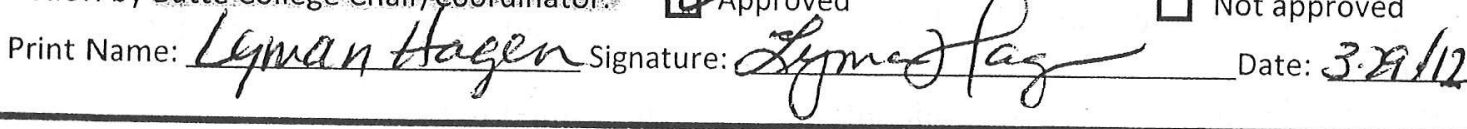

Action by Butte College Area Dean:

Print Name:

Director of CTE Transitions Program:

Signature:

Approved

Signature:
Not approved

Date:

\section{Comments:}

- Students must receive a 70\% or higher on their Final Credit-by-Exam attached to this articulation agreement

- Students must pass the articulated class with a grade of ' $B$ ' or higher

ate returned to CTE Transitions Office:

Date copy of agreement forwarded to High School Site Coordinator: 


\section{BUTTE COLLEGE \\ COURSE OUTLINE}

\section{CATALOG DESCRIPTION}

ANS 20 - Introduction to Animal Science

Prerequisite(s): NONE

3 Unit(s)

Recommended Prep: Reading Level III; English Level III; Math Level II

Transfer Status: CSU/UC

34 hours Lecture

51 hours Lab

This course introduces students to the scientific overview of the livestock industry, supply of animal products and their uses. There will be special emphasis on the origin, characteristics, adaptation and contributions of farm animals to the global agriculture industry. Analysis of the economic trends and career opportunities in animal agriculture will be covered.

\section{COURSE CONTENT}

\section{A. General Goals}

1. The student will develop methods of inquiry through the process of problem-solving and decision-making as distinguished from the storing of facts. The key focus will be specific knowledge and skills necessary for successful livestock production.

\section{B. Objectives}

Upon successful completion of this course, the student will be able to:

1. Identify animal contributions to human needs.

2. Identify life cycles and biotechnological principles of animal production.

3. Collect and evaluate data used to ensure scientifically-based management decisions.

4. Identify livestock body conformation and how it relates to function.

5. List economically significant beef cattle, sheep, dairy cattle and swine breeds and areas of production.

6. List basic nutritional needs and feeding practices of scientific livestock production.

7. Name marketing strategies and market classification of livestock.

8. Demonstrate and understand animal behavior as it relates to health and performance.

9. Discuss issues affecting consumer and producer awareness of animal welfare, food safety and the environment.

10. Identify cultural contributions and ethnic influences on the animal industry.

11. Identify career opportunities and requirements for successful employment.

\section{Unit Titles/Suggested Time Schedule}

1. Introduction to Animal Agriculture

a. Importance of livestock to the World and United States.

b. Economic importance to agriculture.

c. Animal contribution to human needs.

d. Industry is sues and challenges

e. Ethnic contributions.

2. Career and Career Preparation in the Animal Sciences

a. Career preparation

b. Employment opportunities in animal production and management

c. Employment opportunities in international agriculture

d. Future opportunities

3. The Beef Cattle Industry 
4. The Dairy Cattle Industry

5. The Swine Industry

6. The Sheep and Wool Industry

7. The Poultry Industry

8. The Horse Industry

9. Evaluation and Performance of Livestock

a. Identifying external anatomy

b. Evaluating type and conformation

c. Perspective of carcass composition to the live animal

d. Understanding carcass and performance data

10. The Animal Food Industry

a. Food Products and processing

b. Consumption and marketing strategies

c. Trends and future outlook

d. Health and nutritional considerations

11. Reproduction

a. Reproductive organs and their functions

b. Animal breeding

c. Mating systems

d. Fertility

12. Genetics

a. Fertilization

b. Gene modification and interactions

c. Genetic improvement and variation

d. DNA and RNA

13. Nutrition

a. Nutrients

b. Feeds and feed composition

c. Digestive systems

d. Growth and development

14. Animal Health

a. Prevention and the environment

b. Major diseases of farm animals

c. Detecting unhealthy animals

d. Treatment and care

15. Issues Affecting the Animal Industry

a. Animal behavior

b. Animal welfare

c. Advances in biotechnology

d. Government and environmental concerns

e. Food safety and consumer awareness

f. Sustainability of livestock production

Lecture

Topics

Hours

1. Introduction to the Course

2. Introduction to Animal Agriculture

3. Career and Career Preparation in the Animal Science $\quad 1.00$

4. The Beef Cattle Industry

5. The Dairy Cattle Industry

6. The Swine Industry 
7. The Sheep and Wool Industry

8. The Poultry Industry

9. The Horse Industry

10. Evaluation and Performance of Livestock

11. The Animal Food Industry

12. Reproduction

13. Genetics

14. Nutrition

15. Animal Health

16. Issues Affecting the Animal Industry

17. Testing (Lincuding finals week)

Total Hours

Lab

Topics

1. Beef and Dairy Unit, CSUC Farm

2. Sheep and Swine Unit, CSUC Farm

3. Meets lab, Safety and processes, CSUC Farm

3.00

4. Grocery Store - Meat, cheese, butter, ice cream

3.00

5. Purebred beef - EPD's

3.00

6. Commerical cattle operation - weaning, castration 3.00

7. Dairy farm - production cycle

3.00

8. Milk Processing - Cheese plant

3.00

9. Sheep Unit, CSUC lambing and handling sheep

3.00

10. Purebred Sheep farm, Production cycle

3.00

11. Swine Unit, CSUC vaccination, selection, management 3.00

12. Poultry lab, quality of carcasses and eggs 3.00

13. Horse Farm, production cycle 3.00

14. Selection Workshop 3.00

15. Biotechnology and Environmental workshop 3.00

16. North Valley Livestock Tour 6.00

Total Hours

\section{METHODS OF INSTRUCTION}

A. Homework: Students are required to complete two hours of outside-of-class homework for each hour of lecture

B. Lecture/Disucssion

C. Lab/Demonstration

\section{METHODS OF EVALUATION}

A. Written Examinations

B. Laboratory evaluation will consist of problem-solving exercises and/or skills demonstration.

C. Course grade is based on demonstrated proficiency in subject matter and the ability to demonstrate that proficiency, at least in part, by means of essay. 
ANS 20 - Introduction to Animal Science

Final Fall 2011

Name Key

Multiple Choice, True or False (circle the correct letter) and fill in the blank.

1. Rank in order the top three beef feedlot cattle producing states.

_ 3 _ Nebraska, _ 1 _ Texas, _ 2 K Kansas

2. The number one state in terms of Dairy cow numbers.
a. New York
b. California
c. Wisconsin

3. The standard length of lactation for a dairy cow is 305 days.

4. The dry period or rest period for dairy cows is 60 days.

5. Dairy Cows are housed in the:
a. Loafing shed
b. Milking parlor
c. Milk house

6. What is the most troublesome disease of dairy cattle
a. Bangs disease
b. Mastitis
c. Leptospirosis

7. The average $C A$ dairy cow will produce how many pounds of milk per year?
a. 30,500
b. 18,139
c. 22,000
d. 40,000

8. When feeding dairy cows they will eat of body weight in concentrates.

9. When raising dairy calves it is most economical to feed milk replacer for how many days?
a. 30 days
b. 60 days
c. 45 days
d. 90 days 
10. True or False: CMT is a test to determine if there is any mastitis in a cow's udder.

11. Following a positive CMT and treatment, the milk cannot be put in the tank for:
a. 5-7 days
b. $3-5$ days
c. 10-14 days
d. 1 day

12. True or False: Cross breeding in Beef Cattle has had an impact on faster gains and heavier weaning and yearling weights.

13. The purebred cattle producer fits which segment of the Beef Industry?
a. Commercial Cow-calf producer
b. Yearling-Stocker producer
c. Seedstock producer

14. How much gross income, will a dairy cow generate for you if she produces $40000 \mathrm{lbs}$ of milk worth $\$ 16.00 / \mathrm{CWT}$.
a. $\$ 6064$
b. $\$ 8400$
c. $\$ 8800$
d. $\$ 6400$

15. Fill in the missing blanks.

Beef calves are weaned at ___ months and should weigh an average of 600 ibs. Heifers are bred at 15 months and should calve at 24 months. The average daily gain made by feedlot cattle is _ 3 _ Ibs per day. The gestation period for beef and dairy cattle is 9 _months.

16. The ideal bull to cow ratio is:
a. $60: 1$
b. $50: 1$
c. $30: 1$
d. $20: 1$

17. True or False: On the average you could expect to see an 8-12\% improvement in weaning weights as a result of crossbreeding.

18. True or False: Based on feed cost and market price for milk, the dairy industry is somewhat profitable.

19. What is the value of flushing ewes 3 weeks prior to breeding?

Drop multiple eggs increase chance of twins 
20. What 2 diseases of growing lambs are of particular concern to commercial feedlot Operators?
A) Overeating
B) Milk fever
C). Shipping fever
D). Grass Tetany

21. The gestation for sheep is 5 months, for the purebred breeder or project lamb producer; lambs are weaned at 60 lbs. days and should weigh

22. True or False: Because forage on winter range is of poor quality, supplemental feeding of sheep is usually needed to meet nutritional requirements.

23. What area the four primary types of swine operations?
1. farrow to feeder
2. Farrow to finish
3. feeder to finish
4. Seed stock

24. Which is the major type of swine operation?

Farrow to finish

25. Approximately what percent of markets hogs on large commercial operations are conceived via artificial insemination? $60 \%$

26. Why are gilts and sows farrowed in farrowing crates?

a. Save piglets from being crushed

27. The breeding age of swine is 8 months, the gestation period is 3 mon, 3 wks and 3 days , and the national average of pigs weaned per litter is 10

28. Why do we give iron shots to baby pigs at birth?

a. Sows cannot pass iron to piglets through milk, must be given to individual pigs

29. What is the most common form of permanent identification used on pigs?

a. Ear notches

30. Why is docking of tails performed on baby pigs? Reduce fighting and biting 
31. True or False: Swine rations can be supplemented with lysine because it is usually the first limiting amino acid in most swine diets.

32. Please explain lambing percentage. How many ewes would it take to produce 150 lambs when the lambing percentage is $200 \%$ ? Numbers of lambs per ewe. 75 ewes

Please show calculations for the following problem:

33. As a swine manager, how many tons of feed would you expect to buy and pay for the following operation during a 1year period? 2000 sows, average of 12 pigs weaned per litter, 2.5 litters per year with an whole herd feed conversion of $3.1 \mathrm{lbs}$ of feed per pound of pork produced, average weight of $250 \mathrm{lbs}$. Average cost per ton is $\$ 250.00$ (2000 Ibs/ton)

\begin{tabular}{cc}
60,000 & Total pigs $\quad 15,000,000$ \\
23,250 & Total tons of feed \\
\hline $5,812,500 \quad$ Total cost
\end{tabular}
total pounds of pork

34. Calculate the average daily gains
a. Grower pig, $60 \mathrm{lbs}$ in 40 days 1.5
ADG
b. Finisher pig, $165 \mathrm{lbs}$ in 66 days 2.5 ADG
c. Grower/finisher $220 \mathrm{lbs}$ in 115 days 1.9 ADG

35. Where is fiber digested in the gastrointestinal tract of a horse?
a) small intestine
b) large intestine
c) cecum
d) rumen

36. Horses being used for riding or working need more than those not working. energy in their diets

37. What disorder may result from overfeeding grain or lush green pasture to horses a. founder

38. What is the most Number one breed of horse in the US today?
a) Arabian
b) Quarter Horse
c) Thoroughbred
d) Paint

39. What is the length of the estrous cycle of mares?
a) 3-5 days
b) 1-2 days
c) 5-7 days
d) 24 hours

40. What is the duration of gestation in horses? 11 months 
41. List the top four grades of swine
a. US 1
b. US 2
c. US 3
d. US 4

42. What are the yield grades for beef, what criteria is used to determine YG's? (Think about the meats lab at CSUChico)

43. Match the definition to the term and characteristics to the breed.

\begin{tabular}{|c|c|c|}
\hline & 1. gilt & a. castrated male beef \\
\hline & 2. heifer & b. female dairy animal in lactation \\
\hline & 3. boar & c. female pig that has not had a litter \\
\hline b & 4. cow & d. young female sheep \\
\hline$f$ & 5. wether & e. young female dairy animal \\
\hline a & 6. steer & f. castrated male sheep \\
\hline $\mathrm{h}$ & 7. Ram & g. a male pig used for breeding \\
\hline & 8. ewe lamb & h. a male sheep used for breeding \\
\hline
\end{tabular}

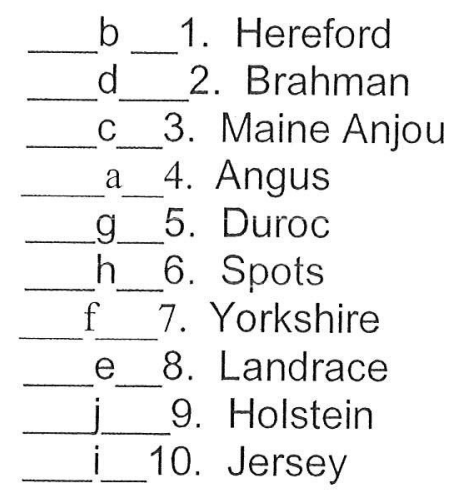
a. black and polled cattle
b. Red with white face cattle, very adaptable
c. Good milkers, red and white
d. Large hump big eared cattle, heat tolerant
e. White hog with big ears, long body
$f$. White hog with erect ears - good mothers
g. Red hog with good gains
h. Black and white markings - good muscle
i. Small breed, tan to dark brown - high butterfat
j. Large Breed, black and white - high production

49. Please share with me what you learned during the meat eating lab experience.

optional

50. Describe what was done during the goat lab - the procedure and reasons for doing so.

optional 
Quality Criteria Seven:

Career Guidance

Career-vocational education staff, guidance counselors, and other resource personnel provide career guidance services to ensure that students enroll in C-VE courses/program that are consistent with their aptitudes, interest, abilities, and career path goals.

All students complete a Student Data Sheet at the beginning of each year and are updated as needed to keep the student's goals in mind. Students in the agriculture program are exposed to a wide range of career opportunities. School counselors are continually made aware of the opportunities for students enrolled in Agriculture. Students are made aware of the agriculture courses meeting the CSU/UC requirements and availability of college credits through the $2+2$ articulation agreement through ButteGlenn Community College.

Each student in an upper level Agriculture class (junior/senior) is taught a whole month of career guidance. First students are giving a personality test done online to determine what their personality is and what career interest or would best suit their personality. Then each student has to research and look for a real job opening, print the job description, fill out a mock application, complete both a resume' and cover letter for the job position. The final part of the career unit is each student has to go through an interview process with at least three industry people on our judging panel. For many of our students this is a new process that allows them to step out of their comfort zone and really helps them prepare for not just the career they want but the process they might have to go to pursue their career goal.

In all courses in the program, industry representatives are utilized strategically as guest speakers to better inform the students of agriculture career opportunities. Field trips and tours are arranged annually to the local farm equipment show, several colleges, and several other agricultural entities to further broaden the spectrum of career awareness and opportunities for agriculture students.

Evidence Documents Include:

- $2+2$ Articulation Agreement

- Examples of Student Data Sheets

- Student work: Resume' \& Cover Letter

- Job Interview Rubric 
September 9, 2011

TO: $\quad$ High School Instructors of 2+2 Articulated Courses

FROM: $\quad$ CTE Transitions (formerly Tech Prep Program) 1 $2+2 / 2+2+2$

RE: $\quad$ Registration/Enrollment Information

Please read carefully. The following guidelines will be helpful for registration of $2+2$ students:

- Please ask your students to take this process seriously, as they are enrolling in a collegelevel experience and misinformation could result in their not receiving credit for the course.

- Remind students to print legibly!

1. YELLOW ENROLLMENT CARD:

(1) Enter ' 10 on blank for year;

(2) Enter current high school student's grade level;

(3) Enter date of birth;

(4) Students names on top line should be printed, no nicknames;

(5) Enter name of high school course;

(6) Enter name of Butte College course (i.e., BCIS 80);

(7) Enter number of college units for the course;

(8) Enter high school instructor's name;

(9) Enter signature on the bottom line;

(10) Enter student's current mailing address \& phone number on the back of the card.

A yellow ENROLLMENT CARD is required for each student in order to receive credit for the course.

2. BUTTE COLLEGE ONLINE APPLICATION: (Because correct information is critical, it's best to go step-by-step in this process). Students who have previously submitted an application to the college are not required to complete another application.

- Please follow the Butte College Online Application handout.

Butte-Glenn Community College

3536 Butte Campus Drive

Oroville, CA 95965

Phone: 530-879-9068
CTE Transitions

2050 Talbert Dr., Suite 500

Chico, CA 95928

FAX: 530-879-0179 


\section{ARTICULATION}

\section{BEGINNING OF YEAR ENROLLMENT INFORMATION}

TO: High School Instructors of $2+2$ Articulated Courses

FROM: $\quad$ CTE Transitions (formerly Tech Prep Program)

SUBJECT: Enrollment Information for $2+2 / 2+2+2$ Articulated Courses

At the beginning of each academic year, high school instructors who teach articulated courses are asked to furnish information to the college regarding student enrollment in those courses. By completing this form you will greatly assist our enrollment procedures:

High School Course Title

College Course Title

High School Instructor's Name

High School Instructor's Email Address

Name of High School

Number of students who wish to gain Butte College credit for the course.

Please attach this form with your Enrollment/Add Cards and return to Butte College CTE Transitions by $\underline{\text { December } 31^{\text {st }}}$. If you have any questions, please feel free to contact us.

Thank you,

Delia Buzatu

Butte Community College

3536 Butte Campus Drive

Oroville, CA 95965

Phone: 530-879-9068
CTE Transitions

2050 Talbert Dr., Suite 500

Chico, CA 95928

FAX: 530-879-0179 


\title{
TECH PREP ARTICULATION AGREEMENT
}

\author{
Date Approved: $\quad 3 / 18 / 09$
}

\begin{tabular}{|l|l|l|l|}
\hline $\begin{array}{l}\text { Yuba } \\
\text { College } \\
\text { Course: }\end{array}$ & $\begin{array}{l}\text { Dept: Agriculture } \\
\text { Course No: AG 45 } \\
\text { Title: Principles of Animal } \\
\text { Science }\end{array}$ & High School or & Ag Veterinary Skills \\
\hline College: & Yuba College & Hours: & 180 hrs \\
\hline
\end{tabular}

A. COLLEGE UNITS: $\underline{3}$ units

B. GENERAL COURSE DESCRIPTION:

An overview of the principles of animal science and the interrelationships of domestic animals and mankind. This course will investigate animal anatomy, physiology, reproduction, nutrition, health, products and by-products as well as behavior and genetics from a scientific perspective.

C. COURSE CONTENT:

1. Animals and man

a. Economic importance

b. Animal contribution to human needs

c. Industry issues and challenges

2. Overview of the livestock industry
a. Beef cattle and dairy
b. Swine
c. Sheep
d. Horse
e. Poultry

3. Principles of genetics and biotechnology
a. Fertilization
b. Gene modification and interactions
c. Genetic improvement and variation
d. DNA and RNA

4. Anatomy and Physiology

5. Reproduction
a. Reproductive organs and their functions
b. Animal breeding
c. Mating systems
d. Fertility

6 . Principles of nutrition
a. Nutrients
b. Feeds and feed composition
c. Digestive systems
d. Growth and development

7. Principles of heath
a. Prevention and the environment
b. Major diseases of farm animals
c. Detecting unhealthy animals
d. Treatment and care 
8. Issues affecting the animal industry
a. Animal behavior
b. Animal welfare
c. Advances in biotechnology
d. Government and environmental concerns
e. Food safety and consumer awareness
9. Animal products and by-products

\section{COMPETENCIES AND SKILL REQUIREMENT (PERFORMANCE OBJECTIVES):}

At the conclusion of this course, the student should be able to:

1. Identify the major influences animals have on mankind now and in the past.

2. Identify the economically significant breeds of beef, sheep and swine.

3. Identify livestock body conformation and how it relates to function.

4. Identify life cycles and biotechnological principles of animal production.

5. Define the terms associated with genetics.

6. Complete a cross and back cross using Mendelian genetics.'

7. Compare and contrast the nutritional needs of animals during growth, development and reproduction.

8. Demonstrate and understand animal behavior as it relates to health and performance.

9. Identify the major needs that animals have to maintain normal health.

10. Discuss issues affecting consumer awareness to animal welfare, food safety and the environment.

11. List at least 10 by-products produced from animals that are used by mankind.

\section{E. CREDIT BY EXAMINATION CRITERIA:}

Students must obtain a grade of ' $B$ ' or better in the course and a grade of ' $C$ ' or better on the final examination.

\section{F. PROCEDURES AND/OR CRITERIA FOR COURSE ARTICULATION:}

1. The high school/ROP instructor will enter an articulation agreement with Yuba College.

2. Students will enroll into the Tech Prep Program during the academic year at their high school/ROP.

3. When the student has completed the approved credit by examination criteria for the course the high school/ROP instructor will provide Tech Prep Office the course grade and final exam grade.

4. Tech Prep processes students that met credit by examination criteria.

5. Students are awarded transcript credit for the articulated course in which they completed.

G. TEXTBOOKS OR OTHER SUPPORTING MATERIALS (INCLUDING SOFTWARE):

Introduction to Veterinary Science, Lawhead and Baker, Thompson Learning First Edition

The Merck Veterinary Manual, Aiello, Merck \& Co, Eight Edition

Official Manual, National FFA Organization (2007)

California Agriculture Record Book, California FFA Association (2007)

Agreement was based on Statewide Career Pathways Project template: Yes $\square \quad$ No $区$

Name of Template used: _ N/A 
Signatures are provided per the Tech Prep Articulation Credit by Examination Agreement Form:

\section{HIGH SCHOOL/ROP/DISTRICT SIGNATURES:}
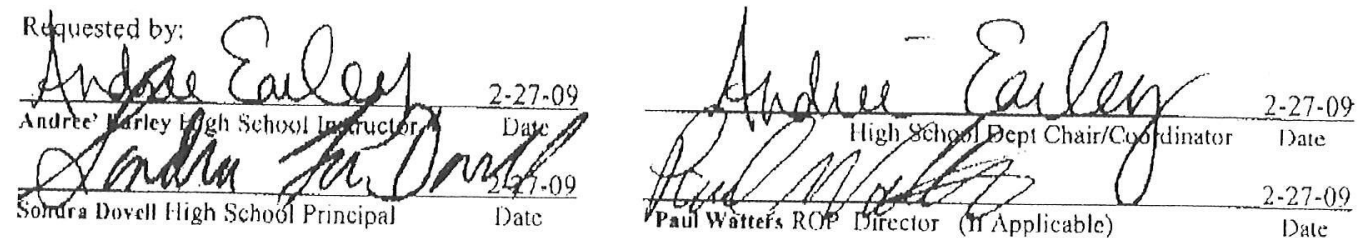

\section{COLLEGE SIGNATURES:}
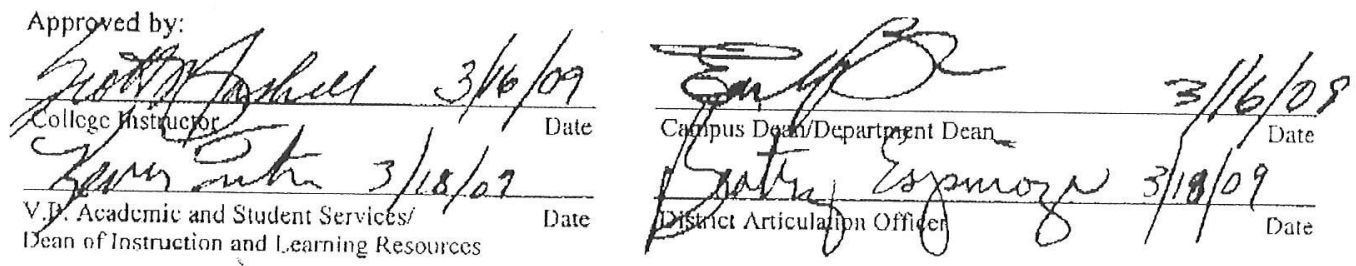


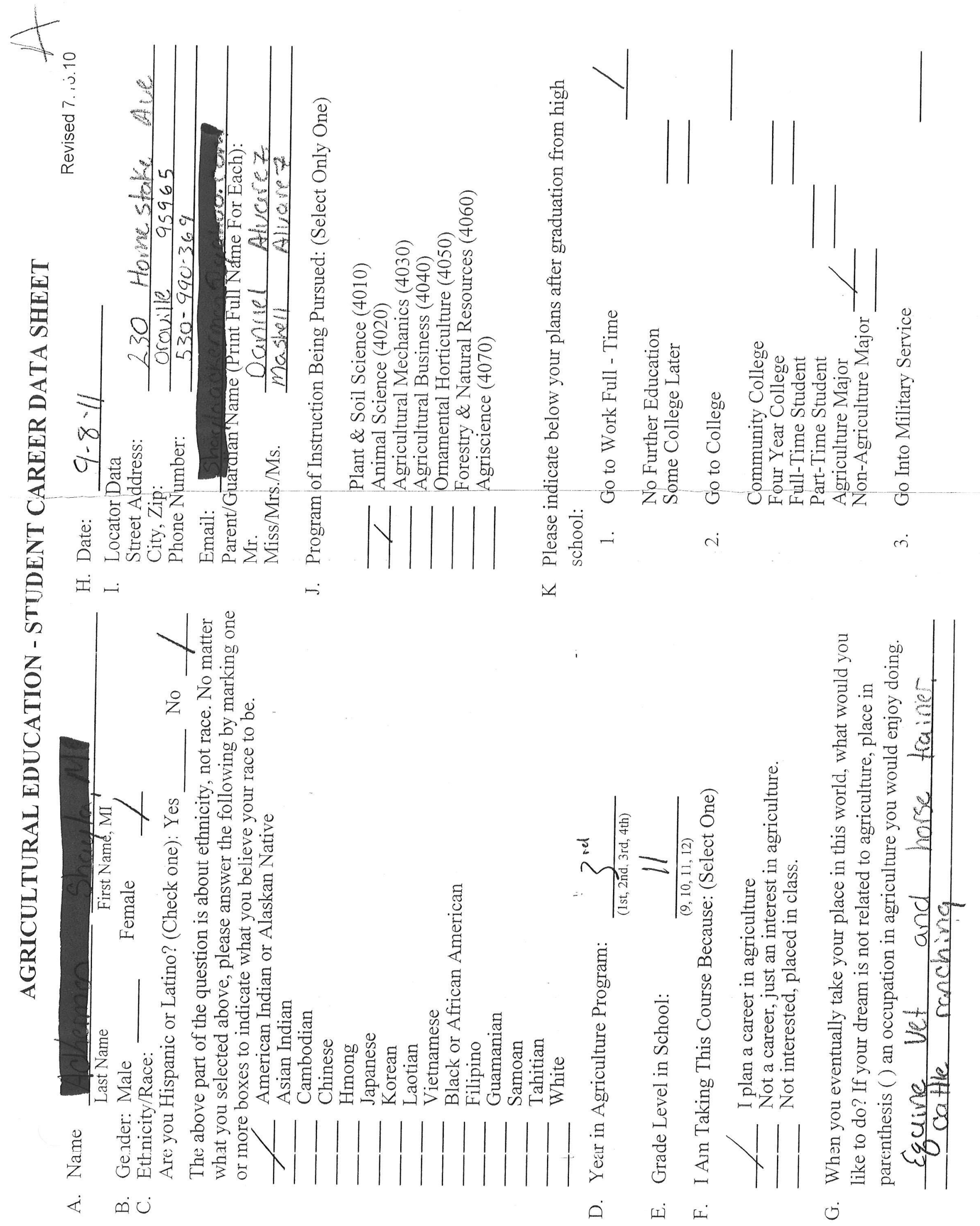




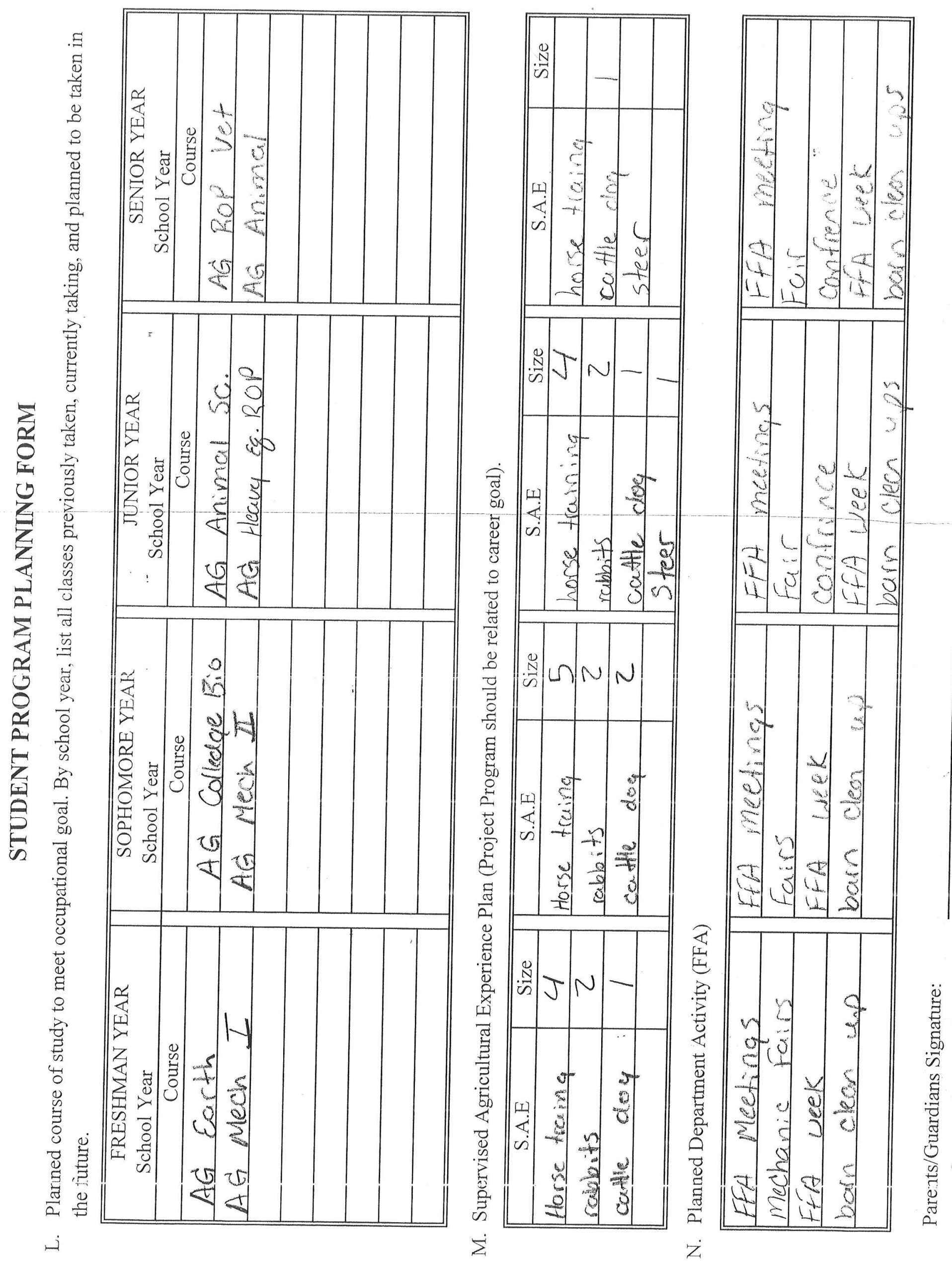


$I$

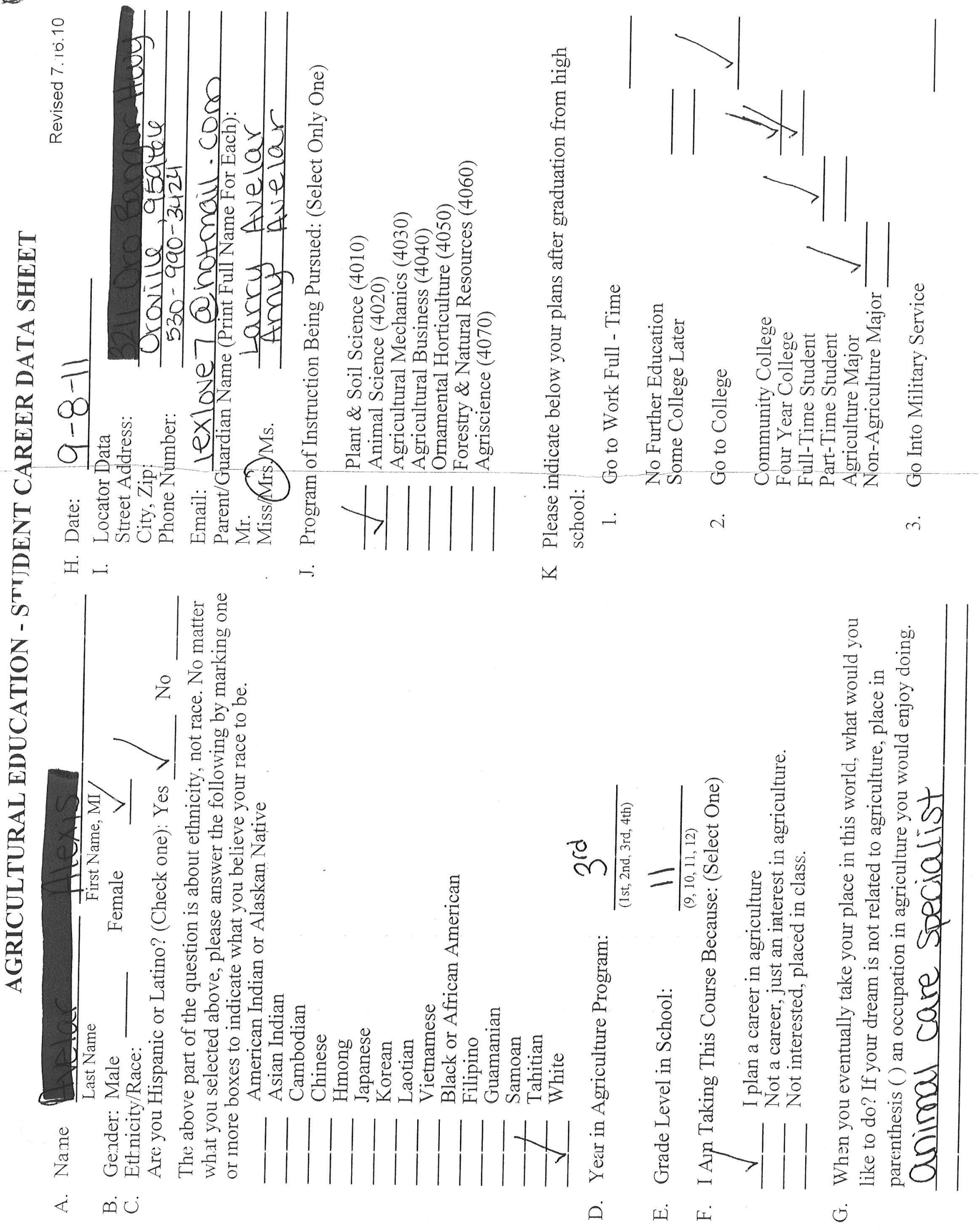




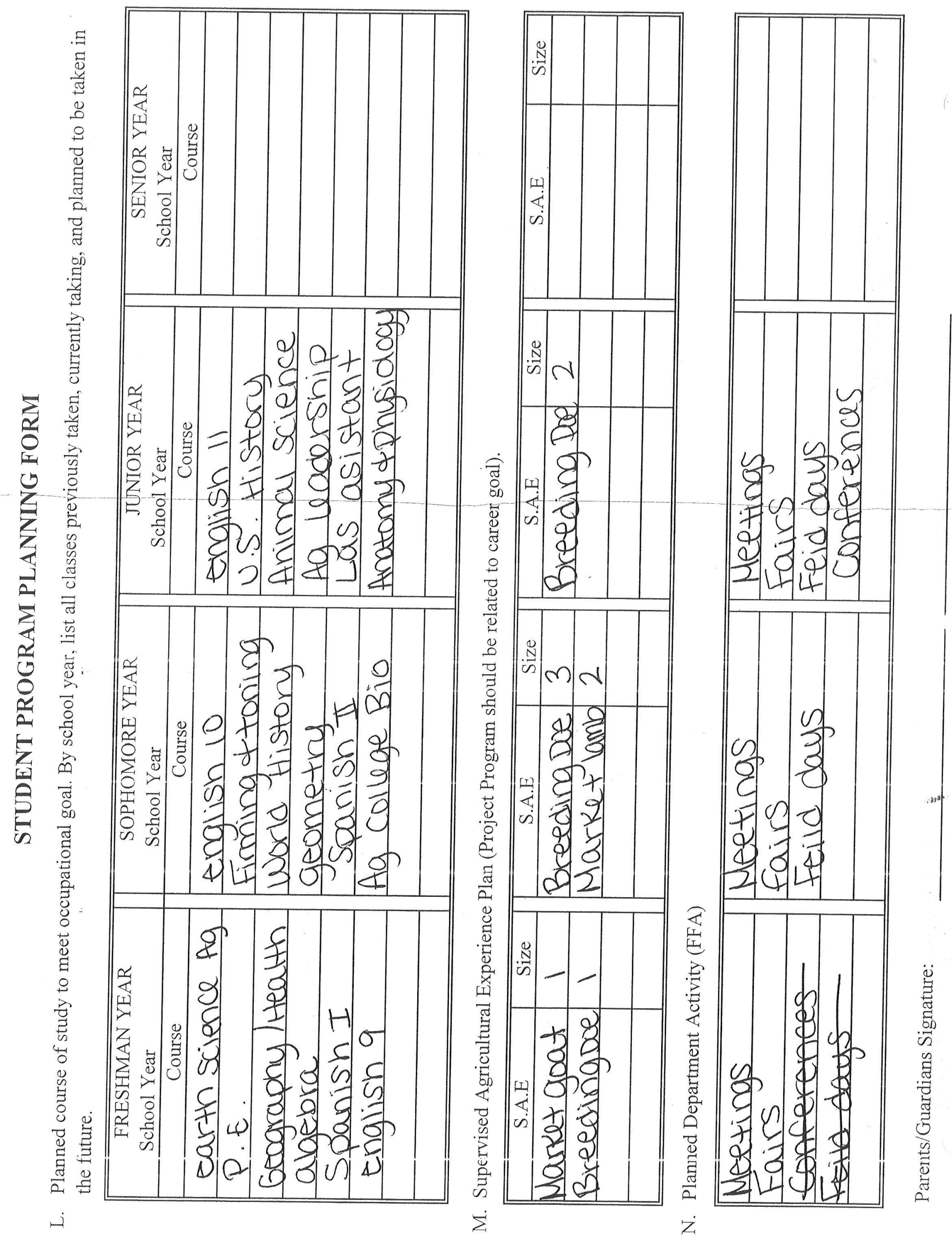




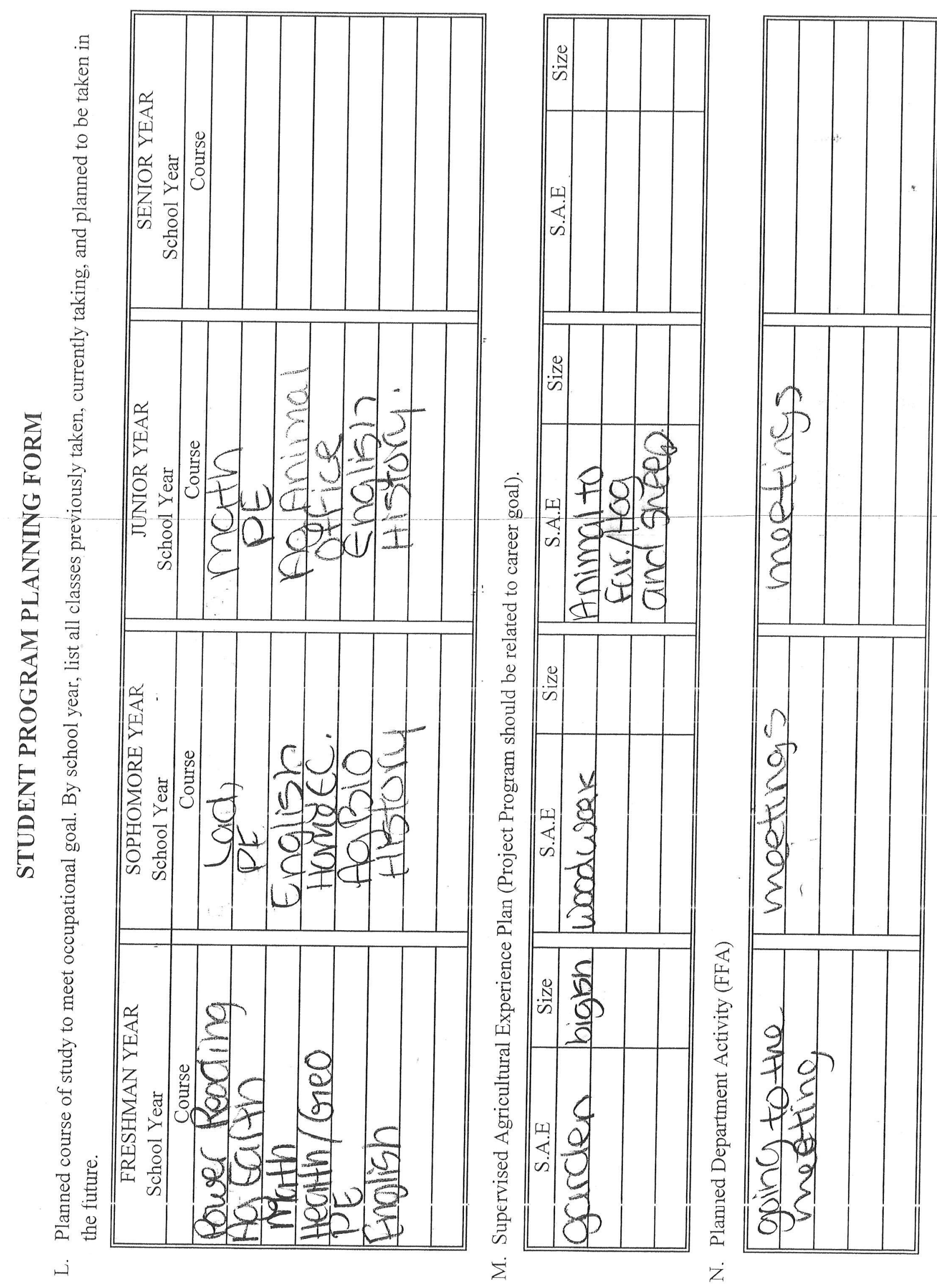

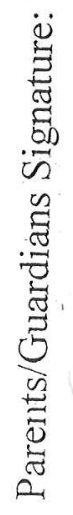




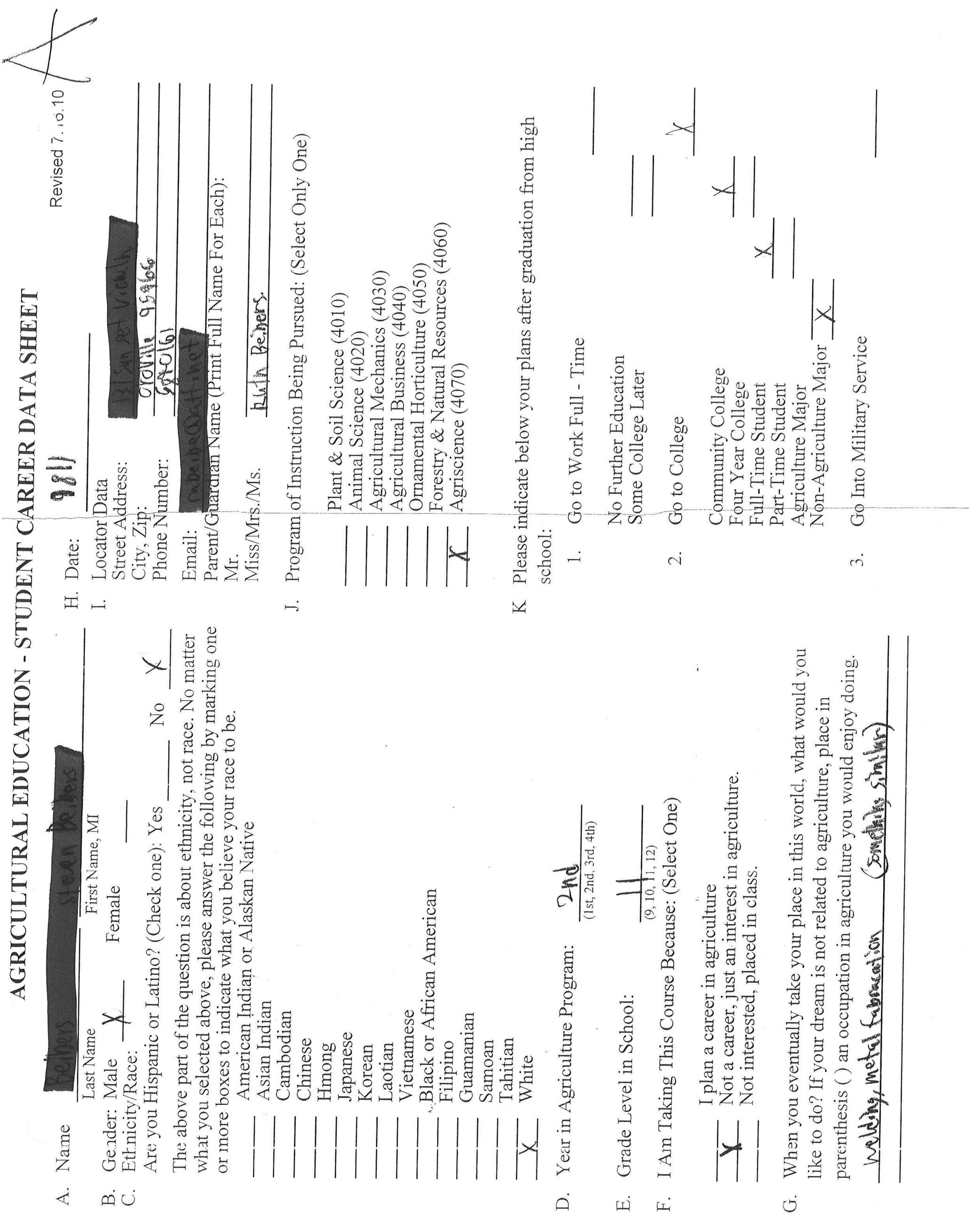




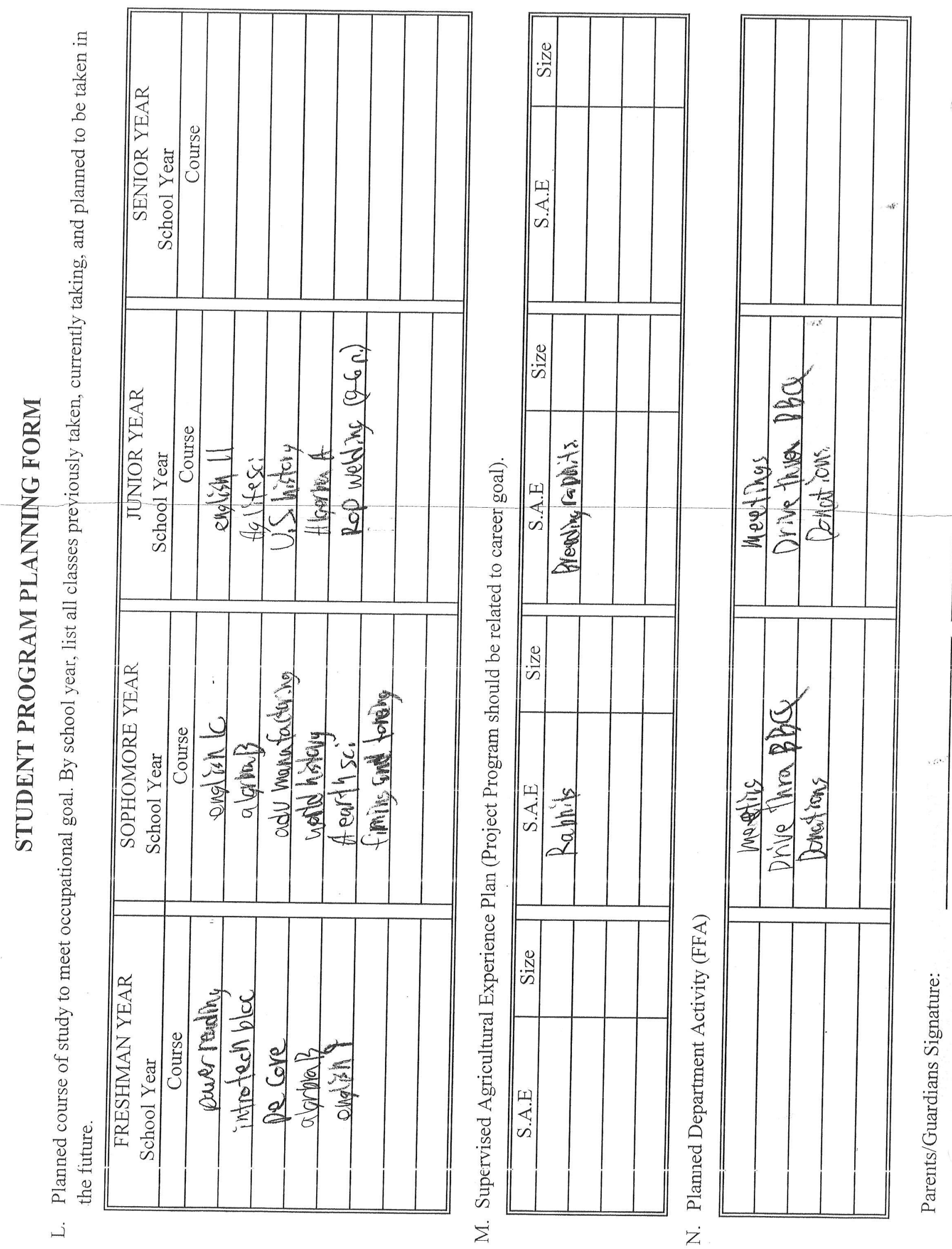




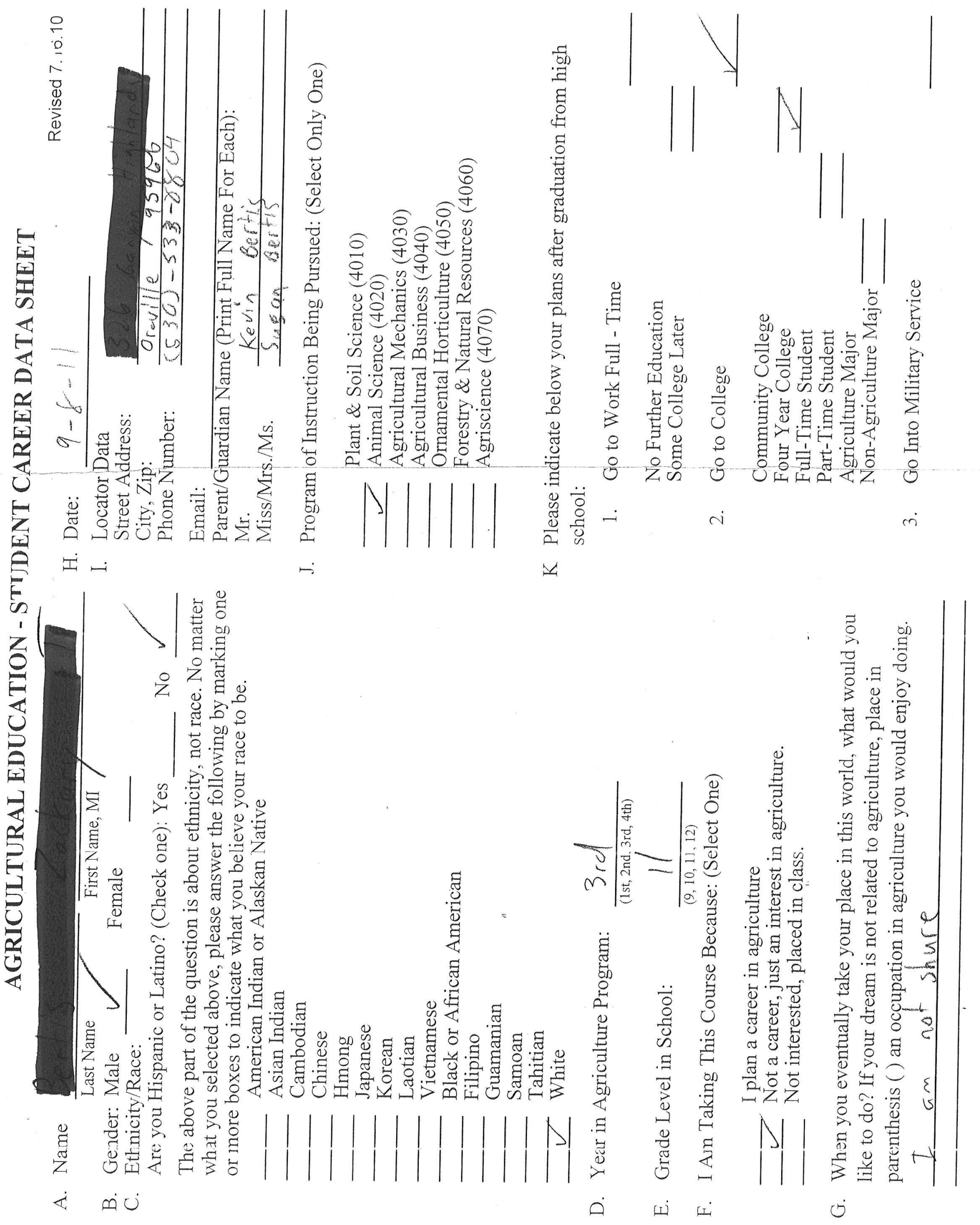




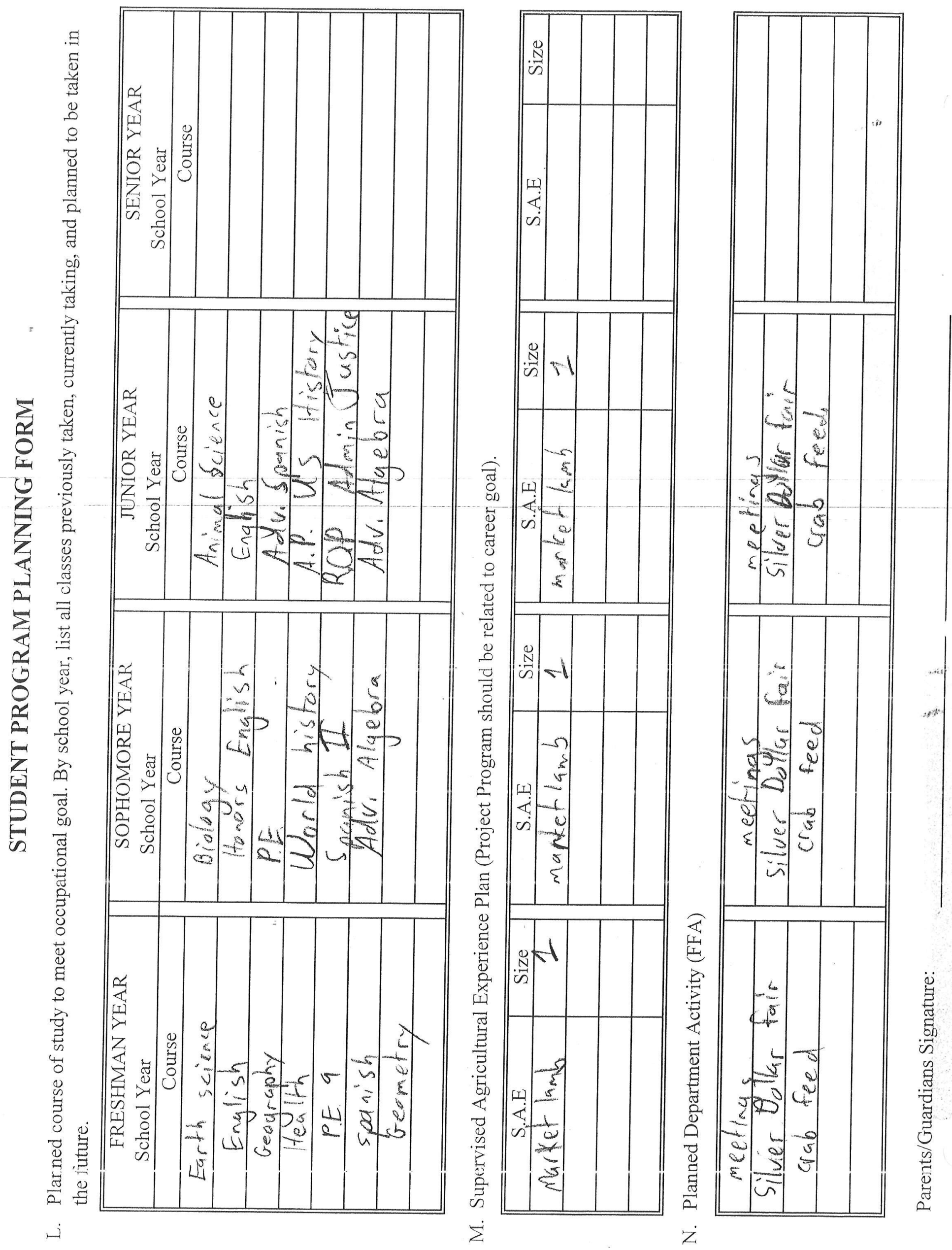




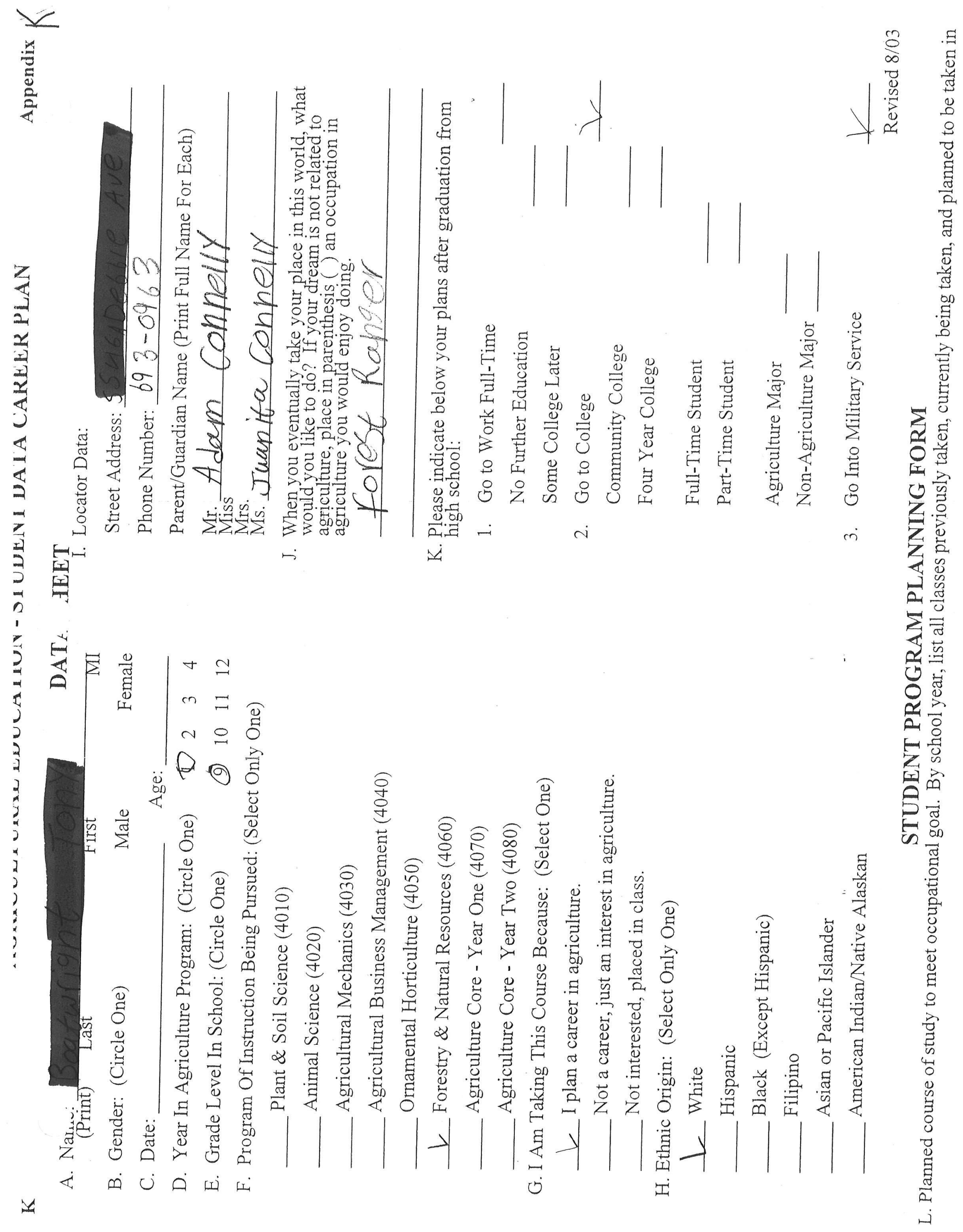




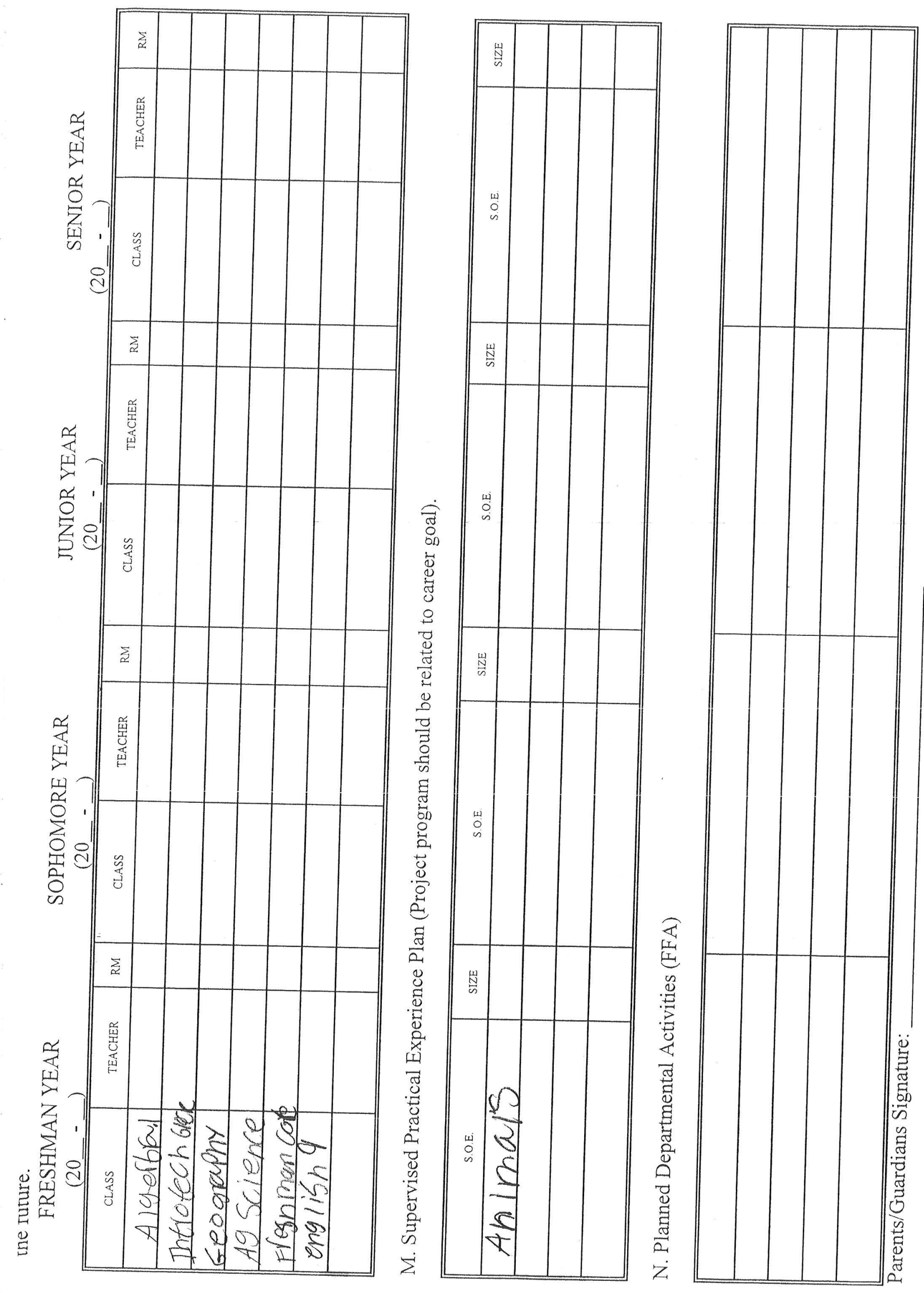




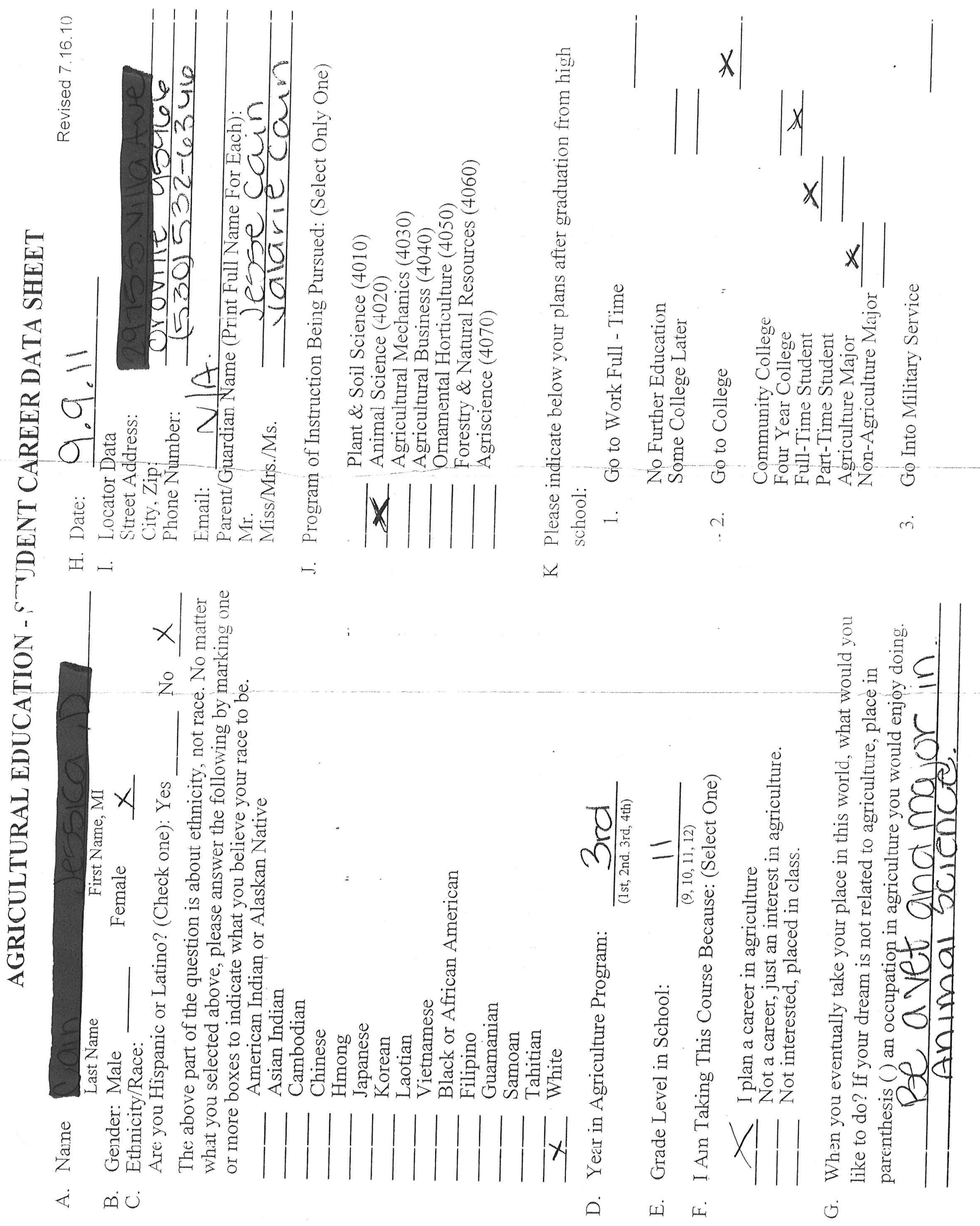




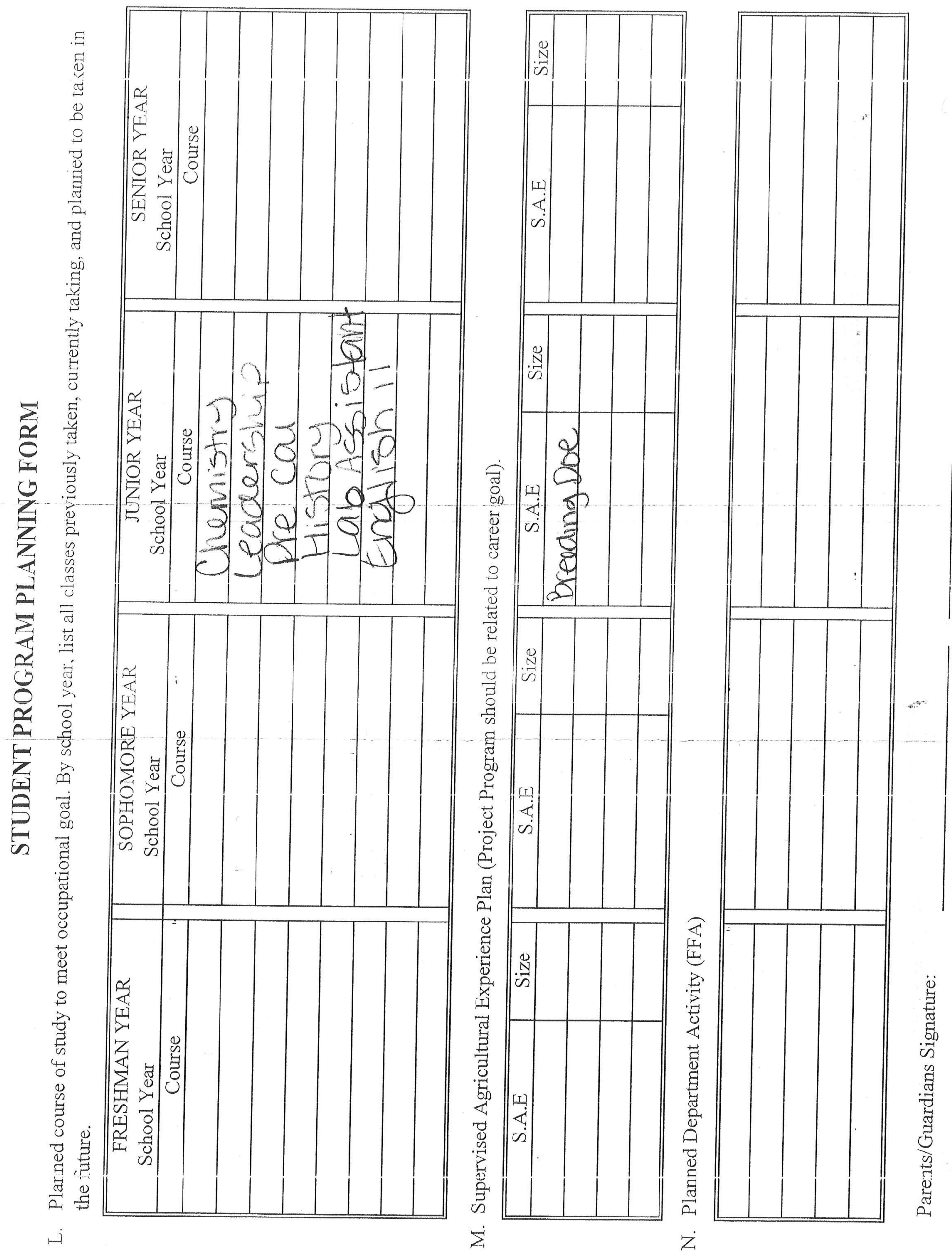




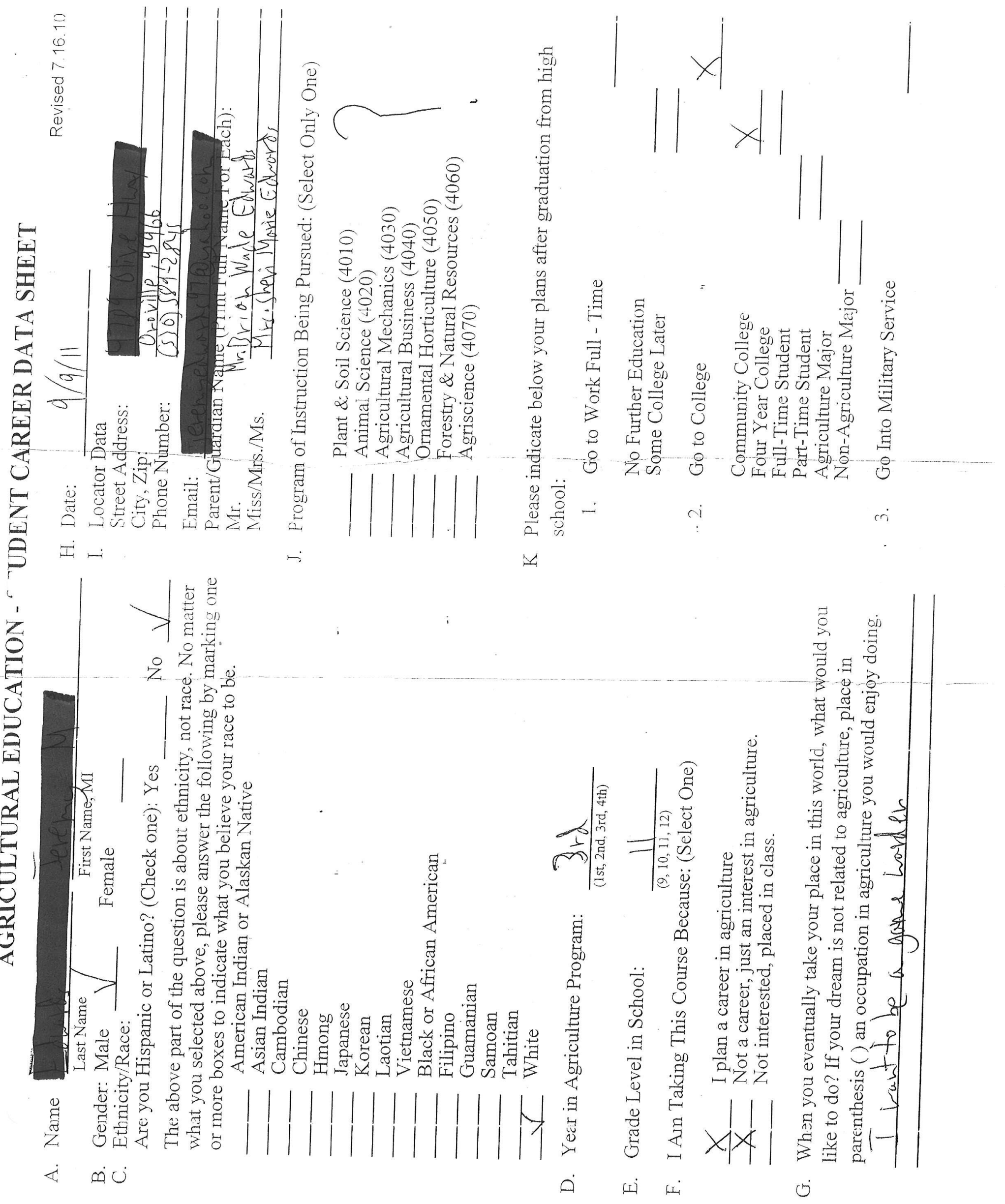




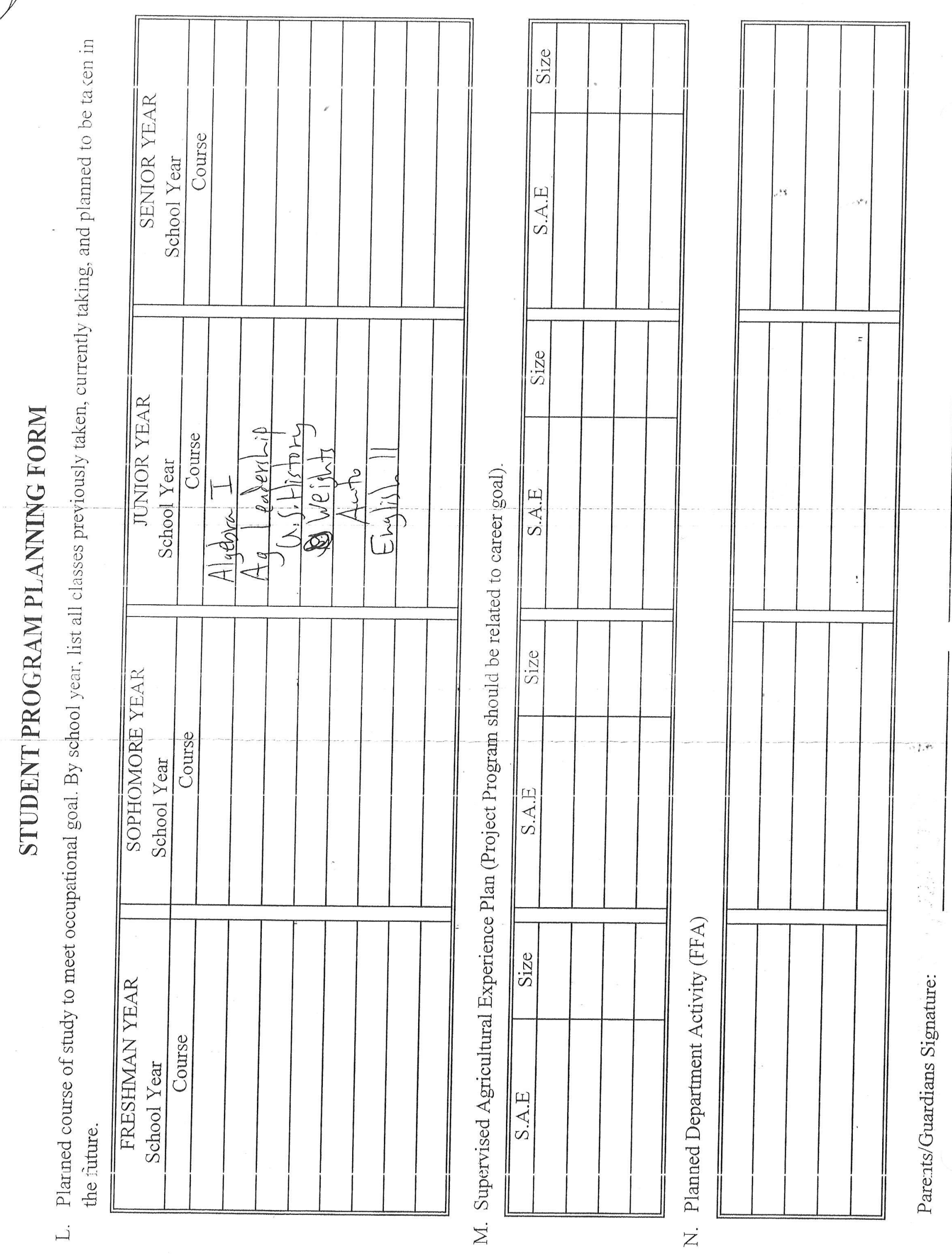



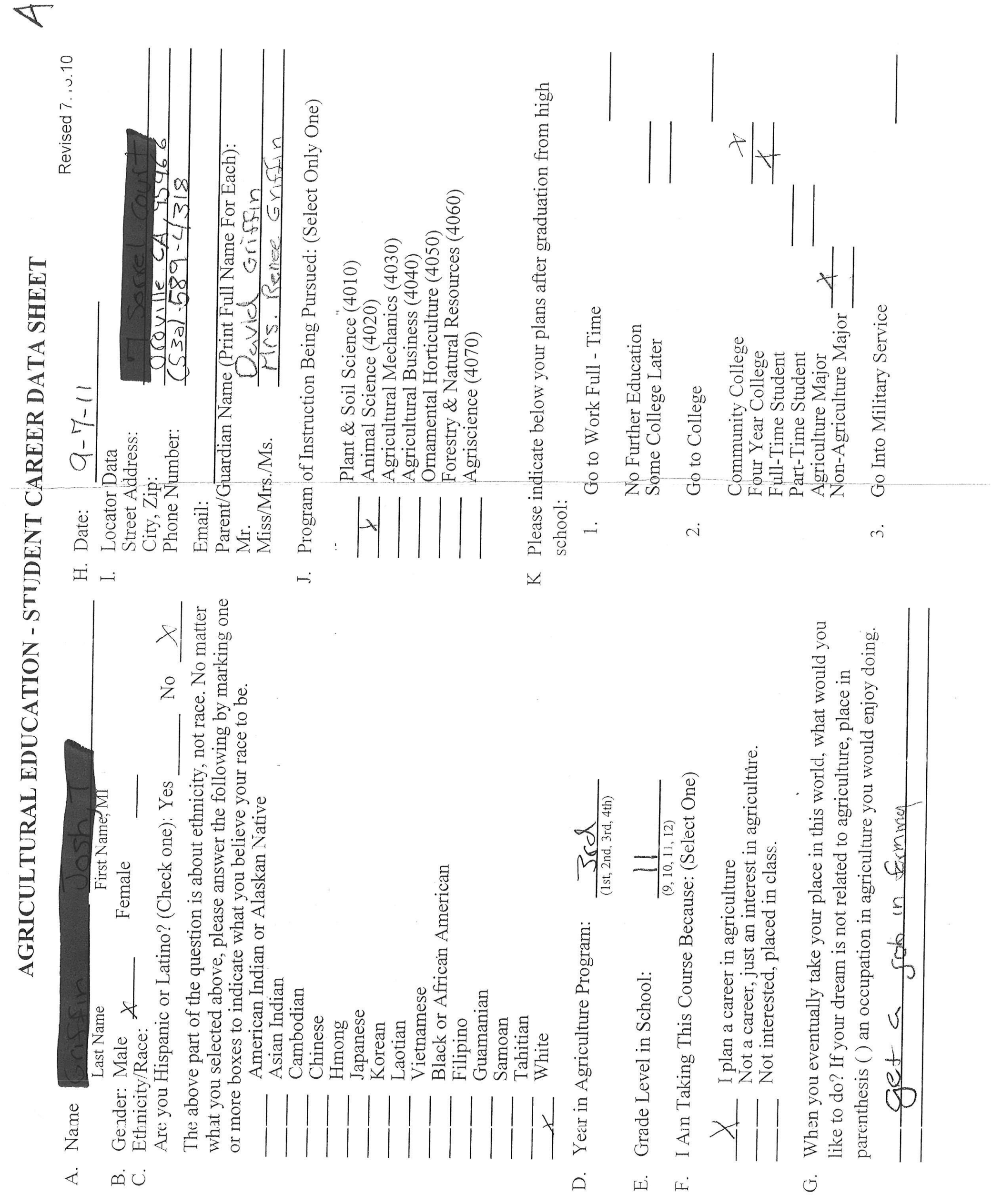


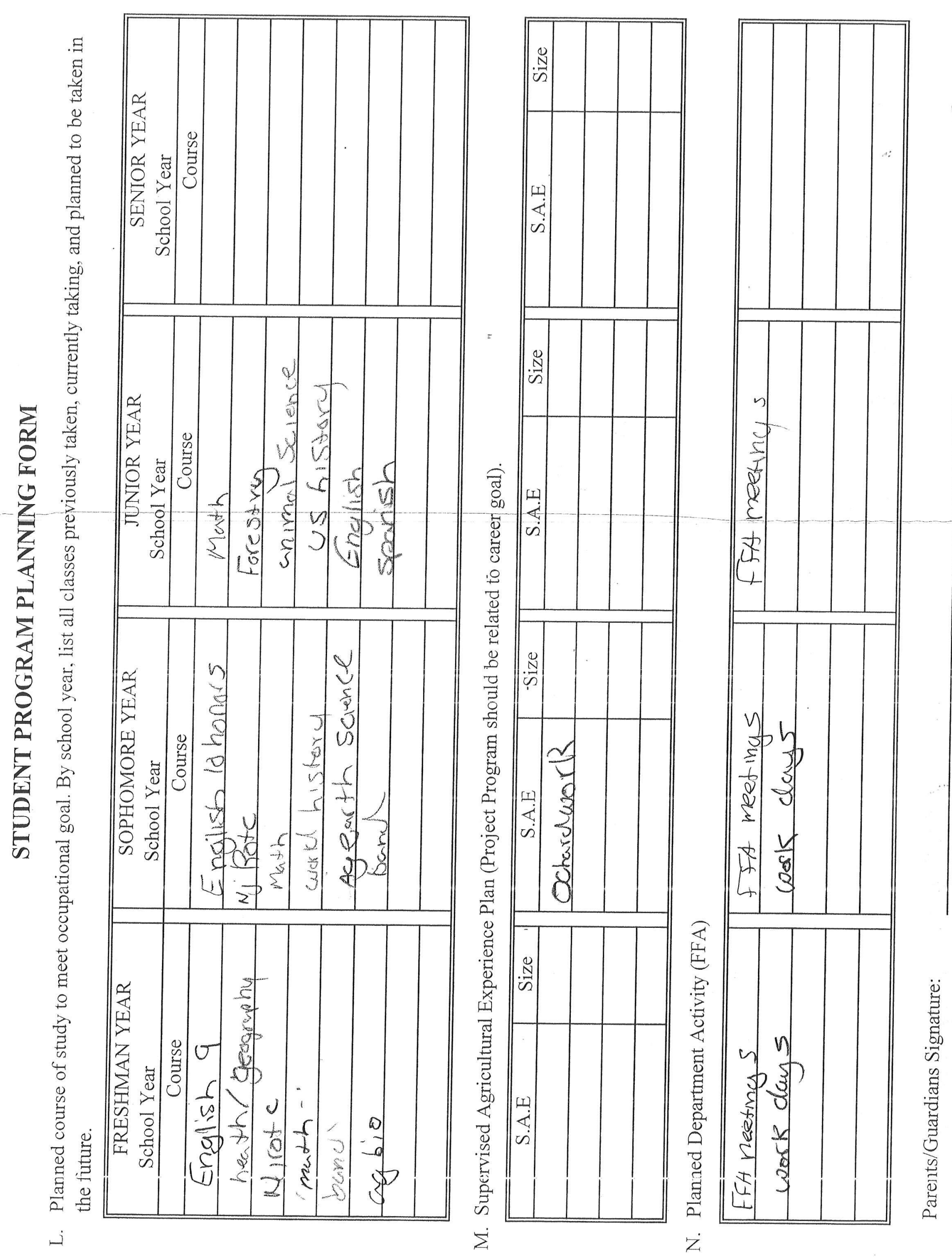




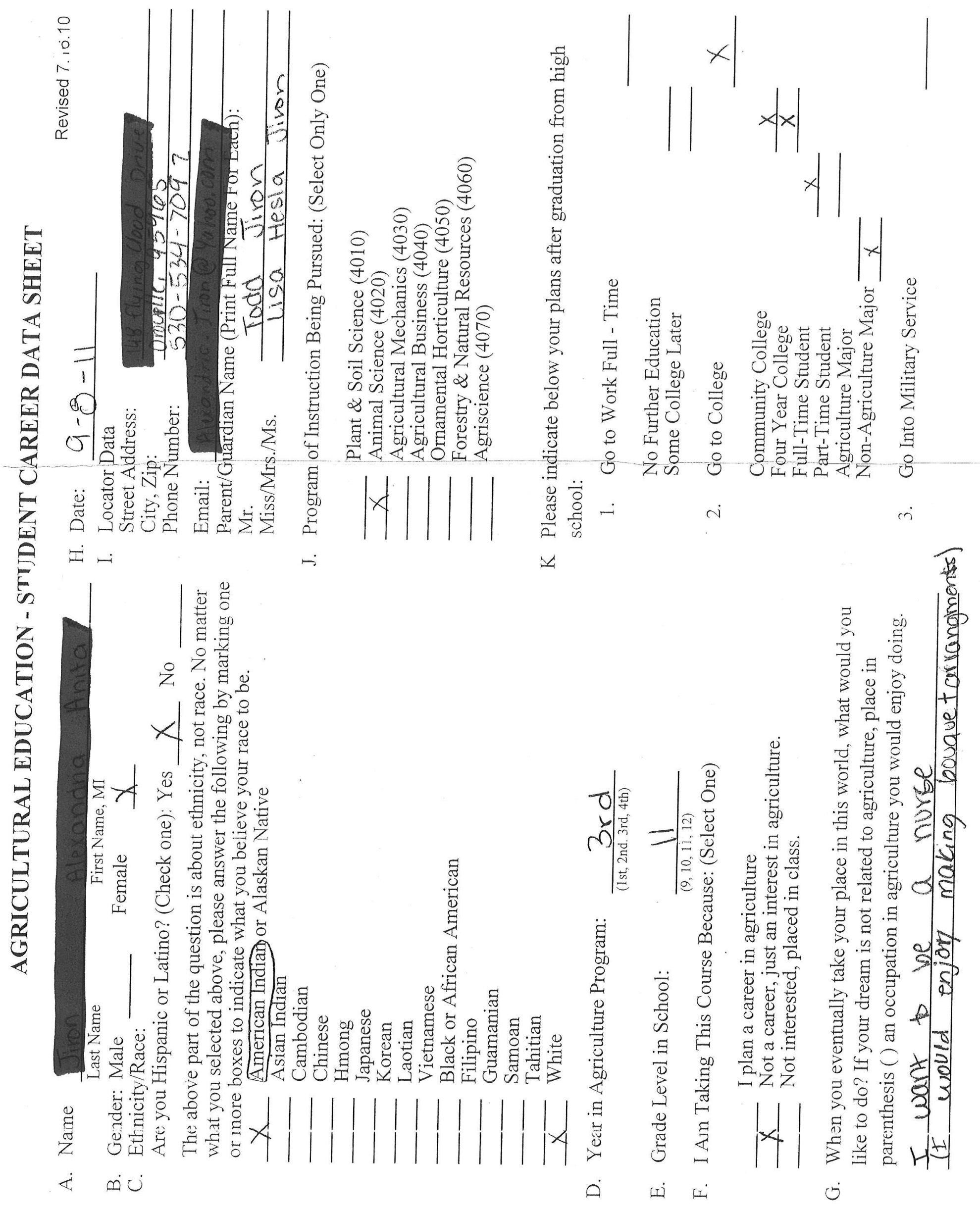




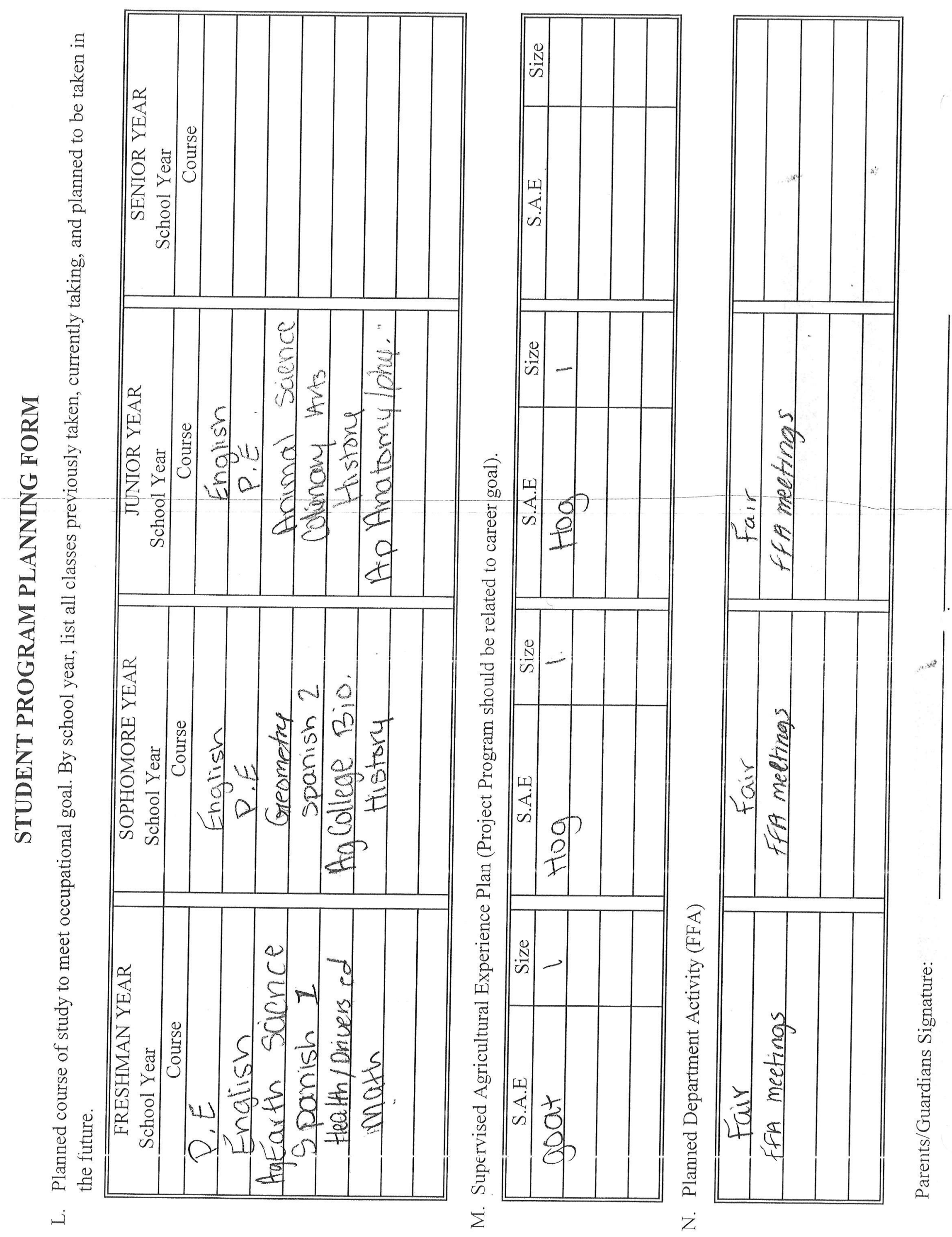




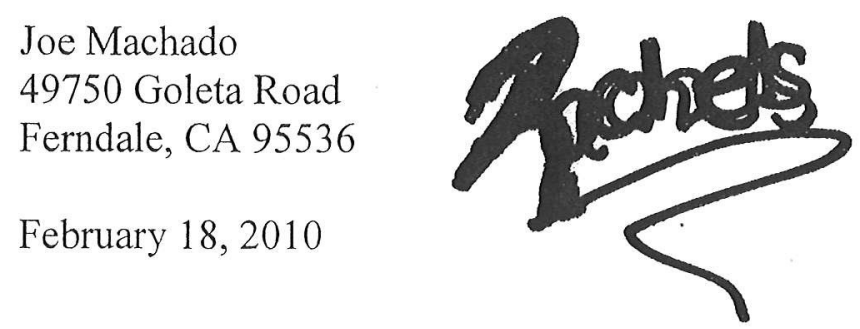

Dear Mr. Joe Machado,

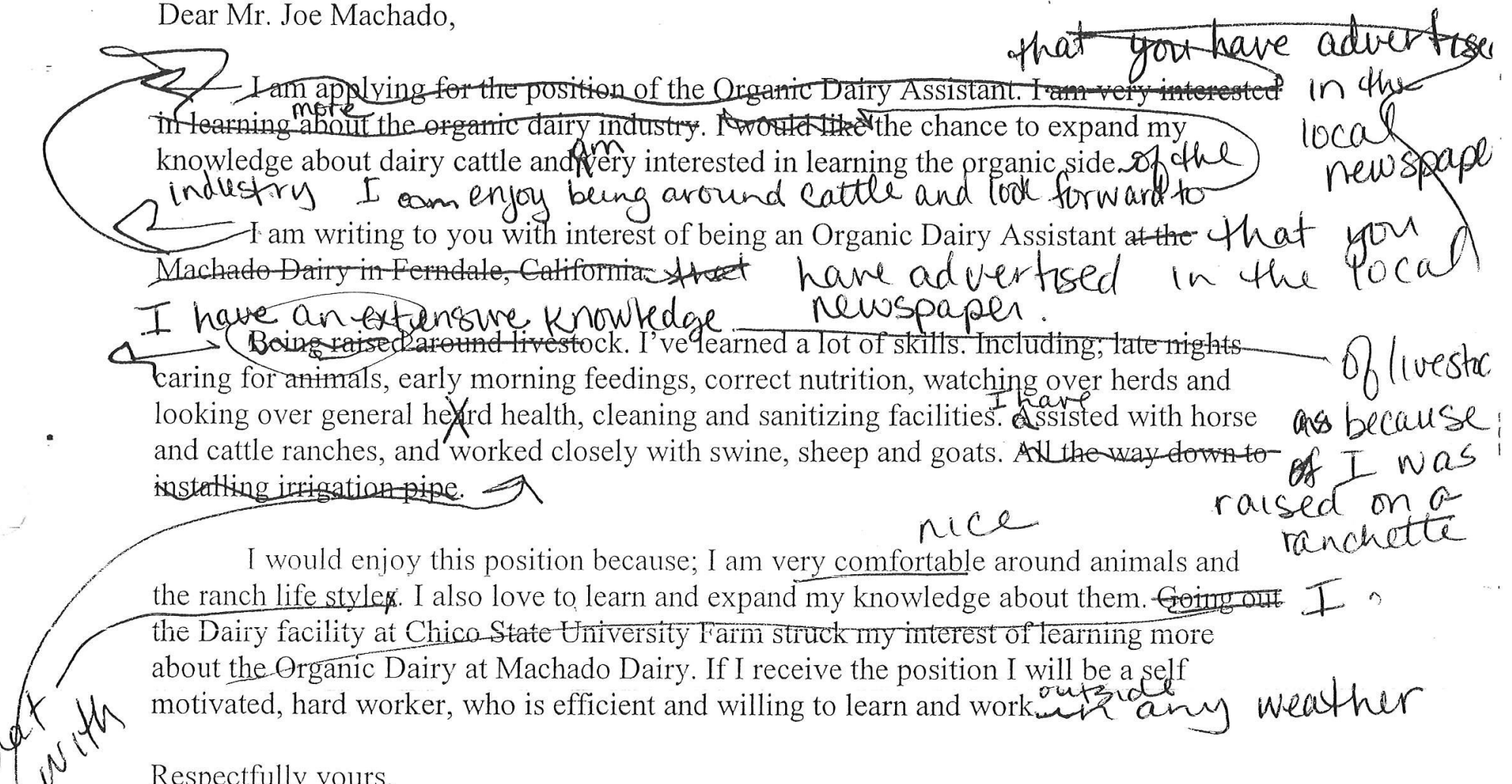

Respectfully yours,

Rachel Castanon Cattoror

to

Hetrecenty visit the new organic Dairy at CSU, Chico University Fan em struck my interest in learning more abeutitue organic dory business. 


\section{$=$ \\ Oroville, CA 95966 \\ (530) 589-5899}

Experience:

President of Ophir 4-H club 2007-2010

- Support leaders and 4-H members

- Make meeting agendas

- Set up and run meetings

- Help members with presentations and project skills

- Organize fair set-up and decorations.

Junior Leader of Ophir 4-H club 2007-2010

- Give examples on what to look for in picking a fair project

- Assist and give showmanship demonstrations

- Help members at fairs get livestock show ready

- 4-H teen camp counselor

Las Plumas FFA 2007 - present

- Holding an officer position as Secretary

- Attend leadership conferences

- Horse judging team

- Best informed Greenhand team and year award

- Opening a closing team

- Serve at FFA fundraisers

- Serve at homeless mission

- Raise pigs and lambs for fair

- Brecding project for 2009-2010 cow and horse.

Butte County Miss Teen Congeniality 2009-2010

- Public interactions throughout Butte County

- Serve at Work training center

- Serve at Veterans dinner

- Appear in parades, and Christmas tree lightings passing out candy and visiting with people.

- Attend any and all county events.

Babysitting 2006-present

- Three kids ages 4,5 and 9

- And one age 1

- Make meals

- Entertain and organize games

- Bathe and put to bed 
Education

- Las Plumas High School 2007-present

- Central Middle School

- Ophir Elementary School

Honors

- Thirty six belt buckles from showing horses

- Fifteen high point awards showing horses

- Star chapter farmer

- Star Greenhand

- Gold award on two Northern California project competitions

- Attitude and achievement trophy, Butte County Fair

- Several showmanship, horsemanship and trail champions open and breed shows

- Reserve FFA champion lamb Silver Dollar Fair

- Reserve FFA champion lamb Butte County Fair

- Safe, Respectful, Responsible student

- Miss Teen Butte County Congeniality 2009-2010

School Activities

- Las Plumas High School cheerleader

- Las Plumas member of FFA

- Secretary of the Las Plumas FFA Chapter

Interests and Hobbies

- Love Cheerleading and dance, hanging oüt with friends, listening to music, riding dirt bikes, and most of all, showing horses, and livestock. 


\section{EXAMPLE OF A COVER LETTER}

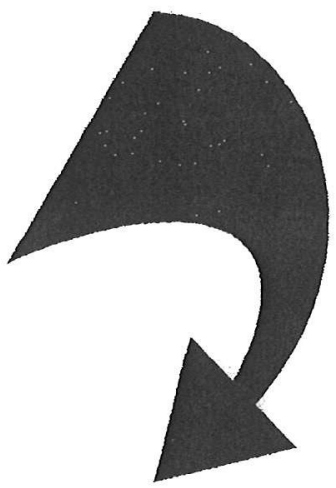

City, State, Zip

Telephone Number

Today's Date

Name of Individual

Name of Company

Address

City, State, Zip

Dear Mr./Mrs.:

FIRST PARAGRAPH

State the reason for the letter, the specific position or type of work you're applying for, and indicate from which resource (newspaper, friend, employment service) you learned of the opening.

Example: In response to your resent advertisement in the Newspaper dated September 3, I am submitting a resume outlining my gualifications for the position.

\section{SECOND PARAGRAPH}

Give a brief summary stating why you feel qualified for the position. If you are a recent graduate, explain how your academic background makes you a qualified candidate for the position.

Example: I enjoy writing and howe been involved with our high school newspaper and yearbook for the past three years. I was recognized as Outslanding High School Editor of California. During my senior year, I wonked at The Print Shop. I had the opportunity to work on layout design, in addition to using several software programs.

\section{THIRD PARAGRAPH}

This is the closing statement saying where you can be reached and thanking the employer.

Example: Enclosed is my resume for your review. I would appreciate the opportunity to meet you and discuss how my skills and experience would fit your personnel needs. You can reach me at (telephome number). Ilook forward to hearing from you and thank you for your consideration.

Sincerely,

Your Name 
Name:

Date:

Period:

\section{LPHS Agricultural Department CAREER COMPUTER SEARCH ACTIVITY FORM}

(Career search must be typed and NO more than TWO pages.)

Chosen Job/Occupation:

1) What are the specific job responsibilities/duties of this job/occupation?

2) What are the working conditions for this job/occupation (circle all that apply)

Indoor

Outdoor

Extensive travel

Little/No Travel

Protective Clothing

Protective Equipment

40-hour work week

Flexible hours

Nights/Weekends

With People

Without People

Office environment

Self- Employed

Business Dress

Casual Dress

Other working conditions of this occupation.... Please list.

3) What is the average starting salary for entry level into this occupation? What is the earning potential? 
4) What skills and abilities are necessary for successful entry into this occupation?

5) What, if any, degrees, advanced degrees, licensing or certification are required for entry into this occupation?

6) What is the Job Outlook for the next $5-10$ years?

7) What might make you leave this occupation?

8) Why might you be successful in this occupation?

9) What other occupations involving similar duties, skills, interests, education/training are available?

10) What major(s) will prepare you for this career?

11) Name two businesses in Northern California where you could work at this career. 


\section{Cover Letters}

Assignment: You are applying for a job and need to write a cover letter to go with your resume for the following scenario:

Big-Time Construction is interested in hiring a high school student who is interested in pursuing a career as an equipment operator. The position will involve basic welding, general equipment maintenance, and equipment operation. Applicants with strong math skills, experience or education in equipment operation/maintenance and a strong work ethic are encouraged to send a cover letter and resume to: Jose Gonzales, Training Supervisor, Big-Time Construction, P.O. Box 25698, Oroville, CA 96069.

Perhaps the only thing job-seekers dread more than writing a resume is writing the cover letter to go with it. True, a resume requires good, solid writing and attention to detail, but a cover letter is addressed to a particular person--whoever is in charge of hiring--and requires the job-seeker to answer the most important question on that person's mind: "Why is this applicant the best qualified candidate for the job?"

How well you write a cover letter may play a large part in how effective your resume will be. A good cover letter may get you an interview; a bad one may make your resume little more than an afterthought.

\section{Cover Letter Content}

The cover letter is your chance to sell yourself to a potential employer as the best candidate for a specific position. As such, it's just as important as your resume. In fact, you should never send out a resume without one.

The most important thing to remember is that your cover letter serves a separate function from your resume and should not be used to repeat the details of your resume, such as work history, education, or personal objectives. The resume is about you, your experience and your skills. The cover letter is about what you can do for the employer.

An effective cover letter should accomplish three things:

1. Introduce Yourself and Your Reason for Writing

The first paragraph needs to grab the hiring manager's attention. Say exactly why you have sent your resume: you are interested in the company and you want to fill a need they have. Demonstrate your interest by indicating any connections between the employer and yourself. Show that you work in the same field, that you share a common professional interest, or that you have been following the company or industry in the 
news.

If you were referred to the company by a mutual friend or associate, mention them; the hiring manager may feel more obligated to respond to your letter. (Don't profess to know more than you do, however. If you make inaccurate statements regarding the company or the industry, the hiring manager will see right through it.) When offering to fill the company's need, be specific as possible. Don't just mention the job position, describe what the company requires from that position.

\section{Sell Yourself}

In the second part of the letter state (briefly) the skills you bring to the table that will specifically meet the employer's needs. There is no need to go into great detail; your resume should take care of that.

Instead, use this section to highlight how you will use your talents and experience to benefit the company. Don't use it to indicate how you think you'll benefit from being employed--with a stack of resumes on her desk and positions to fill, the hiring manager isn't concerned with your personal fulfillment. Keep your use of the personal pronoun "I" to a minimum. Try to use it in this sense: "Here's how I can help you."

\section{Make a Plan}

Close the letter by indicating what you would like to happen next. Don't leave the ball in the employer's court; take action! Tell the potential employer where you can be reached, either by phone or by e-mail, but don't wait for a call. Indicate that if you don't hear from them within a few days, you will follow-up with a phone call to make sure your resume and cover letter have reached the intended recipient, and to arrange a face to face interview. Be assertive but polite. (Some job seekers may want to use a paragraph to explain anything that's not apparent from the resume, such as large gaps in the employment history.)

\section{Formatting Cover Letters}

There is no one "official" format, but here are some basic rules to keep in mind when composing a cover letter:

- A three line block in the top right hand or left hand corner of the page containing: your home street address; city, state and ZIP code; and the date. (The date may be separated from the block by one line.)

- Another three line block, flush left, one space below the date and one space above the greeting. This block contains the addressee's full name and address, including city, state and ZIP code.

- Use a colon after the greeting, not a comma. The greeting should address a specific person in a formal manner. "Dear Ms. Harper:" is perfect; "Dear Jennifer:" is not.

- Use a personalized salutation (not, for example, "To Whom It May Concern"). Make an effort to find out who will be receiving your letter. If necessary, telephone the company 
and ask. If you do not find a specific name, address the letter to "Hiring Manager," "Human Resources Manager," or simply "Manager."

- Paragraphs should be separated by a line of space; indentation is not necessary.

- You may use bullets and bold print in the body of your cover letter to organize and highlight information, and make it easier to read. If you do decide to use them, do so conservatively.

- The closing should read "Sincerely," followed by your signature underneath, then your full name in print underneath that. Always leave enough room for your signature between the closing and your name when you print your cover letter.

\section{sample cover letter}

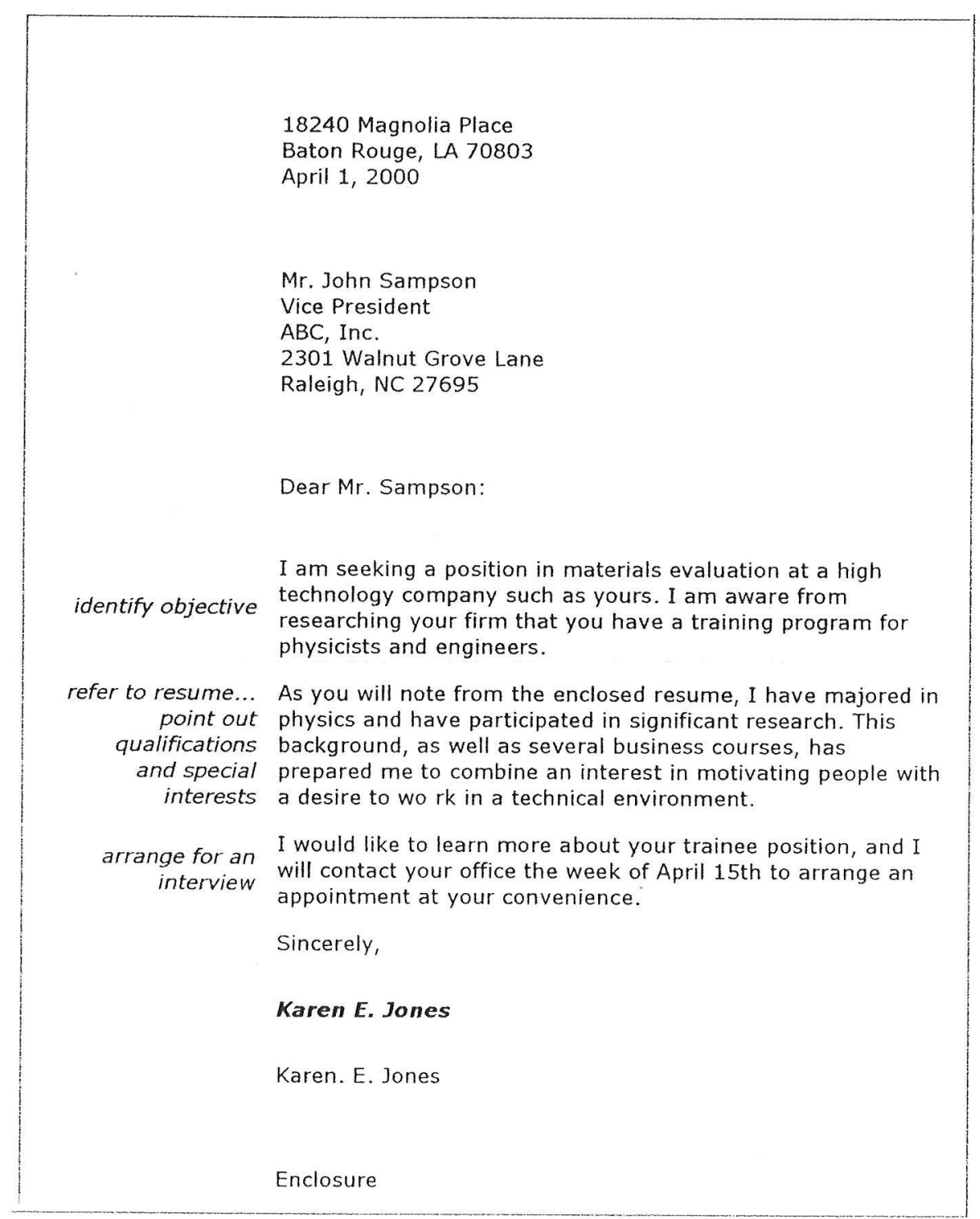



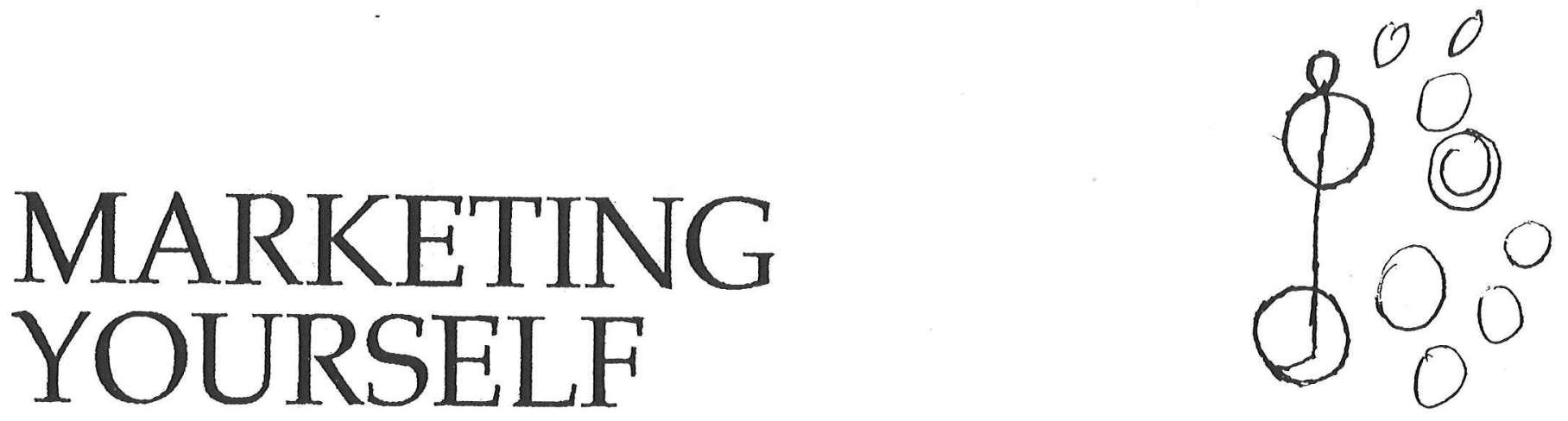

Are you up to the challenge?

"No one will hire me, I'm too young and besides, I have no experience." Sound familiar?

Think about who you are and what career you find interesting. Any career you choose should use your personality strengths, skills and interest, as well as your education and experience. The following questions will help you determine your strengths and accomplishments. The answers to these questions will be the foundation for an interesting and effective resume.

Have you been involved in any project or event?

- What was your role?

- What steps did you follow?

What tools/skills did you learn?

- Did you learn how to use any equipment (computer, tools, etc.)?

- Did you learn a particular software program?

- Were you able to use any organizational skills?

- Did you work with other people to get the job done?

What were the results of the project?

- Was the project successful?

- Did you win an award?

- Were you recognized for any special achievement?

- Was the project completed on time?

What interpersonal skills were developed?

- Did you work with a diverse group of people?

- Did you serve as a committee member or chairperson?

- Did everyone cooperate?

- Did everyone feel equally good about the project? 


\section{PLANNING YOUR RESUME}

What type of resume format you choose will depend on the way you want to present your information. No matter which type you choose, each resume should offer the same basic information.

PERSONAL INFORMATION

Include your name, addness, and phone number-you'd be surprised how many people forget to include their phone number!

CAREER OBIECTIVE

This is not a necessary part of the resume, but it can help you target the right job.

Example: To work as a (job title) for a (type of company).

To work as a news aide for a newspaper.

SKILLSSUMMARY

Include technical skills as well as communication, leadership, and organizational skills. Emphasize business, computer, and industrial-arts skills.

EDUCATIONALINFORMATION

Go beyond courses and diplomas by listing specific important projects. Focus on extracurricular activities if they are closely related to your job objective or if they show examples of leadership, communication, or team-related skills.

EMPLOYMENT HISTORY AND JOB DESCRIPTION

List your employment history, starting with your most recent job. Be sure to list dates and duties, including accomplishments.

\section{ACHIEVEMENTS}

Include volunteer and community work (including all positions of responsibility), awards, and certification programs.

\section{REFERENCES}

Even though you'll probably want to write, "Refenences available upon request" on your resume, and not list names, you should have two or three people who would be willing to write a reference letter or answer a telephone call from someone requesting information about you. 


\section{$\sqrt{\text { RESUME TIPS }}$}

- One page resumes are best, but use two if necessary.

- Choose an easy font to read and don't use a small typeface (12 pt. is preferred). Remember, the resume represents you.

- Select only quality paper.

- List all your good qualities. This is where you market yourself-don't be shy.

- Include a clear and concise career objective.

- Include experience/skills directly related to the career objective.

- Start each sentence with an action word.

- List all related experience--paid or unpaid. Include experience from school activities and committees.

- Research the position and company before the interview.

- Include your GPA under education if you're a student or recent graduate and it's a 3.5 or higher.

- Don't list references from whom you have not received permission or a positive response. 


\section{Quality Criteria Eight: \\ Program Promotion}

There is a systematic plan of program promotion to inform students, parents, counselors, other subject-matter teachers, administrators, board members, community members, and business and industry representatives, of options advantages, quality, accountability, and availability of careervocational education programs.

The Las Plumas High School Agriculture Department actively recruits for the program throughout the year. We have recently re-amped are recruitment program and put on four different recruitment days just designated to get incoming $8^{\text {th }}$ graders hooked into our program. While the high school is experiencing declining enrollment, the Agriculture Department is experiencing increasing enrollment, due in part to effective recruitment strategies.

Our chapter is always promoting our students through various articles, and newsletters. This year our Chapter reporter has focused on producing a quarterly newsletter as well as making sure the community is aware of our students' success. Our chapter website has also gone under reconstruction, appealing to more of our students and having current up-to-date information for both students and parents on it.

In our budget we have put more money towards promoting our program. We recently have put up two new Agriculture Department signs in front of our building. We also purchased t-shirts for our students to wear that has Las Plumas FFA logo at the fair. We have majorly focused on promoting our programs at the local fairs, since that is were the majority of the community sees and accesses our program. For the past two years our chapter has made it a goal and has succeeded in winning in all four species at both fairs the clean barn \& public image awards. We have also increased our competitiveness at the fairs and now Las Plumas FFA is building the name of the chapter to beat.

During FFA week, multiple activities including an appreciation staff BBQ, lunchtime activities for students to be evolved in. We also host an appreciation dinner meeting for a group that has supported our chapter, for example, this year we invited the Butte County Cattlemen's who cook for the majority of our fundraising events.

Agriculture teachers, along with chapter officers and other agriculture student representatives to go to multiple feeders schools to promote the agriculture program and the opportunities it presents for incoming freshman. On-campus recruitment days are usually nine times a year (one during FFA week) were the students actually come to the high school campus. In the fall, we visit the feeder schools just to prepare them for their visits and lay out the basics of what our program offers.

\section{Evidence Documents Include:}

- Promotional Agriculture Program Brochure

- Quarterly FFA Newsletter

- Las Plumas FFA Website

- Pictures of recruitment

- Pictures of Students of fair representing Las Plumas Proudly 


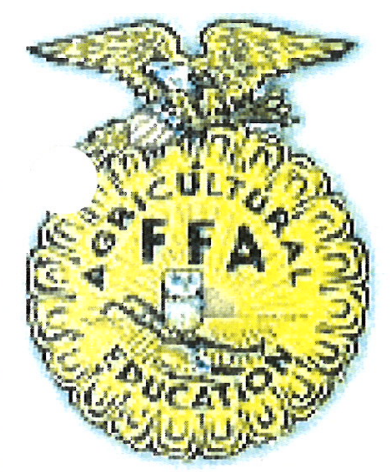

HOME

$\underline{\text { ABOUT US }}$

CONTACT US

CALENDAR

PROJECT SAE'S

CONFERENCES/ APPLICATIONS

RELATED LINKS

\section{EVENTS/MEETINGS}

\section{1-2012 Officers}

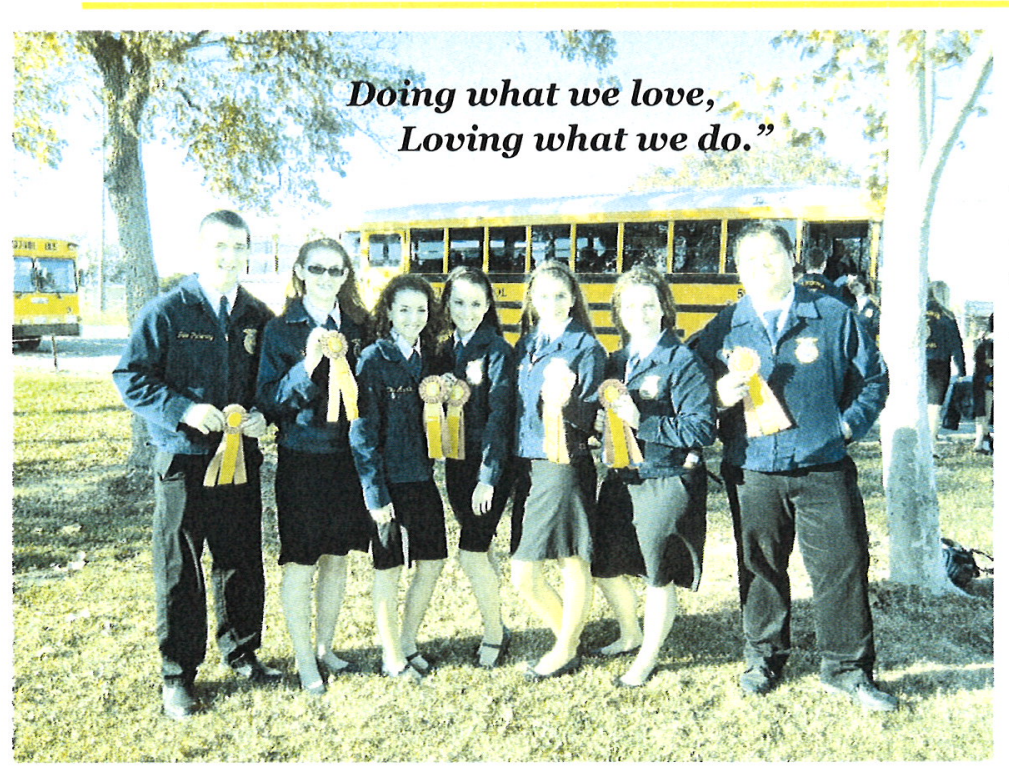

From left to right:

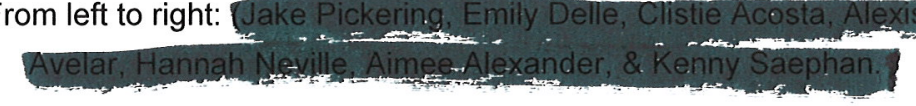

2011-2012 Officer Team

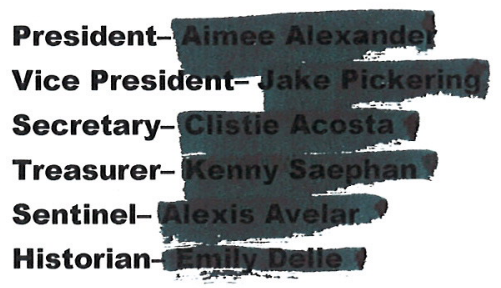

Committee Chairs:

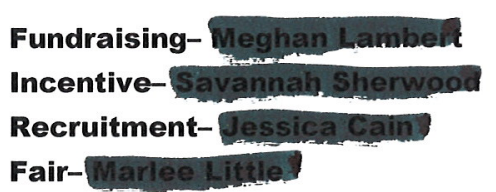

Community Service-

FFA Advisors:

Mrs. Earley, Ms. Aldridge Mr. Knapp, Mr. Diaz

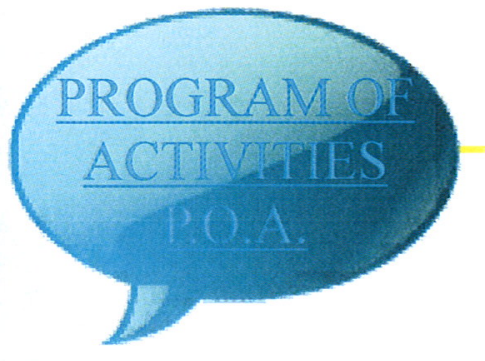

\section{Officer Messages}

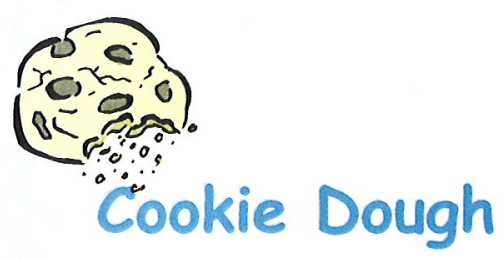

Sales

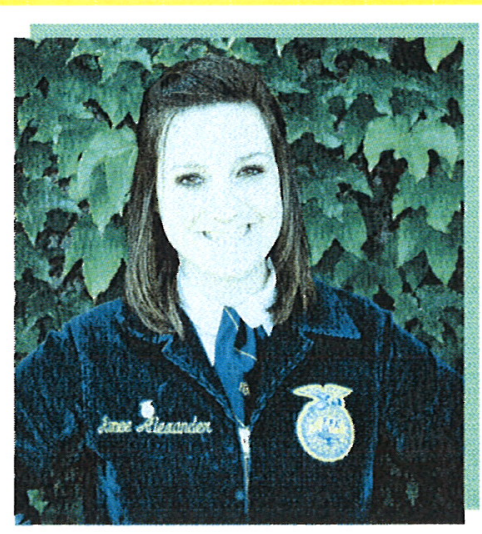

April 17-May 1st

Ask an Ag student!

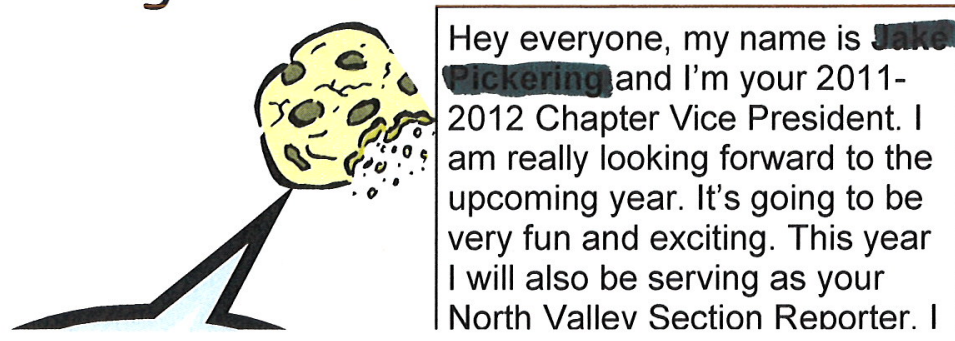

Hey FFA members, my name is Aimee Alexander and I am your 2011-2012 Chapter President. I got Involved in Ag my freshmen year, but why I got Involved is different than most high school students. I've wanted to be a vet since I was three and my eighth grade summer I decided to start looking at colleges. I decided I wanted to go to U.C Davis and they required two years of an $\mathrm{Ag}$ related course. I had no idea what that was so my mom and I looked into it and I discovered that Las Plumas had an FFA Chapter and that it counted as Ag, so two days before school started at Paradise High, I switched schools and came here to LP. My freshmen year I wasn't very involved and I regret that because, now, Ag is everything to me. I have raised Guide Dogs for the Blind and I take market hogs to the fairs as well as a breeding doe. FFA has had a huge impact in my life and has helped me decided what to do with my future. I am now planning on going to Chico State to become an Ag teacher. I encourage all of you members to get as involved as possible because we have a lot of fun coming up this school year. Do your best and get involved and you will be amazed where $\mathrm{Ag}$ can take you! Sincerely, Aimee Alexander 

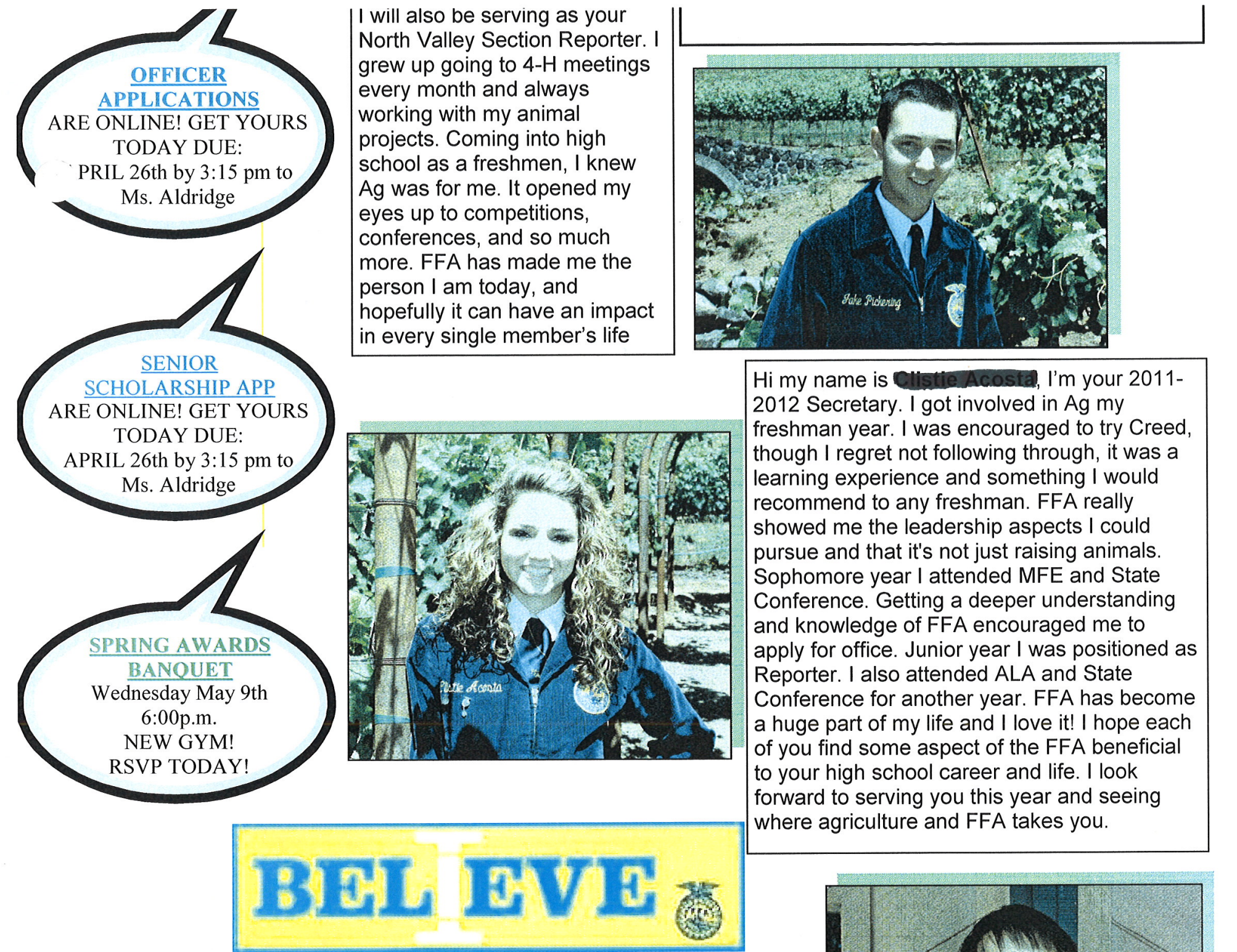

My name is Kenny Saephan and I'm your 2011-2012 Las Plumas Chapter Treasurer. I grew up in a farming family and we have farmed strawberries my whole life. I joined FFA as soon as I got into high school but I was not very involved. I had bad grades and ditched school but my junior year, Mr. Knapp convinced me to join horticulture. I found out how fun FFA was so I applied for treasurer. I'm very excited for this next year and I hope you all have as much fun as I will.

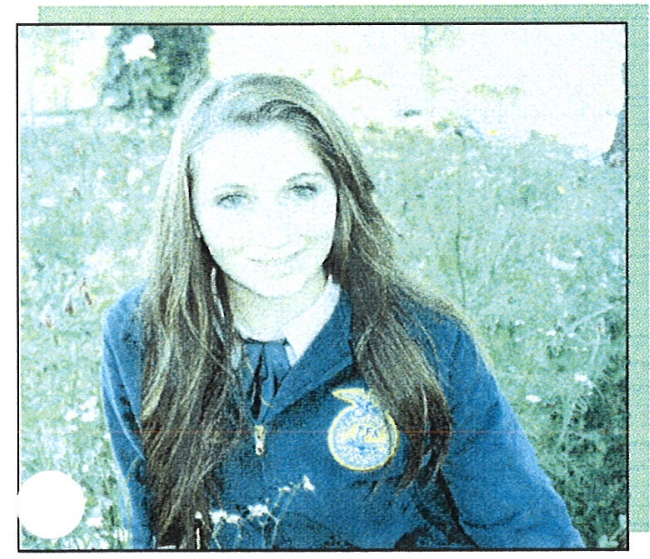

$\mathrm{Hi}$, my name is Hannah Neville I am your 2011-2012 Chapter Reporter. I have been in $\mathrm{Ag}$ since my freshman year and I love it. The people in our Ag department and being involved in agriculture in general, has opened so many doors for me. I have been around agriculture, mainly livestock, my entire life and being in FFA has given me the chance to share my abilities with all of you. The main thing I do in FFA is raise and sell livestock at our local fairs. I have raised hogs for 4 years, tried my luck with meat pen rabbits, and fallen in love with raising cattle. I also attend as many leadership conferences as I can. Outside of FFA I enjoy; cheerleading on the school squad, working on my truck with my dad, and hanging out on my Grandpa Joe's farm with all of his horses. FFA has been awesome for me, and I hope it will be the same for you. I wish

Hi my name is Alexis Avelapl am your 2011-2012 Chapter Sentinel. I am currently a junior and this is my $3^{\text {rd }}$ year in Ag. My freshman year I started to get

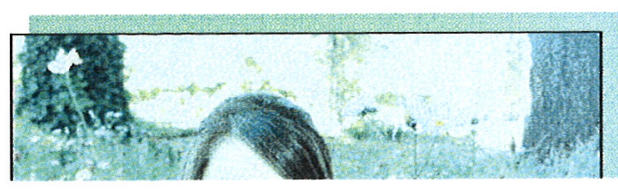




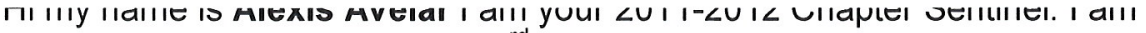
currently a junior and this is my $3^{\text {rd }}$ year in $\mathrm{Ag}$. My freshman year I started to get involved in FFA by doing opening and closing in Colusa, later I took a market goat to Silver Dollar Fair and started my own goat breeding project. My sophomore year I did opening and closing again, also joined the livestock judging team, recruited $8^{\text {th }}$ graders, and took a market lamb to both Silver Dollar and Butte County fairs. Outside of $\mathrm{Ag}$ I play volleyball for our school, I take

ors and AP classes, and work at Jakes Burgers. I enjoy doing things like wakeboarding and being with my family and friends. I hope we encourage you all to get involved!

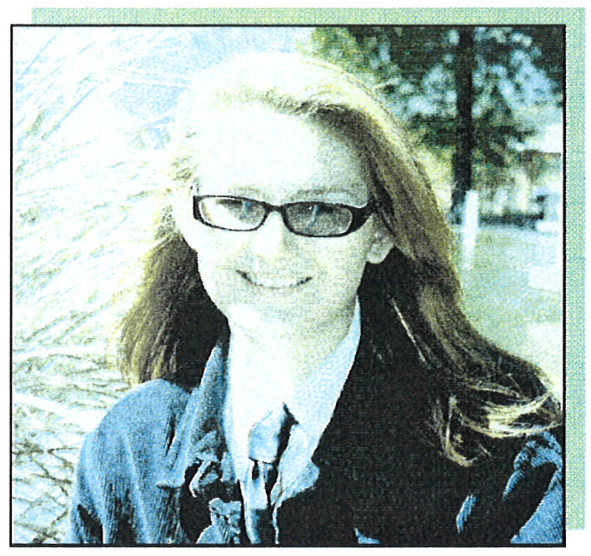

Dear FFA Members,

My Name is Emily Delle and I will be serving as your 2011-2012 Las Plumas FFA Chapter Historian. I got involved with FFA only a year ago when the journalism class got canceled due to lack of enrollment. I got involved with Fundraising, Opening and Closing, Co-Ops, and Parliamentary Procedure competitions and the teams I was on succeeded. These experiences taught me that hard-work, dedication and high personal expectations lead to success.

Outside of FFA I play the bass for my band "Forget About The Donkeys", help lead my local church's youth group, work as an AMF (American Missionary Fellowship) Summer Missionary at Mt. Hope Bible Camp in Forbestown, California and I love to hang out with my friends and do crazy things.

I never dreamed that I would be an FFA Officer but I am excited for this year, and can't wait to see the things that our chapter will accomplish and the experiences we will have.

Home $|\underline{\text { About Us }}| \underline{\text { Contact Us }}|\underline{\text { Calendar }}|$ Project List $\mid$ Employee List $\mid$ Related Links $\mid$ Event 


\section{Las Plumas FFA}

\section{About Us}

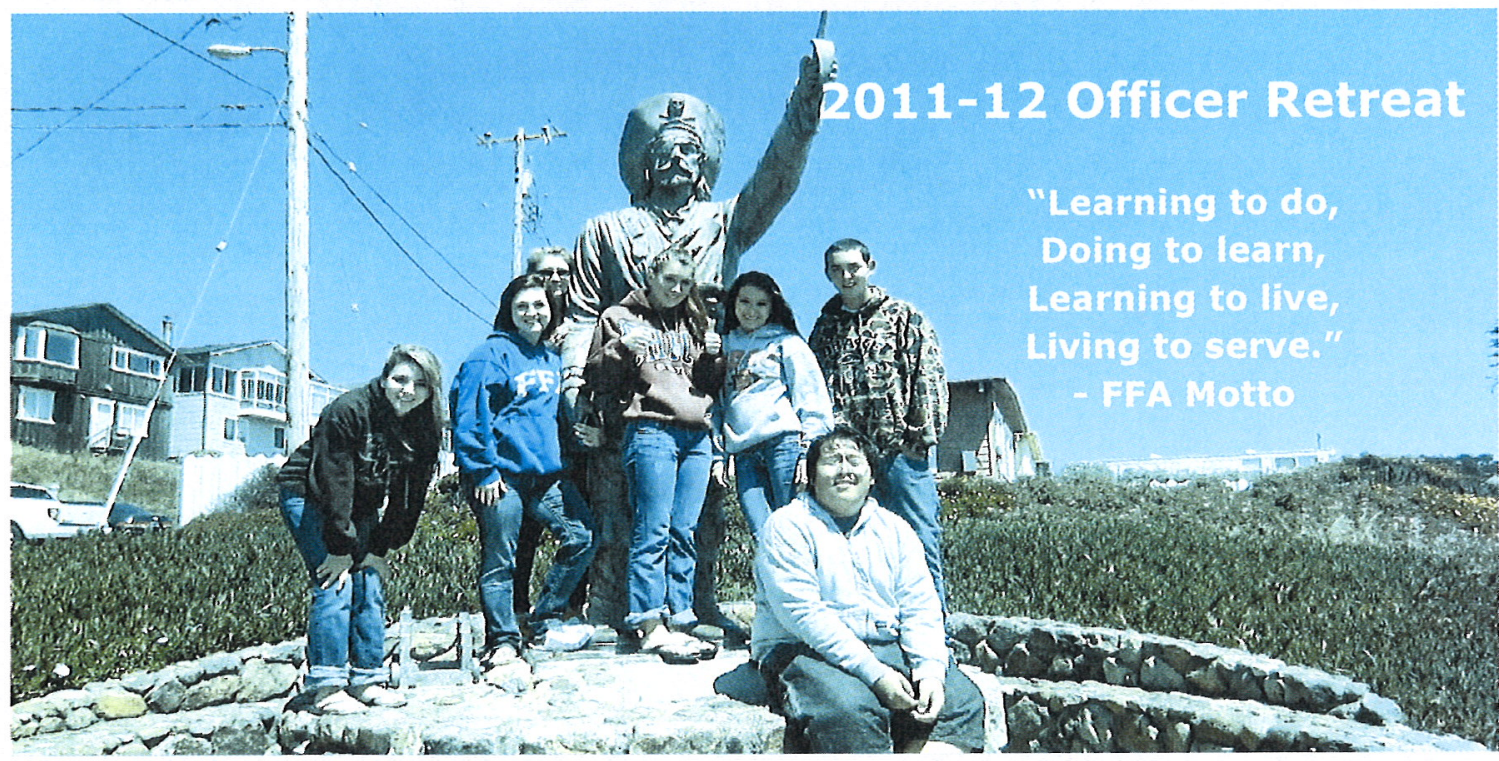

CONFERENCES/

APPLICATIONS

$\underline{\text { RELATED LINKS }}$

"Doing what we love, loving what we do..

\section{LAS PLUMAS FFA CHAPTER GOALS}

At the beginning of the summer of 2011, the 2011-2012 Las Plumas Officer Team and advisors took a retreat to Dillon Beach to plan the new year. They grew as a team, planned the theme of the year, and came up with a few goals for the chapter.

\section{Goal 1- Our objective is to have $65 \%$ retention of each} grade level for the following year.

-Chapter workshop for $10^{\text {th }}$ and $11^{\text {th }}$ graders.

-Make our meetings more interesting. Goal 2- Our objective is to promote our chapter in our community and school.

-Community service.

-Media awareness.

-Showing gratitude for our supporters.

\section{THE FFA MISSION STATEMENT}

FFA makes a positive difference in the lives of students by developing their potential for premier leadership, personal growth, and career success through agriculture education. 
To accomplish this mission, FFA:

Develops competent and assertive agricultural leadership.

Increases awareness of the global and technological importance of

Agriculture and its contribution to our well-being.

Strengthens the confidence of agriculture students in themselves and their work.

Promotes the intelligent choice and establishment of an agricultural career.

Encourages achievement in supervised agricultural experience programs.

Encourages wise management of economic, environmental and human resources of the community.

Develops interpersonal skills in teamwork, communications, human relations and social interactions.

Builds character and promote citizenship, volunteerism and patriotism.

Promotes cooperation and cooperative attitudes among all people.

Promotes healthy lifestyles.

Encourages excellence in scholarship.

I believe in the future of agriculture, with a faith born not of words, but of deeds-achievements won by the present and past generations of agriculturists; in the promise of better days through better ways, even as the better things we now enjoy have come to us from the struggles of former years.

I believe that to live and work on a good farm, or to be engaged in other agriculture pursuits, is pleasant as well as challenging; for I know the joys and discomforts of agricultural life and hold an inborn fondness for those associations which, even in hours of discouragement, I cannot deny.

I believe in leadership from ourselves and respect from others. I believe in my own ability to work efficiently and think clearly, with such knowledge and skill as I can secure, and in the ability of progressive agriculturists to serve our own and the public interest in producing and marketing the product of our toil. 
I believe in less dependence on begging and more power in bargaining; in the life abundant and enough honest wealth to help make it so-for others, as well as myself; I less need for charity and more of it when needed; in being happy myself and playing square with those whose happiness depends upon me.

I believe that American agriculture can and will hold true to the best traditions of our national life and that 1 can exert an influence in my home and community, which will stand solid for my part in that inspiring task.

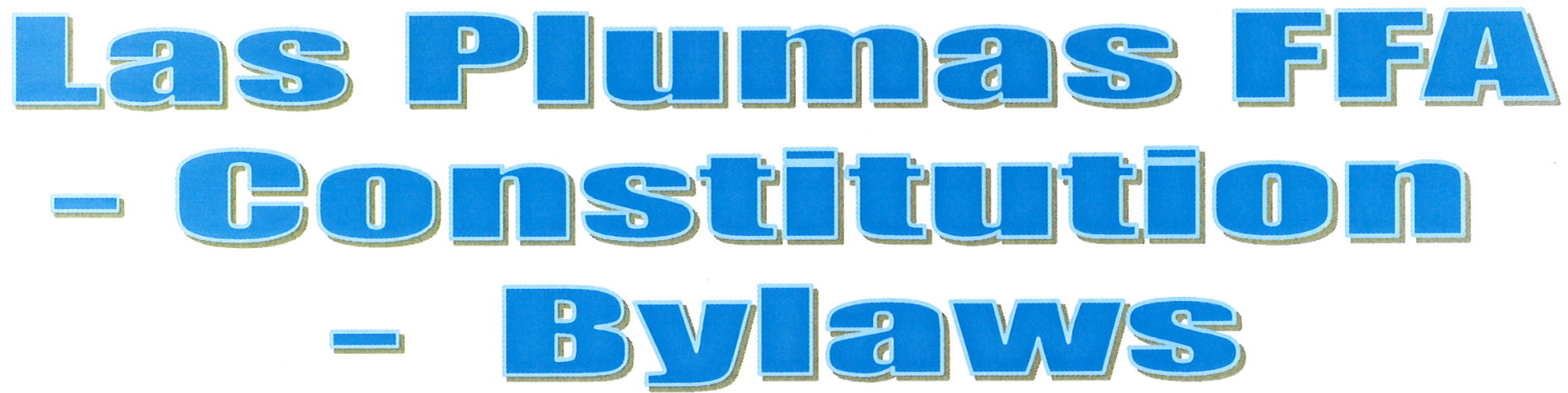

\section{Article 1: Name and Purpose}

Section A: The name and purpose of the organization shall be "The Las Plumas Chapter of the Future Farmers of America". This is chapter number 306 of the California Association of the Future Farmers of America.

Section B: The purpose for which this organization is formed is as follows:

To develop competent, aggressive urban and rural leadership.

To strengthen the confidence of the agriculture person in themselves and his/her work.

To create more interest in the choice of farming occupations as an intelligent alternative.

To encourage cooperative efforts aiming students of the vocational agriculture.

To promote thrift among the students of the vocational education in agriculture.

To promote and improve scholarships.

To encourage organized activities among students and vocational agriculture.

To supplement the regular systematic instruction offered to students of the vocational education in agriculture.

To advance the cause of vocational education in the agriculture in public schools in California.

To encourage members in the development of individual farming programs and establishments in farming.

\section{Article 2: Organization}

Section A: The Las Plumas of the FFA is a local chartered unit of the California Association of the FFA, which is chartered by the National Association of the FFA.

Section B: This chapter accepts in full the qualifications of the Constitution and Bylaws of the California Association FFA as well as those of the National FFA.

\section{Article 3: Membership}

Section A: Membership in this organization shall be active, associative, and honorary.

Section B: Qualifications for membership is outlined in the Constitution of the California Association of the FFA.

! :tion C: The regular work of this chapter shall be carried on by active membership.

Section D: Active members in good standing may vote on all business brought before the chapter.*

*Active members are in good standing when:

$\mathrm{He} / \mathrm{she}$ attends local chapter meeting with responsible regularity.

$\mathrm{He} / \mathrm{she}$ shown interest and takes part in affairs of the chapter.

$\mathrm{He} / \mathrm{she}$ is enrolled in an aaricultural class. 


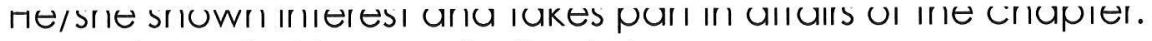

$\mathrm{He} / \mathrm{she}$ is enrolled in an agricultural class.

\section{Article $4:$ Membership Levels and Privileges}

Section A: There are five levels of membership based upon achievement. These levels are:

Member

Greenhand

Chapter FFA Degree

State FFA Degree

American FFA Degree

Section B: Qualification for election to the Greenhand Degree and the Chapter Farmer Degree are outlined in the Constitution of the California Association of the Future Farmers of America.

\section{Article 5 : Officers}

Section A: The officers of the chapter shall be:

President, Vice President, Secretary, Treasurer, Reporter, Sentinel, and Historian.

Section B: The advisor shall be a teacher of vocational agriculture at Las Plumas High School.

Section C: All officers shall be elected as per the bylaws once yearly in the spring. They shall begin their duties upon the closure of the last meeting of the year in which they are elected.

Section D: The officers of the chapter, together with the chairpersons of the major sections of the annual program of work committee, shall constitute the chapter executive committee. The executive committee shall have full power to act as necessary for the chapter in accordance with the action taken at chapter meetings and various regulations and bylaws from time to time.

Section E: Honorary and associate members shall not vote, nor shall they hold an office in the chapter except that of advisor.

Scction F: Chapter officers must:

hold the Chapter FFA Degree for at least one year or receive the degree during officer year. have a 2.0 cumulative GPA

maintain at least a $C$ average and have no F's

requirements may be waived with advisor's approval if there are not enough qualified candidates

\section{Article 6: Meetings}

Section A: Regular meetings shall be held once a month during the school year and at least one executive meeting shall be held during the summer. Special meetings shall be called at any time.

Section B: Two delegates may be elected from the membership to represent the chapter at the regional meeting and the State FFA conference. Teacher committee may also select the representatives.

Section C: A majority of the active member listed on the membership role shall constitute a quorum. A quorum must be present at any meeting at which business is transacted or a vote is taken committing the chapter to any proposal or action.

\section{Article 7 : Dues}

Section A: Local dues shall be fixed annually by majority vote of the active members.

Section B: Full local, state and national dues shall be paid by the agricultural department of the Las Plumas FFA. No dues shall be collected from associate members and honorary members.

\section{Hicle 8: Insignia and Uniform}

Section A: The insignia and the uniform of the FFA shall be the insignia and uniform of the chapter.

Section B: Insignia and uniform used by the members shall be those obtained from authorized officials designated by the national organization of the FFA.

\section{Article 9: Procedures}


Article 9: Procedures

Section A: Parliamentary procedure shall be used in all meetings of this organization in accordance with Robert's Rule of Order.

\section{Article 10: Amendments}

_ction A: This constitution may be amended or revised at anytime upon approval of the chapter, provided the amendment(s) does not conflict and is in accordance with the National Organization.

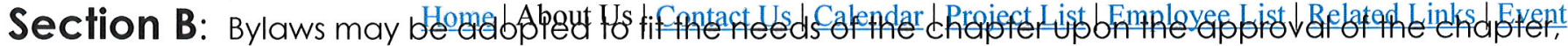
provided it is not conflicting and is still in accordance with the State Association and the National Organization.

\section{Las Plumas Chapter Bylaws}

\section{Article 1 General Statement:}

The bylaws stated should be considered as a part of the Las Plumas FFA Chapter Constitution. It takes two meetings to amend these bylaws. Changes are presented at the first meeting, and a vote on the changes takes place at the second meeting. To make the changes legal, there must be a quorum of $15 \%$ of the chapter members.

\section{Article 2 Officers:}

\section{Section A: Election of Officers}

To become an officer of the Las Plumas FFA Chapter, the following steps must be completed:

The member running must complete and return a Chapter Officer Application to the Advisor in charge. The member must pass a qualification screening.

3 1dvisors will screen and select the officers to their appointed positions.

Section B: Removal of Officers:

Reasons for removal are as follows: grades as stated in the Chapter Constitution

(Article5, Section F), use of alcohol or illegal drugs at public or school functions while 


\section{Las Plumas FFA}

\section{Contact Us}

Like us out on Facebook!

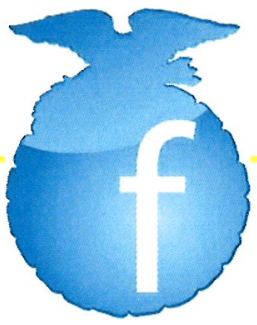

HOME

ABOUT US

\section{CONTACT US}

\section{CALENDAR}

\section{PROJECT SAE'S}

\section{CONFERENCES/} APPLICATIONS

\section{RELATED LINKS}

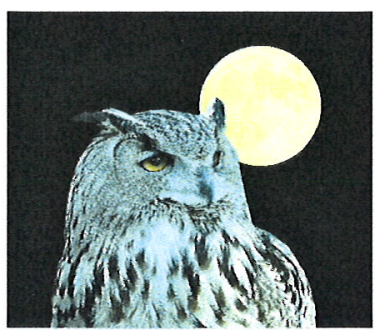

\section{Advisors}

"Stationed by the Owl"

"The owl is a time honored emblem of knowledge \& wisdom being older than the rest of you we are asked from time to time to give advice, we hope that our advice will always be based on true knowledge and ripen with wisdom."

\section{Instructors/Advisors}

Teaches: Ag Leadership, Floriculture, ROP Vet Skills

Email: aearlev@ouhsd.org

538-2310 ext. 2306

Ashleigh Aldridge-

Email: aaldridge@ouhsd.org

538-2310 ext. 2267

Jim Knapp-

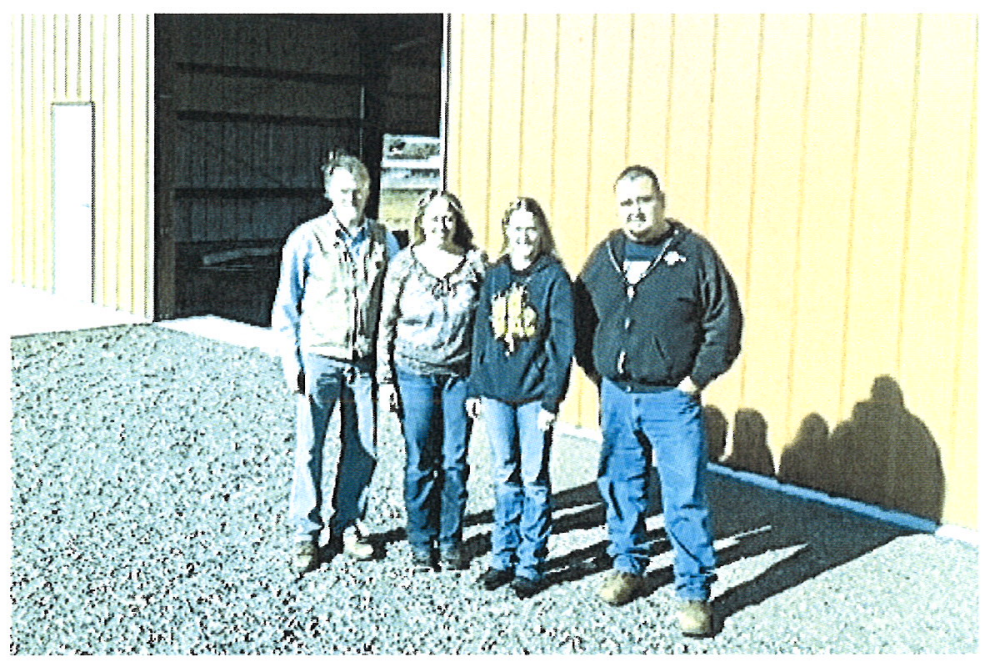

\section{Advisor Web Pages:}

Mr. Knapp (coming soon)

Mr. Diaz (coming soon)

Mrs. Earley (coming soon)

Ms. Aldridge

- Ag Life Science

- Animal Science

Department Head/ FFA Advisor/SAE Supervisor: Beef and Hogs

FFA Advisor/ SAE Supervisor: Sheep, Goats, \& Rabbits

Teaches: Ag Life Science, Animal Science, College Agriculture Biology

FFA Advisor/Recruitment/Horticulture

Teaches: Horticulture/Forestry, and Agriculture Earth Science

Email: iknapp@ouhsd.org

538-2310 ext. 2305

\section{Carlos Diaz-}

FFA Advisor/Agriculture Mechanics/ Ag Shop

Teaches: Ag Mechanics I, Ag Mechanics II, and ROP Heavy Equipment

Email: cdiaz@ouhsd.org

538-2310 


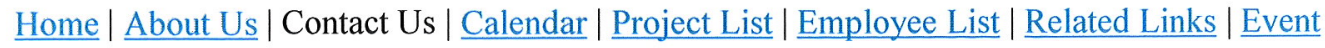




\section{Las Plumas FFA}

\section{SAE'S OR PROJECT INFORMATION:}

As $10 \%$ of your students grade they must be involved in some type of project if it is their second year in agriculture class. Projects have to be agriculture in nature but if needed they can ask their teacher for assistance in selecting a project. An agricultural education program is made up of three integrated parts: Classroom instruction, FFA and Supervised Agricultural Experience (SAE). Students with an SAE learn by doing. With help from their agricultural teachers, students develop an SAE project based on one or more SAE categories:

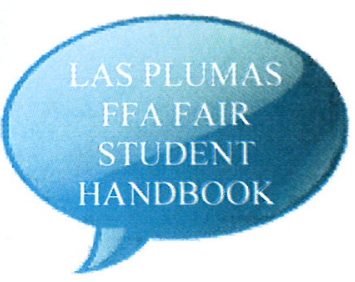

Entrepreneurship- Own and operate an agricultural business (e.g. a lawn care service, a pay-to-fish operation, holiday poinsettia production and sales.) Fair animal projects.

Placement- Get a job or internship on a farm or ranch, at an agriculture-based business, or in a school or factory laboratory. Landscape management.

Research and Experimentation-Plan and conduct a scientific experiment.

$\underline{\text { HOME }}$

$\underline{\mathrm{ABOUT} U \mathrm{~S}}$

\section{CONTACT US}

$\underline{\text { CALENDAR }}$

IECT SAE'S

CONFERENCES/ APPLICATIONS

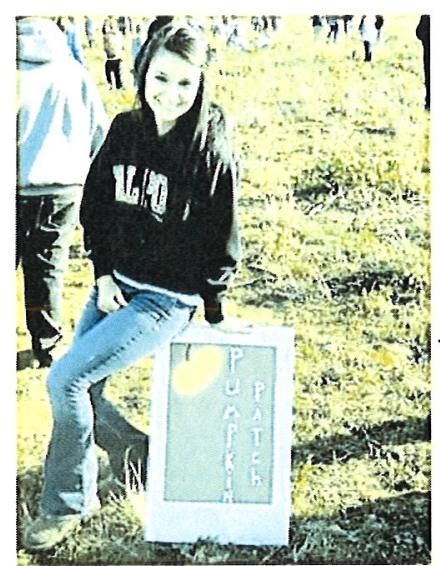

\section{Plant Based Projects-Mr. Knapp}

Project can include owning or working for someone that has any types of plants. Including vegetable production, crop production, grain production,

\section{Forestry/Landscaping Projects}

Include projects that deal with yard work, landscaping, mowing lawns. Timber harvest, wood cutting, and home improvement projects.

\section{Ag Mechanics/Ag Sales Projects-Mr. Diaz}

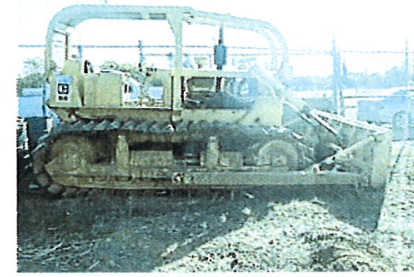

Project build outside of class time such as trailers, fences, chutes, any agriculture mechanics relates. Ag Sales includes working at a feed store, vet office, or butcher shop.

\section{Small Animal Based Projects- Ms. Aldridge}

Small animal care- taking care of small animals example guide dog project. Rabbit, chickens, and goat projects.

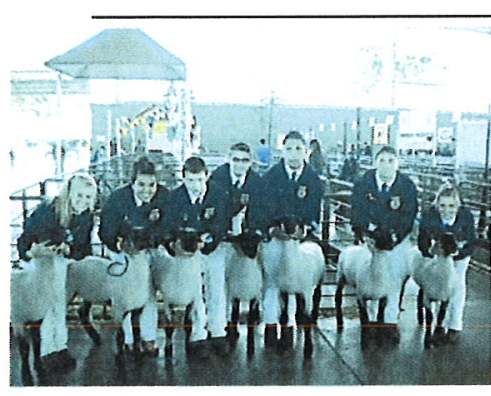

\section{Fair Animal Projects}

\section{Mrs. Earley \& Ms. Aldridge}

Fair animal projects can include Steers, Lambs, Hogs, Goats \& Rabbits. Check with your Ag teacher if you are interested for next year!

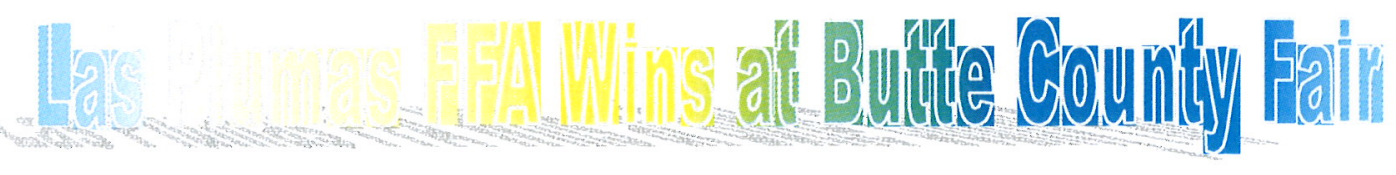



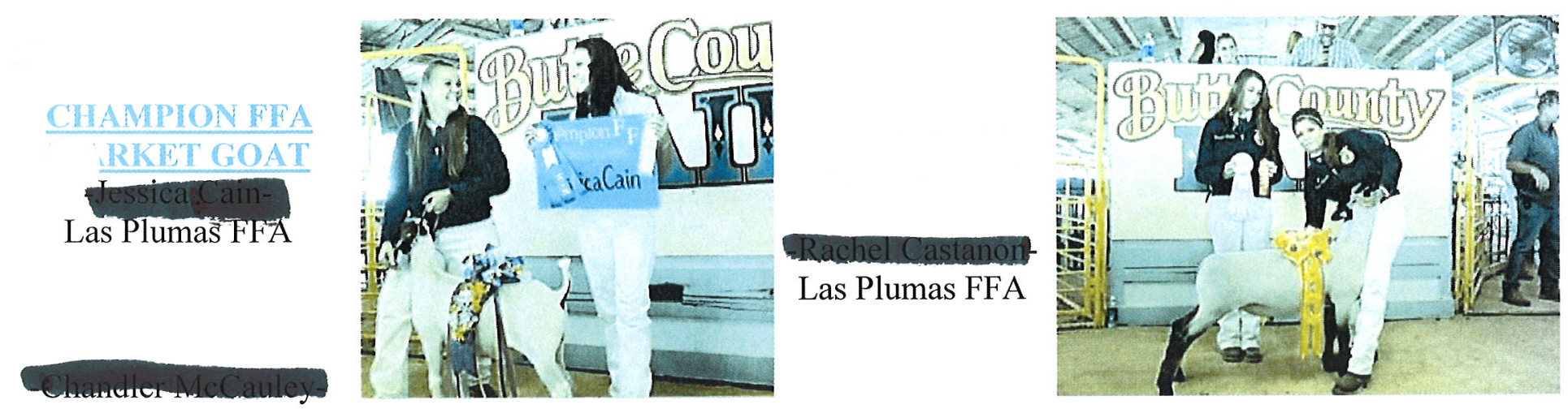

Las Plumas FFA
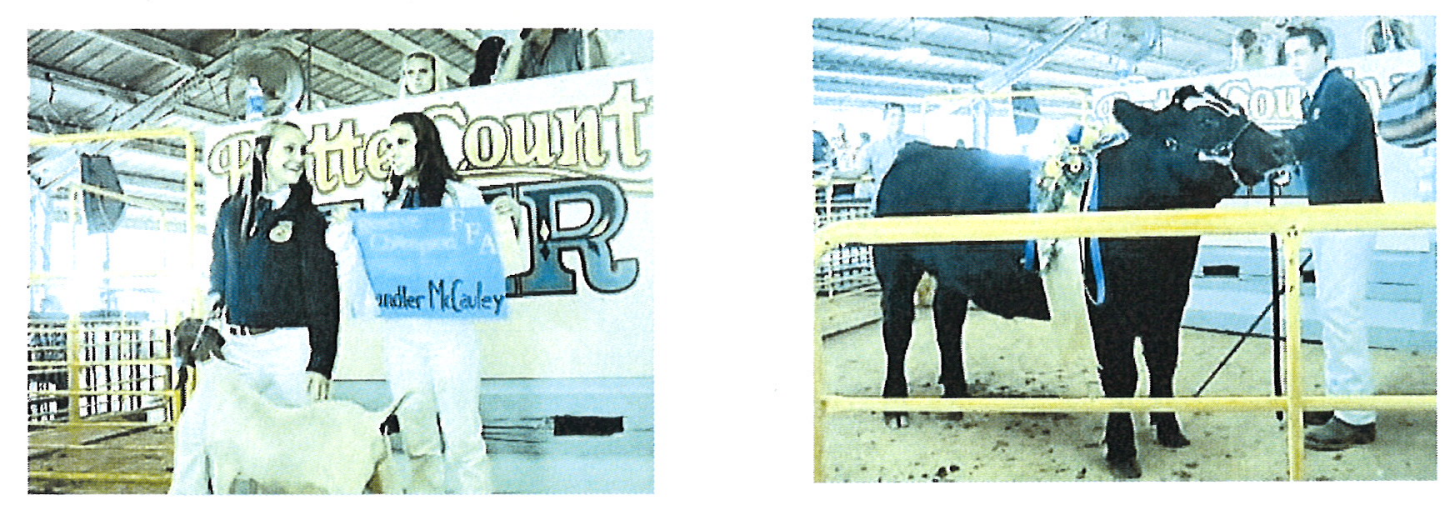

Eake Pickering-
Las Plumas FFA

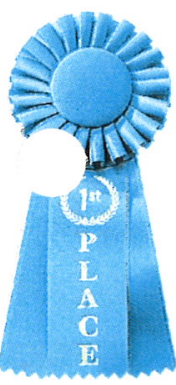

Supreme FFA Showman Winner: Sonia Ceja- Las Plumas FFA

Other Representatives: Jon Jones \& Jake Pickering- Las Plumas FFA

FFA Sheep Showmanship Winner-Sonia Ceja-Las Plumas FFA

FFA Beef Showmanship Winner- Jake Pickering

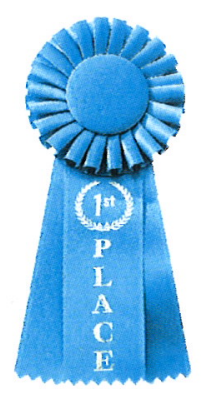

Las Plumas Wins Clean Barn \& Public Image in Beef, Swine, and Goats!!! 


\section{Las Plumas FFA}

\section{FFA Members Stuff/Applications}

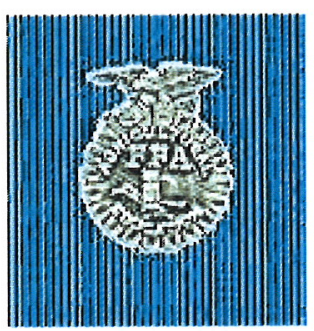

Greenhand Degree application

The Greenhand Degree is designated for those freshman or first year agriculture students who have meet all the requirements. Awarded at our Winter Degree Banquet in December!

Greenhand Application Right click target save as...

\section{$\underline{\text { CONTACT US }}$}

\section{CALENDAR}

\section{PROJECT SAE'S}

\section{CONFERENCES/}

\section{RELATED LINKS}

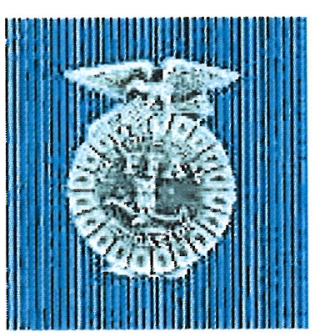

\section{Chapter Degree Application}

Chapter Degree is the next level of degrees awarded and the highest awarded by the chapter. You should of already received your greenhand degree. Meet all requirements. Awarded at Winter Degree Banquet in December!

Chapter Degree Application Right click target save as..

\section{State \& American FFA Degree Application/Proficiency Applications}

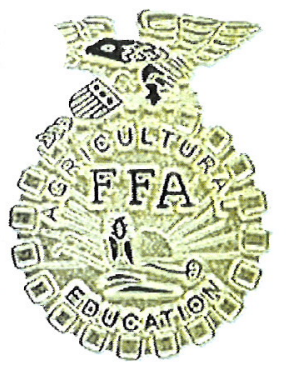

Degrees awarded by the State FFA. Must meet all requirements. Applications and records books must be online. State FFA Degree awarded at regional meeting in March. American Degrees are awarded at the National FFA Convention. Proficiency's awards focus on individual students projects or SAE's.

\section{State FFA Degree App $\quad \underline{\text { Proficiency Placement App }} \quad$ Prof. Entrep App $\quad$ American FFA Degree App}

\section{Conference Applications}

Greenhand Conference- In October is a conference designed for freshman (9th graders) only! 9-12th) In January to help build personal growth and develop leadership skills.

State Conference-(9-12th) End of April. Great Conference for active members who want to go further in our FFA Program. Especially potential FFA Officers!

MFE/ALA Conference Application Right click target and save as...
State FFA Conference Application Right click target and save as...

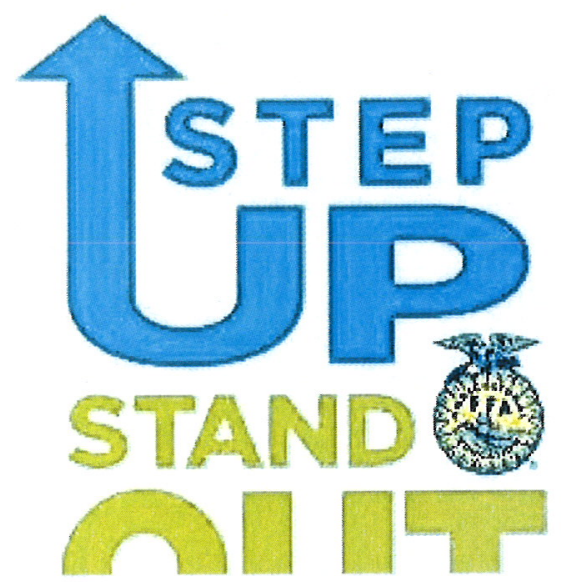

\section{Chapter Officer Application}

Usually come out in April and are due in April. Las Plumas currently has 7 officers that make up the officer team. Plus 5 standing committee chairs.

LP FFA Chapter Officer Application Right click target and save as... 
LP FFA Scholarship comes out in April and is due in April as well as requirements for becoming a program completer.

LP FFA Scholarship and Program Completer Application

Other Scholarships Right click target and save as...

$\underline{\text { Home }}|\underline{\text { About Us }}| \underline{\text { Contact Us }}|\underline{\text { Calendar }}| \underline{\text { Project List }} \mid$ Employee List $|\underline{\text { Related Links }}| \underline{\text { Event }}$ 


\section{Las Plumas FFA}

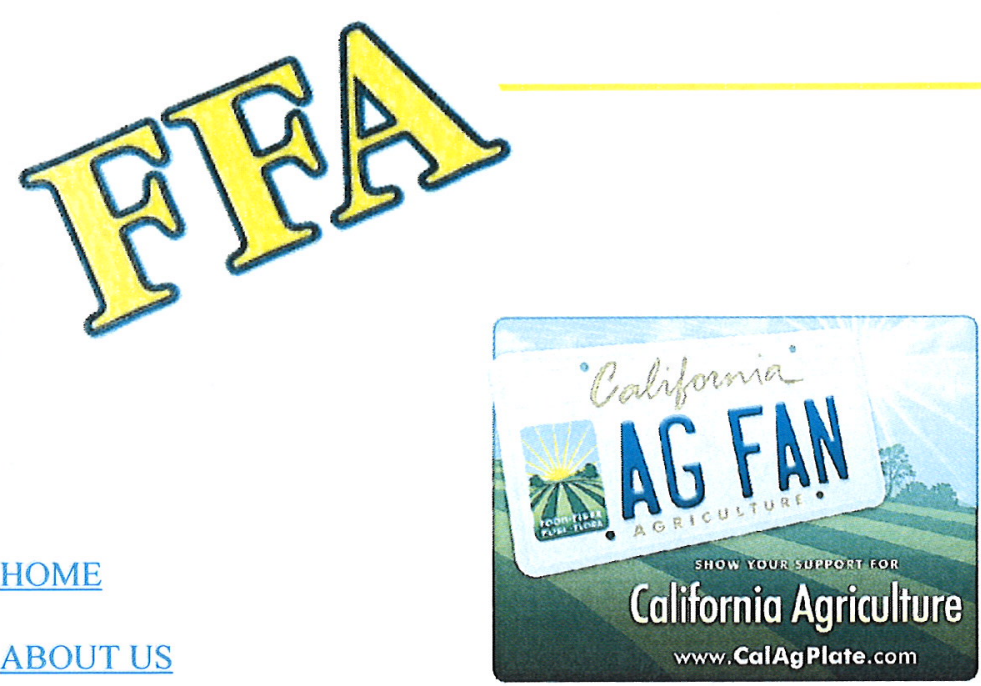

$\underline{\text { CONTACT US }}$

CALENDAR

PROJECT SAE'S

IFERENCES/ h. PLICATIONS

\section{$\underline{\text { RELATED LINKS }}$}

Related Links

http://www.calaged.org

Website resource for California FFA students, and advisors. Calendar of events, resources for student application, teacher curriculum and more.

\section{CHICO STATE AGRICULTURE}

\section{SUPPORT AGRICULTURE}

When you show your support for California agriculture with the purchase of a special interest license plate you are investing in the next generation of our Ag industry's innovators, entrepreneurs, and leaders. Your purchase directly supports youth agriculture programs that have an established record of success. Invest in your future today!

http://www.butte.edu/careers/agriculture/

\section{Agriculture \& Environmental Sciences Instructional Program}

The Butte College offers courses that are tailored to fit the individual. Butte College's programs are designed so that the student can earn an associate degree, a certificate of achievement, or completion of the first two years general education towards an advanced degree.

\section{http://www.csuchico.edu/ag/}

For more than 50 years, the College of Agriculture at California State University, Chico has impacted the quality of life in California and across the nation by educating and equipping agricultural leaders who have the theoretical knowledge, practical experience, and decision-making ability that allows them to excel in their chosen career. The close, friendly nature of our college, combined with an integrated agricultural curriculum and remarkable access to hands-on education, creates a fertile learning environment for our students and the agriculture industry we serve.

\section{LAS PLUMAS HIGH SCHOOL WEBSITE}

\section{OROVILLE UNION HIGH SCHOOL DISTICT}

\section{CAL POLY SAN LUIS OBISPO}

\section{http://cafes.calpoly.edu/}

What will you find in College of Agriculture, Food and Environmental Sciences?

Small classes with expert faculty who take pride in their ability to transform academically motivated students into innovative professionals.

At the heart of a Cal Poly education is our renowned Learn by Doing tradition. Our students have access to state-of-the-art laboratories as well as the university's 10,000 acres of ranchland, orchards, vineyards and forests - Cal Poly's 'living laboratories.'

Together, they provide the hands-on opportunities that are the essence of the Cal Poly experience. 
Together, they provide the hands-on opportunities that are the essence of the Cal Poly experience.

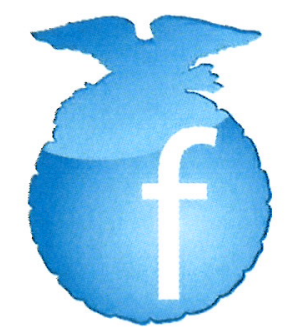

Las Plumas FFA Facebook STUDENTS \& PARENTS

www.facebook.com/pages/Las-Plumas-F FA/249652985084092

Join us on facebook! To stay connected, get updated FFA events, Fundraising, and activities!

Home $\mid$ About Us $\mid$ Contact Us $\mid$ Calendar $\mid$ Project List $\mid$ Employee List $\mid$ Related Links $\mid$ Event 


\section{Las Plumas FFA}

\section{Events/meetings}

\section{Spring Awards Banquet}

2011-2012 Was a record breaking year for the Las Plumas FFA. Students will be recognized for their leadership development, personal growth, and career success. Students will also be recognized for their SAE projects, and participation on any leadership or CDE team. Invitation only! Make sure you RSVP by May 4th.

\section{Past Meetings/Events}

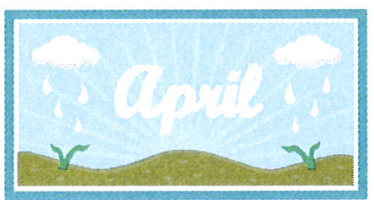

April FFA Meeting

4/17/12 @ 3:15p.m. New Beef Barn

Fair students reminder need 5 FFA meetings to be eligible to show with us at fair. April is the last meeting to accomplish that. We will also be starting a new fundraiser at this meeting. See agenda

\section{$\frac{\text { CONFERENCES/ }}{\text { APPLICATIONS }}$}

EV/ENTS/MEETINGS
Date: 05/09/2012

Contact person: $\mathbf{5 3 8 - 2 3 1 0}$

Contact Person: Andree Earley Email: aearley@ouhsd.org or Ashleigh Aldridge

Email: aaldridge@ouhsd.org
Time: 6:00 p.m.

\section{PROJECT SAE'S}

\section{RELATED LINKS}

March FFA Meeting

3/22/12 @lunch

Ag Shop

- $\quad$ March FFA Meeting Agenda

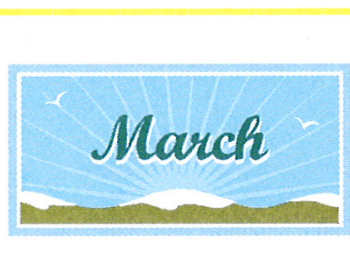

- $\quad$ March FFA Meeting Minutes

February FFA Meeting FFA WEEK 2/21-2/24

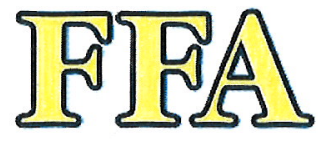

$\bullet$ February FFA Meeting Agenda

February FFA Meeting Minutes

Steak \& Crab Feed Jan. Meeting $1 / 28 / 12 @ 6 p m \quad$ LP New Gym

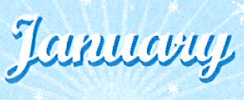

December
Winter Degree Banquet

- Greenhand Degree Recipients

- Chapter Degree Recipients

- Winter Degree Banquet Minutes
11/16/11@ 5:30pm LP FFA Barn

- $\quad$ November FFA Meeting Agenda

- $\quad$ November FFA Meeting Minutes 


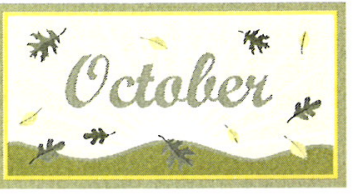

- $\quad$ October FFA Meeting Agenda

- $\quad$ October FFA Meeting Minutes

September FFA Meeting

9/21/11 @ 5:30pmLP FFA Barn

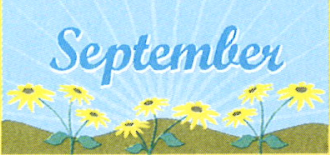

- $\quad$ September FFA Meeting Agenda

- $\quad$ September FFA Meeting Minutes

$\underline{\text { Home }}|\underline{\text { About Us }}| \underline{\text { Contact Us }}|\underline{\text { Calendar }}| \underline{\text { Project List }}|\underline{\text { Employee List }}| \underline{\text { Related Links }} \mid$ Event 
Quality Criteria Nine:

\section{Program Accountability and Planning}

There is an annual program assessment using input from instructors, administration, students, other staff, and advisory committee members which ensures that the program, scope, design, content, instruction, and administration is meeting the program objectives. The annual assessment process is used to develop a Program Improvement Plan for the short and long-term range administration and operation of career-vocational education programs.

The program at Las Plumas High School is assessed for improvement purposes in many ways. In a rotation, we are of course assessed for funding reasons through our regional supervisor, advisory committee, and self-review. One a more "daily operations" level, the department chair oversees the main financial budgets, with each agriculture instructor managing his/her own fiscal allocations, to be monitored by the department chair. Accounting is kept accurately, which is no mental tasks with over fifteen different accounts and funding sources for the department.

Administrators, advisory committee, and students give feed back and suggestions to improve the design and instruction of the program's effectiveness. These suggestions are taken into account during and discussed in order to improve the program in most department meetings. The Fiver-Year plan is categorized as a department chair responsibility; but is reviewed, revisited and modified by all Ag staff and advisory committee members.

It seems even with the highly motivated staff that we currently have the to-do list is continually growing, and we are always coming up with ways to improve our program. The most recent addition of a new Ag Mechanics teacher has been a major asset to our program. What we have been waiting for our former Ag Mech teacher to do for the past two years, was completed within the first couple months of his time at Las Plumas.

Student assessment is performed in a variety of ways from course grades, student reflections on activities/classes, materials utilized in coursework (such as timecards), FFA accomplishments, program completers and graduate follow-up.

\section{Evidence Documents Include:}

- FFA Roster

- - Graduate Follow-up information (project)

- Five Year Plan

- Quarter Reflection samples from students

- Current-year budget 


\section{Graduate Follow-up}

\# CA0166 Oroville - Las Plumas

Las Plumas HS

2380 Las Plumas Ave.

Oroville, CA 95966

Graduates for Spring: 2011 Go

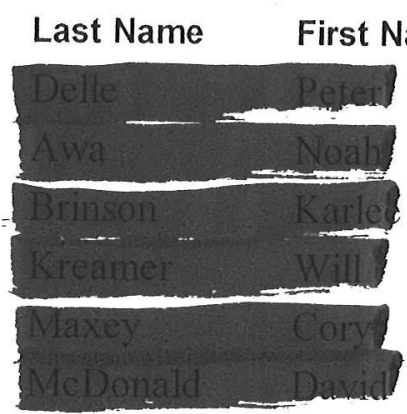

me Graduate Status

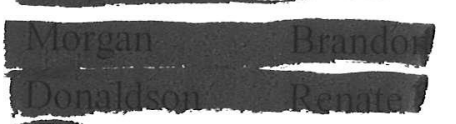

Four Year College-Ag Major

Military-

Military-

Military-

Two Year College-Non-Ag Major

Location or Position Unknown-

Two Year College-Ag Major

Employed - Fulltime-Ag Job

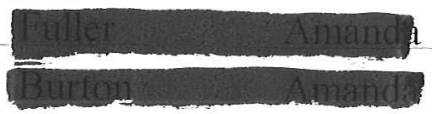

Employed - Parttime-Non-Ag Job

Location or Position Unknown-

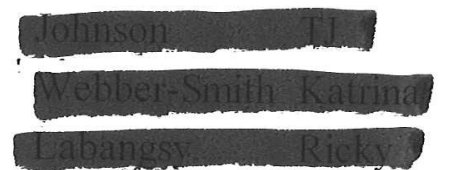

Two Year College-Non-Ag Major

Employed - Parttime-Non-Ag Job

Two Year College-Ag Major

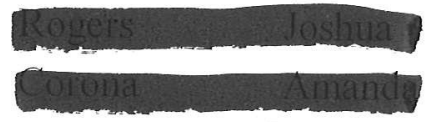

Four Year College-Ag Major

Two Year College-Non-Ag Major

Two Year College-Ag Major

Employed - Parttime-Ag Job

Employed - Fulltime-Ag Job

Location or Position I Inknnwn-

Two Year College-Ag Major

Two Year College-Ag Major

Four Year College-Non-Ag Major

Two Year College-Ag Major

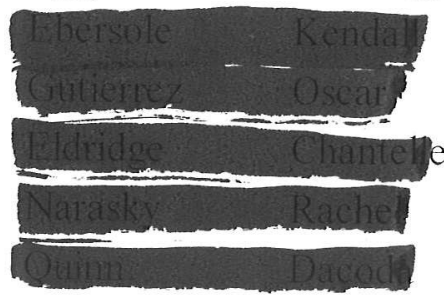

Employed - Parttime-Ag Job

Employed - Fulltime-Ag Job

Two Year College-Ag Major

Employed - Parttime-Non-Ag Job

Two Year College-Non-Ag Major

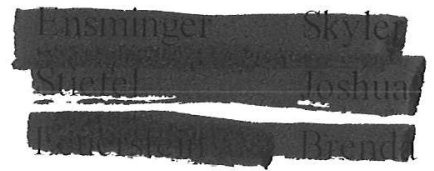

Employed - Fulltime-Non-Ag Job

Employed - Fulltime-Ag Job

Two Year College-Ag Major

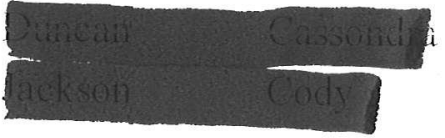

Two Ýaai Collego-Ág Iviajor

Two Year College-Non-Ag Major 
$\because$

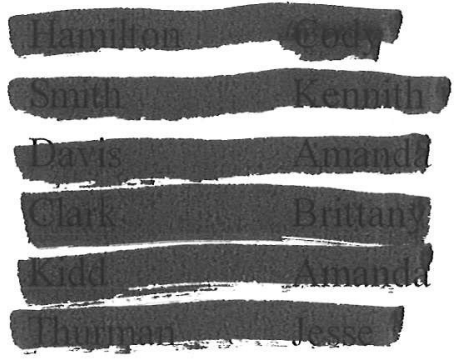

Four Year College-Ag Major

Employed - Parttime-Non-Ag Job

Two Year College-Non-Ag Major

Two Year College-Non-Ag Major

Location or Position Unknown-

Employed - Parttime-Ag Job

Printed: 10/24/2011 9:24:38 AM

Count: 39

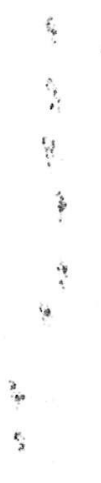

to

s.

4

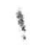

3

is

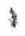

ร.

4 
FFA Roster

\# CA0166 Oroville - Las Plumas

Las Plumas HS

2380 Las Plumas Ave.

Oroville, CA 95966

Year: 2011 Go
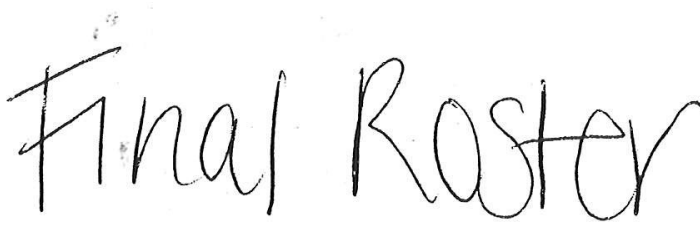

\section{FFA 葆 Last Name First Nam 553257242}

$$
553040153
$$

553550563

0

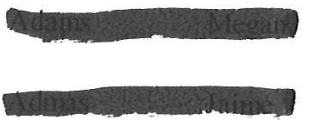

552473166

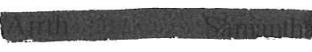

0

553040168

0

0

0

553257244

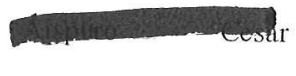

厲
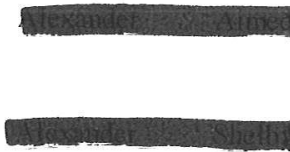

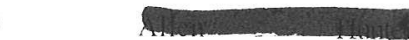

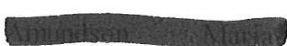

553550564

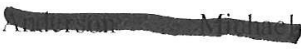

553550565

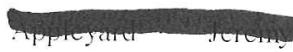

0

553550566
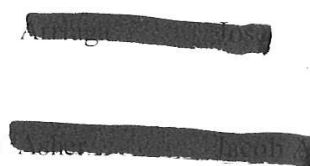

553257243

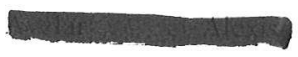

553550567

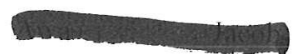

552736671

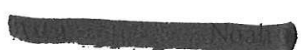

\section{PII}

Plumas

St Zip

Zip

Year Grade

Ave

2380 Las
Plumas
Avenue

2380 Las Oroville Ca $95966 \quad 2 \quad 10 \quad$ F

PLumas

2380 Las Oroville CA $95966 \quad 1 \quad 09 \quad$ F

Plumas

Ave

2380 Las Oroville CA $95966 \quad 6 \quad 14$

Plumas

Ave.

2380 Las Oroville CA $95966 \quad 1 \quad 09 \quad$ M Plumas

Ave

2380 Las Oroville CA $95966 \quad 4 \quad 12$

\section{Plumas}

Avenue

2380 Las Oroville CA $95966 \quad 1 \quad 09$

Plumas

Ave

2380 Las Oroville CA $95966 \quad 1 \quad 09 \quad F$

Plumas

Ave

2380 Las Oroville CA $95966 \quad 1 \quad 09 \quad$ F

Plunas

Ave

2380 Las Oroville CA. $95966 \quad 3 \quad 12 \quad$ F

Plumas

Âre

2380 Las Oroville Ca $95968 \quad 2 \quad 10 \quad$ M

Plumas

Ave

2380 Las Oroville Ca $95966 \quad 2 \quad 10 \quad \mathrm{M}$

Plunas

Ave

2380 Las Oroville CA $95966 \quad 1 \quad 09 \quad M \quad \times \quad 2$ More Agriscience X
Plumas

Ave

2380 Las Oroville Ca $95968 \quad 2 \quad 10 \quad$ M

Plumas

Ave

2380 Las Oroville CA $95966 \quad 3 \quad 11 \quad \mathrm{~F} \quad \mathrm{X}$ White An. Science $X$

Plumas

Ave

2380 Las Oroville Ca $95966 \quad 2 \quad 10^{\circ} \quad \mathrm{M}$

Plumas

Ave

2380 Las Oroville CA $95966 \quad 5 \quad 13 \quad \mathrm{M}$

Plumas

Avenue
White Ag Mech. X

White

An. Science $X$

White Ag Mech. X

Program Mem

Am. Ind.

Ag Mech. $\quad X$

Agriscience $x$

Agriscience $=X$

Agriscience $X$

Plant/Soil $\quad x$

Sci.

Ag Mech. $\quad X$

Agriscience $x$

Agriscience $x$

2 ör More An. Science $\quad X$

White Ag Mech. X

White Ag Mech. X

Whide Agriscience $x$

\begin{tabular}{|c|c|c|}
\hline Race & Program & Mem \\
\hline Am. Ind. & Ag Mech. & $x$ \\
\hline White & Agriscience & $x$ \\
\hline White & Agriscience & $=x$ \\
\hline White & Agriscience & $x$ \\
\hline White & $\begin{array}{l}\text { Plant/Soil } \\
\text { Sci. }\end{array}$ & $x$ \\
\hline 2 or More & Ag Mech. & $x$ \\
\hline White & An. Science & $\begin{array}{l}x \\
0\end{array}$ \\
\hline White & Agriscience & $x$ \\
\hline White & Agriscience & $x$ \\
\hline ôr More & An. Science & $x$ \\
\hline White & $\mathrm{Ag}$ Mech. & $x$ \\
\hline White & Ag Mech. & $x$ \\
\hline Vhide & Agriscience & $x$ \\
\hline are & Agriscience & $x$ \\
\hline
\end{tabular}

- An Science $X$

Hawaiian/Pac Agriscience $x$ Is. 


\begin{tabular}{|c|c|c|c|c|c|c|c|c|c|}
\hline 553040210 & $\begin{array}{l}2380 \text { Las } \\
\text { Plumas } \\
\text { Avenue }\end{array}$ & Oroville CA & 95966 & 2 & 10 & M & White & Agriscience & $x$ \\
\hline 0 & $\begin{array}{l}2380 \text { Las } \\
\text { PLumas } \\
\text { Ave }\end{array}$ & Oroville CA & 95966 & 1 & 09 & $\mathrm{~F}$ & White & Agriscience & $x$ \\
\hline 553550568 & $\begin{array}{l}2380 \text { Las } \\
\text { Plumas } \\
\text { Ave }\end{array}$ & Oroville ca & 95966 & 2 & 10 & M & White & Agriscience & $x$ \\
\hline 0 & $\begin{array}{l}2380 \text { Las } \\
\text { Plumas } \\
\text { Ave }\end{array}$ & Oroville CA & 95966 & 1 & 09 & M & White & Agriscience & $x$ \\
\hline 553257248 & $\begin{array}{l}2380 \text { Las } \\
\text { Plumas } \\
\text { Ave }\end{array}$ & Oroville CA & 95966 & 3 & 11 & F & White & Agriscience & $x$ \\
\hline 553550569 & $\begin{array}{l}2380 \text { Las } \\
\text { Plumas } \\
\text { Ave }\end{array}$ & Oroville Ca & 95968 & 2 & 10 & M & 2 or More & Agriscience & $x$ \\
\hline 553550571 & $\begin{array}{l}2380 \text { Las } \\
\text { Plumas } \\
\text { Ave }\end{array}$ & Oroville $\mathrm{Ca}$ & 95966 & 2 & 11 & M & White & Ag Mech. & $x$ \\
\hline 553550572 & $\begin{array}{l}2380 \text { Las } \\
\text { Plumas } \\
\text { Ave }\end{array}$ & Oroville $\mathrm{Ca}$ & 95966 & 2 & 10 & F & White & Agriscience & $x$ \\
\hline 0 & $\begin{array}{l}2380 \text { Las } \\
\text { PLumas } \\
\text { Ave }\end{array}$ & Oroville CA & 95966 & 1 & 09 & $\mathrm{~F}$ & White & Ag Mech. & $x$ \\
\hline 553257250 & $\begin{array}{l}2380 \text { Las } \\
\text { Plumas } \\
\text { Ave }\end{array}$ & Oroville CA & 95966 & 3 & 11 & M & White & Agriscience & $x$ \\
\hline 0 & $\begin{array}{l}2380 \text { Las } \\
\text { Plumas } \\
\text { Ave }\end{array}$ & Oroville CA & 95966 & 1 & 09 & $\mathrm{~F}$ & 2 or More & Agriscience & $x$ \\
\hline 553550575 & $\begin{array}{l}2380 \text { Las } \\
\text { Plumas } \\
\text { Ave }\end{array}$ & Oroville $\mathrm{Ca}$ & 95968 & 2 & 10 & M & White & An. Science & $x$ \\
\hline 553257252 & $\begin{array}{l}2380 \text { Las } \\
\text { Plumas } \\
\text { Ave }\end{array}$ & Oroville CA & 95966 & 3 & 11 & M & White & Forestry/NR & $x$ \\
\hline ) & $\begin{array}{l}2380 \text { Las } \\
\text { Plumas } \\
\text { Ave }\end{array}$ & Oroville CA & 95966 & 1. & 09 & M & 2 or More & Agriscience & $x$ \\
\hline 553257253 & $\begin{array}{l}2380 \text { Las } \\
\text { Plumas } \\
\text { Ave }\end{array}$ & Oroville CA & 95966 & 3 & 11 & F & White & Forestry/NR & $x$ \\
\hline & $\begin{array}{l}2380 \text { I as } \\
\text { Plumas } \\
\text { Ave }\end{array}$ & Mrnville CA & 95066 & 1 & $1 !$ & ? & 2 or More & An Science & x \\
\hline & $\begin{array}{l}2380 \text { Las } \\
\text { Plumas } \\
\text { Ave }\end{array}$ & Oroville CA & 95966 & 1 & 09 & M & Whitét & Agriscience & $x$ \\
\hline 53550577 क & $\begin{array}{l}2380 \text { Las } \\
\text { PLumas } \\
\text { Ave }\end{array}$ & Oroville ca & 95966 & 2 & 10 & M & Black & Agriscience & $x$ \\
\hline 53040252 & $\begin{array}{l}2380 \text { Las } \\
\text { Plumas } \\
\text { Avenue }\end{array}$ & Oroville CA & 95966 & 4 & 12 & F & Whïte & An. Science & $x$ \\
\hline & $\begin{array}{l}2380 \text { Las } 0 \\
\text { Plumas } \\
\text { Ave }\end{array}$ & Oroville CA & 95966 & 1 & 10 & F & White & Agriscience & $x$ \\
\hline 3040257 & $\begin{array}{l}238 v \text { Las } \\
\text { Plumas } \\
\text { Arenue }\end{array}$ & Uroviile CA Y & 93906 & 4 & 12 & $\mathrm{M}$ & White & Ag Mech. & $x$ \\
\hline
\end{tabular}




\begin{tabular}{|c|c|c|c|c|c|c|c|c|c|c|}
\hline 552818126 & $\begin{array}{l}2380 \text { Las } \\
\text { Plumas } \\
\text { Ave. }\end{array}$ & Oroville CA & 95966 & 5 & 13 & $\mathrm{~F}$ & & White & O.H. & $x$ \\
\hline 553550579 & $\begin{array}{l}2380 \text { Las } \\
\text { Plumas } \\
\text { Ave }\end{array}$ & Oroville $\mathrm{Ca}$ & 95966 & 2 & 10 & $\mathrm{~F}$ & & Black & $\begin{array}{l}\text { Plant/Soil } \\
\text { Sci. }\end{array}$ & $x$ \\
\hline 553550580 & $\begin{array}{l}2380 \text { Las } \\
\text { Plumas } \\
\text { Ave }\end{array}$ & Oroville $\mathrm{Ca}$ & 95968 & 2 & 10 & $\mathrm{~F}$ & & White & An. Science & $x$ \\
\hline 0 & $\begin{array}{l}2380 \text { Las } \\
\text { Plumas } \\
\text { Ave }\end{array}$ & Oroville CA & 95966 & 1 & 09 & M & & White & Agriscience & $x$ \\
\hline 0 & $\begin{array}{l}2380 \text { Las } \\
\text { Plumas } \\
\text { Ave }\end{array}$ & Oroville CA & 95966 & 1 & 09 & M & & White & Ag Mech. & $x$ \\
\hline 553257259 = & $\begin{array}{l}2380 \text { Las } \\
\text { Plumas } \\
\text { Ave }\end{array}$ & Oroville $\mathrm{CA}$ & 95966 & 3 & 11 & $\mathrm{~F}$ & & White & $\mathrm{Ag}$ Mech. & $x$ \\
\hline andan & $\begin{array}{l}2380 \text { Las } \\
\text { Plumas } \\
\text { Ave. }\end{array}$ & Oroville CA & 95966 & 1 & 09 & $\mathrm{~F}$ & & White & Ag Mech. & $x$ \\
\hline 552473185 & $\begin{array}{l}2380 \text { Las } \\
\text { Plumas } \\
\text { Ave. }\end{array}$ & Oroville CA & 95966 & 6 & 14 & M & & White & Agriscience & $x$ \\
\hline 553257260 & $\begin{array}{l}2380 \text { Las } \\
\text { Plumas } \\
\text { Ave }\end{array}$ & Oroville CA & 95966 & 3 & 11 & $\mathrm{~F}$ & & White & Agriscience & $x$ \\
\hline 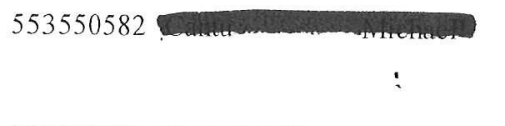 & $\begin{array}{l}2380 \text { Las } \\
\text { Plumas } \\
\text { Ave }\end{array}$ & $\begin{array}{c}\text { Oroville } \mathrm{Ca} \\
\qquad:\end{array}$ & 95968 & 2 & 10 & M & $x$ & 2 or More & Ag Mech. & $x$ \\
\hline 553040293 and & $\begin{array}{l}2380 \text { Las } \\
\text { Plumas } \\
\text { Avenue }\end{array}$ & Oroville CA & 95966 & 4 & 12 & M & & White & Forestry/NR & $x$ \\
\hline$-\sigma_{0}-{ }_{1}$ & $\begin{array}{l}2380 \text { Las } \\
\text { Plumas } \\
\text { Ave }\end{array}$ & Oroville CA & 95966 & 1 & 09 & M & & 2 or More & Agriscience & $x$ \\
\hline 553550584 Con & $\begin{array}{l}2380 \text { Las } \\
\text { Plumas } \\
\text { Ave }\end{array}$ & Oroville $\mathrm{Ca}$ & 95968 & 2 & 10 & $\mathrm{~F}$ & $x$ & 2 or More & An. Science & $x$ \\
\hline 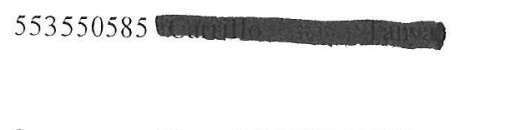 & $\begin{array}{l}2380 \text { Las } \\
\text { Plumas } \\
\text { Ave }\end{array}$ & Oroville Ca & 95966 & 2 & 11 & F & $x$ & 2 or More & An. Science & $x$ \\
\hline 0 & $\begin{array}{l}2380 \text { Las } \\
\text { Plumas } \\
\text { Ave }\end{array}$ & Oroville CA & 95966 & 1 & 09 & M & & $\begin{array}{l}\text { Hawaiian/Pac } \\
\text { Is. }\end{array}$ & Agriscience & $x$ \\
\hline an & $\begin{array}{l}2380 \text { Las } \\
\text { Plumas } \\
\text { Ave }\end{array}$ & Ornville Ca & 05066 & 1 & 09 & $M$ & & White & An Srienre & $\mathrm{x}$ \\
\hline 552736696 & $\begin{array}{l}2380 \text { Las } \\
\text { Plumas } \\
\text { Avenue }\end{array}$ & Oroville CA & 95966 & 5 & 13 & $\mathrm{~F}$ & $x$ & White & Agriscience & $x$ \\
\hline 553550587 & $\begin{array}{l}2380 \text { Las } \\
\text { Plumas } \\
\text { Ave }\end{array}$ & Oroville Ca & 95966 & 2 & 10 & $\mathrm{~F}$ & $x$ & 2 or More & An. Sicience & $x$ \\
\hline 552736697 & $\begin{array}{l}2380 \text { Las } \\
\text { Plumas } \\
\text { Avenue }\end{array}$ & Oroville CA & 95966 & 5 & 13 & $\mathrm{~F}$ & $x$ & Am. Ind. & Ag Mech. & $x$ \\
\hline 0 & $\begin{array}{l}2380 \text { Las } \\
\text { Plumas } \\
\text { Ave }\end{array}$ & Oroville CA & 95966 & 1 & 09 & M & $x$ & White & Agriscience & $x$ \\
\hline 533530588 & $\begin{array}{l}2300 \text { ias } \\
\text { H'lumas } \\
\text { Ave }\end{array}$ & Onviiie la & y5908 & 2 & 10 & $\mathrm{M}$ & $x$ & Lor More & Forestry/NK & $x$ \\
\hline
\end{tabular}




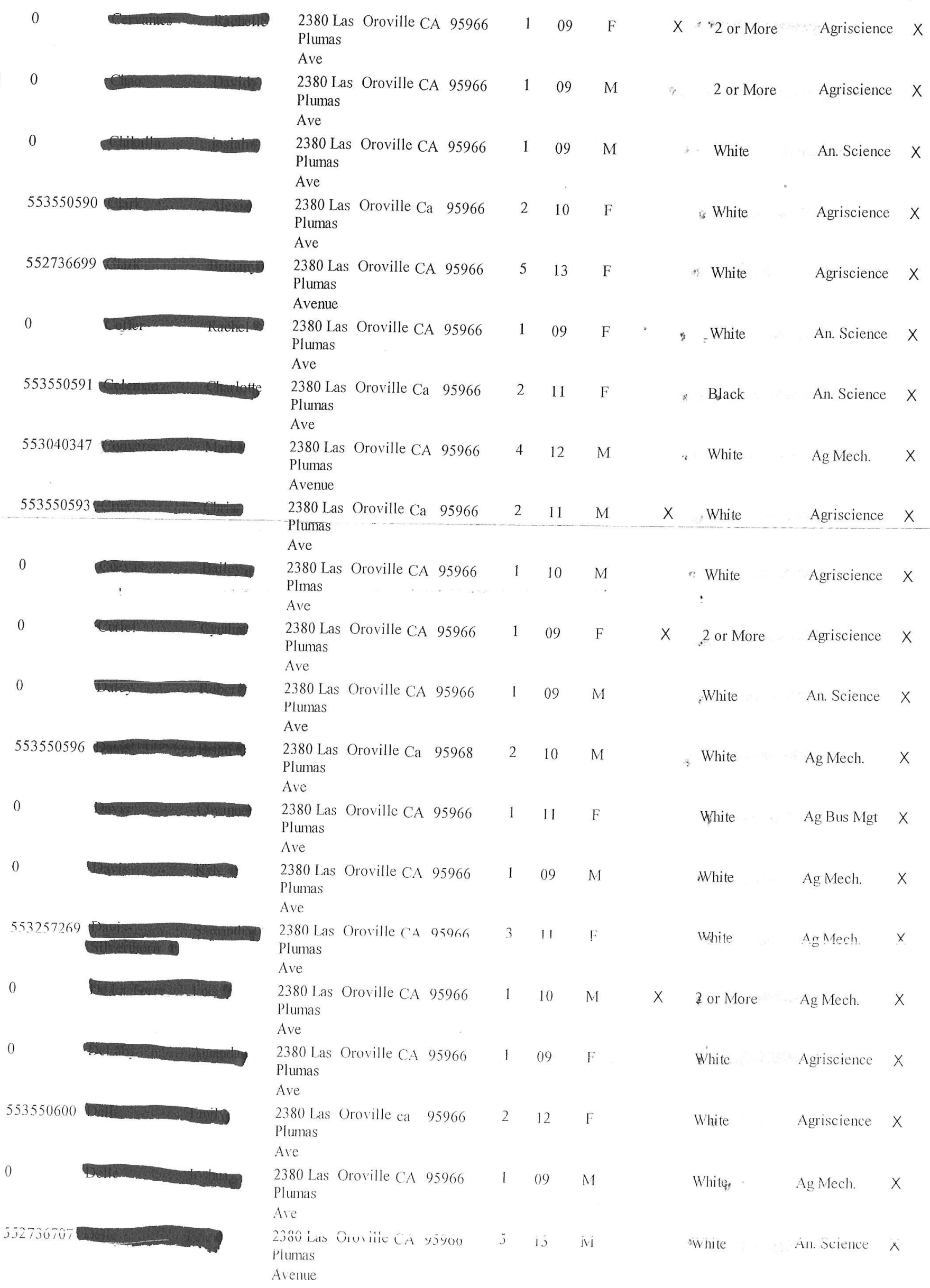




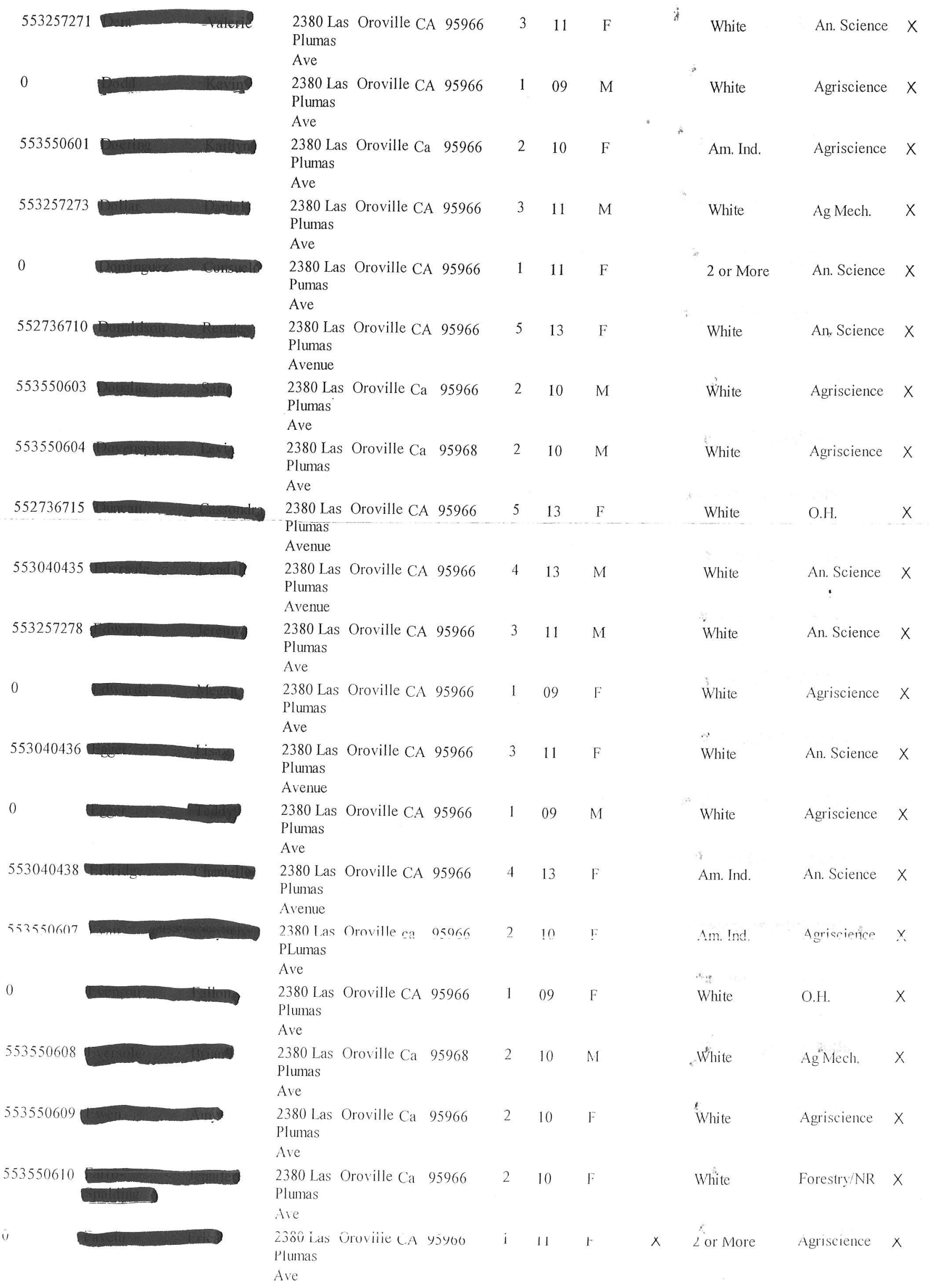




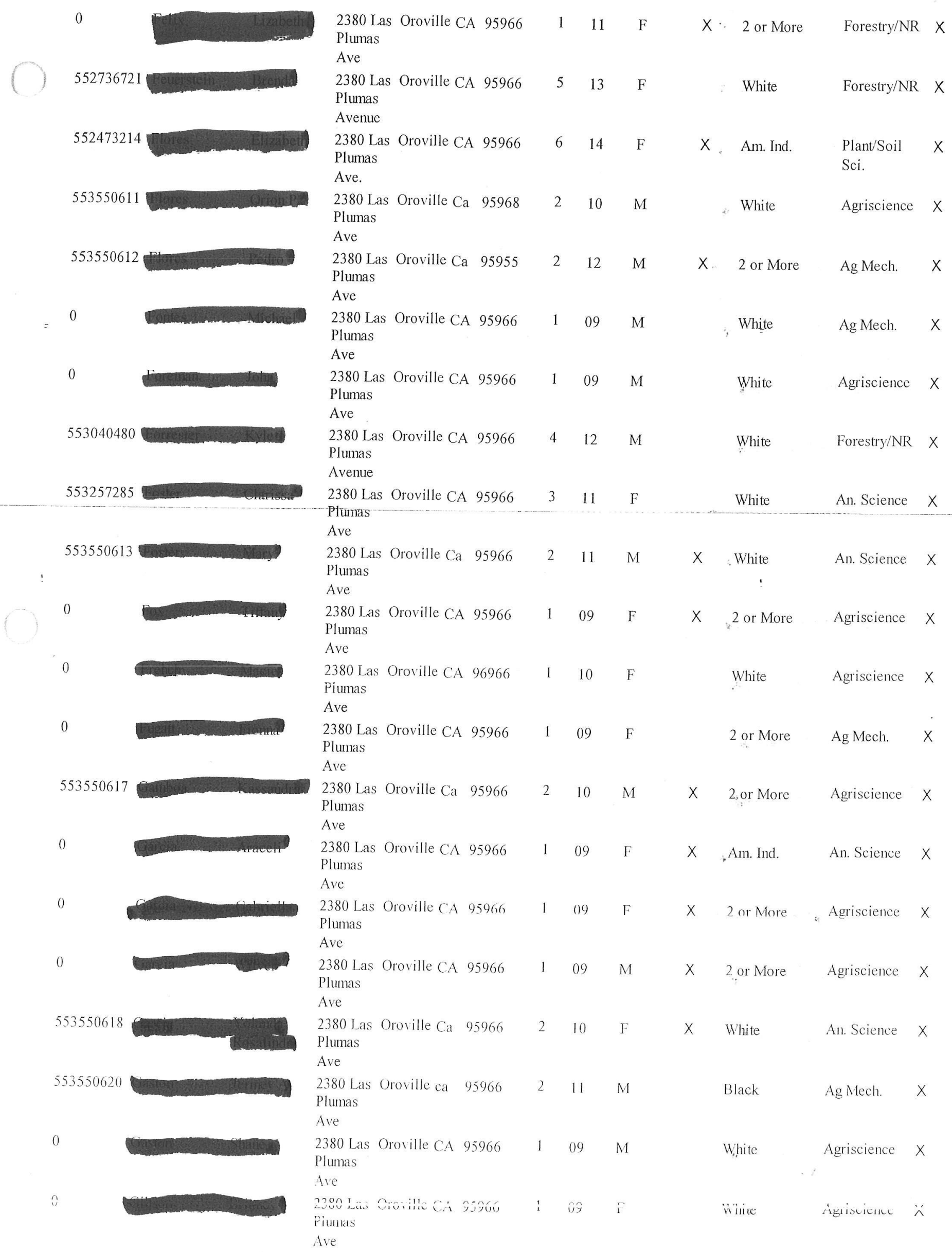




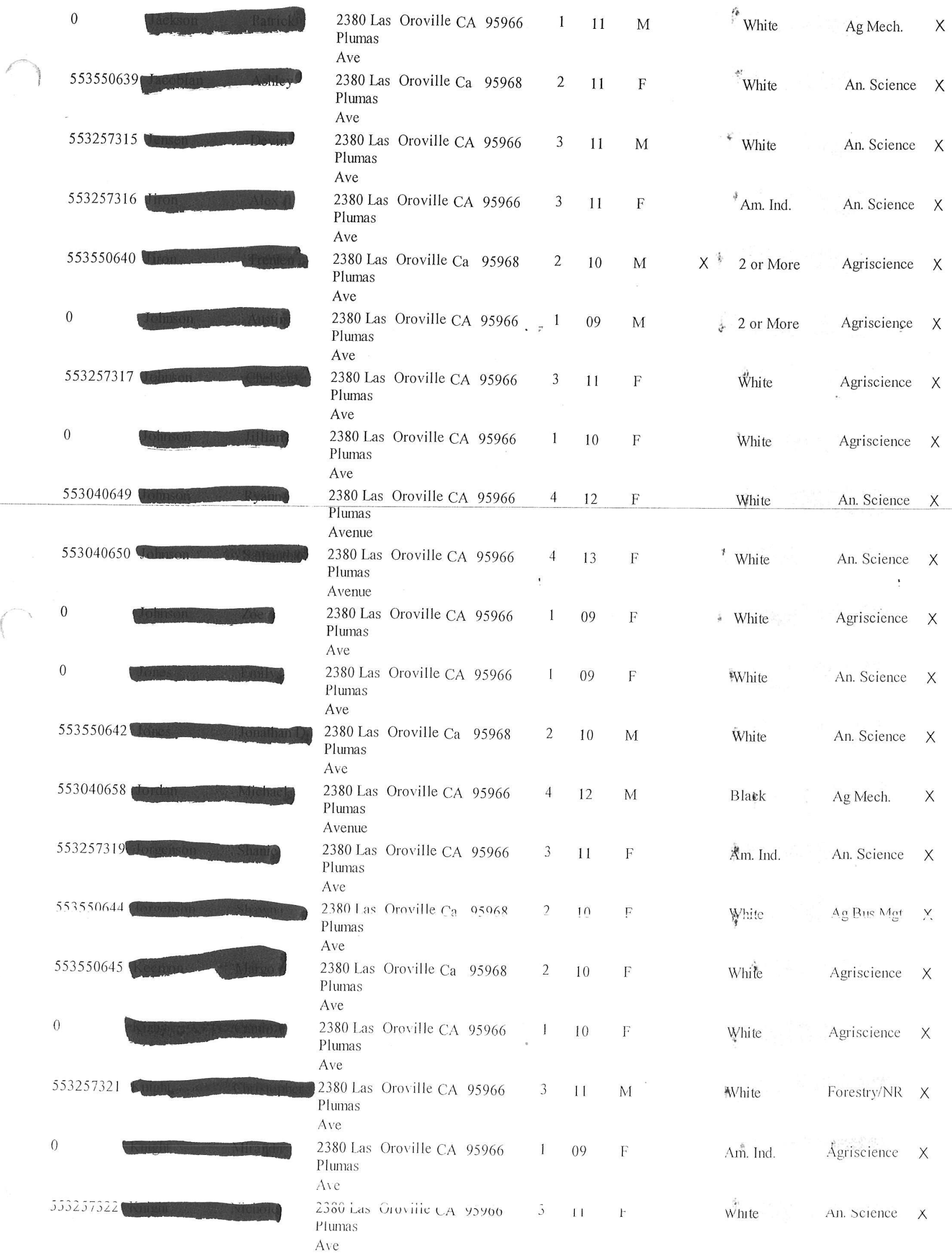




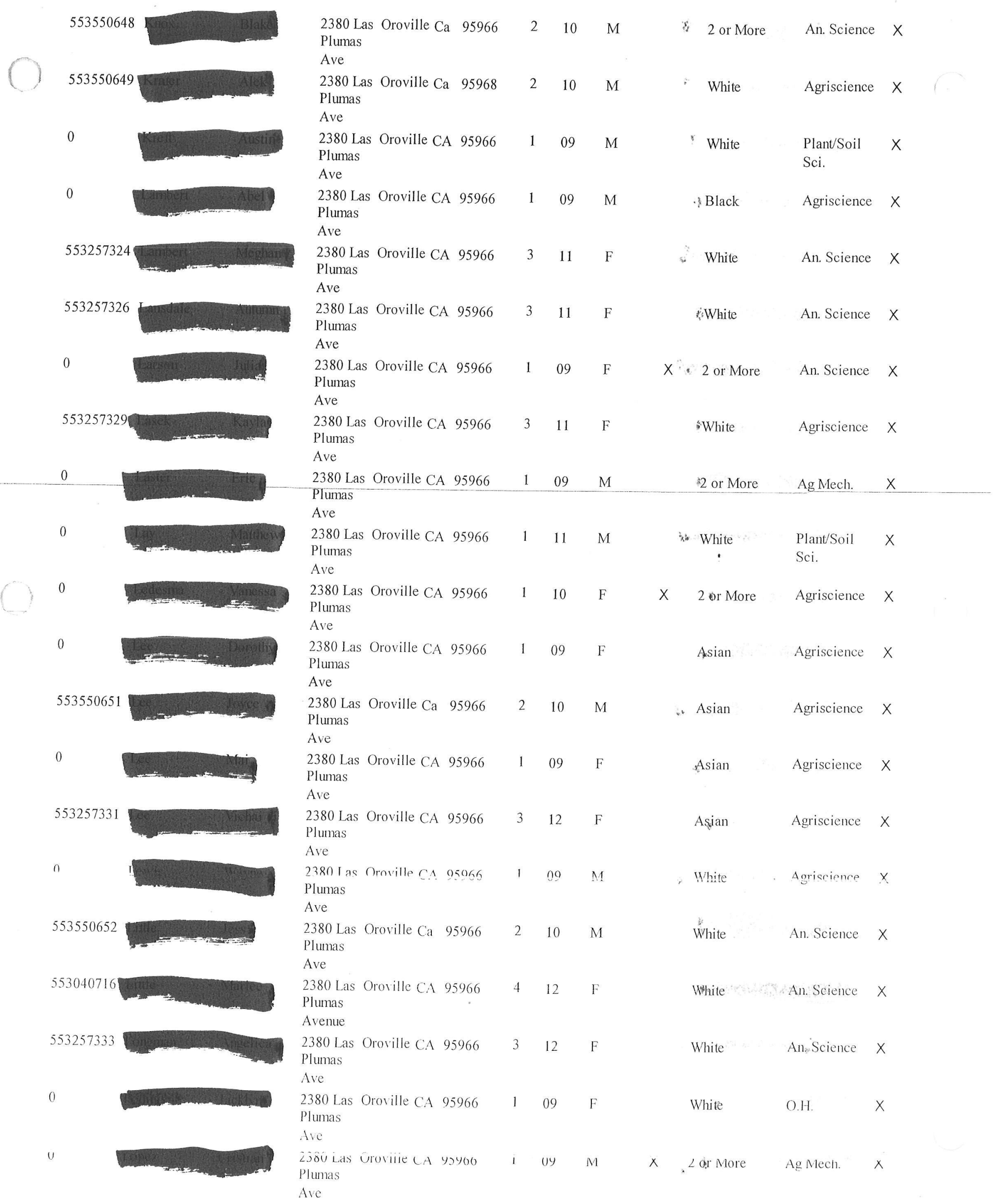




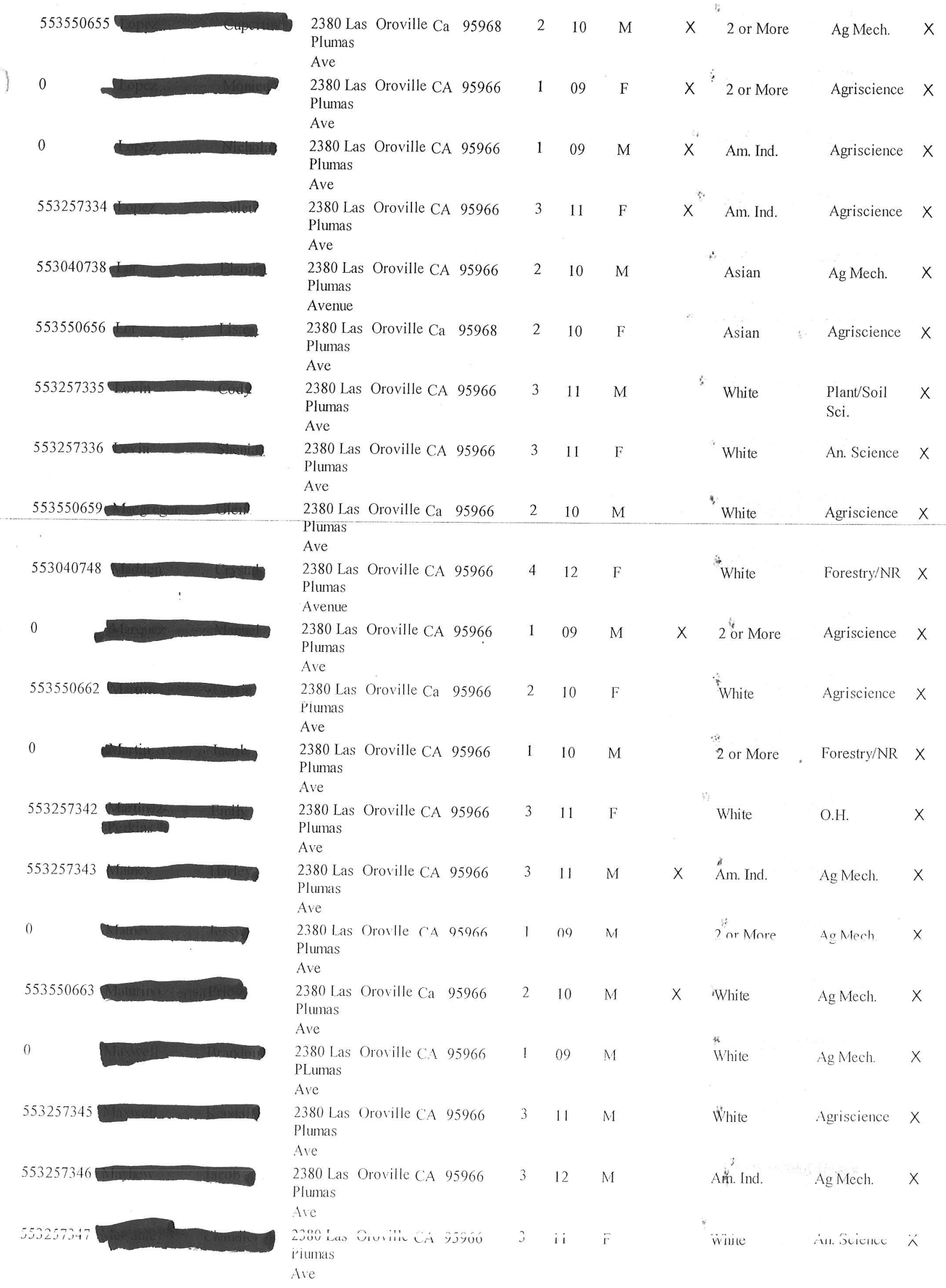




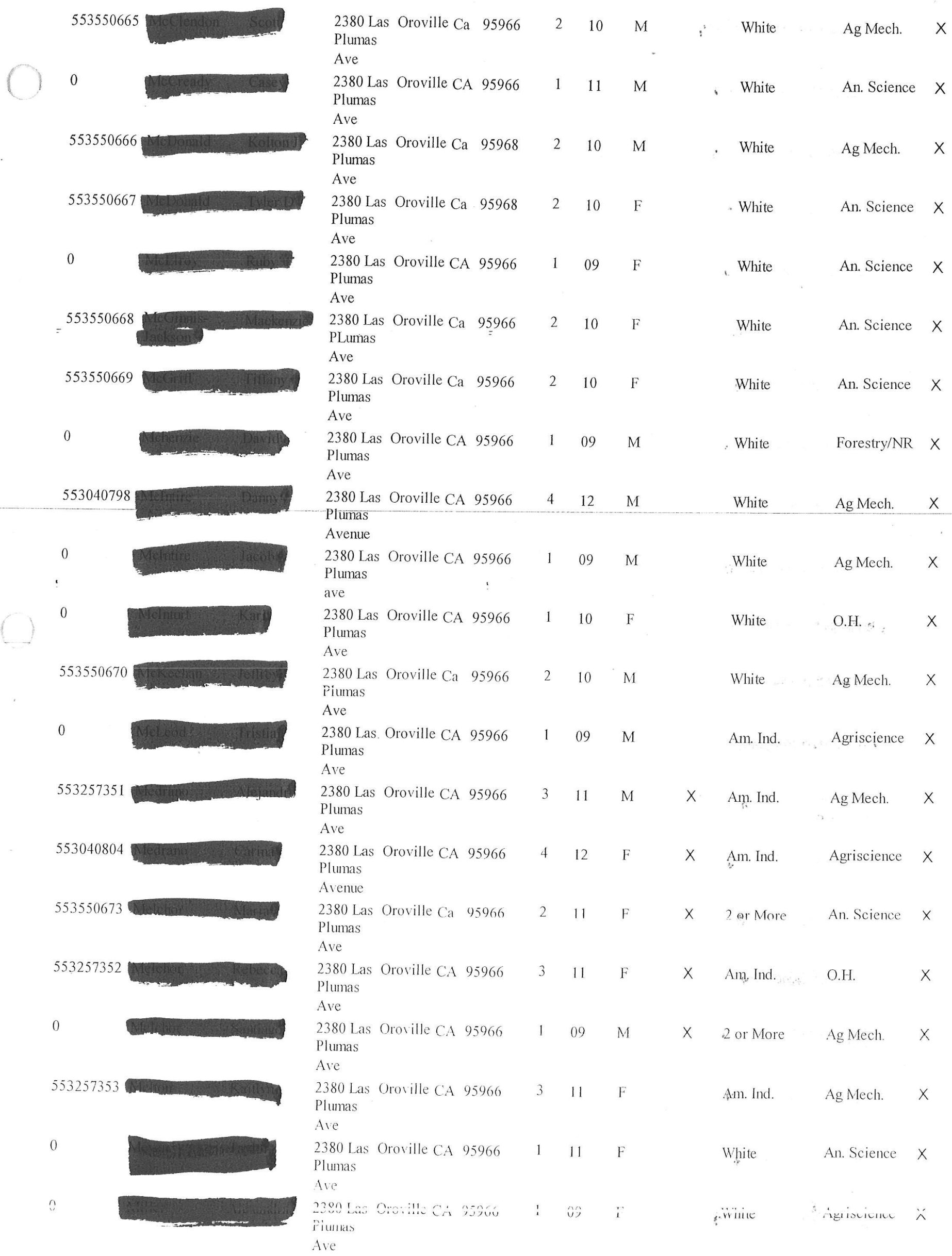




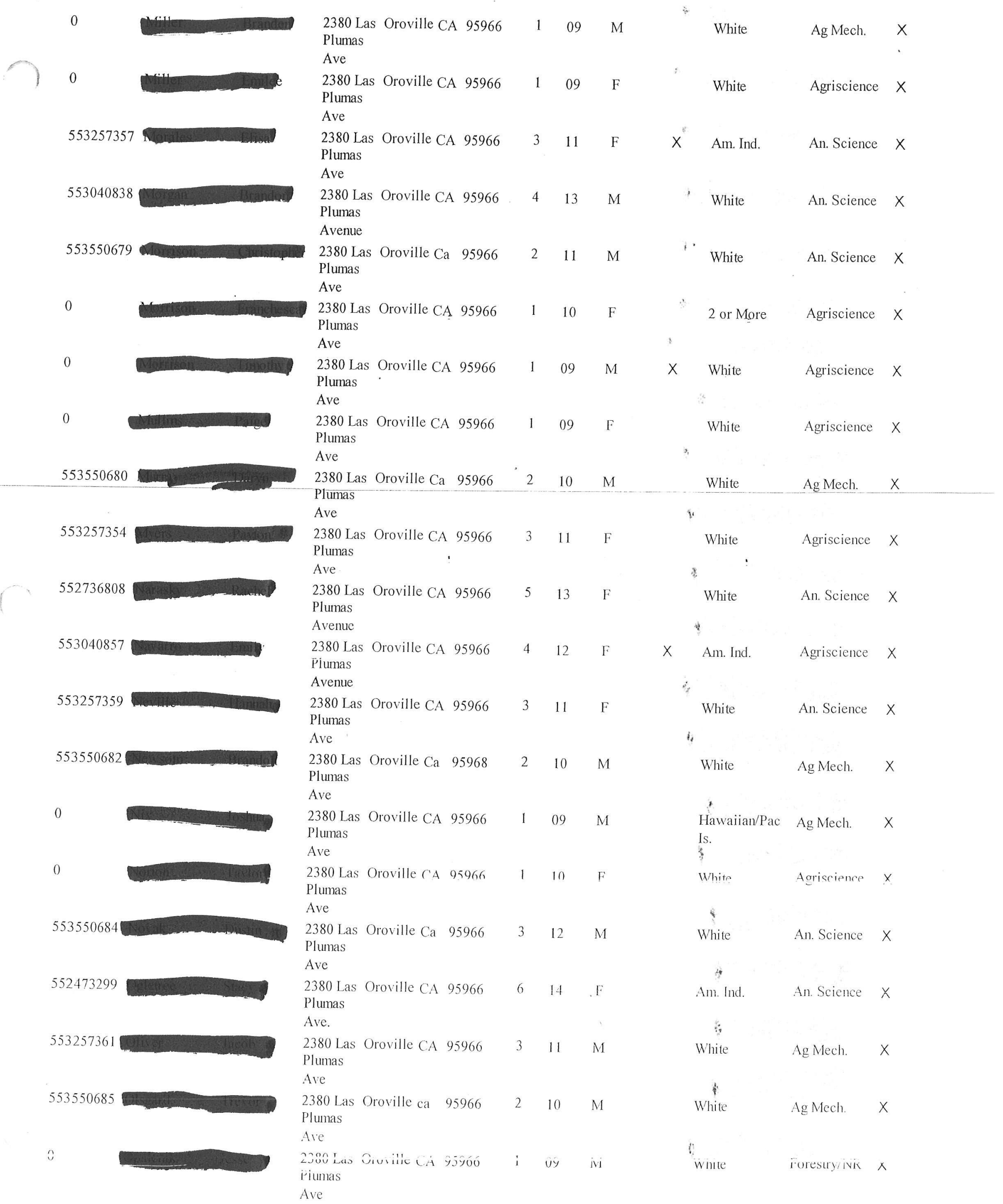




\begin{tabular}{|c|c|c|c|c|c|c|c|c|c|c|}
\hline 553257362 & $\begin{array}{l}2380 \text { Las } \\
\text { Plumas } \\
\text { Ave }\end{array}$ & Oroville CA & 95966 & 3 & 11 & $\mathrm{~F}$ & & White & An. Science & $x$ \\
\hline 553040893 & $\begin{array}{l}2380 \text { Las } \\
\text { Plumas } \\
\text { Avenue }\end{array}$ & Oroville CA & 95966 & 4 & 12 & $\mathrm{~F}$ & & White & An. Science & $x$ \\
\hline 0 & $\begin{array}{l}2380 \text { Las } \\
\text { Plumas } \\
\text { Ave }\end{array}$ & Oroville CA & 95966 & 1 & 09 & $\mathrm{~F}$ & $x$ & Asian & Agriscience & $x$ \\
\hline 0 & $\begin{array}{l}2380 \text { Las } \\
\text { Plumas } \\
\text { Ave }\end{array}$ & Oroville CA & 95966 & 1 & 09 & $\mathrm{~F}$ & & White & Agriscience & $x$ \\
\hline 0 & $\begin{array}{l}2380 \text { Las } \\
\text { Plumas } \\
\text { Ave }\end{array}$ & Oroville CA & 95966 & 1 & 09 & $\mathrm{~F}$ & 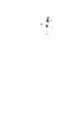 & White & Agriscience & $x$ \\
\hline 553649991 & $\begin{array}{l}21400 \\
\text { Ave } 10\end{array}$ & Madera CA & 93637 & 2 & 10 & F & 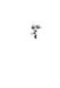 & White & Agriscience & $x$ \\
\hline 0 & $\begin{array}{l}2380 \text { Las } \\
\text { Plumas } \\
\text { Ave }\end{array}$ & Oroville CA & 95966 & 1 & 09 & $\mathrm{~F}$ & & White & Ag Mech. & $x$ \\
\hline 553550692 & $\begin{array}{l}2380 \text { Las } \\
\text { Plumas } \\
\text { Ave }\end{array}$ & Oroville $\mathrm{Ca}$ & 95966 & 2 & 10 & M & & $\begin{array}{l}\text { White } \\
\text { " }\end{array}$ & Ag Mech. & $x$ \\
\hline 0 & $\begin{array}{l}2380 \text { Las } \\
\text { Plumas }\end{array}$ & Oroville CA & 95966 & 1 & 09 & M & & Am. Ind. & Ag Mech. & $x$ \\
\hline 553550693 & $\begin{array}{l}\text { Ave } \\
2380 \text { Las } \\
\text { Plumas } \\
\text { Ave }\end{array}$ & $\begin{array}{l}\text { Oroville } \mathrm{Ca} \\
\ldots\end{array}$ & 95966 & 2 & 10 & $\mathrm{~F}$ & $x$ & 2 or More & O.H. & $x$ \\
\hline 0 & $\begin{array}{l}2380 \text { Las } \\
\text { Plumas } \\
\text { Ave }\end{array}$ & Oroville CA & 95966 & 1 & 09 & $\mathrm{~F}$ & & White & $\begin{array}{l}\text { PlantSoil } \\
\text { Sci. }\end{array}$ & $x$ \\
\hline 0 & $\begin{array}{l}2380 \text { Las } \\
\text { Plumas } \\
\text { Ave }\end{array}$ & Oroville CA & 95966 & 1 & 10 & M & & White & An. Science & $x$ \\
\hline 553550694 & $\begin{array}{l}2380 \text { Las } \\
\text { Plumas } \\
\text { Ave }\end{array}$ & Oroville $\mathrm{Ca}$ & 95968 & 2 & 10 & M & & White & Agriscience & $x$ \\
\hline 553550695 & $\begin{array}{l}2380 \text { Las } \\
\text { Plumas } \\
\text { Ave }\end{array}$ & Oroville $\mathrm{Ca}$ & 95966 & 2 & 10 & M & & White & Forestry/NR & $x$ \\
\hline 553257368 & $\begin{array}{l}2380 \text { Las } \\
\text { Plumas } \\
\text { Ave }\end{array}$ & Oroville CA & 95966 & 3 & 11 & M & & White & An. Science & $x$ \\
\hline 0 & $\begin{array}{l}2380 \text { Las } \\
\text { Plumas } \\
\text { Ave }\end{array}$ & Oroville CA & 95966 & 1 & 09 & $\mathrm{~F}$ & & White & Agriscience & $x$ \\
\hline 553550698 & $\begin{array}{l}2380 \text { Las } \\
\text { Plumas } \\
\text { Ave }\end{array}$ & Oroville Ca & 95966 & 3 & 11 & F & $x$ & $\begin{array}{l}\text { Am. Ind. } \\
y\end{array}$ & Forestry/NR & $x$ \\
\hline 0 & $\begin{array}{l}2380 \text { Las } \\
\text { Plumas } \\
\text { Ave }\end{array}$ & Oroville CA & 95966 & 1 & 09 & M & & $\begin{array}{c}\text { White } \\
3\end{array}$ & Ag Mech. & $x$ \\
\hline 0 & $\begin{array}{l}2380 \text { Las } \\
\text { Plumas } \\
\text { Ave }\end{array}$ & Oroville CA & 95966 & 1 & 09 & M & & $\begin{array}{l}\text { Am. Ind. } \\
3 .\end{array}$ & $\begin{array}{l}\text { Plant/Soil } \\
\text { Sci. }\end{array}$ & $x$ \\
\hline 0 & $\begin{array}{l}2380 \text { Las } \\
\text { Plumas } \\
\text { Ave }\end{array}$ & Oroville CA & 95966 & 1 & 09 & $\mathrm{M}$ & & White & Agriscience & $x$ \\
\hline 553550700 & $\begin{array}{l}2380 \text { Las } \\
\text { Pituncs. } \\
\text { Ave }\end{array}$ & Orosille Ca & 95966 & 3 & 11 & M & & White & Agriscience & $x$ \\
\hline
\end{tabular}




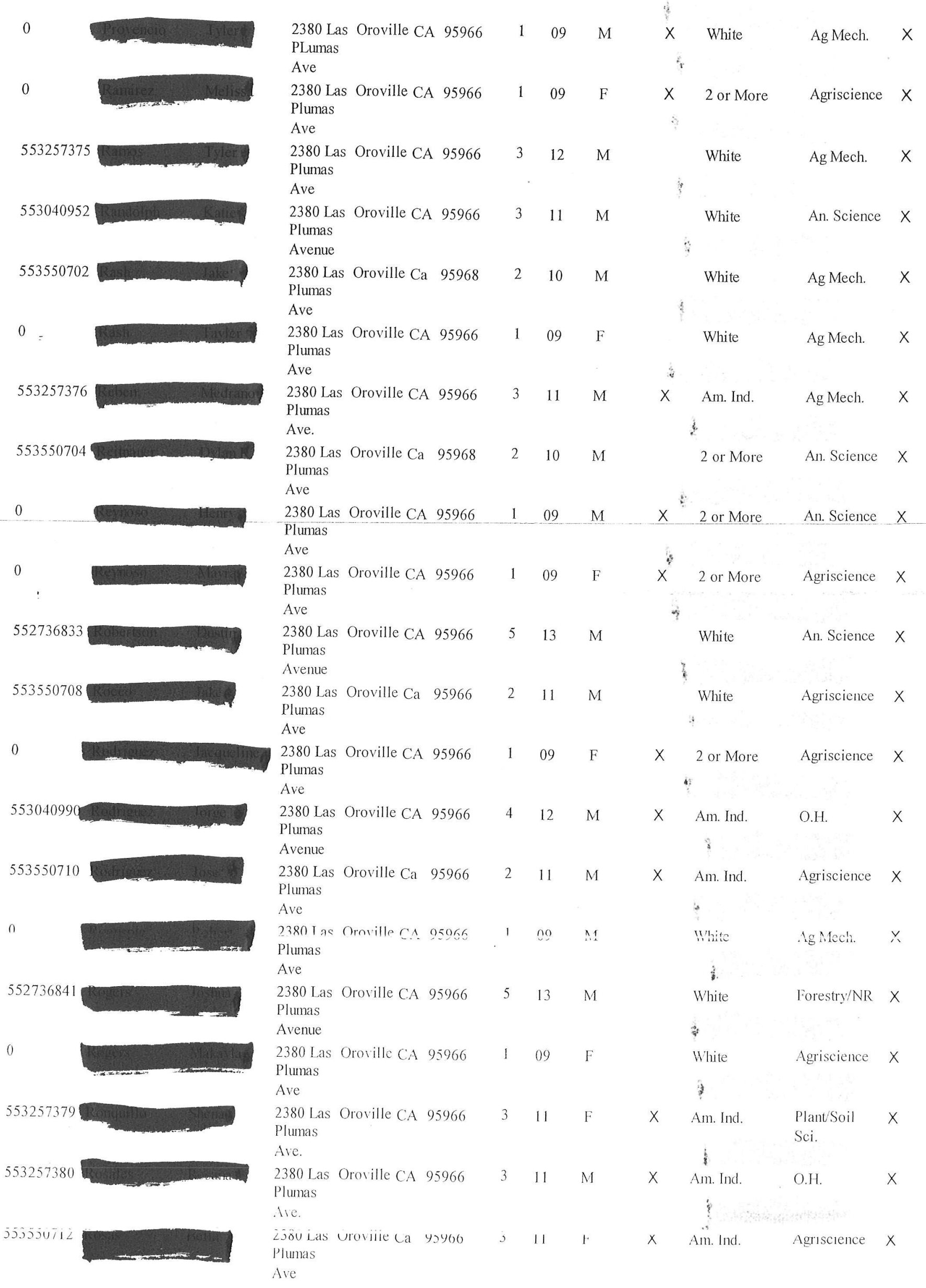




\begin{tabular}{|c|c|c|c|c|c|c|c|c|c|}
\hline 0 & $\begin{array}{l}2380 \text { Las } \\
\text { Plumas }\end{array}$ & Oroville CA & 95966 & 09 & F & & White & An. Science & $x$ \\
\hline 0 & $\begin{array}{l}2380 \text { Las } \\
\text { Plumas } \\
\text { Ave }\end{array}$ & Oroville CA & 95966 & 09 & M & & $\begin{array}{l}\text { Hawaiian/Pac } \\
\text { * Is. }\end{array}$ & Ag Mech. & $x$ \\
\hline 0 & $\begin{array}{l}2380 \text { Las } \\
\text { Plumas } \\
\text { Ave }\end{array}$ & Oroville CA & 95966 & 09 & M & & Asian & $\mathrm{Ag}$ Bus Mgt & $x$ \\
\hline 553041017 & $\begin{array}{l}2380 \text { Las } \\
\text { Plumas } \\
\text { Avenue }\end{array}$ & Oroville CA & 95966 & 12 & M & $x$ & $\begin{array}{l}\text { Hawaiian/Pac } \\
\text { Is. }\end{array}$ & An. Science & $x$ \\
\hline 553550718 & $\begin{array}{l}2380 \text { Las } \\
\text { Plumas } \\
\text { Ave }\end{array}$ & Oroville $\mathrm{Ca}$ & 95966 & 11 & M & $x$ & Am. Ind. & Agriscience & $x$ \\
\hline 0 & $\begin{array}{l}2380 \text { Las } \\
\text { Plumas } \\
\text { Ave }\end{array}$ & Oroville CA & 95966 & 09 & F & $x$ & 2 or More & Ag Mech. & $\begin{array}{l}x \\
=\end{array}$ \\
\hline 553550720 & $\begin{array}{l}2380 \text { Las } \\
\text { Plumas } \\
\text { Ave }\end{array}$ & Oroville $\mathrm{Ca}$ & 95966 & 10 & F & 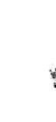 & White & An. Science & $x$ \\
\hline 553550721 & $\begin{array}{l}2380 \text { Las } \\
\text { Plumas } \\
\text { Ave }\end{array}$ & Oroville $\mathrm{Ca}$ & 95966 & 10 & F & & White & Agriscience & $x$ \\
\hline 0 & $\begin{array}{l}2380 \text { Las } \\
\text { Plumas } \\
\text { Ave }\end{array}$ & Oroville CA & 95966 & 09 & F & & 2 or More & Forestry/NR & $x$ \\
\hline 553550726 & $\begin{array}{l}2380 \text { Las C } \\
\text { Plumas } \\
\text { Ave }\end{array}$ & Oroville $\mathrm{Ca}$ & 95966 & 10 & M & & White & Agriscience & $x$ \\
\hline 553257390 & $\begin{array}{l}2380 \text { Las } \\
\text { Plumas } \\
\text { Ave. }\end{array}$ & Oroville CA 9 & 95966 & 11 & M & $x$ & Am. Ind. & Ag Mech. & $x$ \\
\hline 0 & $\begin{array}{l}2380 \text { Las } \mathrm{C} \\
\text { Plumas } \\
\text { Ave }\end{array}$ & Oroville CA & 95966 & 09 & M & 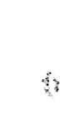 & White & Agriscience & $x$ \\
\hline 0 & $\begin{array}{l}2380 \text { Las } \\
\text { Plumas } \\
\text { Ave }\end{array}$ & Oroville CA 9 & 95966 & 09 & $\mathrm{~F}$ & & White & An. Science & $x$ \\
\hline 0 & $\begin{array}{l}2380 \text { Las } 0 \\
\text { Plumas } \\
\text { Ave }\end{array}$ & Oroville CA 9 & 95966 & 09 & F & & $\begin{array}{l}\text { White } \\
y\end{array}$ & Agriscience & $x$ \\
\hline 0 & $\begin{array}{l}2380 \text { Las } \\
\text { Plumas } \\
\text { Ave }\end{array}$ & Oroville CA 9 & 95966 & 09 & M & & White & Agriscience & $x$ \\
\hline 0 & $\begin{array}{l}2380 \text { Las } 0 \\
\text { Plumas } \\
\text { Ave }\end{array}$ & Oroville CA 9 & 95966 & 09 & M & & White & Ag Mech. & $x$ \\
\hline 552736860 & $\begin{array}{l}2380 \text { Las C } \\
\text { Plumas } \\
\text { Avenue }\end{array}$ & Oroville CA 9 & 95966 & 13 & M & & Ain. Ind. & $\mathrm{Ag}$ Bus Mgt & $x$ \\
\hline 553550728 & $\begin{array}{l}2380 \text { Las O } \\
\text { Plumas } \\
\text { Ave }\end{array}$ & Oroville $\mathrm{Ca} 9$ & 95966 & 10 & M & & White & Agriscience & $x$ \\
\hline 53257393 & $\begin{array}{l}2380 \text { Las } 0 \\
\text { Plumas } \\
\text { Ave. }\end{array}$ & Oroville CA 9 & 95966 & 11 & F & & White & An. Science & $x$ \\
\hline $530+1075$ & $\begin{array}{l}2380 \text { Las } 0 \\
\text { D!uinais } \\
\text { Avenue }\end{array}$ & Oroville CA 9 & 5900 & 10 & $\mathrm{~F}$ & $x$ & $\begin{array}{l}\text { Hispanic Latino } \\
\text { b. }\end{array}$ & O.H. & $x$ \\
\hline
\end{tabular}


https://calaged.csuchico.edu/R2/Scripts/Roster/PrintRoster.asp

\begin{tabular}{|c|c|c|c|c|c|c|c|c|}
\hline 552736886 & $\begin{array}{l}2380 \text { Las } \\
\text { Plumas } \\
\text { Avenue }\end{array}$ & Oroville CA & 95966 & 5 & 13 & $\mathrm{~F}$ & White & An. Science \\
\hline 0 & $\begin{array}{l}2380 \text { Las } \\
\text { Plumas } \\
\text { Ave }\end{array}$ & Oroville CA & 95966 & 1 & 09 & F & White & Ag Mech. \\
\hline 0 & $\begin{array}{l}2380 \text { Las } \\
\text { Plumas } \\
\text { Ave }\end{array}$ & Oroville CA & 95966 & 1 & 11 & $\mathrm{~F}$ & White & An. Science \\
\hline 0 & $\begin{array}{l}2380 \text { Las } \\
\text { Plumas } \\
\text { Ave }\end{array}$ & Oroville CA & 95966 & 1 & 09 & $\mathrm{~F}$ & White & An. Science \\
\hline 553550753 & $\begin{array}{l}2380 \text { Las } \\
\text { Plumas } \\
\text { Ave }\end{array}$ & Oroville $\mathrm{Ca}$ & 95966 & 2 & 10 & $\mathrm{~F}$ & White & Agriscience \\
\hline 553550754 & $\begin{array}{l}2380 \text { Las } \\
\text { Plumas } \\
\text { Ave }\end{array}$ & Oroville Ca & 95966 & 2 & 10 & M & White, & An. Science \\
\hline 553041226 & $\begin{array}{l}2380 \text { Las } \\
\text { Plumas } \\
\text { Avenue }\end{array}$ & Oroville CA & 95966 & 4 & 12 & M & White & Ag Mech. \\
\hline 0 & $\begin{array}{l}2380 \text { Las } \\
\text { Plumas } \\
\text { Ave }\end{array}$ & Oroville CA & 95966 & 1 & 09 & M & White & Agriscience \\
\hline
\end{tabular}

Printed: 10/14/2011 2:05:56 PM

Count: 383 


\section{Las Plumas High School Agriculture Department Graduate Follow-Up}

Name:

Address:

Phone:

Email :

1. What are you doing at the present time?

Attending School

Where

Agriculture related

Full-time

_ Part-time

Where Working

Agriculture related

In the military Full-time

Part-time

Not Working Looking for Work

Homemaker

Other

2. In what type of business or industry are you employed?

3. What is your job title of job description?

4. Which statements best applies to your present occupation?

I am using most of the skills I learned in the Vo-Ag program at LPHS.

I am using some of the skills I learned in the Vo-Ag program at LPHS.

I am not using any of the skills I learned in the Vo-Ag program at LPHS.

5. What type of school are you currently attending?

Junior College (2 Year)

4-year College

Adult Education
Trade/technical school Private business school Other

6. What is your major course of study?

7. What year did you graduate from LPHS? 


\section{Oroville Union High School District \\ Associated Student Body Budget Summary 2012-2013}

School: Las Plumas High School

Club Name/Athletic Team: \#480:Farm

Class year: $n \mid a$

(A) Net Beginning Fund Balance:

$\$ 4,000,-$

Estimated Income: Fundraising events; car wash, cookie dough, concessions cookie dough/show supplies

student animal payments

student feed pauments

student insurance payments $\quad 1,000$

(B) Total Estimated Income

$\$ 20,000$.

(C) Total Income \& Beginning Fund Balance (A plus B) $\$ 24,000$.-

Estimated Expenditures: Cost of events, trips, fundraisers, etc.

$\begin{array}{ll}\text { purchase cooke dough show supplies } & 6,000- \\ \text { surchase, shudent tunimals } & 10,000- \\ \text { burchase, teed payments } & 3,000- \\ \text { purchase insurarte tor animals } & 1,000 .\end{array}$

(D) Total Estimated Expenditures

$\$ 20,000$

(E) Estimated ending fund balance (C minus D)

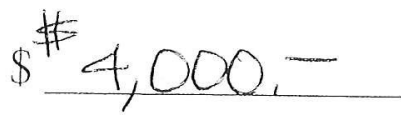

DUE DATE: Friday, May 4, 2012

Turn into Camille Williams in the Student Accounts Office 
School: Las Plumas High School

Club Name/Athletic Team: 113: FFA

(A) Net Beginning Fund Balance:
Class year: $\mathrm{nla}$

$\$ 2,000$.

Estimated Income: Fundraișing events; car wash, cookie dough, concessions Conferences Leadership: Greenhand /MFE/ALA Feld Daypayment CDE. Enents $\begin{array}{ll}\text { FA Jackets/officer jacket payments } & 3,5001^{-} \\ \text {Easter Arrangements } & 1,300^{-}\end{array}$ Miscincome Transfer from steak:scrab profit

(B) Total Estimated Income 130. 800 $\$ 8,830$
$\$ 10,830$

(C) Total Income \& Beginning Fund Balance (A plus B) 100. 3,000

Estimated Expenditures: Cost of events, trips, fundraisers, etc.

CDLe, Registration Greenhard recisstration Officer jackets shirts payments Field day registration/hotel FFA meeting/recnuitment Springl Winter Bat. Sen. Avards/Pt. Aw thp
(D) Total Estimated Expenditures

(E) Estimated ending fund balance (C minus D)

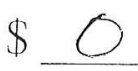

DUE DATE: Friday, May 4, 2012

Turn into Camille Williams in the Student Accounts Office 


\section{Oroville Union High School District \\ Associated Student Body Budget Summary 2012-2013}

School: Las Plumas High School

Club Name/Athletic Team: 484 Agleadershyelass year: nya
(A) Net Beginning Fund Balance:
$\$ 6,000$

Estimated Income: Fundraising events; car wash, cookie dough, concessions

\begin{tabular}{lc} 
National Conwention payments & $3,000-$ \\
\hline Drine Thru BBQ Fall/spring & $6,000-$ \\
Steak iCrab Feed & 20,000 \\
State Convention student payments & 4,000 - \\
\hline
\end{tabular}

(B) Total Estimated Income

$\$ 33,000-$

(C) Total Income \& Beginning Fund Balance (A plus B) $\$ 39,000,-$

Estimated Expenditures: Cost of events, trips, fundraisers, etc.

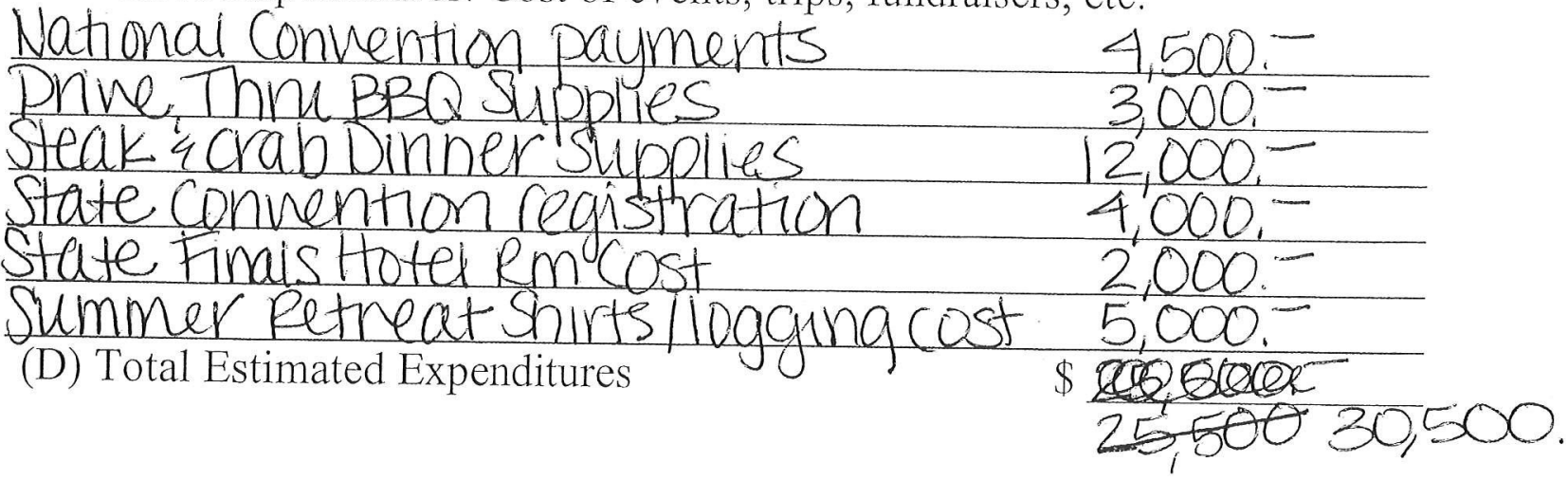

(E) Estimated ending fund balance (C minus D) $\quad \$ 8,500$.

DUE DATE: Friday, May 4, 2012

Turn into Camille Williams in the Student Accounts Office 


\section{Quality Criteria Ten: \\ Student Teacher Ratio}

High quality vocational instruction in agriculture is dependent upon maintaining a student-teacher ratio that ensures effective instructional and safe working conditions. Much of vocational education is action-oriented, hands-on, learning activity. Under these conditions, a lower student-teacher ratio is required than in classes which do not utilize these teaching/learning procedures.

While Las Plumas High School Agriculture Department excels in most areas of the agriculture education model, we fail to satisfy Criteria Ten: Student-Teacher Ratio. The Agriculture Incentive Grant Checklist Quality Criteria Ten states that: Shop and based classes will have no more than 25 students enrolled.

It is in the best interest of the agriculture students to have class size ratios of these proportions. It is the Agriculture Department's position to support this criteria in the interest of student learning and Incentive Grant Funding. However, the school district will not support this criteria; thus funding and the educational value of the desired class ratios are often not met. The department continues to seek the support of the district in this area.

Not meeting this criteria is a challenge for making sure students all get the hands on experience. For example in my Animal Science class I currently have 35 students enrolled which makes it very difficult to monitor and have students experience hands on animal experiences such as halter breaking, and showing with such a large student class. I have to rotate the students through rotations, and they are limited to time restraints.

Also in our shop classes the numbers are much higher than 25 students. This makes our Ag Mechanics teacher change his classroom management and enforce safety so that all students can learn but learn safely. His head constantly has to be monitoring student safety.

We feel it would defiantly benefit not only us but also the students if we had smaller classes even if they were 30 and under. With that many students it is hard to help one on one and give each individual student the attention.

\section{Evidence Documents Include:}

- R-2 Student Data Report

- Class Role Sheet

- Animal Science

- Ag Life Science

- College Ag Biology ( $3^{\text {rd }} \& 4^{\text {th }}$ periods $)$ 


\section{Las Plumas HS}

R2 Student Report

Year:2011

\section{Gender}

\begin{tabular}{|l|l|l|l|}
\hline Schnum & ProgName & Male & Female \\
\hline 283 & Ag Bus Mgt & 4 & 2 \\
\hline 283 & Ag Mech. & 70 & 13 \\
\hline 283 & Agriscience & 69 & 76 \\
\hline 283 & An. Science & 31 & 67 \\
\hline 283 & Forestry/NR & 12 & 9 \\
\hline 283 & O.H. & 3 & 15 \\
\hline 283 & Plant/Soil Sci. & 5 & 7 \\
\hline
\end{tabular}

Hispanic

\begin{tabular}{|l|l|l|}
\hline ProgName & Hispanic & Non-Hispanic \\
\hline Ag Bus Mgt & 1 & 5 \\
\hline Ag Mech. & 19 & 64 \\
\hline Agriscience & 31 & 114 \\
\hline An. Science & 12 & 86 \\
\hline Forestry/NR & 3 & 18 \\
\hline O.H. & 7 & 11 \\
\hline Plant/Soil Sci. & 2 & 10 \\
\hline
\end{tabular}

\section{Race*}

\begin{tabular}{|l|l|l|l|l|l|l|l|}
\hline ProgName & White & Black & Hispanic & $\begin{array}{l}\text { Americian } \\
\text { Indian }\end{array}$ & Asian & $\begin{array}{l}\text { Native Hawaiian/Pacifc } \\
\text { Island }\end{array}$ & $\begin{array}{l}2 \text { or } \\
\text { more }\end{array}$ \\
\hline Ag Bus Mgt & 2 & 0 & 0 & 1 & 1 & 0 & 2 \\
\hline Ag Mech. & 49 & 2 & 0 & 12 & 12 & 2 & 15 \\
\hline Agriscience & 87 & 3 & 1 & 13 & 13 & 2 & 26 \\
\hline An. Science & 75 & 1 & 0 & 6 & 6 & 1 & 13 \\
\hline Forestry/NR & 15 & 0 & 0 & 1 & 1 & 0 & 5 \\
\hline O.H. & 8 & 0 & 1 & 5 & 5 & 0 & 2 \\
\hline $\begin{array}{l}\text { Plant/Soil } \\
\text { Sci. }\end{array}$ & 7 & 1 & 0 & 4 & 4 & 0 & 0 \\
\hline
\end{tabular}

\section{Grade Level}




\section{R2 Teacher Information Las Plumas HS, Oroville Year: 2011}

\begin{tabular}{|l|l|l|l|l|c|c|c|c|c|c|c|}
\hline $\begin{array}{l}\text { Last } \\
\text { Name }\end{array}$ & $\begin{array}{l}\text { First } \\
\text { Name }\end{array}$ & MI & Gender & Ethnicity & $\begin{array}{c}\text { Total } \\
\text { Years } \\
\text { Teaching } \\
\text { Ag. }\end{array}$ & $\begin{array}{c}\text { Credential } \\
\text { Type }\end{array}$ & $\begin{array}{c}\text { 9-Month } \\
\text { Salary }\end{array}$ & $\begin{array}{c}\text { Extended } \\
\text { Contract } \\
\text { Stipend }\end{array}$ & $\begin{array}{c}\text { FFA } \\
\text { Stipend }\end{array}$ & $\begin{array}{c}\text { Department } \\
\text { Head } \\
\text { Stipend }\end{array}$ & $\begin{array}{c}\text { SOE } \\
\text { Period }\end{array}$ \\
\hline Diaz & Carlos & R & Male & Hispanic & 2 & $\begin{array}{c}\text { Agriculture } \\
\text { Specialist }\end{array}$ & 42110 & 3439 & 0 & 0 & $\mathrm{~N}$ \\
\hline Aldridge & Ashleigh & $\mathrm{R}$ & Female & White & 5 & $\begin{array}{c}\text { Agriculture } \\
\text { Specialist }\end{array}$ & 49367 & 3439 & 0 & 0 & $\mathrm{~N}$ \\
\hline Earley & Andree & $\mathrm{M}$ & Female & White & 10 & $\begin{array}{c}\text { Agriculture } \\
\text { Specialist }\end{array}$ & 60983 & 3439 & 0 & 1528 & $\mathrm{Y}$ \\
\hline Knapp & James & $\mathrm{H}$ & Male & White & 21 & $\begin{array}{c}\text { Agriculture } \\
\text { Specialist }\end{array}$ & 68320 & 3439 & 0 & 0 & $\mathrm{~N}$ \\
\hline
\end{tabular}

\begin{tabular}{|l|l|l|l|l|l|}
\hline \multicolumn{2}{|l|}{ Aldridge, Ashleigh } \\
\hline Schedule & Period & Beginning Time & Course Title & Enrollment & Type \\
\hline 1 & 1 & 0750 & Ag Life Science & 19 & Agriscience I \\
\hline 1 & 2 & 0852 & Ag life Science & 29 & Agriscience I \\
\hline 1 & 3 & 1004 & Animal Science & $33 \quad:$ & Animal Science \\
\hline 1 & 4 & 1106 & College Ag Biology & 29 & Ag Biology \\
\hline 1 & 5 & 0149 & College Ag Biology & 29 & Ag Biology \\
\hline 1 & 6 & 0245 & Prep & 0 & Prep \\
\hline
\end{tabular}

\begin{tabular}{|l|l|l|l|l|l|}
\hline \multicolumn{2}{|l|}{ Diaz, Carlos } \\
\hline Schedule & Period & Beginning Time & Course Title & Enrollment & Type \\
\hline 1 & 1 & 0750 & Ag Mfechanic I and II & 33 & Ag Mechanics \\
\hline 1 & 2 & 0852 & Prep & 0 & Prep \\
\hline 1 & 3 & 1004 & Ag Mechanics & 35 & Ag Mechanics \\
\hline 1 & 4 & 1106 & Ag Mechanics & 32 & Ag Mechanics \\
\hline 1 & 5 & 1247 & Ag Equipment and Operation & 18 & Ag Mechanics \\
\hline 1 & 6 & 0245 & Ag Equipment and Operation & 18 & Ag Mechanics \\
\hline
\end{tabular}

\begin{tabular}{|l|l|l|l|l|l|}
\hline \multicolumn{2}{|l|}{ Earley, Andree } & \multicolumn{2}{l|}{} \\
\hline Schedule & Period & Beginning Time & Course Title & Enrollment & Type \\
\hline 1 & 1 & 0750 & Floriculture & 26 & O.H./Floral \\
\hline 1 & 2 & 0852 & Ag Leadership & 23 & Other Ag \\
\hline 1 & 3 & 1004 & Project Period & 0 & SAE \\
\hline 1 & 4 & 1106 & Prep & 0 & Prep \\
\hline 1 & 5 & 0149 & Floriculture and Vet Skills & 28 & Other Ag \\
\hline 1 & 6 & 0245 & Vet Skills & 13 & Animal Science \\
\hline
\end{tabular}




\begin{tabular}{|l|l|l|l|l|l|}
\hline Knapp, James & \multicolumn{2}{l|}{$\mid$} \\
\hline Schedule & Period & Beginning Time & Course Title & Enrollment & Type \\
\hline 1 & 1 & 0750 & Prep & 0 & Prep \\
\hline 1 & 2 & 0852 & Horticulture I and II, Floral II, Forestry & 19 & O.H./Floral \\
\hline 1 & 3 & 1004 & Ag Earth Science & 34 & Agriscience I \\
\hline 1 & 4 & 1106 & Ag Earth Science & 31 & Agriscience I \\
\hline 1 & 5 & 0149 & Ag Earth Science & 35 & Agriscience I \\
\hline 1 & 6 & 0245 & Ag Earth Science & 35 & Agriscience I \\
\hline
\end{tabular}

Printed: 10/24/2011 9:23:55 AM 


\begin{tabular}{|c|c|c|c|c|c|c|c|c|c|c|c|}
\hline Display: Points & Sub & mit Cha & gges! & & Reset C & anges & & & & & \\
\hline Sort By Student & & & & $-Q_{1}$ & 2. A & g Lif & $\mathrm{Sc}$ & ence & $-Y /$ & Idridg & e, A \\
\hline Student Name & Grd & 1 & 2 & 3 & 4 & 5 & 6 & 7 & 8 & Perc & Mrk \\
\hline & Max Points: & 10 & 25 & 25 & 30 & 10 & 5 & 5 & 10 & & \\
\hline$* *$ Gradin & Completed: & & & & & & & & & 0 Ass & imnts \\
\hline & 11 & 10 & 25 & 15 & 30 & 8 & 5 & 5 & 10 & 90.00 & A- \\
\hline & 10 & 10 & 0 & 0 & 0 & 8 & 5 & 0 & 10 & 27.50 & $\mathrm{~F}$ \\
\hline & 10 & 10 & 25 & 25 & 28 & 8 & 5 & 5 & 10 & 96.66 & $A$ \\
\hline & 11 & 10 & 25 & 0 & 18 & 8 & 5 & 5 & 10 & 67.50 & $D+$ \\
\hline & 10 & 10 & 25 & 22 & 28 & 8 & 5 & 5 & 10 & 94.16 & $A$ \\
\hline & 10 & 10 & 15 & 0 & 30 & 8 & 5 & 0 & 10 & 65.00 & D \\
\hline & 10 & 10 & 15 & 20 & 18 & 8 & 5 & 5 & 10 & 75.83 & $\mathrm{C}$ \\
\hline & 10 & 10 & 25 & 5 & 0 & 8 & 5 & 5 & 10 & 56.66 & $\mathrm{~F}$ \\
\hline & 9 & 10 & 0 & 0 & 0 & 8 & 5 & 0 & 10 & 27.50 & $\mathrm{~F}$ \\
\hline 10. & 10 & 10 & 20 & 0 & 19 & 8 & 5 & 5 & 10 & 64.16 & $\mathrm{D}$ \\
\hline 11. & 9 & 10 & 25 & 20 & 15 & 8 & 5 & 5 & 10 & 81.66 & B- \\
\hline 12. & 9 & 10 & 25 & 20 & 30 & 8 & 5 & 5 & 10 & 94.16 & $A$ \\
\hline 13 & 10 & 10 & 25 & 25 & 30 & 8 & 5 & 0 & 10 & 94.16 & A \\
\hline 14. & 10 & 10 & 15 & 0 & 30 & 8 & 5 & 5 & 10 & 69.16 & $D+$ \\
\hline 15. & 10 & 10 & 23 & 15 & 30 & 8 & 5 & 5 & 10 & 88.33 & $B+$ \\
\hline 16. & 9 & 10 & 18 & 0 & 30 & 8 & 5 & 5 & 10 & 71.66 & C- \\
\hline
\end{tabular}




\begin{tabular}{|c|c|c|c|c|c|c|c|c|c|c|c|}
\hline Display: Points & Submit & Change & & $\operatorname{Re}$ & set Cha & nges & & & & & \\
\hline Sort By Student & & & $2-$ & Qt 2 & $\mathrm{Ag}$ & Life & Scie & nce & - YA & Aldridg & e, $A$ \\
\hline Student Name & Grd & 1 & 2 & 3 & 4 & 5 & 6 & 7 & 8 & Perc & Mrk \\
\hline & Max Points: & 10 & 25 & 25 & 30 & 10 & 5 & 5 & 10 & & \\
\hline$* * \mathbf{G}$ & Completed: & & & & & & & & & 0 Assı & mnts \\
\hline & 10 & 10 & 25 & 20 & 30 & 9 & & 5 & 10 & 94.78 & $A$ \\
\hline 2 & 11 & 10 & 18 & 25 & 30 & 0 & 5 & 5 & 10 & 85.83 & B \\
\hline 3 & 9 & 10 & 25 & 20 & 30 & 11 & 5 & 5 & 10 & 96.66 & A \\
\hline 4 & 10 & 10 & 22 & 0 & 0 & 0 & 5 & 5 & 10 & 43.33 & $\mathrm{~F}$ \\
\hline & 9 & 10 & 25 & 25 & 30 & 9 & 5 & 5 & 10 & 99.16 & $A$ \\
\hline & 10 & 10 & 25 & 15 & 30 & 11 & 5 & 5 & 10 & 92.50 & A- \\
\hline 7 & 11 & 10 & 25 & 25 & 30 & 9 & 5 & 5 & 10 & 99.16 & $A$ \\
\hline 8 & 10 & 10 & 25 & 25 & 20 & 11 & 5 & 5 & 10 & 92.50 & A- \\
\hline 9 & 10 & 10 & 25 & 0 & 0 & 11 & 5 & & 10 & 53.04 & $\mathrm{~F}$ \\
\hline 10 & 10 & 10 & 25 & 15 & 30 & 11 & 5 & 5 & 10 & 92.50 & A- \\
\hline 11 & 10 & 10 & 25 & 25 & 27 & 9 & 5 & 5 & 10 & 96.66 & $A$ \\
\hline 12. & 9 & 10 & 20 & 10 & 0 & 0 & 5 & 5 & 10 & 50.00 & $\mathrm{~F}$ \\
\hline 13. & 10 & 10 & 25 & 25 & 30 & 9 & 5 & 5 & 10 & 99.16 & A \\
\hline & 10 & 10 & 25 & 20 & 30 & 0 & 5 & 5 & 10 & 87.50 & $\mathrm{~B}+$ \\
\hline 15 & 10 & 10 & 25 & 25 & 20 & 9 & 5 & 5 & 10 & 90.83 & A- \\
\hline 16 & 10 & 10 & 25 & 15 & 28 & 9 & 5 & 5 & 10 & 89.16 & $\mathrm{~B}+$ \\
\hline 17 & 11 & 10 & 5 & 25 & 30 & 11 & 5 & 5 & 10 & 84.16 & B \\
\hline 18 & 9 & 10 & 25 & 20 & 30 & 11 & & 5 & 10 & 96.52 & A \\
\hline 19 & 10 & 10 & 25 & 20 & 30 & 11 & 5 & 5 & 10 & 96.66 & A \\
\hline & 10 & 10 & 25 & 25 & 27 & 11 & 5 & 5 & 10 & 98.33 & A \\
\hline 21. & 10 & 10 & 25 & 25 & 30 & 9 & 5 & 5 & 10 & 99.16 & A \\
\hline 22. & 10 & 10 & 25 & 15 & 28 & 9 & 5 & 5 & 10 & 89.16 & $\mathrm{~B}+$ \\
\hline 23. & 10 & 10 & 15 & 0 & 0 & 0 & 5 & 5 & 10 & 37.50 & $\mathrm{~F}$ \\
\hline 24. & 10 & 10 & 25 & 25 & 30 & 11 & 5 & 5 & 10 & 100.83 & At \\
\hline 25 & 9 & 10 & 25 & 15 & 30 & 9 & 5 & & & 89.52 & $\mathrm{~B}+$ \\
\hline 26.1 & 11 & 10 & 25 & 25 & 30 & 0 & 5 & 5 & 10 & 91.66 & A- \\
\hline
\end{tabular}


Page: 1

11/28/2011 1:37:01 PM

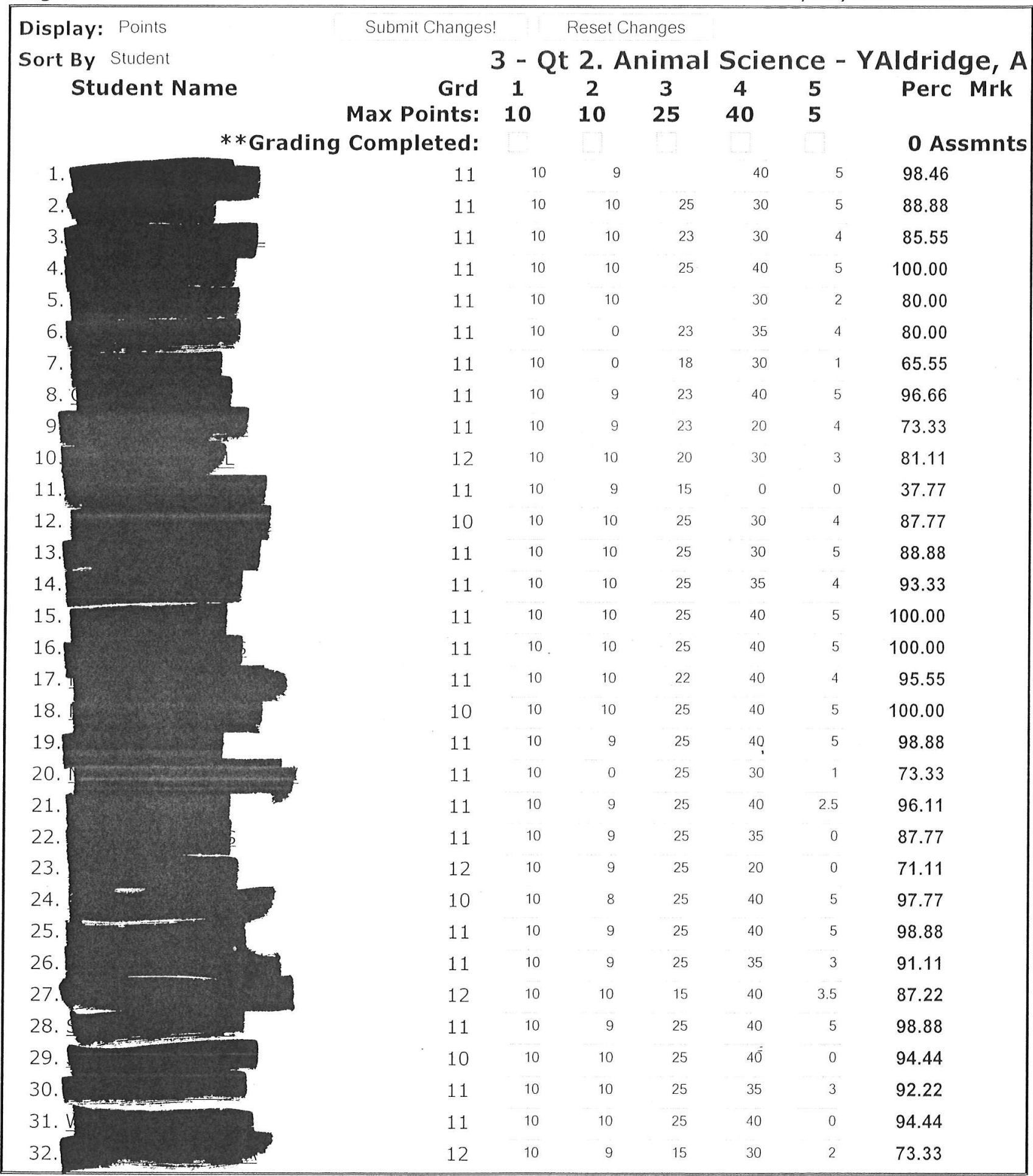




\begin{tabular}{|c|c|c|c|c|c|c|c|}
\hline Display: Points & Submit Change & & Reset & changes & & & \\
\hline Sort By Student & & $4-$ & $2 \mathrm{t} 2$. & Colleg & e Ag & Bio - & YAldridge, A \\
\hline Student Name & Grd & 1 & 2 & 3 & 4 & 5 & Perc Mrk \\
\hline 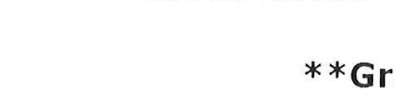 & $\begin{array}{l}\text { Max Points: } \\
\text { Completed: }\end{array}$ & 10 & 25 & 25 & 10 & 50 & 0 Assmnts \\
\hline & 10 & 10 & 25 & 19 & 10 & 0 & 53.33 \\
\hline & 10 & 10 & 25 & 23 & 10 & 0 & 56.66 \\
\hline & 9 & 10 & 25 & 23 & 10 & 46 & 95.00 \\
\hline & 10 & 10 & 25 & 20 & 10 & 33 & 81.66 \\
\hline & 11 & 10 & 0 & 20 & 10 & 0 & 33.33 \\
\hline & 10 & 10 & 20 & 0 & 10 & 0 & 33.33 \\
\hline & 9 & 10 & 25 & 8 & 0 & 0 & 35.83 \\
\hline & 10 & 10 & 25 & 23 & 10 & 0 & 56.66 \\
\hline & 9 & 10 & 20 & 0 & 10 & 0 & 33.33 \\
\hline & 11 & 10 & 23 & 19 & 10 & 30 & 76.66 \\
\hline & 10 & 10 & 24 & 23 & 10 & 0 & 55.83 \\
\hline 12 & 10 & 10 & 23 & 14 & 0 & 0 & 39.16 \\
\hline 13 & 10 & 10 & 0 & 15 & 7 & 0 & 26.66 \\
\hline 14 & 10 & 10 & 25 & 23 & 0 & 47 & 87.50 \\
\hline 15 & 10 & 10 & 25 & 0 & 0 & 0 & 29.16 \\
\hline 16. & 10 & 10 & 20 & 20 & 10 & 40 & 83.33 \\
\hline 17. & 10 & 10 & 23 & 19 & 10 & 40 & 85.00 \\
\hline 18 & 11 & 10 & 25 & 23 & 10 & 45 & 94.16 \\
\hline 19 & 11 & 10 & 25 & 23 & 10. & 38 & 88.33 \\
\hline & 9 & 10 & 25 & 23 & 10 & 30 & 81.66 \\
\hline 21. & 10 & 10 & 23 & 20 & 10 & 42 & 87.50 \\
\hline 22. & 10 & 10 & 25 & 25 & 10 & 45 & 95.83 \\
\hline 23. & 10 & 10 & 20 & 22 & 10 & 40 & 85.00 \\
\hline 24. & 10 & 10 & 25 & 23 & 10 & 42 & 91.66 \\
\hline 25. & 9 & 10 & 25 & 23 & 10 & 49 & 97.50 \\
\hline 26. & 11 & 10 & 23 & 0 & 10 & 36 & 65.83 \\
\hline 27 & 10 & 10 & 18 & 0 & 0 & 40 & 56.66 \\
\hline 28. & 9 & 10 & 25 & 23 & 10 & 41 & 90.83 \\
\hline
\end{tabular}




\begin{tabular}{|c|c|c|c|c|c|c|c|c|}
\hline Display: Points & Subr & mit Changes! & & et Chan & & & & \\
\hline Sort By Student & & $5-$ & Qt 2 & . Col & lege & $\mathrm{Ag} \mathrm{B}$ & $0-Y$ & Aldridge, $A$ \\
\hline Student Name & & Grd & 1 & 2 & 3 & 4 & 5 & Perc Mrk \\
\hline & & Max Points: & 10 & 25 & 25 & 10 & & \\
\hline & $* *$ Grading & Completed: & & & & & & 0 Assmnts \\
\hline $7=$ & & 9 & 10 & 25 & 25 & 10 & 49 & 99.16 \\
\hline & & 10 & 10 & 25 & 23 & 10 & 50 & 98.33 \\
\hline & & 11 & 10 & 20 & 0 & 0 & 45 & 62.50 \\
\hline & & 9 & 10 & 25 & 20 & 10 & 49 & 95.00 \\
\hline & & 10 & 10 & 25 & 0 & 0 & 0 & 29.16 \\
\hline & & 9 & 10 & 25 & 0 & 10 & 48 & 77.50 \\
\hline & & 11 & 10 & 15 & 25 & 5 & 0 & 45.83 \\
\hline & & 10 & 10 & 20 & 23 & 10 & 26 & 74.16 \\
\hline & & 10 & 10 & 25 & 23 & 10 & 44 & 93.33 \\
\hline & & 10 & 10 & 25 & 25 & 10 & 38 & 90.00 \\
\hline 11 & & 10 & 10 & 25 & 0 & 10 & 0 & 37.50 \\
\hline 12 & & 10 & 10 & 25 & 25 & 10 & 42 & 93.33 \\
\hline & & 10 & 10 & 25 & 24 & 10 & 38 & 89.16 \\
\hline & & 10 & 10 & 25 & 25 & 10 & 50 & 100.00 \\
\hline & $7=$ & 10 & 10 & 25 & 20 & 10 & 38 & 85.83 \\
\hline & & 10 & 10 & 25 & 23 & 10 & 33 & 84.16 \\
\hline 17. & & 10 & 10 & 25 & 23 & 10 & 48 & 96.66 \\
\hline 18. & & 10 & 10 & 25 & 23 & 10 & 0 & 56.66 \\
\hline 19. & & 11 & 10 & 20 & 20 & $: 10$ & 0 & 50.00 \\
\hline 20 & & 9 & 10 & 22 & 23 & 10 & 0 & 54.16 \\
\hline 21. & & 9 & 10 & 25 & 23 & 10 & 0 & 56.66 \\
\hline 22. & & 9 & 10 & 25 & 25 & 10 & 50 & 100.00 \\
\hline$x^{2}$ & & 10 & 10 & 25 & 22 & 10 & 30 & 80.83 \\
\hline 24. & & 10 & 10 & 25 & 25 & 10 & 50 & 100.00 \\
\hline 25. & & 10 & 10 & 24 & 0 & 10 & 37 & 67.50 \\
\hline 26 & & 10 & 10 & 20 & 0 & 10 & 0 & 33.33 \\
\hline 27.5 & & 10 & 10 & 25 & 23 & 10 & 37 & 87.50 \\
\hline & & 10 & 10 & 25 & 23 & 10 & 0 & 56.66 \\
\hline
\end{tabular}




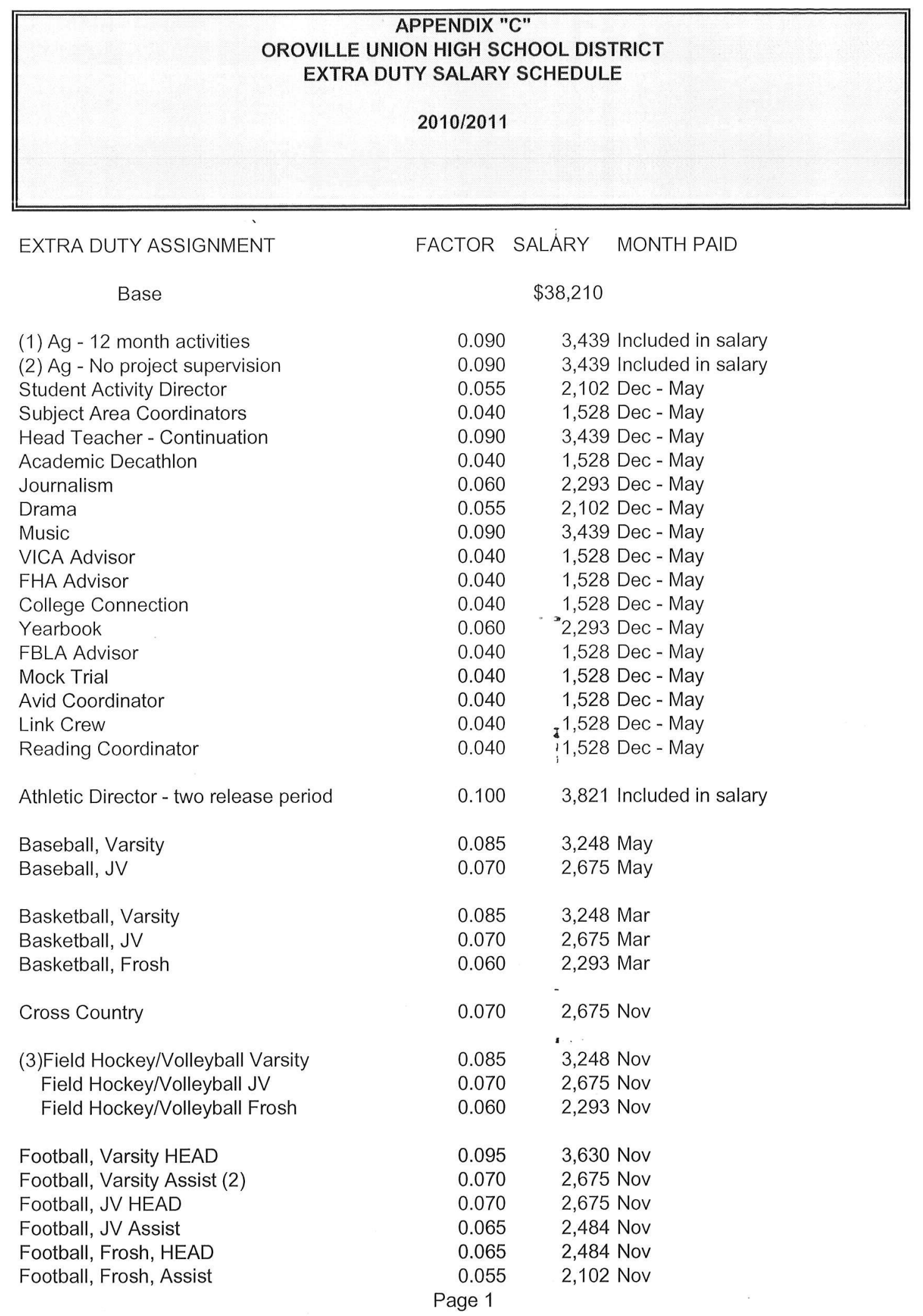




\begin{tabular}{|c|c|c|}
\hline Golf & 0.070 & 2,675 May \\
\hline Soccer & 0.085 & 3,248 Mar \\
\hline Softball, Varsity & 0.085 & 3,248 May \\
\hline Softball, JV & 0.070 & 2,675 May \\
\hline Swimming & 0.070 & $2,675 \mathrm{Nov}$ \\
\hline Tennis & 0.070 & 2,675 Nov - Girls Paid / May - Boys Paid \\
\hline Track, HEAD & 0.085 & 3,248 May \\
\hline Track, Assist & 0.070 & 2,675 May \\
\hline Wrestling, HEAD & 0.085 & 3,248 Mar \\
\hline Wrestling, Assist & 0.070 & 2,675 Mar \\
\hline Pep Squad Advisor & 0.060 & 2,293 Dec - May \\
\hline Flag Coordinator & 0.035 & 1,337 May \\
\hline HOME \& HOSPITAL & & $\$ 24.06$ Hourly \\
\hline SUMMER SCHOOL & STEP 1 & $\$ 26.33$ Hourly \\
\hline AND SATURDAY SCHOOL & STEP 2 & $\$ 27.64$ Hourly \\
\hline & STEP 3 & $\$ 29.02$ Hourly \\
\hline & STEP 4 & $\$ 30.45$ Hourly \\
\hline & STEP 5 & $\$ 31.98$ Hourly \\
\hline
\end{tabular}

(1) Limited to three (3) employees

(2) Limited to one (1) employee

(3) School may participate in either sport, but not both

DRAMA: Full program consists of at least two (2) major productions per year

MUSIC: Includes both instrumental and vocal

SUBJECT AREA COORDINATORS: Each comprehensive high school will pay nine (9) stipends. Subject Area Coordinators will be determined by Site Administration. (The subject areas that the State of California will hold districts responsible for (e.g., frameworks, state-mandated testing) will be included).

EXTRA DUTY: Hourly extra duty pay for all curriculum activities will be compensated at Step 3 of the existing summer school salary rate.

AVID \& READING COORDINATOR: To be funded from categorical programs upon availability of funding.

EFFECTIVE: July 1, 2010

ADOPTED: 8/4/10 


\begin{tabular}{|c|c|c|c|c|c|c|}
\hline \multicolumn{7}{|c|}{$\begin{array}{c}\text { APPENDIX "B" } \\
\text { OROVILLE UNION HIGH SCHOOL DISTRICT } \\
\text { CERTIFICATED SALARY SCHEDULE } \\
\text { SALARY SCHEDULE } 2010 / 2011\end{array}$} \\
\hline STEP & $\begin{array}{c}\text { Class I } \\
\text { BA } \\
\text { OR } \\
\text { BA + } 15\end{array}$ & $\begin{array}{c}\text { Class II } \\
\text { MA } \\
\text { OR } \\
\text { BA + } 30\end{array}$ & $\begin{array}{c}\text { Class III } \\
\mathrm{MA}+15 \\
\mathrm{OR} \\
\mathrm{BA}+45\end{array}$ & & $\begin{array}{c}\text { Class IV } \\
\mathrm{MA}+30 \\
\text { OR } \\
\mathrm{BA}+60 \\
\end{array}$ & STEP \\
\hline 1 & 39205 & 40659 & 42110 & & 43564 & 1 \\
\hline 2 & 40659 & 42110 & 43564 & & 45015 & 2 \\
\hline 3 & 42110 & 43564 & 45015 & & 46466 & 3 \\
\hline 4 & 43564 & 45015 & 46466 & & 47917 & 4 \\
\hline 5 & 45015 & 46466 & 47917 & & 49367 & 5 \\
\hline 6 & 46466 & 47917 & 49367 & & 50821 & 6 \\
\hline 7 & 47917 & 49367 & 50821 & & 52272 & 7 \\
\hline 8 & 49367 & 50821 & 52272 & & 53723 & 8 \\
\hline 9 & 50821 & 52272 & 53723 & & 55174 & 9 \\
\hline 10 & 52272 & 53723 & 55174 & & 56626 & 10 \\
\hline 11 & 53723 & 55174 & 56626 & & 58076 & 11 \\
\hline 12 & 55174 & 56626 & 58076 & i & 59530 & 12 \\
\hline 13 & & 58076 & 59530 & & 60983 & 13 \\
\hline 14 & & & 60983 & & 62433 & 14 \\
\hline 15 & & & & & 63885 & 15 \\
\hline $16 / 18$ & & & 63199 & & 66101 & $16 / 18$ \\
\hline $19 / 21$ & & & 65414 & & 68320 & $19 / 21$ \\
\hline $22 / 24$ & & & 67634 & $=$ & 70537 & $22 / 24$ \\
\hline $25 / 26$ & & & 69851 & & 72752 & $25 / 26$ \\
\hline $27+$ & & & 74284 & & 77187 & $27+$ \\
\hline
\end{tabular}

Longevity: After 15th, 18th, 21st, 24th, 26th and 27th year for Classes III and IV

Clad Credential for those hired prior to September, 1995 and who earned and filed proof of certification in the Superintendents office by September 10, 2005 will receive $\$ 300$ per year. (Revision adopted 12-15-04)

Aasters Degree: $\$ 600$ per year ( Pay one only)

Effective: July 1, 2010

ADOPTED: 


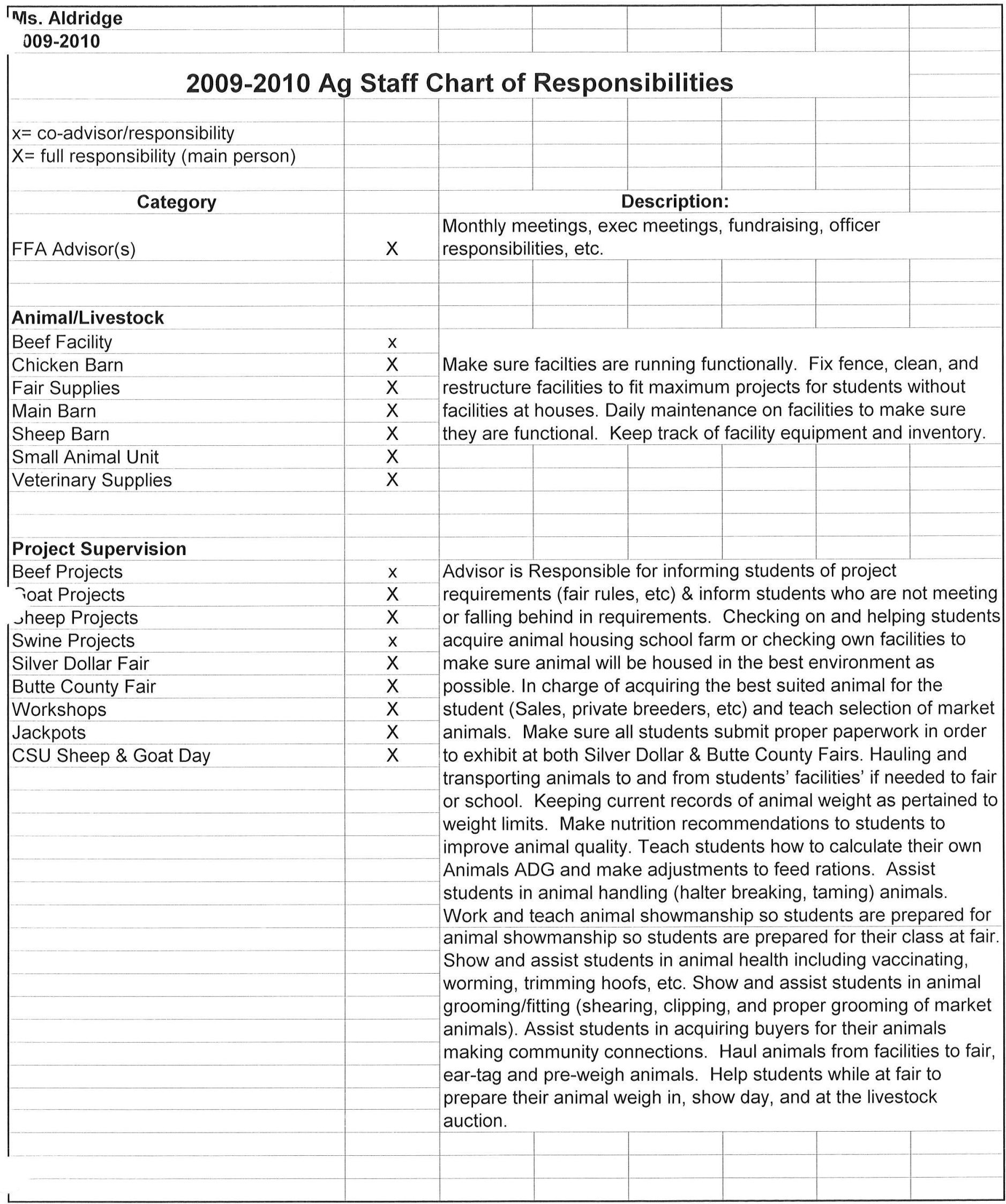




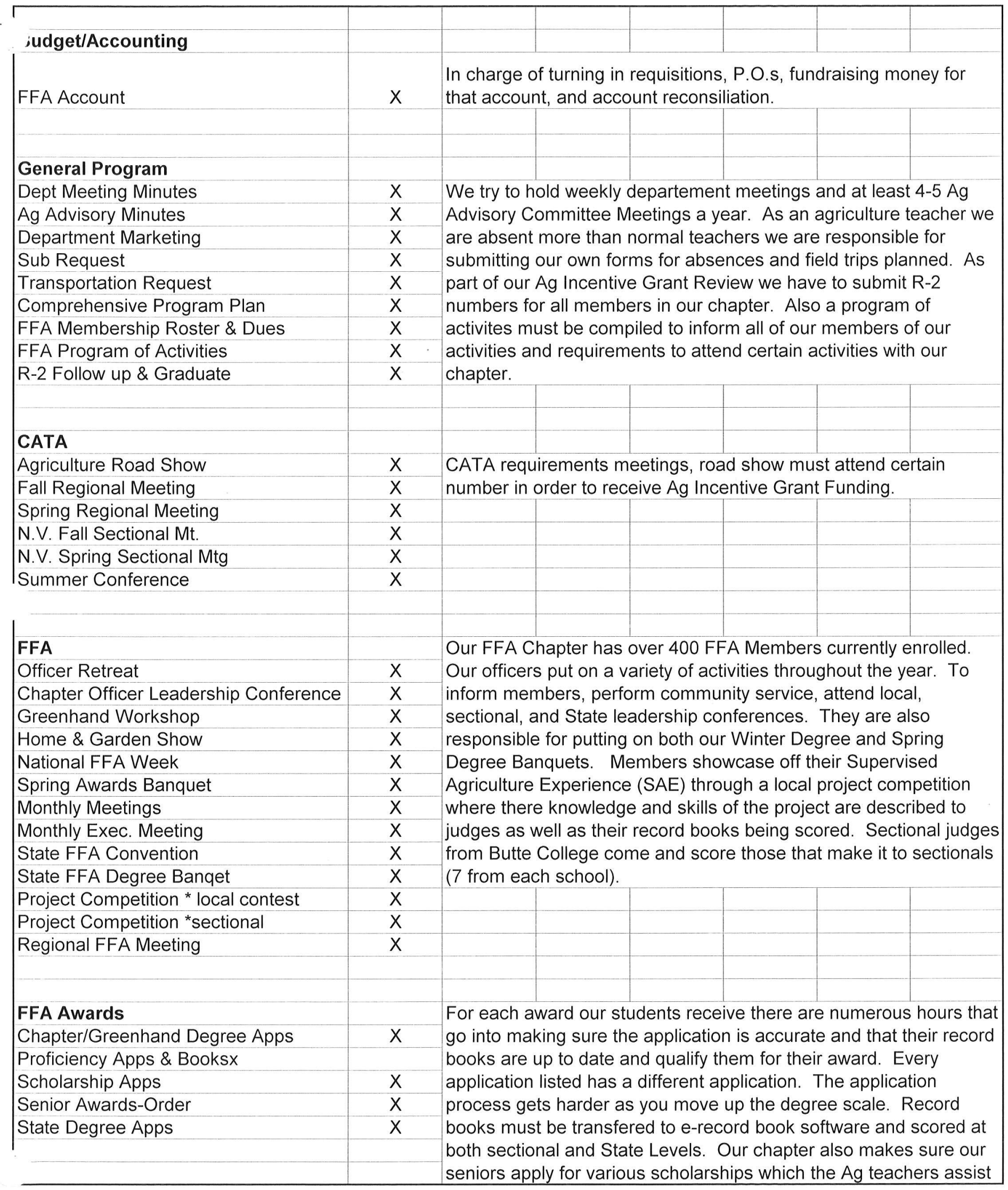




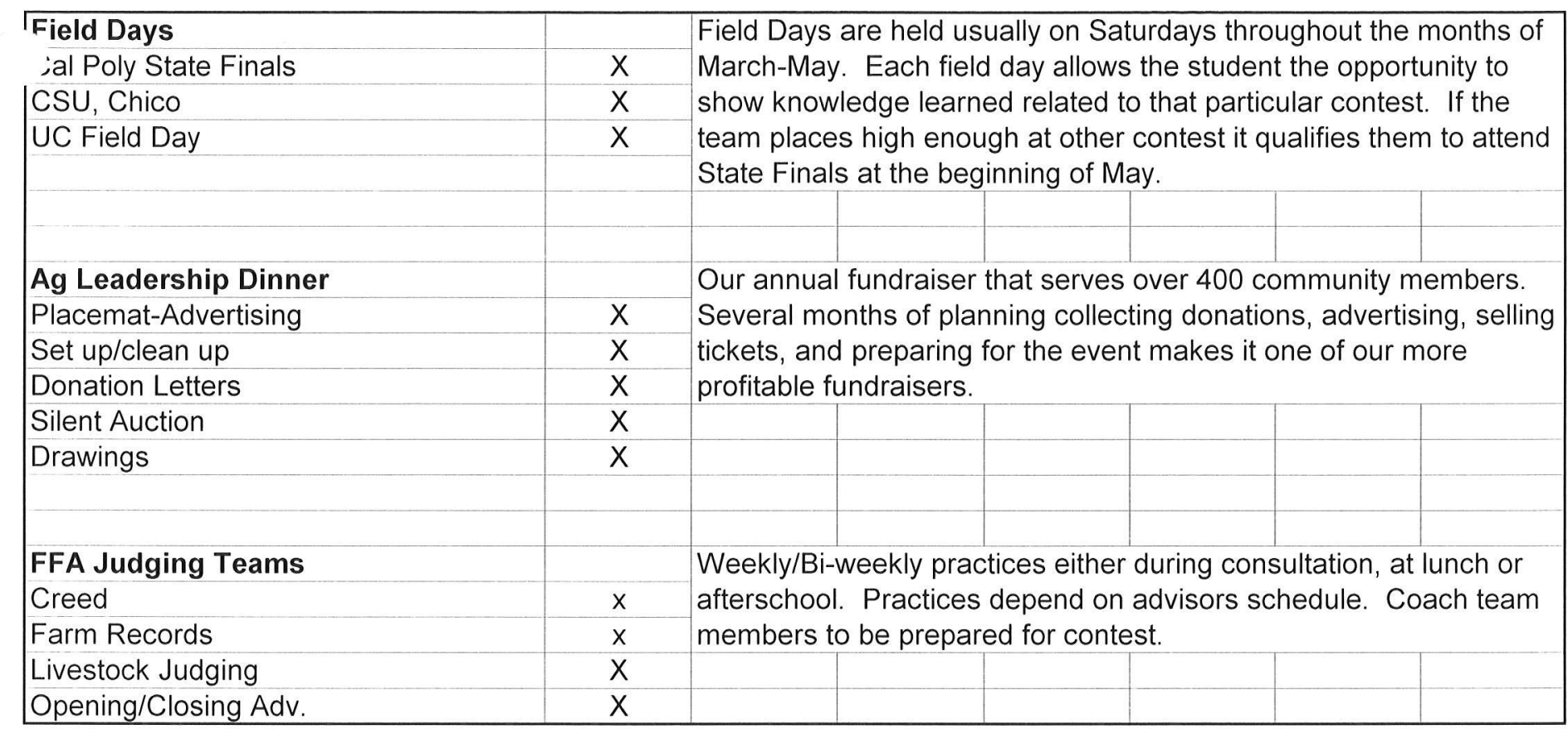




\section{Quality Criteria Twellve:}

\section{Program Achievement}

\section{Quality Criterion 12 (Optional)}

Agriculture education programs that meet Quality Criterion \#12 and have submitted the Quality Criterion 12 Form are eligible for a $\$ 3,000$ adjustment to the Incentive Grant.

The Las Plumas Agriculture department is excited to have finally met the program achievement quality criteria. This is going to continue to be a goal of the Las Plumas Agriculture department.

\section{Evidence Documents Include:}

- Quality Criteria 12 Check List 